\author{
UNIVERSIDADE DE SÃO PAULO \\ FACULDADE DE ECONOMIA, ADMINISTRAÇÃO E CONTABILIDADE \\ DEPARTAMENTO DE ADMINISTRAÇÃO
}

\title{
Fatores Críticos para o Desenho e Implantação de e-business por empresas tradicionais
}

\section{Silvia Novaes Zilber}

Orientador: Prof. Dr. Eduardo P. G. de Vasconcellos

SÃO PAULO

NOVEMBRO - 2002 
- Reitor da Universidade de São Paulo

- Prof. Dr. Adolpho José Melfi

- Diretor da Faculdade de Economia, Administração e CONTABILIDADE

- Prof. Dr. Maria Tereza Leme Fleury

- Chefe de Departamento

- Prof. Dr. Eduardo Pinheiro Gondin de Vasconcellos 
UNIVERSIDADE DE SÃO PAULO

FACULDADE DE ECONOMIA, ADMINISTRAÇÃO E CONTABILIDADE

DEPARTAMENTO DE ADMINISTRAÇÃO

\section{Fatores Críticos para o Desenho e Implantação de e-business por empresas tradicionais}

\section{Silvia Novaes Zilber}

Orientador: Prof. Dr. Eduardo P. G. de Vasconcellos

Tese apresentada à Faculdade de Economia, Administração e Contabilidade da Universidade de São Paulo, como parte dos requisitos para a obtenção do título de doutor em Administração

SÃO PAULO

NOVEMBRO /2002 
FICHA CATALOGRÁFICA

Zilber, Silvia Novaes

Fatores Críticos para o desenho e Implantação de EBusiness por empresas tradicionais - São Paulo, 2002 páginas

Tese - Doutorado

Bibliografia

1.E-Business 2.Estruturas Organizacionais

3.Comércio Eletrônico 4.Internet 5.Indústria

automobilística-Montadoras 6.Modelo de Negócio

I.Faculdade de Economia, Administração e Contabilidade da USP. II.Título

nn 
DEDICATÓRIA 


\section{DEDICATÓRIA}

Dedico essa tese aos meus preciosos filhos: João Pedro, Rafael Francisco e Maria Clara e ao Marcelo 
AGRADECIMENTOS 


\section{AGRADECIMENTOS}

- Ao meu orientador professor Eduardo Vasconcellos por todas as direções indicadas e paciência com minhas idas e vindas

- Ao meu marido e filhos por seu carinho, apoio e amor

- Aos meus pais

- Aos meus amigos Olívio, Heloísa, Isabel, Taciana, Marco, dentre tantos outros que me acompanharam nesse caminho

- Aos professores da banca de qualificação, prof. Isak e prof. Nicolau que muito me ajudaram com sugestões valiosas

- À Valéria do pós, à Cida, Didi e Vanessa, Eloísa, Fabiana e Daniela pelo apoio logístico

- Ao CNPq pela bolsa que obtive dessa instituição

- À Carolina e Michelle, pelo total apoio dado

- A todos os entrevistados que dispuseram de seu tempo de forma atenciosa, prestando enorme colaboração, sem a qual essa tese não existiria

- À lolanda, que ajudou a formatar essa tese

- A Deus, sobre todas as coisas 
SÚMARIO 


\section{Sumário}

\section{LISTA DE FIGURAS}

LISTA DE TABELAS

RESUMO

ABSTRACT

$\begin{array}{ll}\text { Capítulo I } & 1\end{array}$

1. INTRODUÇÃO 2

1.1. Apresentação Do Cenário De E-Business 4

$\begin{array}{lr}\text { Capítulo II } & 22\end{array}$

2. QUESTÕES E JUSTIFICATIVA DA PESQUISA 29

2.1. Objetivo e Questões De Pesquisa 29

2.1.1. Quadro sintético das questões de pesquisa 47

$\begin{array}{ll}\text { 2.2. Justificativa Da Pesquisa } & 49\end{array}$

2.2.1. Quadro das justificativas das questões da pesquisa 52

2.3. Organização Do Restante Do Estudo 55

$\begin{array}{ll}\text { Capítulo III } & 56\end{array}$

3. REVISÃO BIBLIOGRÁFICA

3.1. Aspectos Ligados A E-Business 57

3.1.1. A Internet 57

3.1.2. Definições De E-Business E De Alguns Termos 62 Relacionados Ao Mundo De E-Business

3.1.3. Porque Adotar E-Business: Vantagens E Benefícios 66

3.1.4. Fatores Críticos De Sucesso Na Adoção De E-Business 68 Por Empresas Tradicionais

3.2. Aspectos Da Situação Atual Do E-Business No Brasil 76

3.3. Implantação De E-Business Visto Sob A Ótica De Projetos - 82 Gestão De Projetos

3.4. Aspectos Relacionados À Estrutura Organizacional 88

3.4.1 Estrutura Organizacional E E-Business 102 
3.5. Conceituação De Modelos De Negócios E Suas Implicações Para

O E-Business

3.5.1. O Conceito De Porter Para E-Business-Cadeia De Valor 118

3.5.2. Modelos De E-Business Segundo Weil E Vitale-Modelos 125 Nucleares

3.5.3. Modelo De E-Business Segundo Amit E Zott-Criação De Valor Em E-Business

3.5.4. Modelo De E-Business Baseado No Conceito "Build-ToOrder"

3.5.5. Modelos De E-Business B2b E B2c

Capítulo IV

4. METODOLOGIA DE PESQUISA

4.1. Considerações Sobre A Escolha Do Método De Pesquisa

4.1.1. Tipo De Pesquisa: Estudo De Casos Múltiplos

4.2. Relacionamento Entre As Questões De Pesquisa - Modelo De

Pesquisa

4.3. Algumas Definições

4.4. Seleção Dos Casos Estudados

165

4.5. Procedimento Para A Coleta Dos Dados

4.5.1. Técnica De Coleta De Dados

4.5.2. Fontes De Dados Primários

4.5.3. Fontes De Dados Secundários

4.6. Análise Dos Dados

$\begin{array}{ll}\text { 4.7. A Pesquisa De Campo } & 175\end{array}$

4.8. Limitações Do Método De Pesquisa 179

Capítulo V

181

5. APRESENTAÇÃO E DISCUSSÃO DOS RESULTADOS DOS ESTUDOS DE CASO

5.1. Perfil da Indústria automobilística - ênfase nas montadoras

5.1.1. Cenário Global da Economia e as Montadoras no Brasil 
5.1.2. História recente da Indústria Automobilística na América do Sul- painel dos anos 90 até dias atuais

5.1.3. As montadoras e o e-business

5.2. Apresentação dos Resultados - Descrição dos Casos

5.2.1 Descrição dos casos no que tange à verificação de utilização de modelos de negócio para desenhar e implantar atividades de e-business na empresa

5.2.1.1. Descrição do caso da matriz da montadora A: Verificação da existência de Modelo de negócio para atividades de e-business

5.2.1.2. Descrição do caso da filial brasileira da montadora A: Verificação da existência de Modelo de negócio para atividades de e-business

5.2.1.3. Descrição do caso da matriz da montadora B: Verificação da existência de Modelo de negócio para atividades de e-business

5.2.1.4. Descrição do caso da filial brasileira da montadora B: Verificação da existência de Modelo de negócio para atividades de e-business

5.2.1.5. Descrição do caso da matriz da montadora C: Verificação da existência de Modelo de negócio para atividades de e-business

5.2.1.6. Descrição do caso da filial brasileira da 260 montadora C: Verificação da existência de Modelo de negócio para atividades de e-business

5.2.2 Descrição dos casos no que tange às Estruturas Organizacionais para operacionalizar as atividades de ebusiness da empresa

5.2.2.1. Estrutura Organizacional na montadora A: Matriz

5.2.2.3. Estrutura Organizacional na montadora B: Matriz 
5.2.2.6. Estrutura Organizacional na montadora C: Brasil 319

5.2.3. Quadro Resumo Para Analisar Os Dados Obtidos Sobre A 328 Verificação Da Existência De Modelos De Negócio Para E-Business

5.2.4. Comentários e Análises complementares sobre uso de modelos de negócio para desenhar e implantar atividades de e-busienss

5.2.5. Quadro Resumo Das Análises Sobre Estrutura Organizacional Para Operacionalizar Modelo De E-Business Das Matrizes

5.2.6 Comentários e Análises adicionais sobre estruturas organizacionais

5.2.7. Análises sobre estratégia, modelos de e-business e estrutura organizacional

Capítulo VI

6. CONCLUSÕES, Limitações da pesquisa, recomendações e Sugestões para estudos futuros

6.1. Conclusões

6.2. Limitações do estudo 376

6.3. Recomendações

6.4. Sugestões para estudos futuros

Capítulo VII

380

7. REFERÊNCIAS BIBLIOGRÁFICAS

8. ANEXOS 
LISTA DE FIGURAS 


\section{Lista de Figuras}

Figura 1 Previsões Para O Crescimento Das Transações Eletrônicas 8

$\begin{array}{lll}\text { Figura } 2 & \text { Receitas Mundiais Em E-Commerce } & 11\end{array}$

Figura 3 Porcentagem Das Receitas Da América Latina Atribuídas À 14 Internet

Figura 4 Nível 4 De Utilização Do E-Business 22

Figura $5 \quad$ Nível 5 De Utilização Do E-Business 23

Figura 6 Nível 6 De Utilização Do E-Business 24

Figura 7 Descrição De Uma Iniciativa De E-Business 35

Figura 8 Componentes De Um Modelo De Negócios 36

Figura 9 Níveis De Integração Do E-Business À Empresa 44

$\begin{array}{lll}\text { Figura } 10 & \text { Evolução Do Ce E Os Processos De Negócio }\end{array}$

$\begin{array}{lll}\text { Figura } 11 & \text { Ce No Relacionamento Com Clientes } & 77\end{array}$

Figura 12 Ce Nos Processos De Atendimento A Clientes Por 78

Figura 13 Evolução Da Utilização Das Aplicações De Ce 79

Figura 14 Evolução Da Avaliação Dos Aspectos De Ce 80

Figura 15 Evolução Da Avaliação Das Contribuições De Ce 81

Figura $16 \quad$ Exemplo De Estrutura Funcional Pura 91

$\begin{array}{lll}\text { Figura } 17 & \text { Estrutura Funcional Por Projeto } & 91\end{array}$

$\begin{array}{lll}\text { Figura } 18 & \text { Estrutura Matricial Balanceada } & 95\end{array}$

Figura 19 Estrutura Matricial Funcional 96

Figura 20 Estrutura Matricial Por Projetos 96

$\begin{array}{lll}\text { Figura } 21 & \text { Estrutura Organizacional E-Centrica } & 103\end{array}$

$\begin{array}{lll}\text { Figura } 22 & \text { Estrutura Para Uma Organização E-Centrica } & 104\end{array}$

Figura 23 Mapa Para Análise Do Grau De Integração Do E-Business À 108 Empresa Core

Figura 24 Espectro De Integração Entre "Clicks E Tijolos" 108

Figura 25 A Estrutura De Um Centro De E-Business Numa Indústria 111 
Global

Figura 26 O Modelo De Negócio Media Os Domínios Técnico E

Econômico

Figura 27 Classificação Dos Modelos De Negócio De Internet

Figura 28 Como A Internet Influencia A Estrutura Da Indústria

Figura 29 Aplicações Da Internet Na Cadeia De Valor

Figura 30 Exemplo Do Modelo De E-Business "Direto Ao Consumidor

Figura 31 A Reversão Da Cadeia De Valor

Figura 32 Modelo De Pesquisa

$\begin{array}{lll}\text { Figura } 33 & \text { Nível } 4 \text { De Utilização Do E-Business }\end{array}$

Figura 34 Modelo Conceitual Para Estratégia De E-Business De 208

Figura 35 Modelo De Negócio Para E-Business Da Montadora A Matriz 213

Figura 36 Componentes Do Modelo De Negócio Para E-Business Da 213 Montadora A

Figura 37 Conexão Da Cadeia De Valor Pelas Várias Ferramentas De EBusiness

Figura 38 Modelo De Negócio Para E-Business A Ser Implantado No

Figura 39 Modelo De Negócio Acelerador De Atividades De E-Business Da Matriz Montadora B

Figura 40 Conjunto De Atividades De E-Business Da Matriz Montadora B Geradas Pelo Modelo De Negócio De Aceleração Das Atividades De E-Business

Figura 41 Sistema De Compras Atual Da Montadora B Matriz

Figura 42 Futuro Sistema De Compras Da Montadora B Matriz 240

Figura.43 Modelo De Negócio Para E-Business Concebido Pelo 243 Supervisor De E-Business Para A Montadora B Em 2000 Para Aprovação Pelo Comitê Executivo Da Empresa

Figura 44 Componente B2C Do Modelo De E-Business Proposto Pelo

Supervisor De E-Business Da Montadora B - Brasil

Figura 45 Componente B2B Do Modelo De E-Business Proposto Pelo Supervisor De E-Business Da Montadora B - Brasil 
Figura 47 Objetivos Do E-Business Para A Montadora C - Matriz

Figura 48 Modelo De E-Business Da Montadora C - Brasil 262

Figura 49 Esquema De Distribuição Da Montadora C- Brasil, Por Venda 267 Pela Internet

Figura 50 Estrutura Organizacional Esquemática De E-Business Da Montadora A

Figura $51 \quad$ Estrutura Organizacional Para Implantar Modelo De Negócio

Para E-Business Na Montadora A Da AL

Figura 52 Organograma Da Montadora A No Brasil Incluindo Área De E- 278 Business

Figura 53 Área Dedicada A E-Business Na Área De Compras Da Montadora A Brasil

Figura 54 Organograma Da Área De TI Da Montadora A Brasil

Figura 55 Estrutura Organizacional Utilizada Pelo Modelo "Acelerador De Iniciativas De E-Business”Da Matriz Montadora B

Figura 56 Estrutura Organizacional Da “Conexão Com O Consumidor" $\mathrm{Na}$ Matriz Após Julho De 2001:

Figura 57 Organograma Da Montadora B Brasil Destacando As Áreas Dedicadas A E-Business

Figura 58 Estrutura Organizacional Da Área De Serviço Ao Cliente E

Figura 59 Estrutura Organizacional Da Montadora B Brasil Após União De Áreas

Figura 60 Relacionamento Da Área De E-Business Dentro De Serviço Ao Cliente E Outras Áreas

Figura 61 Identificação Das Áreas De E-Business Dentro Da Montadora B- Brasil

Figura 62 Estrutura Da Diretoria De Compras Referente A E-Business Da Montadora B - Brasil

Figura 63 Metodologia De Projetos Da Montadora B-Brasil

Figura 64 Localização Da Área De Vendas Na Estrut. Org. Montadora B 306 Brasil

Figura 65 Estrutura Organizacional Do Projeto De Venda Direta De Novo Modelo De Carro Popular Pela Montadora B-Brasil 
Figura 67 Estrutura Organizacional Da Área De TI Da Montadora B

Figura 68 Avanço Tecnológico Após E-Business Na Empresa B Brasil

Figura 69 Estrutura Organizacional Da Unidade De E-Business "E-

Figura 70 Estrutura Organizacional Da Montadora C

Figura 71 Estrutura Organizacional Da Montadora C Brasil E

Figura 72 : Área De E-Business Da Montadora C Brasil Em 1999

Figura 73 Organograma Do Projeto De Venda Pela Internet Do Carro

Figura 74 Estrutura Organizacional Do Grupo De E-Business B2c Da Montadora C - Brasil 2002 
LISTA DE TABELAS 


\section{Lista de Tabelas}

Tabela 1 Posição Dos Países No Mundo Por Números De Hosts,

Resultados De 2002

Tabela $2 \quad$ Analisando Um Modelo De Negócios 36

$\begin{array}{lll}\text { Tabela } 3 & \text { Questões De Pesquisa } & 48\end{array}$

Tabela 4A Justificativa Das Questões Propostas Pela Pesquisa 53

Tabela 4B Justificativa Das Questões Propostas Pela Pesquisa 54

Tabela $5 \quad$ Requisitos De Segurança Para Internet 61

Tabela $6 \quad$ Componentes Da Estrutura Organizacional 89

Tabela $7 \quad$ Um Mapa Que Ajuda No Processo Decisório 110

Tabela $8 \quad$ "Building Blocks" Associados Ao Modelo "Direto Ao 129 Consumidor" A Partir Das Competências Essenciais Da Firma

Tabela 9 Crescimento Do Pib-Projeção Para O Triênio Até 2002185

Tabela 10 Estrutura Econômica Para Avaliar Efeitos Econômicos De 200

Tabela 11 Produtos Propiciados Pela Tecnologia De Internet 204

Tabela12 Resultado Da Pesquisa Junto Aos Stakeholders Para 292

Redirecionar O Foco Do Modelo De E-Business E Alterar A Estrutura Da "Conexão Com O Consumidor"

Tabela 13 Representação Gráfica Dos Modelos De E-Business

Identificados Para As Matrizes Das Montadoras

Tabela 14 Representação Gráfica Dos Modelos De E-Business Identificados Para As Filiais Brasileiras Das Montadoras

Tabela 15 Descrição Do Modelo De Negócio Das Matrizes Para EBusiness Através Das Dimensões: Conceito, Capacitações, Valor

Tabela 16 Descrição Do Modelo De Negócio Das Filiais Brasileiras

Para E-Business Através Das Dimensões: Conceito, Capacitações, Valor

Tabela 17 Alguns Resultados Obtidos Pelo Uso De Modelo De Negócio Para Atividades De E-Business Pelas Matrizes Das Montadoras 
Tabela 18 Alguns Resultados Obtidos Pelo Uso De Atividades De EBusiness Executadas Pelas Filiais Brasileiras Das Montadoras

Tabela 19 Papel Da Alta Administração Na Adoção De Modelo De Negócio Para Desenho E Implantação De E-Business Das Matrizes Das Montadoras

Tabela 20 Papel Da Alta Administração Na Adoção De Modelo De Negócio Para Desenho E Implantação De E-Business Das Filiais Das Montadoras

Tabela 21 Comparação De Alguns Aspectos Entre Matrizes E Filiais Das Montadoras

Tabela 22 Desenho do grau de integração encontrado para as estruturas organizacionais de e-business das matrizes das montadoras

Tabela 23 Desenho do grau de integração encontrado para as estruturas organizacionais de e-business das filiais brasileiras das montadoras

Tabela 24 Desenho da estrutura organizacional inicial utilizada para operacionalizar atividades de e-business nas matrizes

Tabela $25 \quad$ Estruturas organizacionais para e-business utilizadas no início do processo de adoção do modelo de negócio para ebusiness para as filiais das montadoras

Tabela 26 Localização das áreas de e-business dentro do organograma da empresa - Brasil

Tabela $27 \quad$ Modificações ocorridas na estrutura organizacional da empresa devido à inserção da estrutura para e-business ao longo do tempo para as filiais brasileiras

Tabela28 Estrutura de TI das filiais brasileiras relacionada a ebusiness

Tabela 29 Comparação entre matriz e filial no que tange a estruturas organizacionais para e-business 
RESUMO 


\section{RESUMO}

A presente pesquisa buscou verificar como uma empresa tradicional, que opera no mundo real respondeu ao desafio de ingressar nos negócios do mundo eletrônico, representado por transações de negócio realizadas sobre uma rede pública, na maioria das vezes, a Internet

Para isso, utilizou-se o conceito de modelo de e-business, como uma ferramenta que auxilia na análise do fenômeno.

$\mathrm{O}$ que se quis verificar foi como as atividades de e-business adotadas afetaram a estrutura organizacional já existente da empresa que o adotou.

Para isso, num primeiro momento verificou-se se a empresa adotou algum modelo de negócio para conduzir suas atividades de e-business e num segundo momento quais foram as estruturas organizacionais utilizadas para operacionalizar as atividades adotadas .

Para isso foram realizados três estudos de casos em montadoras de automóveis.

Os resultados indicam para cada montadora situações diferentes: uma adotou um modelo pata conectar sua cadeia de valor, dando ênfase nas atividades $\mathrm{B} 2 \mathrm{~B}$, outra buscou entregar valor ao consumidor, através de atividades $\mathrm{B} 2 \mathrm{C}$, com o uso de métricas e de uma infraestrutura de $\mathrm{TI}$, a terceira não se valeu de um modelo específico, mas sim da implantação de uma vasta gama de atividades de e-business.

As estruturas organizacionais utilizadas também variaram: apesar de todas estarem integradas às empresas, a primeira utilizou uma estrutura matricial, a segunda uma estrutura com atividades espalhadas sem coordenação ao longo da estrutura organizacional e finalmente a terceira adotou uma estrutura coordenada pela área de marketing.

Quanto a resultados, uma delas ainda está iniciando suas atividades, com resultados baseados em diminuição de custos usando leilões reversos, outra tem muitas atividades, porém dificuldade em mensurar resultados e uma terceira teve uma bem sucedida iniciativa de vendas diretas pela Internet, com receitas acima da expectativa. 


\begin{abstract}
Although many established companies are well positioned to succeed at ebusiness thanks to strong brands, customer relationships and logistical systems, the toughest challenges of e-business are less strategic than organizational.

The thesis focuses on how companies in the "real world" tackle the challenge of doing business on the Internet in organizational terms and how ebusiness initiatives affect existing organizational structures in such companies.

For this, in a first moment, it was utilized the concept of "e-businessmodel", as a tool to better understand the phenomena of e-business adoption.

The concept of e-business is preferred to that of e-commerce because it is more all-embracing. E-business refers to all business transactions on the Internet between a company and its suppliers, partners and customers, as well as inside the company. It were researched three case studies in the Brazilian automotive industry.

In a first moment, it was identified if the enterprise has adopted any business model to conduct the e-business activities and it was identified the characteristics of the business model, when it was present.

After this, it was identified what kind of organizational structure were utilized to implement the e-business activities, defined by a business model or not.

The results show us different situations: one company has adopted a model based on supply chain integration, another has adopted one model focused in the consumer, with IT activities integrated whith e-business activities and another company hasn't adopted any business model at all.
\end{abstract}

There were differences among the organizational structures too: one has adopted a matricial structure, another any activities distributed by the firm and the third has adopted one coordinated structure under Marketing area. 
CAPÍTULO I

INTRODUÇÃO 


\section{Capítulo I}

\section{INTRODUÇÃO}

Se a tecnologia permite, os modelos de negócios mudam: essa é uma afirmação sobre transformação de modelos de negócio e não sobre "web sites" ou "mp3". Novas tecnologias digitais surgem todo dia, muitas delas difíceis de classificar.

Estas tecnologias destacam-se por ter a capacidade de impactar todas as indústrias e representar um dos mais poderosos agentes de mudança dos modelos de negócios na economia atual. O impacto dessas tecnologias no mundo dos negócios faz com que surjam desafios de natureza estratégica: as decisões que os líderes tomam nas empresas relacionadas ao surgimento dessas tecnologias vão direto ao "core" dos negócios que eles executam.

Essas decisões freqüentemente envolvem a arquitetura de novos modelos de negócios, que podem levar a grandes riscos para os negócios existentes na empresa.

Mercado, economia, sociedade e fatores tecnológicos estão criando um ambiente de negócios altamente competitivo, onde os consumidores são o foco. Os fatores citados podem mudar rapidamente, às vezes de uma maneira imprevisível.

Desse modo, as empresas precisam reagir freqüente e rapidamente tanto aos problemas e oportunidades resultantes desse novo ambiente de negócios.

Em virtude da mudança e do grau de incerteza no ambiente competitivo futuro, as empresas operam sob pressão crescente para produzir mais e mais rápido, usando menos recursos.

Boyett e Bouett (apud Turban (2000)) elencam uma série de pressões dos negócios ou condutores. Os autores dizem que para serem bem sucedidas nesse mundo dinâmico, as empresas precisam ter não apenas ações tradicionais como diminuir custos e fechar áreas não lucrativas, mas também atividades inovativas 
como customizar produtos, criar novos produtos ou prover serviço ao cliente na web.

Tanto as atividades tradicionais como as inovativas são chamadas de atividades criticas de resposta. Elas podem ser necessárias em um ou todos os processos da organização. As pressões nos negócios descritas pelos autores são:

- Pressões do mercado e econômicas; -competição acirrada, economia global, tratados regionais (nafta), custo muito reduzido do trabalhador em alguns países, freqüentes e significativas mudanças de mercado, aumento do poder dos consumidores.

- Pressões sociais e ambientais: mudança na natureza da força de trabalho, decisões do governo, crescimento da importância de questões éticas e legais, mudanças políticas rápidas.

- Pressões tecnológicas: rápida obsolescência tecnológica; aumento de inovações e novas tecnologias, rápido declínio no custo da tecnologia versus taxa de performance.

Segundo Scott-Morton e Allen, 1994 apud Turban (2000) as organizações são compostas por cinco elementos-chave (Estrutura Organizacional e Cultura Corporativa, Gestão e Processos de negócios, Estratégia da organização, Indivíduos e regras e finalmente pela Tecnologia da Informação) que estão interrelacionados e que estão rodeados pelo ambiente, que inclui Política, Economia, etc.

Esses cinco componentes da organização estão em condições estáveis, ou equilíbrio, se nenhuma mudança ocorre no ambiente ou nos outros componentes.

A Introdução do CE (comércio eletrônico) e do e-business (negócios eletrônicos) tanto no ambiente como uma iniciativa dentro da empresa cria uma mudança. Organizações instáveis podem ser incapazes de superar a crise ou até de sobreviver; no entanto, as organizações devem se engajar em atividades críticas de resposta. Entretanto, atividades de resposta tradicionais podem não funcionar no ambiente atual.

Assim, velhas soluções precisam ser modificadas, suplementadas ou eliminadas. As organizações precisam tomar medidas proativas para criar 
mudança no marketplace. Essas atividades incluem explorar oportunidades criadas pelos condutores externos, como por exemplo, o Comércio Eletrônico e o e-business, cujas existências foram propiciadas principalmente pelo advento da Internet.

\subsection{APRESENTAÇÃO DO CENÁRIO DE E-BUSINESS}

A Internet é uma infra-estrutura global e descentralizada de comunicação que teve sua origem nos setores militar e acadêmico. Nela, vários serviços, como correio eletrônico, transferência de arquivos, ligação remota, grupos eletrônicos de discussão, estão disponíveis e são integrados através de uma rede de computadores mundial e pública.

A Internet foi uma das ferramentas que possibilitou a mudança das relações de negócios "on-line", permitindo que o consumidor interagisse diretamente com um sistema de informações de empresas através de uma infraestrutura pública.

Ela conecta cerca de 11 milhões de computadores, e cerca de 50 milhões de usuários em 100 países, crescendo a uma taxa de 10-17 por cento por mês (International Internet Usage Forecasts [IIUF], 1998).

Duas características da Internet se destacam: interatividade e conectividade. O primeiro conceito tem suas raízes na teoria da informação e da comunicação, podendo ser resumido como : "Quem diz o que para quem, em que canal e com que efeito".

Assim, essas características de interconectividade e interatividade da Internet fazem-na um meio ímpar, diferente das aplicações anteriores de comunicação de dados entre empresas como, por exemplo o EDI (Electronic Data Interchange) tradicional, o qual é baseado em padrões rígidos de troca de informações em uma rede privada formada por parceiros de negócio prédeterminados.

A Internet é uma estrutura aberta, criando um mercado de acesso espontâneo e de baixo custo. 
A partir de 1995 o crescimento da Internet como um veículo de comunicação foi, segundo Plant (2000), "espetacular", mesmo se comparado a avanços anteriores em tecnologia e provisão de informação.

A realização de negócios através de meio eletrônico permitiu a operação de dois tipos de empresas: aquelas "nascidas" na Internet ou empresas "startup's" que nunca tiveram negócios no mundo real e começaram a operar no meio digital desde sua fundação e as empresas tradicionais, que a partir da visualização de uma oportunidade decidiram participar dos negócios utilizando o mercado eletrônico.

A utilização da Internet por organizações iniciantes, ou "start-up organizations", nascidas na Internet fez surgir nomes como Amazon, eBay e $E^{*} T R A D E$, onde o modelo básico de estratégia competitiva baseava-se nos princípios de custos baixos, grandes volumes e serviços abrangentes, combinados com uma gama de produtos inviável através de canais tradicionais.

Essas empresas iniciaram as atividades do chamado "Comércio Eletrônico" ou simplesmente CE.

Para Turban (2000) Comércio Eletrônico é a entrega de informações, produtos/serviços ou pagamentos através de linhas telefônicas, redes de computadores ou outros meios eletrônicos enquanto que o termo e-business refere-se a uma definição mais ampla, não apenas referindo-se a compra e venda mas também incluindo serviços ao consumidor e colaboração com parceiros de negócios e condução de transações eletrônicas dentro da organização.

De acordo com Lou Gerstner, CEO da IBM "E-business é sobre ciclo de vida, velocidade, globalização, aumento da produtividade, alcance de novos consumidores e compartilhamento de conhecimento pelas instituições para vantagem competitiva".

Nessa pesquisa, vai-se utilizar o conceito de e-business, nesse espectro mais amplo.

Cunningham (2001) define e-business como "transações comerciais conduzidas através de redes públicas ou privadas, incluindo transações públicas e privadas que usam a Internet como veículo de realização. Essas transações 
incluem transferências financeiras, bolsas de ofertas on-line, leilões, distribuição de produtos e serviços, atividades de cadeias de suprimento e redes integradas de empresas".

De acordo com Weil e Vitale (2001) e-business trata de realizar atividades de Marketing, compra, venda, entrega, serviços, e pagamentos por produtos, serviços e informações através de redes não-proprietárias que interconectam uma empresa e seus clientes, agentes, fornecedores, competidores, parceiros e complementadores.

Esse novo meio de fazer negócios produz instrumentos que permitem desde o desenvolvimento de portais na Internet para compra e venda de produtos/serviços, até atividades de gerenciamento da cadeia de suprimentos ou atividades de CRM (customer relationship management- gestão do relacionamento com o cliente) ou mesmo integração entre unidades de negócio diferentes de uma mesma empresa através de intranets (utilização da tecnologia de Internet de modo corporativo, que mantém o acesso às informações internamente à empresa, através de um servidor de acesso controlado "firewall").

Essas transações incluem transferências financeiras, bolsas de ofertas online, leilões, distribuição de produtos e serviços, atividades de cadeias de suprimento e redes integradas de empresas.

É preciso definir outro conceito relevante para a compreensão do fenômeno de e-business, qual seja, mercado eletrônico: um mercado é uma rede de interações e relacionamentos onde informações, produtos, serviços e pagamentos são trocados.

Quando o marketplace (lugar do mercado) é eletrônico, o centro de negócios não é um prédio físico mas sim baseado em uma estrutura em rede de computadores, onde as interações de negócios ocorrem e as informações, produtos , serviços e pagamentos estão digitalizados.

Nos mercados eletrônicos os principais participantes - compradores, vendedores, agentes - estão em lugares diferentes e muitas vezes nem se conhecem, sendo que o meio de interconexão varia entre as partes e pode mudar 
de evento para evento. É comum chamar o mercado eletrônico de marketspace em substituição ao marketplace.

Turban (2000) classifica o e-business a partir da natureza de suas transações nos seguintes tipos:

- Business-to-business (B2B)-inclui transações interorganizacionais (fluxo de informações, comunicação e colaboração entre e intra organizações) e transações no mercado eletrônico entre organizações.

- Business-to-consumer (B2C)- são transações de varejo com compradores individuais

- Consumer-to-consumer (C2C)- consumidores vendem diretamente a consumidores

- Consumer-to-business (C2B) indivíduos que vendem produtos para organizações

O MCT (2000), em seu programa Socinfo (Programa Sociedade da Informação), apresenta outras possíveis aplicações que podem ser desenvolvidas utilizando-se da tecnologia da Internet:

- Government-to-Government (G2G): corresponde às aplicações que permitem a integração entre Instituições Governamentais. Por exemplo, uma aplicação que permita a comunicação pela Internet entre as esferas Federal, Estadual e Municipal.

- Business to Government (B2G): corresponde às aplicações que permitem a integração entre empresas e governo e vice-versa. Por exemplo: os portais do governo destinados à realização de compras por pregão eletrônico.

- Government to Consumer (G2C): corresponde às aplicações que permitem a integração entre o governo e a população de forma em geral. Por exemplo, o aplicativo da Receita Federal para que os contribuintes declarem pela Internet seu imposto de renda.

Outros autores apresentam outras definições a partir de outros tipos de transações. 
Segundo Plant (2000), um dos maiores impactos ocorridos para mercados e investidores no final da década de 90 foi o advento da Internet. O crescimento da Internet foi estrondoso, como mostra a figura 1 a seguir:

\section{FIGURA 1: PREVISÕES PARA O CRESCIMENTO DAS TRANSAÇÕES}

\section{ELETRÔNICAS}

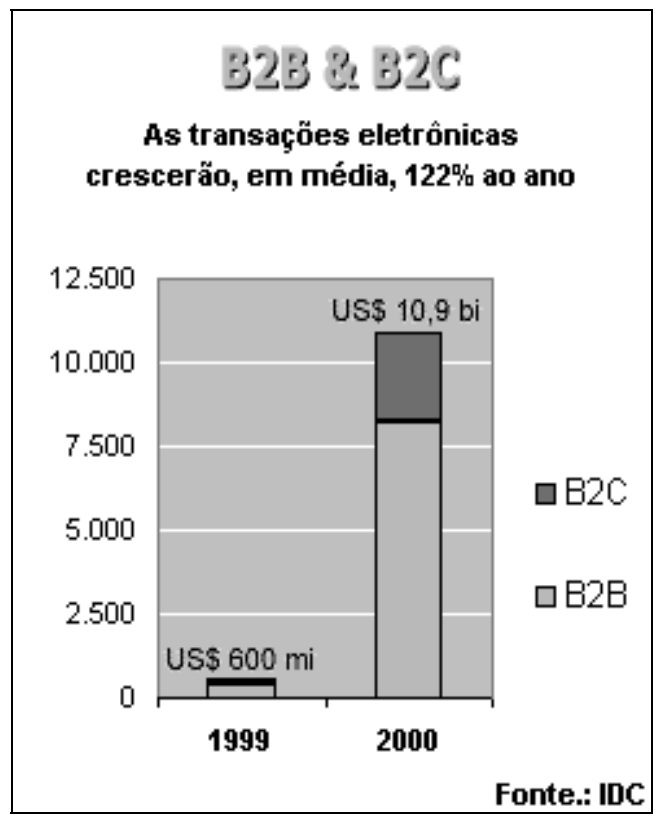

Fonte:IDC's eworld survey, 2001, obtido no site:

www.idcresearch.com

Em termos de Brasil, os seguintes dados de posicionamento quanto a número de hosts da Internet são mostrados a seguir: 
TABELA 1: POSIÇÃO DOS PAÍSES NO MUNDO POR NÚMEROS DE HOSTS, RESULTADOS DE 2002

\begin{tabular}{|c|c|c|c|c|}
\hline \multicolumn{5}{|c|}{ (fonte: Network Wizards 2002) } \\
\hline & País & Julho/02 & Jan/02 & Class. Jan/02 \\
\hline $1^{\circ}$ & Estados Unidos* & 113.574 .290 & 106.182 .291 & $1^{\circ}$ \\
\hline $2^{\circ}$ & Japão (.jp) & 8.713 .920 & 7.118 .333 & $2^{\circ}$ \\
\hline $3^{\circ}$ & Canadá (.ca) & 3.129 .884 & 2.890 .273 & $3^{\circ}$ \\
\hline $4^{\circ}$ & Itália (.it) & 2.958 .899 & 2.282 .457 & $7^{\circ}$ \\
\hline $5^{\circ}$ & Alemanha (.de) & 2.923 .327 & 2.681 .325 & $4^{\circ}$ \\
\hline $6^{\circ}$ & Reino Unido (.uk) & 2.508 .151 & 2.462 .915 & $5^{\circ}$ \\
\hline $7^{\circ}$ & Austrália (.au) & 2.496 .683 & 2.288 .584 & $6^{\circ}$ \\
\hline $8^{\circ}$ & Holanda (.nl) & 2.150 .379 & 1.983 .102 & $8^{\circ}$ \\
\hline $9^{\circ}$ & França (.fr) & 2.052 .770 & 1.670 .694 & $10^{\circ}$ \\
\hline $10^{\circ}$ & Brasil (.br) & 1.988 .321 & 1.644 .575 & $11^{\circ}$ \\
\hline $11^{\circ}$ & Taiwan (.tw) & 1.814 .090 & 1.712 .539 & $9^{\circ}$ \\
\hline $12^{\circ}$ & Espanha (.es) & 1.682 .434 & 1.497 .450 & $12^{\circ}$ \\
\hline $13^{\circ}$ & Suécia (.se) & 1.187 .942 & 1.141 .093 & $13^{\circ}$ \\
\hline $14^{\circ}$ & México (.mx) & 1.004 .637 & 918.288 & $15^{\circ}$ \\
\hline $15^{\circ}$ & Finlândia (.fi) & 986.285 & 944.670 & $14^{\circ}$ \\
\hline $16^{\circ}$ & Dinamarca (.dk) & 872.328 & 707.141 & $16^{\circ}$ \\
\hline $17^{\circ}$ & Bélgica (.be) & 832.853 & 668.508 & $17^{\circ}$ \\
\hline $18^{\circ}$ & Polônia (.pl) & 731.371 & 654.198 & $19^{\circ}$ \\
\hline $19^{\circ}$ & Áustria (.at) & 720.587 & 657.173 & $18^{\circ}$ \\
\hline $20^{\circ}$ & Suíça (.ch) & 667.509 & 613.918 & $21^{\circ}$ \\
\hline $21^{\circ}$ & Noruega (.no) & 634.098 & 629.669 & $20^{\circ}$ \\
\hline $22^{\circ}$ & Argentina (.ar) & 486.296 & 465.359 & $22^{\circ}$ \\
\hline $23^{\circ}$ & Rússia (.ru) & 441.679 & 393.595 & $25^{\circ}$ \\
\hline $24^{\circ}$ & Nova Zelândia (.nz) & 419.517 & 408.290 & $24^{\circ}$ \\
\hline $25^{\circ}$ & Coréia(.kr) & 411.884 & 439.859 & $23^{\circ}$ \\
\hline $26^{\circ}$ & Hong Kong (.hk) & 354.132 & 387.672 & $26^{\circ}$ \\
\hline $27^{\circ}$ & Singapura (.sg) & 339.878 & - & - \\
\hline $28^{\circ}$ & Portugal (.pt) & 266.911 & 263.821 & $27^{\circ}$ \\
\hline $29^{\circ}$ & África do Sul (.za) & 246.954 & 238.462 & $28^{\circ}$ \\
\hline $30^{\circ}$ & Israel (.il) & 232.300 & 223.012 & $29^{\circ}$ \\
\hline
\end{tabular}


Hosts nas Américas

(fonte: Network Wizards 2002)

\begin{tabular}{|c|c|c|c|c|}
\hline & País & Julho/02 & Jan/02 & $\begin{array}{l}\text { Class. } \\
\text { Jan/02 }\end{array}$ \\
\hline $1^{\circ}$ & Estados Unidos* & 113.574 .290 & 106.182 .291 & $1^{\circ}$ \\
\hline $2^{\circ}$ & Canadá (.ca) & 3.129 .884 & 2.890 .273 & $2^{\circ}$ \\
\hline $3^{\circ}$ & Brasil (.br) & 1.988 .321 & 1.644 .575 & $3^{\circ}$ \\
\hline $4^{\circ}$ & México (.mx) & 1.004 .637 & 918.288 & $4^{\circ}$ \\
\hline $5^{\circ}$ & Argentina (.ar) & 486.296 & 465.359 & $5^{\circ}$ \\
\hline $6^{\circ}$ & Chile (.cl) & 130.095 & 122.727 & $6^{\circ}$ \\
\hline $7^{\circ}$ & Uruguai (.uy) & 72.320 & 70.892 & $7^{\circ}$ \\
\hline $8^{\circ}$ & Colômbia (.co) & 46.896 & 57.419 & $8^{\circ}$ \\
\hline $9^{\circ}$ & Rep. Dominicana (.do) & 46.046 & 41.761 & $9^{\circ}$ \\
\hline $10^{\circ}$ & Venezuela (.ve) & 22.541 & 22.614 & $10^{\circ}$ \\
\hline $11^{\circ}$ & Peru (.pe) & 14.611 & 13.504 & $11^{\circ}$ \\
\hline $12^{\circ}$ & Costa Rica (.cr) & 8.022 & 8.551 & $12^{\circ}$ \\
\hline $13^{\circ}$ & Panamá (.pa) & 7.700 & 7.825 & $13^{\circ}$ \\
\hline $14^{\circ}$ & Trinidad e Tobago (.tt) & 6.726 & 6.872 & $14^{\circ}$ \\
\hline $15^{\circ}$ & Guatemala (.gt) & 6.161 & 5.603 & $15^{\circ}$ \\
\hline
\end{tabular}

* (.edu, .us, .mil, . org, .gov e gTLDs)

Fonte: Comitê Gestor da Internet no Brasil, obtido no site: www.cg.org.br/indicadores/

A Internet em 1995 contava com cerca de 30 milhões de usuários, e estima-se que um novo computador conecte-se à rede a cada 27 segundos esse rápido crescimento permite considerá-la como um mercado a ser explorado para bens de consumo. Apesar disso, uma parcela superior a $80 \%$ dos negócios por ela movimentados advém do comércio entre empresas, percentual que se mantém até o momento (SAIKOVITCH, 2000).

O crescimento do volume de negócios eletrônicos é significativo: é projetada uma taxa de crescimento de $41 \%$ anuais nos próximos cinco anos nos 
Estados Unidos, de acordo com o Yankee Group, apud O'Connel (2000) e o comércio business-to-business nos Estados Unidos tem uma expectativa de crescimento de volume de transações de $\$ 138$ bilhões para mais de $\$ 541$ bilhões em 2003.

Já as informações obtidas no sita da IBM (www-3.ibm.com/e-business/Br/ecommerce/index.shtml) sobre volume de transações são outras:"segundo a revista Business Week, "o comércio eletrônico entre empresas é cinco vezes maior que o comércio entre consumidores: no ano passado (2001) alcançou aproximadamente US\$ 43 bilhões. O Forrester Research presume que no ano de 2003 o comércio eletrônico entre empresas terá a possibilidade de chegar a US\$ 1.3 trilhões. Este valor é 10 vezes maior que o comércio eletrônico praticado entre consumidores e constitui $9 \%$ do intercâmbio comercial dos EUA, superando o produto interno bruto da Grã-Bretanha ou Itália."

De qualquer modo, quaisquer dos valores projetados sobre o volume de transações de e-business para os próximos anos mostram ser esse um setor promissor para negócios.

A figura 2 abaixo mostra as receitas obtidas com o e-commerce no mundo inteiro:

FIGURA 2: RECEITAS MUNDIAIS EM E-COMMERCE

RECEITAS MUNDIAIS EM E-COMMERCE

2000-2001 (\$B)

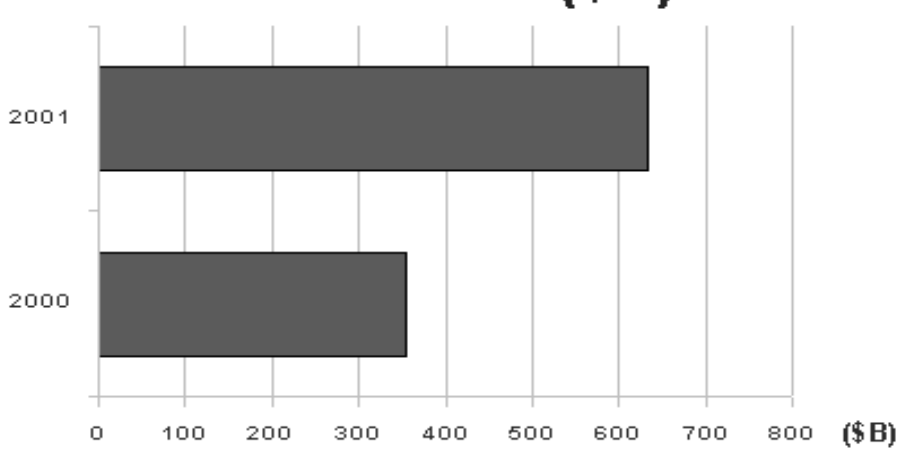

Fonte: IDC's ICMM versão 7.1, primavera 2001

Obtida no site: www.idcresearch.com 
Ainda segundo o IDC (2002), a "bolha" das empresas “ ponto.com" estourou fazendo com que os gastos das empresas refreassem e as empresas adiassem gastos com infra-estrutura de tecnologia e compras de serviços.

Esse "estouro" da bolha deveu-se em parte pelo fato das empresas ponto.com supervalorizarem o mercado potencial à sua disposição: a Internet permite que as empresas atendam um mercado local, regional e até nacional.

Com isso, existia uma perspectiva de crescimento dessas empresas bastante grande. Os investidores investiram maciçamente nessas empresas a partir dessa expectativa de expansão de mercado e receitas.

Um dos entraves a que essa promessa se realizasse ficou por conta de um fator do "mundo real": as empresas ponto.com tem seu valor distintivo na questão da rapidez: maior velocidade para fazer o pedido e efetuar a compra. O problema foi o prazo de entrega: ao diminuir o prazo de entrega de 6 para um dia, por exemplo, as empresas ponto.com comprometeram seus sistemas de logística, pois só vale a pena entregar em curto prazo se existe um volume de lote de produtos a serem entregues que justifique essa entrega. Como o volume de pedidos não cumpriu a expectativa, o custo de transporte de pequenos lotes tornou-se alto, não realizando a expectativa de lucro prometida.

Outro aspecto das receitas geradas não corresponderem à expectativa foi analisado por Porter (2001) quando diz que as empresas que exploraram as tecnologias de Internet ficaram confusas por sinais distorcidos de mercado.

Considerando o lado das receitas na equação de lucros (lucro=receita menos custos): 1-algumas empresas subsidiaram a compra de seus produtos e serviços na Internet, com a intenção de atrair consumidores e alargar sua base de clientes pela Internet, gerando uma demanda artificial, e uma receita abaixo do esperado; 2-alguns compradores usaram a Internet por curiosidade e quando a saciaram, voltaram para seu meio usual de compra.

O crescimento de tantas empresas ponto.com se deu pois elas conseguiam capital de investidores, sem ter que demonstrar viabilidade, ou seja, havia uma "promessa" de retorno. 
Ainda segundo Porter (2001), muitas atividades na Internet eram negócios artificiais competindo através de meios artificiais e proporcionados por capital que até recentemente estava disponível.

Quando as empresas ponto.com não realizaram os lucros prometidos, houve o "estouro" da bolha, que implicou no fato do crescimento das receitas no Mercado de "hosting" da Web nos Estados Unidos decrescer.

Esse mercado (web) que tinha aproximadamente US\$ 4 bilhões em 2000, representando um crescimento de $100 \%$ sobre 1999 , cresceu apenas $25,5 \%$ de 2000 para 2001.

Pesquisas do IDC ainda mostram que as receitas no mercado de serviços de hosting na Web ainda vão começar a acelerar em 2002, alcançando eventualmente US\$ 20,8 bilhões em 2006.

As empresas estão re-direcionando seus processos de negócio internos e abrindo novos canais para serviço ao consumidor e entrega de produtos/serviços, distribuição e "procurement" através da alavancagem de instrumentos que posam habilitar seus aplicativos de "core-business" a serem usados na Web, utilizando a Internet como um meio para transação e conectividade para trocas intra e intraempresas.

Em outras palavras, o Mercado está evoluindo da era "ponto.com" do modelo "Internet-como-negócio" para a noção "pós-bolha" de "negócios sobre a Internet".

O primeiro fator por trás da queda do Web hosting é o estado da economia. Em 2000 havia muitos componentes ajudando a conduzir crescimento no Web hosting incluindo a "economia robusta" dos Estados Unidos, uma vigorosa indústria de Tecnologia da Informação e a Internet.

Todos esses fatores mudaram em 2001, mas mesmo assim, as empresas estão só começando a alavancar o potencial total do web hosting proporcionando oportunidades que farão com que o mercado continue crescendo.

Em termos de Brasil, o comércio eletrônico apresenta claros sinais de evolução. É a conclusão da $4^{a}$ edição da pesquisa "Comércio Eletrônico no 
Mercado Brasileiro", realizada pela Fundação Getúlio Vargas (FGV) de São Paulo.

Segundo o estudo, o setor movimentou US\$2,1 bilhões em 2001 - US\$ 1,6 bilhões proveniente das transações entre empresas (business-to-business ou Bto-B), e os US\$ 500 milhões restantes da venda para consumidores (business-toconsumer ou B-to-C). Artigo obtido no site: IDGnow.terra.com.br de abril 2002.

Esses valores, de acordo com Alberto Luiz Albertin, coordenador da análise e professor da instituição, representam $1,18 \%$ das cifras movimentadas nas transações tradicionais entre empresas, e 0,35\% se comparado ao comércio convencional entre empresas e consumidores.

"Estes índices podem parecer pequenos se analisados isoladamente. Considerando a evolução do setor, a tendência é de crescimento - agora mais cauteloso e buscando retornos efetivos sobre os investimentos realizados", explicou o especialista.

A figura 3 abaixo mostra a evolução das receitas obtidas com a Internet no período 2001 - 2002 para a América latina:

\section{FIGURA 3: PORCENTAGEM DAS RECEITAS DA AMÉRICA LATINA ATRIBUÍDAS À INTERNET}

Porcentagem das receitas da América latina atribuídas à Internet 2000-2001

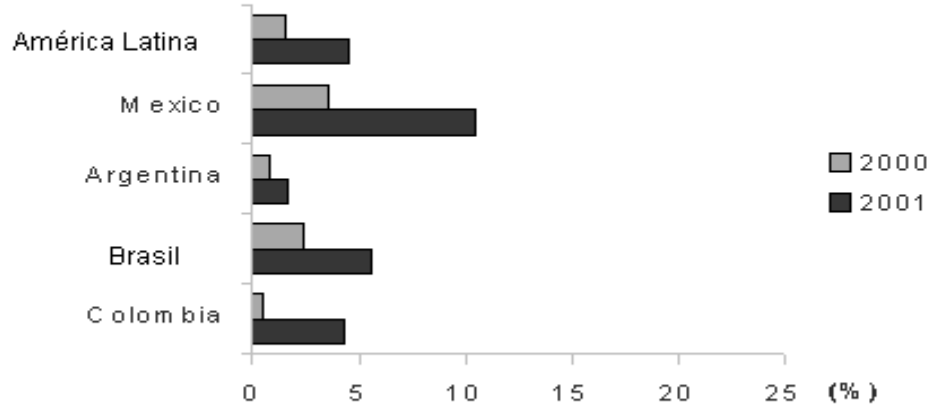

Fonte: IDC\#LA1167G julho 2001;IDC's eworld 2001, obtido no site: WMm.idcresearch.com 
O que se pode observar é que desde sua desregulamentação e liberação para uso como meio transmissor de dados no meio da década de 90 , vários autores (Patel (2000), Tapscott (2000), Slywotzky (2000), Plant (2000), O'Conell (2000)) entendem que a Internet mudou o modo de fazer negócios: a natureza global da tecnologia de e-business, baixo custo de entrada, oportunidade de alcançar centenas de milhares de pessoas (projetada dentro de dez anos), existência de padronização de protocolos, sua natureza interativa, variedade de possibilidades e recursos e rápido crescimento das infra-estruturas de suporte (especialmente a Web) resultam em muitos benefícios potenciais para as organizações, indivíduos e sociedade.

Esses benefícios estão apenas começando a se materializar, mas irão crescer à medida que o e-business se expanda.

Com o uso comercial da Internet surge o conceito de "Nova Economia".

Segundo Weil et Vitale (2001), a Nova Economia ou Economia Digital advém do fato dos negócios existentes migrarem do lugar "real" para o "espaço" ("place to space"): segundo eles, nem todas as partes dos negócios irão migrar, uma parte irá permanecer no "velho mundo".

Essa "nova economia" será, segundo os autores, uma economia do conhecimento, nas quais as cadeias de valor (conjunto de atividades através do qual um produto ou serviço é criado e entregue aos consumidores) de uma firma serão interconectadas eletronicamente.

Já Porter (2001) afirma que “a 'nova economia' aparece menos como uma nova economia do que como uma velha economia que tem acesso a uma nova tecnologia".

Mesmo as frases 'nova economia' e 'velha economia' estão rapidamente perdendo sua relevância, se é que já tiveram alguma".

Segundo ele, a velha economia de companhias estabelecidas e a nova economia de empresas ".com" estão se fundindo, e será difícil distingui-las.

Para ele, o próximo estágio da evolução da Internet envolverá uma mudança na forma de ver "e-business" para "business" e de "e-estratégia" para "estratégia". 
Patel e McCarthy (2000) afirmam que ter presença na Web não é por si só garantia de aumento de vendas ou expansão de mercados, pois pode haver problemas de conflitos de canal, significando uma disputa entre os canais tradicionais de vendas da empresa e seus canais pela rede eletrônica, podendo impactar o volume de vendas virtual.

Outro mal entendido é a idéia de que empresas "brick-and-mortar" ( ou tijolos e argamassa, significando empresas instaladas no mundo físico, que podem ser chamadas de 'tradicionais', pois utilizam-se de canais físicos de comunicação ) estejam em natural desvantagem comparadas a empresas nascidas na Web, puramente virtuais. Eles exemplificam com o setor de alimentos, onde uma infraestrutura física existente pode ser mais importante do que uma estratégia baseada somente na rede.

Segundo Gerstner (2000), presidente e diretor geral da IBM, em seu discurso sobre as tendências das novas gerações de e-business, o que aconteceu com o e-business se compara com o que aconteceu com aquelas outras tecnologias de transformação: primeiro, existe um período de entusiasmo selvagem - uma overdose de otimismo onde a nova tecnologia vai re-escrever as leis de concorrência e as leis econômicas, vai criar nova riqueza por completo, acabar com as velhas indústrias e criar novas.

Como previsto, aquela febre passou e foi substituída por uma desilusão expressiva, pois não surgiram indústrias novas e as lucratividades obtidas não atenderam às expectativas, o que provocou certo ceticismo entre os empresários.

Hoje, os empresários estão numa nova fase onde o importante é integrar a tecnologia na estrutura e organizar a sociedade e o negócio.

Ainda segundo Gerstner, muita gente não se lembrou que a Internet é uma tecnologia. É uma ferramenta muito poderosa, mas que não mudou o comportamento fundamental dos consumidores, como o desejo pela escolha, ou querer inspecionar e, possivelmente, devolver o produto.

Apesar do fato de muitos varejistas da Internet terem "estourado" no cenário, proclamando modelos de negócios totalmente novos, na realidade, 0 negócio deles foi construído em cima de uma proposta de valor com séculos de idade- preço mais baixo. A dificuldade foi não haver um modelo econômico que 
pudesse sustentar estes preços mais baixos ao mesmo tempo em que geravam lucros. E quando eles não puderam mais subsidiar esses modelos com acesso fácil ao capital, veio o colapso dessas empresas.

Segundo ele, hoje o e-business é apenas um negócio real.

Segundo Porter (2001) muitos dos pioneiros dos negócios da Internet, tanto empresas ponto-com quanto empresas já estabelecidas, competiram de maneira que violaram os preceitos da boa estratégia: antes de focar em lucros, eles tentaram maximizar receitas e fatia de mercado a todo custo, perseguindo consumidores indiscriminadamente através de descontos, promoções, etc.

Ao invés de concentrar-se em entregar real valor ao cliente, que implica num preço atraente para o cliente as empresas perseguiram receitas indiretas de fontes como propaganda e taxas de "click-through" de parceiros na Internet.

Ao invés de fazerem acordos, as empresas correram a oferecer cada produto concebido, serviço ou tipo de informação.

Ao invés de conceber sua cadeia de valor de um modo único, elas copiaram atividades dos rivais. Ao invés de construir e manter controle sobre seus ativos proprietários e canais de mercado elas entraram numa profusão de parcerias e relacionamentos de terceirização, erodindo suas características distintivas.

Ao ignorar suas estratégias, esquecendo o que as tornava únicas, as empresas correram a implantar aplicações de Internet e copiar os produtos das ponto.com, comprometendo suas vantagens competitivas ao entrarem em segmentos nos quais elas não tinham distinção.

Isso não precisa ser assim e não o será no futuro.

Quando a Internet vem para reforçar uma estratégia distintiva, fazendo atividade sob medida, a Internet provê uma melhor plataforma tecnológica do que a geração prévia de Tecnologia da Informação.

Segundo Porter (2001), a tecnologia da Informação trabalhava contra a estratégia no passado, pois pacotes de aplicativos de software eram difíceis de customizar e as empresas eram freqüentemente forçadas a mudar para se conformar às " melhores práticas" contidas nos softwares.

Era muito difícil conectar aplicações discretas umas às outras. 
Sistemas de "Enterprise Resource Planning" (ERP) linkavam atividades, mas, de novo a empresa era obrigada a se adaptar às atividades exigidas pelo software.

A Arquitetura de Internet junto com outras melhorias em software e desenvolvimento de ferramentas fizeram com que a TI fosse uma ferramenta mais poderosa para a estratégia.

É muito mais fácil customizar pacotes para Internet para uma empresa que esteja em determinada posição estratégica.

Provendo uma plataforma comum de TI através da cadeia de valo torna possíveis construir sistemas verdadeiramente integrados e customizados que reforçam o ajustamento entre as atividades da cadeia de valor.

Muitas empresas descobriram que fazer pedidos através de um website é apenas uma parte muito pequena do que é necessário para se completar uma venda com sucesso.

O e-business ativa uma reação em cadeia ao longo do resto da empresa: sistemas de preços, estoque, logística, crédito e distribuição e demais atividades na cadeia de abastecimento.

Então, atualmente, os líderes de e-business entendem que sua transformação precisa buscar estes processos comerciais essenciais. E isto atualmente está orientando altos investimentos em aplicativos para a administração da cadeia de abastecimento, e-procurement (compra de materiais pela Internet), administração de relacionamento com o cliente, gerenciamento de conhecimentos.

Por outro lado, num artigo de agosto de 2001 da b2b magazine (www.b2bmagazine.com), Henning Kagermann, CEO da SAP, comentou que o grande gargalo tecnológico hoje para o pleno aproveitamento da Internet é justamente a integração entre os aplicativos de e-business e os aplicativos existentes dentro da empresa, que torna os custos muito grandes.

Recentemente, um relatório da consultoria McKinsey também apontou que a integração limitada e parca é razão de insucesso para iniciativas Internet e CRM, principalmente entre front office e back office. 
Na experiência do executivo, este fato aqui no Brasil deu-se por algumas características que, se fossem abordadas devidamente, evitariam o fracasso: necessidade de aprimoramento tecnológico das organizações; conhecimento real do estágio tecnológico da empresa; quais são os imperativos da mudança; benefícios e métricas de avaliação; nível de envolvimento das pessoas e, fundamentalmente, o apoio no conhecimento adquirido.

Estes fatores e todo o fundamento dos investimentos devem estar calcados na estratégia corporativa que, por sua vez, é a base da estratégia de TI. Ele diz que muitas empresas entraram nesta jornada (o processo de integração dos processos e migração para a Internet) com pouca preparação, faltando conhecimento do "gap" tecnológico.

Muitas empresas investiram sem ter a devida clareza do orçamento total e das métricas de retorno, situação deteriorada pela conjuntura econômica e situacional do país, como a altíssima rotatividade do pessoal de TI, utilização de soluções internacionais sem a devida localização, "tropicalização", pouco investimento em treinamento, preparação das pessoas para mudança de paradigmas e assessoria com pouca qualificação.

O que se observa a partir do discurso desses executivos é que o naufrágio de algumas empresas ".com" não impediu que empresas tradicionais, que tem seus produtos já comercializados pelos canais físicos, vislumbrassem nos negócios eletrônicos uma oportunidade vantajosa, pois elas vêem nesta ferramenta uma maneira de dinamizar seus processos de negócios, melhorar a qualidade e/ou distribuição, aumentar o alcance de seus produtos, diminuir custos de transação ou até mesmo melhorar sua imagem.

Porém, com o naufrágio de muitos negócios na Internet, as empresas tendem a adotar posturas mais cautelosas, analisando mais cuidadosamente pontos fortes e fracos dessa entrada no mercado virtual.

Porter (2001) afirma que apenas integrando-se a Internet dentro da estratégia global da empresa fará com que essa poderosa tecnologia torne-se também uma poderosa força para obter vantagem competitiva.

Segundo ele, empresas que já estão estabelecidas serão mais bem sucedidas quando desenvolverem tecnologias de Internet para reconfigurar 
atividades tradicionais ou quando as empresas encontrarem novas combinações entre as abordagens de Internet e tradicionais.

Constatado o crescimento das atividades de e-business num ambiente globalizado caracterizado por uma competição acirrada entre organizações, e o fato de ser possível ganhar vantagem competitiva com a adoção de e-business por empresas tradicionais, resta saber como a introdução do e-business impacta as organizações: segundo Turban, o e-business pode ajudar a organização a exercer atividades críticas de resposta ao desafio das mudanças no ambiente global de hipercompetição, em três categorias:

-Melhoria do marketing Direto: promoção do produto (riqueza de informações e interações com o cliente); novos canais de vendas; diminuição de custos; redução do ciclo de tempo de entrega; serviços ao cliente e marca ou imagem corporativa.

-Transformações na organização: força a empresa a rápidas adaptações em tecnologia; muda a curva de aprendizagem organizacional (fica mais rápida); mudanças na estrutura da organização para melhor lidar com o e-business (desenho tem que ser diferente do antigo departamento de vendas e marketing); para que a estrutura seja mais flexível e responsiva ao mercado, precisa haver mudanças nos processos. Essas mudanças precisam ser planejadas e bem gerenciadas: antes de "acertar", a organização precisa se empenhar com diferentes experimentações.

Redefinição das organizações: capacitação pra desenvolver produtos inovadores leva a redefinição da missão da empresa; novos modelos de negócios; impactos na manufatura (usando sistemas ERP baseados na web); impactos nas finanças (sistema de pagamento); impactos em recursos humanos, treinamento e educação (necessidade de mão-de-obra especializada e com maior capacitação e necessidade de atualização).

As oportunidades geradas pelo e-business, quais sejam, expansão do mercado, redução dos custos de transação, integração de processos dentro e fora da empresa, formando parcerias com fornecedores e clientes conectados eletronicamente, tornam a adesão ao e-business uma oportunidade atraente para as empresas. 
Para as empresas do meio "físico" ou tradicionais, que vislumbram uma oportunidade de entrada no mercado eletrônico, dadas as estatísticas de crescimento desse meio, há três opções possíveis: não adotar nenhuma iniciativa de e-business, adotar alguma iniciativa denominada "cosmética",ou seja, estabelecer presença na Internet através de um site para fazer propaganda de seus produtos sem realizar nenhuma transação de negócios, ou finalmente entender que a Internet oferece oportunidades estratégicas para diminuir custos nas suas transações com clientes, fornecedores e parceiros e expansão de mercado, adotando iniciativas de e-business que provocam mudanças no modo de operar seus negócios.

O Gartner Group elaborou um modelo de aplicação do e-business para transformar os processos críticos (FLINT at. al, 2001). Na medida em que os empreendedores transformam seus processos para explorar o poder da tecnologia, eles caminham por sete níveis de mudanças e estendem seus processos para integrá-los com aqueles de seus parceiros corporativos, resultando em processos mais baratos, rápidos e melhores.

O grau em que as iniciativas de e-business impactam uma indústria varia desde simplesmente redução na papelada até mudanças fundamentais nas relações de negócio. Eles também variam muito em custo, benefício e risco. Há sete níveis de mudança, de 0 a 6 . No nível 0 , a empresa tem uma infra-estrutura física que suporta somente processos manuais.

- Nível 1: a empresa automatiza processos existentes em cada uma das funções do negócio (por exemplo: implementar um sistema para a contabilidade ou folha de pagamento).

- Nível 2: a empresa reconhece e automatiza processos de negócios que podem cruzar a fronteira organizacional da empresa. Isso geralmente acontece quando a empresa implanta um sistema ERP.

- Nível 3: A empresa começa a prover a seus clientes e fornecedores um limitado acesso remoto para a sua infra-estrutura e processos existentes.

- Nível 4: No nível 4, ela utiliza e-business adotando uma visão extraempresa de seus processos, usando tecnologias para se ligar com seus 
parceiros de negócio. A figura 4 ilustra o nível 4 de utilização do ebusiness.

\section{FIGURA 4: NÍVEL 4 DE UTILIZAÇÃO DO E-BUSINESS}

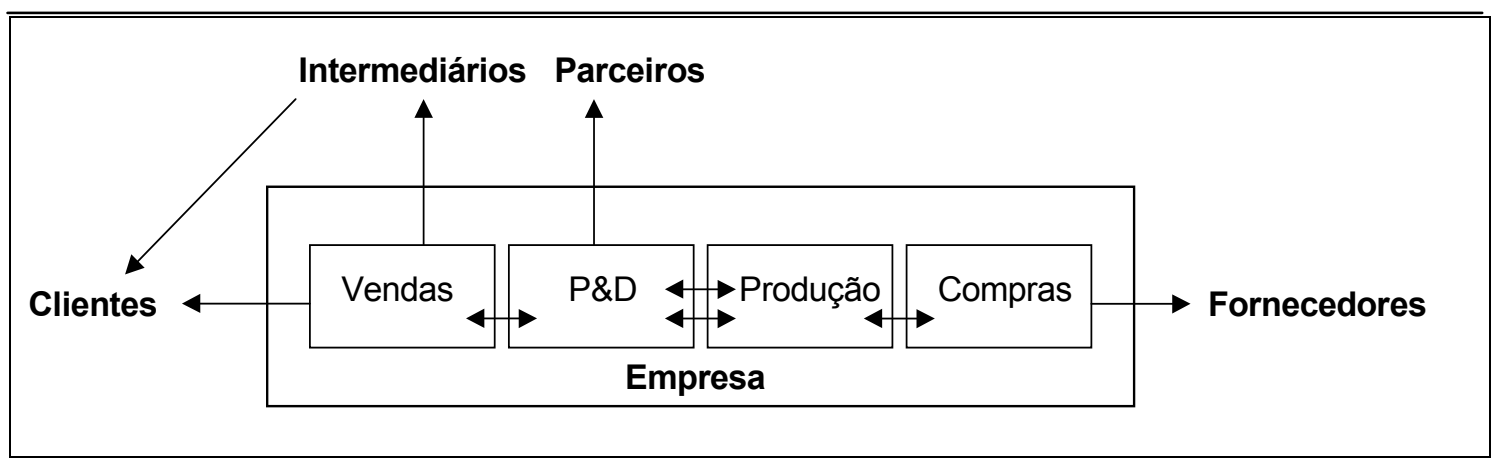

Fonte: Flint, Le Hong e Rozwell (2001), adaptado por Muritiba e Vasconcellos (2001).

- Nível 5: colaboração com parceiros e fornecedores em tempo real. No nível 5, a empresa começa a pensar em si mesma como uma organização em forma de rede que precisa colaborar com seus parceiros de negócio e fornecedores em tempo real. Ela se depara com questões sobre como dar uma maior confiança a alguns parceiros selecionados, e como integrar seus processos com os deles.

A figura 5 ilustra uma empresa no nível 5: 
FIGURA 5: NÍVEL 5 DE UTILIZAÇÃO DO E-BUSINESS

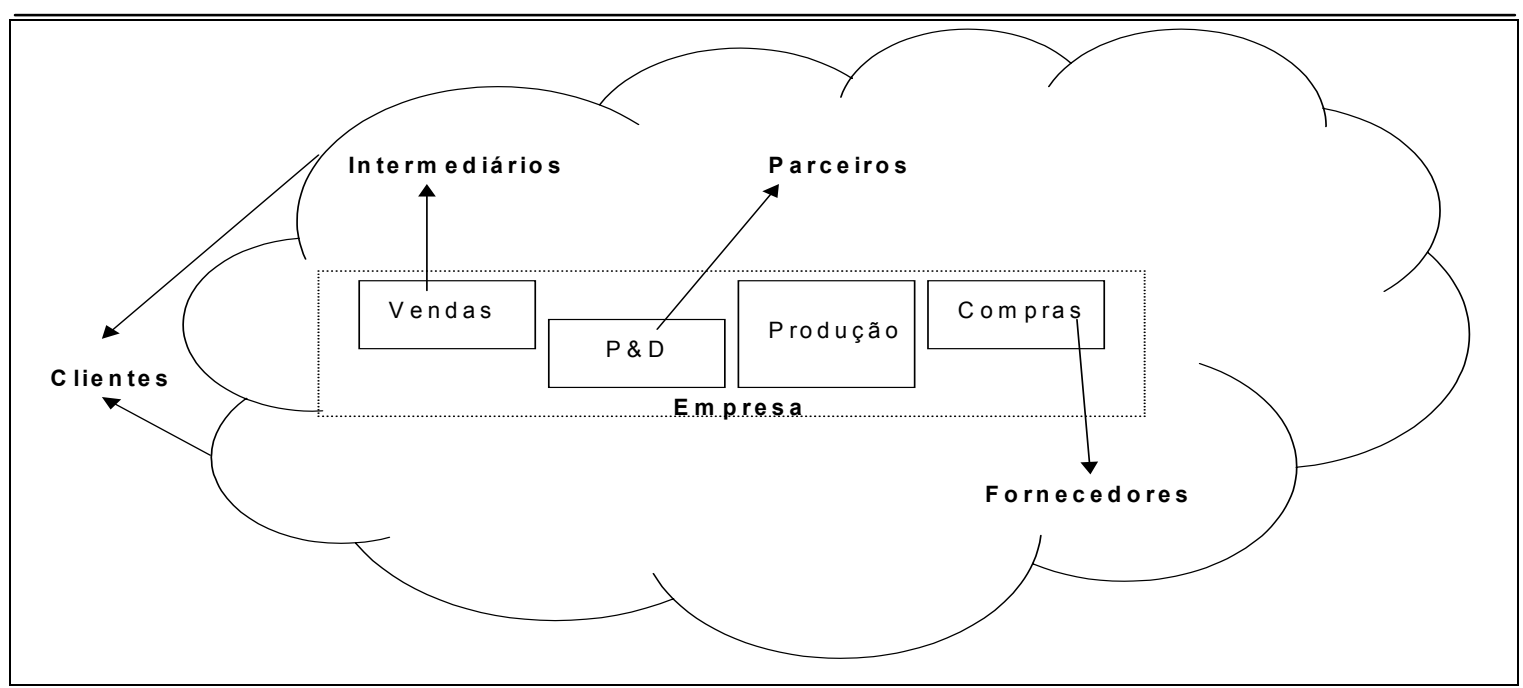

Fonte: Flint, Le Hong e Rozwell (2001) adaptado por Muritiba e Vasconcellos (2001)

- Nível 6: Resposta dinâmica às demandas dos clientes. Quando a empresa atinge o nível 6, ela ganha a habilidade de responder dinamicamente à demanda dos clientes. No setor de viagens, a oportunidade chave é o empacotamento dinâmico dos componentes de passagem, enquanto que no varejo é o processo dinâmico de precificação. Em produtos de consumo, a maior oportunidade é a customização em massa, mas isso só é aplicável a uma minoria de produtos e mercados. Apesar deste nível não funcionar para todas as empresas de um setor, nenhuma empresa deve ignorar a necessidade de responder dinamicamente e em tempo real aos seus clientes.

A figura 6 ilustra o funcionamento do sexto nível de e-business. 
FIGURA 6: NÍVEL 6 DE UTILIZAÇÃO DO E-BUSINESS

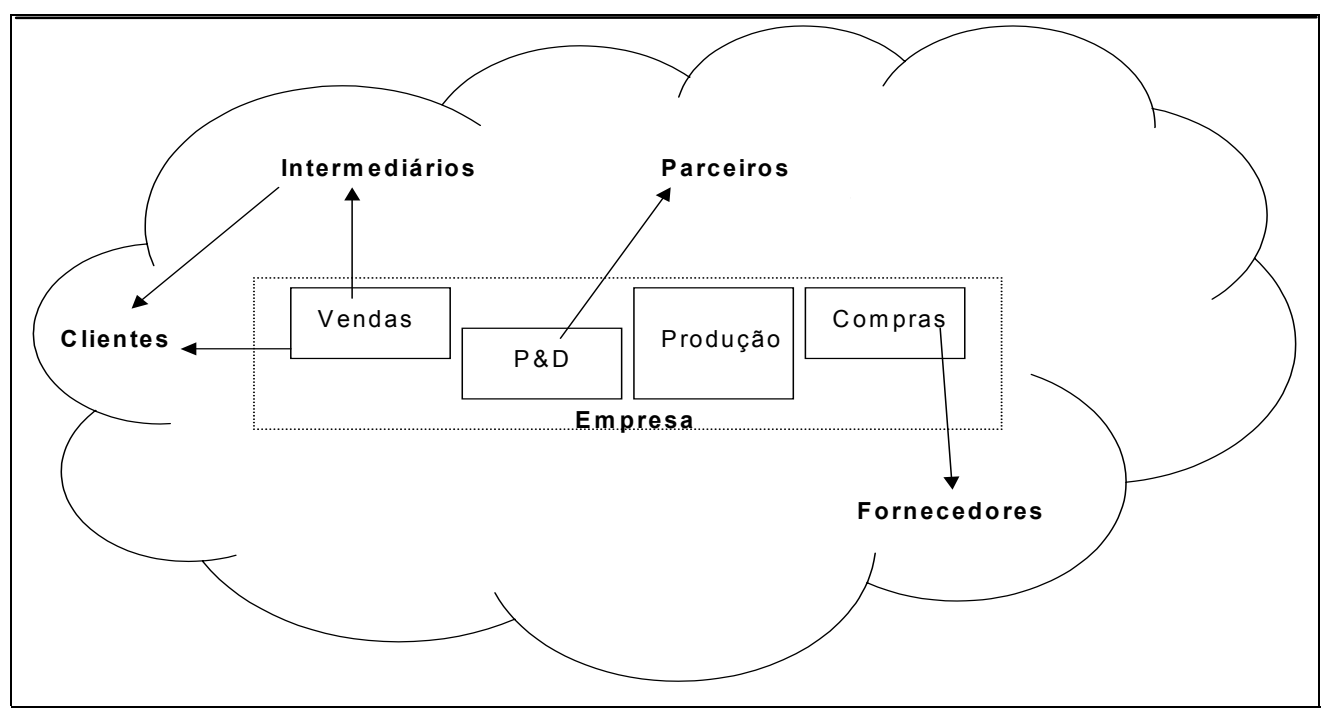

Fonte: Flint, Le Hong e Rozwell (2001) adaptado por Muritiba e Vasconcellos (2001).

As iniciativas de mudança envolvem risco. Na medida em que as empresas desenvolvem seus processos pelos seis níveis de mudança, elas vão sem dúvida encontrar riscos significativos. Mudança nos negócios inclui mudanças de processos e na cultura da organização. A complexidade técnica pode incluir a complexidade dos aplicativos, necessidades de integração e complexidade da nova infra-estrutura de tecnologia.

A presente pesquisa vai se ocupar apenas das empresas tradicionais que decidiram adotar alguma iniciativa de e-business e que estejam pelo menos no nível 4 de utilização de e-business segundo o modelo do Gartner Group, descartando o estudo de empresas puramente virtuais nascidas na Internet ou totalmente ".com" .

Optou-se por não se estudar empresas nascidas na Internet, pois a própria literatura mostra que, passada a euforia inicial das empresas ".com”, a partir do segundo trimestre do ano 2000 ocorreu o "crash" da Nasdaq, bolsa de valores norte-americana que negocia as ações das principais empresas de tecnologia.

Segundo Fleury (2001), esse crash iniciou-se com a queda expressiva no valor das ações da Microsoft, uma das principais empresas na Internet, 
condenada pela justiça americana em processo que envolvia a utilização de recursos ilegais para vencer a concorrência.

Essa queda levou investidores e acionistas a revisarem as expectativas de lucratividade apresentadas pelas empresas que atuavam na Internet. Como boa parte dessas empresas adotou a estratégia de assumir grandes riscos na busca de inovações e novos mercados, investindo para isso grande quantidade de recursos, boa parte dos papéis negociados sofreu forte desvalorização.

As empresas a partir daí necessitam maior embasamento para provar que os modelos de negócios adotados têm realmente a capacidade de gerarem receitas e lucros.

Dentro dessa perspectiva de empresas já estabelecidas no "mundo real" aproveitarem a oportunidade de ingressar na Internet para realizar negócios, segundo uma pesquisa do The Boston Consulting Group, conduzida por Freeland e Stirton (2000) em teoria, muitas empresas já estabelecidas no mundo real estão bem posicionadas para serem bem sucedidas em e-commerce: possuem os ativos críticos- marca forte, relacionamentos com clientes estabelecidos e sistemas de logística existentes- que podem dar a essas empresas vantagens sobre empresas nascidas na net.

Porém, na prática, as empresas não estarão aptas a explorar esses bens a menos que consigam se organizar efetivamente para e-business.

De fato, para grandes companhias, os maiores desafios do e-business não são tanto de ordem estratégica quanto de natureza organizacional.

Essa conclusão foi fruto de um estudo de 4 meses sobre e-business conduzido pelo The Boston Consulting Group.

Dentre as descobertas dessa pesquisa, Freeland e Stirton (2000) elencam:

- sucesso de uma estratégia de e-business de uma empresa recai na habilidade que a empresa tem em se organizar apropriadamente. Em muitas situações, a falha da estratégia recaiu sobre problemas organizacionais.

- Embora muitas grandes empresas estejam focadas em estabelecer seu negócio online, muitas negligenciam as mudanças e ligações com seus 
negócios off-line que são necessárias para fazer seus negócios online funcionarem.

- Obter a estrutura certa - o desenho organizacional da unidade de ebusiness e suas ligações com o "core business"- é importante. Mas conseguir a infra-estrutura correta - pessoas, instrumentos, cultura e processos - pode ser mais importante. O melhor desenho organizacional no mundo não pode corrigir a infra-estrutura errada.

Foi dentro dessa perspectiva que se desenvolveu essa pesquisa: para as empresas tradicionais, ou seja, aquelas que não nasceram na Internet, quais são os desafios ou fatores críticos a serem superados no que tange às adaptações ou modificações em sua estrutura organizacional para operacionalizar suas atividades de e-business?

Em termos de Brasil, como as empresas tradicionais estão incorporando as atividades de e-business às operações já existentes?

As empresas tem adotado algum modelo de negócios para conceber suas atividades de e-business?

O que se constatou através da revisão da literatura feita até o presente momento foi uma lacuna no que tange a estudos de casos brasileiros sobre como está sendo conduzido o processo de adoção e implantação dos negócios de ebusiness pelas empresas brasileiras já estabelecidas no mercado real, chamadas doravante de empresas "tradicionais" (em oposição às empresas "start-up" nascidas na Internet).

Quanto a estudos sobre o e-business no setor industrial brasileiro, que pode ser considerado "tradicional", uma vez que é constituído de empresas não natas na Internet, o "gap" mostrou-se ainda maior e conquanto a literatura aponte um crescimento nas atividades de e-business B2B (ou entre empresas), há poucos estudos sobre o setor industrial e a caracterização de seus negócios eletrônicos.

É nesse contexto que se insere a presente pesquisa. 
A pesquisa foi realizada no setor industrial, visando conhecer o cenário do e-business no segmento de montadoras de automóveis na indústria automobilística.

A pesquisa foi conduzida inicialmente com base em fontes secundárias, tendo em vista levantar-se o estado da arte do tema (revisão bibliográfica).

Em seguida foram aplicadas entrevistas semi-estruturadas junto a executivos das empresas escolhidas para os casos estudados, dos vários departamentos das empresas, escolhidos de acordo com o grau de envolvimento do executivo com o e-business da empresa.

Essas entrevistas buscaram esclarecer fatos relativos ao processo de adoção de e-business pelas empresas, identificando se as empresas utilizaram algum modelo de negócios para implantar as atividades de e-business, e caso afirmativo, identificando quais foram esses modelos.

Num momento posterior a pesquisa procedeu à identificação dos desenhos organizacionais praticados pelas empresas para implantação desse e-busines.

Uma das bases teóricas para a realização da pesquisa foi a de que a adoção de uma inovação (no caso, o e-business) por uma empresa traz impactos sobre ela que afetam desde sua maneira de lidar com o mercado, até transformações internas à empresa e mesmo sua definição de organização, sendo, portanto, importante verificar se e qual tipo de modelo de negócio de ebusiness foi adotado e suas conseqüências para a operação da empresa (reestruturação interna em termos de integração à empresa e estrutura organizacional resultante).

Outro referencial teórico recai sobre o uso da análise da cadeia de valor da empresa, baseada em Porter (2001) para a avaliação dos resultados obtidos.

Outra base teórica reside no estudo das estruturas organizacionais possíveis para a execução de um negócio, pois é importante verificar como o arranjo obtido pode proporcionar à empresa vantagem competitiva, garantindo sua sobrevivência no mercado. 
QUESTÔES E JUSTIFICATIVA DA PESQUISA 


\section{Capítulo II}

\section{QUESTÕES E JUSTIFICATIVA DA PESQUISA}

Esse capítulo tem como objetivo fazer a apresentação das questões que serão tratadas pela presente pesquisa, contextualizando-as, para em seguida apresentar a justificativa de sua realização.

\subsection{OBJETIVO E QUESTÕES DE PESQUISA}

O objetivo da presente foi verificar se a empresa adotou algum modelo de negócios para implantar suas atividades de e-business, verificando como essas atividades (descritas por um modelo ou não) afetaram a estrutura organizacional já existente da empresa que as adotou.

Vale ressaltar que as empresas estudadas são empresas que já atuavam no "mundo real", ou seja, empresas ditas tradicionais, pois não nasceram na Internet.

Mais especificamente, estudou-se na presente pesquisa o setor industrial, menos explorado na literatura recente, no caso o segmento da indústria automobilística e dentro deste, o segmento de montadoras.

Trata-se de um segmento bastante competitivo da economia brasileira, que traz consigo uma série de inovações tecnológicas e possui um parque industrial instalado no Brasil há mais de cinqüenta anos, o que configura seu caráter "tradicional", no sentido de não ser nascido na Internet.

A partir dessa perspectiva, o que se quer estudar é o que as empresas estão realizando em termos de e-business para que se possa analisar como elas o estão fazendo, em termos de estruturas organizacionais.

Dado que a empresa adotou determinadas atividades de e-business (o que as empresas estão fazendo, explicadas por um modelo de negócios ou não-que constitui o primeiro foco da pesquisa), um segundo foco de interesse da pesquisa é em como essas atividades foram adotadas, em termos de acomodação das atividades dentro de uma estrutura organizacional já existente e em operação, 
realizando processos de negócio e alocando pessoas dentro dessa determinada estrutura ou transformando a estrutura existente.

A partir dos interesses declarados, são as seguintes questões específicas de pesquisa a serem investigadas:

1. A empresa adotou algum tipo de modelo de negócio para conduzir o desenho e implantação das atividades de e-business?

2. Qual(is) foram a(s) estrutura(s) organizacional(is) experimentadas para desenhar e implantar as atividades de e-business adotadas, ao longo do tempo?

Entende-se por desenhar as atividades de e-business 0 ato de escolher quais atividades de e-business a empresa vai adotar, relacionando-as às áreas da empresa que irão utilizá-las e alocando-as em determinada posição da estrutura organizacional da empresa, estipulando quais os requisitos tecnológicos serão necessários para que essas atividades aconteçam.

Entende-se por Implantar as atividades de e-business 0 ato de tornar 0 desenho operacional., ou seja, fazer com que o desenho de e-business determinado entre em ação, seja operacionalizado, traduzido em atividades executáveis.

Entende-se por atividades de e-business, aquelas atividades que se utilizam de ferramentas de e-business (ou aplicativos específicos) para efetuar negócios (independente do tipo de participantes envolvidos:entre empresas, entre empresa e consumidor final, dentre outros) utilizando o meio eletrônico.

Segue-se explicação detalhada de cada uma das questões de pesquisa. 


\section{1- A empresa adotou algum tipo de modelo de negócio para conduzir o desenho e implantação das atividades de e-business?}

Essa questão quer investigar se foi usado um modelo de negócio para orientar, conduzir as ações da empresa referentes ao desenho e implantação das suas atividades de e-business. O modelo de negócio seria uma ferramenta para orientar o rumo dessas atividades para determinados objetivos.

Como existem diversas abordagens sobre o conceito de modelo de negócio, entendeu-se serem necessárias algumas explicações preliminares do que se entende por modelo de negócio e como será tratado esse assunto nessa tese.

Durante o processo de migração de empresas tradicionais para a Internet, as mesmas vão se deparar com alguns desafios, como: cultura da empresa e liderança, conflitos de canal (tradicional e virtual), redução de custos, encontrar perfil adequados de pessoas para trabalhar em e-business, infra-estrutura necessária de tecnologia de Informação.

Para superar esses desafios, a empresa terá que considerar e experimentar um "portfólio" de iniciativas potenciais de e-business. Para auxiliar e avaliar esse processo de migração, vários autores desenvolveram uma série de modelos de negócio.

Segundo Applegate (2001) o modelo de negócio descreve de um modo sucinto como o negócio está estruturado, que tipo de pessoas são necessárias para aquele negócio e quais os papéis que elas desempenham.

Nesse sentido, a descrição das atividades de e-business por meio de um modelo facilita a análise dessa estrutura do negócio e dos papéis das pessoas nessa estrutura.

Chesbourgh (2001) ressalta que a criação de um modelo de negócios difere da noção convencional de estratégia, uma vez que o modelo de negócios é mais do que uma tentativa de hipotetizar uma iniciativa exploratória dentro de um mercado, ele é mais do que isso: é um plano de ação completamente elaborado e definido. 
Ele resulta menos de uma escolha calculada de um menu com diversas opções de alternativas bem entendidas e mais de um processo de adaptações seqüenciais a novas informações e possibilidades, filtradas por uma lógica heurística (resultado da experiência passada) que foi estabelecida por sucessos prévios.

A maioria das grandes corporações não possui apenas uma iniciativa de ebusiness, mas muitas delas. Nesse sentido, a utilização de um modelo de negócio pode ser útil pra facilitar a coordenação dessas atividades e clarificar quais os objetivos pretendidos com o conjunto das atividades, além de facilitar a análise dos resultados obtidos, podendo avaliar se os resultados atenderam aos objetivos pretendidos.

Porém, a empresa pode optar por desenvolver as atividades de e-business separadamente, sem nenhum "fio condutor" entre elas, ou um modelo de negócio. A opção por adotar um modelo de negócio para conduzir as atividades de ebusiness da empresa, ou conduzi-las de forma separada vai depender da estratégia da empresa no que tange à condução dessas atividades.

É uma decisão da alta administração da empresa.

As montadoras perseguem simultaneamente tanto oportunidades de negociação "online" com seus consumidores finais, caracterizando uma iniciativa de e-business de business-to-consumer (B2C) quanto oportunidades de realizar negócios "online" com seus fornecedores, distribuidores (dealers) e parceiros, caracterizando oportunidades business-to-business (B2B).

Para visualizar como estão organizados esses empreendimentos dentro da empresa, o conceito de modelo de negócios pode ser útil.

A partir do final da década de 1990, vários autores que escrevem sobre ebusiness começaram a se preocupar com a necessidade de elaboração de modelos de e-business que expliquem as relações entre a empresa que o adota e seus clientes, fornecedores e parceiros.

Amit e Zott (2001) citam em seu "paper" sobre criação de valor em ebusiness, que a perspectiva de modelo de negócio está quase ausente da literatura acadêmica, com algumas exceções: Venkatraman e Henderson (1998) definem um modelo de negócio como um plano coordenado para desenhar 
estratégias ao longo de três vetores: interação com o consumidor, configuração do ativo e alavancagem do conhecimento.

Amit e Zott (2001) desenvolveram um modelo de negócio para avaliar o valor criado pelo e-business onde o modelo de negócio descreve o conteúdo, estrutura e governança de transações designadas para criar valor através da exploração de oportunidades de negócio.

Esse modo sucinto diz como a companhia interage com outras na indústria e como ela faz dinheiro e entrega valor aos consumidores, fornecedores, parceiros, empregados e acionistas.

Turban (2000) propõe a classificação do e-business a partir do tipo de participantes envolvidos em negociações no mercado eletrônico:

- B2B- Business-to-Business: envolve transações entre empresas utilizando a Internet. Inclui fluxo de informações inter e intraorganizacionais, comunicação e colaboração. Inclui transações no mercado eletrônico entre organizações.

- B2C- Business-to-Consumer: são transações de varejo com compradores individuais realizadas no meio eletrônico. EX: Amazon.com.

- $\quad$ C2C -Consumer-to-Consumer: consumidores vendem diretamente para consumidores utilizando o meio eletrônico.

- Nonbusiness EB-instituições que não são de negócios, como instituições acadêmicas, organizações sem fins lucrativos, sociais e governamentais.

- B2E (business to enterprise) ou Intrabusiness (organizacional) - Inclui todas as atividades internas da organização, usualmente utilizando intranets (Internet de acesso restrito), envolvendo troca de bens, serviços e informações. Inclui desde a venda de produtos corporativos para os empregados, até treinamento on-line e atividades de redução de custo. 
Weil e Vitale (2001) utilizam o conceito de modelo de negócios do ebusiness como uma ferramenta útil para analisar iniciativas de e-business e para descrever a migração de negócios tradicionais para o novo mundo eletrônico.

Eles definem modelo de e-business como "uma descrição dos papéis e relacionamentos entre os consumidores, clientes, aliados e fornecedores de uma firma, descrição essa que identifica os principais fluxos de produtos, informações, e dinheiro e os principais benefícios para os participantes".

Os elementos que definem cada modelo são: estratégia, forma organizacional, processos, cadeia de valor e competências essenciais. Também devem ser identificados através dos modelos, os fatores críticos de sucesso.

Eles procuraram com sua nomenclatura abranger vários tipos de relações de negócios, independente do fato dos envolvidos serem empresas ou consumidores individuais, mas sim baseados nos fluxos existentes de produtos, serviços, dinheiro e informações entre os participantes.

Esses autores definiram sete tipos de modelos atômicos de e-business, que podem se combinar para formar o modelo final de e-business da firma. São eles: -Provedor de conteúdo( Exemplo: AOL Time Warner), Direto ao consumidor (Ex: Dell.com), "Full-service provider" - Provê uma gama completa de serviços em um domínio (por exemplo, finanças, saúde, indústria química) diretamente ou via aliados. Ex: GE Supply Company; Intermediário ( Ex: eBay, Yahoo!); -Infraestrutura compartilhada (Ex: Covisint - Exchange integrado para fornecimento, formado por várias montadoras); -Integrador de Valor na Rede (Ex: Cisco Systems); Comunidades Virtuais ( Ex: Amazon.com Community).

Segundo Weil e Vitale (2001), uma iniciativa de e-business pode ser descrita pelo diagrama abaixo: 
FIGURA 7: DESCRIÇÃO DE UMA INICIATIVA DE E-BUSINESS

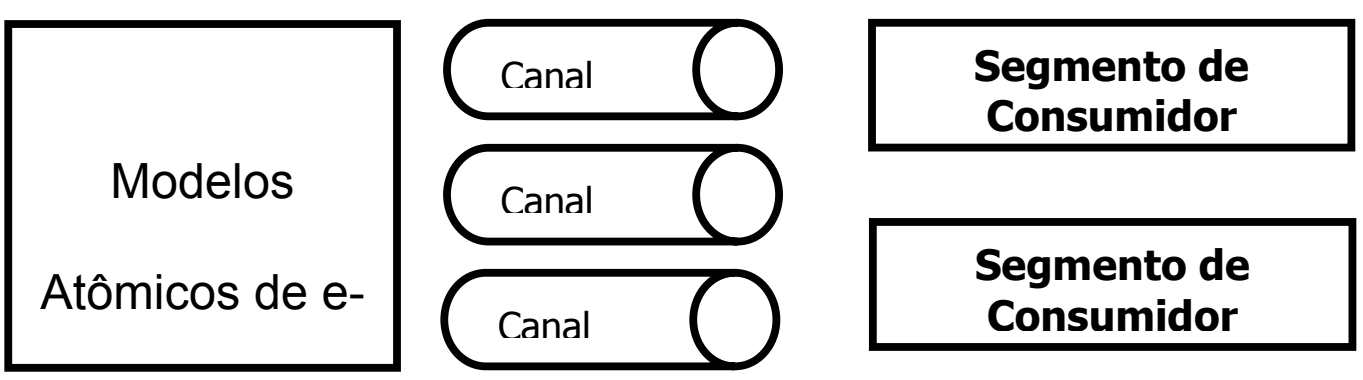

CAPACITAÇÕES DE INFRAESTRUTURA DE TECNOLOGIA DE INFORMAÇÃO

Fonte: viell e vitale (2001)

A caixa da esquerda descreve os modelos de e-business segundo Weil e Vitale (2000) sendo implementados pela iniciativa da firma, os quais combinam alguns dos sete modelos atômicos de e-business. A firma implementa o modelo, via uma coleção de canais eletrônicos (por exemplo, Internet, Intranet, EDI), para um conjunto específico de segmentos de consumidores.

As capacitações de infra-estrutura de $\mathrm{TI}$ (fornecida pela própria firma ou adquirida de fora) permitem a concretização da iniciativa de e-business.

A análise do modelo proposto ajuda a identificar as fontes de receita geradas pela iniciativa de e-business bem como os segmentos de clientes atingidos.

Applegate (2001) cita a importância do foco em modelos de negócios: segundo ela, gastou-se quase um século construindo modelos na era Industrial que definem como as companhias conduzem negócios desde o início de 1900. Como resultado, sabe-se o que quer dizer se alguém diz: "Eu vendo seguros" ou "Eu vendo carros".

A figura abaixo mostra os blocos de um modelo de negócios e as relações entre eles. 
FIGURA 8: COMPONENTES DE UM MODELO DE NEGÓCIOS

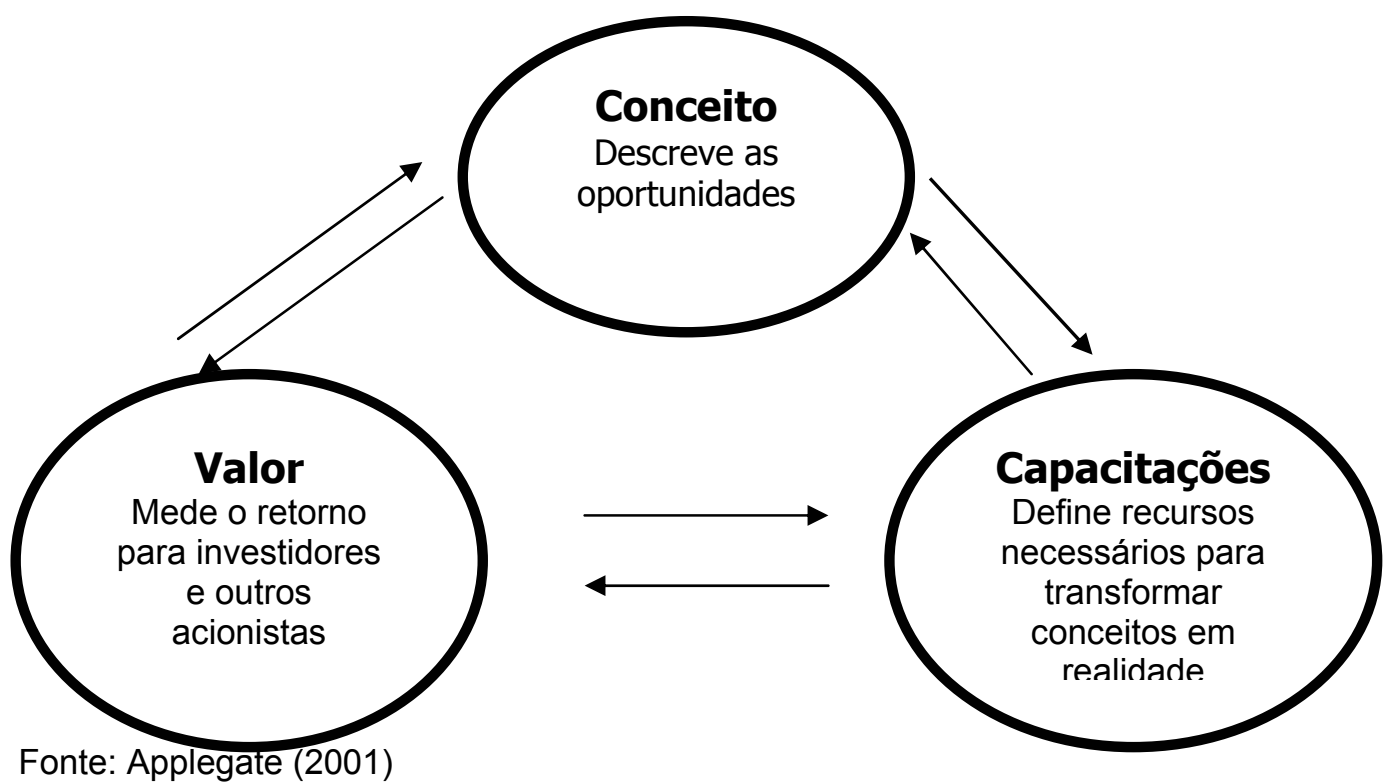

quadro abaixo ressalta categorias de análise para cada componente do

modelo e resultados para cada categoria:

TABELA 2: ANALISANDO UM MODELO DE NEGÓCIOS:

\begin{tabular}{|c|c|}
\hline O que é? & Como conseguiremos? \\
\hline $\begin{array}{l}\text { Um conceito de negócios de uma } \\
\text { organização define: } \\
\text { - Oportunidades de mercado } \\
\text { - } \quad \text { produtos e serviços oferecidos } \\
\text { - } \quad \text { Einâmica competitiva } \\
\text { - Estratégia para capturar uma posição } \\
\text { - } \quad \begin{array}{l}\text { Opominante } \\
\text { negóes estratégicas para desenvolver o } \\
\text { negócio }\end{array} \\
\end{array}$ & $\begin{array}{l}\text { - } \quad \text { Atrair uma grande e leal comunidade? } \\
\text { Entregar valor para todos os membros da } \\
\text { - } \quad \text { Pomunidade? } \\
\text { Precificar o produto para alcançar rápida } \\
\text { - } \quad \text { Levaano? } \\
\text { - } \quad \text { Gerar múltiplas fontes de receitas? } \\
\text { - } \quad \text { Administrar risco e crescimento? }\end{array}$ \\
\hline 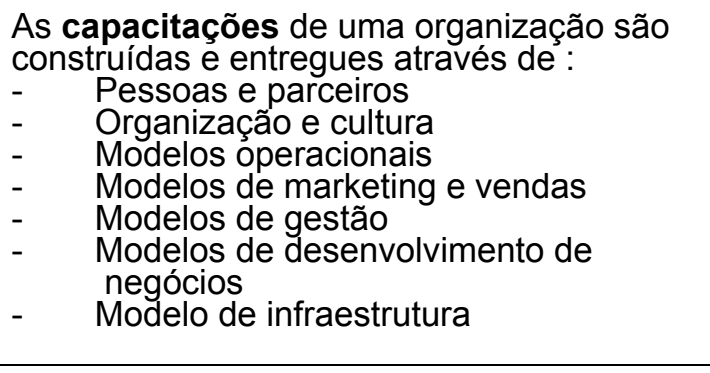 & 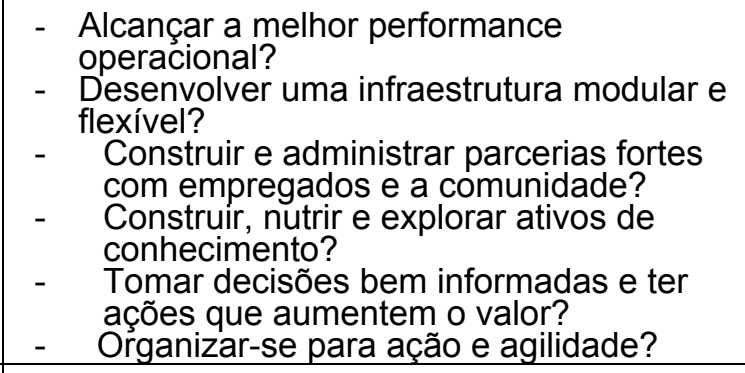 \\
\hline $\begin{array}{l}\text { Valor é mensurado por: } \\
-\quad \text { benefícios que retornam aos acionistas } \\
-\quad \text { benefícios para a firma } \\
-\quad \text { fatia de mercado e performance } \\
-\quad \text { Marca e reputação } \\
-\quad \text { Performance financeira }\end{array}$ & 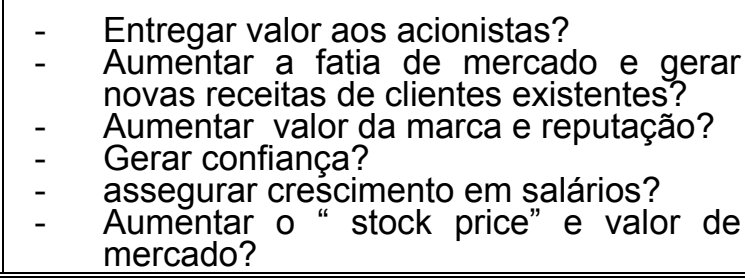 \\
\hline
\end{tabular}

Fonte: Applegate (2001) 
Portanto, nessa pesquisa, uma primeira questão refere-se à investigação sobre a existência de algum tipo de modelo de negócio para descrever as atividades de e-business da empresa, e seu papel na condução da implantação das atividades de e-business na empresa.

A decisão sobre o uso ou não de um modelo de negócio voltado para as atividades de e-business e sobre que tipo de modelo adotar é tomada pela alta diretoria da empresa. Daí, verificar o papel da alta administração no processo de adoção de um modelo para e-business é um aspecto relevante a ser observado.

A criação de um modelo de negócio pode auxiliar a empresa na observação dos resultados alcançados através da implantação daquele modelo.

Os resultados podem ser financeiros; de melhoria de relacionamento com clientes, fornecedores e/ou parceiros; melhorias no desenvolvimento de novos produtos, melhoria nos processos internos da organização, dentre outros.

Weil e Vitale (2001) associam os resultados obtidos ou fontes de receita possíveis, à implantação de cada modelo de e-business proposto por eles.

De uma maneira genérica, as fontes de receitas podem vir de: vendas diretas pela Internet (advindas do modelo direto ao consumidor), taxas de transação advindas de intermediação na Internet (com o uso, por exemplo, do modelo de intermediário), pagamento por informações e conselhos (por exemplo, no modelo provedor de conteúdo), taxas por serviços e comissões, propaganda e taxas de alistamento, fatia do aumento da receita advinda das operações de Internet, ou fatia da diminuição de custos advinda de determinado serviço de Internet.

Além dos resultados citados acima, também foram contabilizados resultados acerca da melhoria da comunicação interna na empresa ou com seus parceiros, agilidade na obtenção de informações, aumento do alcance dos clientes, simplificação e globalização de práticas comerciais e difusão pela empresa, melhoria e ampliação das informações obtidas sobre os clientes.

Segundo Amit e Zott (2001) valor é criado pelo e-business pelo modo como as transações são habilitadas. 
Em e-business, em particular, habilitar algumas transações requer uma rede de capacitações desenhadas por múltiplos atores, incluindo consumidores, fornecedores e complementadores.

Os autores elaboraram um modelo para avaliar a criação de valor em ebusiness onde existem quatro condutores de valor: -eficiência (ao reduzir assimetria das informações entre vendedores e compradores, velocidade da transmissão da informação, etc); -complementariedades (quando um conjunto de bens provê mais valor do que cada um individualmente); -retenção (valor em ebusiness é aumentado pelo quanto os consumidores são motivados a comprar novamente); -novidade ou inovação (p.ex., criar valor conectando partes que antes da inovação não eram conectadas).

Chesbrough (2001) diz que as firmas capturam valor de novas tecnologias de dois modos básicos: através da incorporação da tecnologia em seus negócios atuais ou através do lançamento de novos negócios que explorem a tecnologia em novas arenas de negócios.

O'Connel (2000) ainda cita como resultados obtidos pelo uso do ebusiness: ampliação dos serviços oferecidos ao cliente; clientes podem fazer suas próprias escolhas, flexibilidade dos serviços oferecidos.

Barrenechea (2001) cita como resultados obtidos com o uso da Internet:

- Melhoria da satisfação do cliente

- Alinhamento com a concorrência

- Redução de custos operacionais

- Melhoria da comunicação e satisfação entre funcionários

- Expansão do conhecimento da marca

- Encontro de novos mercados para produtos e serviços

- geração de novas fontes de receita

- Melhoria do relacionamento com parceiros

- Melhoria do tempo de chegada do produto ao mercado

- Criação de novos canis de distribuição

- Melhoria do gerenciamento da cadeia de fornecedores

- Delegação de poderes aos clientes para configuração de produtos ou serviços 
- Melhoria do gerenciamento do estoque.

- Slywotzky (2000) cita como resultados obtidos:

- Customização: os produtos oferecidos pela Internet podem ser "customizados" de acordo com as preferências do consumidor

- Feedback instantâneo: para cada escolha que um consumidor faça dentre vários produtos a serem vendidos pela Internet, esse custo é avaliado imediatamente.

- Captura de informações sobre os clientes

- Turban (2000) cita os possíveis resultados a serem alcançados com o uso da Internet:

- Redução de estoques ao facilitar a gestão de suprimentos: o processo inicia-se com o pedido do comprador, usando manufatura "just-in-time".

- Diminuição dos custos de telecomunicações

- E-business pode deflagrar um processo de reengenharia de processos e causar mudanças em processos aumentando a produtividade do pessoal de vendas e da administração.

- Melhoria da imagem, melhoria dos serviços ao consumidor, aumento da produtividade, eliminação de papel, diminuição do tempo do ciclo e de entrega, encontro de novos parceiros, melhoria do acesso à informação, aumento da flexibilidade.

Outra possibilidade de análise dos resultados obtidos pelo e-business vem da análise da cadeia de valor, conforme sugere Porter(2001).

Segundo ele, quando uma empresa compete em qualquer indústria, ela realiza um certo número de atividades criadoras de valor, discretas (no sentido de não serem contínuas) mas interconectadas, tais como operar uma força de vendas, fabricar um componente, ou entregar produtos, e essas atividades tem pontos de conexão com as atividades dos fornecedores, canais de distribuição e consumidores.

A cadeia de valor é uma estrutura para identificar todas essas atividades e analisar como elas afetam tanto os custos da empresa quanto o valor entregue aos compradores. 
Como cada atividade envolve a criação, processamento e comunicação da informação, a Tecnologia da Informação (e também a Internet) tem uma forte influência sobre a cadeia de valor.

A vantagem especial da Internet é a habilidade de linkar uma atividade com outras e fazer com que os dados criados numa atividade estejam largamente disponíveis em tempo real tanto dentro da empresa como fora para fornecedores, canais e consumidores.

Mais detalhes sobre os resultados obtidos pelo e-business a partir da criação de valor na cadeia de valor da empresa serão expostos na revisão da bibliografia. Apenas vale ressaltar que os resultados obtidos podem ser avaliados sob essa ótica.

Alguns desses resultados obtidos pelo uso de atividades de e-business foram levantados em cada empresa e apresentados no capítulo referentes a resultados encontrados.

\section{Resumo questão 1}

A presente questão de pesquisa buscou, então, verificar a existência de modelo de negócio para conduzir o desenho e implantação das atividades de ebusiness adotadas pelas empresas estudadas, identificando o tipo de modelo de negócio utilizado, quando fosse o caso e avaliar alguns resultados obtidos pelas empresas estudadas com a implantação das atividades de e-business. Quando possível, foi analisado o comportamento da alta direção quanto à decisão sobre o uso ou não de modelo para implantar as atividades de e-business.

2- Qual(is) foram a(s) estrutura(s) organizacional(is) experimentadas para desenhar e implantar as atividades de e-business adotadas, ao longo do tempo?

A estrutura organizacional, descreve, segundo Oliveira (2001), a ordenação e o agrupamento de atividades e recursos, visando ao alcance de objetivos e resultados estabelecidos. 
Quando uma empresa decide implantar o e-business na sua empresa, sendo que já existem atividades e processos em andamento, haverá um impacto dessa nova atividade sobre as atividades existentes.

Segundo Freeland e Stirton (2000), analisando os resultados de uma pesquisa realizada pelo The Boston Consulting Group sobre organização para o e-business, os maiores desafios do e-business não são tanto de ordem estratégica quanto de natureza organizacional.

Eles afirmam que o sucesso de uma estratégia de e-business de uma empresa recai na habilidade que a mesma tem em se organizar apropriadamente.

Em muitas situações, a falha da estratégia de e-business recaiu sobre problemas organizacionais, pois embora muitas grandes empresas estejam focadas em estabelecer seu negócio online, muitas negligenciam as mudanças e ligações com seus negócios off-line que são necessárias para fazer seus negócios online funcionarem.

Há diversas opções para que a nova atividade possa acontecer:

- pode-se constituir uma nova área, com pessoas contratadas de fora ou realocadas de outras áreas da empresa.

- pode-se aproveitar as pessoas existentes e fazer com que elas compartilhem suas atividades rotineiras com as geradas pelo novo negócio (e-business), num tipo de estrutura chamada matricial.

- pode-se criar uma estrutura totalmente independente da estrutura existente, não integrada aos negócios rotineiros.

Um dos fatores que distingue o e-business dos negócios tradicionais é sua necessidade de convergência: convergência de plataformas técnicas e convergência de capacidades de negócios.

No nível técnico, o e-business usa a convergência de múltiplas tecnologias numa infraestrutura eletrônica integrada (Internet, sistemas globais de telefonia, padrões de comunicação TCP/IP, TV a cabo, uso de browsers para acessar informação, databases de produtos e clientes, etc) para conduzir seus negócios.

Mas e-business também requer convergência das capacidades de negócios dentro e inter firmas -integração de processos de negócio, workflows, infraestruturas de TI, conhecimento e bancos de dados. 
Dada a percepção por parte da empresa das oportunidades oferecidas pelo e-business, a empresa pode ter três alternativas (Turban, 2000):

- Criar um novo modelo de negócio, separado da empresa com o ebusiness como principal condutor do processo

- Gerar um modelo de negócios secundário em torno do e-business

- Usar o e-business como uma ferramenta dentro do modelo de negócios existente.

Quanto a esse aspecto, Gulati e Garino (2000) num artigo sobre integração ou não do e-business à estrutura física já existente de uma empresa no mundo "real," cunharam a expressão : "faça o mix certo de tijolos e 'clicks'", ou seja, os autores afirmam que existe uma gama imensa de combinações entre deixar o negócio e-business totalmente separado da empresa ou de maneira oposta, totalmente integrado aos seus negócios.

Os autores defendem que não é necessário manter as iniciativas de Internet separadas dos negócios tradicionais da empresa. As empresas mais inovadoras que estão participando da Internet estão integrando suas operações virtuais e físicas. A chave para o sucesso baseia-se em como o processo de integração é administrado.

É necessário para o sucesso do empreendimento que a empresa analise alguns fatores - segundo os autores: marca, gestão, operações e estrutura de capital- para depois decidir qual é o "mix" mais apropriado para a empresa: subordinação total, parcial, ou nenhuma do e-business à estrutura já existente.

Quanto aos benefícios de uma ou outra alternativa, Lientz (2001) cita que manter o e-business dentro da empresa faz com que a empresa possa se mover mais rapidamente para o e-business numa escala limitada, a gestão pode ser pressionada por velocidade .

Os problemas dizem respeito a : implementar a estratégia pode ser algo disruptivo para os negócios regulares, onde a companhia consegue suas receitas; à medida que o e-business cresce em diferentes departamentos, haverá conflitos surgindo entre as transações de negócios regulares e e-business, como por exemplo promoções, cronograma de produção, relacionamento com fornecedores, e outras áreas podem ser impactadas. 
Ainda segundo ele, se a empresa optar por separação, há níveis de separação: pode haver compartilhamento da estrutura de armazenamento, serviço de suporte ao consumidor, compartilhamento de marketing, compartilhamento de recursos de TI e outros sistemas. Uma vantagem da separação é a implementação do e-business sem a bagagem da atual organização, além do fato de que os negócios regulares podem continuar seus processos normais, sem interferência do e-business.

Outros autores também abordam a importância sobre a decisão a respeito do nível de integração do e-business à empresa, e serão tratados com maiores detalhes no capítulo referente a revisão da literatura.

É importante ressaltar que as mudanças de tipo de relacionamento entre empresa virtual e real ao longo do tempo podem sofrer mudanças: o nível de integração do e-business em relação aos negócios tradicionais da empresa pode sofrer modificações.

Um exemplo que ilustra isso é a corretora financeira Charles Schwab: segundo Slywotsky (2000) a eSchwab, sua empresa na Internet, começou como uma empresa completamente separada da organização "core", o que lhe trouxe vantagens e desvantagens: separada , a empresa pode desenvolver uma gestão inovadora, longe dos sistemas e cultura da empresa-mãe.

Por outro lado, os consumidores pressionavam para a reintegração; por fim, houve a integração das duas empresas, criando um modelo híbrido entre real e virtual. Fica a questão: ao longo da história do e-business na empresa, quais são as variáveis críticas que influenciam as mudanças de relacionamento entre real e virtual ou integração versus não integração aos negócios existentes?

Esse é um bom exemplo de como a forma de e-business pode se modificar ao longo do tempo, implicando que o modelo de e-business adotado no caso Schwab - vendas diretas - pode implicar tanto numa estrutura totalmente separada da empresa -como era no início-como integrada à empresa-que resultou em melhores resultados, pois os clientes exigiam que a marca fosse única.

O aspecto do arranjo organizacional possível quando da implantação de ebusiness por uma empresa que já realiza negócios no "mundo real" é visto por 
Muritiba e Vasconcellos (2001) de acordo com a seguinte classificação quanto a arranjos organizacionais possíveis:

FIGURA 9: NÍVEIS DE INTEGRAÇÃO DO E-BUSINESS À EMPRESA

\begin{tabular}{|c|c|c|c|}
\hline Nível 1 & Nível 2 & Nível 3 & Nível 4 \\
\hline $\begin{array}{l}\text { As estruturas dos } \\
\text { negócios virtual e } \\
\text { tradicional são } \\
\text { totalmente } \\
\text { separadas. Não } \\
\text { há nenhum } \\
\text { compartilhamento } \\
\text { de recursos, e } \\
\text { existe duplicação } \\
\text { das áreas da } \\
\text { empresa. }\end{array}$ & $\begin{array}{l}\text { O negócio eletrônico } \\
\text { é estabelecido como } \\
\text { uma empresa } \\
\text { separada ou uma } \\
\text { unidade estratégica } \\
\text { de negócios. Há } \\
\text { áreas em } \\
\text { duplicidade, porém } \\
\text { há também alguns } \\
\text { recursos sendo } \\
\text { compartilhados. }\end{array}$ & $\begin{array}{l}\text { É estabelecida uma } \\
\text { área para o e- } \\
\text { business. Há, } \\
\text { porém, } \\
\text { compartilhamento } \\
\text { entre áreas da } \\
\text { empresa tradicional } \\
\text { e não há áreas em } \\
\text { duplicidade. }\end{array}$ & $\begin{array}{l}\text { O negócio eletrônico } \\
\text { fica descentralizado } \\
\text { pelas áreas da } \\
\text { empresa. }\end{array}$ \\
\hline \begin{tabular}{|l|}
$\square \square$ \\
$\square \square \square$
\end{tabular} & & & \\
\hline & & & \\
\hline
\end{tabular}

Fonte: Muritiba e Vasconcellos (2001)

Os arranjos possíveis vão depender numa esfera mais ampla, do que a empresa pretende com a implantação do e-business, ou seja, como o e-business pode ajudar no cumprimento dos objetivos globais da empresa estabelecidos a partir de sua estratégia?

Assim, é preciso não se esquecer que a estratégia da empresa com o estabelecimento de objetivos globais é o condutor das iniciativas da mesma em todas as direções, inclusive na condução dos negócios de e-business. 
Vários autores (Lientz (2001), Tapscott (1998), Plant (2000), Robert \& Racine (2001), Kalakota (1999), Turban (2000)) ressaltam a importância da integração entre os objetivos da empresa e sua estratégia global com o desenho de e-business a ser adotado pela empresa: para o sucesso desse empreendimento os investimentos infraestrutura tecnológica para implementar o e-business devem estar "linkados" aos planos da organização, às suas estratégias e táticas, sendo que deve estar claro para a organização todos os requerimentos necessários para a consecução daqueles objetivos.

As questões básicas estratégicas que devem ser levantadas pela alta direção da empresa são: "Como transformar a velha empresa em um novo desenho de empresa?" E "Como fazer uma ponte para superar o gap de capacitação entre" as necessidades físicas de hoje " $\mathrm{e}$ " as necessidades digitais de amanhã" ?" .

Portanto, é importante verificar quais as relações entre os objetivos globais da empresa, como um "fator orientador" ao desenho de e-business.

Além de identificar o quão integrada está a estrutura de e-business à estrutura organizacional existente, foi identificada qual o tipo de estrutura empregada.

A literatura identifica uma série de estruturas organizacionais possíveis:

- Estruturas tradicionais: funcional, divisional (por produtos, por processos, geográfica, por mercados) e estruturas inovativas: matricial, unidade estratégica de negócios, holding.

As características de cada uma delas, além de critérios para sua escolha, bem como questões acerca da autoridade e responsabilidade dos indivíduos dentro de uma estrutura organizacional serão abordados em detalhes na revisão da literatura.

Outro ponto a se considerar ainda dentro da questão dos tipos de estrutura utilizados para a implantação do e-business, trata da existência (ou não) de alterações desses arranjos ao longo do tempo.

Pensando na adoção de e-business pela empresa sob a ótica de adoção de uma inovação, existe a perspectiva de análise desse fenômeno a partir da formulação e implantação de projetos, com todo seu fundamento teórico. 
Nessa perspectiva, pode-se pensar numa implantação de e-business como algo que segue as fases do ciclo de vida de um projeto, que são segundo Shtub (1994): fase conceitual de desenho, quando a empresa percebe que será necessário desenvolver um projeto, seguida pela fase de desenvolvimento ou desenho preliminar de sistema onde o gestor do projeto planeja o mesmo num nível de detalhe suficiente para realizar cronograma de atividades e orçamento inicial.

Uma vez que o projeto seja aprovado, entrará numa próxima fase de detalhamento do desenho, seguida pela fase de produção e finalmente finalização.

Ora, cada uma dessas fases pode envolver uma ou mais pessoas, dependendo da amplitude do projeto (no caso, do tipo de ferramenta de ebusiness a se implementar), sendo necessário que se organize uma estrutura adequada para cada fase, podendo ser a mesma para várias dessas fases ou não.

O sucesso da implantação depende em grande parte da organização apropriada para sua consecução.

A interrupção no trabalho de rotina para alocar as pessoas certas para o projeto de implantação de e-business, a alocação de tarefas específicas para indivíduos da empresa ou subcontratados (terceirizados), a gestão e controle durante o processo e finalmente a integração das partes dentro do todo préespecificado constituem tarefas da administração de um projeto.

Além do próprio processo de execução de um projeto, que contempla fases diversas e pode precisar de estruturas diversas para ser executado, outras variáveis podem afetar a forma organizacional empregada para se implantar e operar o e-business: fatores externos à firma podem impactar essas decisões: ambientes recessivos, que forçam a tomada de decisão por cortes de pessoal acabam por influenciar a forma organizacional adotada; necessidade de conseguir maior produtividade com realocação de pessoas para esse fim, decisões estratégicas que implicam em reorganização da estrutura organizacional, dentre outras. 


\section{Resumo questão 2}

Essa questão de pesquisa vai tratar de analisar as estruturas adotadas durante a concepção e implantação do e-business, verificando as mudanças na estrutura organizacional encontradas ao longo do tempo.

\subsubsection{QUADRO SINTÉTICO DAS QUESTÕES DE PESQUISA}




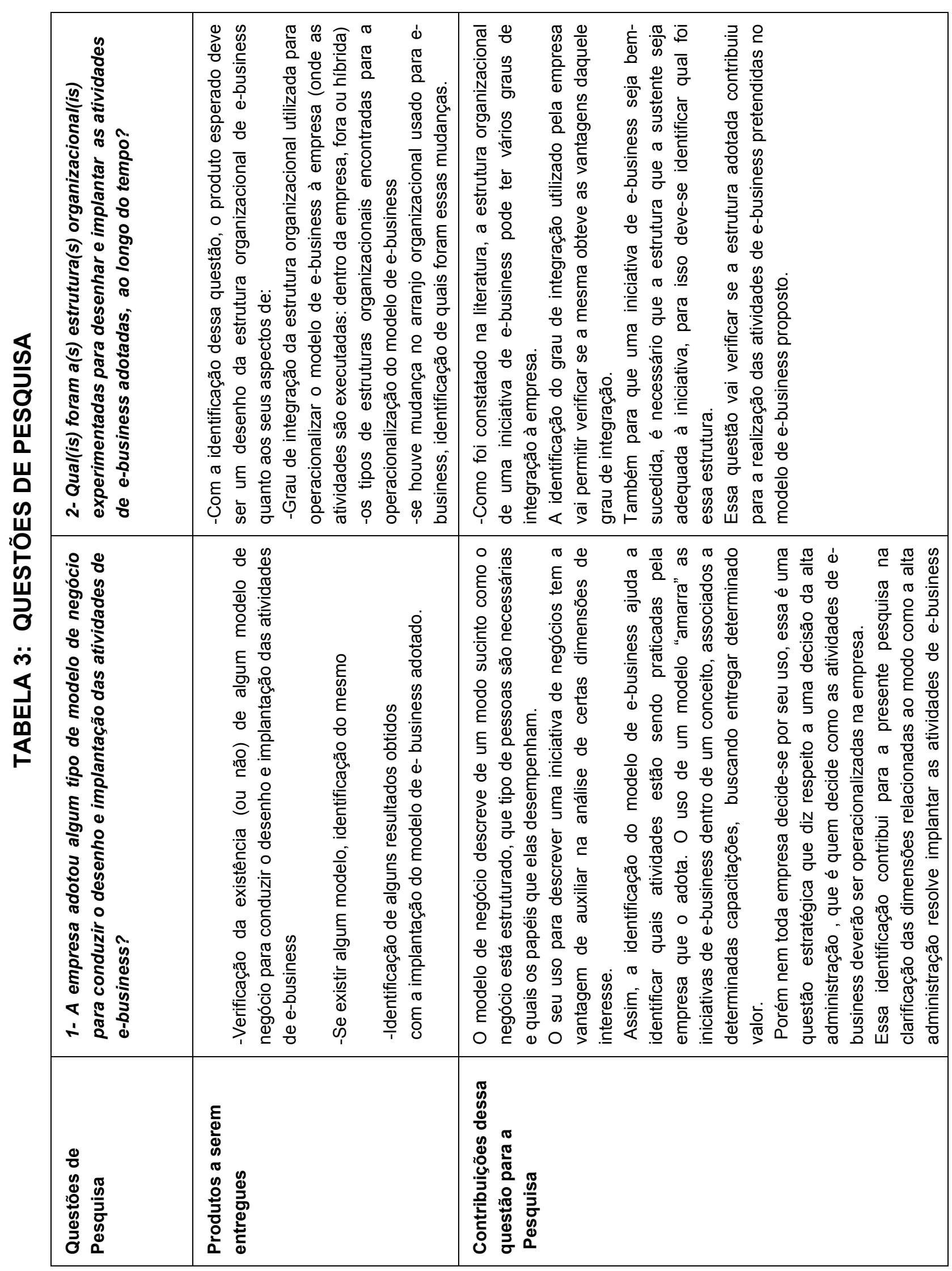


É importante ressaltar que as questões de pesquisa são interrelacionadas: dado uma decisão sobre que modelo de negócio relacionado a e-business vai (ou não) ser adotado por uma firma, existe uma maneira mais adequada de inseri-lo nos negócios e processos já realizados pela firma, aproveitando sinergias e evitando superposições, que vai implicar na adoção de determinado nível de integração do e-business à empresa.

Dada essa forma de integrar o e-business à empresa, determinadas estruturas organizacionais serão empregadas para operacionalizá-lo, buscando o atingimento de determinados objetivos o que implicará na obtenção de determinados resultados (sejam esses resultados referentes a receitas que se quer obter, diminuição de custos, parcerias que se quer estabelecer, melhorias em processos internos, entre outros).

\subsection{JUSTIFICATIVA DA PESQUISA}

Quando da revisão da literatura para a presente pesquisa o que se constatou foi a quase ausência de dados sobre o e-business na realidade brasileira.

Todas as questões que serão tratadas nessa pesquisa encontraram arcabouço teórico e exemplos na literatura estrangeira, porém raríssimas informações sobre a realidade das nossas empresas.

Esse é um primeiro ponto a ser considerado que justifica o presente trabalho.

Mesmo na literatura internacional, são recentes as publicações que tratam de aspectos mais acadêmicos de estudo, como a elaboração de modelos de ebusiness que possam facilitar sua análise, ou mesmo sobre fatores críticos de sucesso. Pode-se observar que boa parte da revisão bibliográfica contem materiais que datam do ano de 2000, 2001.

Portanto, um trabalho que aborde o e-business a partir da busca de compreensão sobre quais modelos de e-business foram utilizados pelas empresas que o adotaram, verificando se a adoção desses modelos refletiu em mudanças radicais ou incrementais na empresa, principalmente no que tange aos 
arranjos organizacionais experimentados e resultados obtidos, é bem-vindo como uma forma de ampliar os conhecimentos no que tange ao cenário brasileiro.

Mesmo porque a nossa realidade possui particularidades que diferem da realidade norte-americana, de onde provem boa parte do arsenal teórico: o mercado brasileiro possui outra dinâmica, o volume de transações no mercado eletrônico ainda é bastante inferior ao americano e a cultura empresarial é bastante diversa.

O estágio tecnológico em que se encontram nossas empresas também é diverso do norte-americano; mesmo nossa infraestrutura de telecomunicações, fundamental para o desenvolvimento do e-business encontra-se em ampliação: por exemplo, a tecnologia "wireless", considerada como um dos grandes diferenciais para o e-business nas próximas décadas ainda não é uma realidade no Brasil.

A cultura do empresariado americano é diferente do empresariado brasileiro, portanto os aspectos culturais mencionados como barreiras e/ou fatores críticos de sucesso para a implantação de e-business são importantes de serem estudados.

Assim, como primeiro aspecto a justificar essa pesquisa tem-se a lacuna existente de trabalhos acadêmicos sobre o assunto, além da contemporaneidade do assunto.

Outro aspecto trata da contribuição que esse trabalho traz para a análise de aspectos críticos na implantação de e-business.

O que se viu num primeiro momento de e-business, como constatado na revisão da literatura apresentada, foi o fracasso de muitas de suas iniciativas.

Nesse segundo momento, as empresas necessitam de análises sobre fatores importantes para viabilizar o negócio.

Por exemplo, se um modelo de negócio e-business tem sua operacionalização através da forma menos adequada de integração, problemas de comunicação com os clientes podem acontecer, trazendo problemas que não estão diretamente relacionados ao modelo escolhido e sim com a forma como foi implantado na empresa. 
A não identificação do modelo de e-business adotado pela empresa pode atrasar a análise de algumas variáveis relevantes (como por exemplo, forma organizacional mais adequada, estrutura de TI necessária, objetivos estratégicos do e-business) para escolha do melhor desenho de e-business .

A importância do levantamento desses fatores deve-se ao fato de que se a iniciativa de e-business não corresponder às expectativas, fica difícil analisar se o modelo de negócio era inadequado (por exemplo, as ferramentas escolhidas não estavam alinhadas com a estratégia da empresa) ou se foi um problema estrutural: as pessoas escolhidas para gerir aquela iniciativa não tinham a autoridade devida e não tinham à sua disposição um desenho organizacional adequado que permitisse à consecução de seus objetivos.

Ou mesmo se o nível de integração adotado não estava adequado, duplicando atividades ou ignorando sinergias possíveis entre o e-business e os negócios tradicionais.

Assim, entendeu-se que o estudo das questões escolhidas de pesquisa mostrou-se relevante para preencher lacunas do conhecimento sobre a adoção de e-business por empresas tradicionais, justificando a realização desse estudo.

Analisar o impacto de uma mudança antes de sua implementação reduz o risco de falha. Problemas criados por uma iniciativa de e-business são caros e difíceis de consertar uma vez que esteja implementado.

Os administradores podem apoiar-se em modelos de negócio para capturar a essência de uma iniciativa de e-business. Como já foi dito, um modelo de negócios pode ser representado por cinco elementos: estratégia, forma organizacional, processos, cadeia de valor e competências essenciais.

Questões relacionadas ao nível de integração do e-business na empresa relacionam-se a uma preocupação em entender as relações de dependência e responsabilidades de cada instituição. Busca-se saber até que ponto o novo negócio virtual terá liberdade de atuar, ou deverá estar subordinado à organização tradicional; ou ainda onde se encaixará exatamente a área virtual dentro da estrutura da empresa tradicional: cada tipo de solução deve estar integrado à estratégia global da empresa, de modo a se alcançar os resultados pretendidos. 
Essa pesquisa pode contribuir no âmbito acadêmico a que se esclareçam questões pouco abordadas na literatura, como a questão da integração do ebusiness à empresa, ou as estruturas organizacionais mais adequadas para sua implantação, que carecem de exemplos brasileiros, pois toda literatura está voltada para os casos internacionais.

Ora, o Brasil apresenta algumas peculiaridades em termos de "gap" tecnológico, falta de integração dos aplicativos de software dentro e fora da empresa, além de haver uma economia de mercado diferente da norte-americana , com diferenças culturais no que tange a compras via catálogo ou utilização de leilões aliados a questões de confiança nos parceiros, características essas que tornam esse cenário rico de ser explorado.

Para as empresas, essa pesquisa busca colaborar no levantamento de "práticas" administrativas que ajudem-nas a selecionar os modelos de negócio mais adequados à sua estratégia e objetivos corporativos, trazendo uma contribuição quase inédita no que tange aos aspectos de desenho organizacional relacionado com a adoção de e-business.

\subsubsection{Quadro das justificativas das questões da pesquisa}

A seguir será apresentado um quadro que resume a justificativa de cada questão estudada: 
TABELA 4A: JUSTIFICATIVA DAS QUESTÕES PROPOSTAS PELA PESQUISA.

\begin{tabular}{|c|c|}
\hline $\begin{array}{c}\text { Questão de } \\
\text { Pesquisa }\end{array}$ & Justificativa \\
\hline $\begin{array}{l}\text { 1- A empresa } \\
\text { adotou } \\
\text { algum tipo } \\
\text { de modelo } \\
\text { de negócio } \\
\text { para } \\
\text { conduzir o } \\
\text { desenho e } \\
\text { implantação } \\
\text { das } \\
\text { atividades de } \\
\text { e-business? }\end{array}$ & $\begin{array}{l}\text { A identificação do tipo de modelo utilizado, quando pertinente, deve } \\
\text { estar associados a um tipo de resultado obtido. } \\
\text { Uma empresa normalmente adota uma série de atividades de e- } \\
\text { business em várias áreas: por exemplo: adoção de e-procurement } \\
\text { para agilizar o processo de compras, efetuando pedidos e emitindo } \\
\text { requisições de compras pela Internet; pode também realizar vendas } \\
\text { diretas pela Internet e pode ainda manter um site institucional da } \\
\text { empresa para fornecer informações aos clientes, além de manter um } \\
\text { call center. } \\
\text { o modelo de negócio busca facilitar o processo de análise e } \\
\text { entendimento dessas atividades, para melhor decidir sobre quais } \\
\text { atividades adotar e como operacionalizá-las. Porém, a empresa pode } \\
\text { optar por implantar suas atividades de e-business sem ter esse fio } \\
\text { condutor que é o modelo de negócio para orientar o desenho e } \\
\text { implantação das atividades de e-business. A presente pesquisa } \\
\text { buscou identificar qual foi o comportamento das empresas estudadas: } \\
\text { optaram por um modelo orientador das decisões quanto a e-business, } \\
\text { ou preferiram conduzir as atividades de e-business segundo outros } \\
\text { critérios; nesse caso, quais foram os critérios orientadores da } \\
\text { implantação das atividades de e-business? }\end{array}$ \\
\hline
\end{tabular}




\section{TABELA 4B: JUSTIFICATIVA DAS QUESTÕES PROPOSTAS PELA PESQUISA}

\begin{tabular}{|c|c|}
\hline $\begin{array}{c}\text { Questão de } \\
\text { Pesquisa } \\
\end{array}$ & Justificativa \\
\hline $\begin{array}{l}\text { 2- Qual(is) foram } \\
\text { a(s) estrutura(s) } \\
\text { organizacional(is } \\
\text { ) experimentadas } \\
\text { para desenhar e } \\
\text { implantar as } \\
\text { atividades de e- } \\
\text { business } \\
\text { adotadas, ao } \\
\text { longo do tempo? }\end{array}$ & $\begin{array}{l}\text { O sucesso de uma estratégia de e-business de uma empresa recai na } \\
\text { habilidade que a empresa tem em se organizar apropriadamente. Em } \\
\text { muitas situações, a falha da estratégia recai sobre problemas } \\
\text { organizacionais. } \\
\text { Em termos organizacionais, um dos desafios das empresas } \\
\text { tradicionais que decidem adotar alguma iniciativa de e-business } \\
\text { refere-se justamente à escolha de qual nível de integração haverá } \\
\text { entre os negócios real e virtual. As vantagens e desvantagens de se } \\
\text { operar o e-business totalmente separado da empresa ou totalmente } \\
\text { integrado ou uma escolha intermediária a essas deve ser feita } \\
\text { Identificando-se quais fatores foram relevantes nessa escolha. } \\
\text { Essa escolha terá implicações sobre as formas organizacionais que } \\
\text { se irá adotar. } \\
\text { A escolha da forma organizacional mais adequada à implantação do } \\
\text { e-business depende de outras variáveis, como a tecnologia envolvida, } \\
\text { os aportes financeiros necessários àquela estrutura, o grau de } \\
\text { comunicação necessário entre as partes envolvidas, e as questões de } \\
\text { atribuição de responsabilidade/autoridade, bem como a questão da } \\
\text { coordenação das atividades. } \\
\text { Esses fatores levarão a diferentes tipos de barreiras que surgirão à } \\
\text { implantação (por exemplo, resistência dos funcionários à mudança), } \\
\text { bem como a diferentes fatores de sucesso, afetando } \\
\text { conseqüentemente o atingimento dos objetivos que se quer alcançar } \\
\text { ao implantar o e-business. } \\
\text { Muitas vezes a organização escolhida para implantar o modelo } \\
\text { desejado de e-business não é a mais adequada, resultando no } \\
\text { insucesso da iniciativa por problemas organizacionais e não } \\
\text { estratégicos. } \\
\text { Daí a importância do estudo desse aspecto na presente pesquisa, } \\
\text { para auxiliar na definição dos fatores críticos para implantação de e- } \\
\text { business no que tange aos aspectos organizacionais. } \\
\text { Tais informações são relevantes tanto no âmbito acadêmico, por } \\
\text { contribuir com o levantamento de fatores críticos ao bom desempenho } \\
\text { do modelo de e-business no que tange a aspectos organizacionais, } \\
\text { quanto para as empresas, que poderão se beneficiar dessas } \\
\text { informações para implantações posteriores de estruturas } \\
\text { organizacionais voltadas a operacionalizar determinados modelos de } \\
\text { e-business. }\end{array}$ \\
\hline
\end{tabular}




\subsection{ORGANIZAÇÃO DO RESTANTE DO ESTUDO}

O estudo foi organizado em capítulos, sendo que após a introdução (capítulo 1) e apresentação das questões e justificativa da pesquisa (capítulo 2), o capítulo 3 apresenta a fundamentação teórica ou revisão bibliográfica, abordando temas relacionados a conceitos de e-business, modelos de negócios para ebusiness, tópicos sobre estruturas organizacionais (tipos, condicionantes para adoção, estrutura organizacional e e-business, dentre outros), literatura sobre gestão de projetos (uma vez que a introdução do e-business na empresa pode ser entendida sob essa ótica), uma abordagem sobre o fenômeno no Brasil e alguns exemplos.

O capítulo 4 relata e justifica a abordagem metodológica adotada na pesquisa, assim como os critérios de definição do rol de empresas pesquisadas, bem como os critérios utilizados para as análises elaboradas.

O capítulo 5 apresenta os resultados da pesquisa com a descrição dos casos estudados e sua análise.

O capítulo 6 encerra com as conclusões, limitações e recomendações da pesquisa.

Seguem a bibliografia e os anexos. 
CAPÍTULO III

REVISÃO BIBLIOGRÁFICA ב 


\section{Capítulo III}

\section{REVISÃO BIBLIOGRÁFICA}

\subsection{ASPECTOS LIGADOS A E-BUSINESS}

\subsubsection{A INTERNET}

Segundo Carvalho (1999), a Internet nasceu de um projeto de defesa do governo federal dos EUA,onde o Pentágono financiou um projeto da ARPA (Advanced Research Projects Agency) cujo objetivo era criar uma rede de comunicação indestrutível.

Em 1982 os protocolos de transmissão e de endereçamento TCP/IP ( transmission Control Protocol and Internet Protocol) tornam-se operacionais e a rede passa a ser denominada Internet. Tais protocolos permitem que um número ilimitado de redes de computadores se interliguem e atuem como se fossem uma única rede.

A partir de 1989 com a desagregação da União Soviética nos 15 países atuais, as preocupações originais do projeto ARPANet deixam de ser relevantes, implicando na liberação da Internet em 1992 do controle estatal, permitindo-a desenvolver-se com recursos privados.

Surgem os componentes críticos da rede, desenvolvidos por Berners-Lee, um pesquisador do Laboratório Europeu de Física QuÂntica localizado na Suíça;

1. HTTP (HyperText Transport Protocol) -que permite ao browser comunicar-se com os servidores de rede

2. HTML(HyperText Makeup Language)-linguagem na qual as páginas de rede são escritas

3. URLs (Uniform resource locators) os endereços utilizados para identificar páginas e outras informações alocadas na Internet.

Em 1992, Berners-Lee, doou sua criação ao mundo, criando a rede mundial WWW-World Wide Web (Clemente 1997). 
Em 1993, Marc Andreesen lança o primeiro Web Browser, denominado "Mosaic". Um browser é um software que fica instalado no computador do usuário que permite a visualização do código HTML das páginas da Web, que, por sua vez, residem em computadores denominados "servidores"da rede.

Segundo Carvalho (1999), toda literatura sobre Internet traz a conclusão de que se está diante de um fenômeno mundial, cujas consequências ainda são pouco conhecidas. Questões a serem exploradas abordam a natureza deste fenômeno, suas dimensões básicas e seus possíveis desdobramentos nos planos dos negócios.

Duas características da Web se destacam: interatividade e conectividade. O primeiro conceito tem suas raízes na teoria da informação e da comunicação, podendo ser resumido na acertiva: "Quem diz o que para quem, em que canal e com que efeito". A questão da conectividade pode ser resumida na lei de Metcalfe (Downes \& Mui1998), em que o valor da rede aumenta exponencialmente à medida em que mais e mais agentes econômicos (empresas e consumidores) estão a ela conectados.

Assim, essas características de interconectividade e interatividade da Web fazem-na um meio ímpar, diferente das aplicações anteriores de comunicação de dados entre empresas como, por exemplo o EDI (Electronic Data Interchange) tradicional, o qual é baseado em padrões rígidos de troca de informações em uma rede privada formada por parceiros de negócio pré-determinados. A Web é uma estrutura aberta, criando um mercado de acesso espontâneo e de baixo custo.

Em termos de evolução do número de usuários, Saikovitch (2000) cita que a Internet no início dos anos 80 era constituída de aproximadamente 25 redes ligadas, em 1995 já incluía mais de 44 mil, estendida por 160 países e mantendo o registro de 26 mil entidades comerciais. Entre 40 a 50 milhões de computadores já estavam conectados aos "hosts"da internet e esse número crescia, estimandose o aumento de 10 a $20 \%$ ao mês.

Em 1999, segundo a Forrester Research (Gurovitz, 1999:158) havia nos Estados Unidos 33,5 milhões de domicílios "on-line", com 13,1 milhões comprando na Web, em média ES\$ 1.385 por ano; para 2003, há previsão de 
52,3 milhões de domicílios conectados, dos quais 40,3 comprarão em média, ES\$ 2.678 .

No Brasil, levantamento feito pelo IDC, em abril de 1999 (Gurovitz, 1999:158) indica que havia 3,8 milhões de internautas e 331 mil compradores, gastando em média ES\$ 215 por ano. Para o ano de 2003 a estimativa é de 7,5 milhões de internautas, 1,126 milhões de compradores, com gasto médio anual de US\$ 675, o que mostra crescimento acentuado, apesar as diferenças: cerca de $25 \%$ da população americana tem acesso à rede contra menos de $3 \%$ dos brasileiros.

O comércio global por via eletrônica superou US\$ 55 bilhões em 1998, devendo chegar a US\$1,3 trilhão em compras e vendas corporativas globais em 2003, correspondendo a $9,4 \%$ de todo o comércio corporativo mundial (Yanakiew:1999).

Em termos de estratégia corporativa, a Internet pode oferecer vantagem competitiva pelo fato de possibilitar abordagens inovativas de distribuição, determinando novas maneiras de atender mercados. A longo prazo, pode-se pensar em relações auto-sustentáveis entre distribuidor e consumidor. Tal conexão será crucial para o marketing internacional em nível negócio-a-negócio, pois, somente as firmas que puderem interagir com sistemas sofisticados de acompanhamento e colocação de pedidos de grandes varejistas serão elegíveis para fornecedores. (Saikovitch, 2000 citando Czinkota\&Ronkainen, 1998:811).

Saikovitch (2000) cita que algumas empresas estão desenvolvendo estratégias criativas para estabelecer relacionamentos mais próximos com seus consumidores como:

- fornecer suporte, atualização de software e serviços de hardware para os clientes em nível mundial (Sun Microsystems);

- serviço de "tracking" que permite aos clientes acompanhar pacotes e estimar prazos de entrega em qualquer lugar do mundo (Federal express);

- demonstração de sistemas e software aos usuários da internet pela home page da empresa (Digital Equipment Corp.) 
Segundo Czinkota \& Ronkainen (1998) ,para empresas norte-americanas , ter um site na Web tornou-se necessário, se não por outro motivo, para manter a imagem-sua falta pode transmitir uma imagem negativa. As razões mais importantes para possuir um site incluem Ter acesso a clientes internacionais efetivos e potenciais 24 horas por dia, usar a Web como um novo canal e uma forma de aumentar a lealdade à marca, servindo para atrair os interessados na firma e em seus produtos para gerar "dicas "de vendas.

A influência da Internet no Marketing Digital pode ser relacionada como descrito por Chleba (1999):

- Interatividade-usuário encontra informação desejada com facilidade por meio de troca de dados

- Personalização - atende individualmente clientes por serviço on-line

- globalização-a internet conecta instantaneamente o mundo dos negócios, permitindo obtenção de informações pelos clientes em qualquer lugar do mundo

- integração - troca de dados entre empresas com baixo custo

- Convergência- nova mídia tem múltiplos formatos de distribuição de informação

Outra questão que se coloca quando do uso da Internet para o Comércio Eletrônico refere-se aos requisitos de segurança, conforme quadro abaixo proposto por Kalakota \& Whinston (1997) 
TABELA 5: REQUISITOS DE SEGURANÇA PARA INTERNET

\begin{tabular}{|c|c|}
\hline Termo & Definição do Conceito \\
\hline Privacidade & $\begin{array}{l}\text { A habilidade de controlar quem pode (ou não) Ter acesso } \\
\text { a informačões e sob quais condições }\end{array}$ \\
\hline Autenticidade & $\begin{array}{l}\text { - A habilidade de conhecer as identidades das partes que } \\
\text { estão em comunicação }\end{array}$ \\
\hline Integridade & $\begin{array}{l}\text { - A segurança de que a informação arquivada ou } \\
\text { transmitida não foi alterada }\end{array}$ \\
\hline Disponibilidade & $\begin{array}{l}\text { - A habilidade de saber quando os serviços de informação e } \\
\text { comunicação estarão (ou não) disponíveis }\end{array}$ \\
\hline Bloqueio & $\begin{array}{l}\text { A habilidade de bloquear informações indesejáveis ou } \\
\text { intrusões }\end{array}$ \\
\hline
\end{tabular}

A segurança na Internet é importante pois, trata-se de um fato virtual que se transforma em uma ameaça real para a organização.

Acrescentando ao que foi dito sobre a natureza da Web e suas implicações para os negócios, pode-se dizer que a Internet (Mougayar 1998):

$\Rightarrow \quad$ É uma rede que permite conectar áreas internas à organização entre si e aos vários parceiros de negócios que compõem o sistema de valor da empresa. Esta conexão permite compartilhar informações, conhecimentos e automatizar processos empresariais;

$\Rightarrow$ É um canal de comunicação distinto com o mercado, que se adiciona às alternativas tradicionais de comunicação de marketing;

$\Rightarrow$ É um mercado, à medida que pode gerar novas fontes de receita para a empresa;

$\Rightarrow$ É uma plataforma de compra, venda e transações financeiras tanto com clientes e distribuidores quanto com fornecedores e bancos;

$\Rightarrow$ É uma plataforma de desenvolvimento de aplicativos computacionais para rede cliente-servidor.O desenvolvimento de softwares aplicativos centrados na Internet está se tornando um paradigma na estratégia de sistemas de informação das empresas. 
Outro impacto da Web nos negócios, refere-se aos custos de transação: a Web, enquanto meio de comunicação multi-direcional afeta fortemente tanto as questões de coordenação hierárquica (internas à empresa) quanto a coordenação do mercado (transações que transpõem os limites da organização).

Carvalho (1999) cita Gupta \& Basu (1989) (p.76), que discutem como a tecnologia de informação afeta os padrões de coordenação econômica, hipotetizando as formas pelas quais a proliferação dos meios eletrônicos de coordenação afetam os custos de transação de agenciamento nas organizações. Impactos no sentido de redução dos custos de coordenação externa (transação) ou interna (agenciamento) são listados como benefícios passíveis de serem percebidos pelo gerente funcional no processo de adoção da Web na estratégia funcional.

\subsubsection{DEFINIÇÕES DE E-BUSINESS E DE ALGUNS TERMOS RELACIONADOS AO MUNDO DE E-BUSINESS}

Rayport \& Sviokla (1994) entendem o mercado físico e o virtual como dois fenômenos independentes, eventualmente até conflitantes.

Eles utilizam os conceitos de conteúdo ( conjunto de atributos contidos no produto ou serviço oferecido pela empresa), contexto (maneira com a qual o conteúdo é organizado) e infraestrutura (é o que permite a consumação da transação comercial com os clientes).

Eles propõem um modelo onde, no mercado físico, estes 3 elementos são inseparáveis, enquanto que o mercado virtual permite o gerenciamento de cada um deles em separado. Essa possibilidade de desagregar os elementos que compõem o sistema de valor de uma organização e operar em cada um deles de forma independente cria oportunidades no mercado virtual para novos entrantes ameaçarem posições de empresas estabelecidas e com raízes profundas no mercado físico.

Quanto à definição de e-business, O'Connel (2000) o define como algo que descreve os negócios habilitados pela tecnologia que tem certas características de negócios e tecnológicas. De uma perspectiva tecnológica, as intranets nesses 
negócios estão se misturando às extranets e padrões e e-commerce são a pedra angular dos sistemas de negócios e processos. De uma perspectiva de negócios, os princípios de e-business focam numa grande integração entre clientes e a empresa, entre sistemas internos e sistemas de clientes e entre a empresa e seus fornecedores e parceiros.

Esse autor faz uma distinção entre e-business e e-commerce, onde ecommerce é um subgrupo do e-business e é um termo usado para descrever as transações eletrônicas baseadas em Internet incluindo EDI (Electronic Data Interchange), pagamentos de contas, processamento de pedidos, interação com o consumidor, etc.

Ainda esse autor diz que e-business é sobre trocar ricas informações a um custo quase zero usando redes de comunicações existentes e softwraes padrões que rodam virtualmente sobre qualquer computador existente em qualquer lugar do mundo.

Segundo Lientz e Rea (2001) o e-business não precisa acontecer somente na Web. A Web é hoje o meio mais comum, mas há outros meios de fazer ebusiness. Pode ser empregado EDI. Podem ser estabelecidos links diretos com fornecedores ou consumidores que "bypassam" totalmente a Internet e a Web.

Para Turban (2000) é um conceito emergente que descreve o processo de comprar e vender ou trocar produtos, serviços e informações via rede de computadores, incluindo a Internet.

Kalakota e Whinston (1997) definem CE sob várias perspectivas:

- De uma perspectiva de comunicações, CE é a entrega de informações, produtos e serviços ou pagamentos sobre linhas telefônicas, redes de computadores ou qualquer outro meio eletrônico.

- De uma perspectiva de processos de neg;ócios, CE é a aplicação de tecnologia para a automação dos processos de negócios e fluxo de trabalho.

- De uma perspectiva de serviços, CE é uma ferramenta que serve aos desejos da firma, clientes e gestão para cortar custos enquanto melhora a qualidade dos bens e melhora a velocidade de entrega do serviço 
- De uma perspectiva online, CE provê a capacidade de comprar e vender produtos e informações sobre a Internet e outros serviços online.

Para Turban, muitos usam o termo e-business que se refere a uma definição mais ampla de CE, não apenas vendendo e comprando mas também oferecendo serviços aos consumidores e colaborando com parceiros de negócio e conduzindo transações eletrônicas dentro de uma organização.

Nessa pesquisa vai-se utilizar o termo e-business nessa perspectiva mais ampla, de negócios internos e externos à firma realizados eletronicamente.

Define-se EDI (Electronic Data Interchange ) como uma transferência direta computador a computador de documentos padrão de negócios, como ordens de compra, por exemplo, através de uma rede privada.

Turban (2000) define Intranets como uma rede corporativa LAN ou WAN que funciona com tecnologia da Internet atrás de um "firewall" (sistemas de proteção que consiste num nó da rede com hardware e software que isola uma rede privada de redes públicas ) da empresa .

Uma extranet é uma rede que faz o "link" das intranets de parceiros de negócios usando uma rede virtualmente privada sobre a Internet.

Cunningham (2001) define que os dólares provenientes do comércio eletrônico B2B vem de:

- venda e transferência de mercadorias antes que alcancem a transação com o usuário final

- Processos de desenvolvimento e de fabricação subcontratados

- Joint ventures e cadeias de suprimentos

- Serviços de suporte para os produtos e serviços no mercado.

Segundo ele, Comércio eletrônico entre empresas ou B2B pode ser entendido como transações comerciais conduzidas através de redes públicas ou privadas incluindo transações públicas e privadas que usam a Internet como veículo de realização. Essas transações incluem transferências financeiras, bolsas de oferta online, leilões, distribuição de produtos e serviços, atividades de cadeias de suprimentos e redes integradas de empresas.

Esse autor define: 
- Portal- caminho para entrada - ou gateway. São centros de informações fornecendo notícias, visualizações e informações relevantes. É lá que as pessoas vão para obter informações específicas para as tarefas individuais e rotinas diárias.

Mercados digitais:

- Aquisição -são sistemas que formam o coração da cadeia de suprimento. A maioria das funções de aquisição são executadas utilizando-se a Internet para ganhar acesso direto às empresas dos fornecedores através de vínculos ou de um componente sublicenciado do mercado digital,

- Bolsas de ofertas- lugar onde os fornecedores, compradores e intermediários podem se reunir e oferecer produtos um ao outro de acordo com um grupo de regras comerciais predefinidas.

- Leilão-empresa se registra e tem que concordar com uma série de regras; tempo, preço e volume são as variáveis mais importantes na maioria dos leilões.

- leilão reverso - as empresas com mercadorias com demanda oferecem esses produtos ou serviços para que outras empresas façam seus lances.

- cadeia de suprimentos-uso das estratégias B2B para dar suporte às operações da empresa. Os sistemas utilizados permitem aos contribuintes da cadeia de suprimentos visualizar informações sobre a situação do estoque, pedidos e entregas dentro da estrutura do processo de produção. Como muitas empresas já fizeram o investimento necessário à criação desses relacionamentos interdependentes com os fornecedores e parceiros de negócios, a Web oferece uma oportunidade única para estender e melhorar esses sistemas.

Barrenechea (2001) diz que todo site que possibilita a venda por intermédio da Web é um mercado eletrônico ou o componente de um.

Outro termo bastante utilizado em e-business trata do Exchange: a Net Market Makers define-os como "mercados bilaterais, em que compradores e fornecedores negociam preços, em geral com um sistema de proposta de compra e de proposta de venda, em que os preços flutuam para cima ou para baixo". Para 
Barrenechea (2001) os sites de leilão, agregadores de catálogos também são considerados exchanges, enquanto outros autores não os consideram.

Os exchanges privados foram os primeiros exchanges eletrônicos. Cada um era hospedado por uma empresa dentro do firewall desta e usado para compra dentre um grupo de fornecedores pré-autorizados. Muitos destes exchanges foram implementados utilizando-se EDI, uma tecnologia dispendiosa que está rap[idamente perdendo terreno para a Internet.

Exchanges verticais: cada um destes é específico de um setor da economia, definido de maneira ampla ou restrita.

Exchanges horizontais: lidam com produtos e serviços que não são específicos de um setor, o de materiais de escritório é um candidato óbvio a um Exchange horizontal.

\subsubsection{PORQUE ADOTAR E-BUSINESS: VANTAGENS E BENEFÍ́CIOS}

\section{Slywotzky (2000) cita alguns benefícios do e-business:}

- Alcançar novos conjuntos de consumidores - alcança aqueles que estão distantes geograficamente ou são diferentes em tamanho e tipo daqueles previamente servidos, conectando a empresa com os clientes em locais remotos da cadeia de valor.

- Novas proposições para os clientes - e-business possibilita a criação de novos e mais eficientes "marketplaces" para oferecer linhas expandidas de produtos e serviços, melhorando a acuracidade e tempo com o qual a firma pode resolver os problemas dos clientes

- Novos modelos de lucros- e-business possibilita novas fontes de receita e lucratividade, permitindo maximizar o valor da informação nos sistemas da empresa enquanto reduz o capital e custos de operação

- Novas formas de controle estratégico - e-business facilita a criação de redes consumidor/fornecedor, alarga e aprofunda os relacionamentos e gera novas economias de escala, escopo que ajudam a atrair e reter clientes. 
- Lientz e Rea (2001) consideram diferentes perspectivas de benefícios:

- Direção geral da empresa - melhoria das mensurações dos negócios, redução de custos, melhor conhecimento dos consumidores e fornecedores

- Tecnologia da Informação- quando TI implementa um sistema, não há geralmente benefícios para $\mathrm{TI}$, apenas adicional manutenção e suporte. E-business pode prover benefícios (como uma moderna infra-estrutura) que reduza ou estabilize o suporte.

- Departamentos de negócios- eles e a organização recebem benefícios com o e-business em termos de redução do trabalho burocrático e melhoria da produtividade

- Clientes-podem receber uma larga gama de benefícios em termos de seleção, escolha, facilidade de pedido, retorno, cancelamento e outras transações

- Fornecedores- benefícios em termos de custos e mesmo melhorias das vendas bem como produtividade e eficiência

- Direção da empresa no longo termo- e-business deve apoiar os objetivos e direcionamento da empresa. Também deve tornar os objetivos mais fáceis de serem alcançados.

- Processos de negócios- os processos de negócios e transações geram as receitas e custos para os negócios. Aqui está onde os benefícios chave da implantação de e-business deve estar.

- O'connel (2000) cita como benefícios do e-business:

- Aumento das vendas- a Internet é uma mídia global, oferecendo para a empresa a oportunidade de gerar lideranças, penetrar rapidamente em mercados (locais e globais) usando os recursos existentes mas sem custos da mídia tradicional

- Maior rapidez para chegar ao mercado - aumenta resposta da empresa às mudanças do mercado. Usando e-business a firma pode mudar ou atualizar as informações instantaneamente.

- Diminuição de custos - reduz o custo das redes tradicionais de vendas. 
- Aumento da fatia de mercado- dando aos consumidores e aos consumidores dos concorrentes razões para comprar da sua firma. Será que o concorrente pode prover os mesmos produtos que a sua firma com menos tempo e por menor custo? Será que o negócio do concorrente está aberto 24 horas por dia, 7 dias da semana?

- melhor gestão da cadeia de suprimentos-a gestão da cadeia de suprimentos determina a distribuição de informação em tempo real, dados e bens através de todo spectrum de negócios. O e-business foca sobre seus consumidores, fornecedores e parceiros de negócios para maximizar a eficiência e produtividade em cada área da rede de negócios.

- Serviços ao cliente- usando as tecnologias de e-business e os conceitos nos processos de serviço dos clientes cria o conceito de selfservice para o cliente. Serviço ao cliente foca em atrair, auxiliar e manter cleintes lucrativos. Para alcançar um modelo bem sucedido de cliente self-service, softwares front-end de e-business devem estar integrados com os sistemas de back-office, dando aos consumidores um acesso controlado e seguro aos dados requeridos.

\subsubsection{FATORES CRÍTICOS DE SUCESSO NA ADOÇÃO DE E- BUSINESS POR EMPRESAS TRADICIONAIS}

Passado o primeiro momento do nascimento do e-business na Internet, onde muitas empresas não alcançaram os resultados esperados, as empresas agora querem promover iniciativas que tenham um resultado efetivo.

Entende-se por fatores críticos de sucesso aqueles fatores que devem estar presentes e não podem ser negligenciados numa implantação de e-business para garantir que a mesma seja bem sucedida e consiga atingir os objetivos propostos. Um fator crítico de sucesso tem caráter classificatório, meritório, enquanto uma barreira tem caráter restritivo. 
A literatura descreve uma série de prescrições como sendo fatores críticos de sucesso ao empreendimento de e-business.

Alguns fatores descritos por Kanter (2001) ilustram os dez maiores erros que uma empresa pode cometer ao implantar o e-business:

1. Espalhar pequenas iniciativas de e-business da empresa ao longo da estrutura organizacional: desperdício com alternativas menores que podem não trazer nenhum lucro ou vantagem adicional para a empresa.

2. Formar comitês de criação das novas áreas de Internet, com pessoas de áreas não relacionadas que já estejam responsáveis por mais cinco trabalhos cada, sem as libertar de seus trabalhos regulares. Essa é uma maneira de não priorizar a iniciativa de e-business.

3. Encontrar soluções mais simples e menos trabalhosas de e-business, sem uma análise de custo benefício. Por exemplo Criar um website e achar que seu trabalho acabou por aí. Eles não interligam com o sistema de pagamentos, não pensam se vão operar 24 horas, não pensam nada sobre a marca da empresa.

4. Contratar fornecedores que não compartilham da mesma cultura da empresa. Outro erro comum é criar uma competição entre dois fornecedores desenvolvendo simultaneamente o mesmo trabalho, por falta de confiança no trabalho dos fornecedores.

5. Um erro comum é duplicar simplesmente o negócio tradicional da empresa, criando uma alternativa semelhante on-line e encarando a Internet como uma ferramenta isolada.

6. Insistir em aplicar todos os padrões do negócio tradicional ao negócio virtual: controles de custo, rendimentos, fontes de recrutamento, políticas de remuneração, procedimentos de compras.

7. Sob a bandeira da descentralização e autonomia das unidades de negócio, recompensar cada unidade por sua performance individual, e não oferecer nenhum incentivo extra para cooperar com a unidade virtual da sua empresa.

8. Comparar a performance da empresa somente com competidores tradicionais no mundo físico, tratando os competidores on-line como 
efêmeros, e sem considerar a possibilidade de outras empresas de indústrias não relacionadas poderem roubar os clientes da empresa usando a Internet. As empresas da internet são empresas mais livres em determinarem sua própria direção, fazendo com que possam atuar em outros mercados.

9. Disponibilizar aos seus funcionários ferramentas que eles são incapazes de usar, requerendo mudanças que os confundem.

10. E por último, esquecer-se de que é o cliente quem dirige o negócio. Encarar a Internet como uma oportunidade para que a empresa se comunique com os clientes é um erro na medida em que ignora a contribuição que os clientes teriam para dar à empresa, sob a forma de informação.

Os erros descritos acima levaram a autora a tecer algumas considerações sobre os fatores de sucesso para a implantação de e-business:

1. Na dúvida sobre fazer grandes investimentos em e-business ou não, crie pequenos experimentos que tragam rápidos resultados e possam convencer os mais resistentes a mudanças.

2. Novos negócios necessitam times dedicados com espaço e autonomia; esses times precisam ser responsáveis quanto à realidade dos negócios além de ter algum responsável na hierarquia mais alta da empresa para arcar com as maiores responsabilidades.

3. Reconhecer que o e-business exige mudanças sistêmicas em muitas maneiras de trabalhar. São necessários bons negociadores para negociar através da empresa, ou não se conseguirá superar os obstáculos.

4. É mais fundamental ter a cultura certa do que a estratégia certa. As chaves para o sucesso não estão fora na Internet, mas dentro, nas atitudes e cultura da organização frente às mudanças.

Nesse sentido, Weil e Vitale (2001) destacam que é necessário identificar quais as competências essenciais da empresa para que se escolha um modelo de e-business adequado a essas competências. 
É importante que após uma análise estratégica das competências essenciais da firma, e das oportunidades e ameaças analisadas, estabeleça-se um portfolio de iniciativas de e-business, que serão escolhidas a partir dos benefícios gerados por cada uma.

Para se obter melhores resultados para se montar uma estratégia de ebusiness, os autores sugerem que se forme um time de pessoas com os seguintes atributos:

- pessoas que tenham contato com o cliente e com entendimento da estratégia da firma

- tecnólogos que trabalhem para firma há algum tempo

- pessoas com experiência prática, voltadas para o mercado

- gerentes seniores que tenham a ganhar com a iniciativa

- pessoas orientadas a resultados e finanças assim como o executivo de finanças

Uma empresa não é transformada porque cria um site na Internet: o sucesso exige repensar o modo como todo trabalho na organização é realizado.

Turban (2000) indica como fatores críticos de sucesso:

- Conduzir educação e treinamento necessários;

- Rever os modelos atuais de distribuição e de cadeia de suprimentos;

- Entender o que os clientes e parceiros esperam da Web;

- Reavaliar a natureza dos produtos e serviços (torná-los digitais se possível);

- Dar um novo papel para o departamento de recursos humanos;

- Estender os sistemas atuais para fora da empresa, linkando os produtos da empresa com outros diretórios, comunidades bem como integrando as atividades de back-end com as intranets de parceiros e fornecedores;

- Encontrar novas fatias de mercado;

- Desenvolver uma estratégia de Marketing "web-centrada";

- Participar na criação e desenvolvimento de um marketplace virtual;

- Instalar um estilo de gestão baseado em e-business. 
- Segundo Slywotzky (2000) para que uma iniciativa de e-business seja bem sucedida é necessário que:

- Os executivos responsáveis pela iniciativa devem focar no consumidor e em elementos de um bom "design" de negócios em primeiro lugar e depois na tecnologia. Devem entender que a digitalização é valorosa somente se aumenta a proposição de valor para o consumidor.

- Os executivos devem partilhar uma clara visão e focar nos problemas chave da empresa e como o desenho de negócio precisa mudar para resolver esses problemas

- Os executivos precisam comunicar numa linguagem comum quando discutirem os problemas, necessidades, planos e visões para as pessoas de desenvolvimento internas e externas à firma.

- A mudança provocada pelo e-business deve acontecer nas mentes das pessoas da própria firma, senão elas nunca estarão comprometidas com o negócio.

- Investir tempo e dinheiro para comunicar a estratégia de e-business e o desenho do negócio de forma clara e contínua de modo a cada membro da organização estar "conectado" ao alto executivo

- Plant (2000) descreve como fatores críticos de sucesso para a implantação de e-business os seguintes aspectos:

- Quanto à estratégia: foco em alinhamento entre estratégia corporativa e estratégia de e-business e planejamento para implantação

- Quanto à estrutura: foco em tornar-se uma e-organização. A empresa deve alavancar seu extenso auto conhecimento e conhecimento do mercado para reduzir seus custos e recriar seus processos de uma maneira mais flexível

- Quanto a sistemas, a empresa deve focar em integração de tecnologias.

- Quanto a pessoas, o papel do ClO: reter pessoal de perfil técnico e gerencial; identificar parceiros e consultores externos. Construir 
confiança interna, comunicação e criar oportunidade de crescimento para os empregados.

- Quanto aos perfis, o papel do ClO: gerir os relacionamentos, desenvolver flexibilidade interna, desenvolver uma atmosfera de intraempreendedores, desenvolvendo perfis técnicos.

- Quanto a estilo e valores compartilhados: liderança deve vir do topo; a tecnologia permite à organização adicionar valor ao consumidor através de provisão de informação.

Assim, os fatores críticos de sucesso podem ser divididos nas seguintes categorias: aspectos relativos a pessoas (formação de equipes, atribuição de autoridade e responsabilidades, envolvimento da alta administração, comprometimento dos funcionários, treinamento, capacitação das pessoas) , aspectos relativos a tecnologia (integração de tecnologias, sistemas compatíveis com transações nas redes), aspectos relativos à estrutura da organização, aspectos relativos a processos de negócio, aspectos relativos a cultura da organização, aspectos relacionados a relacionamento com clientes, fornecedores e parceiros.

Segundo Weil e Vitale (2001) os dez princípios que a liderança de uma empresa deve observar para garantir o sucesso de uma iniciativa de e-business são:

1. Migrar em direção ao e-business combinando as forças do "place" e do "space" - A migração do negócio real para o virtual e a certa combinação entre os dois modos de operar vai depender de respostas a certas questões: Quais são realmente as competências da firma?; Como podemos nutrir essas competências? Qual nossa posição na cadeia de valor da indústria?

2. Identificar os valores de e-business e suas "liabilities" e a dimensão dos desafios e oportunidades

3. Investir num portfolio de iniciativas de e-business

4. Identificar e investir em blocos de e-business baseados nas "core competencies" 
5. Criar uma cultura de experimentação estratégica

6. Analisar o modelo de negócios, os canais, os segmentos e a capacidade de infra-estrutura de ATI quando avaliar cada iniciativa de e-business

7. Proteger e utilizar o que a firma possui: os relacionamentos, os dados e transações.

8. Liderar a determinação das capacidades requeridas de infra-estrutura de TI

9. Entender as características do modelo de negócios e-business

10. Preparar-se para a aquisição de empresas ".com"que tem um perfil que encaixa na firma e que esteja tendo problemas de fluxo de caixa.

O'connel (2000) cita alguns fatores que tornam o processo de implantação de e-business mais fácil:

- Questionar tudo - perguntar sobre que produtos desenvolver, grupos de consumidores a serem atingidos, processos necessários para atingir as demandas dos clientes; evidenciar possíveis conflitos.

- Estabelecer objetivos - listar itens mensuráveis a serem atingidos com o funcionamento do e-business. Trabalhar em times, com experiência de planejadores para definir pressupostos, eventos do negócio, regras e fatores críticos de sucesso.

- designar um responsável pelo e-business para legitimar a iniciativa

- Manter canais de comunicação abertos para ouvir e responder

- trabalhar em equipe

- Elaborar uma avaliação do negócio e cronograma para atividades de longo prazo

Principais barreiras/dificuldades à implantação de e-business pela empresa:

Vários autores (Turban (2000), Kalakota (1999), Plant (2000), Lientz (2001)) recomendam a criação de um time representado por várias áreas funcionais e a elaboração de um planejamento com detalhes de ordem tecnológica, como "Web hosting”, segurança e controle. A não criação desse time 
pode ser considerada como uma barreira à implantação da iniciativa de ebusiness.

Lientz (2001) descreve uma série de barreiras à implantação do ebusiness, quais sejam:

1. Barreiras internas de natureza técnica e tecnológica:

2. Muitos dos sistemas existentes nas empresas foram desenhados para funcionar antes do fenômeno "e-" ou ".com".

3. Resistência dos funcionários ao negócio

4. Processos de negócio e Políticas atuais da empresa

5. A Organização existente de negócios

6. Influência do cliente e/ou fornecedor

7. Problemas de Cultura

8. Demanda competitiva por recursos

9. Expectativas da alta administração

Uma possível dificuldade surgida com a implantação do e-business por empresas tradicionais refere-se a conflitos de canal:

A Internet oferece um novo canal para o consumidor final, e as empresas podem considerar a possibilidade de deixar seus canais existentes e seus parceiros, o que pode causar um conflito de canal.

WEILL e VITALE (2001) citam um exemplo de conflito de canal, que acontece quando o mesmo consumidor final poderia conseguir duas proposições de valor pelo canal direto (vendas on-line) ou pelo canal intermediário (via distribuidores) de uma empresa alimentícia. Os autores propõem algumas opções que poderiam evitar um conflito de canal:

Segmentar por cliente: utilizar um segmento-alvo de clientes on-line diferente do segmento-alvo utilizado pelo canal tradicional.

Segmentar por produto: é uma outra alternativa para diferenciar o alvo da empresa tradicional do alvo de suas vendas pelo canal direto on-line.

Redefinir as responsabilidades do revendedor: redefinir as atividades tanto da empresa quanto do revendedor, por exemplo deixando com que o test 
drive seja feito pelo revendedor, mas o pedido do produto seja feito pelo site. As vendas portanto teriam sua porcentagem redistribuída.

Nova marca: desenvolver uma nova marca on-line, que tenha uma proposição de valor diferente da marca tradicional para o consumidor.

Direcionar as vendas para o distribuidor: nesta alternativa, a empresa estaria utilizando o canal on-line para estabelecer relacionamento com o cliente, e não necessariamente as vendas.

\subsection{ASPECTOS DA SITUAÇÃO ATUAL DO E-BUSINESS NO BRASIL}

A Pesquisa de Comércio Eletrônico no Mercado Brasileiro comprova a evolução do CE neste mercado, com um aumento de utilização das aplicações de CE pelas empresas e também um aumento do número de empresas que passaram a utilizar os meios eletrônicos nos seus processos de negócio. Embora os índices de valores praticados neste ambiente em relação ao mercado como todo, seja ainda baixo, apresentam crescimento significativo.

As empresas cada vez mais estão utilizando a infra-estrutura de Internet e das aplicações de CE como os meios para a realização de seus processos de negócio, com clara predominância daqueles relativos ao atendimento a cliente, conforme apresenta a figura 10. 


\section{FIGURA 10: EVOLUÇÃO DO CE E OS PROCESSOS DE NEGÓCIO}

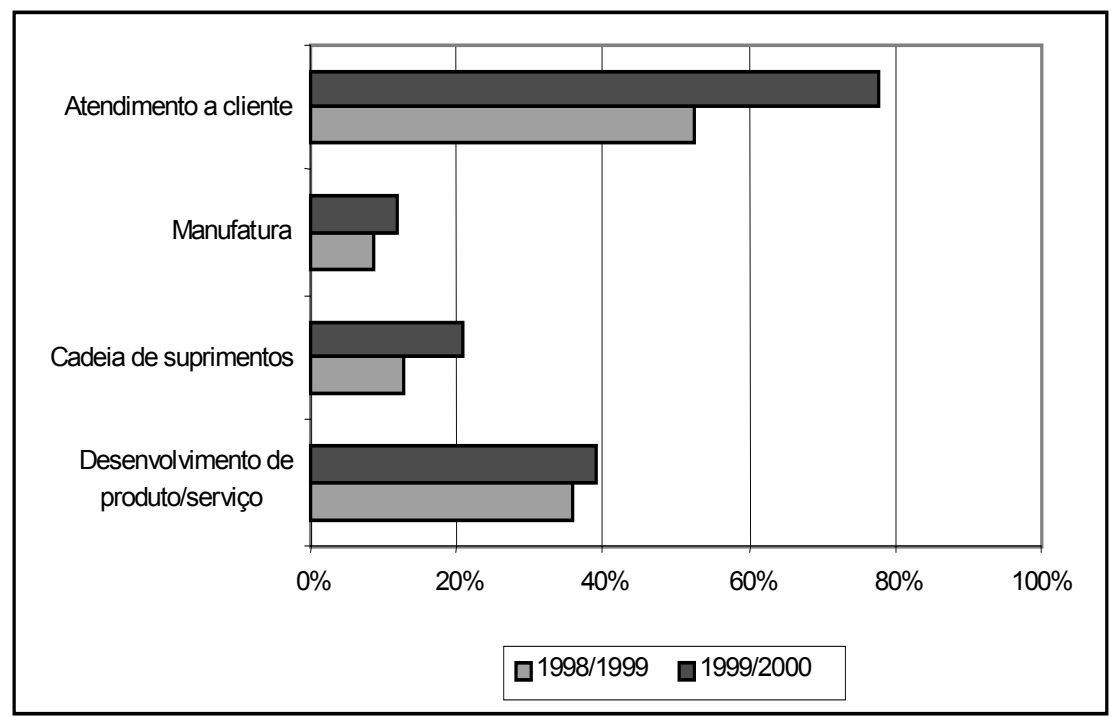

Fonte: Albertin (2000c)

Esta utilização ainda está significativamente voltada para a disponibilização de informações institucionais e de produtos e serviços, mas com clara tendência de realização de transações.

O Setor de Comércio é o que apresenta maior índice de utilização de CE no seu relacionamento com clientes, sendo que esta situação é bastante influenciada pela utilização de Home Page e catálogos eletrônicos para a divulgação de informações para os clientes, conforme apresenta a figura 11.

\section{FIGURA 11: CE NO RELACIONAMENTO COM CLIENTES}

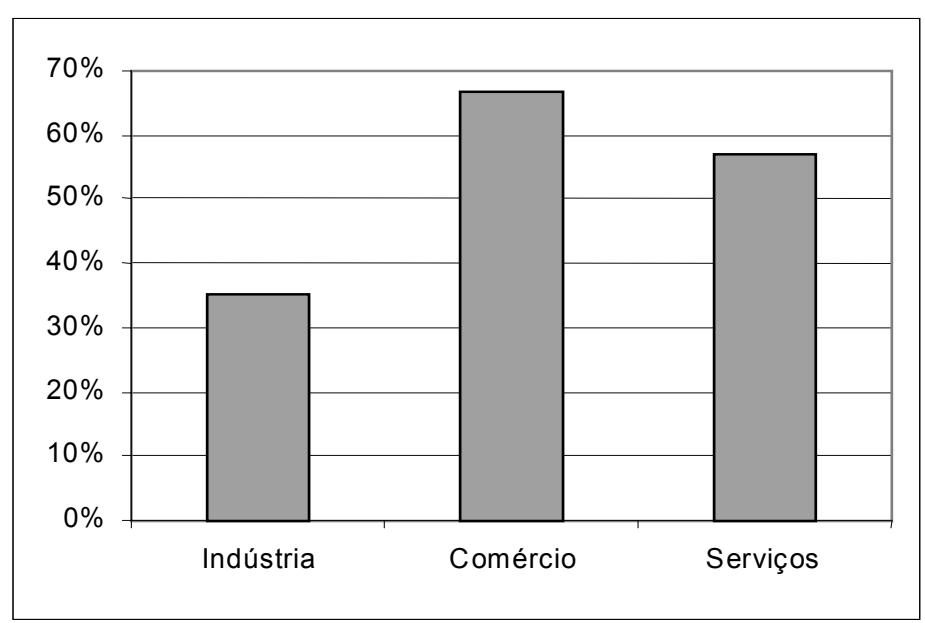

Fonte: Albertin (2000c) 
Os processos referentes a atendimento a clientes são os que apresentam maiores índices de utilização das aplicações de CE, justificando uma análise mais detalhada dos seus subprocessos.

Um número bastante elevado de empresas utiliza as aplicações de CE nos seus subprocessos de Divulgação de Informação sobre Produtos/Serviços, conforme apresenta a figura 12.

\section{FIGURA 12: CE NOS PROCESSOS DE ATENDIMENTO A CLIENTES POR SUBPROCESSOS}

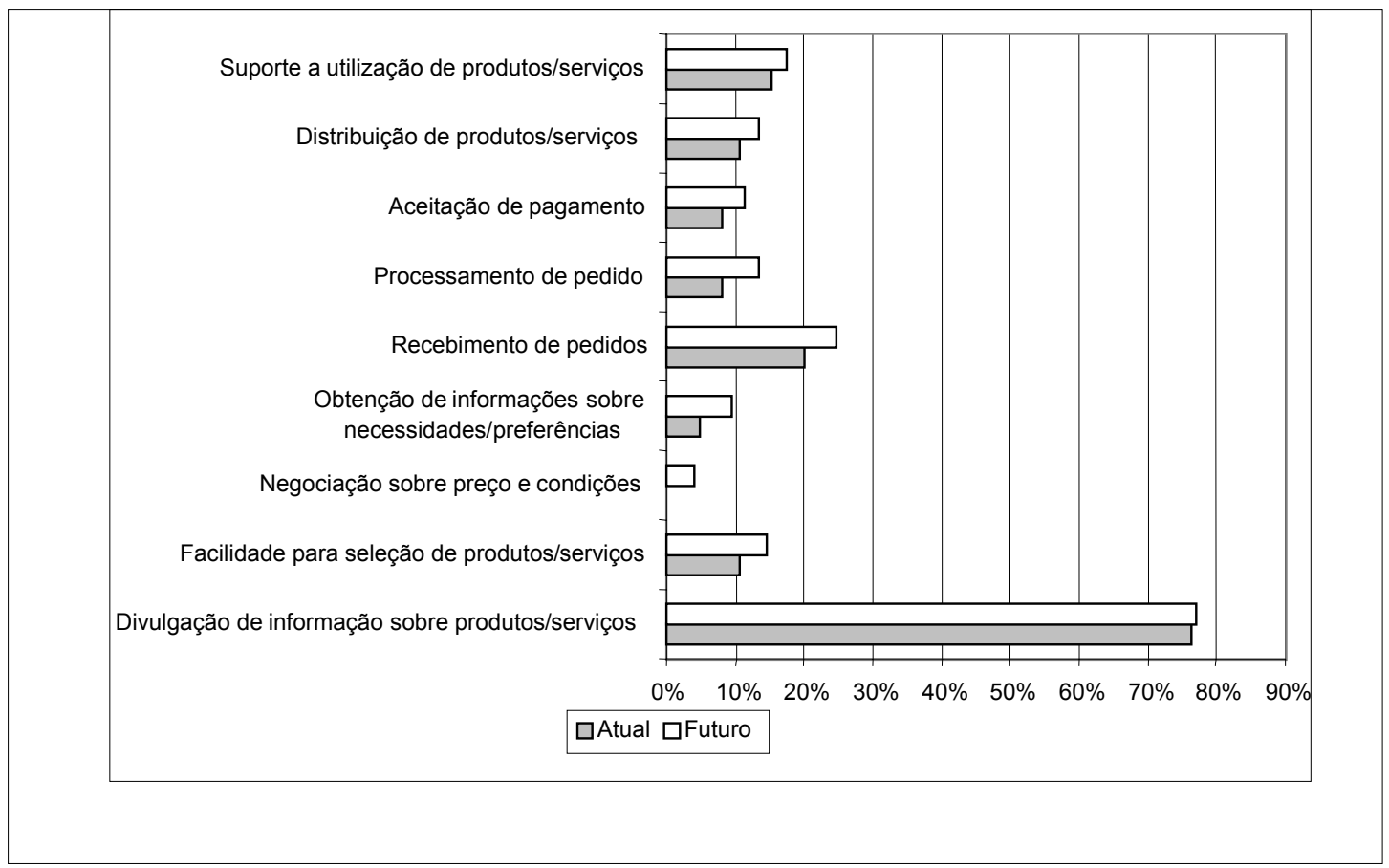

Fonte: Albertin (2000c)

Em relação aos demais subprocessos, o número de empresas que os utilizam é significativamente menor, sendo que esta situação tem previsão de algumas mudanças por parte das empresas.

A utilização das aplicações de CE apresenta bastante aderência em relação aos processos de negócio nos quais são utilizadas, concentrando-se nas aplicações já consideradas consolidadas, conforme apresenta a figura 13. 


\section{FIGURA 13: EVOLUÇÃO DA UTILIZAÇÃO DAS APLICAÇÕES DE CE}

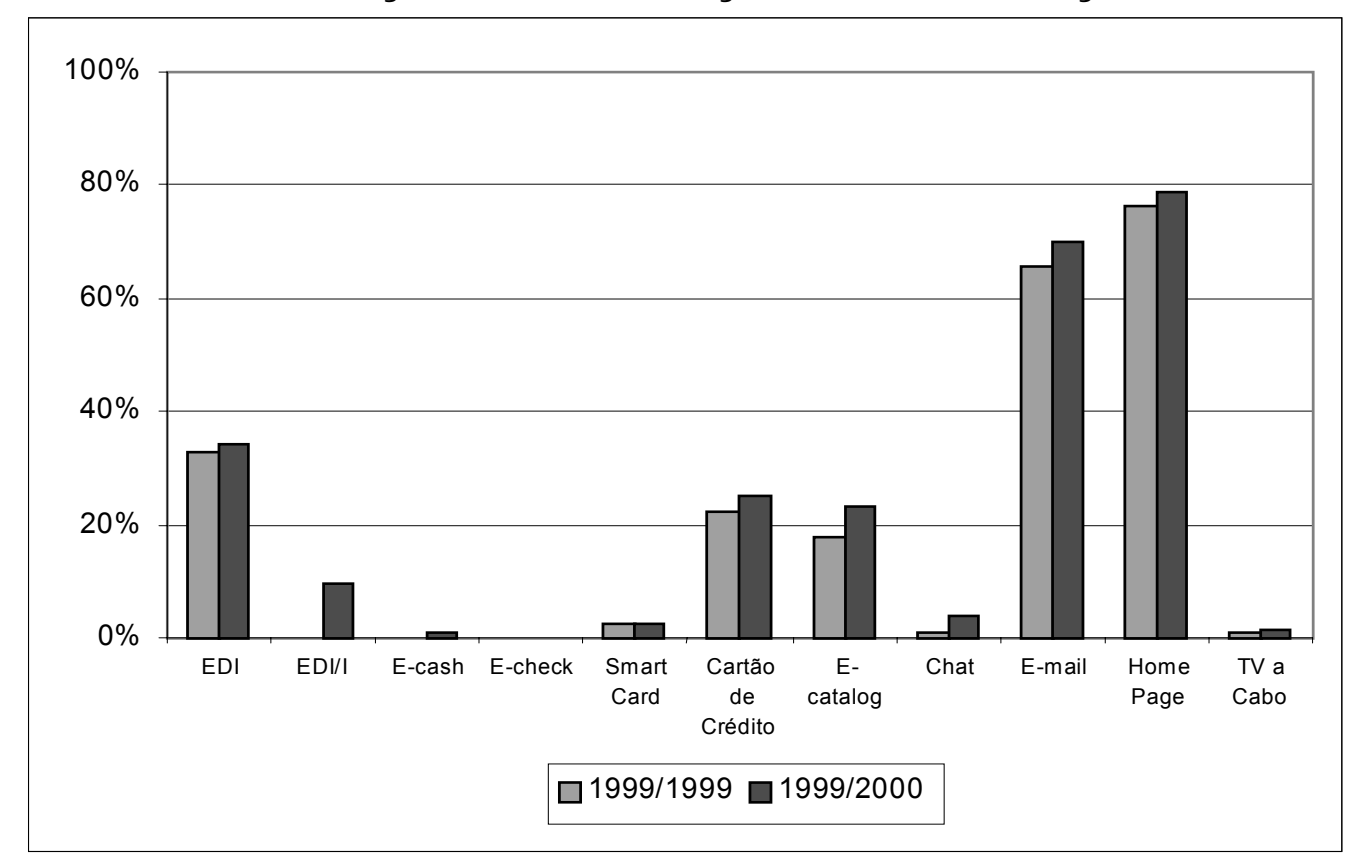

Fonte: Albertin (2000c)

As aplicações utilizadas permitem que as empresas assimilem este novo ambiente digital sem grandes revoluções imediatas, tanto para a adoção por parte de seus participantes como de seus fornecedores e clientes.

As aplicações com maior utilização são aquelas necessárias para a realização dos subprocessos que as empresas estão mais fortemente direcionando para o ambiente digital.

A maior mudança prevista é em relação à utilização da troca eletrônica de dados pela Internet, confirmando que as empresas percebem a Internet como uma infra-estrutura pública que permite realizar integração eletrônica com restrições mínimas.

Na sua pesquisa, Albertin (2000c) conclui que as aplicações de CE mais intensamente utilizadas pelas empresas pesquisadas ainda são basicamente aquelas que já podem ser consideradas como bastante assimiladas neste novo ambiente de Internet, incluindo Home Page, correio eletrônico e troca eletrônica de dados. 
A utilização das aplicações de CE para a integração das empresas com seus clientes já é praticada por aproximadamente $60 \%$ das empresas pesquisadas, destacando-se aquelas dos setores de Comércio e Serviços.

Atualmente, as empresas estão utilizando as aplicações de CE principalmente nos processos referentes à divulgação de informações sobre produtos e serviços. A previsão das empresas é que os próximos processos a serem apoiados nestas novas tecnologias serão os referentes a transações e troca de informações.

O desempenho da infra-estrutura pública de comunicação, Internet, utilizada pelas aplicações de CE ainda não restringe a sua utilização pelas empresas. Porém, esta situação pode vir a restringir com a expansão nos processos que envolvam transações e conteúdo. As mudanças tecnológicas atuais demonstram que o ambiente está sendo preparado para evitar tal situação.

Os aspectos avaliados como relevantes na Pesquisa de Albertin demonstram amplamente o amadurecimento do mercado brasileiro em relação ao $\mathrm{CE}$, ao considerar os aspectos necessários para mais um ciclo de expansão da utilização dos meios eletrônicos nos processos de negócio, conforme apresenta a figura 14.

\section{FIGURA 14: EVOLUÇÃO DA AVALIAÇÃO DOS ASPECTOS DE CE}

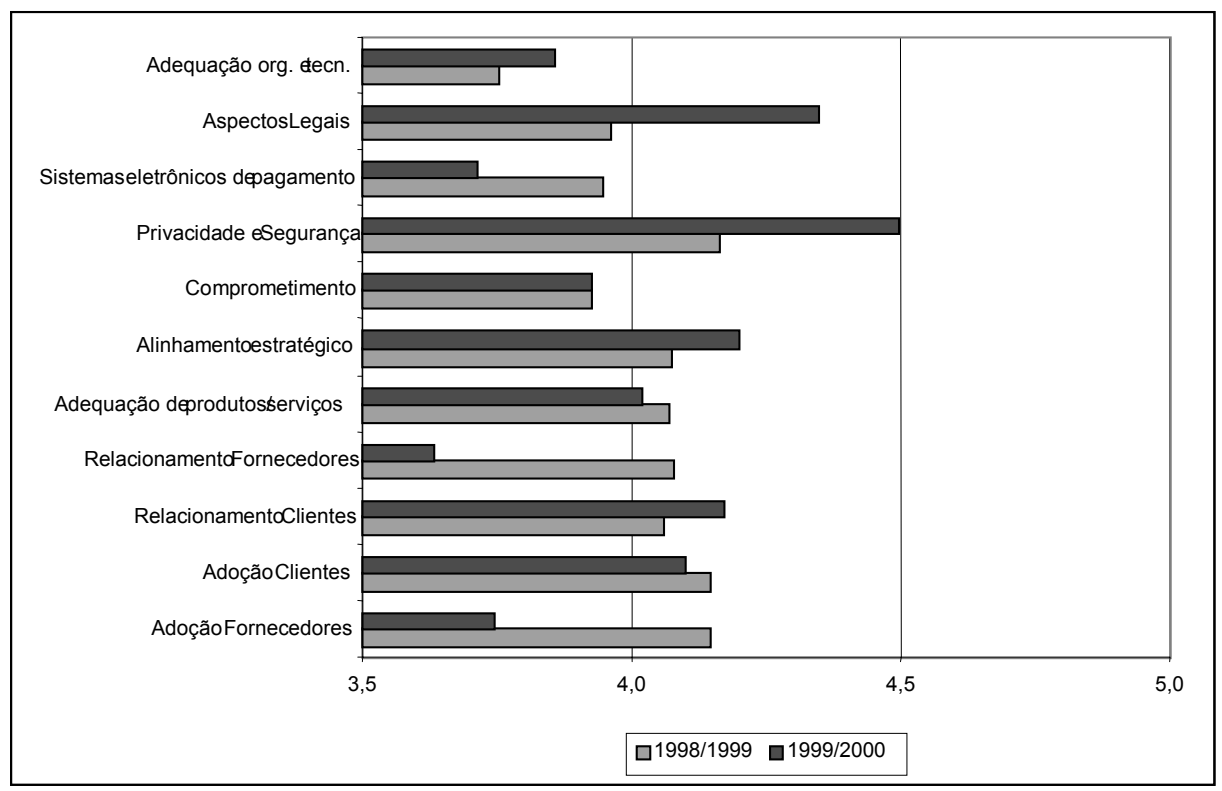

Fonte: Albertin (2000c) 
As empresas avaliam como mais importantes os aspectos de segurança e legais, o que é considerado coerente com a utilização atual e as tendências; ou seja, a busca pela utilização de CE nos processos que envolvem troca de informação e transações exige um ambiente com segurança mais efetiva, ao mesmo tempo que as características deste novo ambiente exigem revisão e adequação dos aspectos legais atuais para sua expansão.

A mudança mais importante está relacionada com a distinção que as empresas estão fazendo entre os vários aspectos, deixando de considerar tudo ao mesmo tempo importante e privilegiando aqueles relativos à segurança e a privacidade, condição necessária para a evolução do CE.

Os próximos aspectos que devem receber maior atenção das empresas são a adequação organizacional e tecnológica, o relacionamento com fornecedores e os sistemas eletrônicos de pagamento, para viabilizar a utilização das aplicações de CE para a realização de transações.

A avaliação das contribuições oferecidas pelo CE também demonstra o amadurecimento do mercado brasileiro e a coerência com a importância atribuída aos vários aspectos, conforme apresenta a figura 15.

\section{FIGURA 15: EVOLUÇÃO DA AVALIAÇÃO DAS CONTRIBUIÇÕES DE CE}

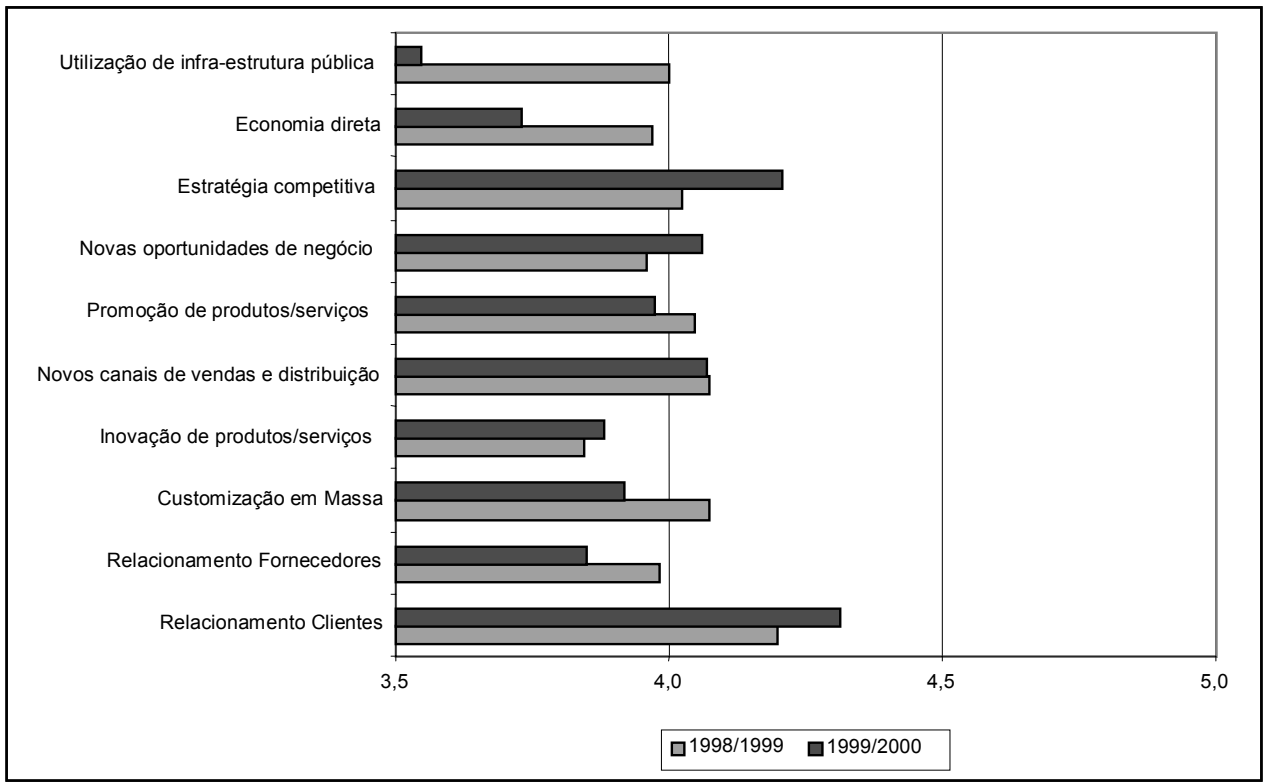

Fonte: Albertin (2000c) 
A consolidação da melhoria do relacionamento com clientes confirma o CE como sendo o grande facilitador da integração eletrônica da empresa com seus clientes, que permitirá a realização de processos voltados para a identificação e satisfação das necessidades destes.

Esta situação garante melhores armas competitivas para as empresas e a exploração de novas oportunidades e a utilização de novos canais de vendas e distribuição.

Os resultados da Pesquisa de Comércio Eletrônico no Mercado Brasileiro permitem concluir que as empresas já estão efetivamente utilizando o CE, porém ainda focando somente uma parte dos seus processos de negócio, que são aqueles referentes ao relacionamento externo com seus clientes. O próximo estágio da sua evolução será permear também os processos internos e integrálos com os externos de forma automática, criando o novo ambiente de negócio.

\subsection{IMPLANTAÇÃO DE E-BUSINESS VISTO SOB A ÓTICA DE PROJETOS - GESTÃO DE PROJETOS}

Segundo Shtub et al (1994), projeto pode ser definido como um conjunto de esforços para cumprir uma tarefa específica não rotineira ou de baixo volume.

Embora projetos sejam não repetitivos, eles podem tomar uma quantidade significativa de tempo e podem ser grandes ou complexos o suficiente para serem geridos de forma separada das ações rotineiras.

Para Lewis (1995) é um trabalho único que tem início e final definidos , um objetivo claramente definido ou um escopo de trabalho a ser executado, um orçamento pré-definido e usualmente uma organização temporária que é desmantelada uma vez que o projeto esteja completo.

Para Kerzner (1992) um projeto pode ser considerado uma série de atividades e tarefas que :

- tem um objetivo a ser completado dentro de certas especificações

- tem datas de início e final definidos

- tem limites de orçamento 
- consome recursos.

Para Obrien (1974) a gestão do projeto ocorre quando a gestão dá ênfase e espcial atenção em conduzir atividades não repetitivas com o propósito de atingir um único conjunto de objetivos.

A gestão do projeto envolve o planejamento do projeto e seu monitoramento e inclui alguns itens:

- Planejamento do projeto

- Definição das necessidades de trabalho

- definição da quantidade de trabalho

- definição dos recursos necessários

- Monitoramento do projeto

- Acompanhamento do progresso

- comparação da situação atual com a prevista

- análise dos impactos

- fazer ajustes

Um projeto bem administrado deve alcançar os seguintes objetivos:

- dentro do tempo

- dentro do custo

- atingir a performance desejada ou nível tecnológico

- utilização dos recursos designados efetivamente e eficientemente

Os benefícios potenciais da gestão do projeto são:

- Identificação das responsabilidades das funções para assegurar que todas as atividades sejam levadas em conta

- Minimizar a necessidade de "reports" contínuos

- Identificação dos limites de tempo para o cronograma

- Identificação de uma metodologia para análises de custo-benefício

- Mensuração do que foi realizado contra os planos

- Identificação inicial de problemas de tal forma a proceder ações corretivas

- Melhorar a capacitação para planejamentos futuros

- Saber quando objetivos não podem ser alcançados ou serão excedidos 
Segundo Kerzner(1992) e Lewis (1995) a gestão do projeto é o planejamento, organização, direção e controle dos recursos de uma companhia para um objetivo de relativo curto-prazo que foi estabelecido para atingir objetivos e metas específicos.

Para Kerzner, a gestão de projetos utiliza a abordagem de sistemas para gestão, utilizando estrutura funcional (a hierarquia vertical) designada para um projeto específico (hierarquia horizontal). Essa abordagem também pode ser chamada de matricial.

Segundo Shtub (1994) a gestão de projetos difere da gestão de uma empresa típica. $O$ objetivo de um time de projeto é alcançar sua missão prédeterminada e se desfazer. Poucas firmas estão num negócio para atingir apenas um objetivo e então desaparecer.

Num projeto, um time é colocado junto dentre pessoas que normalmente tem suas funções em outras partes da organização. Essas pessoas podem ser designadas para trabalhar "full-time" no projeto até sua conclusão ou podem ser designadas para trabalhar apenas parte do tempo no projeto e dispender o resto do tempo com suas atividades rotineiras. Depois que o projeto está acabado, o time normalmente se dispersa e seus membros retornam para suas atividades normais.

Como regra geral, segundo Lewis (1995), um projeto tem um ciclo de vida que consiste em 6 fases: concepção, definição, desenho, desenvolvimento ou construção, aplicação e pós-finalização:

Concepção:

- " inputs" de marketing

- estudos sobre a tecnologia, estudos de factibilidade, etc

- um levantamento sobre os concorrentes

- Definição:

- Especificação de objetivos

- estabelecer alvos

- procedimentos para assegurar a qualidade

- estabelecer sistemas de controle 
- estabelecer a organização do projeto

Desenho:

- arquitetura e engenharia do projeto

- revisão dos desenhos

- avaliação de relatórios

- revisar custos e alvos de performance

- Desenvolvimento ou construção:

- Primeiras unidades

- começam campanhas de vendas

- procedimentos de controle de qualidade

\section{Aplicação:}

- instalação e testes de campo

- começa a desmanchar a estrutura

- começa a propaganda

- avaliar e consertar problemas e redesenho

- Pós-finalização

- fim da estrutura montada

- análises posteriores do final do projeto

- relatórios finais

- fechamento

Cleland e King (1988) definem as seguintes fases do ciclo de vida de um projeto:

- Conceituação

- Definição

- Produção

- Operacionalização

- "Livrar-se do projeto"

Conceituação:

- determinar as necessidades existentes ou as deficiências potenciais de sistemas existentes 
- estabelecer conceitos de sistema para prover um guia inicial estratégico para superar as deficiências existentes ou potenciais

- determinar a factibilidade técnica, ambiental e econômica inicial do sistema

- examinar alternativas de cumprir os objetivos do sistema

- Prover respostas iniciais às questões:-quanto o sistema vai custar?;-o sistema estará disponível?;-o que o sistema fará?;-como o sistema estará integrado aos sistemas existentes?;

- identificar os recursos humanos e materiais requeridos para suportar o sistema;-selecionar desenhos iniciais de sistemas que irão satisfazer os objetivos de sistema;-determinar as interfaces do sistema;-estabelecer a organização do projeto

Fase de definição:-preparação de planos detalhados;-determinação de custos realistas, cronograma e requisitos de performance;-identificação e preparação inicial dos documentos requeridos para apoiar o sistema, como políticas, procedimentos, orçamento,etc;

Fase de produção

- atualizar planos detalhados;-identificar e gerir recursos;-verificação das especificações do sistema de produção;-início da produção, construção e instalação;-preparação final e disseminação de política e procedimentos;desenvolvimento de manuais;-desenvolvimento de planos para apoiar o sistema durante fase operacional

Fase operacional:-uso dos resultados do sistema pelo consumidor;integração dos produtos do projeto com os sistemas organizacionais existentes;provisão de feedbacks para os planejadores organizacionais para desenvolvimento de novos projetos e sistemas;-avaliação da adequação dos sistemas de suporte

Fase de "livrar-se do projeto" :-desenvolvimento de planos transferindo responsabilidades para as organizações de suporte;-transferência de recursos para outros sistemas;-desenvolvimento de "lições aprendidas com o sistema" para inclusão em dados qualitativos e quantitativos:

- $\quad$ avaliação da imagem para o consumidor 
- $\quad$ maiores problemas encontrados e suas soluções

- $\quad$ avanços tecnológicos

- avanço no conhecimento

- novas ou melhores técnicas de gestão

- recomendações para futuras pesquisas.

A variabilidade de medidas a serem feitas durante as fases do projeto focam em certas dimensões genéricas de projeto: custo, tempo e performance.

Segundo Pinto e Slevin (1988) identificaram os fatores mais críticos para o sucesso de um projeto, quais sejam:

- Missão do projeto-clareza inicial dos objetivos e duração geral do projeto

- Apoio da alta administração-comprometimento da alta administração para prover os recursos necessários e autoridade ou poder para o sucesso do projeto

- Cronograma e planos do projeto - especificação detalhada do projeto com os passos e ações individuais para a implementação do projeto

- Consulta ao cliente-comunicação e consulta e escuta ativa para todas as partes envolvidas

- Pessoal-recrutamento, seleção e treinamento das pessoas necessárias para o time do projeto

- tarefas técnicas-disponibilidade das tecnologias necessárias e expertise para cumprir os passos técnicos necessários

- aceitação do cliente-o ato de vender o projeto final para os usuários

- monitoramento e feedback-provisão a tempo de informação de controle abrangente em cada estágio de implantação do processo

- comunicação - provisão de uma rede apropriada e dados necessários para todos os participantes-chave na implementação do projeto

- troubleshooting - habilidade em lidar com crises inesperadas e desvios do plano 


\subsection{ASPECTOS RELACIONADOS À ESTRUTURA ORGANIZACIONAL}

A seguir vários aspectos relacionados a estrutura serão abordados, tais como componentes da estrutura organizacional, principais tipo de estruturas organizacionais, fatores para decisão sobre centralização versus descentralização, dentre outros.

Segundo VASCONCELLOS e HEMSLEY (1997), a estrutura de uma organização pode ser definida como resultado de um processo através do qual a autoridade é distribuída, as atividades são especificadas e um sistema de comunicação é delineado, permitindo que as pessoas realizem as atividades e exerçam a autoridade que lhes compete para a obtenção dos objetivos organizacionais.

Para Vasconcellos (1982), a estrutura é composta por três componentes básicos que estão inter-relacionados: sistema de atividade, sistema de autoridade e sistema de comunicação.

O sistema de atividade é o resultado da alocação de atividades entre membros da organização, que deverá abranger as atividades que se espera da cúpula da organização, dos níveis intermediários e dos níveis mais baixos da hierarquia, de tal modo que cada indivíduo ou agrupamento de indivíduos seja responsável por uma parcela das atividades da organização.

O sistema de autoridade pode ser definido resumidamente como o poder para tomar decisões e comandar pessoas, delegado pela organização ao indivíduo para o exercício de suas funções. O sistema de autoridade é a distribuição deste poder formal a todos os membros da organização, de tal forma que todos saibam as decisões que lhes competem e quais são os seus subordinados diretos.

Para Reinhold (1992) autoridade é o poder garantido aos indivíduos (possivelmente através de suas posições) que o permite tomar decisões finais para os outros seguirem.

Responsabilidade é a obrigação de indivíduos em seus papéis na organização formal de modo a cumprir ordens efetivamente. 
O sistema de comunicação em uma organização é a rede através da qual fluem as informações que permitem o funcionamento da estrutura de forma integrada e eficaz.

A estrutura organizacional tem 3 componentes básicos, ilustrados pelo Quadro 6: a departamentalização, que tem por objetivo definir o agrupamento dos recursos e materiais em Unidades Gerenciais; a definição de atribuições, que especifica as atividades, níveis de atividade e fluxos principais de comunicação, e o nível de formalização, que diz respeito ao grau de especificidade das normas e procedimentos que operacionalizam os dois componentes anteriores.

TABELA 6: COMPONENTES DA ESTRUTURA ORGANIZACIONAL

\section{COMPONENTES DA ESTRUTURA ORGANIZACIONAL}

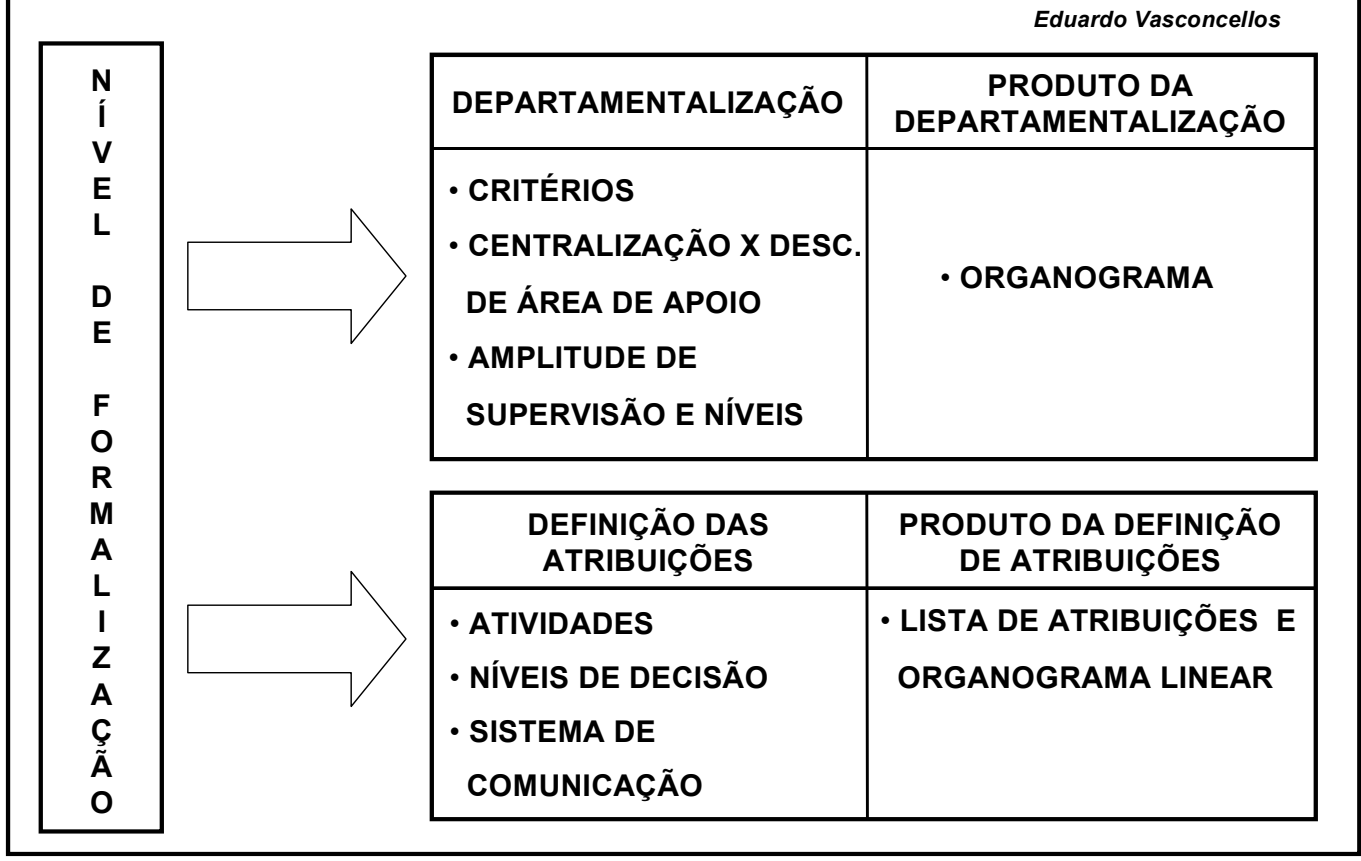

Fonte: VASCONCELLOS e HEMSLEY (1997)

Para Oliveira (1995), há três níveis de influência da estrutura organizacional: o estratégico, o tático e o operacional.

Os condicionantes da estrutura organizacional são os fatores que influenciam em sua definição e desenho, em uma empresa. 
Vasconcellos (apud OLIVEIRA, 1995) resume os condicionantes da estrutura organizacional em:

- objetivos e estratégias;

- ambiente;

- tecnologia;

- recursos humanos.

Assim, os componentes, condicionantes e níveis de influência da estrutura organizacional se combinam de acordo com o quadro 5.

\section{Modelos de Estrutura Organizacional}

\section{Estruturas Tradicionais}

As estruturas tradicionais são aquelas que se constituem em níveis hierárquicos de responsabilidade. Existem vários tipos de estruturas tradicionais, e alguns tipos são descritos a seguir:

\section{Estrutura funcional}

A departamentalização funcional tem como critério básico a área do conhecimento necessário para a realização da atividade. Assim, todas as pessoas que se utilizam dos conhecimentos de uma mesma área ficariam juntas na mesma unidade. A grande vantagem deste tipo de estrutura é permitir uma especialização nas várias áreas técnicas além de melhor utilizar os recursos humanos e materiais nestas áreas.

a) Estrutura funcional pura: 


\section{FIGURA 16: EXEMPLO DE ESTRUTURA FUNCIONAL PURA}

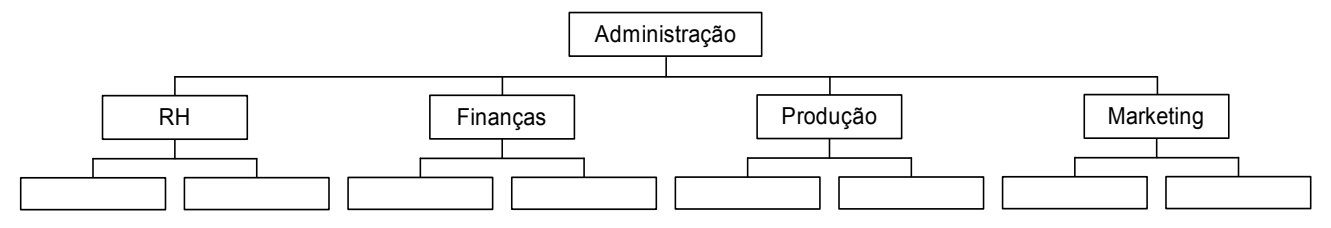

Fonte: Vasconcellos e Hemsley (1997)

b) Estrutura funcional por projeto

A figura 17 mostra um exemplo de estrutura funcional por projeto.

FIGURA 17: ESTRUTURA FUNCIONAL POR PROJETO

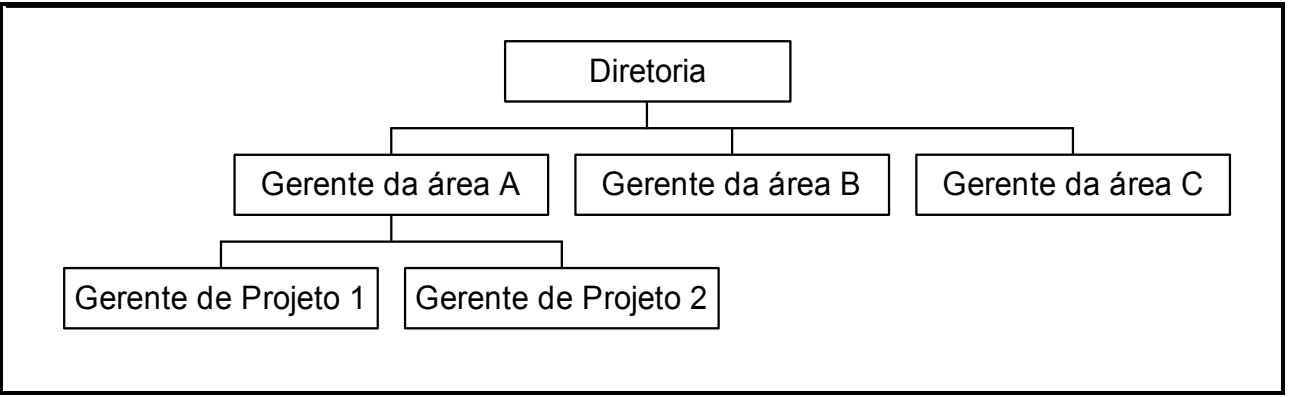

Fonte: Vasconcellos e Hemsley (1997)

Características comuns às estruturas funcionais:

- Altos níveis de formalização

- Unidade de comando

- Especialização elevada

- Comunicação vertical

- Utilização de formas tradicionais de departamentalização

\section{Estrutura Geográfica}


Quando a organização opera em áreas geográficas diferentes e existe necessidade de tratá-las de forma diferenciada, a departamentalização por área geográfica pode ser adotada.

Este tipo de estrutura, por filiais, permite conhecer melhor os problemas de área geográfica.

\section{Estrutura por Processo}

Muitas vezes, as atividades na organização podem ser agrupadas conforme as fases de um processo. Normalmente isso ocorre no setor de produção. Cada uma destas unidades é um departamento que reúne todo o pessoal envolvido naquela fase específica do processo.

\section{Estrutura por Clientes}

Este tipo de estrutura é o mais indicado quando a organização trabalha com diferentes tipos de clientes, exigindo tratamento especializado para cada tipo de cliente.

\section{Estrutura por Produtos ou Serviços}

Quando os produtos da empresa são muito diversificados, é interessante dividir sua estrutura organizacional de acordo com os produtos que a empresa fabrica.

As estruturas de 2 a 5 acima descritas podem resumidamente ser chamadas de estruturas organizacionais divisionais segundo Certo e Peter (1993), que acontece quando a empresa adquire ou desenvolve novos produtos em diferentes indústrias ou mercados.

Cada divisão pode operar de forma autônoma sob a direção de um gerente de divisão, que se reporta diretamente ao presidente.

As divisões podem basear-se em linhas de produtos (automóveis, aviões), mercados (consumidores, compradores industriais), áreas geográficas (norte, sul, internacional) ou canais de distribuição (lojas de varejo, vendas por catálogos).

As vantagens do uso em projetos das estruturas tradicionais segundo Reinholdt (1992) são, dentre outras: facilitar a realização de orçamentos e 
controle de custos, melhor controle técnico, provê continuidade nas disciplinas funcionais, políticas, procedimentos e linhas de responsabilidade são claramente definidas e entendidas; canais de comunicação são verticais e bem estabelecidos.

Desvantagens das estruturas tradicionais: nenhum indivíduo é diretamente responsável pelo projeto total; não provê ênfase necessária numa estrutura orientada por projeto de modo a cumprir tarefas; decisões normalmente favorecem grupos funcionais mais fortes; não há foco no consumidor; resposta às necessidades do cliente são lentas; dificuldade em atribuir responsabilidades.

\section{Estruturas Inovativas}

As estruturas inovativas propõem formas diferentes de lidar com os problemas do que as estruturas tradicionais apresentam. Dentre as estruturas inovativas, destacam-se diversos modelos, cujos principais estão descritos a seguir.

\section{Estrutura de Unidade de Negócio}

A Unidade Estratégica de Negócios (UEN) é adotada por empresas que, devido à elevada diversidade ou tamanho, têm dificuldades em controlar suas divisões.

A estrutura de unidade de negócios é adotada por organizações que possuem linhas de produtos distintas e que requerem estratégias diferenciadas, sendo que algumas atividades ficam centralizadas, tais como as áreas de finanças, planejamento e processamento de dados. Cada Unidade de Negócios tem um nível de autonomia maior do que o proporcionado pela estrutura multidivisional e também conta com centros próprios de apuração de resultados.

Segundo Certo e Peter (1993) algumas vantagens das unidades estratégicas de negócios são: melhora a coordenação entre as divisões, facilita o planejamento distintivo e em profundidade em nível de corporação e negócio, direciona a responsabilidade sobre unidades de negócios distintas.

Desvantagens dessa estrutura: coloca outra camada hierárquica entre as divisões e a administração corporativa, pode aumentar a concorrência pelos recursos corporativos, pode dificultar o papel do vice-presidente do grupo, pode 
aumentar a dificuldade na definição do grau de ayutoridade dos vice-presidentes do grupo e dos gerentes divisionais.

\section{Estrutura de Holding}

De acordo com OLIVEIRA (1995), uma holding pode ser definida como uma empresa cuja finalidade básica é manter ações de outras empresas, que são por ela controladas, o que constitui sua única atividade.

\section{Estrutura Matricial}

A estrutura matricial surgiu como uma solução devido à inadequação da estrutura funcional para as atividades integradas, isto é, aquelas que para serem realizadas exigem interação entre as áreas funcionais. Um aspecto particular da estrutura matricial é a dupla ou múltipla subordinação, o que tende a aumentar o nível de conflitos.

Segundo Reinhold (1992) essa estrutura é aconselhável para empresas condutoras de projetos.

O administrador do projeto reporta diretamente ao vice-presidente e diretor geral e tem total responsabilidade pelo sucesso do projeto.

Quando duas ou mais formas de estrutura são utilizadas simultaneamente sobre os mesmos membros de uma organização, a estrutura resultante chama-se matricial. Assim, como a matriz é uma combinação de estruturas, há vários tipos de estrutura matricial dependendo da dosagem de cada tipo de estrutura combinada.

\section{Matricial balanceada}

Na matricial balanceada - ou matricial pura - a autoridade entre gerentes de projeto e gerentes funcionais é dividida de maneira igual. Isto significa que a área de decisão de um gerente é igual à área de decisão do outro.

Os gerentes de projeto e funcionais têm o mesmo nível hierárquico e graus de autoridade semelhantes, embora em áreas diferentes.

Todos os gerentes de projetos interdisciplinares somente gerenciam projetos, não ocupam cargos funcionais simultaneamente. 
A comunicação entre o gerente de projeto e a equipe técnica do projeto é sempre direta, sem passar através dos gerentes funcionais.

Desvantagens: o nível de conflitos é maior pois a divisão de autoridade é bastante equilibrada

A figura 18 mostra um exemplo de estrutura matricial balanceada.

FIGURA 18: ESTRUTURA MATRICIAL BALANCEADA

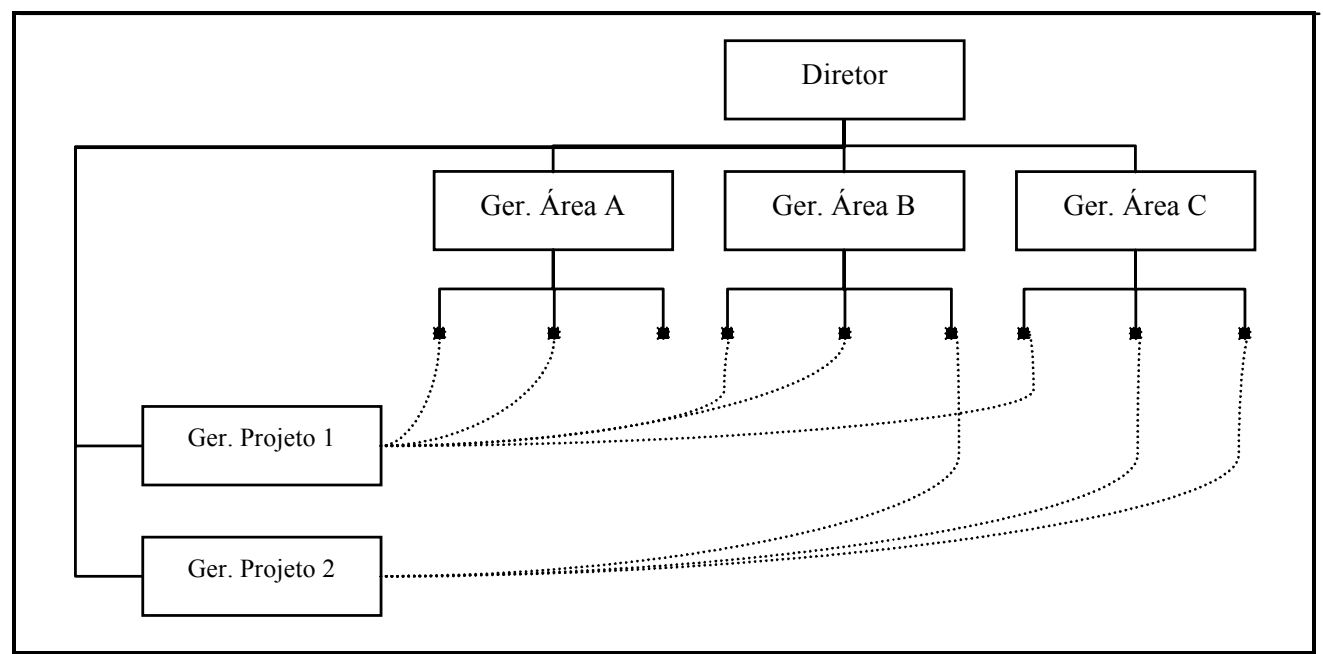

Fonte: Vasconcellos e Hemsley (1997)

\section{Estrutura Matricial Funcional}

É a matriz na qual o nível hierárquico do gerente de projetos é inferior ao do gerente funcional:ele está subordinado a um dos gerentes funcionais. $O$ gerente de projetos está alocado geralmente à área técnica que tem mais afinidade com a natureza do projeto.

Muitas vezes, este tipo de matriz não se reflete no organograma da empresa, parecendo uma estrutura funcional. Mas na operação real, é uma matriz funcional. Este é o tipo de estrutura mais comum, porque é fácil alocar um gerente de projetos abaixo do gerente funcional no caso de um projeto específico.

Este tipo de matriz é muito usado em organizações com poucos projetos interdisciplinares e com baixo grau de prioridade.

A figura 19 mostra um exemplo de estrutura matricial funcional. 
FIGURA 19: ESTRUTURA MATRICIAL FUNCIONAL

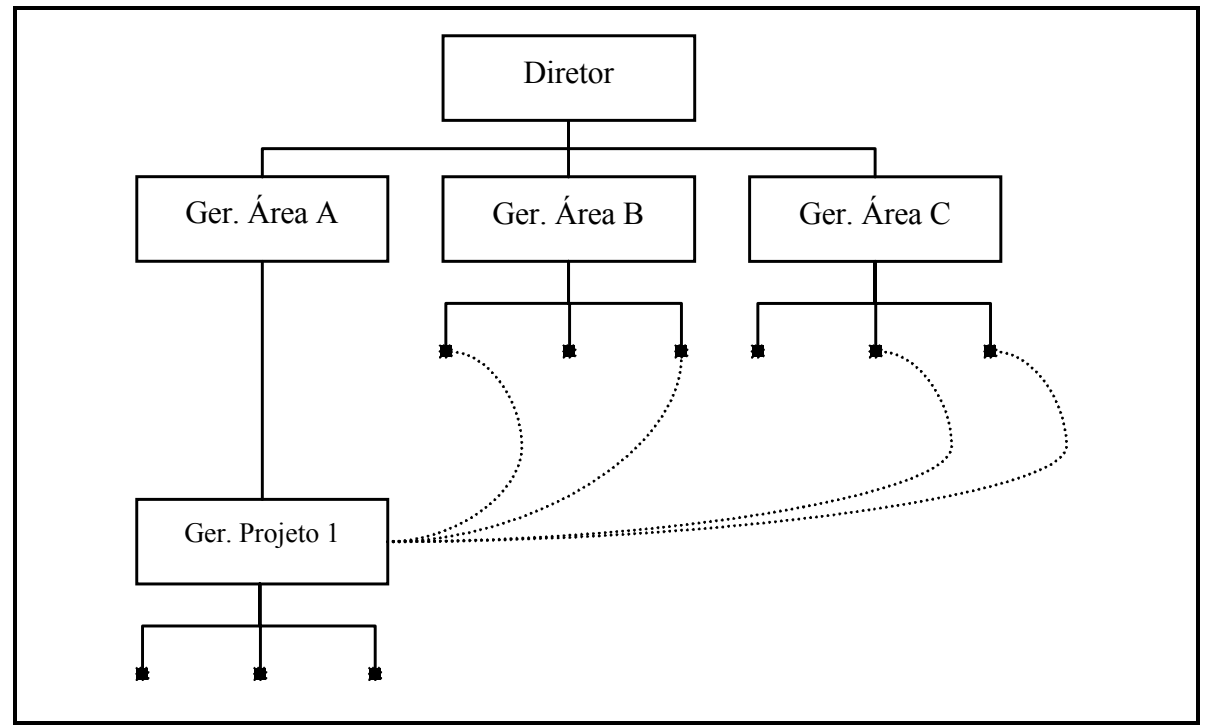

Fonte: VASCONCELLOS e HEMSLEY (1997)

\section{Estrutura Matricial por Projetos}

Neste tipo de matriz, os gerentes de projeto têm nível hierárquico superior aos gerentes funcionais.

Geralmente é utilizada quando os projetos interdisciplinares têm prioridade para o sucesso da Organização. Fisicamente, geralmente os especialistas são transferidos para o local do próprio projeto.

A figura 20 a seguir mostra um exemplo de estrutura matricial por projetos.

FIGURA 20: ESTRUTURA MATRICIAL POR PROJETOS

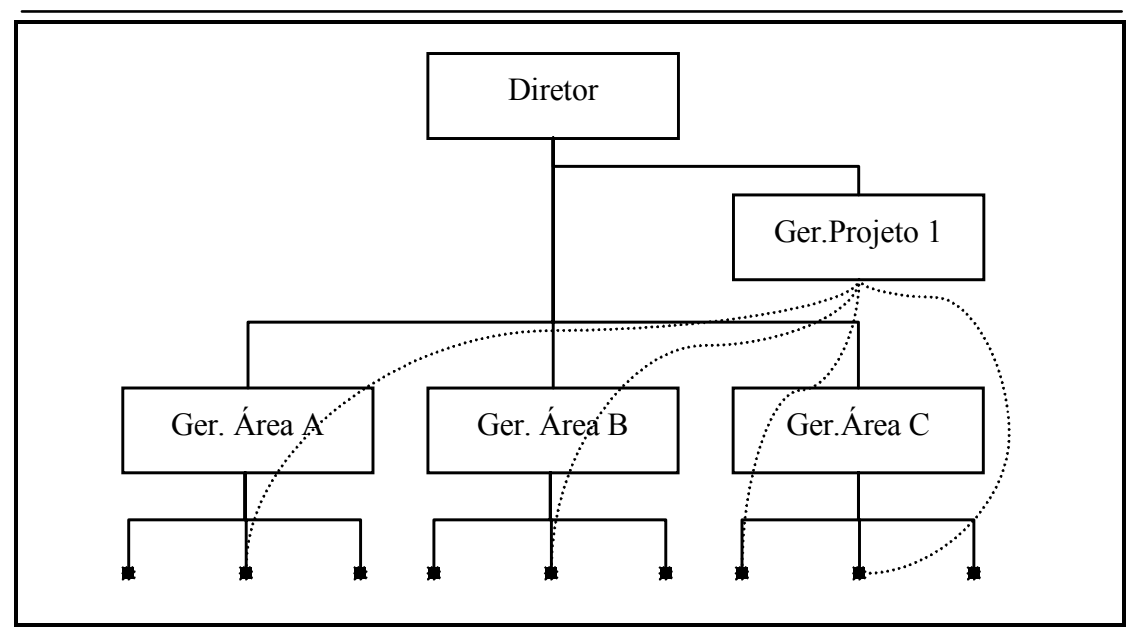

Fonte: VASCONCELLOS e HEMSLEY (1997) 
Vantagens deste tipo de matriz (projeto) sobre ou outros tipos (pura e funcional):

- Cumprimento dos prazos: é maior pois o gerente de projetos tem mais autoridade sobre os recursos

- Controle do orçamento do projeto é maior pois o gerente de projeto tem mais autoridade e controle para o orçamento

Já a eficiência no uso dos recursos é maior na Matricial Funcional porque há muita duplicação de atividades na Matricial por Projetos.

Uma variação da matriz por projetos é a matriz por produtos, que depende do que a empresa vende. Ela surge quando há muitos produtos diferentes, tornando-se necessário um gerente para cada produto ou grupo de produtos. Para tornar seu produto um sucesso, o gerente de produto tem que interagir com várias unidades funcionais da empresa que se relacionam com seu produto.

\section{Geração de conflitos na estrutura matricial}

Os conflitos, na estrutura matricial, acontecem geralmente entre o gerente de projeto e o gerente funcional. As principais causas para este conflito são:

- Utilização de recursos humanos: muitas vezes o gerente de projeto solicita ao gerente funcional aqueles técnicos que ele considera mais adequados para trabalhar em seu projeto. Esta solicitação nem sempre está de acordo com a melhor distribuição das atividades dentro da área funcional, visto que os técnicos prestam serviços a vários projetos.

- Utilização de recursos materiais: como os recursos estão sendo utilizados ao mesmo tempo para vários projetos e também para as atividades especializadas, tendem a serem disputados pelos gerentes funcional e de projetos.

- Prazos, qualidade técnica, abordagem técnica: nem sempre os prazos estipulados pelos gerentes funcionais coincidem com a idéia de prazo que o gerente de projeto tinha. O mesmo acontece com a definição que 
cada um dá à qualidade do projeto, ou com o que consideram ser mais correto no desenvolver das atividades.

- Ambigüidade quanto à autoridade e à responsabilidade: com freqüência se nota elevado grau de informalidade quanto à determinação de autoridade final, o que é muitas vezes uma razão de conflito.

\section{Avaliação da Estrutura Organizacional}

A avaliação da estrutura organizacional é o procedimento através do qual se verifica o que a estrutura organizacional tem de vantagens e de pontos negativos.

Para tanto, de acordo com OLIVEIRA (1995), deve-se fazer um levantamento da estrutura organizacional atual, e um delineamento da estrutura organizacional ideal.

\section{Centralização versus descentralização na estrutura organizacional}

Oliveira (1995) trata a centralização e descentralização como fatores mais ligados a autoridade e responsabilidade de pessoas: centralização é a maior concentração do poder decisório na alta direção de uma empresa.

Descentralização é a menor concentração do poder decisório na alta administração de uma empresa, sendo, portanto, mais distribuído pelos seus níveis hierárquicos.

\section{Principais vantagens da descentralização:}

- possibilidade de gerar maior especialização nas diferentes unidades organizacionais;

- maior tempo à Alta Administração para outras atividades;

- possibilidade de gerar efeito competitivo, o que pode aumentar a produtividade;

- maior facilidade de definição de objetivos e metas para as unidades organizacionais e as pessoas; 
- possibilidade de maior desenvolvimento das pessoas no aspecto administrativo e gerencial;

- possibilidade de maior motivação;

- possibilidade de maior participação;

- possibilidade de atendimento mais rápido às necessidades da empresa e das unidades organizacionais;

- melhor desenvolvimento da capacitação gerencial e profissional;

- tomadas de decisão mais próximas da ocorrência dos fatos;

- diminuição de conflitos entre os vários níveis hierárquicos da empresa;

- tendência a maior número de idéias inovadoras.

\section{Principais desvantagens da descentralização :}

- inabilidade de algumas pessoas em manter observação sobre as modificações das condições locais ou de uma operação complexa, provocando decisões sem visão de conjunto;

- possibilidade de efeitos negativos na motivação;

- risco de duplicar esforços para executar determinadas atividades;

- maior dificuldade de normatização e de padronização;

- maior ineficiência na utilização de recursos (humanos, financeiros, materiais e equipamentos) da empresa e

- maior dificuldade de coordenação de atividades que envolvem alto nível de interdependência.

Vasconcellos (1979) indica quatro condicionantes da estrutura organizacional que devem ser analisados para se identificar os fatores que favorecem a descentralização de uma área na empresa:

Objetivos e estratégia da organização: Dependendo dos objetivos e da estratégia da organização, ela tenderá a descentralizar áreas que podem ser consideradas de apoio na empresa. A descentralização será favorecida, por exemplo, se os objetivos da empresa forem definidos com clareza e largamente aceitos na empresa; outros fatores que favorecem a descentralização de uma área são a possibilidade de se medir com facilidade os resultados da área e a facilidade em se estabelecer ações voltadas ao alcance dos resultados. 
Natureza da atividade e da tecnologia: quanto mais diversificadas forem as atividades e menos interdependentes, mais favorável será a descentralização.

Ambiente externo: a descentralização será favorecida, por exemplo, por uma menor flutuação da demanda, maiores volumes de produção e de demanda de serviços, níveis mais altos de turbulências que geram mudanças constantes no trabalho, maior dispersão geográfica e maior dificuldade de comunicação.

Fator humano: a descentralização será favorecida, por exemplo, quanto maior a capacidade técnica dos funcionários, maior a capacidade de coordenação de seus líderes, maior o grau de informalidade na estrutura e melhor o clima organizacional da empresa.

O Quadro mostra para cada condicionante da estrutura, a situação que favorece a descentralização.

\section{Escolha da forma Organizacional}

Na escolha da forma organizacional, Reinhold (1992) diz que não existe uma boa ou uma má estrutura organizacional, existe a apropriada ou imprópria.

Até os mais simples tipos de mudanças podem causar conflitos: criação de uma nova posição, o aumento ou diminuição do controle, centralização ou descentralização, podem resultar em maiores mudanças no subsistema sóciotécnico.

Ele diz que existem três tarefas que precisam ser consideradas devido a natureza variada das organizações: controle, integração e relações externas.

Para decidir se a melhor estrutura para determinada tarefa é uma estrutura por projetos, algumas características devem ser existir:

- Projeto deve ser definível em termos de objetivos específicos

- Infrequente, único, ou não familiar para a presente organização

- Complexo com relação à interdependência de tarefas detalhadas

- crítico para a empresa

Quatro parâmetros fundamentais devem ser analisados quando se considera a implantação de uma forma organizacional por projetos:

- Dispositivos de integração

- Estrutura de autoridade

- Distribuição de influências 
- Sistema de Informações

A gestão por projetos é um meio de integrar todos os esforços da empresa, especialmente pesquisa e desenvolvimento, ao selecionar uma forma organizacional adequada.

- Duas questões surgem quando se pensa no desenho organizacional para facilitar o trabalho dos integradores:

- É melhor estabelecer um departamento formal de integração ou simplesmente estabelecer posições de integração independentes umas das outras?

- se posições de integração individuais são estabelecidas, como ela deve estar relacionada à estrutura maior?

Segundo Shtub (1994) um projeto pode ser visto como um pequeno negócio dentro de uma grande empresa cujo objetivo último é sair do negócio quando todas as tarefas estiverem completas. Em algum ponto, a empresa tem uma série de projetos em andamento e em várias fases de finalização.

O desafio para a alta direção é julgar orçamentos, recursos e prazos para manter o conjunto de projetos fluindo harmoniosamente.

É dentro dessa perspectiva que o autor sugere o uso de estrutura matricial para prover o uso balanceado de recursos humanos.

A organização matricial pode ser vista como uma organização por projetos superposta a uma organização funcional com interfaces bem definidas entre times de projetos e elementos funcionais.

Segundo esse autor, a escolha de determinada estrutura organizacional para gerir projetos é baseada em vários critérios:

- Número de projetos e sus importância relativa

- Nível de incerteza dos projetos

- Tipo de tecnologia usada

- Complexidade do projeto

- Duração dos projetos

- recursos utilizados pelos projetos

- Custo de "overhead"

- requisitos de dados 
Para Certo e Peter (1993) quando se implementa uma estratégia, os administradores devem levar em consideração tanto a estrutura formal como a informal, por 3 razões:

1. se a estrutura tiver muitos níveis hierárquicos e a estratégia não puder ser implementada efetivamente ou alterada rapidamente para acomodar as condições que estão mudando, então o sucesso da implantação pode ser comprometido. Em alguns casos a estrutura organizacional formal precisa ser alterada.

2. É preciso saber que níveis de administradores e que pessoas dentro da organização serão responsáveis pelas diversas tarefas de implementação. Mudanças radicais ou redirecionamento organizacional são tarefas típicas do presidente enquanto que mudanças de estratégia de rotina podem ficar sob controle dos escalões médios da administração

3. Pode ser usada uma organização informal para facilitar o sucesso da implementação.

\subsubsection{ESTRUTURA ORGANIZACIONAL E E-BUSINESS}

Segundo Plant (2000) examinando a história das estratégias de ecommerce, percebe-se que muitas organizações tiveram ótimas estratégias conceituais em e-commerce que falharam na sua execução.

Segundo ele, o sucesso vem de um modelo de negócios que envolva cada área de negócios da empresa provedora de conteúdo contribuindo para o modelo de negócios global.

Em termos de estrutura organizacional, existem na organização vários proprietários de conteúdo, que são membros da organização que disponibilizam as informações no site da empresa ou tem sua função afetada pelo site e seu uso (por exemplo, logística, compras, serviços).

As situações de organização tradicional nas quais existe um comando horizontal e predominam estruturas de controle não funcionam bem para e- 
commerce, que requer uma estrutura muito mais adaptativa, na qual o chefe funcional de e-commerce seja central à estrutura organizacional.

Isso permite a cortar o overhead de informações e tornar o processo de tomada de decisão mais rápido do que se o CEO tivesse que verificar cada item de cada departamento antes de passar as decisões para os cabeças de departamentos, que então fariam a comunicação aos seus pares.

O autor sugere então uma organização web-centrada, onde o chefe do ecommerce está bem servido ao ter uma relação próxima, rápida com os outros grupos de comando.

O autor propõe a seguinte estrutura:

FIGURA 21: ESTRUTURA ORGANIZACIONAL E-CENTRICA

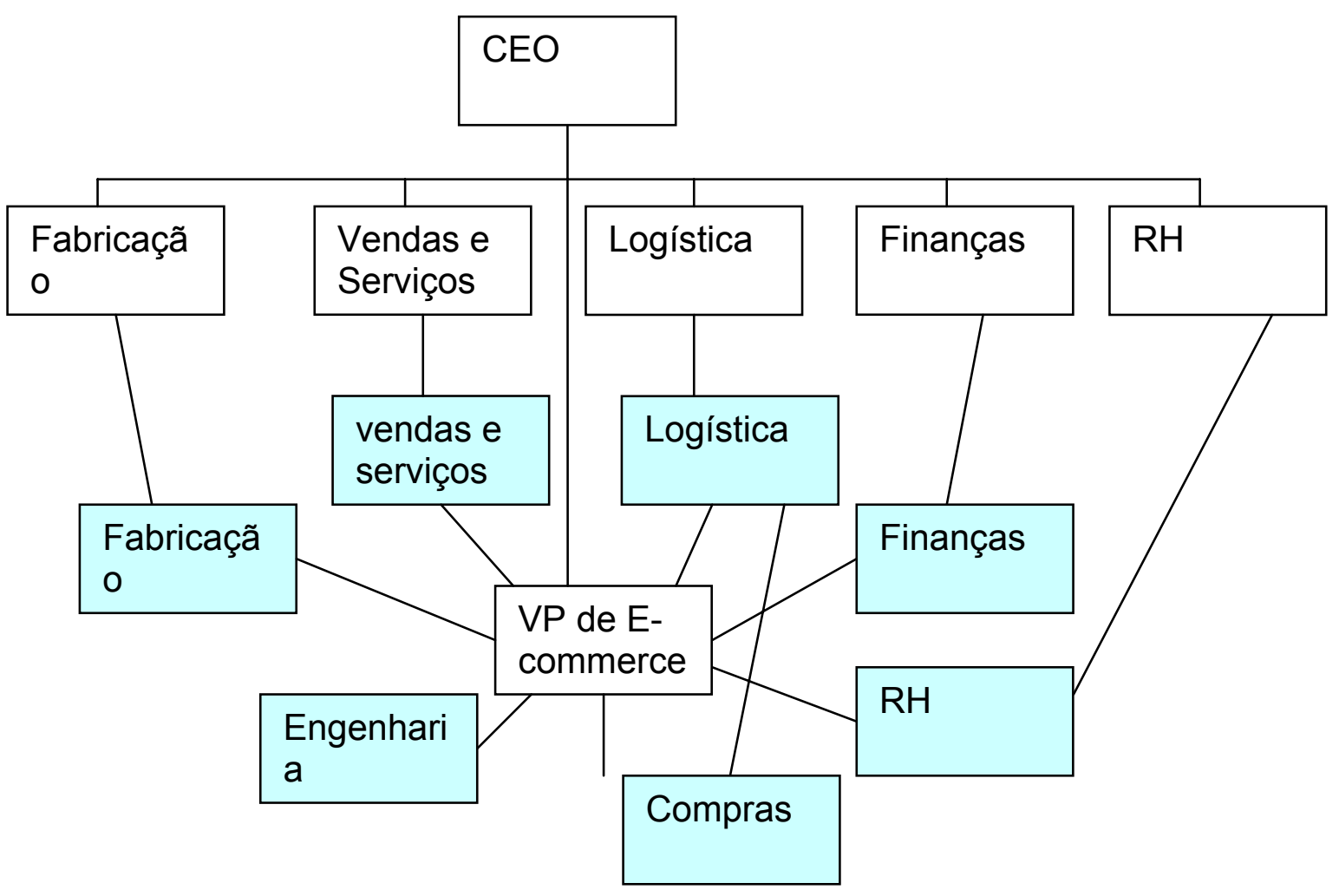

Fonte: Plant (2000) 
Nessa estrutura, existe um vice-presidente de E-commerce que tem subordinado a ele várias pessoas que fornecem o conteúdo de suas respectivas áreas, os chamados "content ownners" ou " possuidores de conteúdo" .

O autor sugere uma estrutura do seguinte tipo para implantar as estratégias de e-commerce:

FIGURA 22: ESTRUTURA PARA UMA ORGANIZAÇÃO E-CENTRICA

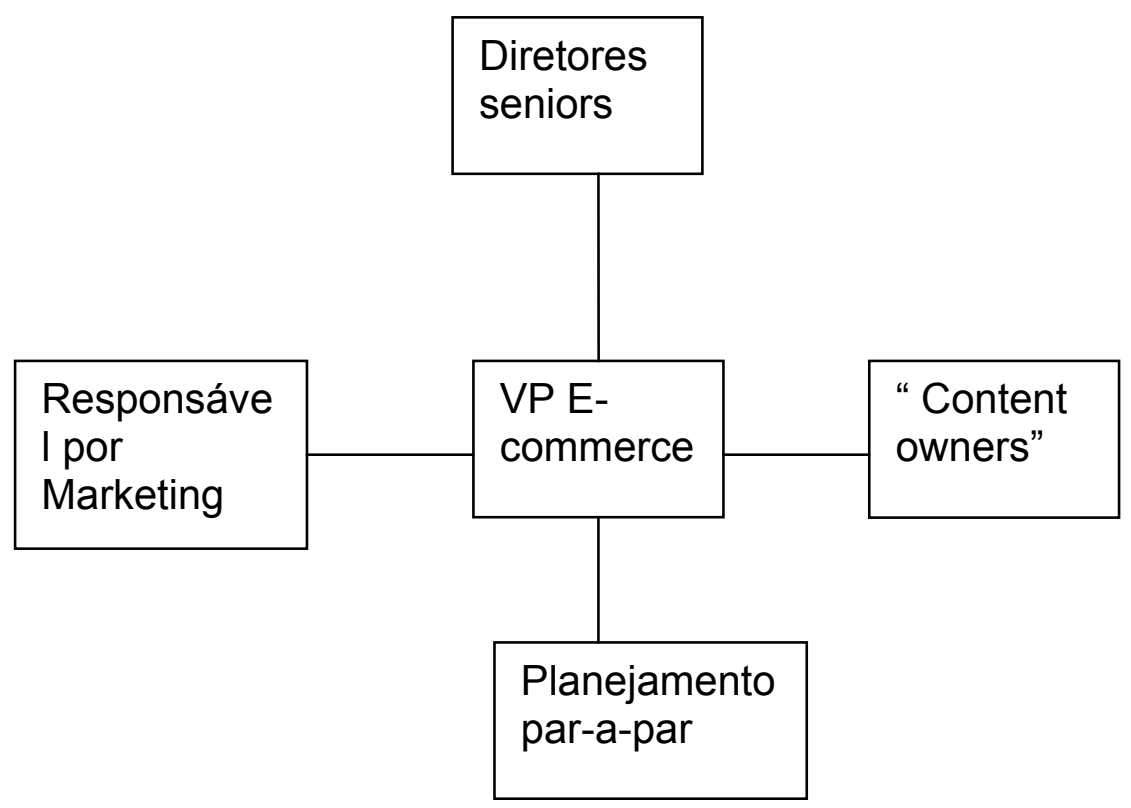

Fonte: Plant (2000)

Essa estrutura proposta pelo autor pode ser uma unidade funcional encarregada com a integração e desenvolvimento de estratégias de Internet.

Ela pode ser um subgrupo de uma unidade tradicional como Marketing ou pode ser uma função especialista criada especialmente para assuntos de ecommerce e tecnologia.

Um primeiro problema que se estabelece ao se implantar uma estrutura de e-commerce é onde encontrar o $\mathrm{ClO}$ responsável pelo e-commerce e o CEO: dentro ou fora da organização? 
Segundo Plant (2000) os CIO para e-commerce não precisam ser técnicos.

Muitas vezes os esforços para essa atividade necessitam muito mais de uma pessoa criativa do que técnica.

Outra solução é terceirizar a atividade, mantendo um staff mínimo na empresa e nomeando grupos de e-commerce na empresa contratada, conforme as necessidades.

O perfil das pessoas envolvidas em e-commerce devem conjugar aspectos técnicos e aspectos relativos a gestão dos negócios.

$\mathrm{O}$ autor continua dizendo que um dos condutores de sucesso de uma estratégia de Internet é a liderança demonstrada pelos níveis seniors da organização.

Nas organizações onde as iniciativas de Internet não foram bem sucedidas, dois fatores contribuíram para isso:

- Os executivos seniores não viram a relevância da Internet em sua indústria

- A organização estava absorvida em outros projetos técnicos, como por exemplo, implantação de ERP, com a exclusão de outros projetos.

As demandas de tecnologia também podem conflitar com o sucesso da implantação de iniciativas de e-business, exigindo que exista uma interação maior entre os CEO e CIO.

O vice-presidente de e-commerce deve ser servido por um canal aberto e informal de controle com o grupo de seniors executivos mas também deve ter um grau de autonomia e autoridade para criar e desenvolver conteúdo.

Esse vice-presidente interage e compartilha iniciativas, sendo que a integração com esses grupos é facilitada por grupos multifuncionais que tenham perfil técnico e de negócios juntos.

Segundo Weil e Vitale (2001), o time de pessoas envolvidas em e-business deve possuir os seguintes atributos:

- Pessoas que sabem entender o cliente e com entendimento das intenções estratégicas da firma

- Pessoas com perfil técnico que trabalhem na firma há um bom tempo 
- pessoas com perfil prático orientado para mercado

- Diretores seniors que tenham muito a ganhar

- pessoas orientadas a resultados e finanças como o chief financial officer (CFO)

O número de pessoas envolvidas não é tão importante quanto a boa cobertura desses perfis.

Um consultor externo com uma forte ferramenta para gerir diversos grupos lidando com problemas desafiadores pode facilitar o processo.

Segundo os autores, uma parte do grupo que vai implantar e-business deve se preocupar em identificar quais modelos servem aos objetivos estratégicos da firma e outra parte do grupo deve identificar qual modelo melhor se adapta às capacitações existentes na firma.

A seguir, a lista de modelos resultantes irá indicar aqueles mais adequados a serem implantados.

Kalalota e Robinson (1999) citam que um problema importante para o sucesso do e-business é responder a questão sobre quem é o responsável por criar a arquitetura de e-business.

O arquiteto de e-business é a figura central nesse tipo de organização, encarregado com a responsabilidade end-to-end e a autoridade para os processos multifuncionais.

Normalmente para essa posição vital falta um real entendimento do perfil necessário para executá-lo.

Para criar valor via desenho de e-business a empresa precisa responder a duas questões críticas:

- Como estruturar a empresa em termos de e-business para assimilar cada mudança do negócio?

- Como estruturar uma arquitetura de e-business num ambiente caracterizado por rápidas mudanças tecnológicas, freqüente introdução de novos produtos, mudanças nas demandas do consumidor, evolução das normas e práticas da indústria? 
Para o autor a integração do e-business é um fator importante, onde a integração front-office não é suficiente, é necessário compartilhar as informações com parceiros ou fornecedores terceirizados.

Para Freeland e Stirton (2000) o desenho organizacional da nova estrutura online dentro de uma empresa já existente leva à questão de integração: a nova estrutura deve estar dentro ou fora da organização "core"?

Segundo os autores, não existe uma resposta única. Encontra-se uma larga variedade de desenhos organizacionais possíveis, desde empresas independentes totalmente separadas da empresa "core" até novas unidades de negócio que se reportam a um CEO comum ou COO, para organizações totalmente integradas dentro das unidades de negócio existentes.

Qual estrutura faz sentido numa situação específica depende da estratégia de e-commerce da empresa e de qual modelo de negócio exatamente a empresa está perseguindo.

Os autores propõem duas dimensões estratégicas para a escolha do grau de integração:

- Alavancagem - ou o grau para o qual o e-commerce vai elevar os lucros a partir dos ativos existentes no "core" business. Irá a integração online e off-line dos negócios beneficiar os consumidores? Ou: Será que o novo negócio online vai ter ganhos com o uso de marcas, ativos, capacidades , infraestrututra da empresa existente?

- A segunda dimensão trata da ruptura- ou o grau com o qual o novo negócio irá destruir o outro.

A partir disso os autores propõem o seguinte mapa para analisar o grau de integração do e-business à empresa "core": 


\section{FIGURA 23: MAPA PARA ANÁLISE DO GRAU DE INTEGRAÇÃO DO E- BUSINESS À EMPRESA CORE}

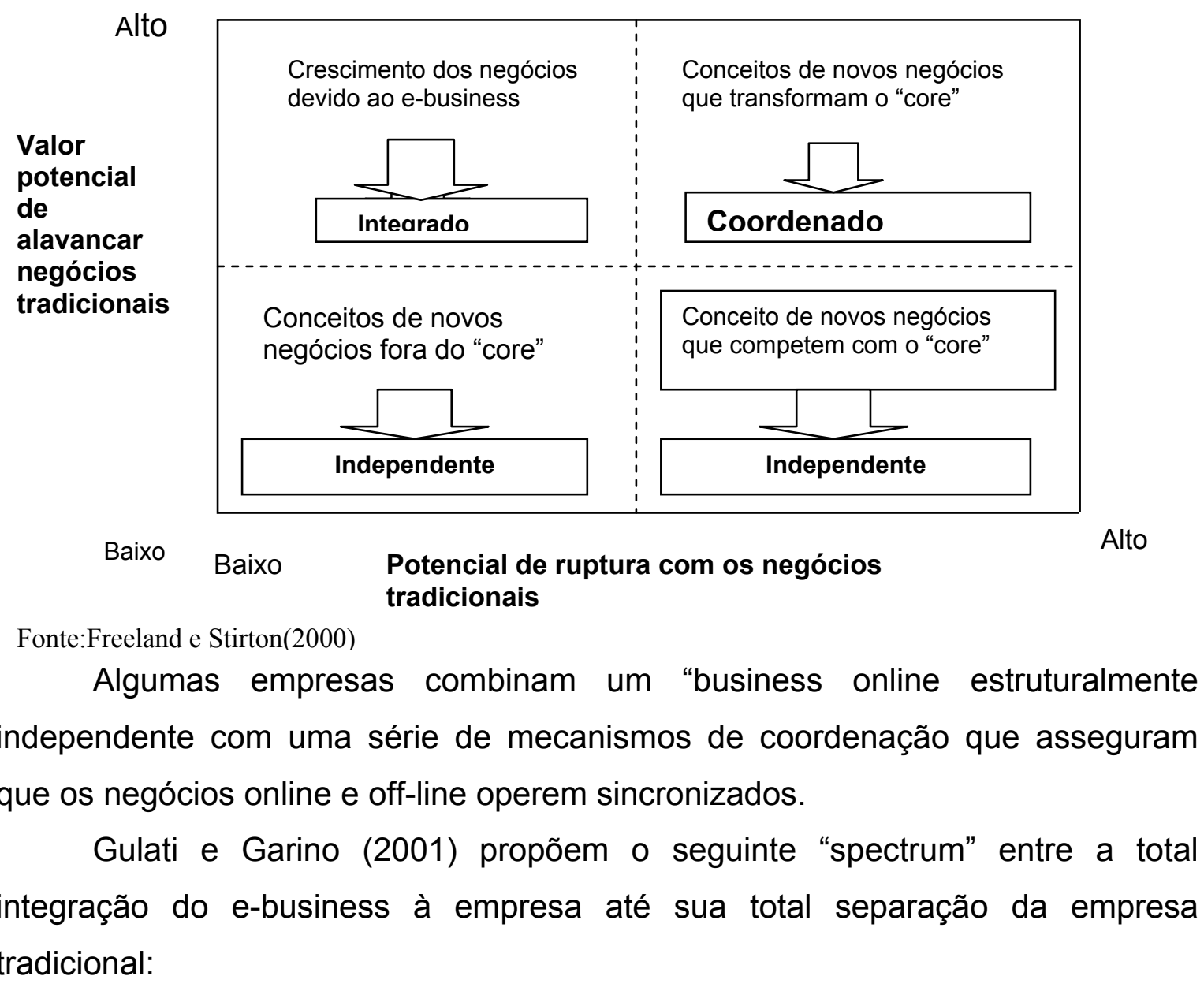

FIGURA 24: ESPECTRO DE INTEGRAÇÃO ENTRE "CLICKS E TIJOLOS"

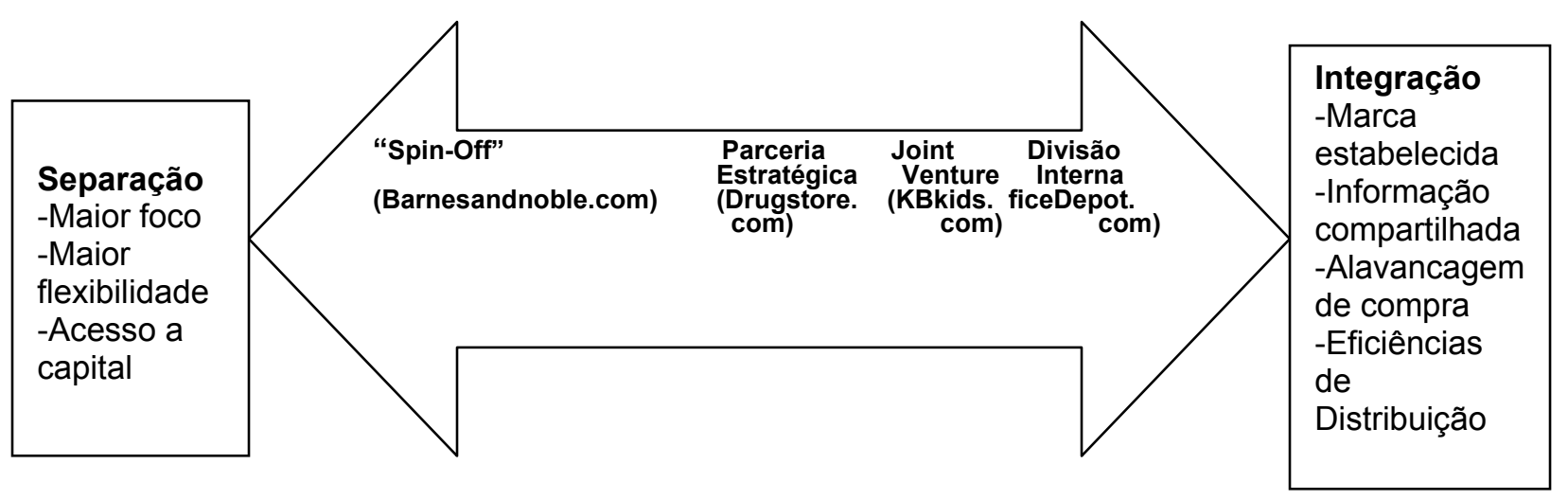

Fonte: Gulati e Garino (2000) 
É importante ressaltar que no modelo acima, esse spectrum é contínuo, com uma infinidade de gradações nos níveis de integração do e-business à empresa.

A decisão sobre separação-integração do e-business à empresa não é uma escolha binária.

Segundo os autores, ao invés dos executivos se perguntarem: "eu devo desenvolver um canal de Internet próprio "in-house" ou uma iniciativa totalmente separada? " eles deveriam se perguntar: "Qual grau de integração faz sentido para nossa companhia?"

A Integração pode trazer diversos benefícios para a empresa que está iniciando um novo empreendimento no mercado de e-business. Entre estes benefícios estão: a promoção mútua da marca, a informação compartilhada pelas duas empresas, um maior poder de barganha com fornecedores, economias de escala e de distribuição.

Marca -A escolha de integrar as marcas ou mantê-las separadas é uma escolha entre confiança e flexibilidade. Escolhendo-se confiança, os clientes farão mais visitas ao site, terão menos medo de usar o cartão de crédito etc. Já uma marca nova pode se adaptar melhor a outros tipos de clientes, podendo ser gerenciadas com mais flexibilidade.

Gestão administrativa -relaciona-se às atitudes da direção quanto ao modelo de negócios da empresa. Um time integrado pode alinhar melhor objetivos e estratégias, encontrar e explorar sinergias, e compartilhar conhecimentos. Times separados podem ter maior foco no negócio, inovar com mais liberdade e evitar contaminar o modelo de negócios de uma empresa com o da outra.

Operações-As decisões sobre integrar ou não as operações devem estar, entre outros fatores, baseadas na força que uma companhia tem perante seus fornecedores, assim como seus sistemas de informação e sua facilidade de uso para a Internet. A integração pode gerar economias de custos, um site mais informativo, uma vantagem competitiva acima dos competidores com menor poder de barganha. A separação deixa a 
companhia construir sistemas customizados e desenvolver sistemas de Internet que podem atingir uma performance superior.

Estrutura de Capital das empresas-A separação geralmente torna possível conseguir capital mais fácil ou mais barato dos investidores.

O quadro 7 apresenta um sumário das decisões que os autores propõem com relação a integrar ou não as partes virtual e real de uma empresa.

\section{TABELA 7: UM MAPA QUE AJUDA NO PROCESSO DECISÓRIO}

\begin{tabular}{l}
\hline \multicolumn{3}{c}{ MEPARAÇÃO } & MNTEGRAÇÃO \\
\hline
\end{tabular}

\section{ADMINISTRAÇÃO}

Os executivos atuais têm as habilidades e experiencia necessárias para gerirem um canal de Internet?

Eles estão dispostos a julgar as iniciativas de Internet por um grupo de critérios bem diferentes?

\section{CANAL}

Vai haver conflitos de canal?

A internet ameaça fundamentalmente o canal tradicional?

\section{OPERAÇÕES}

Os nossos sistemas de distribuição ficarão bem traduzidos para a Internet?

Os nossos sistemas de informação provêm um fundamento sólido em que se buscar?

Os nossos sistemas constitui uma vantagem competitiva significativa?

\section{CAPTAÇÃO DE RECURSOS}

Precisamos de capital externo para bancar o negócio?

Algum produtor, distribuidor ou outro parceiro é uma parte chave para o sucesso do negócio?

Fonte: GULATI e GARINO, 2000, adaptado por Muritiba e Vasconcellos (2001) 
Quanto à questão de governança, Freeland e Stirton (2000) sugerem a adoção de um pequeno centro de e-commerce dentro da estrutura organizacional, dotado de autoridade para tomadas de decisão.

Segundo os autores, nas fases iniciais do e-commerce muitas empresas possuíam várias unidades de negócio ou áreas funcionais exercendo atividades de e-business com relativa pequena coordenação.

A abordagem era deixar uma centena de iniciativas fluírem, para encorajar experimentação, aprendizado e respostas rápidas aos desafios competitivos.

Porém, muitas empresas perceberam que essa descentralização, em adição a levar ao desperdício e duplicação, também poderia comprometer a efetividade dos esforços de e-business.

$\mathrm{Na}$ pesquisa elaborada pelos autores junto a centenas de grandes empresas de vários setores, eles descobriram uma tendência da criação de uma pequena, mas poderosa unidade central de coordenação de ebusiness que se reporta direto ao CEO.

Esse centro de e-business dá o contexto estratégico e gerencia o portfolio de iniciativas de e-business, conforme figura 25 :

\section{FIGURA 25: A ESTRUTURA DE UM CENTRO DE E-BUSINESS NUMA INDÚSTRIA GLOBAL}

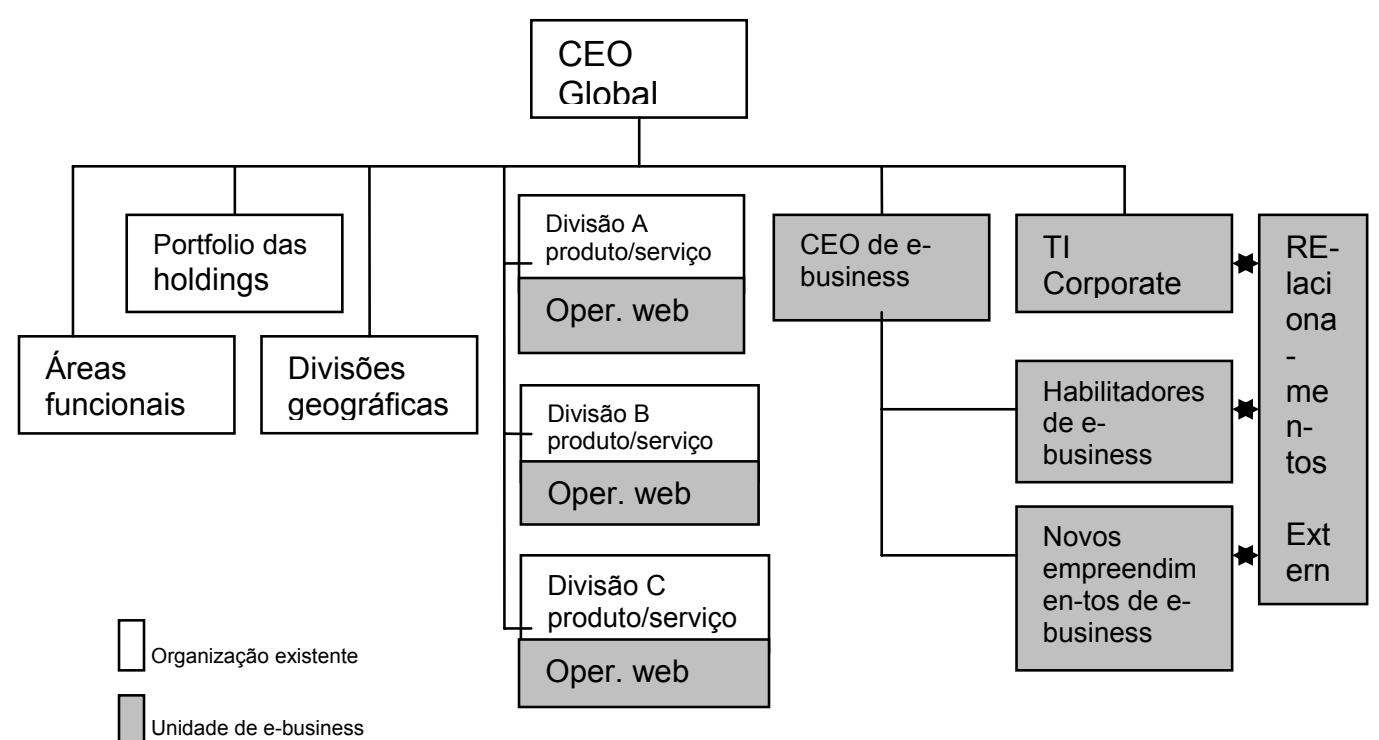


Os habilitadores de e-business provem serviços compartilhados para a unidade de e-business, em serviços especializados em Internet.

\subsection{CONCEITUAÇÃo DE MOdELOS DE NEGÓcIOS E SUAS IMPLICAÇÕES PARA O E-BUSINESS}

Rappa (2000) ressalta que muito se fala sobre como a web muda os modelos de negócio tradicionais, porém existem poucas evidências do que exatamente isso quer dizer.

O comércio eletrônico traz novos modelos de negócio, porém também "reinventa" modelos existentes consolidados.

Um bom exemplo são os leilões eletrônicos, onde os leilões são uma das mais antigas formas de agenciamento usadas em todo o mundo, para itens como commodities, antiguidades, etc. A Web popularizou o modelo de leilões e alargou sua aplicabilidade para uma vasta gama de produtos e serviços.

Segundo Timmers (1998) alguns modelos de e-business são essencialmente uma re-implementação eletrônica de formas tradicionais de fazer negócios.

Outros modelos estão longe de ser tradicionais, e buscam modos inovativos de agregar valor através da administração da informação gerada na Internet e de uma rica funcionalidade, não sendo possível utilizá-los a não ser com o uso da Internet.

A criação desses novos modelos só é factível devido às características de abertura e conectividade da Internet.

Chesbourgh (2001) em seu "paper" sobre o papel do modelo de negócios na captura de valor advinda da inovação, afirma que o papel do modelo de negócios para uma inovação é assegurar que o "core" tecnológico da inovação seja transformado num empreendimento economicamente viável.

Ele propõe que o modelo de negócio seja um mediador entre os domínios técnico e econômico, conforme demonstra a figura a seguir: 


\section{FIGURA 26: O MODELO DE NEGÓCIO MEDIA OS DOMÍNIOS TÉCNICO E ECONÔMICO}

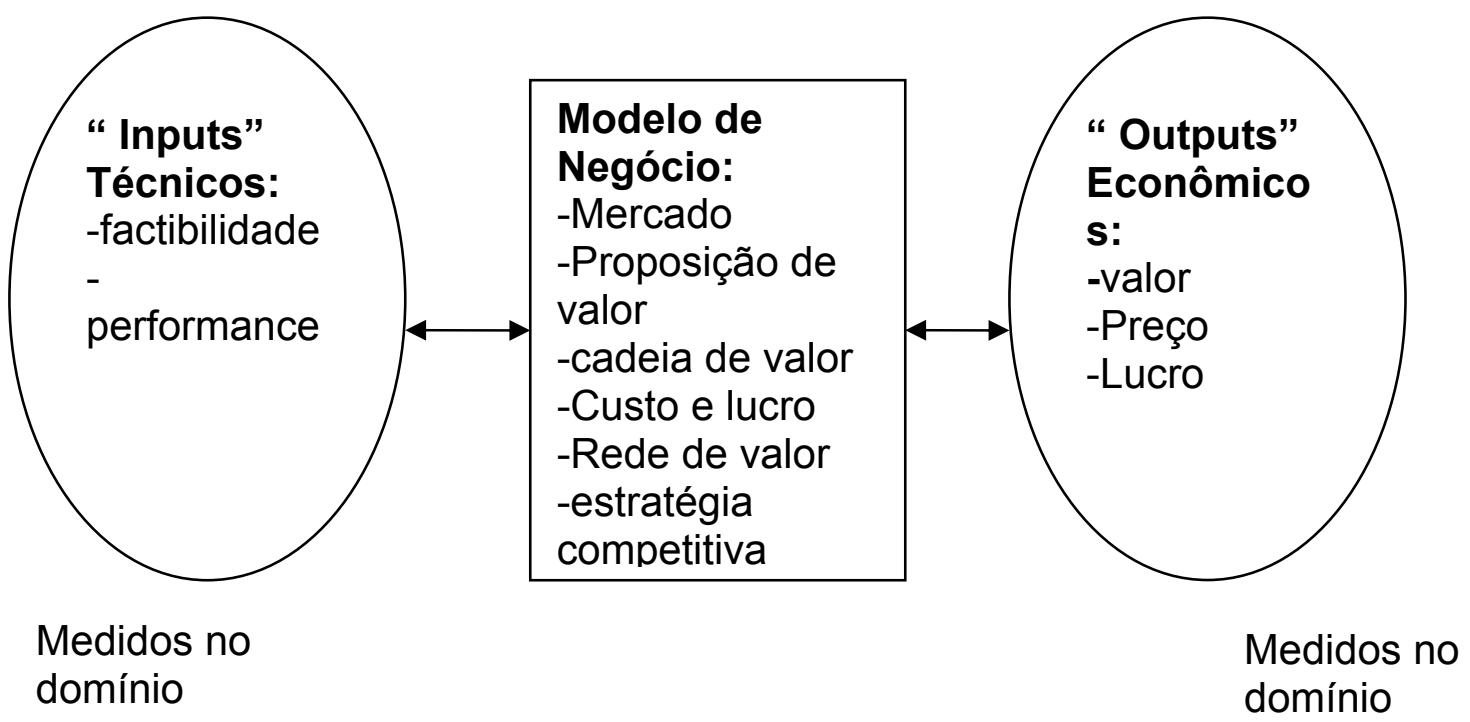

Fonte: Chesbrough (2001)

Kalakota e Robinson (1999) sugerem que a definição de valor em ebusiness é definido em termos da experiência total do consumidor. O que há de novo num modelo de e-business, segundo eles, são os conceitos de integração, dentro e fora da empresa para que se possa criar uma empresa usando uma nova tecnologia (rede ou Internet, por exemplo) que seja centrada no cliente. A outra palavra que define o modelo de e-business é a customização ou personalização.

O modelo de e-business deve entregar valor para o cliente através da velocidade (empresas devem construtir e reconstruir produtos e processos para prover serviços mais rápidos), conveniência, personalização e preço.

O valor em termos de "experiência total do cliente" : usar a tecnologia para inovar, entreter e enriquecer a experiência inteira que o cliente experimenta ao se envolver com o produto, desde a seleção do produto por parte do consumidor, o pedido até o recebimento e serviço.

Outros conceitos associados ao modelo de e-business: o conceito de selfservice e prover soluções integradas, integração de vendas e serviços (customização e integração)- para melhorar a retenção do cliente as empresas 
devem desenvolver e gerir relacionamentos com os clientes via melhor integração entre vendas e serviços utilizando para isso a tecnologia de Internet para obtenção e transmissão de informações, permitindo a criação de valor.

Segundo Timmers (1998) o comércio eletrônico na Internet pode tanto ser complementar aos negócios tradicionais ou representar uma linha completamente diferente de negócios.

Segundo esse autor, a definição de modelo de negócios abrange:

- Uma arquitetura para o produto, serviço e fluxo de informações, incluindo uma descrição de vários atores do negócio e seus papéis;

- Uma descrição dos benefícios potenciais para os vários atores no negócio

- Uma descrição das fontes de receitas.

- Timmers (1998) observa sobre os negócios atuais na Internet que:

- A Tecnologia de informação e comunicação viabilizam uma larga gama de modelos de negócio;

- A capacitação permitida pelo estado-da-arte da tecnologia é apenas um critério na seleção do modelo

- A tecnologia por si só não provê direcionamento para selecionar um modelo em ternos comerciais

- O direcionamento para o desenvolvimento de tecnologia vem da definição de novos modelos

- muitos dos modelos concebidos (lembrar que esse paper é de 1998) ainda não foram experimentados comercialmente.

O autor cita alguns novos modelos de negócio advindos com a Internet:

- E-shop: promove bens e serviços de uma empresa, podendo incluir confecção do pedido e possibilidade de pagamento, combinados com outros canais tradicionais de marketing. 
- e-procurement - procura eletrônica de bens e serviços. Benefícios vem da ampla escolha de fornecedores, os quais devem ser capazes de lidar com custo mais baixo, melhor qualidade, melhoria na entrega e custo reduzido de busca (por exemplo, especificações cuidadosas podem ser " downloaded" ou "baixadas" pelos fornecedores, ao invés de colocadas no correio). Negociação eletrônica e contratação podem melhorar o tempo gasto com a procura, seus custos e conveniência.

- E-auction (leilões eletrônicos)- oferece uma implementação eletrônica dos mecanismos tradicionais de leilão.

- e-mall - uma coleção de e-shops, normalmente enriquecidos por um “ guarda-chuva" comum, por exemplo, uma marca bem conhecida.

- comunidades virtuais-membros adicionam informações dentro de um ambiente básico provido por uma empresa de comunidade virtual

- "value chain service provider" -especializa-se em uma função específica para a cadeia de valor, como pagamentos eletrônicos ou logística, com, a intenção de fazê-lo dentro de sua vantagem competitiva distintiva.

- Ex: bancos - podem encontrar novas oportunidades usando redes.

- "value chain integrator" - foca em integrar múltiplos degraus da cadeia de valor, com o potencial de explorar a informação que flui entre esses degraus e adicionar valor.

Obs: não foram descritos todos os modelos indicados pelo autor, pois o que se queria era observar que existem modelos de e-business mais inovativos e outros menos. Para consultar todos os modelos, ver artigo.

O autor elenca onze modelos de negócio na Internet e produz um mapa desses modelos ao longo de duas dimensões:

- a primeira dimensão dá o grau de inovação. Ele varia de uma versão essencialmente eletrônica de um modo tradicional de fazer negócios até modos mais inovativos de fazer negócios, como por exemplo, externalizando via Internet funções que antes eram executadas dentro da empresa ou ainda oferecendo funções que não existiam antes. 
- a segunda dimensão trata a extensão de integração de funções diversas na cadeia de valor, variando desde modelos com uma única função (por exemplo, e-shops que só provem a função de marketing sobre a Internet) até funcionalidades totalmente integradas, como a "value chain integration".

O mapa resultante desses novos modelos fica:

\section{FIGURA 27: CLASSIFICAÇÃO DOS MODELOS DE NEGÓCIO DE INTERNET}

Múltiplas

funções/Integrada

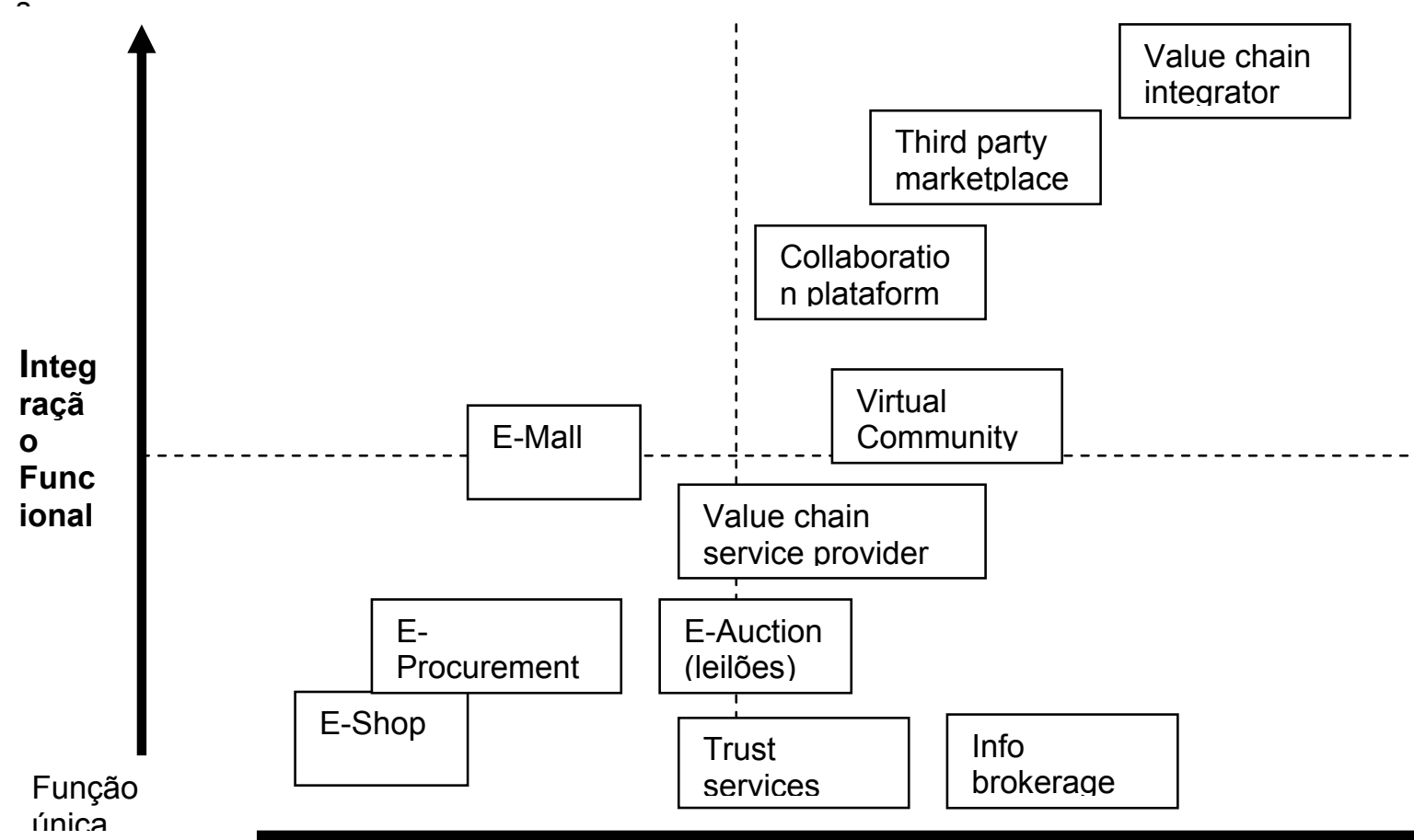

Baixo

Alto

Grau de Inovação

Fonte: Timmers (1998). 
No canto esquerdo inferior estão, basicamente, os e-shops, os quais são versões eletrônicas de modos tradicionais de vendas somente.

No outro extremo, está o modelo de "value chain integration", o qual não pode ser feito de forma tradicional, é criticamente dependente de tecnologia da informação para permitir que a informação flua através de redes e crie valor adicional pela integração desses fluxos de informação.

Entre esses dois modelos de e-business extremos estão modelos de negócios que encontram algum grau de analogia em negócios não eletrônicos: algumas funcionalidades podem ser reimplementadas por serviços eletrônicos (como exemplo, tem-se o "value chain service provision", que pode oferecer pagamento eletrônico, que também é feito de forma tradicional) bem como novas funcionalidades podem ser providas pela Internet (como por exemplo o " smart card support" oferecido por esse mesmo modelo de e-business ).

Segundo Applegate (2001), o e-business é construído através da combinação de uma variedade de modelos de negócio. Esses negócios são então linkados com outros através de redes múltiplas de cadeia de valor para criar a “ web para a Web".

Ao incorporar múltiplos modelos de negócio que geram diferentes fontes de receita advindas da mesma infraestrutura, uma rede de negócios pode mais eficientemente utilizar recursos, atender às necessidades dos clientes por soluções integradas e gerar valor adicional do mesmo nível de investimento.

Ao linkar a web de negócios dentro da firma com uma rede de negócios composta por uma web de negócios muito maior, uma organização pode alavancar os recursos da comunidade de modo a aumentar o valor entregue a todos os seus membros.

Daí a importância da identificação dos tipos de modelo de negócio de ebusiness utilizados pela empresa: verificar se os resultados estão sendo realmente alavancados e o valor entregue ao cliente está realmente maior.

A seguir será mostrado como diversos autores enfocam a questão da idealização de um modelo de negócios para e-business. 


\subsubsection{O CONCEITO DE PORTER PARA E-BUSINESS-CADEIA DE VALOR}

Para Porter (2001) toda a retórica sobre " Indústrias de Internet" , " estratégias de e-business" e " nova economia" mascaram o que a Internet verdadeiramente é: uma "enabling technology" , que na falta de tradução melhor pode ser entendida como tecnologia "possibilitadora" - um poderoso conjunto de ferramentas que pode ser usado de forma inteligente- ou não- em quase toda indústria e como parte de quase toda estratégia.

A questão chave para ele não é se deve -se desenvolver tecnologia de Internet- as empresas não tem escolha se querem se manter competitivas, precisam adotá-la- mas como explorá-la.

Ganhar vantagem competitiva com isso não requer uma nova abordagem radical para negócios.

Apenas requer construção em cima de estratégias comprovadamente efetivas.

A Internet por si raramente será uma vantagem competitiva.

A maioria das empresas bem sucedidas nesse aspecto usam a Internet como complemento aos modos tradicionais de competição e não aquelas que estabeleceram suas iniciativas apartadas de suas operações estabelecidas.

Segundo o autor, empresas que desenvolveram tecnologia de Internet muitas vezes ficaram confusas com sinais distorcidos do mercado, criados por métricas erradas, como por exemplo, receitas distorcidas, custos e preços analisados por métricas financeiras equivocadas adotadas pelas empresas.

Essa foi a causa da "euforia" advinda num primeiro momento das empresas 'ponto.com'.

Segundo ele é necessário retornar aos fundamentos: valor econômico para a empresa nada mais é que a diferença entre preço e custo e só é mantido através de uma lucratividade sustentável: gerar receitas, reduzir despesas ou simplesmente fazer algo útil para desenvolver tecnologia de Internet não é uma evidência suficiente de que valor tenha sido criado. 
Ele ressalta que é preciso distinguir a tecnologia de Internet dos usos da Internet: são os usos da Internet que podem criar valor.

Para ver como a Internet pode criar valor é necessário analisar dois fatores fundamentais que determinam a lucratividade:

-Estrutura da Indústria- que determina a lucratividade do competidor médio

-Vantagem Competitiva sustentável- que permite a uma empresa superar o competidor médio

Quanto à estrutura da indústria, Porter afirma que a Internet tem o potencial de expandir bastante determinada indústria, por exemplo, a indústria de ensino à distância, mas a Internet não cria a indústria.

Quer seja a indústria nova ou velha, a atratividade de uma indústria é determinada por cinco forças de competição: a intensidade da rivalidade entre competidores existentes, as barreiras de entrada para novos competidores, 0 desafio de produtos ou serviços substitutos, o poder de barganha dos fornecedores, e o poder de barganha dos compradores.

Para analisar a estrutura da indústria e seus efeitos sobre a Internet, Porter propõe o seguinte modelo: 


\section{FIGURA 28: COMO A INTERNET INFLUENCIA A ESTRUTURA DA INDÚSTRIA}

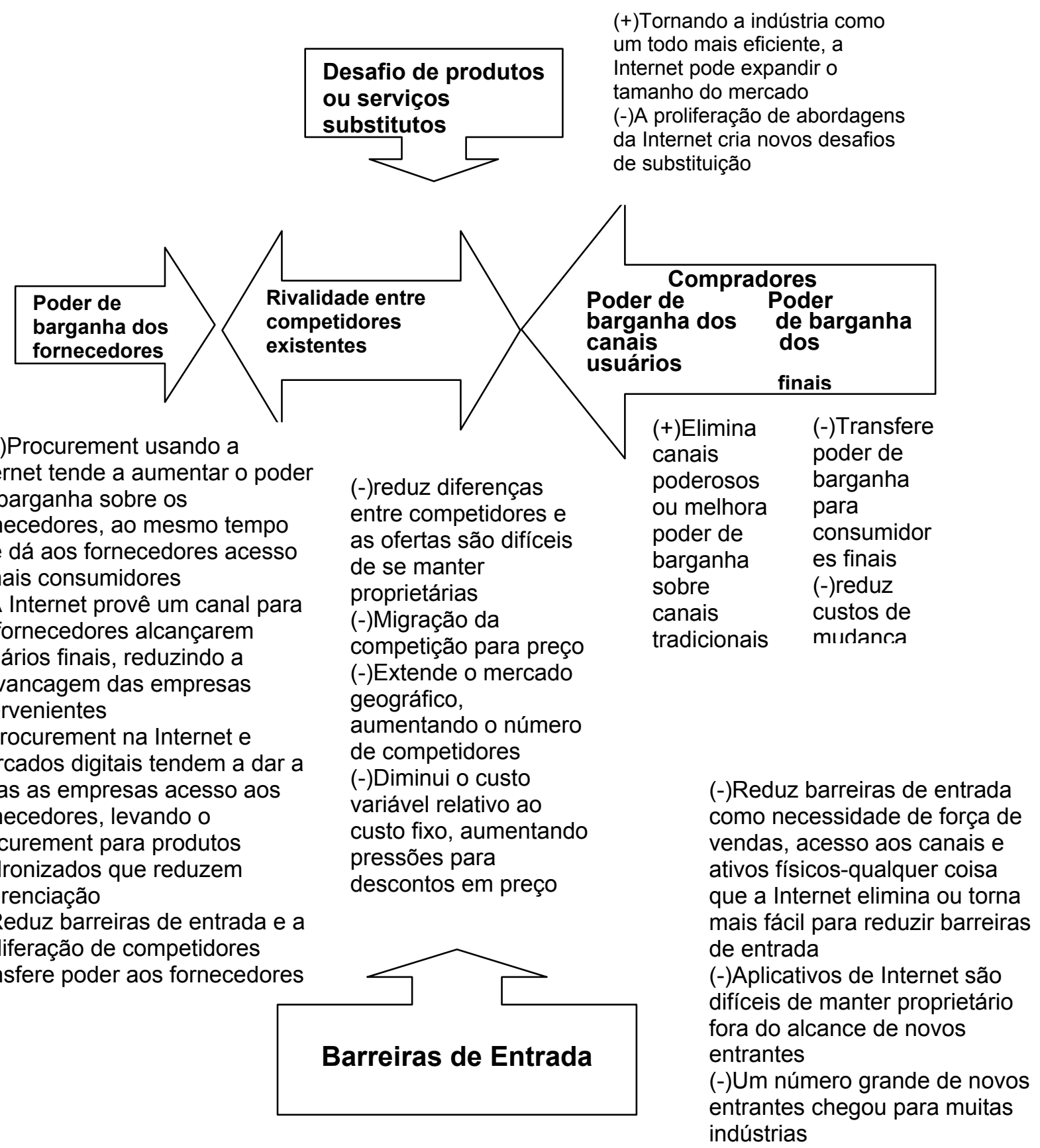

Fonte: Porter (2001) 
A partir da observação da figura acima, o efeito global da Internet sobre a estrutura da indústria é negativo.

O grande paradoxo da Internet é que seus maiores benefícios- tornar a informação largamente disponível, reduzir a dificuldade de compras, marketing e distribuição, permitir que compradores e vendedores encontrem-se e façam negócios mais facilmente-também torna para as empresas mais difícil transformar esses benefícios em lucros.

Sobre a Internet e a vantagem competitiva, Porter (2001) afirma que vantagens de custo e preço podem ser alcançadas de duas maneiras: efetividade operacional -fazendo as mesmas coisas que os concorrentes, porém de melhor maneira (por exemplo, melhores tecnologias, pessoas melhor treinadas, uma estrutura de gestão mais efetiva), ou através do posicionamento estratégicofazendo coisas diferentes dos competidores, de forma a entregar um tipo de valor único para o consumidor (por exemplo serviços diferentes, diferentes arranjos logísticos, etc).

Quanto à efetividade operacional, Porter afirma ser difícil sustentá-la pois, a abertura da Internet combinada aos avanços na arquitetura de software, ferramentas de desenvolvimento, e modularidade tornou muito mais fácil para as empresas desenhar e implementar aplicações, caindo algumas barreiras para imitação.

Como tornou-se mais difícil sustentar vantagens operacionais, o posicionamento estratégico torna-se mais importante.

Segundo Porter (2001), o que aconteceu com muitas empresas pioneiras na Internet, sejam empresas ponto.com, sejam empresas já estabelecidas, foi que elas violaram os bons preceitos da estratégia: ao invés de focar em lucros, elas tentaram maximizar receitas e fatia de mercado a todo custo.

Empresas bem estabelecidas também caíram na armadilha da Internet: esquecendo aquilo que as tornava únicas, elas correram a implantar as mais recentes aplicações de Internet e copiar as ofertas das ponto.com, comprometendo a vantagem competitiva de empresas líder.

Não precisa ser assim no futuro: quando a Internet vem para reforçar uma estratégia distintiva, realizar atividades sob medida e melhorar o ajuste, a Internet 
provê uma plataforma tecnológica melhor do que as gerações prévias de TI. TI trabalhava contra a estratégia no passado. Pacotes de Aplicativos de Software eram difíceis de customizar e as empresas eram freqüentemente forçadas a mudar o modo como conduziam suas atividades de modo a estar conforme as " melhores práticas" contidas nos softwares.

Era muito difícil conectar aplicações discretas umas com as outras. ERP (enterprise resource planning) linkava atividades do sistema, mas de novo as empresas eram obrigadas a adaptar seu modo de fazer as coisas ao software.

Como resultado, TI foi uma força para padronizar atividades e aumentar a convergência competitiva.

Sobre a cadeia de valor, Porter afirma que essa é uma ferramenta básica para entender a influência da tecnologia da informação nas empresas: a cadeia de valor é um conjunto de atividades através da qual um produto ou serviço é criado e entregue aos consumidores.

Sobre as aplicações da Internet na cadeia de valor, Porter (2001) propõe o seguinte quadro: 
FIGURA 29: APLICAÇÕES DA INTERNET NA CADEIA DE VALOR:

Infraestrutura da firma:

-Sistemas Web-based, financeiros e ERP

-relações com investidores online (disseminação de informações, conference calls)

\section{Gestão de recursos humanos}

-Administração de benefícios de modo "self-service"

-treinamento web-based

-Compartilhamento e disseminação de informações baseadas na Web

-relatórios de tempo e despesas eletrônicos

\section{Desenvolvimento tecnológico}

-desenho colaborativo do produto entre locais diferentes e com participantes de vários sistemas

-Diretórios de conhecimento acessíveis de todas as partes da organização

-acesso em tempo real por P\&D às informações sobre vendas e serviços

\section{Procurement}

-Planejamento da demanda permitido pela Internet

-outros links de compras, estoques e sistemas com fornecedores

-requisição de pagamento automatizada

-Procurement direto e indireto via marketplaces, exchanges, leilões

\section{Logística}

Interna

-Cronograma,

embalagem,

gestão de

estoques,

gestão da

demanda,

planejamento

integrados e

em tempo real

através da

empresa e

seus

fornecedores

-

disseminação

pla empresa

sobre dados

em tempo real

do estoque
Logística

externa

-Troca de

informações

cronograma,

e tomada de

decisões

integradas

em plantas,

contratos

conjuntos e

fornecimento

de

componentes

-Informações

em tempo

real sobre

capacidade

prometida e

disponível

para força de

vendas e

canais

\section{-transações}

de pedidos

em tempo

real

iniciados por

um

consumidor

final, pessoa

de vendas

ou parceiro

de canal

-gestão de

canal

integrada

-acesso do

consumidor

e canais ao

desenvolvim

ento de

produto e

status de

entrega
Marketing e

Vendas

-canais de

vendas

online

-informação

em tempo

real sobre o

consumidor

interno e

externo

configuraçã

o de produto

online

-marketing

sob medida

ao

consumidor

via perfil do

consumidor

-feedback

em tempo

real do

consumidor
Serviço pósvenda

-suporte online para o consumidor -processo de pedido online self-service

-serviços

de

acesso

ao

consumi

dor em

tempo

real

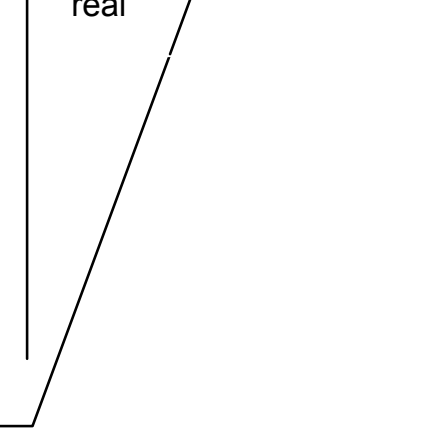

Fonte: Porter (2001) 
Porter vê a Internet muito mais como complemento do que algo que vá redimensionar todos os modos convencionais de fazer negócios.

Em algumas indústrias, o uso da Internet representa somente um modesto deslocamento de práticas bem estabelecidas.

As atividades virtuais não eliminam a necessidade por atividades físicas, mas freqüentemente amplificam sua importância.

Sobre separação ou integração dos negócios eletrônicos aos tradicionais, Porter observa que algumas empresas acreditam que a nova economia opera sob novas regras e deixam suas operações de Internet em unidades separadas, por medo de canibalização. Uma unidade separada também pode ajudar na relação com investidores.

Porém Porter observa que geralmente separação organizacional mina a capacidade da empresa em ganhar vantagem competitiva.

Ao criar estratégias separadas de Internet ao invés de integrá-la na estratégia global, as empresas falham em capitalizar sobre seus ativos tradicionais, reforçando competição.

Toda empresa precisa de um programa agressivo para desenvolver a Internet através da sua cadeia de valor, usando a tecnologia para reforçar a tradicional vantagem competitiva e complementar os modos existentes de competir.

A Internet não é uma tecnologia de ruptura para as empresas existentes ou já estabelecidas.

Ela raramente nulifica as mais importantes fontes de vantagem competitiva numa indústria, em muitos casos ela torna aquelas forças mais importantes.

O valor de integrar métodos tradicionais e Internet cria vantagens potenciais para empresas já estabelecidas.

Isso não quer dizer que se deva configurar a Internet em termos de tradicionais " tijolos e cimento" , as empresas já estabelecidas terão mais sucesso se desenvolverem a tecnologia de Internet para reconfigurar atividades tradicionais ou quando encontrarem uma nova combinação entre as abordagens tradicionais e de Internet. 


\subsubsection{MODELOS DE E-BUSINESS SEGUNDO WEIL E VITALE- MODELOS NUCLEARES}

Weil e Vitale (2001) propuseram uma série de modelos de e-business com a intenção de eliminar a distinção entre B2B ou B2C, ou seja, não importa se a relação é entre empresas ou entre empresa e consumidor individual, o que importa são os fluxos de produtos, dinheiros e informações entre as partes envolvidas.

Eles procuraram com seus modelos dar um caráter mais abrangente para $\mathrm{o}$ e-business.

Segundo eles, todos estão colocando "e's" e "."(dots ou pontos) em todo lugar para lembrar diariamente que existe um novo modo de trabalhar. A revolução "e" e "ponto" pode se declarar vitoriosa quando e-business se tornar business e ".com" tornar-se uma corporação.

Os modelos tem por objetivo auxiliar os administradores a capturar a essência de uma iniciativa de e-business, combinando cinco elementos utilizados para representar um negócio : estratégia, estrutura organizacional, processos de negócio, cadeia de valor (série de atividades praticadas pela corporação para atingir seus objetivos nos vários estágios do processo produtivo, sendo que o valor adicionado por essas atividades contribui com o lucro e posição competitiva da empresa) e "core competencies" (ou competências essenciais da organização).

Eles utilizam o conceito de modelos atômicos de e-business: existe um número finito de modelos atômicos de e-business, cada um pode ser descrito por: objetivos estratégicos, fontes de receitas, fatores críticos de sucesso e competências "core" requeridas.

O modelo de e-business é então, a combinação de modelos atômicos que melhor descreve as atividades da firma em e-business numa iniciativa particular. 
Esse modelo inclui os papéis e relacionamentos entre os clientes da firma, aliados e fornecedores e os principais fluxos de produtos, informações e dinheiro além dos principais benefícios para os participantes.

Segundo Weil e Vitale (2001) um modelo é representado pelos seguintes elementos:

- as principais entidades no modelo e-business, incluindo a firma de interesse e seus consumidores, fornecedores e aliados.

- Os principais fluxos de produtos, informações e dinheiro.

- As receitas e outros benefícios que os participantes recebem

- As empresas podem analisar o modelo de e-business para deduzir:

- se o modelo tem alguma contradição que leve a não viabilidade ou a conflitos

- as competências essenciais e processos-chave necessários a implementar o modelo

- a posição de cada "player" na cadeia de valor da indústria

- a forma organizacional para implementação

- o tipo de capacidades da infra-estrutura de Tecnologia da Informação requerida. 


\section{FIGURA 30: EXEMPLO DO MODELO DE E-BUSINESS "DIRETO AO CONSUMIDOR":}
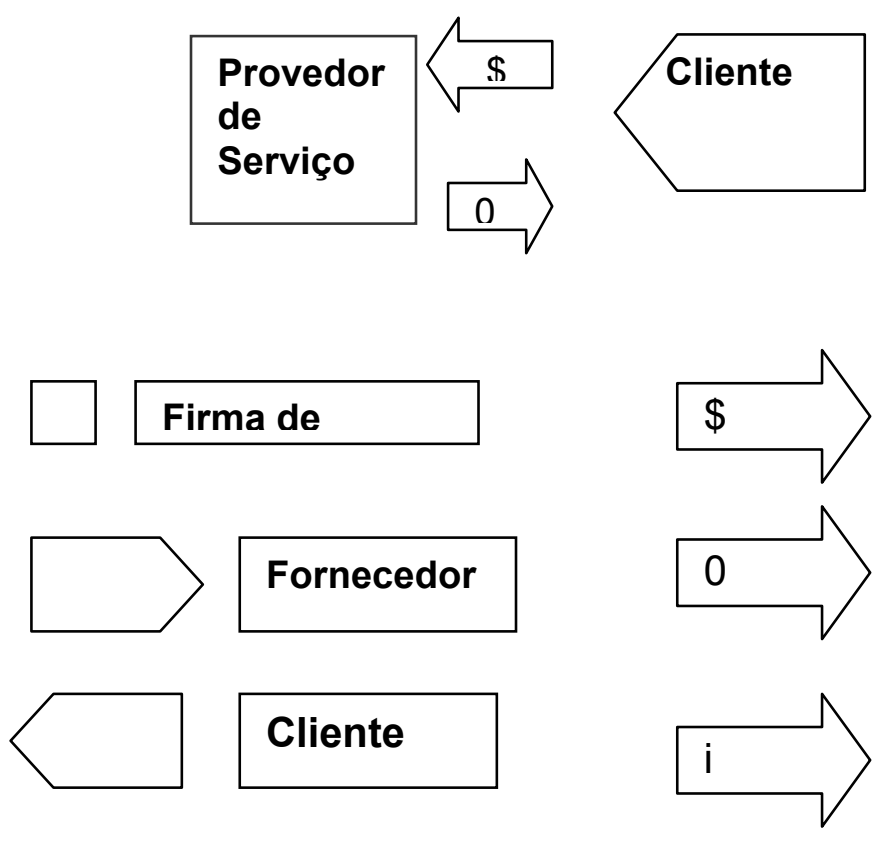

Fluxo de dinheiro

Fluxo de produto

Fluxo de informação
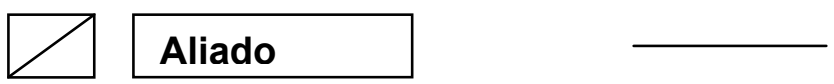

Relacionamento

\section{Relacionamento}

Firma de interesse: organização cujo modelo de negócio é ilustrado pelo esquema

Fornecedor: organização ou indivíduo do qual a firma de interesse obtém bens, serviços ou informações

Cliente:organização que consome os produtos, serviços ou informações da firma de interesse

Aliado: organização cujos produtos ajudam a aumentar a demanda pelos produtos da firma de interesse 
Relacionamento primário: a firma que possui o relacionamento direto com o consumidor, que lhe dá a oportunidade de ter a maior parte das informações desse cliente

Relacionamento eletrônico: uma conexão digital através da qual mensagens fluem em ambas as direções. Essa conexão pode ser a Internet.

Fluxo de dinheiro: indica um pagamento de uma parte para a outra, em troca de produtos, informações ou serviços

Fluxo de produto: indica transferência de produtos físicos ou digitais de uma parte para outra

Fluxo de informações: mensagens fluem através de relacionamentos eletrônicos. Não é um produto digital. Normalmente é o resultado de pesquisa sobre um produto ou serviço e normalmente é de graça.

Os autores propõem que cada um dos sete modelos atômicos (direto ao consumidor, provedor de conteúdo, etc) seja uma estrutura atômica que uma empresa pode adotar para implantar determinadas operações de e-business.

Esses modelos nucleares podem ser combinados como blocos para formar o modelo geral de e-business adotado pela empresa.

Esses autores buscaram com essa classificação de e-business fugir da nomenclatura B2B (business to business) e B2C (business to consumer) que classifica $O$ modelo segundo $\circ$ relacionamento seja entre empresa e cliente individual ou entre empresa e empresa.

Para os autores, as competências essenciais da firma levam a identificar "building blocks" que serão os responsáveis em prover uma plataforma de iniciativas de e-business.

Cada modelo de e-business é composto por esses " building blocks" ou "atividades de e-business" , que são na verdade ferramentas de e-business a serem implantadas para operacionalizar aquele modelo.

Para ilustrar essa relação, os autores elencam uma série de " building blocks" derivados das competências essenciais de uma firma que deve implantar um modelo de e-business do tipo " direto ao consumidor" : 


\section{TABELA 8: “ BUILDING BLOCKS” ASSOCIADOS AO MODELO "DIRETO AO CONSUMIDOR" A PARTIR DAS COMPETÊNCIAS ESSENCIAIS DA FIRMA}

\begin{tabular}{|c|c|}
\hline Competências essenciais & $\begin{array}{c}\text { "Building Blocks" de e-business } \\
\text { típicos }\end{array}$ \\
\hline $\begin{array}{l}\text { Formar e gerir parceiras estratégicas } \\
\text { com forncedores e outros na cadeia de } \\
\text { suprimentos }\end{array}$ & $\begin{array}{l}\text {-Desenvolver uma rede de contatos } \\
\text { pessoais com outros players na cadeia } \\
\text { de suprimentos } \\
\text {-Informação detalhada sobre as } \\
\text { capacidades, lucraticvidade e valor } \\
\text { adicionado de outros players na cadeia } \\
\text { de suprimentos }\end{array}$ \\
\hline $\begin{array}{l}\text { Usar informações sobre o consumidor } \\
\text { para aumentar vendas e serviço }\end{array}$ & $\begin{array}{l}\text { Databases do consumidor identificando } \\
\text { um nível detalhado de compras por } \\
\text { tempo }\end{array}$ \\
\hline Prospecção efetiva do consumidor & $\begin{array}{l}\text { Força de vendas capaz de explorar } \\
\text { informações deralhadas para elevar } \\
\text { vendas }\end{array}$ \\
\hline $\begin{array}{l}\text { Gerir processos de negócios e } \\
\text { integração de sistemas }\end{array}$ & $\begin{array}{l}\text {-atividades baseadas em custos } \\
\text {-sistema integrador de informações (ex: } \\
\text { ERP) }\end{array}$ \\
\hline
\end{tabular}

Fonte: Weil e Vitale (2001)

Os " building blocks" ou " atividades a fazer" gerados a partir da identificação das competências essenciais da firma resultam num portfolio de atividades de e-business dentro de um modelo "direto ao consumidor ", no exemplo acima.

Assim, para cada tipo de modelo de e-business, existe uma variada gama de atividades de e-business que o compõe, sendo que a importância estratégica, 
o tamanho e os investimentos nesse portfolio dependem da extensão dos desafios e oportunidades da firma, ou seja, quanto maior o "score" da oportunidade $\mathrm{X}$ desafio, maior o investimento nesse portfolio de atividades de ebusiness.

Como exemplo, um determinado modelo direto ao consumidor de determinada firma pode oferecer vendas diretas através de um determinado site na Internet e ter ferramentas como CRM, ERP e SCM associados a essa venda, enquanto que em outra firma o modelo direto ao consumidor consiste apenas em vandas diretas através de um portal.

A grande utilidade da proposição de modelos segundo Weil e Vitale é no auxílio para a escolha do portfolio de atividades de e-business a serem desenvolvidas pela firma.

Os modelos de e-business propostos por Weil e Vitale (2001) são:

- Provedor de conteúdo - provê conteúdo (informação, produtos e serviços digitais) via intermediários. Exemplo: AOL Time Warner.

- Direto ao consumidor - Provê bens e serviços direto ao consumidor. Ex: Dell.com.

- "Full-service provider" - Provê uma gama completa de serviços em um domínio (por exemplo, finanças, saúde, indústria química) diretamente ou via aliados. Ex: GE Supply Company.

- Intermediário - Junta compradores e vendedores através da concentração de informações (ex: leilões). Ex: eBay, Yahoo!

- Infra-estrutura compartilhada - Junta múltiplos competidores cooperando para compartilhar infra-estrutura comum de Tecnologia da Informação. Ex: Covisint - Exchange integrado para fornecimento, formado pela GM, Ford e Daimler-Chrysler.

- Integrador de Valor na Rede - Coordena atividades através da criação de valor na rede, buscando, sintetizando e distribuindo informações. Ex: Cisco Systems. 
- Comunidades Virtuais - Criam e facilitam uma comunidade online de pessoas com um interesse comum, permitindo interação e provisão de serviços. Ex: Ex: Amazon.com Community.

É importante identificar quais são as competências essenciais da firma para cada modelo de e-business, pois analisando a compatibilidade entre 0 modelo escolhido e as "core competencies" necessárias para realizá-lo de forma eficiente, pode-se descobrir que aquele modelo seja impraticável para as competências daquela firma e proceder à escolha do modelo mais adequado às suas competências.

Autores como Weil e Vitale (2001) acreditam que a escolha das iniciativas de e-business devem se basear nessas competências.

Eles descrevem para cada modelo quais são as principais "core competencies".

Cada modelo também tem associado a ele objetivos estratégicos que devem ser atingidos com a operação do e-business e prevê uma fonte de receitas a partir desse modelo.

\subsubsection{MODELO DE E-BUSIENSS SEGUNDO AMIT E ZOTT-CRIAÇÃO DE VALOR EM E-BUSINESS}

Amit e Zott (2001) desenvolveram um modelo de negócio para avaliar o valor criado pelo e-business onde o modelo de negócios descreve o conteúdo, estrutura e governança de transações designadas para criar valor através da exploração de oportunidades de negócio.

O conteúdo da transação refere-se a bens ou informações que estão sendo trocados e aos recursos e capacitações requeridos para permitir a troca.

A estrutura de transação refere-se às partes da troca e o modo como essas partes estão " linkadas". Também inclui a ordem na qual as trocas acontecem (ou, a seqüência) e o mecanismo de troca adotado para permitir as transações.

A escolha da estrutura da transação influencia a flexibilidade, adaptabilidade e escala das transações. 
A governança da transação refere-se ao modo como as informações fluem , os recursos e bens são controlados pelas partes relevantes. A importância do modelo criado pelos autores reside, segundo eles, na sua utilidade em explicar e predizer um fenômeno empírico (criação de valor em e-business).

Para os autores, então, o modelo de e-business trata das transações que ocorrem entre as partes envolvidas na transação (compradores, vendedores, parceiros) onde o valor total criado através desse modelo de negócio é igual à soma dos valores apropriados por cada parte.

\subsubsection{MODELO DE E-BUSINESS BASEADO NO CONCEITO "BUILD- TO-ORDER"}

Segundo Tapscott et all (2001), as cadeias de valor desenvolvem, produzem e entregam produtos ou services para atender a um conjunto específico de necessidades do cliente.

As cadeias de valor primeiro identificam e definem as necessidades, depois desenvolvem e constroem as soluções.

Através de uma seqüência de etapas, as Cadeias de Valor transformam matérias-primas em produtos acabados e serviços.

Tradicionalmente, as iniciativas de melhoramento concentram-se na eficácia do processo e do custo.

A lógica fazer-e-vender do capital físico impulsionava o antigo modelo de produção.

O marketing esforçava-se em quantificar e predizer a demanda do consumidor, mas basicamente a integração do cliente era frágil.

Os bens eram desenhados para mercados de massa e eficácia de produção.

O estoque é o mal necessário da produção de rotina. A Ford e GM na década de 1990 automatizaram os elos com seus fornecedores apenas para transferir o problema de gestão de estoques aos fornecedores de seus fornecedores. 
Esse modelo apóia uma abordagem fazer-e-vender, sendo que as projeções de demanda impulsionam esses modelos .

Segundo os autores existe um segundo tipo de cadeia de Valor que é uma espécie de produção de oficina que cria soluções personalizadas em resposta a demandas únicas.

Nesse modelo, as oficinas são movidas pela demanda. Somente depois de vender um bem é que ela o fabrica. Nesse modelo o cliente participa do projeto fornecendo os dados necessários para sua realização.

Esse é o chamado modelo " build-to-order" ou fazer sob a demanda de um pedido, utilizado por exemplo pela empresa Dell de computadores, onde um computador é montado a partir de subconjuntos ou módulos separados, segundo a prescrição do cliente.

Esse modelo pressupõe uma rede de parceiros integrados à empresa, para fornecer os módulos a serm montados, para quem são delegadas as atividades de fabricação de componentes.

Essa delegação não é nada simples. Cada pedido de um grande cliente requer extensa customização.

A Cisco, empresa produtora de dispositivos e software de rede (uma das principais responsáveis pelos "encanamentos" da Internet) e seus revendedores, para cada pedido precisam especificar as necessidades únicas de seus clientes, projetar a solução e depois configurar, entregar e instalar um pacote de hardware/software personalizado.

O conceito “ build-to-order” faz lembrar KALAKOTA e ROBINSON (1999), para quem todo modelo de e-business implica em uma transformação estrutural para a empresa que o aplica.

De acordo com os autores, uma característica fundamental nas estruturas organizacionais de empresas que resolverem utilizar os negócios eletrônicos é a existência de estruturas mais flexíveis.

Para lidarem com a mudança, as empresas e unidades de negócio autônomas necessitarão de um desenho de sua estrutura eficiente, que permita 
que elas reajam rapidamente e de maneira contínua, permitindo um alto nível de inovação, e de mudança rápida da estratégia de negócio quando for necessário.

Os autores analisam as diferenças existentes entre o desenho de um negócio tradicional e o desenho de um negócio de e-business.

FIGURA 31. A REVERSÃO DA CADEIA DE VALOR

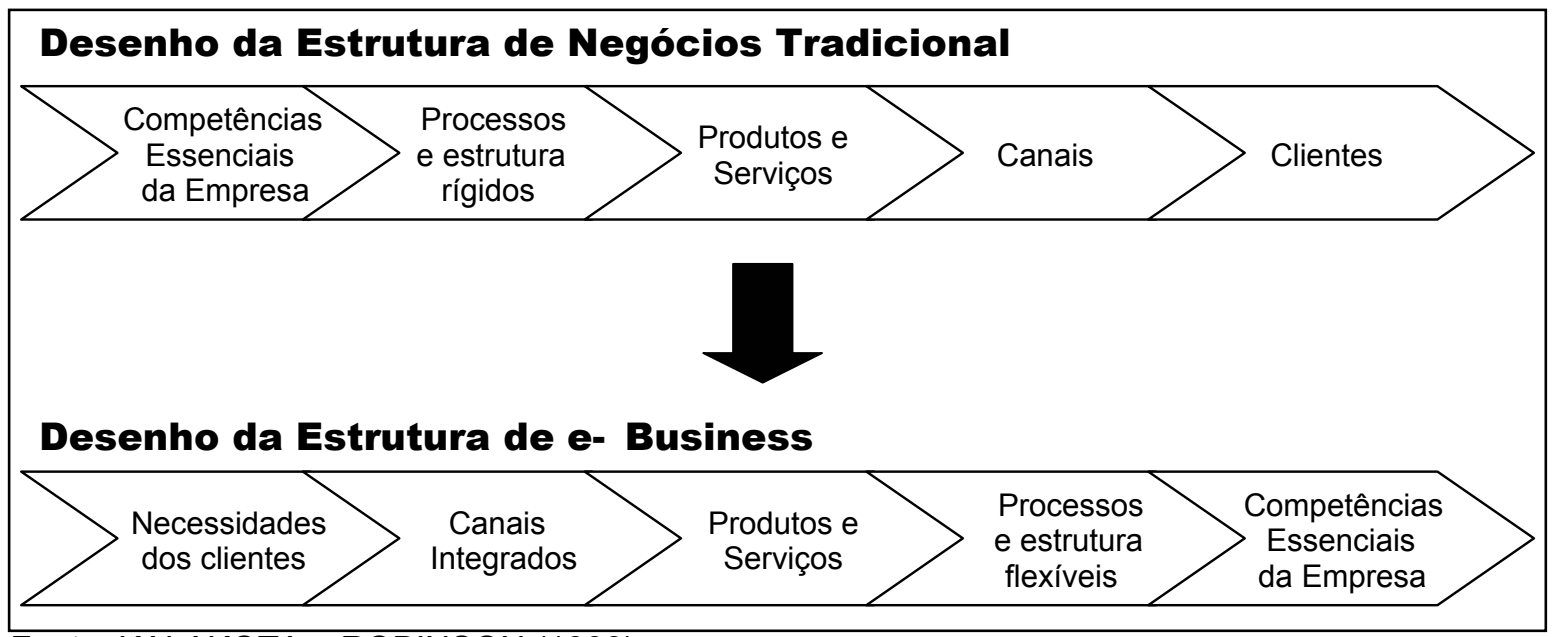

Fonte: KALAKOTA e ROBINSON (1999).

Eles consideram que à medida que surgem nova tecnologias e novas necessidades dos clientes, os administradores acham difícil criar novos desenhos de negócio pois foram treinados para concentrar-se em melhoria de produtos, aumentar fatia de mercado e aumentar receitas. Também no mundo de ebusiness, a distinção entre produtos e serviços é tênue.

Assim, o sucesso depende de criar novas " ofertas de produtos" nas quais os clientes vejam valor.

Empresas de sucesso não só adicionam velor, mas inventam-no.

Para isso é que as empresas devem reverter sua cadeia de valor, para colocar foco nas necessidades do consumidor.

\subsubsection{MODELOS DE E-BUSINESS B2B E B2C}

Algumas características podem ser descritas a partir dos modelos de e-business B2B (business to business) que define relacionamentos de 
negócio entre empresas utilizando a Internet e sobre o B2C (business to consumer ) que descreve o relacionamento entre empresas e consumidor individual .

\section{Modelo B2B}

Esse modelo implica que ambos os compradores e vendedores são corporações de negócios.

Esse modelo cobre um largo espectro de aplicações segundo Turban (2000) que possibilitam que uma empresa ou negócio forme relacionamentos eletrônicos com seus distribuidores, vendedores, fornecedores e outros parceiros.

As aplicações de B2B acessam os seguintes tipos de informações:

- Produto- Especificações, preços,etc

- Consumidor- compras históricas, perfil

- Fornecedor- linha de produtos, condições de vendas,...

- Processo do produto- capacidades, comprometimentos

- Transporte- custos, tempo

- Estoque- níveis, locais

- Competidor- benchmarking, market share

- Vendas e marketing- promoções

- Processos e performance da cadeia de suprimentos

Os relacionamentos entre negócios podem ser melhor compreendidos no contexto da cadeia de suprimentos.

A cadeia de suprimentos congrega todas as atividades associadas com 0 fluxo e transformação de bens a partir do estágio de matérias-primas até 0 usuário final.

Ela pode ser dividida em atividades "upstream" ou a montante envolvendo entradas de material e serviços dos fornecedores, atividades internas envolvendo a fabricação e embalagem dos produtos e atividades 'downstream' ou a jusante envolvendo a distribuição e vendas dos produtos para distribuidores e consumidores. 
Historicamente muitos dos processos na cadeia de suprimentos eram geridos através de transações via papel (requisições de compras, pedidos, etc).

É aqui que as aplicações de B2B tem lugar, elas podem servir como habilitadores da cadeia de suprimentos podendo oferecer uma distintiva vantagem competitiva.

Uma vez que o 'supply chain management' (ou gestão da cadeia de suprimentos) compreende a coordenação da geração de pedidos, tomada dos pedidos e execução/distribuição dos produtos, serviços e informações, as empresas envolvidas podem ser estudadas do ponto de vista do comprador ou consumidor.

Segundo Kalakota e Robinson (1999) os elementos de uma execução de uma cadeia de suprimentos são: entrada do pedido, processamento do pedido, confirmação do pedido, planejamento da execução, processo de produção, processo de distribuição.

O e-business é capaz de criar aplicativos que integrem eletronicamente todas essas fases do SCM.

O e-business permite o compartilhamento das informações ao longo do processo, criação de sistemas de mensuração conjuntos e planejamento colaborativo com fornecedores, redesenhar produtos e processos de maneira mais eficiente.

As entidades -chave do B2B são:

- Companhia vendedora-perspectiva de gestão de marketing

- Companhia compradora-perspectiva de gestão de procurement

- Intermediário eletrônico- um intermediário provedor de serviços

- Plataforma de rede-Internet, intranet ou extranet

- Protocolos e comunicação-por exemplo EDI

- Sitema de informações de back-end-possivelmente implementado usando intranet e sistemas Enterprise Resource planning (ERP)

Marketing Eletrônico- a plataforma B2B pode ser usada para vender os produtos e serviços da empresa para empresas consumidoras sobre a Internet. 
Gestão de Procurement- O e-procurement refere-se a todos os processos relativos a compras de bens e serviços sobre a Internet. Segundo Kalalota e Robinson (1999) e-procurement tem uma perspectiva comercial ou de transação.

Do ponto de vista de compras da empresa, o B2B é um meio de facilitar a gestão de procurement (ou compras) ao reduzir preço de compra e tempo gasto na procura e pedido.

Segundo Kalakota e Robinson (1999) procurement tem uma conotação mais ampla do que compras, pois envolve todo o processo de compra, transporte, estoque e recebimento.

Nesse modelo o marketplace orientado para o comprador pode ser usado para que os compradores anunciem RFQ ( request for quotations - ou cotação) para fornecedores potenciais para compras competitivas. Para os fornecedores o objetivo é conseguir fazer uma oferta vencedora.

Os intermediários eletrônicos fazem a intermediação entre compradores com uma vasta gama de fornecedores e outros intermediários.

Turban (2000) distingue dois modelos de B2B: supplier oriented marketplace, onde os compradores usam o mesmo marketplace provedor de fornecedores. Um exemplo desse modelo são os leilões eletrônicos.

Outro modelo de B2B segundo ele são os buyer oriented marketplacesonde os departamentos de compras das empresas tem que entrar com o pedido no sistema de informações da empresa. Nesse modelo um comprador abre um mercado eletrônico em seu próprio servidor e convida potenciais fornecedores a fazer ofertas sobre RFQs anunciadas. Seria o modelo de leilão reverso, que hoje em dia não precisa necessariamente acontecer somente no servidor da própria empresa, já existem terceiros que realizam leilões reversos. Utiliza o processo de "electronic bidding":

-Compradores preparam o projeto de biddings com as informações necessárias

-Compradores colocam isso na Internet

-Identificam potenciais fornecedores

-Convidam fornecedores a fazer ofertas 
-Fornecedores pegam informações na Internet

-Fornecedores fazem lances (bids)

-Compradores avaliam lances e negociam eletronicamente para alcançar as melhores propostas

-compradores aceitam a oferta que mais vai de encontro aos seus interesses.

Fazem parte do processo de e- procurement:

- Seleção dos produtos online- Catálogos online economizam tempo e papel.

- Pedido eletrônico (Electronic ordering) - Coloca pedidos para os fornecedores via entrada eletrônica de dados um sistema de procurement

- Aplicação de integração- procurement toca virtualmente cada aspecto da organização e dos sistemas usados para executá-lo, daí a necessidade de integração.

- Um bom aplicativo de procurement deve:

- Automatizar a seleção (catálogos) e compra de bens e serviços

- Cortar custos administrativos envolvidos em compras através da organização

- Integrar o fornecimento, pedido, e processo de pagamento dentro de soluções padrões end-to-end

- Enviar e receber eletronicamente todo o escopo de documentos necessários pelos compradores (pedidos de compra e requisição, avisos de embarque, etc).

\section{Modelo B2C}

Envolve o relacionamento da empresa com consumidores individuais.

Uma ferramenta básica que pode ser bem utilizada pelo e-business é o CRM ou Customer Relationship Management.

Segundo Kalakota e Ropbinson (1999) os consumidores não se importam em como a empresa guarda suas informações ou como ela as combina de fontes diferentes para dar a eles o que eles querem. 
Só o que eles sabem é que querem excelentes serviços e o produto que desejam.

Os objetivos do CRM são:

- Usar o relacionamento existente com o consumidor para aumentar as receitas

- Usar informação integrada para fornecer excelente serviço

- Introduzir mais processos de vendas e procedimentos que sejam reprodutíveis

- Criar novo valor e estimular a lealdade

- Implementar uma solução estratégica mais proativa.

Ao investir em aplicações de CRM as empresas esperam construir melhores programas de retenção de clientes que maximizem as receitas.

As 3 fases do CRM são:

- Adquirir novos consumidores - através da diferenciação, com os conceitos de inovação e conveniência

- Melhorar a lucratividade dos consumidores existentes- reduzindo custos e oferecendo serviços ao cliente

- Reter consumidores lucrativos ao longo do tempo- conceito de adaptabilidade: ouvir as necessidades dos clientes e oferecer novos produtos.

- Os processos chave de CRM são:

- Vendas- cross-sell, up-sell e televendas

- Marketing direto e execução- prover uma grande quantidade de informações para os consumidores de forma rápida, eficiente e fácil.

- Serviço ao cliente e suporte

- Serviços de campo

- Gestão da retenção

Para que um sistema de Internet possa oferecer todas essas atividades relativas a CRM, ele precisa de cinco tipos de integração para ser efetivo: 
- Conteúdo do cliente

- Informação de contato com o consumidor

- Processos de negócio end-to-end

- A extensão dos parceiros da emrpesa

- Sistemas de front-office e back-office

- Requisitos para um bom programa de CRM: Toda a empresa precisa ter foco no consumidor, não apenas uma unidade de negócios

- requer transição de infraestrutura centrada num "silo" para uma infraestrutura integrada centrada no consumidor

- Organizações globais que lidam com línguas, culturas diferentes precisam prover serviços customizados usando tecnologia de Internet por exemplo, pois é difícil conseguir essa customização com tecnologias tradicionais.

Quanto ao ponto de contato com o cliente, a tecnologia propicia uma vasta gama: callcenters, "storefronts" (vitrines), kiosks e vendas pessoa-a-pessoa. 


\section{CAPÍTULO IV}

METODOLOGIA DE PESQUISA $\overline{\mathrm{C}}$ 


\section{Capítulo 4}

\section{METODOLOGIA DE PESQUISA}

\section{APRESENTAÇÃO}

Este capítulo apresenta a metodologia do estudo, compreendendo algumas considerações sobre metodologia, a escolha do tipo de pesquisa e a justificativa do seu emprego, bem como considerações sobre a escolha dos casos estudados, coleta de dados e análises dos mesmos.

Para a realização da pesquisa, uma fase inicial compreendeu o levantamento da fundamentação teórica da pesquisa, através de uma revisão bibliográfica ampla, compreendendo temas referentes à:

- Levantamento do estado da arte do tema, a partir de fontes e dados secundários tradicionais e aspectos relevantes sobre suas características, como definições sobre e-business, fatores de sucesso para sua adoção, dentre outros;

- Apresentação de vários modelos de negócios voltados para e-business, assim como aspectos relacionados à sua implantação e obstáculos à mesma;

- Migração de empresas tradicionais para a Internet, impacto dessa migração sobre os negócios, infraestrutura de TI necessária para suportála, alinhamento da estratégia corporativa global e estratégia de ebusiness, dentre outros;

- Fatores críticos de sucesso para implantação de e-business por empresas tradicionais e barreiras à implantação

- Tópicos relacionados à caracterização de estruturas organizacionais e critérios para sua seleção

- Aspectos relacionados ao desenho e implantação de projetos, além de itens relacionados à gestão de projetos. 
O embasamento teórico compôs-se de obras que definiram modelos de ebusiness, propondo uma nomenclatura a partir dos tipos de transações entre determinados atores (Weil e Vitale (2001), Turban (2000), dentre outros autores), proposta de modelos de e-business a partir da análise da cadeia de valor (Porter (2001), Timmers (1998), Amit (2001), Applegate (2001), Chesbrough (2001), dentre outros).

Para fazer a análise das estruturas organizacionais utilizadas para implantar o e-business foram utilizados principalmente os seguintes autores: Vasconcellos (1997), Kerzner(1992), Cleland (1988), Oliveira (2001), Certo e Peter (1993), Freeland e Stirton, dentre outros.

Para avaliar os resultados obtidos a partir da implantação do e-business os seguintes autores foram consultados: Turban (2000), Weil e Vitale (2001), O’Connel (2000), Slywotzky (2000), Barrenechea (2001), dentre outros.

Muitos outros autores foram consultados para questões específicas, bem como inúmeros 'papers'acadêmicos e publicações especializadas.

Porém, os autores acima foram citados como principais referências para cada questão de pesquisa investigada.

A seguir serão apresentadas considerações sobre a escolha do método de pesquisa, bem como escolha dos casos, coleta e análise dos dados.

\subsection{CONSIDERAÇÕES SOBRE A ESCOLHA DO MÉTODO DE PESQUISA}

Para se compreender a escolha da metodologia utilizada na presente pesquisa, é pertinente a revisão de alguns conceitos básicos acerca da atividade científica e o papel da metodologia na investigação científica.

Quanto à atividade científica, pode-se dizer que o "objeto" de pesquisa refere-se à classificação metódica dos fatos, seguida pela identificação de suas 
relações e seqüências repetitivas", segundo definição formulada por Karl Pearson e citada por Castro (1977), onde o termo "fatos" diz respeito à atmosfera do cientista, pois, segundo o cientista Pavlov, citado ainda em Castro, "sem eles nossa teoria não passa de um esforço vazio".

Ainda segundo Castro (1977), pode-se definir metodologia "como um conjunto de regras de como proceder no curso da investigação" e segundo Gay e Diehl (1992:6), o método científico ordena uma pesquisa genérica de acordo com as seguintes etapas:

- reconhecimento e definição do problema;

- formulação de hipóteses;

- coleta de dados;

- análise dos dados;

- apresentação das conclusões, buscando a confirmação ou negação das hipóteses.

O presente estudo pode ser considerado de natureza exploratória pela contemporaneidade do fenômeno estudado e pelo pouco conhecimento acadêmico acumulado sobre o assunto.

O estudo exploratório, conforme apontam Selltiz et al. (1974), tem como objetivo "familiarizar-se com um fenômeno ou conseguir nova compreensão deste...nos casos em que o conhecimento é muito reduzido". Embora existam restrições a esse tipo de estudo, os estudos exploratórios mostram-se adequados quando a massa crítica de conhecimentos sobre um assunto não é extensa e importante, ao se constituírem etapas iniciais para a realização de estudos mais estruturados como os causais e descritivos.

A opção pelo estudo exploratório também é feita por Mattar (1996) que os indica para os casos em que há pouco conhecimento acumulado e sistematizado sobre um tema.

Segundo Selltiz (1974) em muitas áreas de relações sociais, não existem hipóteses significativas, sendo necessário fazer muitas pesquisas exploratórias antes de ser possível formular hipóteses. Ainda segundo esse autor, cada estudo tem seu objetivo específico, mas pode-se agrupar os objetivos de uma pesquisa em alguns agrupamentos mais genéricos: 
1. Estudos Exploratórios - tem por objetivo familiarizar-se com o fenômeno ou conseguir nova comprrensão deste, para poder formular um problema mais preciso de pesquisa ou criar novas hipóteses;

2. Estudos Descritivos - cujo objetivo prende-se à obtenção de exatidão, de modo a reduzir o viés e ampliar a precisão da prova obtida;

3. Estudos Causais -exigem processos que não só reduzam o viés e aumentem a precisão mas também permitam inferências quanto à causalidade.

Quanto ao aspecto particular da pesquisa em Administração de empresas, vale ressaltar as considerações feitas por Easterby-Smith et al. (1991):

- as questões da Administração se mostram multidisciplinares e ecléticas, na medida em que administradores, em geral, lidam com questões culturais, funcionais e técnicas, valendo-se de conhecimentos de vários campos e lidando com especialistas de diversas formações;

- os administradores se apresentam como pessoas muito atarefadas e com agendas exigentes e apertadas. Da mesma forma, potenciais entrevistados ocupam cargos de importância nas organizações, o que, naturalmente, pode se constituir num obstáculo para o acesso do pesquisador;

- a Administração se apresenta como uma ciência aplicada, exigindo a conjugação de pensamento e ação, o que pode levar à questão da aplicabilidade genérica dos resultados de uma pesquisa.

A natureza do fenômeno estudado torna extremamente difícil generalizar resultados e se constitui na diferença básica entre pesquisa em Administração e a de outras áreas do conhecimento, conforme explicitam Gay \& Diehl, (1992).

A pesquisa em Administração de Empresas lida com situações de considerável dificuldade de explicar, predizer e controlar, em função de sua natureza complexa envolvendo pessoas, instituições, ambiente em mudança 
contínua, jogos de poder e, não simplesmente, relações determinísticas de causa e efeito.

A partir da revisão bibliográfica executada para a presente pesquisa, constatando a falta de estudos no assunto em questão (identificação de estruturas organizacionais adotadas por empresas tradicionais que migram para a Internet realizando e-business), conclui-se que a presente pesquisa assume características de estudo exploratório, tendo a finalidade de esclarecer aspectos ainda não muito explorados por outras pesquisas, uma vez que para se caracterizar como estudo descritivo seria necessário pressupor-se muitos conhecimentos anteriores do problema a ser pesquisado.

Como foi apresentado na revisão da literatura, existe um maior volume de considerações sobre a adoção de modelos de e-business por parte de empresas tradicionais, no que tange a aspectos externos à empresa: relacionamento com fornecedores, clientes e parceiros, com alguma ênfase na necessidade de alinhamento dessa adoção com a estratégia corporativa.

Porém não se encontrou nenhuma referência quanto a aspectos internos à organização, mais precisamente quanto à estruturação interna da empresa ou seu desenho organizacional a partir da escolha do modelo de e-business adotado.

Mesmo no que tange a aspectos relacionados a e-business, não foi encontrado na literatura informações sobre casos brasileiros, ou seja, análise do e-business no Brasil sob a ótica de identificação de novos modelos de e-business.

Após a revisão bibliográfica empreendida, foi feito um levantamento das empresas que tiveram experiência prática com o problema estudado, qual seja, empresas tradicionais que adotaram o e-business, analisando exemplos que estimulem a compreensão dos mecanismos encontrados nessa adoção .

O estudo exploratório consistiu em investigações "ex-post-facto" sobre relações entre variáveis em estruturas sociais reais, utilizando para tal, casos selecionados de maneira não probabilística, ou seja, de maneira intencional, sem qualquer relacionamento causal.

Seu ponto forte consiste na capacidade de aquisição de informações úteis para que se estabeleçam fundamentos mais realistas para o desenvolvimento de pesquisas posteriores, contribuindo para o avanço da teoria e também para 
solução de problemas práticos, uma vez que o pesquisador teve contato real com os acontecimentos sociais, organizacionais e comportamentais que constituem sua unidade de pesquisa.

Assim, decorrente do gênero de pesquisa empreendido- estudo exploratório- não há a preocupação em se estabelecer relações entre variáveis dependentes e independentes, comprovando ou não hipóteses pré-estabelecidas.

As pesquisas exploratórias são desenvolvidas com o objetivo de proporcionar visão geral, de tipo aproximativo, acerca de determinado fato.

Este tipo de pesquisa é realizado especialmente quando o tema escolhido é pouco explorado e torna-se difícil sobre ele formular hipóteses precisas e operacionalizáveis.

O objetivo do desenvolvimento deste tipo de pesquisa exploratória é desenvolver hipóteses pertinentes e propostas para mais questões.

No caso, tal pesquisa pode contribuir para aprofundamentos futuros sobre fatores críticos para tomada de decisão quanto ao modelo de e-business adotar , ou quanto ao nível de integração do e-business com a empresa tradicional mais adequado e ainda sobre as estruturas organizacionais mais convenientes na configuração do e-business na empresa.

\subsubsection{TIPO DE PESQUISA: ESTUDO DE CASOS MÚLTIPLOS}

O desenvolvimento desta pesquisa exploratória utilizou o método de estudo de casos múltiplos, com a apresentação de três casos, que foram estudados em profundidade.

Como o caráter da presente pesquisa é exploratório, visando delinear de modo mais esclarecedor o problema de pesquisa, entendeu-se que a melhor exploração do tema dar-se-ía através de entrevistas pessoais.

Segundo Yin (1990) o estudo de caso é a estratégia preferida quando as questões são colocadas sob a forma de "Como" ou "Porque", que é o caso presente, onde se pergunta: "Como está estruturado o negócio de e-business?" e "Por que foi utilizado determinado modelo de e-business?" 
O estudo de caso permite uma investigação para obter as características mais significativas e holísticas.

O objetivo do desenvolvimento deste tipo de pesquisa exploratória é desenvolver hipóteses pertinentes e propostas para mais questões.

Tecnicamente, o autor define estudo de caso como uma investigação empírica que:

- Trata de um fenômeno contemporâneo num contexto de situação real;

- As fronteiras entre o fenômeno e seu contexto não é claramente evidente e;

- Utiliza múltiplas fontes de evidências.

Alguns problemas relativos ao estudo de caso: viés no tratamento dos dados (problema que pode acontecer em outros tipos de estudos), prover pouca base para generalização-o que pode ser atenuado com o uso de múltiplos casos.

Ainda segundo Yin (1990), há dois tipos de generalização possíveis: a generalização estatística, onde uma inferência sobre a população é feita com base na coleta de dados empírica sobre uma amostra. O estudo de caso inserese na "generalização analítica".

Os casos, porém, não são unidades amostrais, portanto não se pode fazer uma generalização dos resultados do caso do mesmo modo que se faz a generalização dos resultados estatísticos de uma pesquisa quantitativa.

Múltiplos casos podem ser considerados como experimentos múltiplos, e a generalização deve ser feita de maneira analítica, na qual uma teoria desenvolvida previamente é usada como base de comparação com os resultados empíricos.

Os resultados empíricos podem ser considerados mais potentes se forem usados dois ou mais casos, porém não suporta uma teoria rival à qual serviu de apoio. A teoria serve como base para generalização dos resultados obtidos através do estudo de casos. 
A distinção entre o caso único e casos múltiplos se faz a partir de alguns pontos: o caso único se justifica quando ele representa o "caso crítico" para testar determinada teoria, que não é o que acontece na presente pesquisa: não há aquela empresa que vai determinar se há ou não um modelo mais adequado para se analisar a implantação de e-business.

Outras ocasiões em que pode ser usado é quando ele é o único caso ou o "caso revelador", o que também não ocorre nessa pesquisa. A vantagem de usar vários casos deve-se ao fato das evidências coletadas levarem o estudo global a ser olhado de forma "mais robusta".

Segundo o autor, não se deve encarar o estudo de casos múltiplos como uma analogia da lógica de amostragem, onde cada caso é encarado como um respondente, mas sim, dentro da lógica de "reforço" ou cópia dos resultados, considerados como múltiplos experimentos.

O autor defende então a lógica da "replicação" dos casos. Cada caso selecionado deve predizer resultados similares ou contrários, porém, neste caso por razões previsíveis. Essa lógica da "replicação " difere da amostragem, pois nesta última, um número de respondentes é assumido como representante de um número grande de sujeitos, onde um número pequeno representa o todo.

Um caso, diferentemente, deve cobrir o fenômeno de interesse e seu contexto, o que impediria um tratamento estatístico devido ao número imenso de variáveis.

Sob esse aspecto, a pesquisa caracteriza-se como de opinião, pois enfoca o que os entrevistados avaliam sobre cada aspecto perguntado, sendo a análise feita sobre esses dados de opinião.

Por meio de três estudos de caso, este trabalho visa discutir como os conceitos até então colocados são tratados na prática organizacional, contribuindo para sua operacionalização.

A seguir são descritos os aspectos metodológicos para a realização deste estudo. 


\subsection{RELACIONAMENTO ENTRE AS QUESTÕES DE PESQUISA - MODELO DE PESQUISA}

Esse item tem por objetivo esclarecer quais as relações entre as questões de pesquisa abordadas nesta tese.

A definição de e-business utilizada nessa tese é a de caráter mais amplo observada na revisão da literatura e compreende negócios internos e externos à firma realizados eletronicamente.

A empresa indicada no modelo é uma empresa dita "tradicional" o que significa não ser uma empresa nascida na Internet, e sim uma empresa que já estabelecida no mundo real, com uma estrutura organizacional determinada e em operação, composta por recursos e relações já existentes.

Como foi levantado na literatura, a escolha das iniciativas de e-business por uma empresa e sua possível configuração num modelo de e-business deve ter uma relação estreita com a estratégia da empresa e a implantação do ebusiness deve estar alinhada com os objetivos globais da mesma (Porter (2001), Turban (2000), Tapscott(2000), Weil e Vitale (2001), dentre outros).

Uma vez analisada a estratégia vigente e a partir das oportunidades externas, como acesso à Internet, análise das forças da indústria, dentre outros, a empresa terá em mãos um portfólio de possíveis atividades de e-business a implantar, identificando quais segmentos de clientes se deseja atingir com tais iniciativas e quais objetivos se deseja alcançar, possibilitando o desenho das atividades de e-business que se quer implantar.

As iniciativas de e-business identificadas como oportunidades pela empresa podem seguir um determinado modelo de negócio a partir dos relacionamentos estabelecidos dentro e fora da empresa com funcionários, clientes, fornecedores, parceiros e concorrentes.

Essas iniciativas são operacionalizadas através do estabelecimento de um desenho organizacional determinado, que pode sofrer transformações ao longo do tempo. 
A partir da implantação dessas atividades de e-business, dentro de determinado arranjo organizacional, determinados objetivos são pretendidos e efetivamente determinados resultados são alcançados.

Um possível desenho desses relacionamentos pode ser observado na figura abaixo: 
FIGURA 32: MODELO DE PESQUISA

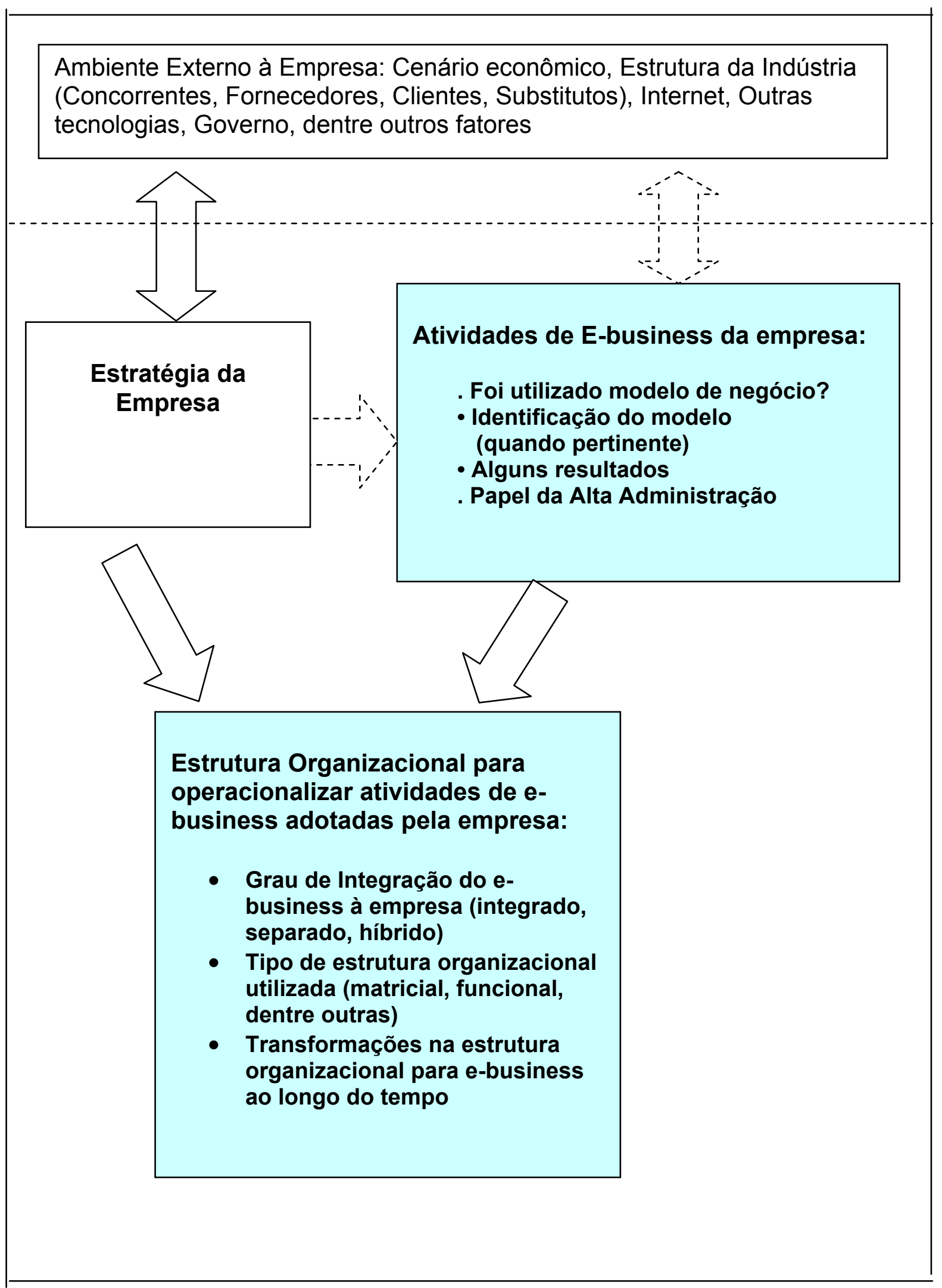


A presente pesquisa teve dois focos principais de estudo, identificados pelas caixas sombreadas do modelo de pesquisa, quais sejam:

\section{Quanto às atividades de e-business da empresa:}

Verificação se foi utilizado Modelo de Negócio para o desenho e implantação das atividades de e-business da empresa.

Um modelo de negócio segue a definição apresentada no início dessa tese, como sendo a de Applegate (2001): o modelo de negócio descreve de um modo sucinto como o negócio está estruturado, que tipo de pessoas são necessárias para aquele negócio e quais os papéis que elas desempenham, sendo seus componentes: conceito, capacidades e valor.

A existência de um modelo de negócio para as atividades da empresa representa um caminho, uma orientação para essas atividades de acordo com determinados objetivos.

Por outro lado, a empresa pode não adotar nenhum modelo de negócio para suas atividades de e-business, que serão implantadas segundo outros critérios, a descobrir nessa pesquisa quando for o caso da não existência de modelo de negócio orientador das atividades de e-business da empresa.

Existem inúmeros tipos de modelo de negócio que podem ser utilizados para as atividades de e-business: fez parte dos objetivos dessa pesquisa identificar quais tipos de modelo de negócio para o desenho e implantação das atividades de e-business foram utilizados pelas empresas estudadas, quando pertinente (ou seja, quando foi utilizado algum modelo).

Haja ou não um modelo para orientá-las , as atividades de e-business numa empresa determinam certos resultados, alguns dos quais serão apresentados no item referente a modelos do capítulo sobre apresentação dos resultados.

A alta administração da empresa é quem decide como será feito o desenho e implantação das atividades de e-business da empresa, utilizando-se ou não de modelos de negócio. Daí, foram apresentados alguns resultados acerca do papel da alta administração das empresas no que tange à essa escolha: adoção ou não de modelos para desenho e implantação de e-business e quais tipos de modelos. 
2. Estruturas organizacionais empregadas para operacionalizar as atividades de e-business da empresa - aqui se identificou o tipo de estrutura empregada (matricial, funcional, unidade de negócio, etc) e o grau de integração dessa estrutura à empresa, bem como se ocorreram mudanças nessas estruturas ao longo do tempo.

Como prescreve a literatura, a adoção de determinado modelo de ebusiness acontece a partir de determinados preceitos ditados pela estratégia da empresa.

Aliás, vários autores (Porter (2001), Weil e Vitale (2001), Lientz (2001), dentre outros) sublinham a importância de se desenvolver uma iniciativa de ebusiness a partir da estratégia da empresa, ou seja, o e-business deve estar alinhado com a estratégia global da empresa e deve servir para cumprir seus objetivos e não ser um fim em si mesmo.

A seta que vai da estratégia para a caixa relativa às atividades de ebusiness no modelo de pesquisa acima está mostrando que a estratégia da empresa é quem deve nortear a elaboração dessas atividades de e-business; o fato da seta estar tracejada indica que se quer verificar se realmente as empresas estudadas fizeram esse caminho, ou seja, idealizaram suas atividades de e-business a partir da estratégia ou se a iniciativa de e-business estava desvinculada da mesma.

As atividades de e-business também devem levar em conta aspectos externos à empresa, como o tipo de e-business praticado pelos concorrentes, que tipo de clientes se quer atingir com a Internet, etc.

A linha tracejada da seta que vai das atividades de e-business para o ambiente externo quis verificar se nos casos estudados houve uma observação desses fatores externos para implantação do e-business.

Quanto à estrutura organizacional, num primeiro momento identificou-se o grau de integração da estrutura organizacional de e-business utilizada para operacionalizar as atividades de e-business adotadas.

A explicação detalhada dos graus de integração possíveis encontra-se na descrição da questão 2 de pesquisa dessa tese, podendo variar numa vasta gama 
de níveis, desde uma estrutura totalmente separada da empresa, até uma estrutura totalmente integrada à estrutura organizacional já instituída.

Também se identificou o tipo de estrutura organizacional empregada conforme nomenclatura e classificação explicada em detalhes na revisão da literatura (matricial, funcional, etc).

A seta que vai da estratégia para a estrutura organizacional deve-se ao fato de vários autores, dentre eles Vasconcellos (apud OLIVEIRA, 1995), identificarem os objetivos e estratégias da empresa como sendo alguns dos condicionantes (fatores que influenciam em sua definição e desenho) da estrutura organizacional dessa empresa.

A seta que vai das atividades de e-business identificadas para a estrutura organizacional indica que a operacionalização dessas atividades de e-business pela empresa tradicional se dá através de ajustes, modificações ou mesmo criação de determinada estrutura organizacional pela empresa que o adotou.

Gulati e Garino (2000) e Muritiba e Vasconcellos (2001) são alguns dos autores que estabelecem uma relação entre as atividades de e-business adotadas e a estrutura organizacional mais adequada para operacionalizá-las em termos de grau de integração do e-business à empresa que o adota.

Quanto ao tipo de estrutura, Vasconcellos (1997) propõe vários tipos de estruturas chamadas inovativas que se prestam a implementar funções não usuais na empresa.

Reinhold (1992) e a literatura sobre gestão de projetos fornecem base para se discutir quais estruturas organizacionais mais adequadas para se implementar determinado projeto e suas transformações ao longo das diversas fases de implantação dessa inovação, no caso estudado, o e-business.

O Modelo acima pressupõe que a firma possui uma estratégia; a empresa está submetida ao ambiente externo, de onde surgem oportunidades, como por exemplo, a possibilidade de uso da Internet para fazer negócios, bem como desafios, por exemplo, o fato dos concorrentes já estarem inseridos na Internet utilizando-o como meio para ampliar sua base de clientes, realizando negócios eletrônicos. 
Utilizou-se o conceito de Porter (1990) para estratégia como sendo a busca de uma posição competitiva favorável em uma indústria, a arena fundamental onde ocorre a concorrência. A estratégia visa a estabelecer uma posição lucrativa e sustentável contra as forças que determinam a concorrência na indústria.

Duas questões norteiam a escolha da estratégia por uma empresa: a atratividade da indústria em termos de rentabilidade a longo prazo e os fatores que determinam essa atratividade; e os determinantes da posição competitiva relativa dentro de uma indústria.

Ainda segundo Porter (2001) em um artigo sobre a Internet e a estratégia, esse autor diz que o valor econômico para uma empresa nada mais é que a diferença entre preço e custo; para responder a pergunta de como a Internet pode ser usada para criar valor econômico, esse autor sugere que é necessário analisar dois fatores que determinam a lucratividade: a estrutura da indústria, que determina a lucratividade do competidor médio e a vantagem competitiva sustentável, que permite à empresa superar a média do competidor.

$\mathrm{Na}$ revisão da literatura foi visto o modelo das cinco forças de Porter que analisa a estrutura da indústria e como cada um de seus componentes é afetado pela Internet.

Quanto à obtenção de vantagem competitiva, Porter prescreve que vantagens em custo e preço podem ser obtidas de duas formas: efetividade operacional, que, no caso da Internet, apesar de ser um instrumento que provê grande efetividade operacional, não provê vantagem competitiva, pois todos competidores tem acesso às mesmas tecnologias, o que os iguala; e posicionamento estratégico-como é difícil sustentar vantagens operacionais, o posicionamento estratégico torna-se mais importante.

Os princípios do posicionamento estratégico elencados por Porter (2001) dos quais essa tese se vale são:

-retorno sobre investimento de longo prazo superior- somente atrelando a estratégia a uma lucratividade sustentável irá garantir que um real valor econômico seja gerado.

-entregar uma proposição de valor ou conjunto de benefícios para o consumidor diferente daqueles oferecidos pelos competidores 
-estratégia precisa ser refletida numa cadeia de valor distintiva. Para estabelecer vantagem competitiva, a empresa precisa fazer diferentes atividades que os rivais ou atividades similares de um jeito diferente. Precisa configurar um modo de conduzir a manufatura, logística, serviços, e assim por diante diferente dos competidores e sob medida para sua diferenciada proposição de valor.

-estratégia envolve "trade-offs" ou negociações: a empresa precisa abandonar ou esquecer alguns produtos, serviços ou atividades de modo a ser única em outros.

-a estratégia define como todos elementos de uma empresa devem se ajustar juntos. A estratégia envolve fazer escolhas através da cadeia de valor que são interdependentes, todas as atividades da empresa precisam ser reforçadas umas pelas outras. O desenho de produto, por exemplo, deve reforçar sua abordagem para os processos de manufatura e ambos devem alavancar o modo como é conduzido o serviço de pós-vendas.

-Finalmente, estratégia envolve continuidade de direção.

Ter uma estratégia requer um forte foco em lucratividade mais do que em crescimento, uma habilidade em definir uma única proposição de valor e disposição em escolher o que não fazer.

Ter uma única proposição de valor significa que a empresa deve estabelecer um conjunto de benefícios para o cliente diferente dos que os competidores oferecem. Estratégia não é uma questão de oferecer tudo para o consumidor. A estratégia define um modo de competir que entrega um valor único para o cliente num particular conjunto de usos ou para um particular conjunto de consumidores.

Nesse sentido, o conceito de estratégia de Porter é usado nessa tese, pois dentre tantas atividades possíveis de e-business, a empresa deve escolher aquelas que permitam a ela obter e manter vantagem competitiva, focando na questão da maior lucratividade e não apenas em crescimento.

Alguns exemplos de estratégia na indústria automobilística: aumento da fatia de mercado de determinado produto em X\%, ampliação do mercado 
consumidor na Ásia em y\%, criação e lançamento de um novo modelo de carro econômico no mercado latino americano para atingir o segmento $C$ de consumidores, aumentar a exportação do modelo B para o mercado latinoamericano em z\%, e assim por diante.

A partir das considerações feitas acima por Porter (2001) as atividades de e-business adotadas devem ir de encontro a essa estratégia adotada pela empresa: por exemplo, se o objetivo é o lançamento de um novo modelo de carro econômico para o mercado da América Latina, a montadora pode pensar numa atividade de e-business que contemple esse lançamento através de vendas diretas pela Internet, por exemplo.

Se a estratégia da empresa é cortar custos operacionais em $X \%$, pode-se pensar na implantação de atividades B2B, que encerrem atividades de eprocurement na compra de materiais produtivos e não-produtivos, diminuindo assim o custo total da operação em uma parcela que contribua para a diminuição de custo almejada.

Com essas considerações mostrou-se que a componente "estratégia" é de suma importância na definição das atividades de e-business de uma emrpesa.

Porém, para essa tese, o foco não foi o esclarecimento das estratégias utilizadas pelas montadoras estudadas, mesmo porquê as empresas não quiseram revelar suas estratégias para publicação.

A menção de um ou outro fator estratégico foi obtida através de publicações na mídia especializada e quando possível e pertinente foi feita alguma associação com o fenômeno que estava sendo estudado, qual seja, a identificação das atividades de e-business e das estruturas organizacionais para operacionalizá-las.

O ambiente externo à empresa mostrado no modelo proposto nessa tese compreende o cenário econômico nacional e mundial, a estrutura da indústria (seguindo o modelo de Porter(1990) de análise das 5 forças competitivas que determinam a rentabilidade da indústria: fornecedor, comprador, substituto, concorrência e novos entrantes), governo, novas tecnologias, dentre outros.

O uso da Internet pode deixar menos claros esses limites entre o que é externo à firma ou não, permitindo que fornecedores troquem informações com a 
empresa ou mesmo realizem projetos conjuntos usando a rede mundial de computadores para facilitar essas trocas.

O ambiente externo fornece alguns fatores condicionantes para a elaboração da estratégia bem como deve ser analisado para a adoção do modelo de e-business mais adequado à empresa.

\subsection{ALGUMAS DEFINIÇÕES}

Algumas definições são apresentadas nesse ítem, uma vez que muitos dos termos utilizados nessa tese apresentam diversas abordagens por parte dos diversos autores que o tratam, de modo a facilitar a compreensão dos termos referidos quando da apresentação dos resultados.

A) E-Business: quaisquer transações de negócios, dentro e/ou fora da firma, feitas através de meio eletrônico (Internet, intranet, extranet, EDI/I, etc).

B) Modelo de negócio: Um modelo descreve de um modo sucinto como o negócio está estruturado, que tipo de pessoas são necessárias e quais os papéis que elas desempenham. Seus componentes são: Conceito- descreve as oportunidades; -Capacitações- define recursos necessários para transformar conceitos em realidade; -Valor - mede o retorno para investidores e outros acionistas.

O modelo de negócios congrega uma série de atividades de e-business. As atividades são escolhidas de acordo com as características de cada modelo.

C) Desenho das atividades de e-business: Escolha de quais atividades de e-business a empresa vai adotar, relacionando-as às áreas da empresa que irão utilizá-las e alocando-as em determinada posição da estrutura organizacional da empresa, estipulando quais os requisitos tecnológicos serão necessários para que essas atividades aconteçam. 
D) Implantação das atividades de e-business- Entende-se por Implantar as atividades de e-business o ato de tornar o desenho operacional., ou seja, fazer com que o desenho de e-business determinado entre em ação, seja operacionalizado, traduzido em atividades executáveis.

E) Estrutura de e-business: identifica a estrutura organizacional mais toda a estrutura de apoio necessária (infraestrutura de $\mathrm{TI}$, recursos financeiros, dentre outros) para colocar em ação as iniciativas de e-business. Ela surge como resultado da implantação das atividades de e-business e é necessária para que se implemente uma iniciativa de e-business.

F) Ferramentas de e-business- são os produtos eletrônicos oferecidos pela Internet: e-procurement, callcenter, sites, portais, leilões eletrônicos, RFQ (request for quotation), catálogos, dentre outros, que são utilizados pelas atividades de e-business.

G) Atividades de e-business: são as atividades relacionadas a ebusiness. Por exemplo: compra e venda de bens utilizando Internet, uso de Exchange para fazer negócios, coordenar a cadeia de suprimentos através de ferramentas de e-business (como e-procurement), fazer projetos colaborativos com parceria entre empresa e fornecedor através do uso da Internet, dentre outros.

H) Supply Chain management (SCM)- Gestão da cadeia de suprimentos. Os relacionamentos em e-business B2B (entre empresas) podem ser melhor compreendidos no contexto da cadeia de suprimentos.

A cadeia de suprimentos congrega todas as atividades associadas com o fluxo e transformação de bens a partir do estágio de matérias-primas até o usuário final. A gestão da cadeia de suprimentos compreende a coordenação da geração de pedidos, tomada dos pedidos e execução/distribuição dos produtos, serviços e informações relacionados ao pedido. Historicamente muitos dos 
processos na cadeia de suprimentos eram geridos através de transações via papel (requisições de compras, pedidos, etc).

O e-business é capaz de criar aplicativos que integrem eletronicamente todas essas fases do SCM.

I) e-Procurement- É uma ferramenta de e-business. O e-procurement refere-se a todos os processos relativos a compras de bens e serviços sobre a Internet. Do ponto de vista de compras da empresa, o B2B é um meio de facilitar a gestão de procurement (ou compras) ao reduzir preço de compra e tempo gasto na procura e pedido.

Segundo Kalakota e Robinson (1999) procurement tem uma conotação mais ampla do que compras, pois envolve todo o processo de compra, transporte, estoque e recebimento.

Nesse modelo o marketplace orientado para o comprador pode ser usado para que os compradores anunciem RFQ ( request for quotations - ou cotação) para fornecedores potenciais para compras competitivas. Para os fornecedores o objetivo é conseguir fazer uma oferta vencedora.

J) Mercado Eletrônico- Um mercado é uma rede de interações e relacionamentos onde informações, produtos, serviços e pagamentos são trocados. Quando o mercado é eletrônico, os centros de negócio não são um prédio físico mas um lugar provido por uma infraestrutura de rede onde as interações ocorrem.

Normalmente são construídos sobre redes públicas de acesso livre, como a Internet.

K) Leilões eletrônicos- É uma ferramenta de e-business. Leilão que ocorre no mercado digital. Empresa se registra em determinado servidor e tem que concordar com uma série de regras; tempo, preço e volume são as variáveis mais importantes na maioria dos leilões.

-Leilão reverso - as empresas com mercadorias com demanda oferecem esses produtos ou serviços para que outras empresas façam seus lances. 
Num leilão eletrônico reverso (online ou electronic bidding) um comprador abre um mercado eletrônico em seu próprio servidor ou utiliza o serviço de terceiros e convida potenciais fornecedores a fazer ofertas sobre RFQs anunciadas.

L)Aquisição-são sistemas que formam o coração da cadeia de suprimento. A maioria das funções de aquisição são executadas utilizando-se a Internet para ganhar acesso direto às empresas dos fornecedores através de vínculos ou de um componente sublicenciado do mercado digital,

M) Exchange: a Net Market Makers define-os como "mercados bilaterais, em que compradores e fornecedores negociam preços, em geral com um sistema de proposta de compra e de proposta de venda, em que os preços flutuam para cima ou para baixo". Os exchanges privados foram os primeiros exchanges eletrônicos. Cada um era hospedado por uma empresa dentro do firewall desta e usado para compra dentre um grupo de fornecedores pré-autorizados. Muitos destes exchanges foram implementados utilizando-se EDI, uma tecnologia dispendiosa que está rapidamente perdendo terreno para a Internet. Hoje existem exchanges públicos, onde várias empresas podem participar e são hospedados por terceiros, não por determinada firma proprietária.

N) EDI, Intranet e Extranet- Define-se EDI (Electronic Data Interchange ) como uma transferência direta computador a computador de documentos padrão de negócios, como ordens de compra, por exemplo, através de uma rede privada.

Turban (2000) define Intranets como uma rede corporativa LAN ou WAN que funciona com tecnologia da Internet atrás de um "firewall" (sistemas de proteção que consiste num nó da rede com hardware e software que isola uma rede privada de redes públicas ) da empresa.

Uma extranet é uma rede que faz o "link" das intranets de parceiros de negócios usando uma rede virtualmente privada sobre a Internet, onde o acesso é permitido através da distribuição de senhas ou códigos de acesso aos participantes externos à firma. 
O) e-Catalogs ou catálogos eletrônicos-ferramenta de e-business. É a disponibilização de informações sobre os produtos ou serviços pelos fornecedores de forma eletrônica.

P) CRM ou Customer Relationship Management- é a administração do relacionamento com o cliente. Os objetivos do CRM são:-usar o relacionamento existente com o consumidor para aumentar as receitas;-usar informação integrada para fornecer excelente serviço;introduzir mais processos de vendas e procedimentos que sejam reprodutíveis;criar novo valor e estimular a lealdade; implementar uma solução estratégica mais proativa.

Ao investir em aplicações de CRM as empresas esperam construir melhores programas de retenção de clientes que maximizem as receitas.

As 3 fases do CRM são:adquirir novos consumidores, melhorar a lucratividade dos consumidores existentes, reter consumidores lucrativos ao longo do tempo.

O e-business disponibiliza algumas ferramentas que podem ser utilizadas para implementar atividades de CRM: call centers ("help desk" onde consumidores podem se comuinicar com a empresa através de telefone, fax e email), aplicativos para armazenar informações sobre os compradores (databases), portais de serviços ao consumidor, sites de informações sobre empresa e produtos, dentre outros.

Q) Internet - rede pública autoregulada que conecta milhões de redes de computadores pelo mundo todo

R) Cadeia de Valor-: a cadeia de valor é um conjunto de atividades criadoras de valor discretas mas interconectadas, através das quais um produto ou serviço é criado e entregue aos consumidores. Essas atividades tem pontos de conexão com as atividades dos fornecedores, canais e consumidores. As atividades de valor são as atividades física e tecnologicamente distintas, através das quais uma empresa cria um produto valioso para os seus compradores. $\mathrm{O}$ valor em termos competitivos é o montante que os compradores estão dispostos a 
pagar por aquilo que uma empresa lhe oferece. É medido pela receita total, reflexo do preço que o produto de uma empresa impõe e pela quantidade que ela pode vender.

A margem é a diferença entre o valor total e o custo coletivos das atividades de valor. As atividades da cadeia de valor, segundo Porter (1990) são: atividades de apoio (infra-estrutura da empresa, gerência de recursos humanos, desenvolvimento de tecnologia e aquisição) e atividades primárias (envolvidas na criação física do produto e na sua venda e entrega para o consumidor: logística interna, operações, logística externa, marketing e vendas e serviço).

O valor é adicionado ao produto através do seguinte mecanismo: ao executar uma série de atividades para atingir seus objetivos, cada estágio de atividade dentro da cadeia adiciona um valor extra àquela atividade, sendo que o produto final é a soma dos valores adicionados ao longo da cadeia.

S) Modelo "build-to-order"- Existe um segundo tipo de cadeia de Valor que é uma espécie de produção de oficina que cria soluções personalizadas em resposta a demandas únicas.

Nesse modelo, as oficinas são movidas pela demanda. Somente depois de vender um bem é que ela o fabrica. Nesse modelo o cliente participa do projeto fornecendo os dados necessários para sua realização.

Esse é o chamado modelo " build-to-order" ou fazer sob a demanda de um pedido, utilizado por exemplo pela empresa Dell de computadores, onde um computador é montado a partir de subconjuntos ou módulos separados, segundo a prescrição do cliente.

Esse modelo pressupõe uma rede de parceiros integrados à empresa, para fornecer os módulos a serm montados, para quem são delegadas as atividades de fabricação de componentes.

Essa delegação não é nada simples. Cada pedido de um grande cliente requer extensa customização.

T) "Costumer Experience"- Esse conceito descreve as fases do ciclo "experiência do consumidor" : 
O ciclo completo de "experiência do consumidor" é: desenvolver conscientização sobre o produto, quando o consumidor se dá conta de que tem necessidade de determinado produto ("awareness"); pesquisa das características que interessam no produto, escolhendo entre várias opções ("research"); ir em busca do produto, procurá-lo pelos diversos pontos de venda ("shop"); comprar o produto ("purchase"); manter o relacionamento do cliente com a empresa que vendeu o produto através de serviços pós-venda ("maintain"); desfazer-se do produto antigo e iniciar novo processo de compra ("dispose/re-purchase").

Esse conceito é usado pelas empresas para que elas possam atender as necessidades do cliente em todas as suas fases de "experiência" com o produto.

U) Telemática- Conjunto de sistemas que permite comunicação à distância entre um veículo ou o seu condutor com outro veículo ou com uma central de controle. Esse sistema pode indicar o trajeto mais curto ou mais adequado para chegar ao destino (sistema de navegação). Esse sistema também vai ser capaz de prover acesso à Internet a partir do veículo, fazendo com que seu usuário acesse um portal e obtenha informações sobre a cidade na qual está, mapas rodoviários, etc.

\subsection{SELEÇÃO DOS CASOS ESTUDADOS}

Os casos estudados nessa pesquisa foram determinados de forma não probabilística e intencional.

Essa técnica pode ser justificada, conforme indicam Selltiz et al. (1974), por permitir a seleção dos componentes do estudo de acordo com as características estabelecidas como necessárias para agrupar casos típicos nesta população, ou seja, empresas que se notabilizam pela adoção de e-business.

Para a presente pesquisa optou-se por estudar um único setor da economia, para que os resultados pudessem ser comparados dentro de uma mesma realidade, com características semelhantes no que tange a tipo de produto produzido, tipo de cliente (ou mercado), tipo de fornecedores, submissão aos mesmos tipos de regras governamentais., enfim, optou-se por empresas de 
um mesmo setor para que o foco de estudo fosse o e-business, submetido aproximadamente às mesmas condições externas à firma.

Como o setor de serviços já possui uma exploração um pouco maior no que tange a estudos sobre iniciativas de e-business, optou-se por estudar o setor industrial.

McAfee (2000) afirma que a partir de 1999 as empresas envolvidas em atividades baseadas em Internet business-to-business beneficiaram-se de uma atenção da mídia e dos investidores, que antes eram devotados apenas a potais, provedores de conteúdo e outras empresas de B2C (devotadas a business-toconsumer).

Após os problemas enfrentados por esse mercado em março-abril de 2000 (a explosão da " bolha” e a queda das ações da Nasdaq), esse entusiasmo diminuiu e o interesse pelo B2B cresceu.

Porém, segundo o autor, nenhum desse interesse é devotado às indústrias de manufatura, apesar de previsões feitas pela empresa de pesquisa IDC afirmarem que os gastos em desenolvimento de infraestrutura para web debtro do setor de manufatura deverão atingir US\$ 24 bilhjões, enquanto os gastos em serviços financeiros será de US\$16,6 bilhões, apesar do fato desses dois setores terem tamanhos comparáveis.

Esse fato justifica o interesse pelo setor de manufatura no Brasil.

Dentro desse setor escolheu-se o segmento da indústria automobilística e dentro desse segmento, o sub-segmento de montadoras.

Fine e Raff (2000) em seu artigo sobre as inovações propiciadas pela Internet na Indústria automobilística norte americana notam que essa indústria tem uma grande complexidade e vários problemas são propostos para seus dirigentes.

Sua cadeia de suprimentos é vasta e profunda.

Seus problemas tecnológicos abrangem áreas diversas como aerodinâmica, engenharia mecânica, engenharia elétrica e de materiais, engenharia civil, dentre outros.

Custos de design são grandes, levando a uma competição por preços em todos seus segmentos. 
A necessidade de coordenar atividades físicas apresenta grandes desafios combinatórios em planejamento, controle da produção e distribuição.

Tecnologias de rede (Internet, World Wide Web,etc) prometem mudanças no escopo e custo de coordenação oferecendo melhorias na facilidade e rapidez de comunicação.

Portanto, essa indústria é um candidato natural para avaliar o melhor uso dessas tecnologias emergentes.

Os outros elos da cadeia desse segmento, quais sejam, fornecedores de autopeças e distribuidores de veículos não fazem parte do foco de estudo, que se ateve essencialmente às montadoras.

Existem referências a esses atores (fornecedores e distribuidores), quando se fez necessário explicitar determinada situação da montadora que os envolvesse.

A opção pelo segmento da indústria automobilística, mais especificamente pelas montadoras, deu-se em função de algumas de suas características:

- -É uma das maiores indústrias na economia brasileira

- -Segmento de alta competitividade;

- - Concorrência acirrada entre empresas;

- -Segmento intensivo em tecnologia

- -Segmento que investe em inovações tecnológicas tanto em sistemas de produção quanto em métodos de marketing

- -Parque industrial instalado há mais de cinqüenta anos no Brasil , o que denota sua característica de "tradicional" no que diz respeito a estar implantado no meio físico e não ter nascido na Internet

- -Notícias veiculadas na mídia sobre iniciativas desse segmento na área de e-business, mostrando potencial para o estudo.

Dentro desse segmento, foram escolhidas montadoras que tinham plantas instaladas há mais de cinqüenta anos no Brasil, situadas na grande São Paulo, pela facilidade de acesso. 
Foram contatadas várias empresas e escolhidas três delas que mostraram disposição em ceder informações, com a colaboração de vários de seus gerentes e diretores que se prontificaram a participar das entrevistas individuais propostas.

Além da escolha determinada pelo fato da empresa pertencer ao segmento de montadoras, outros critérios foram utilizados para essa escolha:

- Foram escolhidas empresas que se encontravam no nível 4 de adoção de e-business segundo critérios de pesquisa realizada pelo Gartner Group , realizada por Flint (2001) que elaborou um modelo de aplicação do ebusiness para transformar os processos críticos.

Na medida em que os empreendedores transformam seus processos para explorar o poder da tecnologia, eles caminham por sete níveis de mudanças e estendem seus processos para integrá-los com aqueles de seus parceiros corporativos, resultando em processos mais baratos, rápidos e melhores.

No nível 4, ela utiliza e-business adotando uma visão extra-empresa de seus processos, usando tecnologias para se ligar com seus parceiros de negócio. A figura a seguir ilustra o nível 4 de utilização do e-business.

FIGURA 33: NÍVEL 4 DE UTILIZAÇÃO DO E-BUSINESS

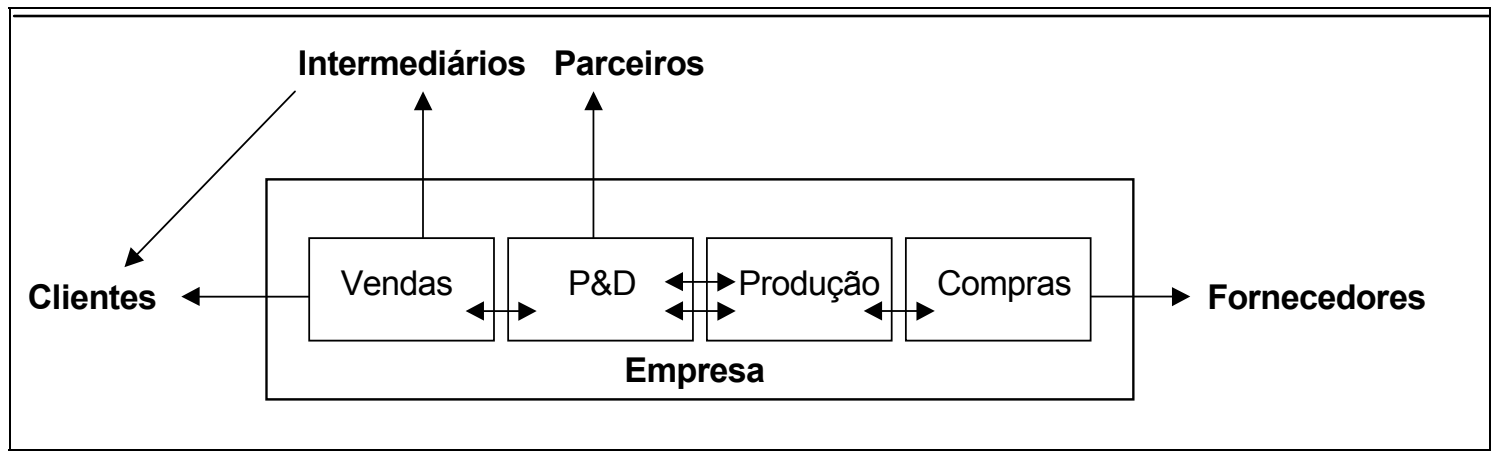

Fonte: Flint, Le Hong e Rozwell (2001), adaptado por Muritiba e Vasconcellos (2001).

- Outro critério para a escolha das empresas da amostra foi o fato dela ter iniciado a iniciativa de e-business há pelo menos um ano e o negócio estar em operação. 
Algumas das empresas entrevistadas pediram sigilo quanto à revelação de sua identidade, portanto não serão identificadas pelos nomes.

\subsection{PROCEDIMENTO PARA A COLETA DOS DADOS}

\subsubsection{TÉCNICA DE COLETA DE DADOS}

A orientação da coleta de dados pela realização de entrevistas em profundidade indica o caráter qualitativo do estudo, em que as variáveis relevantes ainda não estão estabelecidas.

Da mesma forma, conforme apontam Aaker \& Day (1982), o objetivo de maior interação com o entrevistado, de tal forma que as informações apresentem maior profundidade e riqueza de explanações, e o número relativamente pequeno de respondentes, só parcialmente representativo da população, justificam a caracterização da pesquisa como qualitativa.

Aaker \& Day (1982) enfatizam a escolha por pesquisa qualitativa com entrevistas em profundidade, comentando que, na prática, este procedimento analítico tem aplicação útil com executivos, especialistas e outros agentes com pequena disponibilidade de tempo para atendimento a entrevistadores.

$\mathrm{Na}$ realização da pesquisa foram utilizados tanto dados primários como secundários, os primeiros correspondendo, basicamente, à aplicação de pesquisa de campo, que será descrita a seguir.

Triviños (1990) indica que a pesquisa qualitativa se desenvolve de forma dinâmica, em contínua retroalimentação entre a coleta e o tratamento dos dados, característica que permite ao pesquisador correlacionar as informações coletadas.

A pesquisa qualitativa, segundo Bryman (1989), possui algumas características que se mostram mais adequadas a estudos da natureza da presente pesquisa, pois: 
- Destaca a interpretação dos fenômenos estudados;

- Foca o contexto em que o problema se insere e o seu processo de desenvolvimento;

- Fundamenta-se num processo menos estruturado de levantamento de dados, permitindo ao pesquisador alterar o curso de ação inicial, ao se apresentarem dificuldades de realização de algumas das etapas previstas, ou ao se perceberem aspectos novos que se mostram relevantes para sua abordagem;

- Permite ao pesquisador, pela sua proximidade com o objeto de análise, apreender informações sobre seu funcionamento e, ainda, uma melhor análise dos resultados e percepção das nuanças do ambiente e dos processos estudados, que continuam ocorrendo durante sua intervenção.

\subsubsection{FONTES DE DADOS PRIMÁRIOS}

Segundo Churchill (1983) dados primários se referem aos levantados diretamente dos indivíduos que se deseja pesquisar e obtém informações sobre eles.

Nesta pesquisa, dados primários foram obtidos mediante entrevistas semiestruturadas realizadas em montadoras.

O método de coleta de dados primários pode apresentar duas vertentes, a saber - comunicação ou observação. No primeiro caso, o respondente é contatado para a obtenção da informação desejada, com a aplicação de um questionário (estruturado, semi-estruturado ou não-estruturado, disfarçado ou não-disfarçado), com perguntas e respostas que podem ser orais ou escritas.

$\mathrm{Na}$ observação, o pesquisador coletará dados, visualizando e utilizando algum meio mecânico para gravar as informações, sem a necessidade de interface com qualquer pessoa.

Nesta pesquisa, foi utilizado apenas o método da comunicação com a utilização do roteiro de perguntas semi-estruturado e não-disfarçado, aplicado às empresas escolhidas, no caso, compostos por montadoras. 
O roteiro, eventualmente, foi adaptado às condições do entrevistado, permitindo-se e até estimulando-se os respondentes a se manifestar sobre aspectos da questão julgados relevantes. A pesquisadora, no entanto, sempre manteve sua atenção voltada para cobrir os pontos fundamentais propostos na pesquisa.

Dessa forma, a pesquisa de campo foi realizada por meio de entrevistas, aplicando-se instrumento de coleta, referente a questionário semi-estruturado, não-disfarçado, aplicado aos profissionais que atuavam em áreas que tivessem relacionamento direto com o e-business da empresa montadora, desde áreas dedicadas exclusivamente ao e-business, até áreas que utilizavam ferramentas de e-business, mas não se constituíam áreas exclusivamente dedicadas.

Foram entrevistados, então, executivos (diretores, gerentes e até supervisores) das áreas de e-business (quando existia tal área exclusiva), determinadas áreas de marketing, marketing estratégico, área de estratégia da empresa, área de compras, área de vendas e área de Tecnologia da Informação, na indicação de serem as pessoas envolvidas com e-business na empresa e que portanto, possuíam as informações desejadas.

Em cada empresa, existia um contato inicial, como a pessoa que lidava com e-business e a partir desse contato, eram indicadas as demais pessoas de áreas de interesse.

Os roteiros de entrevista utilizados são apresentados nos Anexos A e B, sendo seus conteúdos detalhados e explicados, a seguir, ao se discorrer sobre a pesquisa de campo. Esses roteiros, numa concepção preliminar, foram submetidos a pré-testes, que possibilitaram maior adequação e melhor formulação das questões para o perfil dos potenciais entrevistados.

Alguns dos pré-testes foram feitos com consultores em implantação de ebusiness em empresas, num total de três consultores, para se verificar a pertinência das questões, acrescentar aspectos mais realísticos e testar a compreensão das questões formuladas.

O primeiro roteiro, de caráter genérico, foi apresentado às diversas áreas da empresa. 
O segundo roteiro foi apresentado para as pessoas da área de Tecnologia da Informação da empresa, por possuir questões mais específicas para a área de TI, uma vez que na revisão da literatura diversos autores ressaltaram a necessidade de uma infraestrutura de TI devidamente dimensionada e inserida numa estratégia adequada para que as iniciativas de e-business possam ser bem sucedidas.

Entrevistaram-se de quatro a seis indivíduos por empresa; as entrevistas foram programadas para um período de tempo de uma hora e meia e na verdade tiveram uma duração que variava entre uma hora e meia a duas horas e meia, em função do interesse e disponibilidade de tempo do entrevistado.

Alguns dos entrevistados tiveram mais de uma reunião, em função de obtenção de complemento de informações. Isto representou um total de cerca de 30 horas de pesquisa de campo.

Para direcionar a entrevista pessoal, realizada na empresa, foi utilizado um roteiro de perguntas e assuntos abordados.

Foram entrevistados para a realização dos estudos de caso:

- Membros da alta diretoria das empresas que tenham grau de influência sobre o e-business

- O responsável pela idéia do negócio

- O responsável por sua implantação

- O responsável por sua operação atual

- Executivos das diversas áreas afetadas pela operação de e-business

Além das entrevistas pessoais, houve troca de informações via Internet, com a resposta de algumas questões através desse veículo, para complementar as entrevistas pessoais, além do fornecimento de material complementar enviado por e-mail .

Foram realizadas 16 entrevistas, em três montadoras, todas localizadas na região da grande São Paulo.

Optou-se por não gravar as entrevistas, tomando-se notas durante sua realização para não inibir os respondentes, que se mostraram preocupados com o caráter confidencial das informações prestadas. 


\subsubsection{FONTES DE DADOS SECUNDÁRIOS}

Ghauri et al. (1995) definem dados secundários como informações coletadas por outros, muitas vezes, com propósitos diferentes dos que o estudo se propõe. Essa característica é importante, pois recomenda cautela, devido a possíveis distorções que a interpretação desses dados possa causar, além de, naturalmente, a possibilidade de, em alguns casos, a fonte não ser totalmente isenta ou confiável.

Foram utilizados dados secundários disponíveis em publicações e periódicos sobre o tema e sobre o setor - alvo da pesquisa, correspondendo também a livros, dissertações e teses já produzidas, além de fontes estatísticas e informações de instituições ligadas ao setor automobilístico.

A Internet foi largamente utilizada para obtenção de informações complementares sobre as iniciativas de e-business de cada uma delas, no que tange aos seus aspectos internacionais, ou seja, informações sobre o e-business das matrizes dessas montadoras.

Também muitos artigos, acadêmicos ou não, foram extraídos de sites da Internet.

Como existe uma profusão de fontes na Internet, procurou-se restringir os artigos extraídos de publicações advindas de instituições consagradas, como a Harvard Business Review, ou a Sloan Management Review, além de publicações em revistas especializadas no setor automotivo e na área de e-business, que tem sites na Internet.

O objetivo dos dados secundários foi permitir a análise de documentos da empresa que contam o histórico de seu negócio de e-business, bem como informações complementares, sobre estratégia da empresa, painel do setor automotivo, evolução do e-business, entre outros.

A partir dos dados obtidos nas entrevistas foram elaborados os estudos de caso de cada uma das empresas estudadas, levando-se em conta os aspectos de interesse para a presente pesquisa. 


\subsection{ANÁLISE DOS DADOS}

Com relação ao tratamento dos dados, não foram utilizados procedimentos estatísticos para a análise das informações, já que não seria possível precisar o grau e a direção do erro amostral, o que impediria um estudo estatístico (MATTAR, 1996).

Como a pesquisa tem caráter exploratório, não houve intenção de estabelecer correlações entre variáveis.

O que foi feito foi comparar os dados obtidos através das entrevistas e dados secundários com o referencial teórico, construindo-se um quadro de análise onde foi possível, comparando-se para cada variável de interesse o conteúdo do disposto na literatura e o encontrado experimentalmente, de modo a se formar conclusões sobre aspectos de interesse.

Os dados foram obtidos por métodos diferenciados, permitindo descrever, conforme apontam Ghauri et al. (1995:93) uma triangulação, tendo como base principal, as entrevistas pessoais orientadas por questionários semi-estruturados, com questões abertas e fechadas.

Também foram realizadas pesquisas documentais e pela Internet de materiais disponibilizados pelas próprias empresas e de publicações das entidades ligadas ao setor e literatura de cunho acadêmico.

Yin (1990) define a análise de dados como: "exame, categorização, tabulação ou qualquer outra combinação das evidências, para se abordar as proposições iniciais de um estudo". O autor aponta, ainda, a dificuldade de sua realização por não se dispor de muitas fórmulas pré-estabelecidas, levando o investigador a depender, sobremaneira, do seu próprio estilo e rigor na interpretação dos dados que tem em mãos.

O capítulo de apresentação dos resultados (capítulo 5) se orientou pelas perguntas da pesquisa, transformadas em tópicos.

Assim, de forma seqüencial, procurou-se identificar os modelos de ebusiness encontrados $e$ as estruturas organizacionais adotadas para operacionalizá-lo. 
Para manter o sigilo desejado pelos entrevistados, as empresas entrevistadas foram identificadas como montadora A, B e C .

Os métodos de análise dos dados primários utilizados foram os da análise de conteúdo, na qual procura-se descrever, objetiva e sistematicamente, o conteúdo das comunicações, tendo-se por objetivo sua interpretração. As citações de respostas individuais se justificam de modo a ilustrar melhor os pontos de vista dos respondentes para as questões levantadas.

\subsection{A PESQUISA DE CAMPO}

A pesquisa, realizada por meio de entrevistas abertas, teve como objetivo levantar informações referentes aos modelos de e-business adotados pelas empresas entrevistadas, bem como os tipos de arranjos (ou estruturas) organizacionais adotados para sua operacionalização.

As anotações feitas durante as entrevistas, submetidas a análise de conteúdo, são apresentadas no capítulo 5 dessa tese.

As informações levantadas compreenderam:

- Dados sobre como se deram as primeiras iniciativas de e-business na empresa, determinando de quem foi a iniciativa: direção global (mundial) da empresa, iniciativa regional, qual área dentro da empresa;

- um breve histórico de como essas primeiras iniciativas se transformaram e como surgiram outras

- dados sobre a evolução do e-business, falando sobre os primeiros produtos, como se constituíram as equipes de projeto, áreas envolvidas, fatores que contribuíram para o tipo de estrutura obtida

- Dados sobre objetivos pretendidos e fontes de receita a serem geradas

- as estruturas organizacionais das empresas, mais precisamente a localização das áreas de e-business dentro da empresa, procurando identificar se existia área específica ou se as iniciativas estavam pulverizadas pela empresa, bem como os níveis hierárquicos responsáveis pelas atividades de e-business e a caracterização de 
responsabilidades / autoridade, além de informações sobre reestruturações internas para operacionalizar o e-business

- informações sobre o e-business e a estratégia da empresa

- identificação dos tipos de relacionamentos em e-business : dentro e fora da empresa: B2B, B2C, B2E, e assim por diante, bem como determinar o fluxo de informações /produtos obtidos com esses relacionamentos para caracterizar os possíveis modelos de e-business praticados

- Informações sobre a situação atual e perspectivas futuras

A dificuldade e mesmo impossibilidade de se pesquisarem todas montadoras no Brasil justificam-se pela sua:

- Dispersão geográfica,

- Algumas delas estarem instaladas há pouco tempo no país

- Importância no mercado relativamente menor;

- Tempo disponível para a elaboração da pesquisa;

- Necessidade de aplicação direta dos questionários, devido à complexidade dos assuntos tratados, que implicou em tempo gasto.

Por essas razões optou-se por um número menor de entrevistas, configurando-se uma amostra intencional orientada para montadoras de automóveis (as outras montadoras são de máquinas como tratores, etc).

A Associação Nacional dos Fabricantes de Veículos Automotivos Anfavea congrega 25 empresas instaladas no Brasil, das quais 16 montadoras de automóveis e comerciais leves: o roteiro de entrevistas foi aplicado para três delas, situadas na região da grande São Paulo.

O foco da pesquisa foi a adoção de e-business por parte dessas montadoras.

Sua instalação no país data de mais de quarenta anos e, como subsidiárias principais na América Latina, sua estrutura, atribuições e responsabilidades se estendem às atividades de diversas plantas no Brasil e na América do Sul. 
Uma primeira questão a se resolver foi a de se saber quem seriam as pessoas ou áreas a serem contatadas, uma vez que se pretendiam entrevistas pessoais, o que foi solucionado da seguinte maneira: a partir de um primeiro contato obtido, a pessoa da própria empresa apresentava algumas pessoas para contato e a pesquisadora pedia indicação de outras pessoas de áreas que the interessassem.

Cabe destacar que as entrevistas foram conduzidas de modo proveitoso, com a colaboração dos entrevistados, que , geralmente se punham à disposição para quaisquer informações necessárias, apenas com restrições com relação à identificação de informações individualizadas (no caso de duas montadoras apenas). Algumas informações foram um pouco penalizadas devido a essas restrições, porém não chegaram a prejudicar os dados necessários.

As áreas entrevistadas foram, de maneira geral: Marketing, Tecnologia da Informação, Vendas, Compras, área de estratégia da Empresa e Área de ebusiness propriamente dito, quando existia na empresa formalmente estabelecida.

Como o mesmo questionário foi respondido por pessoas de diferentes áreas na empresa, pode-se ter uma visão mais abrangente do cenário de ebusiness do que se apenas uma área fosse entrevistada.

Para a área de Tecnologia da Informação foi apresentado um questionário específico, dada a importância da área ressaltada na literatura, que indica como fator fundamental na operacionalização de um e-business que gere resultados, uma infraestrutura de Tecnologia da Informação adequada.

Outras áreas como compras e vendas também foram entrevistadas, pois algumas iniciativas de e-business encontravam-se lá instaladas.

As entrevistas compreenderam os seguintes blocos de questões:

- Identificação da empresa e do entrevistado

Essas informações obtidas junto a órgãos de classe, sites da Internet e revistas especializadas tiveram como objetivo a orientação da pesquisadora com relação às empresas pesquisadas. 
- $\quad$ Estrutura organizacional :

Localização no organograma da empresa as áreas de e-business e os níveis hierárquicos correspondentes

- Evolução do e-business na empresa:

Como foram as primeiras iniciativas, papel da matriz no direcionamento das mesmas, prioridade dessas iniciativas, principais produtos, como se constituíram as equipes para o desenho e implantação do e-business (áreas envolvidas, responsabilidade, nível de formalização, parceiros, contribuição a nível mundial...), principais fatores que contribuíram para a estrutura resultante; objetivos pretendidos e fontes de receita a serem geradas.

- Autoridade e responsabilidade relativos ao negócio virtual:qual maior cargo hierárquico, pessoa contratada do mercado ou não, designação da responsabilidade e autoridade para uma série de atividades elencadas relacionadas ao e-business

- Como foi a integração dos processos realizados no dia-a-dia com as novas atividades de e-business

- Estágio atual: Como está organizada a área hoje, portfolio de serviços / produtos

- Qual a relação do e-business com a estratégia corporativa

Para a área de Tecnologia da Informação foi apresentado um questionário específico, dada a importância da área ressaltada na literatura, que continha os seguintes tópicos:

- Organograma da área de $\mathrm{TI}$, destacando responsáveis por $\mathrm{TI}$ e possíveis alterações no mesmo

- Qual a prioridade das ações de e-business para a área e quem decidia sobre essa priorização 
- Evolução do e-business na empresa: como se constituíram as equipes de projeto para implementação do e-business no que tange ao pessoal de $\mathrm{TI}$

- Dados sobre a adequação da infraestrutura de TI para a implantação do e-business, além da identificação das capacitações necessárias

- Relação da estratégia de TI com o e-business e definição de objetivos a alcançar

\subsection{LIMITAÇÕES DO MÉTODO DE PESQUISA}

Alguns problemas relativos ao estudo de caso: viés no tratamento dos dados (problema que pode acontecer em outros tipos de estudos), prover pouca base para generalização, o que pode ser atenuado com o uso de múltiplos casos.

Segundo Yin (1990) há dois tipos de generalização possíveis: a generalização estatística, onde uma inferência sobre a população é feita com base na coleta de dados empírica sobre uma amostra.

O estudo de caso insere-se na "generalização analítica". Os casos porém, não são unidades amostrais , portanto não se pode fazer uma generalização dos resultados do caso do mesmo modo que se faz a generalização dos resultados estatísticos de uma pesquisa quantitativa.

Múltiplos casos podem ser considerados como experimentos múltiplos, e a generalização deve ser feita de maneira analítica, na qual uma teoria desenvolvida previamente é usada como base de comparação com os resultados empíricos.

Os resultados empíricos podem ser considerados mais potentes se forem usados dois ou mais casos, porém não suporta uma teoria rival à qual serviu de apoio. A teoria serve como base para generalização dos resultados obtidos através do estudo de casos.

O método de estudo de caso, segundo Yin (1990), é criticado por uma suposta falta de rigor na sua utilização por parte de alguns pesquisadores, que podem deixar passar viéses, influenciando resultados e conclusões. $O$ autor 
recomenda que seu uso deva ser feito com o investigador "dedicando um grande esforço no seu projeto e realização" (1990).

Yin (1990) esclarece que o "estudo de caso como método de pesquisa não deve ser confundido com o elaborado para fins didáticos, que tem como objetivo estabelecer uma estrutura para discussão e debate entre estudantes".

A maior limitação do método do estudo de caso é a de não se permitir generalização para a população, da qual se extraiu uma amostra para pesquisa.

Os estudos realizados neste trabalho, embora tenham buscado um grau de profundidade adequado, ainda se mostraram em pequeno número e o seu objetivo de uso é o da replicação, conforme explicitado anteriormente, e não a de sua generalização.

Essa limitação, conforme afirma Yin (1990), é comum a outros métodos de pesquisa, por exemplo, o de experimentos.

Outra limitação quanto ao método adotado pode ser aquela resultante da subjetividade das respostas: o entrevistado dá o seu ponto de vista, que é interpretado pelo entrevistador, sob uma ótica própria.

A subjetividade advinda das entrevistas tentou ser minimizada ao se entrevistarem várias pessoas da mesma empresa, de modo a se obter diversos pontos de vista sobre o mesmo fenômeno; porém, sempre resta algum subjetivismo, considerado aqui como limitação desse método 
CAPÍTULO V

APRESENTAÇÃO E DISCUSSÃO DOS RESULTADOS DOS

ESTUDOS DE CASO 


\section{Capítulo V}

\section{APRESENTAÇÃO E DISCUSSÃO DOS RESULTADOS DOS ESTUDOS DE CASO}

Antes de iniciar a apresentação e discussão dos casos, será feita uma breve introdução que apresenta um cenário atual do setor automobilístico, com alguns aspectos do segmento de montadoras e outros sobre e-business nas montadoras.

Essa introdução encontra-se no item 2.1-Perfil da Indústria Automobilística.

Após esse item, tem início a apresentação dos resultados obtidos a partir da pesquisa realizada pelo método de estudos de caso.

Os resultados estão divididos em seis blocos de resultados assim descritos:

O primeiro bloco de resultados trata da descrição dos casos (ítem 5.2) sob a ótica das duas questões de pesquisa dessa tese, e está assim subdividido:

- descrição dos casos quanto à verificação de existência ou não de modelo de negócio para conduzir o desenho e implantação das atividades de e-business adotadas pelas empresas estudadas (item 5.2.1).

- descrição dos casos quanto às estruturas organizacionais que foram implantadas ao longo do tempo para operacionalizar as atividades de e-business adotadas (item 5.2.2).

Seguem-se quatro blocos com resumos e comentários acerca dos resultados obtidos:

-o segundo bloco de resultados apresenta uma série de quadros resumo acerca da existência de modelo de negócio voltado para e-business (item 5.3).

-o terceiro bloco de resultados apresenta uma série de comentários sobre a existência de modelo de negócio voltado para e-business (item 5.4). 
-o quarto bloco de resultados apresenta uma série de quadros resumo acerca das estruturas organizacionais identificadas para operacionalizar as atividades de e-business (item 5.5).

-o quinto bloco de resultados apresenta uma série de comentários sobre as estruturas organizacionais identificadas para operacionalizar as atividades de e-business (item 5.6).

-o sexto bloco de resultados traz outras análises que foram julgadas pertinentes (item 5.7).

\subsection{PERFIL DA INDÚSTRIA AUTOMOBILÍSTICA - ÊNFASE NAS MONTADORAS}

Esse item tem por finalidade contextualizar as montadoras em seu ambiente: muitas das decisões acerca de investimentos e direcionamento estratégico partem de uma resposta das montadoras ao seu ambiente econômico e competitivo.

Essa introdução se exlpica por se entender que os resultados obtidos para o e-business não podem ser analisados fora de um contexto mais amplo, sob pena de não ficar claro se os resultados obtidos são somente devido a uma implantação do e-business conduzida de determinada maneira ou se o contexto econômico onde estão inseridas as montadoras teve influência marcante na condução dos resultados.

Como essa é uma pesquisa de caráter qualitativo, não se estabeleceu correlação entre variáveis, porém é importante analisar o cenário mais amplo onde estão inseridas as montadoras para melhorar as condições de análise dos resultados obtidos.

Assim, num primeiro momento, foi traçado um painel sobre o cenário econômico recente (final dos anos 1990 e início dos 2000).

Feito isso, algumas caracetrísticas das montadoras e suas recentes transformações são tratadas, de modo a esclarecer a ligação existente entre as decisões de e-business e o momento econômico, trasformações tecnológicas e cenário competitivo em que se insere essa indústria. 
Apresentação e Discussão dos Resultados dos Estudos de Caso

\subsubsection{CENÁRIO GLOBAL DA ECONOMIA E AS MONTADORAS NO BRASIL}

Antes de começar a falar das montadoras, vale lembrar que o mundo, liderado pelos Estados Unidos, passou por um período de expansão nos anos 90. Em 2000, o crescimento médio foi da ordem de 4,8\% (publicado em : Valor setorial-Agricultura e seus insumos -obtido no site: www.valoronline.com.br/setoriais).

Em 2001, no entanto ocorreu interrupção importante nas principais economias, num caso raro de desaceleração sincronizada da atividade mundial, com impactos no comércio entre os países e nos preços dos produtos transacionados.

Essa desaceleração globalizada foi desencadeada pela redução de investimento no setor de tecnologia, após o estouro da bolha da "Nova Economia", com conseqüente desequilíbrio da economia americana.

Do lado da demanda houve corrosão do patrimônio do consumidor.

No segundo trimestre de 2001, o crescimento dos Estados Unidos e dos países da área do euro foi próximo de zero e o Japão sofreu forte retração.

Além disso, é crescente o número de países em desenvolvimento cujas economias também começam a desacelerar.

Na América Latina, ocorreu sensível desaceleração das economias da Argentina e do México, além do Brasil.

Segundo as expectativas do Fundo Monetário Internacional (FMI), em 2002 deve ser revertido o ciclo de queda da economia mundial, em geral, e da americana em particular. O crescimento do PIB previsto pelo FMI é conforme quadro abaixo: 
TABELA 9: CRESCIMENTO DO PIB-PROJEÇÃO PARA O TRIÊNIO ATÉ 2002

\begin{tabular}{l|c|c|c}
\hline & $\mathbf{2 0 0 0}$ & $\mathbf{2 0 0 1}$ & $\mathbf{2 0 0 2}$ \\
\hline \hline Mundo & 4,8 & 3,2 & 3,9 \\
\hline Japão & 1,7 & 0,6 & 1,5 \\
\hline Estados Unidos & 5,0 & 1,5 & 2,5 \\
\hline União Européia & 3,4 & 2,4 & 2,8 \\
\hline \hline
\end{tabular}

Fonte: FMI

Essas informações mostram-se relevantes para essa tese, pois como está se tratando dos investimentos em e-business, é necessário contextualizá-los, ou seja, os investimentos em e-business feitos pelas montadoras não estão apenas atrelados ao êxito ou não da iniciativa, mas aos fatores econômicos mais amplos que regem os investimentos em geral feitos pelas empresas no período.

No seu relatório anual, o CEPAL (2002) apresenta um cenário nada animador para a América Latina.

As perspectivas para 2002 são classificadas pelo estudo como "decepcionantes".

$O$ desaquecimento da economia mundial e a instabilidade nos mercados financeiros devem provocar uma queda de $0,8 \%$ no Produto Interno Bruto (PIB) regional neste ano. Além disso, a região receberá menos recursos externos pelo quarto ano consecutivo e atingirá um índice de desemprego anual de $9 \%$.

A grave crise que enfrenta a Argentina explica, em grande parte, a retração da economia, já que, excluindo esse país, o PIB regional mostraria uma ligeira expansão de pouco mais de 1\% em 2002.

Além da crise argentina, as incertezas políticas regionais e a volatilidade das bolsas de valores mundiais fizeram com que a recessão iniciada no fim de 2001 se agravasse no primeiro semestre deste ano. 
Apesar das grandes diferenças entre os países, a desaceleração econômica atinge toda a região. O documento mostra que este ano a região completará "meia década perdida", o que deve impactar diretamente na redução de cerca de $2 \%$ no PIB per capita em relação a 1997 . Desde a primeira metade da década de 1980 não se registrava uma situação tão adversa.

O estudo afirma que as possibilidades de recuperação do PIB da região dependem de uma retomada das economias dos EUA e da Europa. Caso isso ocorra, a previsão é de um crescimento de 2,5\% a 3\% em 2003.

A Cepal destaca que as perspectivas para o Brasil em 2002 são pessimistas devido ao processo eleitoral, que afetou negativamente as atitudes de investidores, provocando altas sucessivas na cotação do dólar. O PIB do país teve uma retração de $1 \%$ nos primeiros três meses do ano e a instabilidade nos mercados deve limitar as perspectivas de reativação da economia no segundo semestre.

Em 2002, a entrada de capitais flutuará em torno de US\$50 bilhões de dólares, cifra muito menor do que a média anual de US $\$ 74$ bilhões recebidos entre os anos de 1996 e 1998. A análise destaca que o recuo de entrada de capital dos mercados financeiros internacionais provocou um encarecimento dos créditos para quase todos os países especialmente Argentina, Brasil e Uruguai.

Esses dados são pertinentes pois mostram uma desaceleração de investimentos feitos no Brasil, o que impacta diretamente as montadoras, que tem suas matrizes no exterior.

Em notícia publicada no jornal “ O Estado de São Paulo” (2002), o jornal constata que as Montadoras já vinham operando com elevada ociosidade, mas o quadro se agravou.

Muitas vezes considerada carro-chefe na arrancada do crescimento econômico, a indústria automobilística dessa vez está indo a reboque da crise de confiança que abala o País.

Os empresários do setor iniciaram o ano com expectativa de aumentar a produção em 5\%, mas começam a mudar o discurso. Há quem ache que repetir os dados de 2001, com a fabricação de 1,8 milhão de veículos, já será um bom resultado. O ranking atual coloca a indústria brasileira em $10 .^{\circ}$ lugar. 
As montadoras já vinham operando com elevada ociosidade, mas o quadro se agravou. Levando-se em conta a capacidade instalada equipamentos e fábrica funcionando com dois ou três turnos de trabalho -, há linhas de montagem utilizando menos de $30 \%$ de sua capacidade. A MercedesBenz de Juiz de Fora (MG) foi construída para fabricar 70 mil veículos ao ano. A previsão, entretanto, é de que apenas 9 mil unidades do Classe A e 6 mil do Classe C para exportação sejam fabricados neste ano.

A Ford já tinha no $A B C$ uma fábrica capaz de produzir anualmente 160 mil carros em três turnos, mas está operando somente com um. Recentemente, inaugurou na Bahia uma nova filial com condições de colocar no mercado até 250 mil unidades de produtos da família Amazon. Começou com o mais barato deles, o novo Fiesta - na faixa de $\mathrm{R} \$ 19$ mil. Juntando os demais modelos da marca, a previsão é de produzir 96 mil automóveis até dezembro.

O setor investiu cerca de US\$ 20 bilhões nos últimos anos no Brasil e montou estrutura para produzir, hoje, 2,8 milhões de automóveis e comerciais leves. Juntando caminhões e ônibus, a capacidade passa de 3 milhões de veículos.

Todas as grandes montadoras anunciaram férias coletivas no segundo trimestre de 2002 e algumas iniciaram demissões. A General Motors concluiu um programa de saídas incentivadas - o funcionário é demitido, mas recebe salários extras - e cortou cerca de 700 postos de trabalho em São Caetano do Sul e São José dos Campos. Com a filial de Gravataí (RS), a montadora tem capacidade de produzir cerca de 600 mil veículos. A meta estabelecida para as duas fábricas paulistas para pagamento de participação nos lucros aos funcionários é de 260 mil.

As perspectivas para 2002 , segundo previsões da ANFAVEA publicadas nas "EXPECTATIVAS DO SETOR AUTOMOTIVO Balanço de 2001 e perspectivas para 2002" (obtido no site: Automotivebusiness.com.br) é de que serão fabricados no país 1,8 milhão de veículos, quando a previsão no início do ano era de 1,9 milhão de unidades. As vendas de importados e nacionais, previstas em 1,7 milhão, não devem passar de 1,6 milhão de veículos. Os números da entidade para 2002 são 
conservadores, colocando a produção entre 1,80 milhão e 1,85 milhão. As vendas domésticas devem ficar entre 1,60 e 1,65 milhão.

A média anual de investimentos da indústria automobilística se manteve em US\$ 1,2 bilhão entre 1991 e 1995, crescendo para US\$ 2,1 bilhão em 19962000 e para US\$ 2,3 bilhão de 2001 a 2003.

A capacidade de produção das montadoras cresceu de 2,2 milhões de unidades/ano para 3,2 milhões/ano entre 1997 e 2001. Nesse mesmo período a produção efetiva foi de 2,1 milhões em 1997; 1,6 milhão em 1998; 1,4 milhão em 1999; 1,7 milhão em 2000 e 1,8 milhão (estimado) em 2001. Vale lembrar que os números de produção incluem exportações.

Em 1998 o Brasil atingiu o recorde de US\$ 5 bilhões em exportações. O volume de vendas externas nos anos seguintes foi de US\$ 3,6 milhões, US\$ 3,9 bilhões, US\$ 4,2 bilhões (estimado). A previsão para 2002 é de US\$ 4,5 bilhões a US $\$ 4,8$ bilhões. O modelo que inspira o governo brasileiro e a Anfavea é o do México, que avançou significativamente no mercado externo com tratados de livre comércio e sistemas de preferência.

As negociações do Brasil avançam na direção do México, Venezuela, Chile, China e África do Sul.

Dado esse quadro bastante recente da indústria, é interessante verificar a evolução pela qual passou o setor nos últimos anos, até chegar a essa situação.

\subsubsection{HISTÓRIA RECENTE DA INDÚSTRIA AUTOMOBILÍSTICA NA AMÉRICA DO SUL- PAINEL DOS ANOS 90 ATÉ DIAS ATUAIS}

A cadeia automotiva é bastante complexa, porém de forma resumida, sua estrutura pode ser assim descrita: no centro da cadeia existem as montadoras, responsáveis pela montagem final do veículo e da fabricação de algumas partes essenciais, que são sua "core competence", como o motor, dentre outros. 
As montadoras tem por um lado uma cadeia de fornecedores bastante complexa, que em geral tem a forma de uma "pirâmide de fornecimento", com o topo dessa pirâmide composto por grandes fornecedores de subconjuntos montados, sendo os fornecedores de primeiro nível; abaixo dessas empresas na pirâmide, existem as empresas de segundo, terceiro nível e assim por diante.

Descendo na pirâmide, chega-se aos níveis mais baixos que fornecem componentes isolados e normalmente são compostos por empresas de menor porte.

Do outro lado da cadeia existe uma vasta rede de distribuidores ou "dealers" que fazem a ponte entre a montadora e o consumidor final.

Até recentemente, o cliente da montadora era na verdade o distribuidor, uma vez que todo serviço de compra era efetuado através desse intermediário.

O advento da Internet possibilitou a existência de uma relação direta entre montadora e cliente final.

Após essa breve descrição da cadeia automotiva, algumas considerações serão tecidas sobre a situação dessa indústria nos anos 90.

Segundo Santos (2001), nos anos 90, o crescimento da demanda por veículos nos países em desenvolvimento e as políticas governamentais favoráveis foram acompanhados por uma aceleração dos investimentos das montadoras e de seus fornecedores em novas unidades e na modernização de plantas velhas.

A América do Sul, uma das áreas inseridas no processo de internacionalização das empresas, embora a evolução da indústria na região tenha fortes oscilações, apresentou expansão da capacidade de produção e especialização das atividades.

A indústria automobilística apresenta grande concorrência em face da saturação e maturidade dos principais mercados.

Em conseqüência, as empresas vêm buscando novas oportunidades de crescimento e lucros. Suas estratégias orientam-se para as mudanças competitivas e abrangem a diferenciação crescente de produtos, associações, 
alianças e, principalmente, a expansão geográfica de sua atuação através da internacionalização das atividades.

O aumento das exportações e a realização de joint-ventures e de investimentos na produção, distribuição e comercialização de veículos são estratégias adotadas nesse processo.

Nos anos 90, o crescimento significativo da demanda nos mercados de países em desenvolvimento e as políticas governamentais favoráveis foram acompanhados por uma aceleração dos investimentos das montadoras e de seus fornecedores em novas unidades e na modernização de plantas existentes.

A incorporação de novas demandas, a redução de custos e a menor influência dos sindicatos também foram fortes atrativos.

No processo de internacionalização, as empresas americanas foram as que mais se destacaram, sendo porém seguidas pelas européias e algumas japonesas. Estima-se, com base na produção de 1999, que, do total de carros produzidos pela General Motors e pela Ford, 45\% e 51\%, respectivamente, foram fabricados fora da América do Norte.

Igualmente, a Honda (Japão) produziu 49\% de seus carros no exterior, enquanto que, da produção total da Volkswagen e da Fiat, 34\% e 37\%, respectivamente, foram gerados em países não pertencentes à União Européia.

Inversamente, as empresas coreanas são as que menos se internacionalizaram.

$\mathrm{Na}$ América do Sul as montadoras européias e americanas apresentam maior participação tanto em carros como em comerciais leves, enquanto a atuação das empresas asiáticas ainda é pequena.

As montadoras japonesas possuem unidades de produção ainda de pequena escala e as coreanas não produzem na região, embora ambas tenham participação significativa nas vendas dos países andinos.

As empresas européias estão tentando aumentar sua participação na América do Sul, na região do Mercosul, e na América do Norte, através do México, e em outras regiões da Europa e Turquia. 
$\mathrm{Na}$ busca crescente de redução de custos e aumento de lucros, as estratégias das montadoras evoluíram para uma redivisão da produção em bases mundiais com a incorporação das unidades dos mercados emergentes em sua rede de produção.

De modo geral, foram integrados como lugares de manufatura de atividades menos avançadas e mais intensivas em trabalho. No entanto, os países com infra-estrutura e bases de fornecimento desenvolvidas permitiram operações mais avançadas e tornaram-se plataformas regionais.

A difusão dessa organização das atividades da indústria trouxe profundas transformações na indústria dos países emergentes, com unidades integradas e não de atuação isolada e com reflexos sobre o padrão de comércio exterior, a engenharia local e o parque fornecedor.

Podem ser destacadas algumas das mudanças:

- Reorganização da rede fornecedora para a entrega de componentes e módulos em qualquer região e para apoiar a produção enxuta, estendendo-se o conceito de sistemas modulares, fornecedores diretos etc.

- Desenvolvimento de veículos para mercados diferentes baseados na construção de carros mundiais/regionais em plataformas e componentes comuns compatíveis com uma variedade de carrocerias.Através do compartilhamento de plataformas e módulos criaram-se vantagens de economias de escala e reduziu-se a vulnerabilidade ao excesso de capacidade, agravado pelos novos investimentos. As diferenças entre os veículos mostram-se evidentes para o consumidor em aspectos como exterior, estilo, interior e desempenho do motor.

- Centralização do desenho e P\&D e reagrupamento dos centros de pesquisa nos países principais da indústria, o que reduz o papel das subsidiárias, embora esforços consideráveis sejam feitos para adaptar diversos modelos às condições locais e às características 
da demanda. O mesmo comportamento vem se repetindo com fornecedores-chave que estão centralizando essa atividade. No entanto, a evolução da indústria nas regiões emergentes apresenta grandes oscilações. As fortes flutuações da produção e da venda nesses países derivaram de problemas internos, mas pode-se perceber também a influência de crises externas como a do México, da Ásia e da Rússia. Na América do Sul, houve desaceleração da economia nos principais países e redução da produção da indústria automobilística a partir de 1997, quando foram alcançados os maiores volumes de produção e venda. Paralelamente, diversos projetos de investimento em produção de veículos tiveram início nesse período na região do Mercosul.

A década de 90 trouxe um novo cenário para a indústria na região. Além das modificações nas estratégias comentadas anteriormente, as políticas de abertura comercial e aquelas específicas para o setor automobilístico contribuíram para a elevação da demanda doméstica e para a modernização da cadeia automotiva.

Estimulou-se a reestruturação da produção dos fabricantes de veículos na região, aproveitando-se as facilidades de comercialização entre os integrantes de cada bloco regional e procurando-se alcançar economias de escala. Nota-se também maior integração entre as unidades instaladas nos respectivos blocos da América do Sul, em vez de operarem como entidades independentes em seus países.

Os investimentos realizados na região destinaram-se à renovação de produtos, modernização e construção de instalações, sendo que dois padrões podem ser verificados:

- A reestruturação e a modernização da indústria do Mercosul e estão voltadas para operações com economias de escala e com fábricas especializadas por produto, porém com flexibilidade de modelos de uma mesma plataforma ou conjunto de módulos; e 
- Na região andina, encontram-se fábricas com baixa escala de produção e diversidade de modelos e plataformas e alguns casos de associações com empresas locais ou entre montadoras.

No Brasil, novas unidades foram implantadas com formas originais de organização da produção, destacando-se o consórcio modular e suas variantes, que são experimentados por vários fabricantes como a Volkswagen, em Rezende, a PSA, em Porto Real, a Ford, em Camaçari, e a General Motors, em Gravataí.

O consórcio modular compreende um parque de fornecedores diretos localizados na área da fábrica montadora e tem impactos sobre a rede fornecedora, sobretudo para os novos fabricantes do país.

As montadoras americanas e européias possuem unidades nos diversos países da região e são dominantes quando se pensa em produção e vendas no Mercosul. Na região andina, que apresenta maior peso de importações, as empresas asiáticas, notadamente as japonesas, têm forte participação nas vendas, verificando-se baixo volume de produção local. As fábricas com maior volume de produção situam-se no Mercosul.

A América do Sul representou 4\% da produção mundial em 2000.

Destacam-se como maiores mercados e maiores produtores o Brasil e a Argentina, responsáveis por $92 \%$ da produção da região.

O mercado brasileiro é o mais significativo, já tendo alcançado um total de vendas de quase 1,9 milhão de unidades em 1997, quatro vezes mais que o mercado argentino. Venezuela, Colômbia e Chile vêm a seguir, porém registraram quedas significativas na produção e nas vendas.

A recuperação desses países terá impacto regional na indústria automobilística na região andina.

As vendas totais da região em 2000 foram 9,3\% superiores em relação ao ano anterior, alcançando 2,2 milhões de unidades.

Esse desempenho foi fortemente influenciado pelo comportamento da indústria brasileira, que teve aumento de $14,6 \%$. 
O crescimento expressivo que atraiu os principais fabricantes foi verificado até 1997, embora em 2000 os principais países tenham apresentado aumento nas vendas e na produção, à exceção da Argentina. De fato, entre 1991 e 1997, a América do Sul registrou uma variação de 126\% na produção, sendo de $98 \%$ o aumento de produção na região andina e de $130 \%$ no Mercosul.

Como as exportações de veículos destinam-se sobretudo à própria região, sendo inclusive um dos objetivos dos investimentos locais, a situação econômica instável de vários países tem afetado negativamente o desempenho exportador. Majoritariamente, as exportações do Brasil vão para a Argentina. Diante desse quadro, outros mercados vêm sendo buscados,inclusive com assinatura de acordos comerciais, podendo-se observar nesse momento a redução da participação da América do Sul e da Argentina nas exportações do Brasil.

O mercado brasileiro é o mais significativo: o total de vendas chega a ser quase quatro vezes maior do que no mercado argentino, que está em segundo lugar. Em todos os países há unidades de produção, à exceção do Paraguai, cujas vendas foram de 15 mil unidades em 1999.

Houve uma mudança significativa na estrutura de oferta da indústria automobilística no âmbito do Mercosul. Os investimentos foram realizados dentro de um processo de reestruturação de atividades, buscando, principalmente:

- Integração das operações na América do Sul, podendo-se incluir em alguns casos o México;

- Produtos dedicados por fábrica nos maiores mercados, explorando economias de escala;

- Recebimento para montagem do mesmo componente, com facilidades de intercâmbio entre os fornecedores das diversas plantas;

- Base de fornecimento integrada à planta; e

- Fornecedores internacionais, programas globalizados de produção e plataformas mundiais. 
As indústrias automobilísticas brasileira e argentina concentram-se na produção de automóveis, embora a participação de comerciais leves venha crescendo em todos os países. Até o início dos anos 90, as produções brasileira e argentina estiveram voltadas para carros médios e grandes, com escala de produção inadequada.

Tendo em vista os diferentes tamanhos de mercado e as características das vendas locais, as montadoras inicialmente dividiram a produção em carros com motor 1.0 e picapes derivadas no Brasil e carros com motores mais potentes, sedan e comerciais leves na Argentina. Atualmente, devido às mudanças ocorridas nesses países, houve um distanciamento da especialização prevista, transferindo-se linhas de produtos da Argentina para o Brasil.

Em função do potencial de vendas na região, vários investimentos foram realizados visando ao aumento da produção, sobrepondo-se às crises financeiras de 1997 a 1999. O aumento da produção está cada vez mais voltado para os grandes mercados nacionais, regionais ou globais, e o investimento automotivo nos países emergentes está concentrado.

No Brasil e na Argentina, o principal interesse é o grande mercado regional, que atraiu principalmente empresas americanas e européias.

É importante destacar que a análise da cadeia de fornecimento mostra que é proeminente a importação de peças e componentes dos Estados Unidos e da Europa em todos os países, especialmente na indústria argentina, que já contava com parque fornecedor.

Essa situação é minimizada no Brasil, uma vez que o país possui parque fornecedor já desenvolvido que vem se reestruturando em função das demandas das montadoras, embora se verifique déficit comercial. A incorporação da indústria local à produção mundial trouxe mudanças devido à queda do número de fornecedores diretos e à redução das engenharias locais, pois a pesquisa de desenvolvimento e a padronização de desenhos e de componentes realizadas nos centros especializados levaram à diminuição correspondente no trabalho de adaptação nos países emergentes.

O comportamento das montadoras nos diversos países traz semelhanças interessantes. A maioria deles encorajou a indústria automobilística como parte 
das políticas de substituição de importações nos anos 60 e 70, operando com baixa escala de produção e diversidade de modelos.

Na América do Sul, a expansão e a modernização começaram nos anos 90 como resultado da política de liberalização comercial e das estratégias adotadas para fazer face às mudanças competitivas. Apesar das medidas gerais de abertura comercial, a indústria contou com políticas específicas nos diversos países sem que tenha ocorrido também o mesmo em relação à cadeia de fornecimento.

A reestruturação e a melhoria de processos na região tomaram formas diferentes, mas há elementos comuns, como, por exemplo:

- a realização de economias de escala, que permanece importante para determinadas etapas da produção, facilitada por mercados regionais;

- a implementação de flexibilidade de operação propiciada pelos novos processos e organização da produção;

- a especialização localizada e a padronização entre afiliadas no que se refere às faixas de modelos e componentes;

- as melhorias tecnológicas com a introdução de plantas modernas e práticas organizacionais modernas;

- o desenvolvimento de recursos humanos necessários à operação das melhorias tecnológicas do processo de produção com padrões de treinamento voltados para o aumento da eficiência e da qualidade e para o uso de novos métodos de produção;

- a reorganização da rede fornecedora, adotando-se o relacionamento com um número limitado de fornecedores-chave; e

- a reestruturação do setor fornecedor com a redução do número de fabricantes, o fechamento e a aquisição de empresas, o aumento da participação de empresas estrangeiras e o domínio de mercado pelos fornecedores-chave mundiais. 
Houve uma aproximação da indústria desses países aos padrões mundiais, inclusive da rede fornecedora.

Por outro lado, a maior integração no sistema de produção global afetou adversamente algumas capacidades das afiliadas. Em função das políticas visando à redução de custos e à diminuição da vulnerabilidade ao excesso de capacidade, desenho e desenvolvimento foram centralizados e componentes padronizados, reduzindo, assim, o trabalho realizado em subsidiárias, que permaneceu apenas em alguns casos.

No entanto, observando-se os grandes pólos de produção, é difícil imaginar que possa existir uma indústria classe mundial que não tenha capacidade de engenharia e experiência manufatureira.

Da mesma forma, como um dos grandes atrativos do investimento da produção de veículos no Brasil foi a existência de parque fornecedor desenvolvido, verifica-se que só países com capacitação tecnológica e densa rede de fornecedores atraem empresas tecnologicamente dinâmicas.

Tendo em vista a situação atual de excesso de capacidade instalada com reestruturações ocorrendo em algumas empresas e instabilidade de vendas, é necessário atentar-se para a consolidação da rede já criada.

Os investimentos realizados ao longo dos últimos anos contemplaram a especialização e a complementaridade das unidades montadoras de veículos, assim como a modernização dos fornecedores.

As crises recentes dificultaram o processo de adensamento da indústria, porém as políticas de médio e longo prazos devem estar voltadas para a consolidação do complexo automotivo na região, com maior envolvimento dos diversos elos da cadeia produtiva e aumento do fornecimento regional de partes e componentes e de engenharia.

A adoção do e-business pelas montadoras brasileiras insere-se no quadro acima, de reestruturação da indústria obedecendo a práticas globais, com fábricas mais flexíveis, processos organizacionais mais modernos, fornecimento globalizado com poucos fornecedores-chave, produtos dedicados por fábrica 
num contexto nacional de economia recessiva atual, tendo passado por uma boa fase de crescimento até o final dos anos 90.

\subsubsection{AS MONTADORAS E O E-BUSINESS}

Fine e Raff (2000) em seu paper sobre as inovações propiciadas pela Internet na Indústria automobilística americana traçam um breve histórico dessa indústria, por seus vários períodos, desde a produção artesanal, passando pelo fordismo, a produção em massa (dominada por empresas americanas), produção enxuta (a partir das mudanças ocorridas na Toyota japonesa), com seu conceito de melhoria contínua, até as mudanças mais recentes provocadas pela Chrysler nos anos oitenta, que, após chegar quase à bancarrota, resolveu mudar seu relacionamento com seus fornecedores, introduzindo nos Estados Unidos o conceito de Empresa Extendida, que preconizava relações de longotermo com seus fonecedores para desenvolvimento de subsistemas inteiros, com compartilhamento de benefícios e economia de custos envolvendo fornecedores, acelerando atividades de " outsorcing" na área de desenvolvimento e tecnologia.

Em seu artigo esses autores querem investigar como o acesso à Internet e a comunicação baseada na web pode alterar as práticas e a produtividade na indústria automotiva.

Eles usam a emrpesa Dell fabricantes de computadores para ilustrar como a Internet pode impactar uma indústria: a Dell usa o modelo "Dell Direct" e com essa abordagem eliminou links na cadeia de suprimento tanto para cima como para baixo.

Para baixo, Dell eliminou varejistas e canais de distribuição ao vender direto ao consumidor final através da Internet numa base " make-to-order" ou " fazer-sob-pedido" .

Para cima, a vantagem da Dell vem da integração end-to-end da cadeia de suprimento com canais d demanda. 
Usando partes obtidas de catálogos, Michael Dell começou a montar e vender computadores de seu quarto na Universidade do Texas nos anos 80 . 0 processo básico mudou pouco desde então.

Hoje a Dell computers pega pedidos de PC's e workstations customizadas pelo telefone e pelo site da Internet, começando a construir as máquinas quase imediatamente após o pedido ser feito e entrega o pedido assim que o computador está pronto, freqüentemente dentro de 24 horas.

A empresa não carrega estoques de bens finais, e nem emprega nenhum varejista ou distribuidor que tenha estoques.

As capacidades "build-to-order" da indústria de Pc's aumentou significativamente com a estrutura modular da plataforma de produto

Os autores investigam se a indústria automobilística também pode operar desse modo.

As pressões para reduzir os tempos dos ciclos na indústria automotiva são muito grandes.

Cada vez mais os veículos são menso mecânicos e mais elétricos.

Muitas firmas querem explorar a promessa da telemática (capacidades de telecomunicações nos veículos) para usar o veículo como um portal para uma larga gama de novos serviços a serem vendidos ao consumidor.

Para analisar o impacto das tecnologias de rede sobre a indústria automotiva Fine e Raff (2000) propõe a seguinte estrutura: 


\section{TABELA 10: ESTRUTURA ECONÔMICA PARA AVALIAR EFEITOS ECONÔMICOS DE TECNOLOGIAS DE REDE SOBRE A INDÚSTRIA AUTOMOBILÍSTICA}

\begin{tabular}{|c|c|}
\hline 1-Desenvolvimento de Produto & 3-Sistemas de manufatura \\
\hline $\begin{array}{l}\text { 1.1-Facilidade de mudanças em } \\
\text { Engenharia }\end{array}$ & 3.1-Melhorar a fabricação \\
\hline 1.1.1-Custo de fazer mudanças & 3.1.1-Setups mais rápidos \\
\hline $\begin{array}{l}\text { 1.1.2-Porta de entrada para melhoria da } \\
\text { qualidade }\end{array}$ & $\begin{array}{l}\text { 3.1.1.1-Tamanhos de lotes menores, diminuição } \\
\text { do estoque }\end{array}$ \\
\hline 1.2-Diminuir custo direto de comunicação & 3.1.1.2-Maior capacidade de utilização \\
\hline $\begin{array}{l}\text { 1.3-Diminuir custo de coordenação de } n \\
\text { atividades }\end{array}$ & 3.1.2-Facilidade em montagem \\
\hline $\begin{array}{l}\text { 1.4-Velocidade do ciclo de } \\
\text { desenvolvimento de produto }\end{array}$ & 3.2-Mais outsourcing \\
\hline 2-Procurement e Fornecimento & 4-Veículo “ Order-to-Delivery" \\
\hline $\begin{array}{l}\text { 2.1-Redução dos custos de transação } \\
\text { em compras }\end{array}$ & $\begin{array}{l}\text { 4.1-Redução dos tempos do ciclo " pedido-a- } \\
\text { entrega" }\end{array}$ \\
\hline 2.1.1-Processos existentes mais velozes & 4.1.1-Menores níveis de estoques no "pipeline" \\
\hline 2.1.2-Redesenho de processos & $\begin{array}{l}\text { 4.1.2-Melhor casamento do fornecimento com a } \\
\text { demanda }\end{array}$ \\
\hline $\begin{array}{l}\text { 2.2-Consequencias de pedidos } \\
\text { agregados }\end{array}$ & $\begin{array}{l}\text { 4.1.2.1-Preços mais altos para maior satisfação } \\
\text { dos clientes }\end{array}$ \\
\hline $\begin{array}{l}\text { 2.2.1-Compra de volumes maiores em } \\
\text { firmas de terceiros }\end{array}$ & 4.2-Custos dos canais de varejo \\
\hline 2.2.2-embarque de volumes maiores & 4.2.1-Menores comissões de vendas \\
\hline $\begin{array}{l}\text { 2.3-Consequencias de competição em } \\
\text { preços }\end{array}$ & 4.2.2-Menos dealers e "overhead" total menor \\
\hline 2.3.1-redução da margem & $\begin{array}{l}\text { 4.2.3-Menores custos de embarque para menos } \\
\text { pontos de estoque }\end{array}$ \\
\hline \multicolumn{2}{|l|}{ 2.3.2-Redução do custo } \\
\hline \multicolumn{2}{|l|}{ 2.4-Logística } \\
\hline $\begin{array}{l}\text { 2.4.1-Redução do tráfego de pedidos } \\
\text { devido a melhor informação }\end{array}$ & \\
\hline
\end{tabular}


Apresentação e Discussão dos Resultados dos Estudos de Caso

As oportunidades surgidas em desenvolvimento de produtos são importantes, pois esses desenvolvimentos são muito caros nessa indústria, onde muitos projetos custam de 1 a 3 bilhões de dólares e extendem-se por 2 a 4 anos, consumindo milhões de homens-hora de engenharia.

Portanto desenvolvimentos mais rápidos de novos produtos são vistos como fonte importante de vantagem competitiva.

Como esse processo é intensivo em informação, é naturalmente talhado para inovações baseadas em rede.

O uso de Internet nos desenvolvimentos de engenharia pode fazer declinar os custos de comunicação diretos e de oportunidade uma vez que a comunicação em rede permite que o e-mail tome lugar de encontros face-a-face ou telefonemas entre os parceiros de desenvolvimento, sejam dentro da mesma firma ou entre firmas diferentes.

Aumenta cada vez mais o número de pessoas envolvidas nas tomadas de decisão, porém elas levam menos tempo coletivamente e não requerem mais reuniões das pessoas num mesmo espaço físico.

O elemento mais importante é que com a comunicação e coordenação mais baratas e feitas mais freqüentemente, os custos fixos do desenvolvimento do novo produto é mais baixo e o ciclo de desenvolvimento do produto todo acontece mais rápido.

Isso permite aos fabricantes levar desenhos para o mercado mais rapidamente, permitindo melhor casamento entre os produtos oferecidos e os desejos do consumidor.

Quanto às oportunidades em procurement e fornecimento, Fine e Raff (2000) afirmam que os custos de transação de compras irão cair ao se usar marketplaces conectados em rede, bem como serviços burocráticos serão automatizados, tornando-se mais rápidos e eficientes.

Processos -como identificação, seleção de fornecedores, revisão e aprovação do pedido-serão mais rápidos e eficientes.

As novas tecnologias de comunicação também oferecem oportunidades para pedidos agregados que tem grandes conseqüências para custos: o procurement baseado na web faz a publicação das necessidades e termos do 
pedido de forma mais barata e melhora a qualidade do recebimento de propostas a serem comparadas.

Isso é de extrema importância numa indústria com um custo típico de materiais da ordem de $50 \%$ do custo total para muitas empresas e produtos.

A montadora pode usar tecnologia para obter e manter informações atualizadas sobre capacidades de fornecedores e performance e usar isso para concentrar pedidos nos fornecedores mais eficientes.

Se a informação sobre toda cadeia de suprimento está disponível de uma maneira transparente, a empresa pode usar o fator de escala de todos seus pedidos para obter vantagens de seus fornecedores em todos os níveis .

Todas as considerações acima resultam em economias de escala em produção e distribuição.

Em adição, as tecnologias de rede também podem levar a maior competição de preço na cadeia de fornecimento.

As margens dos fornecedores devem diminuir dada a estrutura básica de custo: haverá mais competição direta por pedidos, além de fazer com que os fornecedores fiquem motivados a investir mais em inovações para redução de custos, fazendo com que no longo prazo, os custos baixem.

Quanto às oportunidades na fabricação, devido à redução dos custos de transação e busca, um ambiente de comunicação mais rápida e flexível pela cadeia de suprimento da indústria automotiva pode levar a um maior uso de módulos comuns através dos fabricantes de automóvel e seus fornecedores diretos. Essa modularidade pode encorajar firmas a terceirizar a maior parte das suas atividades, levando as firmas a se especializarem em certas espécies de módulos.

Para Helper e MacDuffie (2000) o desenho modular de produto na indústria automotiva é o fator que habilita essa indústria trabalhar sob a ótica " build-to-order".

Os autores também citam a empresa Dell como exemplo da necessidade de modularidade d o produto para permitir o feito-para-comprar: o computador é composto de módulos fisicamente independentes, seus componentes, que são montados numa interface comum. 
Há um grande interesse no desenho e produção modular por parte da indústria montadora como um modo de cortar custos e gerir complexidades.

Ocorre que atualmente a arquitetura para automóveis ainda é substancialmente integral do que modular e fechada mais do que aberta.

Muitos componentes não são padronizados e não tem interface comum, sendo muito interdependentes de outros componentes, para um modelo particular de automóvel. Isso afeta a capacidade de uso do modelo " build-toorder " nessa indústria.

Porém há certas vantagens na combinação do desenho modular e " buildto-order" : as escolhas para o consumidor são limitadas, porém podem atender um certo nível de customização.

A produção modular, na qual os fornecedores constroem módulos e entregam-nos em seguida para as montadoras, pode tornar o processo de montagem final muito mais curto e simples.

E por último, construir produtos customizados reduz os estoques de produtos finais enormemente.

Sobre o impacto da Internet sobre o " build-to-order" , os autores falam que o procurement intermediado pela Internet facilita a disseminação de informações de pedidos de maneira rápida e com baixo custo, melhora o cronograma de produção, mudanças da engenharia e outras informações cruciais.

Dentro da variedade de meios que conectam as montadoras e fornecedores, como o EDI (proprietary electronic data interchange), a Internet oferece custo mais baixo, alta velocidade e conectividade universal necessárias para tornar a " build-to-order" factível.

César (2002) em seu artigo sobre o e-business e as montadoras no Brasil ressalta que quando em um mercado que comercializa centenas de milhares de unidades por quadrimestre a diferença entre o primeiro e o segundo colocado é de apenas 2.394 vendas, e deste para o terceiro de 3.717 , sobra pouca margem para erros. 
Se, além disso, o setor em questão vendeu $13,4 \%$ a menos do que no mesmo período do ano anterior, cortar gastos e elaborar novas estratégias para atrair o consumidor tornam-se prioridades.

Este é exatamente o retrato que a Associação Nacional dos Fabricantes de Veículos Automotores (Anfavea) tirou da indústria automobilística brasileira nos primeiros quatro meses do ano de 2002.

Segundo o autor, a ordem é alavancar os projetos de e-business.

Em uma ponta, as empresas investem para interligar com maior eficiência toda a cadeia de produção; na outra, apostam em estratégias de venda online.

O autor propõe o seguinte quadro sobre o que a tecnologia de Internet propicia às montadoras:

\section{TABELA 11: PRODUTOS PROPICIADOS PELA TECNOLOGIA DE INTERNET}

O que a tecnologia está proporcionando aos fabricantes de automóveis

\begin{tabular}{l|l}
\hline Inventário: & $\begin{array}{l}\text { a tendência é construir fábricas ligadas na Web, fazendo com que } \\
\text { a informação da demanda trafegue entre concessionárias, } \\
\text { montadoras e fornecedores de autopeças. Todos ganham. O } \\
\text { revendedor reduz seus custos com inventário, o fabricante produz } \\
\text { com uma projeção de demanda próxima da real, assim como o } \\
\text { fornecedor de autopeças. }\end{array}$ \\
\hline Venda online: & $\begin{array}{l}\text { as concessionárias serão partes atuantes das vendas pela internet. } \\
\text { Sem elas, o modelo é impossível, pois são as responsáveis pela } \\
\text { entrega dos veículos. As montadoras também não as alijaram do } \\
\text { processo e criaram estratégias que as ajudaram a modernizar suas } \\
\text { infra-estruturas tecnológicas. }\end{array}$ \\
\hline Compras \\
eletrônicas: & $\begin{array}{l}\text { as montadoras querem usar o poder de fogo conjunto para forçar } \\
\text { os fornecedores a reduzir seus preços. O portal Covisint, que } \\
\text { reúne GM, Ford e DaimlerChrysler, em conjunto com Renault e } \\
\text { Nissan, é o duto digital pelo qual vão trafegar os pedidos online de } \\
\text { partes e peças. Mesmo nos EUA, sofre resistência, principalmente } \\
\text { da indústria de autopeças. }\end{array}$ \\
\hline \hline
\end{tabular}

\section{COVISINT}


É interessante esclarecer alguns aspectos sobre o COVISINT, uma vez que essa é uma plataforma de e-business totalmente voltada para a indústria automobilística.

As informações abaixo foram retiradas do próprio site do COVISINT www.covisint.com/cgi-bin/printerfriendly.cgi

O COVISINT (COmmunicate VISibility INTernet) foi criado em 2001 e é uma plataforma de Internet criada por joint venture entre três empresas do setor automobilístico, DaimlerChrysler, Ford e GM, para ser um novo canal de negócios no mundo do e-business, principalmente na negociação de compras de materiais, peças e serviços.

Juntaram-se às três empresas iniciais as empresas Nissan, Peugeot e Renault e a perspectiva é que outras montadoras façam parte desse grupo.

A origem dessa plataforma foi nas montadoras americanas, que já tinham uma Exchange própria para relacionamento com o fornecedor.

A união dessas montadoras objetivava uma maior escala para diminuição de custo, além de padronização e uniformização das relações de e-commerce com os fornecedores, reduzindo custos operacionais e o período de negociação.

Ainda hoje o COVISINT é uma empresa de capital fechado, mas que conta com participações acionárias.

A proposta do COVISINT é permitir a interligação de toda a cadeia automotiva de maneira a fazer com que na hora em que o consumidor efetive seu pedido na revenda isto já represente o pedido de compra para o fabricante de parafusos que vai ser utilizado pelo fornecedor do componente. Até o financiamento e o seguro do veículo já poderão ser definidos e contratados neste mesmo momento.

O COVISINT é um exemplo do modelo de e-business de infraestrutura compartilhada, como foi proposto por Weil e Vitale (2001). Nesse tipo de modelo a propriedade é compartilhada entre companhias que competem fora desse mercado eletrônico.

Esse também é um bom exemplo da proposta de Porter (2001) para o ebusiness, onde a Internet deve integrar toda cadeia de valor de uma empresa e conectá-la aos seus fornecedores e clientes para obter valor. 
Segundo Baldi e Borgman (2001) o conceito do COVISINT é planejado para ser uma Exchange central não apenas para os fabricantes participantes mas para todos os membros da cadeia de suprimentos.

Esse empreendimento tem a expectativa de alcançar receitas anuais, advindas de taxas de transação, propaganda e serviços de no mínimo U\$ 3 bilhões.

COVISINT pretende cobrir as três áreas funcionais do lado da compra dos e-markets verticais:

-e-Procurement- planeja criar um marketplace global no qual os participantes da indústria possam comprar e vender uma vasta gama de materiais produtivos e não-produtivos e serviços. Leilões, catálogos, requisição por cotação bem como ferramentas de gestão estão incluídas nesse bloco.

-Supply Chain Management- Covisint irá permitir às organizações individuais de observar o atual e futuro status do fluxo de materiais, níveis de estoques e gargalos de capacidade de suas respectivas cadeias de suprimentos. Os parceiros de negócio poderão se comunicar e desenvolver cronogramas de produção e embarque usando informações padronizadas e sistemas comuns.

-E-development- um produto de workspace virtual que permitirá a colaboração em tempo real e integração entre vários partners via Internet num ambiente seguro.

Os motivos para utilização de um consórcio ao invés do uso de exchanges privadas, podem ter várias perspectivas segundo Baldi e Borgman (2001) :

-Um e-market baseado em consórcio provê um padrão para comunicação e coordenação entre os participantes, que devem fazer os custos de transação diminuírem em relação a uma Exchange privada;

-Uma Exchange centralizada faz com que o desenvolvimento e custos operacionais sejam compartilhados pelos participantes, levando aos participantes custos reduzidos de infraestrutura uma vez que eles constroem apenas uma conexão com a Exchange ao invés de várias interfaces com todas as exchanges. 
Um dos produtos oferecidos pelo COVISINT que tem sido mais utilizado é o leilão.

No Brasil, a partir de 2001 o COVISINT abriu um pequeno escritório para atender as filiais das montadoras que operam leilões utilizando essa ferramenta aqui.

A adesão a um leilão acontece sempre a partir de convite da montadora.

É sempre a montadora quem define quem pode participar, num processo que hoje se origina na sua própria lista de fornecedores, mas que, no futuro deverá se apoiar no grande banco de dados que será formado a partir das fichas cadastrais preenchidas a cada leilão.

Até julho de 2002, a única ferramenta utilizada pelas montadoras usuárias do COVISINT foi o leilão.

\section{“Experiência do cliente"}

Outro aspecto que tem tido bastante repercussão quando se trata do relacionamento da montadora com o cliente, trata do ciclo de "experiência do cliente".

A empresa de consultoria ATKearney (2000) aplica um modelo conceitual para descrever como deve ser a elaboração de estratégia de e-business por montadoras: 
FIGURA 34: MODELO CONCEITUAL PARA ESTRATÉGIA DE E-BUSINESS DE MONTADORAS

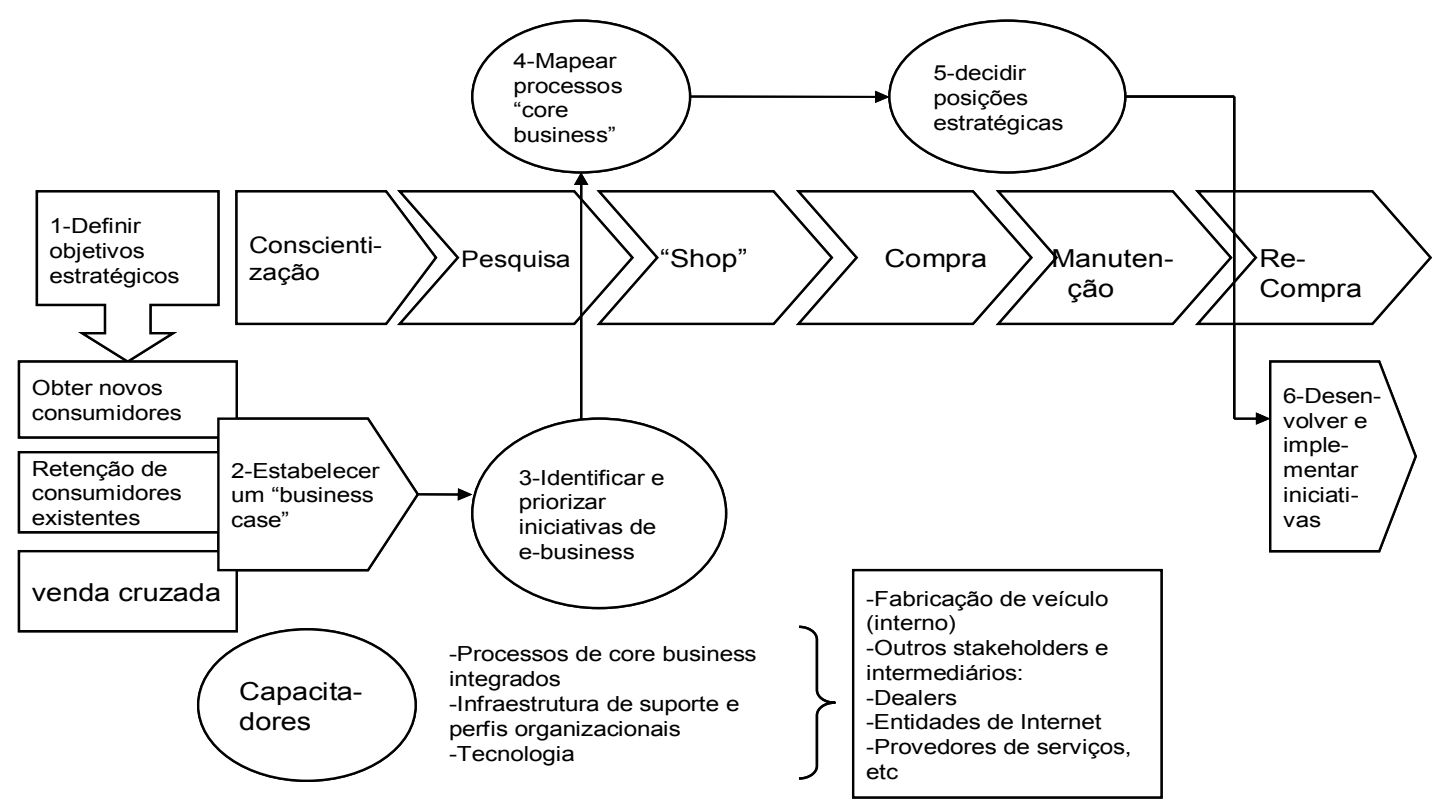

Fonte: AT Kearney (1998)

Esse modelo descreve as fases do ciclo "experiência do consumidor" : primeiro, o cliente tem uma fase de conscientização da necessidade por determinado produto, onde ele descobre que o produto existe, depois ele passa por uma fase de pesquisa, para verificar quem são os fabricantes daquele produto, quais os tipos de produto que existem para atender àquela necessidade, quais as características que ele deseja no produto, etc.

Segue-se a fase de "shop", que seria uma fase de busca pelo produto.Finalmente vem a compra, a fase de manutenção do cliente com serviços pós-venda e depois a fase de recompra, ou seja, a compra de um novo produto. 


\subsection{APRESENTAÇÃO DOS RESULTADOS - DESCRIÇÃO DOS CASOS}

Esse item apresenta os resultados obtidos na aplicação de roteiro de entrevistas (ver Anexos A e B) junto a executivos das montadoras de automóveis.

Para manter as condições de confidencialidade pedida por alguns entrevistados, as montadoras são referidas como montadora A, B e C.

$O$ primeiro bloco de resultados trata descrição dos casos quanto à investigação sobre a existência de modelos de negócio para desenhar e implantar e-business nas empresas estudadas. Compreende o item 5.2.1.

$O$ segundo bloco de resultados trata da descrição dos casos quanto às estruturas organizacionais utilizadas para operacionalizar as atividades de ebusiness adotadas. Compreende o item 5.2.2.

$\mathrm{Na}$ descrição dos casos dentro do primeiro bloco de resultados sobre verificação da existência de modelo de negócio para atividades de e-business, foram apresentados resultados quanto a:

-Verificação da existência de modelo

-Identificação do modelo utilizado (se pertinente)

-Apresentação de alguns resultados obtidos pelo uso do modelo.

-Papel da alta administração na implantação de e-business

$\mathrm{Na}$ descrição dos casos dentro do segundo bloco de resultados sobre identificação das estruturas organizacionais encontradas para operacionalizar as atividades de e-business, foram apresentados resultados quanto a:

-Grau de integração da estrutura organizacional para e-business à empresa

-Tipos de estrutura organizacional encontrados

-Mudanças nas estruturas organizacionais ao longo do tempo

Não era intenção inicial dessa pesquisa apresentar resultados referentes às matrizes das montadoras; a idéia inicial era ater-se apenas aos resultados obtidos sobre as filiais brasileiras das montadoras A, B e C. 
Porém ao efetuar as entrevistas e a coleta de dados indiretos (publicações e informativos na mídia) constatou-se que seria difícil esclarecer a situação brasileira se antes não fosse mostrado como a matriz americana abordou a questão da adoção de e-business, uma vez que a decisão sobre desenvolvimento de iniciativas de e-business no Brasil partiram diretamente das matrizes, não foi uma decisão que partiu do Brasil.

Quanto à estrutura organizacional, as relações entre matrizes e filiais são estreitas em termos de subordinação: todas as filiais brasileiras têm um presidente nacional, mas também tem um superior regional (normalmente um responsável pela América Latina) ao qual se reportam, além das áreas corporativas responderem para os dirigentes globais das áreas, que ficam na matriz.

Assim, mudanças na estrutura organizacional da matriz refletem-se muitas vezes nas estruturas organizacionais das filiais brasileiras, trazendo conseqüências para o desenho dessas estruturas nas filiais.

Pelos motivos acima expostos, entendeu-se ser importante apresentar a evolução do e-business na matriz e suas conseqüências para as filiais brasileiras, bem como apresentar as mudanças ocorridas nas estruturas organizacionais das matrizes em virtude da adoção do e-business.

Desse modo as descrições dos casos apresentados nos dois primeiros blocos dividem-se em resultados obtidos para a matriz e para as filiais em cada um dos blocos.

\subsubsection{DESCRIÇÃO DOS CASOS NO QUE TANGE À VERIFICAÇÃO DE UTILIZAÇÃO DE MODELOS DE NEGÓCIO PARA DESENHAR E IMPLANTAR ATIVIDADES DE E-BUSINESS NA EMPRESA}

Os relatos abaixo são baseados em materiais fornecidos pelas montadoras, nas entrevistas realizadas nas montadoras com diversos executivos, além de informações colhidas na Internet em publicações especializadas (na indústria automotiva e em publicações sobre ebusiness, TI, e-commerce, dentre outras). 
Vai-se descrever o caso sob a ótica da verificação da existência de modelo de negócio para e-business da matriz para em seguida destacar as diferenças encontradas no Brasil.

Os itens 5.2.1.1 até 5.2.1.6 tratam das descrições dos casos quanto ao aspecto de verificação de existência e identificação de modelo de negócio para desenhar e implantar atividades de e-business na empresa.

\subsubsection{DESCRIÇÃO DO CASO DA MATRIZ DA MONTADORA A: VERIFICAÇÃO DA EXISTÊNCIA DE MODELO DE NEGÓCIO PARA ATIVIDADES DE E-BUSINESS}

Essa empresa forneceu um material de divulgação elaborado pela matriz em 2001 que continha a história da criação da estrutura de e-business da empresa, estrutura essa que se iniciou em 2000 na matriz.

A empresa $\mathrm{A}$ (o relato refere-se à matriz) já possuía algumas ferramentas de e-business em 1999.

Esse foi o ano de pico para as atividades de e-business, e a empresa começou a refletir mais profundamente sobre a necessidade de desenvolver atividades de e-business de forma mais sistemática.

Os desafios e oportunidades a serem enfrentados enquanto empresa automotiva atuando globalmente eram:

-Abriram-se novas perspectivas de envolvimento com fornecedores numa rede.

-Todo dia milhões de clientes visitavam os sites da empresa com seu "showroom" e a empresa gostaria de satisfazer as necessidades desses clientes

-a comunicação móvel ganhou importância nos últimos anos e como consequência existe uma demanda por serviços integrados de telecomunicações aos veículos.

-Para uma empresa com mais de 300 mil empregados ao redor do mundo, a possibilidade de cooperação em rede parecia razoável. 
A partir disso, a empresa empreendeu uma análise em cooperação com todas suas unidades de negócios e departamentos corporativos para examinar em que medida as novas condições estruturais requeriam um ajuste nas estratégias existentes.

Decidiram que os principais objetivos do e-business na empresa seriam:

-Criar uma conexão contínua linkando as unidades internas umas às outras e aos fornecedores

-Tornar os processos internos mais eficientes através do uso da rede

-Expandir essas conexões ao consumidor através da rede.

Essa abordagem levou à criação de um modelo de negócio para ebusiness, que foi operacionalizado através de uma estrutura de e-business chamada "Iniciativa net" lançada em outubro de 2000.

A missão da "Iniciativa net" definida a partir desse modelo de e-business foi: "fazer da montadora A a primeira companhia automotiva totalmente conectada em rede através de toda sua cadeia de valor" .

A intenção da implementação do modelo de e-business originando a "iniciativa net" foi tornar a empresa mais rápida, mais eficiente e mais competitiva através de todas as áreas, desde compras a vendas.

O nome da iniciativa foi escolhido para enfatizar a total integração em rede de cada aspecto de suas atividades.

Foi usado o conceito de cadeia de valor para definir os componentes do modelo de negócio. 


\section{FIGURA 35: MODELO DE NEGÓCIO PARA E-BUSINESS DA MONTADORA A MATRIZ}

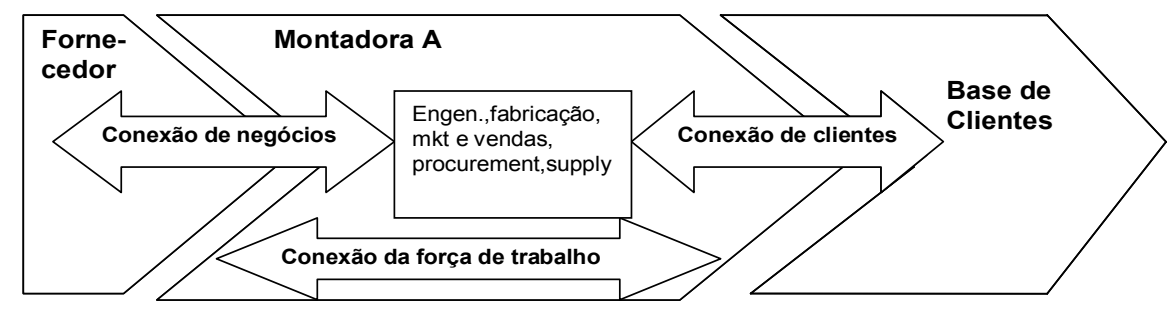

A partir da análise da cadeia de valor, o modelo de negócio para ebusiness que explica as atividades de e-business na empresa é o representado abaixo:

FIGURA 36: COMPONENTES DO MODELO DE NEGÓCIO PARA EBUSINESS DA MONTADORA A

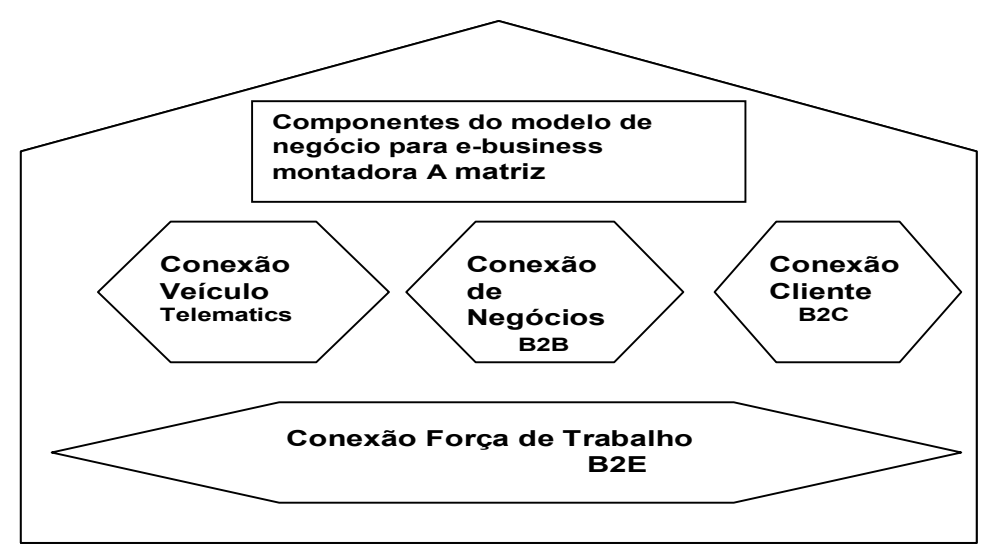

Os componentes desse modelo de negócio para e-business são:

- -Conexão de negócios: 
- Estabelecido para permitir mais contínua e eficiente colaboração com fornecedores (Business-to-Business). A Internet oferece novas oportunidades para redesenhar modelos e processos de cooperação.

- Conexão Cliente:

Criado para atingir links mais fortes entre o consumidor e a empresa (B2C) com a ajuda da Internet. Todas as medidas nessa área servem ao objetivo de dar suporte a atividades de vendas e marketing por toda a empresa.

- Conexão veículo:

Lida com as possibilidades de colocar os veículos na rede (telematics). Para uma emrpesa automotiva como a montadora A é natural que o ebusiness esteja incorporado dentro dos veículos.

- Conexão Força de Trabalho:

Serve para conectar na rede toda força de trabalho da emrpesa (Business-to-employee ou B2E) para acelerar os processos internos e dar aos empregados a oportunidade de usar a Internet de acordo com suas necessidades individuais.

Após dois anos do lançamento da "iniciativa net" pela matriz A vários planos e conceitos foram desenvolvidos, vários projetos se iniciaram e alguns resultados começaram a ser alcançados.

Todos os projetos foram lançados com base em objetivos financeiros claramente definidos.

Alguns projetos dentro de cada componente da "Iniciativa net":

\section{A) Ferramentas em Conexão de negócios - ligar em rede toda cadeia de valor}


- e-Engineering: Conjunto de esforços para otimizar os processos de desenvolvimento de produto, reduzindo custos, reduzindo atividades desnecessárias e melhorando o fluxo de informações.

Abordagem -acelerar o processo de desenvolvimento do veículo. Transformação do processo de comunicação em processos universalmente conectados em rede, permitindo o fluxo de informações em tempo real.

Com a comunicação em tempo real todas unidades funcionais e sistemas de fornecedores envolvidos no processo de desenvolvimento obtem informação atualizada sobre o status do desenvolvimento.

Resultados: - transparência na administração das mudanças em termos de tempo, custo e conteúdo; -redução e documentação de todo processo de mudanças. Melhorias no processo do desenho do carro, aumentando a precisão no desenho dos veículos, reduzindo perdas, trazendo novos veículos para o mercado mais rapidamente.

-e-Procurement: As decisões de procurement afetam as relações de longo prazo com os fornecedores e determinam diretamente o custo do produto bem como sua qualidade.

A estratégia de e-business da montadora A foca na utilização de tecnologias baseadas em web para otimizar as tarefas " core" de procurement:

-Análise de informações visando fornecedores e mercado

-Preparação de critérios de procurement com desenvolvimento de produtos e logística

-Procedimentos de busca de preço

-Gestão de contratos

-Online bidding events (leilões reversos)

-Catalogue Buying (compras online sem papel)

-e-Docs (troca de documentos com parceiros e cotações online)

A melhoria nessas tarefas e em outros aspectos de procurement tem o potencial de reduzir o tempo do processo, além dos gastos envolvidos- desde as especificações e documentação do pedido até a seleção dos fornecedores. 
Como resultado, o tempo envolvendo todo o processo de procurement pode ser levado adiante com menos passos, traduzindo-se em menor custo.

Por outro lado, as ferramentas de Internet vem crescendo em importância para a coordenação e orientação estratégica da rede de procurement internacional da montadora A.

Nesse sentido, a montadora A está comprometida com a filosofia de Empresa Extendida, através de uma comunicação aberta com seus fornecedores dentro do e-Procurement.

Dentro do e-Procurement, estão sendo efetuadas as seguintes atividades:

1. Eventos de 'online biddings' (lances ou ofertas eletrônicos): Negociações via Internet

- $\quad$ Tempo requerido para colocação da oferta reduzido em cerca de $80 \%$ em casos individuais

- $\quad$ grandes licitações da ordem até de EUR 3,5 bilhões colocados via procedimentos de online bidding

- $\quad 43 \%$ de licitações de um detrminado modelo de carro a ser lançado colocado online

Os benefícios que a empresa obteve com o "online bidding" foram:

-Redução do tempo de negociação de semanas para dias ou mesmo horas;-Redução do custo de viagens e encontros; -Transparência no posicionamento competitivo de preços;-Rápida determinação da oferta ótima através da habilidade em ver todas as combinações de alternativas de ofertas.

Em outubro de 2001 a montadora A havia excedido suas projeções originais da quantidade de negócios a serem processados através do COVISINT (portal automotivo que efetua processos de leilões eletrônicos, ofertas eletrônicas, dentre outros produtos de eprocurement. Esse é um portal corporativo, do qual participam várias montadoras e fornecedores utilizando uma infraestrutura compartilhada). 
2. Compra por catálogos eletrônicos -procurement online sem papel.

Os funcionários podem acessar o sistemade catálogo eletrônico eShop via Internet, onde podem pedir materiais não produtivos diretamente online.

Acordos globais permitiram resultados em condições de procurement mais efetivas em custo.

Pedidos sem o uso do papel gerou uma redução de custo do processo em $50 \%$.

Os catálogos são preparados pelo COVISINT com base nos dados dos fornecedores e então transferidos para o sistema de catálogo eShop. Um grupo definido de usuários tem acesso ao eShop via Intranet e dali podem enviar pedidos através do COvisint diretamente para 0 fornecedor.

eShop é a primeira solução global de procurement na empresa, tendo passado por uma fase piloto no início de 2002.

As suas vantagens são:

-Redução de custo do processo em 50\% pelo não uso de papel e procedimentos diretos de procurement;-Redução dos custos de material através do uso efetivo de contratos existentes;-Provisão de informação detalhada, evitando erros no planejamento;-redução de tempos de entrega através de conexão baseada na Internet com fornecedores;-redução de estoques.

\section{3. eDocs}

Troca de documentos sem a utilização de papéis com parceiros fornecedores

4. Gestão Avançada da Qualidade-otimização do processo de Planejamento da qualidade via Internet. Uso de plataformas de comunicação baseadas na web para o asseguramento da qualidade de partes entregues, utilizando um aplicativo específico para isso.

Atividades dentro do e-Supply: 
Apresentação e Discussão dos Resultados dos Estudos de Caso

Tem como abordagem padronizar e acelerar a comunicação com fornecedores.

Atualmente uma combinação do EDI (Electronic data Interchange) e ferramentas baseadas na web cobrem partes da rede de fornecedores, devido à necessidade de altos investimentos financeiros e problemas de integração requeridos pelo EDI.

No futuro a empresa quer aumentar a introdução e adoção de sistemas comuns baseados na web, para permitir transparência na comunicação.

O e-Supply chain management cortou custos em logísticas.

A rede universal da empresa com seus fornecedores parceiros até o mais baixo nível na cadeia de suprimento permite planejamento em tempo real para todos fornecedores envolvidos.

Os pedidos feitos automaticamente trouxeram:

-Tempo exigido para comunicação entre as partes reduzido em 92\%;Identificação e prevenção de possíveis gargalos;-Estoques ao longo de toda cadeia de suprimentos reduzido;-Evitou-se excesso de capacidade

Atividades de e-Ordering: Integração dos dealers (ou distribuidores)

Devido ao papel importante das concessionárias no processo de venda de automóveis, uma vez que é ela quem tem contato direto com, o cliente e conhece suas expectativas, foi criada essa ferramenta de e-ordering para compreender toda sistemática do processo produtivo, de forma a tornar 0 concessionário totalmente integrado à empresa, para poder realizar os pedidos mais rapidamente, eficientes e com total transparência.

Global ordering: o link com o consumidor.

O processo de pedido de um determinado modelo de carro tem sido transferido para a Internet desde 1997.

Desde maio de 2001 o global ordering tem sido usado por uma série de modelos de carros da empresa em vários países:

-Transparência no processo de pedido do consumidor aumentou

-Tempo de processamento do pedido reduzido de 40-50 dias para 12-15 dias 
-redução de custos ao evitar passos intermediários no processo de pedido.

Vantagens para o dealer: verificação imediata para confirmar se o veículo pedido pode ser construído; quando o pedido é feito, o dealer recebe confirmação da data de entrega final e pode informar 0 consumidor imediatamente.

Resumindo: a montadora A já obteve alguns resultados a partir de suas iniciativas na "conexão de negócios" com progressos em conectar seus processos de negócios, no entender da empresa.

As áreas envolvidas nesse processo foram Desenvolvimento, Procurement \& Supply, Logística e Produção, onde as atividades criaram condições para acelerar processos e fluxos de trabalho, estabelecendo novos modelos colaborativos e, segundo a montadora afirma, aumentando a lucratividade da empresa como um todo.

\section{B)-Ferramentas em Conexão Cliente}

-Abordagem: Fortalecer o relacionamento com o cliente através de contatos regulares.

\section{Website:}

Elaboraram um website corporativo, onde apresentam as marcas e produtos disponíveis.

Através de um sistema de acesso personalizado, serviços personalizados são providos ao cliente para auxiliá-lo durante todo ciclo de vida do produto.

Para os dealers, aqui considerados como clientes, são disponibilizadas informações necessárias durante todo processo de venda através da web com ferramentas que permitem construir homepages regionais.

$\mathrm{Na}$ área de carros de passageiros, a empresa tem um website que oferece aos consumidores um canal adicional com vastas informações que apóiam o processo de vendas.

-cerca de $50 \%$ de seus clientes conseguem informações pela Internet -cerca de 20 milhões de páginas visitadas por mês mundialmente 
-presença na web global com 50 versões regionais

\section{Portal}

Serviços de mobilidade acessíveis através de qualquer canal.

Portal oferece serviços móveis como " routing” , tráfego de informações, tempo e informações.

Base para aumentar a lealdade do cliente e retenção do cliente Acesso 24 horas via www, WAP, call centers e PDA

Base paea futuros serviços móveis no veículo.

\section{Vendas diretas na web}

Em 2000, uma das divisões da empresa estabeleceu um canal virtual de vendas.

Compreende configuração do produto, informações sobre preço, financiamento, apresentação visual do produto.

Ainda tem um volume pequeno.

\section{Serviços de financiamento}

Um portfolio de informações, planejamento, e ofertas de transação para financiamento de carros novos.

\section{Conexão Partner}

Sistema de apoio baseado na web para a rede de dealers, para suporte à venda. Inclui informações sobre produtos, e online-ordering.

\section{C) Ferramentas em Conexão Força de trabalho}

Conectar em rede todos os funcionários para tornar seus esforços de trabalho mais eficientes.

\section{Portal do funcionário}

É baseado em padrões de tecnologia group-wide.

Provê acesso a informações internas e externas, processos de trabalho e aplicações para todos os empregados. 


\section{ePeople}

Automação dos fluxos de RH.

O projeto ePeople segue a padronização baseada em group-wide de todos os processos envolvendo pessoas.

No futuro, todos os executivos e funcionários terão acesso ao sistema pessoal, permitindo-lhes obter informação atualizada e lidar com processos pessoais por conta própria:

-estabelecimento de sistema pessoal padronizado baseado na web

-Processos de pessoal Padronizados universalmente através do grupo

-Custos administrativos mais baixos, mais qualidade na administração de pessoal.

Processos de recursos humanos serão uniformizados para todos empregados e alguns deles serão executados automaticamente.

Um database uniformizado será usado para garantir que não haverá redundâncias.

\section{D) Ferramentas em Conexão Veículos}

Garantir mobilidade ativa e passiva em qualquer período para os consumidores.

Poder oferecer serviços de telecomunicações móvel através do veículo.

Prover assistência aos clientes quando estão nas estradas, oferecendo informações sobre as localidades, hotéis, rstaurantes, etc.

Gravação de dados de um dado veículo e processamento subseqüente num computador de bordo.

Integração do GPS para dar o exato posicionamento do veículo.

Todos esses serviços estão dentro da área de telemática.

\section{Inovações em telemática}

-Desenvolvimento de veículo com acesso à Internet

-Serviço de emergência

\section{Telemática em carros de passageiros e carros inteligentes}

Soluções de telemática integradas e ofertas pós-vendas 
Integração de serviços de navegação e comunicação móvel.

A partir da explicação das ferramentas utilizadas em cada componente do seu modelo de e-business, o conceito da cadeia de valor integrada pelo ebusiness através de suas várias ferramentas fica conforme figura abaixo:

\section{FIGURA 37: CONEXÃO DA CADEIA DE VALOR PELAS VÁRIAS FERRAMENTAS DE E-BUSINESS}
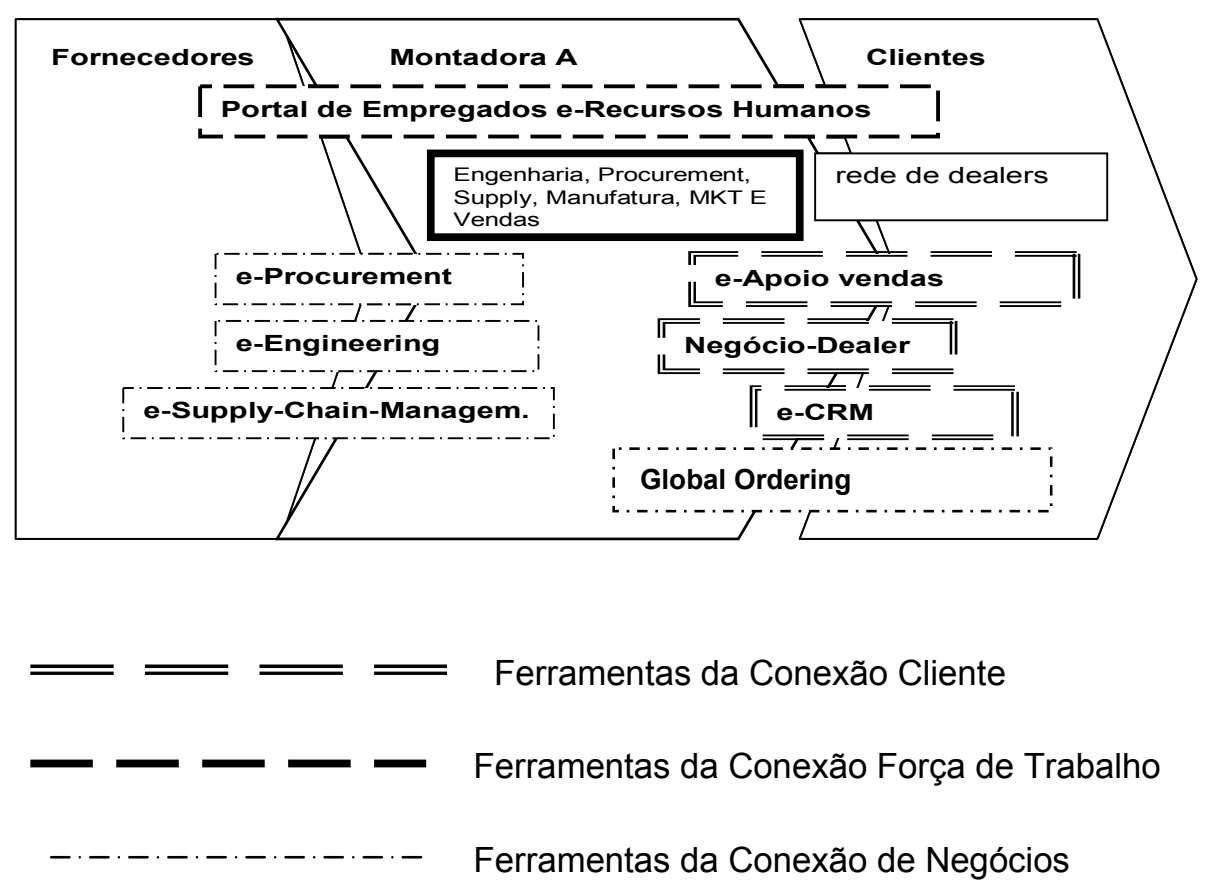

\subsubsection{DESCRIÇÃO DO CASO DA FILIAL BRASILEIRA DA MONTADORA A: VERIFICAÇÃO DA EXISTÊNCIA DE MODELO DE NEGÓCIO PARA ATIVIDADES DE E- BUSINESS}

Histórico do e-business na montadora A no Brasil:

1998-surgiram iniciativas de e-business na matriz

No Brasil: em 1998-começa o desenvolvimento do site institucional da empresa. 
98 e 99: objetivo: colocar a marca na Internet e estar presente

98: criado site da montadora A no Brasil, personalizando o site institucional global, traduzindo as partes pertinentes (relativas a marcas e produtos no Brasil)

2000: funções do site: demonstração de produtos, colocar portfolio e mostrar a empresa, uma iniciativa mais de marketing- gerência de comunicação, independente dos produtos.

A idéia de atender aos desafios da Internet implantando um modelo de negócio para e-business no Brasil veio em 2001, quando a matriz decidiu enviar para cá uma pessoa de lá com experiência em e-business para implantar o modelo utilizado na matriz aqui no Brasil.

Essa pessoa veio para cá em julho de 2001 para implantar o mesmo $\underline{\text { modelo }}$ utilizado na matriz.

Portanto, o modelo a ser implantado era:

FIGURA 38: MODELO DE NEGÓCIO PARA E-BUSINESS A SER IMPLANTADO NO BRASIL EM 2001 PELA MONTADORA A FILIAL

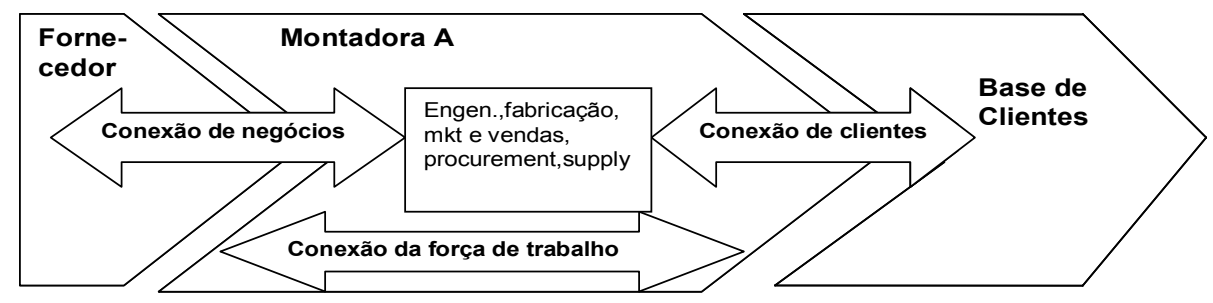

Para implantar esse modelo de negócio no Brasil a matriz indicou um gerente da empresa que trabalhava na matriz com e-business para consolidar , desenvolver e alavancar as iniciativas de Internet na América Latina.

Com esse objetivo, o diretor nomeado pela matriz para implantar o modelo no Brasil iniciou um processo de sensibilização quanto às iniciativas de e-business. 
A missão do modelo no Brasil também continuava a ser: "conectar todas as cadeias de valores com uma plataforma global-integração de ferramentas".

As funções da área de e-business no Brasil são:

1-desenvolvimento local das iniciativas de e-business

2-Repassar conceitos da matriz

3-Apoio para as outras áreas no que tange a:

-conceitos de e-business (modificação da cultura)

-Recursos de uso de software

-Know how (interno e externo)

Aqui no Brasil a área de e-business lida apenas com aspectos estratégicos: são repassadas as estratégias formatadas pela matriz para as áreas que vão fazer uso das atividades B2B, B2C e B2E.

Os projetos de $\mathrm{B} 2 \mathrm{~B}$, onde existe o ato de comprar produtos e ver o quanto economizou na operação através da utilização de ferramentas de e-business (como por exemplo o uso de leilões eletrônicos), tem mais viabilidade, mais apoio por parte da diretoria, no caso , a diretoria de Compras, pois dá um retorno no momento em que é realizado.

Ao passo que B2C, não dá para medir o quanto o cliente está satisfeito no curto prazo, não há retorno direto, daí os investimentos são baixos, pois a alta direção não quer desenvolver projetos onde não percebe o retorno.

A preferência do diretor de e-business vindo da matriz recaiu em atividades de e-business cujos resultados fossem facilmente mensuráveis, de modo a mostrar para a alta direção da montadora brasileira que valia a pena investir nas iniciativas de e-business.

$\mathrm{Na}$ área de $\mathrm{B} 2 \mathrm{~B}$, o COVISINT trouxe representante que lida com a montadora A.

A matriz da montadora A comprou a idéia, instituiu COVISINT como parceira efetiva de trabalho de prospecção e contratação de fornecedores. 
Covisint vende aplicativos que são ferramentas para realizar atividades junto a fornecedores, por exemplo: monta estrutura necessária para a realização de leilões.

Os leilões organizados pelo Covisint utilizam aplicativos padronizados, não desenvolvidos pela montadora $\mathrm{A}$.

O funcionário do COVISINT prepara sistema para leilão e fornecedores indicados pela montadora A acessam um portal (extranet) com determinada senha. Existem diferentes estratégias: leilão reverso e leilão direto.

Outra área que tem sido foco do modelo de e-business no Brasil é a área de RH da montadora A brasileira: hoje (2002) área de e-business ajuda na definição das estratégias e desenvolvimento de sistemas para a área de $\mathrm{RH}$.

B2V (business to vehicle)- relacionada a Telemática.

Esse ano houve um rallye onde foi testado um veículo da montadora A de alta tecnologia, com recursos para navegar sozinho.

B2V-prestação de serviços para o usuário, utilizando tecnologia de comunicação para agregar valor ao produto. Principal utilização no Brasil: rastreamento de caminhões para prevenção de roubo de cargas

$\mathrm{Na}$ verdade, a área de B2BV pode ser entendida como B2C, uma vez que presta serviços ao cliente final, entregando um produto de alta tecnologia que $o$ diferencia no mercado.

Porém, pelo modelo da montadora $\mathrm{A}$, as iniciativas em telemática constituem um bloco separado no modelo de e-business (B2V).

Numa comparação entre a empresa matriz e a filial brasileira, fica clara a diferença na intensidade de uso de ferramentas de e-business.

Existem maiores dificuldades no Brasil para implantação de ferramentas.

Mesmo com as dificuldades- envolvimento da alta direção, dificuldade em mostrar quais resultados podem ser alcançados, custo na adaptação dos aplicativos à realidade brasileira, situação econômica do país - várias áreas começam a construir projetos: função da "Iniciativa net" no Brasil é coordenar atividades que eram pulverizadas pelas diversas áreas. 
A "Iniciativa net "global foi criada para fazer a convergência dos negócios, por dois anos foi criada para alavancar o negócio, para mobilizar as áreas, e para decidir sobre investimentos.

Hoje Europa e nafta agora podem cuidar do e-business sozinhas e a estrutura global foi desmontada.

No Brasil a expectativa de que isso ocorra- desmonte de uma estrutura centralizadora e coordenadora das atividades de e-business - é para 2003.

Dificuldades de fazer a "tropicalização" do modelo de e-business criado pela matriz da montadora $A$ vem de vários fatores:

-Por exemplo, em outros ambientes a nota fiscal é uma aplicação padronizada e pode-se usar no mundo todo. No Brasil não existe essa padronização.

-Existe solicitação da matriz de aplicar certas iniciativas de e-business e as pessoas das áreas diziam: "já estamos sobrecarregados", ou seja, não existe envolvimento nem interesse da alta diretoria das áreas corporativas em implantar ferramentas de e-business.

-Cenário econômico brasileiro recessivo e instável não ajuda a motivar a implantar o e-business, existem outras áreas prioritárias.

Por outro lado, o diretor de e-business no Brasil destaca que as áreas tem uma grande dependência da matriz, tendo dificuldades de gerar iniciativas.

As áreas esperam soluções prontas.

Porém, o e-business é uma atividade para pensar: como utilizar as ferramentas de e-business de modo a obter vantagens com seu uso?

Levou quase um ano para explicar o que era e-business.

Algumas áreas não tiveram o menor interesse.

-Compras foi a área que demonstrou o maior interesse - o argumento seria diminuição de custos, portanto os benefícios eram avaliados de modo quantitativo.

Em julho de 2001 com a utilização do COVISINT foram realizados de 10 a 15 leilões de material não produtivo na América Latina com economia de 10\%.

Para convencer as pessoas sobre a vantagem do uso de e-business, precisaram criar mecanismos de mensuração, para verificar benefícios e 
economia: mais fácil na átrea de Compras, pois os benefícios são mensuráveis quantitativamente.

Pela iniciativa da área de Compras, com a coordenação da área de ebusiness para o projeto, foi criado um site na Internet de e-procurement para viabilizar canal de comunicação com fornecedores em outubro de 2001:

-abrir canal eletrônico de comunicação com fornecedores.

-Fizeram evento para lançar documentação eletrônica.

-Para explicar para os fornecedores o que era, a maneira como ia ser a transição: não mais via papel, mas respondendo cotação de forma eletrônica.

No dia do evento foi explicado:

-como responder a coletas

-identificação, senha

-certificação

As ferramentas de e-procurement usadas pela área de compras são:

-leilões reversos - está sendo criado com economia de 10 a $40 \%$ (material indireto) e direto(10 a 15\% de economia)

-catálogos - em fase de estudo de viabilidade de custo-definindo qual vai ser a plataforma: covisint ou outr plataforma. A idéia é usar o covisint, pois é empresa do grupo. A medição dos resultados foi feita a partir da última compra ou de peças de mercado.

-Troca de documentação eletrônica: cotação: sendo usada desde out 2001.

Hoje, 30\% da capacidade de compras está na Internet.

Resultados alcançados: melhor preço e fornecedor.

Existe resistência por parte dos fornecedores.

Falta trabalho mais forte por parte dos compradores da montadora $\mathrm{C}$ para mudar a cultura dos fornecedores

Hábito é ir à montadora $\mathrm{C}$, conversar, ver o rosto do comprador.

Sindipeças e Anfavea tem feito trabalho nesse sentido, de mudar a cultura dos fornecedores de modo a utilizarem mais a Internet para operações de fornecimento. 
Também existe um problema interno à montadora $C$ para o uso de eprocurement: cultura dos compradores-resistência `a mudança.

A definição dos projetos na área de Compras é feita pelo diretor de ebusiness + supervisor de estratégia + coordenadora de e-business da área de Compras.

Em julho de 2001 a montadora C organizou um encontro sobre eprocurement reunindo as montadoras que integram o COVISINT.

Depois dessa reunião, conseguiram trazer um escritório do covisint para cá (por exemplo tinham problemas em usar o front end em inglês- muitos fornecedores não falam inglês) .

Em agosto de 2001 houve a instalação de um escritório do Covisint no Brasil, com cerca de 10 funcionários, cujo objetivo era atender os clientes - no caso as montadoras- interessadas em utilizar aplicativos fornecidos pela Covisint. No caso do Brasil as ferramentas mais procuradas são o leilão eletrônico e o catálogo.

Em setembro de 2001 a empresa realizou o primeiro leilão reverso- com a coordenadora do e-business em compras havia um time de pessoas da área de estratégia, mais pessoas da área de compras, com $70 \%$ do tempo alocado para e-business. Dificuldade: pessoal de compras ainda não via resultado em usar e-business, não vêem vantagem e tem medo de ameaça ao cargo.

Novembro de 2001 utilização da ferramenta de RFQ-request for quotation Dez 2001-e-catálogo

Hoje já foram feitos 20 leilões reversos.Planejamento de mais 20 até dezembro de 2002 e ano que vem mais 30.

Estão fazendo "business case" sobre viabilidade do catálogo.

Segundo a coordenadora de e-business em compras, "O trabalho é que quando põe alguma coisa na Internet, tem que atualizar informações: informação publicada , mas válida, tem que atualizar (compras)"

Hoje só tem implantado o leilão reverso e RFQ (request for quotation).

Quer expandir para outros documentos de compras de forma eletrônica:

-8 passos para a qualidade (quando detecta algum problema, com peça crítica, tem que acompanhar passo a passo) - querem fazer de forma eletrônica. 
Estão sempre linkados com as ferramentas da matriz, seguem metodologia estabelecida por ela.

Vantagens do e-procurement:

Ocupação do tempo do comprador:

Antes depois do e-procurement

$10 \% \quad 50 \%$ - negociação, desenvolvimento de novas fontes

$40 \% \quad 30 \% \quad$ cotação

$20 \% \quad 10 \%$ follow up

$30 \% \quad 10 \% \quad$ tarefas manuais

O uso do Covisint gerou o seguinte problema com fornecedores: leilão diminui preço, fornecedores se sentem pressionados.

O uso de leilão superou as expectativas em termos de redução de custos (não conseguiria isso numa negociação tradicional).

Coordenadora achou que ia demorar mais tempo para fazer isso: de julho a setembro já fizeram o primeiro leilão.

Segundo a coordenadora de e-business em Compras "O novo modelo de negócios implica repensar processos-oportunidade para olhar para dentro da empresa (num momento de poucas vendas)".

Foi área de Compras que mais utilizou o COVISINT.

Custos para o uso do COVISINT para efetuar leilões:

-preparar os fornecedores

-versão em português

-call center com versão para o Brasil

A partir dos dados apresentados, pode-se concluir que a implantação do modelo de e-business da matriz na montadora A do Brasil teve as seguintes características:

-Idéia era aplicar o mesmo modelo utilizado na matriz

-Problema: dificuldade com a sensibilização da alta diretoria para ebusiness: não perceberam vantagens advindas do e-business 
-Estratégia: dar foco em atividades B2B que apresentam resultados mais mensuráveis.

-A área de e-business não tem autoridade para tomada de decisão quanto a investimentos em e-business: isso cabe aos diretores de áreas corporativas.

Portanto, o modelo no Brasil teve um direcionamento para atividades $\mathrm{B} 2 \mathrm{~B}$, e algumas iniciativas em B2E (relacionamento dentro da emrpesa), porém as atividades de e-business ainda estão numa fase inicial, começando a gerar projetos em e-business.

Projetos em andamento:

-projetos em qualidade- sistemas de melhoria de qualidade do fornecedor -componente B2B do modelo de e-business

-desenvolvimentos conjuntos- para utilizar "cad" da matriz-componente B2B

-projeto de catálogo- B2B

-projeto para "request for quotation" - B2B

-engenharia: desenvolvimentos conjuntos com fornecedores on line - B2B

-RH : vários projetos para oferecer serviços on-line para colaboradores Ex: reserva de vôo online - B2E

-Logística: supply chain managenment - B2B

-Relacionamento com dealer - B2C

\subsubsection{DESCRIÇÃO DO CASO DA MATRIZ DA MONTADORA B: VERIFICAÇÃO DA EXISTÊNCIA DE MODELO DE NEGÓCIO PARA ATIVIDADES DE E-BUSINESS}

Em junho de 1999 foi criada uma força tarefa pela montadora B levada a cabo pelo CEO da época e outros executivos seniors.

Antes de apresentar o modelo utilizado pela empresa, é importante contextualizar essa iniciativa em termos de época histórica e do importante papel do CEO da corporação global e dos executivos por ele indicados para empreender a tarefa de criação de estrutura de e-business para a empresa. 
O início de 1999 coincide com o auge do "boom" de Internet, com as ações da NASDAQ (bolsa de empreendimentos de alta tecnologia) em alta, o que moveu muitas empresas já estabelecidas a promoverem iniciativas nessa área, como já foi identificado na revisão da literatura dessa tese.

A montadora B contava com um presidente global na época (CEO da corporação como um todo) que se sensibilizou bastante com a utilização da Internet para obter vantagem competitiva: esse executivo colocou para a montadora B na época dois objetivos: tornar-se líder mundial em satisfação ao cliente e executar e-business.

Ele via a montadora B não só como líder no mercado de carros, mas como provedora de customização e acesso à Internet.

Sua missão era reformular a montadora B de uma empresa manufatureira para uma "Web-savy" ("inteligência em web"), supercapacitada tecnologicamente voltada totalmente para mercado e consumidor.

Para isso foram feitos muitos investimentos para mudar o modelo de negócio: esse novo modelo não seria sobre plantas fabris e equipamentos, mas deixaria em evidência as marcas, a construção de marcas e o relacionamento com clientes.

Segundo artigo retirado do site www.forbes.com sobre o modelo a ser adotado pela empresa B para entrar no e-business, John Akasie, nesse artigo de 17-07-2000, afirma que a empresa gostaria de ser em 2010 como a CISCO, empresa fabricante de micros num sistema "build-to-order", que implica em montar o computador após o pedido ter sido feito. (obs: vários artigos foram retirados da Internet, de várias fontes, porém para preservar a identidade da montadora, não foram citados).

A Internet seria o facilitador para isso: em termos de B2B a empresa B previa a substituição de uma cadeia de suprimentos externa por uma "owned manufacturing company"; e em termos de B2C, ele criaria condições para facilitar a contínua interação com os consumidores, oferecendo várias formas de enriquecer o valor da marca.

A idéia inicial era utilizar um modelo semelhante ao da Dell Computer, de entregas sob pedido, oferecendo customização em massa de seus produtos 
para compradores. Por outro lado, a montadora B gostaria de transferir a responsabilidade de estoque para seus fornecedores ou permitir que os mesmos pudessem controlar os estoques para a montadora.

A visão e estratégia da montadora B focam quase exclusivamente em construção de relacionamentos através de ativos intangíveis, como global branding, satisfação do cliente e lealdade, uma idéia de "valor total" para o cliente.

A mesma filosofia centrada no cliente pode ser vista na estratégia de ebusiness dessa empresa, que provê um modo de tocar o consumidor em cada ponto do ciclo de vida do relacionamento (busca pelo produto, compra, construção, finanças, possuir o produto).

Enquanto por um lado as ações da montadora B revelam seu comprometimento com o cliente, parece ser possível que haja uma certa fraqueza nesse modelo de negócio: poderia ser requerida mais ênfase na gestão dos relacionamentos com fornecedores.

A montadora concorrente (que é a empresa $C$ dessa pesquisa) também estava lançando nos Estados Unidos o seu modelo de negócio voltado a ebusiness, o que motivou o CEO global da montadora $B$ responder prontamente com o lançamento da iniciativa de e-business própria.

Cabe lembrar que o segmento de indústria automotiva é extremamente competitivo e quando uma novidade é lançada, as outras montadoras lançam algo semelhante logo em seguida, seguindo o modelo de Porter (1985) sobre o "first mover" como aquele que obtem vantagem competitiva e o primeiro seguidor como aquele que também obtem vantagens.

A estratégia de e-business para a empresa era multifocada: os objetivos eram aumentar receitas através de vendas "build to order" e através da criação de estratégias de serviços que criariam pacotes de serviços a serem entregues no carro do cliente (Telematics).

Essa era a componente B2C do modelo de negócio.

A montadora B também teve iniciativas precursoras nas operações de negócios internos à empresa: no princípio de 2000 eles planejaram oferecer para cada empregado um computador pessoal, uma impressora e acesso à Internet 
por US\$ 5 mensais (em parceria com a Hewlewtt Packard, UUNet e PeoplePC), para garantir que todos os funcionários estivesses conectados em rede.

Os objetivos do e-business na visão desse CEO: iria ajudar a reinventar "core process" tais como planejamento da produção, alcançar consumidores através de qualquer dispositivo on-line, melhorar o processo de compras, enriquecer a experiência do consumidor e possuidor de veículo de qualquer marca da montadora $B$, além de criar plataforma móvel web para integrar serviços de Internet dentro do veículo.

$\mathrm{Na}$ visão desse executivo, o B2B na empresa serviria para cortar as perdas e desperdícios na cadeia de suprimentos e com o B2C a empresa encontraria o modo de conectar a cadeia de suprimentos diretamente com o comprador do carro.

No entanto, esse executivo acreditava que o e-business dizia mais respeito a rapidez, conveniência na compra e informações do que a corte de custos.

Ele resolveu mudar de uma visão centrada nos dealers (ou distribuidores) , onde o consumidor escolhe o produto de uma limitada seleção de um lote de dealers para uma visão centrada nos consumidores finais, onde o comprador compra o que realmente quer.

Essas mudanças forçariam transformações nos dealers, antes especializados no que $\circ$ fabricante mandava e não no que o consumidor realmente queria.

Segundo o executivo, os dealers iriam se reinventar a si próprios como resultado da Internet.

Usando a Internet, ele mudaria o modelo de "push model" para um "pull model": ao invés do fabricante "empurrar" seu modelo para o consumidor, o consumidor- estimulado pela propaganda -vai puxar o produto através da cadeia de fornecimento.

Acreditava que com esse posicionamento viriam transformações culturais na empresa seguidas de economias de custos e aumento das receitas.

Algumas parcerias foram estabelecidas:

-Usar CarPoint da Microsoft para vendas e informações 
-Yahoo para contato direto com o consumidor

-Price-line.com para leilões on-line

-TeleTech para ajudar a prover sistema de callcenter para apoio a cliente

Além dessas iniciativas, do lado do B2B (business to business) a montadora B criou uma Exchange no final de 1999 para compras de fornecedores online, através de leilões eletrônicos e outros recursos, que rendeu uma economia de US\$ 9 bilhões através da cadeia de fornecedores.

Para acelerar a produção de projetos de e-business, foi criada em 1999 a unidade de negócios "Conexão com o consumidor", baseada no conceito do modelo de negócio chamado: "business-development-accelerator-unit".

Esse modelo tinha como missão gerar e acelerar oportunidades em ebusiness e ajudar a montadora $B$ a focar naquelas mais críticas.

Esse modelo de "aceleração de atividades de e-business" tinha como objetivos acelerar o desenvolvimento das iniciativas de e-business de maior prioridade. Ele também tinha como objetivos apoiar e coordenar os relacionamentos e parcerias com organizações externas líderes em ecommerce.

Esse modelo era composto por 4 blocos:

FIGURA 39: MODELO DE NEGÓCIO ACELERADOR DE ATIVIDADES DE EBUSINESS DA MATRIZ MONTADORA B

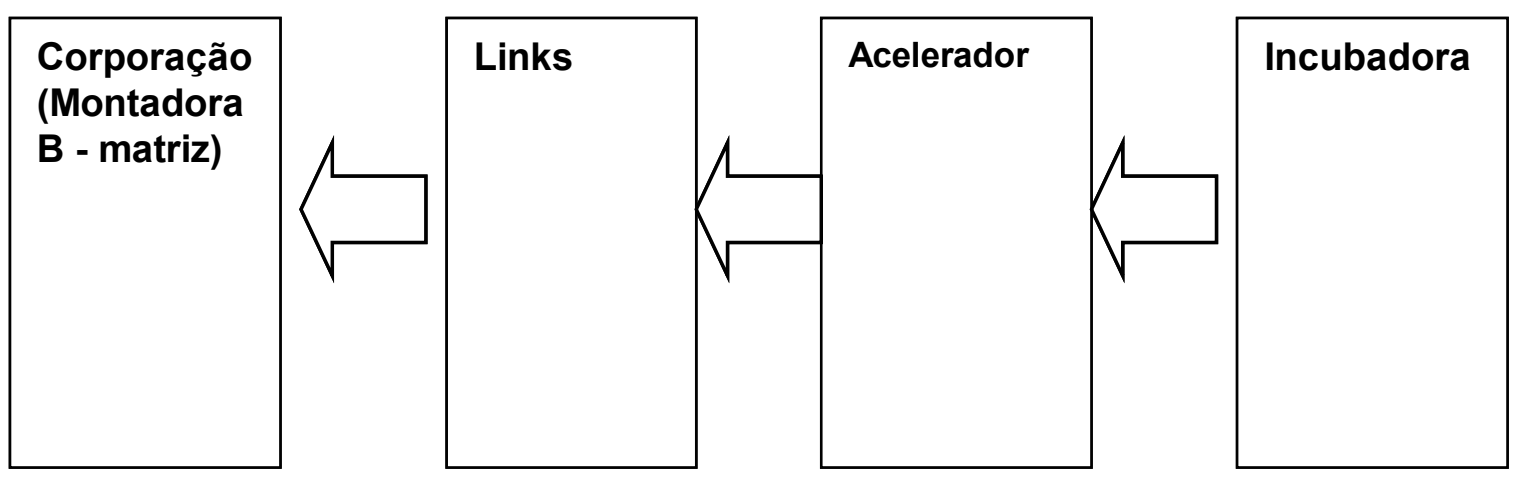




\section{Incubadora:}

Responsável em criar novas iniciativas em e-business, tanto em B2B como em B2C.

O processo de incubação de iniciativas era o seguinte: a incubadora deveria gerar idéias. Essas idéias gerariam joint ventures com empresas de tecnologia para realizar iniciativas de e-business, que ficariam "incubadas" na montadora B, aproveitando de sua infraestrutura, até serem lançadas no mercado.

Exemplo de algumas iniciativas (os nomes não foram revelados nessa tese para manter a empresa não identificada):

-portal de Vendas Diretas (joint venture com a Trilogy para fazer web site para dealer- feito um portal para cada marca (são 7)) ;

-Telematics: joint venture com a empresa Qualcomm para trazer Internet para dentro do carro;

-Covisint: parceria com a Oracle- Exchange de e-commerce na auto indústria, com iniciativa conjunta de diversas montadoras. É um marketplace de B2B que visa economizar em custos administrativos usando a Internet para automatizar a compra de suprimentos e materiais, além de permitir desenvolvimentos conjuntos com fornecedores.

-Call center- joint venture com a TeleTech para implementar ferramentas de Customer Relationship Management no call center.

-Logística com dealers: parceria com a empresa UPS Logistics para diminuir prazo de entrega dos carros para os dealers.

Accelerador: priorizava as iniciativas geradas e acelerava o processo de implantação daquelas mais prioritárias.

Links: Faziam um link das iniciativas geradas e priorizadas no "acelerador" com as necessidades de negócios corporativos.

Utilização pela Corporação: Por fim, os produtos produzidos pelas joint ventures geradas eram utilizados pela corporação (montadora B). 
Assim, a parceria foi a chave para a estratégia de aquisição de conhecimento da montadora $B$ segundo o executivo presidente da unidade de negócios "conexão com o consumidor".

$\mathrm{Na}$ maioria dos empreendimentos de e-business, a montadora fez parcerias com empresas líderes em Internet ou em software.

Segundo ele essas parcerias levaram a montadora B a obter tecnologia e experiência que não tinham.

Elas aceleraram o passo no qual a empresa conseguia atingir seus objetivos e ajudou a empresa na sua transformação cultural.

Como eles poderiam se tornar uma empresa focada no cliente? As parcerias foram o modo como a empresa implementou seus objetivos.

Mais de 20 empreendimentos foram anunciados desde setembro de 1999 até janeiro de 2000 .

Todos usando a estrutura explicada acima de aceleração de iniciativas.

Através do uso desse modelo de negócio foram criadas mais ou menos 16 empresas sendo que no auge do processo de geração de iniciativas chegou a ter 25 empresas.

Muitas delas encerraram suas atividades por não darem o retorno esperado.

As atividades de e-business podem ser assim descritas, de acordo com o tipo de participantes da atividade: 
Fatores Críticos para o Desenho e Implantação de e-business por empresas tradicionais

237

Apresentação e Discussão dos Resultados dos Estudos de Caso

FIGURA 40: CONJUNTO DE ATIVIDADES DE E-BUSINESS DA MATRIZ MONTADORA B GERADAS PELO MODELO DE NEGÓCIO DE ACELERAÇÃO DAS ATIVIDADES DE E-BUSINESS

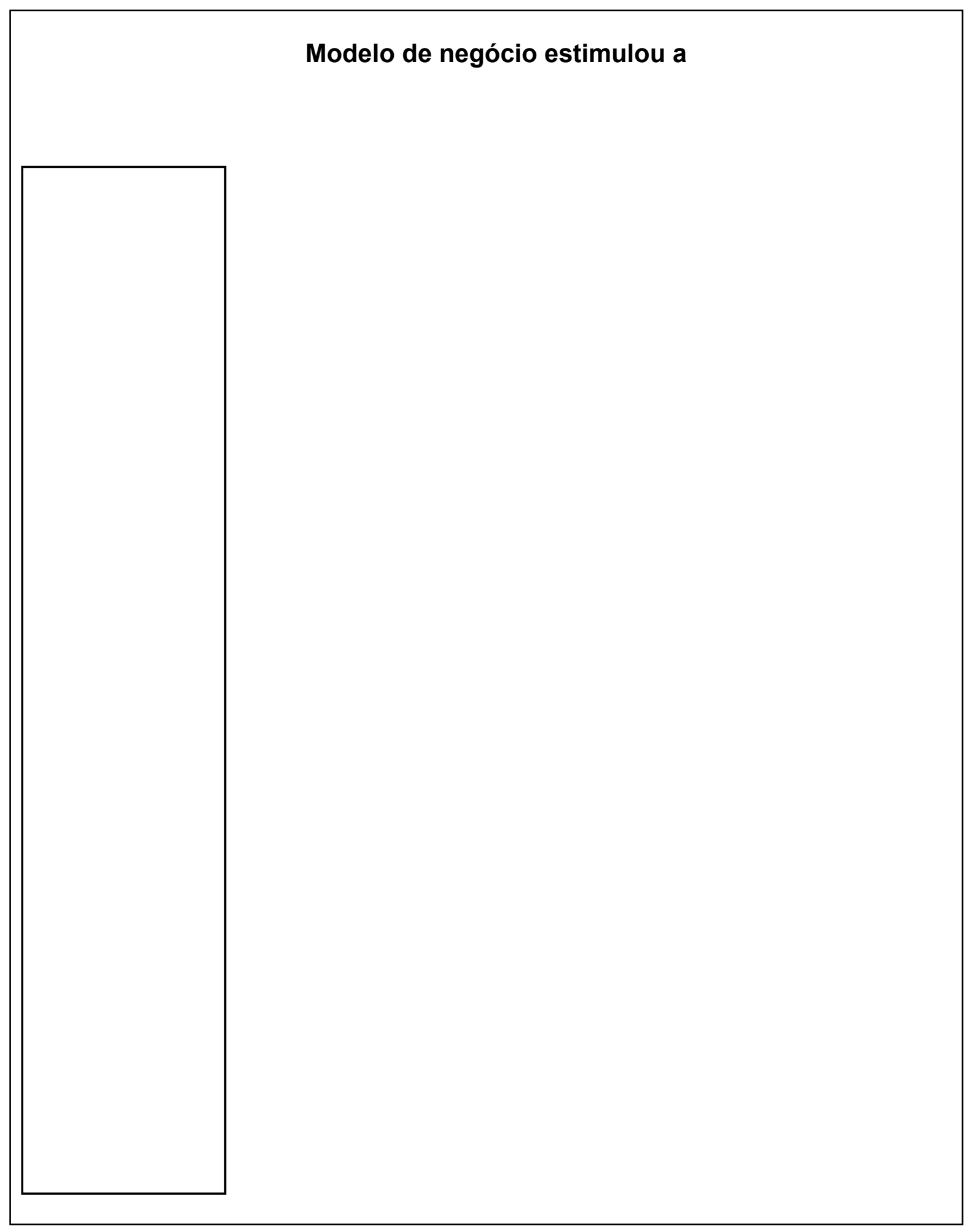

Silvia Novaes Zilber 
O B2C é visto pela empresa como fundamental, dando inclusive o nome da estrutura de e-business - "Conexão com o consumidor" - para revelar o foco no cliente.

Na visão do CEO global, toda a área de conexão com o cliente e melhoria do processo completo de venda - desde o momento que a empresa se comunica com o cliente, percorrendo o ciclo de vida do produto, caminhando pela venda e serviço de pós-venda - ainda era insatisfatório naquela época, final de 2000.

Em 2000 os portais de callcenter e venda pela Internet ainda não haviam trazido os resultados que esse CEO havia previsto.

Começou a se manifestar mais fortemente uma preocupação quanto à questão dos projetos atenderem uma necessidade específica e serem factíveis, atendendo a prazos e orçamento.

Ou seja, uma preocupação com o retorno sobre os investimentos, que não era tão clara até então.

Houve uma série de mudanças na estrutura organizacional de e-business da empresa a partir de 2001

Quanto à componente B2B do modelo de e-business da empresa, em 1999 a empresa B anunciou a formação de uma Exchange privada como um mercado central eletrônico para suas atividades de procurement em novembro, voltada para a compra de componentes para carros.

Após esse evento, a montadora $B$ desenvolveu uma iniciativa em ebusiness da empresa que ainda está em andamento (ainda não foi implantada) que partiu da estrutura "conexão com o consumidor" e hoje é gerida pela área de Compras Globais da empresa.

Trata-se da elaboração de um programa de procurement que visa fazer uma re-engenharia nos processos de "core business" e sistemas para Compras, Requisições e Pagamentos.

É uma solução de sistema baseada na Internet com um escopo global, chamada nessa tese de "eCompras" (para não revelar o nome verdadeiro utilizado pela empresa). 
Esse sistema aumenta a capacidade de utilizar a informação disponível enquanto provê melhor comunicação interna e com os fornecedores.

Esse projeto já existe há dois anos na empresa e sua implantação está prevista para início de 2003.

Seus objetivos são:

- Interconectar estrategicamente a montadora B globalmente com sua base de fornecedores e o mundo

- Ter foco no mercado, com rapidez e eficiência

- Construir relacionamentos mais fortes com o fornecedor

- Gestão baseada em conhecimento

- Prover uma interface simplificada para seus fornecedores

- Acesso via internet sem uso de papel

- Virtualmente integrada

Com o portal de eCompras, os fornecedores poderão realizar as seguintes atividades apenas utilizando a Internet:

-Visualizar as ordens de compra

-Faturamento

-Recebimentos, status do pagamento e embarques atrasados

-Receber e enviar pedidos de cotação

A idéia é de que através dessa ferramenta, as relações entre os fornecedores e a montadora B mudem drasticamente, com a gestão das contas dos fornecedores on-line, comunicação feita sem o uso de papel, aumento da velocidade e acesso às aplicações da montadora B sete dias por semana, 24 horas por dia.

Hoje já existem poucas ferramentas do eCompras funcionando, mais relacionadas a treinamento de fornecedores para uso do sistema.

Hoje o acesso ao eCompras é do seguinte modo: 
FIGURA 41: SISTEMA DE COMPRAS ATUAL DA MONTADORA B MATRIZ

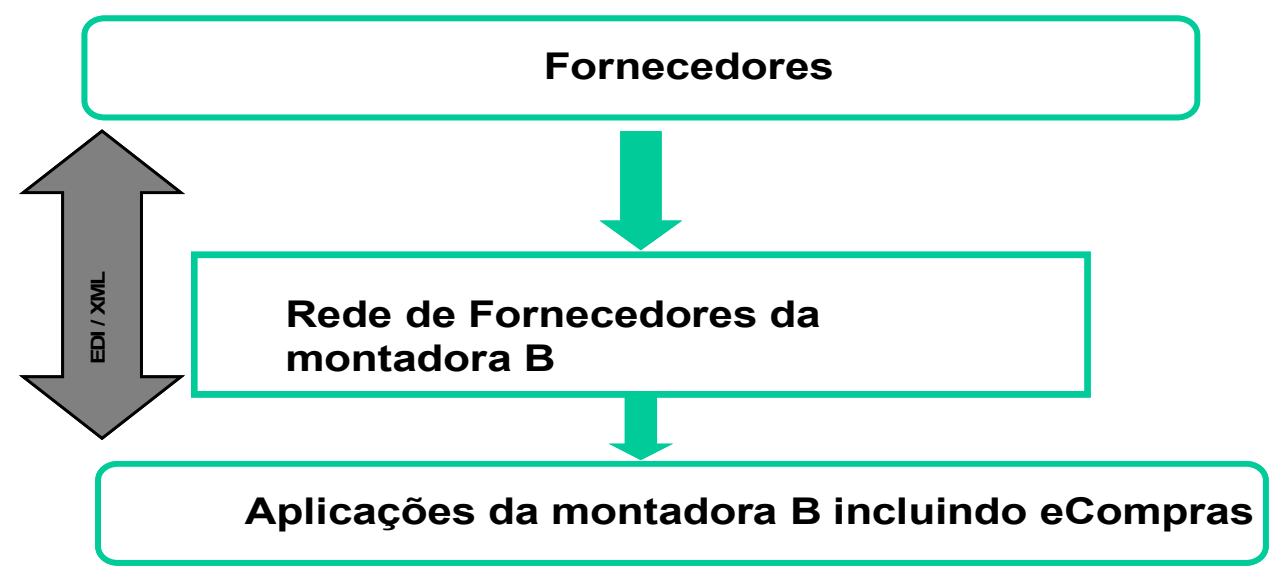

No futuro, os fornecedores irão acessar o eCompras através do COVISINT:

FIGURA 42: FUTURO SISTEMA DE COMPRAS DA MONTADORA B MATRIZ

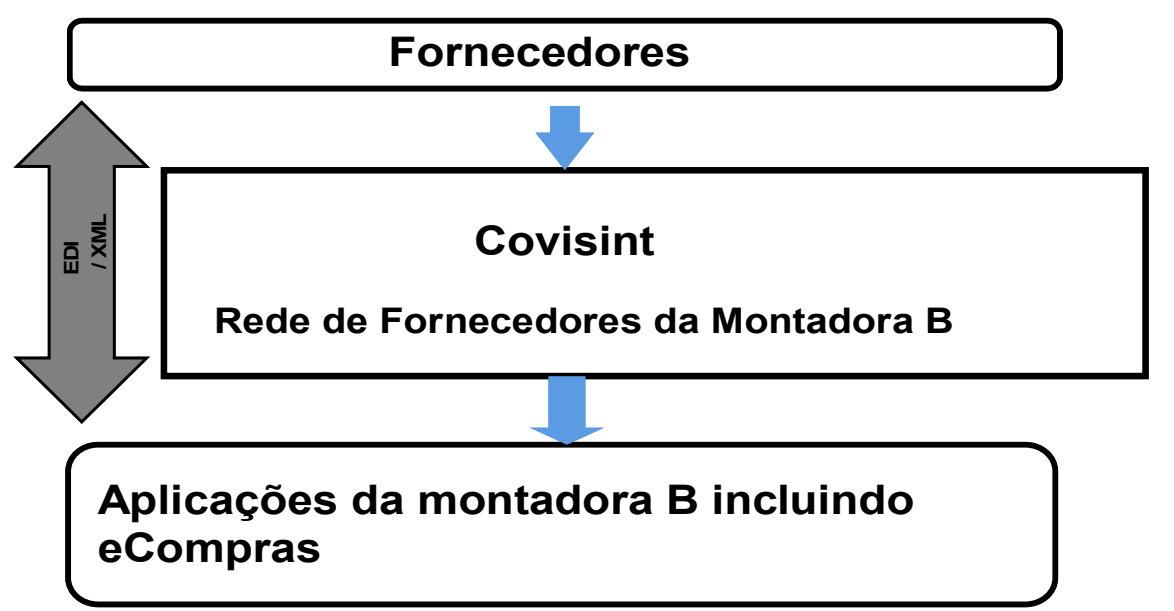

O sistema "eCompras" possui as seguintes capacitações:

-Menos tempo e dinheiro gastos em transações de procurement

-Eliminar existência de processos e sistemas duplicados

-Processos de comunicação mais fáceis e rápidos

-A nova tecnologia e suas ferramentas possibilitam tanto à montadora $\mathrm{B}$ quanto a seus fornecedores reduzirem custos. 
"eCompras" está sendo desenhado e desenvolvido para os compradores globais da montadora $B$, Fornecedores e requisitantes através dos esforços do time de programa global eCompras e o setor de Operações de Compras Globais da montadora B.

Apesar dessa ferramenta eCompras ainda não estar em operação totalmente, pensou-se ser importante citar esse projeto que tem uma conotação mais voltada para os fornecedores, uma vez que as iniciativas do grupo "Conexão com o consumidor" eram basicamente voltadas ao consumidor.

Em resumo, o modelo de e-business é mais voltado para atividades $\mathrm{B} 2 \mathrm{C}$, sendo que as atividades B2B mais importantes (cração de um sistema de eprocurement - eCompras) agora estão sendo tocadas pela área de Compras Globais da matriz da montadora B.

\subsubsection{DESCRIÇÃO DO CASO DA FILIAL BRASILEIRA DA MONTADORA B: VERIFICAÇÃO DA EXISTÊNCIA DE MODELO DE NEGÓCIO PARA ATIVIDADES DE E-BUSINESS}

Histórico do e-business

Já utilizava EDI na relação com distribuidores e fornecedores (B2B)

-baseado no pacote "renpac" da embratel (ainda é utilizado).

Utilizando o pacote renpac da embratel, em 1997/1998 implantaram (entre distribuidores e montadora B Brasil):

- sistema de garantia-reembolso.

-sistema de pedidos de veículos

-final de 98-começaram a trabalhar com Internet.

Em 1999 houve uma iniciativa da área de Marketing, com envolvimento das áreas de TI da empresa e serviços: colocação de portal na Internet (iniciativa $\mathrm{B} 2 \mathrm{C})$.

Nessa época existiam as seguintes áreas de e-business na empresa:

B2E (business to enterprise): dentro da empresa-área de $\mathrm{RH}$ com iniciativas isoladas 
B2S (Business to Supplier)-área de compras liderara iniciativas de relacionamento com forncedores. Na verdade, era uma iniciativa $B 2 B$, que foi "rebatizada" pela empresa.

B2C: dealer - serviço ao cliente

Foram iniciativas isoladas, não constituíam um modelo de negócio no sentido de ser condutor das atividades existentes.

As atividades que aconteceram nessa época tinham basicamente $o$ objetivo de automatizar processos existentes (manuais) e melhorar comunicação.

Em final de 1999 começou iniciativa de organização das atividades, iniciativas de fazer projetos de forma mais organizada.

A função de supervisão de e-business foi criada no início de 2000 para ser responsável por iniciativas e-business para a América do sul. Estava abaixo de uma gerência de e-business, que por sua vez respondia para uma diretoria de Marketing estratégico.

A criação dessa supervisão aconteceu em decorrência do fato da matriz da montadora $B$ ter feito um grande aporte de capital na filial brasileira voltado a iniciativas de e-business.

Essa verba durou de final de 1999 ao final de 2001.

A matriz não fez nenhuma recomendação quanto a tipo de projetos ou tipo de iniciativas ou modelos a adotar: apenas fez o investimento financeiro, que deveria ser direcionado para atividades de e-business.

Isso vai de encontro com a filosofia da estrutura de e-business da matriz, que preconizava o lançamento de iniciativas de e-business, inclusive tendo criado lá uma estrutura "aceleradora de iniciativas" , como foi descrito no item anterior. Porém , a matriz não fez nenhuma recomendação em utilizar o modelo que estava sendo usado lá.

O que acontecia eram reuniões periódicas do supervisor de e-business brasileiro com o "e-board" da estrutura de e-business da matriz para verificar andamento das iniciativas.

Essa área criada- supervisão de e-business- tinha então caráter estratégico dentro da montadora B- Brasil. 
O supervisor fazia parte do "e-board" da estrutura de e-business da matriz mostrada no item sobre estrutura organizacional da matriz da montadora B (item 5.2.2.3 dessa tese), ou seja, ele era o representante da América Latina no "board" estratégico da estrutura de e-business existente na matriz.

Esse supervisor concebeu em 2000 um modelo de negócio para direcionar as atividades de e-business com a função de propor, a partir desse modelo, uma estrutura operacional centralizada na área de estratégia da montadora B Brasil que coordenasse as atividades de e-business.

O modelo proposto tinha o seguinte formato:

FIGURA 43: MODELO DE NEGÓCIO PARA E-BUSINESS CONCEBIDO PELO SUPERVISOR DE E-BUSINESS PARA A MONTADORA B EM 2000 - PARA APROVAÇÃO PELO COMITÊ EXECUTIVO DA EMPRESA

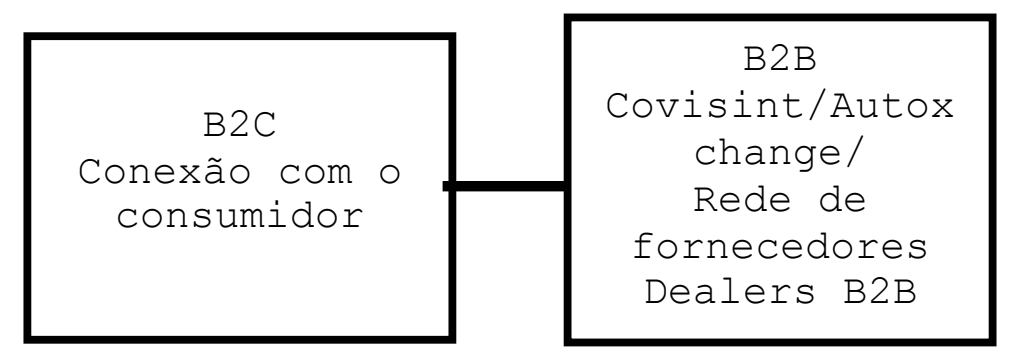

O supervisor de e-business no Brasil concebeu esse modelo como base para uma organização de e-business: times multifuncionais voltados para projetos em cada uma das áreas acima.

Os objetivos desse modelo eram:

- Injetar E-Business na montadora B - Brasil dando responsabilidades para cada departamento específico

- Mais do que recursos, o Brasil necessitava de envolvimento da alta direção

Esse modelo pressupunha uma estrutura operacional para realizar:

- Implementação da estratégia

- Boa coordenação

- Interação e envolvimento

- Obter Recursos adequados 
Para a componente B2C do modelo de e-business, o supervisor propôs o seguinte esquema:

FIGURA 44. COMPONENTE B2C DO MODELO DE E-BUSINESS PROPOSTO PELO SUPERVISOR DE E-BUSINESS DA MONTADORA B BRASIL

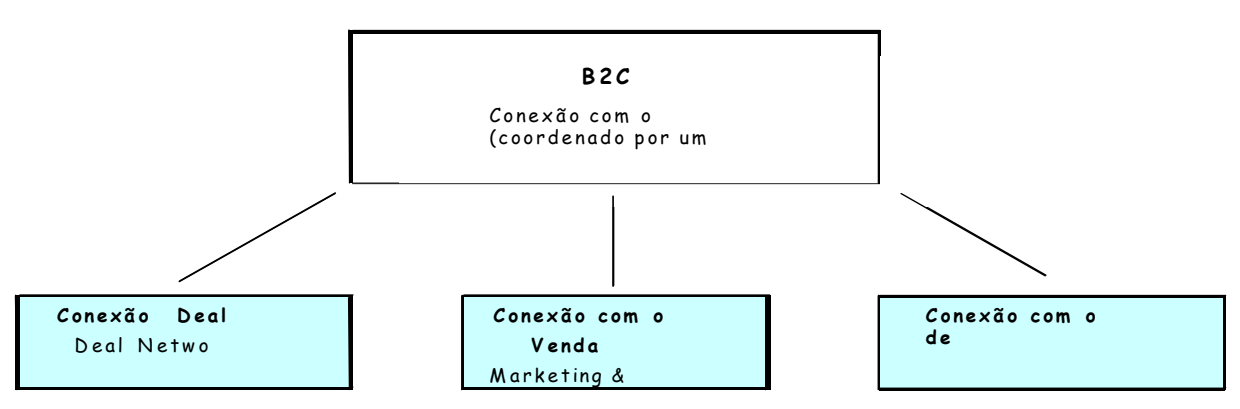

Para a componente B2B, foi proposto o seguinte modelo:

FIGURA 45: COMPONENTE B2B DO MODELO DE E-BUSINESS PROPOSTO PELO SUPERVISOR DE E-BUSINESS DA MONTADORA B BRASIL

Conceito básico do site B2B

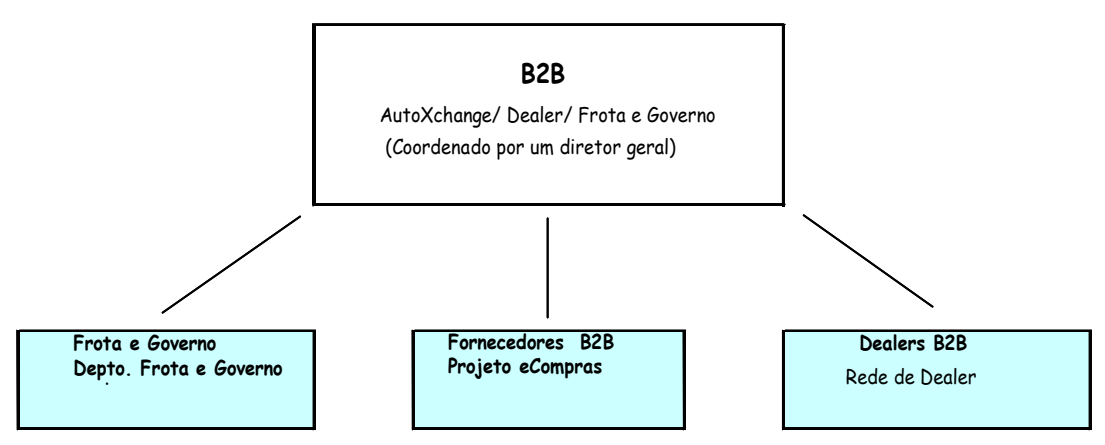


A coordenação dessas atividades estaria centralizada na área de ebusiness da empresa, estabelecendo um representante de e-business em todas as áreas corporativas da empresa. Esses representantes formariam times de projetos coordenados pela área de e-business.

Para essa estrutura o supervisor argumentava que necessitaria de oito elementos, três supervisores e cinco analistas.

A estrutura porém não foi aceita pelas instâncias superiores e a área de e-business ficou composta somente pelo supervisor de e-business dedicado em tempo integra a essas atividades e seu diretor, que se dedicava parcialmente às atividades de e-business.

O modelo proposto não foi aceito, pois não obteve comprometimento das áreas .

Os problemas alegados para não adesão ao modelo de e-business proposto: não havia disponibilidade de alocação do tempo das pessoas.

-Não teriam tempo para se dedicar aos projetos.

O resultado é que não houve formalização dessa estrutura.

Mas , mesmo sem estarem formalmente organizadas, as atividades de Internet foram tomando esse formato, de iniciativas B2B focadas naquelas áreas e $\mathrm{B} 2 \mathrm{C}$, como o supervisor havia recomendado.

Como havia acontecido um aporte de capital substancial pela matriz objetivando o desenvolvimento de atividades de Internet na filial brasileira e resto da América latina, e como esse dinheiro havia sido entregue numa fase inicial diretamente às áreas corporativas da montadora B no Brasil, houve uma quantidade grande de atividades de e-business acontecendo em 2001, porém sem uma coordenação formalizada, já que o modelo proposto não fora aceito.

Como conseqüência, em 2001 as atividades de e-business começaram a se sobrepor. Várias áreas diferentes fazendo coisas repetidas, ou não dando a solução ideal da primeira vez.

Porisso, a partir de meados de 2001 o supervisor de e-business começou a centralizar a verba destinada a e-business.

Como não existia um modelo de e-business orientador das diversas atividades, ele criou uma "estrutura de governança", onde um comitê formado 
pelo presidente da empresa, mais diretores corporativos, mais diretor de negócios estratégicos e diretor de TI priorizavam a alocação das verbas para as diversas áreas.

O supervisor de e-business estratégico era o responsável pela distribuição da verba para as diversas áreas após essa priorização.

Nessa época (meados de 2001) existiam cerca de 400 projetos. Para priorizar os projetos, o supervisor de e-business estratégico criou o seguinte processo de avaliação:

-impacto no negócio da empresa (retorno)

-facilidade de implementação

-inovação

A partir daí, escolhia um portfolio de projetos.

Antes desses critérios: implementava tudo, pois havia verba disponível, gerando os problemas citados: duplicação de esforços e atividades.

Esse processo de priorização dos projetos fez com que a implantação dos projetos demorasse, mas na opinião do supervisor de e-business estratégico, permitiu dar foco às iniciativas.

Como foram mensurados os resultados:

-resultados de vendas diretas

-qual incremento obtido de vendas pela Internet (difícil mensurar)

-propaganda na web: o que economizava em termos de propaganda na TV

Instituíram algumas medidas: tinham 15 metrics. Alguns diretores acreditavam nesses resultados, outros não.

Exemplo de indicadores: resultados de fidelização de clientes (pessoas registradas nos web sites).

-dealer: melhoria de processos (" burocracia" -pagamento antes por boleto, pedido tinha 5 etapas, agora é direto pela web)

-e-learning: treinamento: avaliaram quanto economizava com ensino a distância. 
Assim, as atividades de Internet ficaram alinhadas com as necessidades de negócios- estavam totalmente integradas com a estratégia do negócio, uma vez que as iniciativas partiam das áreas.

Em janeiro de 2002 foi desativada estrutura de e-business dedicada aqui no Brasil.

Foi uma decisão da matriz: na matriz começou a desmontar aos poucos a estrutura de e-business dedicada.

Segundo avaliação do supervisor de e-business, as joint ventures criadas pela estrutura da matriz absorveram muito dinheiro e estão dando prejuízo. Por exemplo, projeto de telemática custou 250 milhões de dólares e não deu retorno ainda.

As vendas também não aumentaram na matriz após essas iniciativas.

Um dos únicos projetos lucrativos foi o call center na matriz.

Porisso a decisão da matriz em desativar a estrutura de "governance" do Brasil, que na verdade se resume em não mandar mais verba para investimento e realocar o supervisor de e-business para outras atividades estratégicas, não só o e-business.

Não é mais o supervisor de e-business que decide sobre a alocação da verba: voltou para o sistema anterior: área de $\mathrm{TI}$ e área de negócios decidem: área sugere e TI implementa.

Voltou para o formato de inovações dia-a-dia.

Quanto ao impacto que o e-business provocou nos negócios da empresa, a inovação foi a resposta obtida pela maioria dos entrevistados: inovação em sistemas e processos. A modernização da empresa também foi citada como resposta.

Exemplos de integração do e-business aos processos de negócio da montadora B Brasil:

$\mathrm{Na}$ área de B2B:

-Dentro do processo de melhoria da qualidade:

-canal para distribuidor reportar ocorrências

-depois, canal de comunicação com relação a serviços 
-Treinamento para os dealers:

-tem histórico dos mecânicos acessível na Internet -treinamento online para os mecânicos dos dealers -conceitos básicos de mecânica e elétrica -criaram “ universidade”, vai avançando os estágios -incentivam distribuidores a usar, pontuam os distribuidores distribuindo bônus, treinamento é importante para ganharem bônus -B2D-modernização do portal do distribuidor (Venezuela, Argentina, Brasil e Chile)

-Extranet:

-portal dos distribuidores com senhas -portal dos fornecedores

-Intranet

-Internet pública

Peças (serviço ao cliente): todo pedido de peça é feito pela web-rastreamento da peça- pode agendar entrega da peça.

Questionário para distribuidores para avaliar qualidade-compromissoparticipação.

-Área de Compras: Uma iniciativa que não fazia parte dos processos existentes em Compras e que foi possibilitado pela Internet: leilão virtual.

É uma iniciativa B2B onde a ferramenta de leilão foi desenvolvida no Brasil pelo pessoal de TI da montadora B, não utilizaram o COVISINT.

Gerou resultados: economias de custos

O leilão : nasceu porcausa do e-business

Exemplo de leilão: peças obsoletas- montaram leilão para liquidar peças. Lote misto: peças atraentes e não.

A área de peças prepara os lotes, divulga, sistema fácil de utilizar, distribuidores cadastrados-leilões tem sido bem sucedidos. Consegue vender melhor do que se venderia normalmente. 
Hoje na área de Compras estão em uso duas ferramentas de e-business: o leilão e a cotação.

-Cotação (cotação enviada via Internet para fornecedor ). Intenção: eliminação do papel.Sistema corporativo é o mesmo. Só que em vez de fax, vai via Internet. Benefícios: economia de papel e fax, tempo do comprador. Antes: comprador tem que digitar todos os dados para digitar cotação, hoje os dados já vem via eletrônica.

-economia de tempo e dinheiro com papel e fax.

-leilões reversos: conseguiu baixar preço

Hoje: esforços para que todos os fornecedores se conectem.

Site para responder cotações está no ar há 2 anos.

Problema:o fornecedor, pois o sistema funciona direto- falta treinamento.

Tem 2000 fornecedores cadastrados. Tem uma pessoa de compras dando suporte para dúvidas de como responder cotação, como entrar no site, existe um caminho por segurança, para acessar e às vezes fornecedor desiste no primeiro obstáculo.

Cerca de 900 fornecedores estão conectados.

-Comunicação com os distribuidores sobre peças e serviços-fazem um jornal de negócios.

-Produto de e-business vindo da matriz: "serviço total" - avalia processos do distribuidor na elaboração de um serviço ao cliente final. , se distribuidores seguem esses procedimentos, tem um rendimento melhor. A montadora $B$ tem todas as etapas do processo e vê como distribuidor está em termos de objetivos.

-Fornecedores: projeto para avaliar entrega de peças, performance dos fornecedores.

-criação de formulários eletrônicos para diminuir uso de papel.

$\mathrm{Na}$ área de B2C:

-Portal da montadora $\mathrm{B}$, gerido pela área de marketing

-Clubes (comunidade virtual)-clube do picapeiro- sustentado pela montadora B- área de marketing (CRM); clube kids, voltado para crianças 
-Venda direta de modelo de carro popular -lançado pela Internet , distribuidor também faz pela Internet.

-2002-Lançamento de novo modelo de carro popular

Todos essas atividades de e-business surgiram a partir da "injeção" de verba feita pela montadora, num primeiro momento sem haver muita coordenação, o que gerou uma sobreposição de atividades e num segundo momento a coordenação para distribuição de verbas pelo supervisor de ebusiness.

Segundo o supervisor de e-business da área de serviço ao cliente, a Internet faz o papel de um outro canal e não tem tratamento distinto dentro da empresa, é apenas uma ferramenta na opinião desse supervisor.

A única ferramenta de Internet que realmente gera uma receita adicional aos negócios existentes é o leilão.

Desse modo, não houve um planejamento de e-business, foi mais uma adequação das áreas para entrar na web (nova ferramenta).

Os principais produtos de Internet da montadora B são: portais com clientes, portal dos distribuidores, portal dos fornecedores, intranet (para comunicação entre os funcionários e troca de informações).

A montadora B ganhou muitos prêmios oferecidos por publicações especializadas em e-business por iniciativas B2B em 2001 (por iniciativas: volume de iniciativas, consistência de iniciativas).

Os resultados tangíveis contabilizados: resultados financeiros e vendas.

Resultados não tangíveis: melhoria de serviços, satisfação dos clientes, grande melhoria do diálogo com os distribuidores.

Resultados referentes a controles: manuais passaram para sistemas-mais efetivos. 


\subsubsection{DESCRIÇÃO DO CASO DA MATRIZ DA MONTADORA C: VERIFICAÇÃO DA EXISTÊNCIA DE MODELO DE NEGÓCIO PARA ATIVIDADES DE E-BUSINESS}

As informações aqui relatadas são fruto das entrevistas conduzidas na montadora C, a partir das quais obteve-se complementação dos dados através de visitas a sites da Internet da própria corporação, além de artigos em publicações especializadas sobre a criação da estrutura de e-business e notícias sobre sua evolução ao longo do tempo (período 1999-2002) obtidos na Internet.

Antes de 1999 a montadora C tinha várias iniciativas de e-business diferentes acontecendo por toda a empresa e através das diversas unidades globais da empresa.

Não havia coordenação entre as atividades e nenhum compartilhamento do conhecimento.

O resultado trazia alto custo para a empresa, por duplicação de atividades e recursos muitas vezes e uma experiência online pobre para a empresa.

Por esse motivo, em agosto de 1999 foi formada uma estrutura dedicada a e-business chamada nessa tese de "e-business C" para nomear a estrutura de e-business criada pela montadora $\mathrm{C}$ voltada para e-business.

O objetivo dessa nova unidade de negócios era disponibilizar uma vasta gama de produtos e serviços integrados para o consumidor, de modo a trazê-lo mais próximo à empresa usando mercados eletrônicos que entregam os produtos sob a promessa de tempo real, interatividade, e relacionamento customizado.

Por exemplo, essa nova unidade deveria alavancar iniciativas inovativas como os serviços "eShop", telemática e "Operações de Serviços de peças" para criar uma nova classe de aplicações para veículos e serviços relacionados.

O "eShop" é um website global de "shopping" (ato do consumidor buscar pelo produto percorrendo os pontos de venda disponíveis) e compras voltado para o consumidor (o nome eShop é fictício, para não revelar o nome da montadora). A idéia era de que esse website fosse implantado em cada mercado que a montadora $\mathrm{C}$ fizesse negócio no mundo. 
Além de alavancar as atividades existentes, a nova unidade de negócios pretendia chegar até o chão de fábrica para transformar as operações tradicionais automotivas em uma empresa global de e-business.

Segundo o CEO global da montadora C, a Internet fundamentalmente muda o modo como os negócios são conduzidos.

Naquele momento, então, o CEO achava que a Internet iria interferir nos processos de negócio, mudando o modo como os processos de negócios ocorrem.

Para responder a esse desafio, a alta direção da empresa decidiu investir todo o poder de suas inovações tecnológicas e forças de seus recursos humanos e financeiros na Internet para enriquecer o modo como a empresa desenvolve seus relacionamentos com o consumidor.

Assim, mais uma vez, vê-se o envolvimento da alta direção da empresa, investindo recursos financeiros, humanos e tecnológicos na Internet voltados para o consumidor.

Segundo esse CEO, a montadora $\mathrm{C}$ já tinha uma forte presença baseada na Internet nas operações tradicionais de negócios. O que eles fizeram foi combinar essas iniciativas num único lugar para assegurar tornarem-se líderes em comércio eletrônico alavancando a Internet e suas capacitações globais de comunicação.

A idéia dessa nova unidade era alavancar a "expertise" através de toda a empresa e integrar o e-commerce através de todas as divisões de negócio tradicionais da empresa.

O grupo "e-business C" serviria como um catalisador para melhorar a "experiência do consumidor", melhorar eficiência e cortar custos.

A idéia do novo negócio era remodelar o modo como a empresa faz negócios combinando desenvolvimento de negócios, e-marketing estratégico, evendas, e-gestão do produto e departamentos de tecnologia e operações sob um líder global.

A empresa teria vantagem por já ter uma forte performance de seus grupos existentes. 
Na época da criação da unidade de negócios, a montadora $C$ tinha mais de 100 Web sites voltados para consumidor ao redor do mundo e já operava o site de vendas "eShop", site baseado nos Estados Unidos voltado para serviços de compras, que teve mais de 650 mil visitas de "shopping" de novos veículos em junho de 1999.

É bom ressaltar que o eShop não faz a venda pela Internet, ele permite ao consumidor configurar seu carro, com opções disponibilizadas pela montadora.

Outro serviço já existente era seu serviço de Telemática, um sistema avançado de comunicação que executa várias tarefas como alertar times de resgate de emergência quando o airbag do carro é acionado, por exemplo.

Além desse serviço, o serviço de telemática oferece conectividade à Internet ativado por sistema de voz.

Esse sistema, segundo a empresa, tem um grande potencial junto aos consumidores, de tal modo que seria incluído em aproximadamente um milhão de carros e caminhões da empresa entre o primeiro e segundo semestres de 2000.

Esse é um sistema que exemplifica a tecnologia provendo um relacionamento direto com o consumidor.

Segundo o CEO do novo grupo "nossa missão é fazer da montadora C a líder global em e-business na nossa indústria".

Ele segue dizendo que, naquela época (1999) a empresa ainda tinha uma vasto leque de atividades de e-business ao redor do mundo. Quando trouxessem todas essas iniciativas sob um único grupo estratégico, eles teriam um alcance maior do que qualquer outra empresa no mundo.

Outro aspecto da estratégia trata do relacionamento com os "dealers": a empresa $\mathrm{C}$ pretendia naquela época alavancar infraestrutura de Internet e tecnologia da informação para trabalhar mais próximo com sua extensa rede de distribuidores de modo a atender as mudanças exigidas pelos consumidores.

Parte da estratégia desse novo negócio é estreitar as alianças entre as iniciativas de e-commerce dos dealers e aquelas da empresa $\mathrm{C}$ de modo a elas 
não parecerem separadas aos olhos do consumidor, e ainda obter vantagem da vasta quantidade de informação que a empresa tem disponível.

A empresa comprometeu-se a ser parceira dos seus dealers enquanto faziam esse novo modelo prosseguir em frente, uma vez que muitos dos dealers da empresa C estavam se movendo para fazer vendas pela Internet. Portanto, a integração de seus sistemas simplifica os processos de "shopping" e compras permitindo uma conexão com seus consumidores.

(Obs: o ato de "shopping" não tem uma tradução razoável para o português, é algo como "sair para as compras e olhar as vitrines", algo que se faz antes de comprar).

A partir desse posicionamento estratégico e com total apoio da alta diretoria da empresa, aliás, estimulado por ela, o seguinte modelo de e-business pode representar as atividades de e-business a partir de 1999, concentradas num grupo único, unidade de negócios, o "e-business C" :

\section{FIGURA 46: MODELO DE E-BUSINESS DA MONTADORA C - MATRIZ}

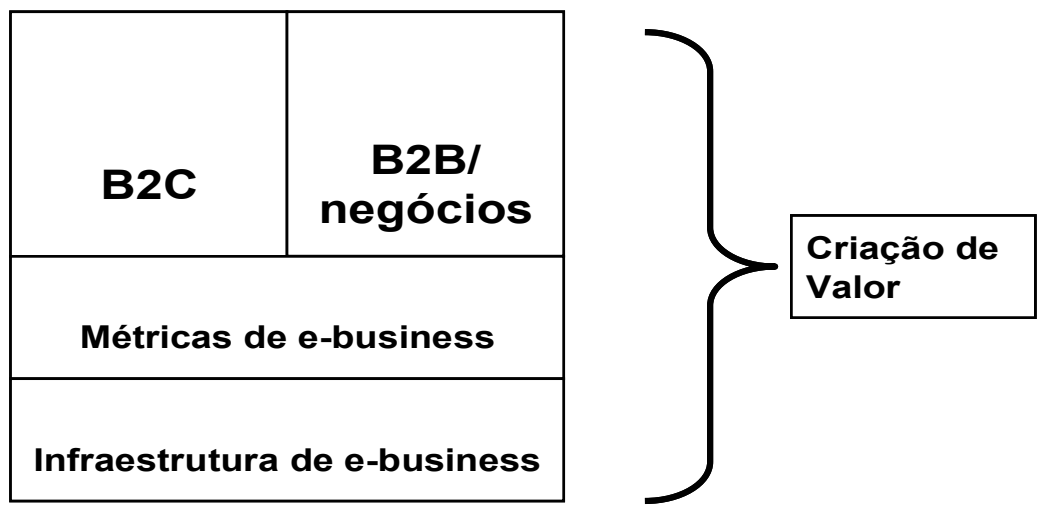

Esse modelo contempla as atividades de e-business com o consumidor (B2C), com outras empresas (B2B), além de envolver a questão das métricas que mensuram resultados alcançados, que não estavam explícitas no modelo das outras montadoras descritas nessa tese e contempla a infraestrutura necessária, dando a relevância para os apspectos de TI necessários à operacionalização do e-business.

Quanto aos objetivos do e-business para a montadora C, podem ser descritos através da seguinte figura: 
FIGURA 47: OBJETIVOS DO E-BUSINESS PARA A MONTADORA C MATRIZ

\begin{tabular}{|c|c|c|}
\hline B2C & B2B & Criação de valor \\
\hline $\begin{array}{l}\text {-Estreitar e } \\
\text { expandir os } \\
\text { relacionamen- } \\
\text { tos com o } \\
\text { consumidor } \\
\text {-Crescimento } \\
\text { das receitas } \\
\text {-Resposta } \\
\text { mais rápida } \\
\text {-Liderança }\end{array}$ & $\begin{array}{l}\text {-Reduzir } \\
\text { Custos } \\
\text {-Tornar-se mais } \\
\text { rápida } \\
\text {-Melhorar a } \\
\text { qualidade } \\
\text {-Liderança }\end{array}$ & $\begin{array}{l}\text {-Alavancar a "expertise in-house" } \\
\text {-e-business ser responsável por } \\
\text { uma porção da criação de valor } \\
\text {-Não ser necessário que } \\
\text { montadora C seja } 100 \% \\
\text { proprietária }\end{array}$ \\
\hline
\end{tabular}

A construção desse modelo levou em consideração o estabelecimento de alianças estratégicas com partners de sucesso na Internet (como AOL, edmunds.com, etc), de tal modo a :

- Atingir os seguintes objetivos:

-Auxiliar na geração de tráfego

-Gerar liderança

-Promover os produtos da montadora $\mathrm{C}$ de um modo favorável

- Construir uma presença difundida globalmente

- Parceria com as empresas de "primeira classe"

Numa primeira fase, o objetivo da montadora $C$ era utilizar e-business para melhorar e enriquecer o relacionamento com o consumidor.

Investimentos foram feitos no período de 1999-2000.

Após essa data, o ano de 2001, passada a euforia com o fenômeno das empresas ponto.com e com o mundo mergulhado numa recessão mundial, o discurso se torna diferente. 
Numa apresentação em outubro de 2001, o CEO da unidade de negócios dedicada a e-business da montadora C matriz, numa conferência de negócios (transcrição obtida no site da empresa) faz uma avaliação dos resultados até então e sobre a sobrevivência do e-business na empresa.

Segundo ele, com o quadro recessivo da época, dado que os orçamentos são limitados (discurso diferente do lançamento da iniciativa, quando o CEO falava em envolver todos os recursos humanos e financeiros em iniciativas de ebusiness) e que muitas empresas ponto.com desapareceram, por que se deve continuar a fazer e-business?

Segundo ele, essa é uma questão com um detalhe: os ambientes de 1991 e o de 2001 são totalmente diferentes: há dez anos atrás a única conexão com o consumidor era o telefone e hoje existe a Internet, até sem fio, conectando as empresas a seus consumidores, permitindo transações instantâneas.

Haja recessão ou não, a conexão vai estar lá.

E se os consumidores estão "agressivamente" online, a influência daquela conexão vai se extender, mesmo durante tempos desafiadores.

A questão não é sobre "e-" , mas sobre o que o consumidor quer.

Nesse discurso fica evidente a questão do uso estratégico de Internet como uma ferramenta para melhor atingir os consumidores.

Para mostrar a importância da Internet para a montadora C, o CEO global da empresa relata que $52 \%$ dos consumidores entram online para procurar por um veículo ('shop") e depois vão aos dealers.

A expectativa na época era de que esse número saltasse para $75 \% \mathrm{em}$ dois anos, representando cerca de 11 milhões de veículos cujo início do processo de venda se deu pela Internet.

O ano de 2001 foi um ano de maturação e construção de iniciativas B2C. Eles pretendiam até o final de 2001 ter o site "eShop" em atividade em 40 países.

Eles realizaram uma campanha de incentivo, na qual ofereciam $0 \%$ de juros de financiamento até o fim de determinado mês sobre todos os modelos da montadora C. 
Desde o início dessa campanha houve um aumento de $29 \%$ no tráfego do "eShop" e $131 \%$ de aumento em "leads" enviados aos dealers. Em adição a isso, a taxa de fechamento desses "leads" para os dealers foi bastante alta: $21 \%$.

Esse foi um exemplo de como o consumidor usa a Internet em apoio a uma campanha de incentivo offline.

Para o CEO do "e-business C" esse foi um exemplo de como esse Web site pode melhorar $\mathrm{o}$ alcance de iniciativas de marketing offline.

$O$ interesse deles na época era trabalhar para redefinir o processo de compra do consumidor.

Em 2001, outra iniciativa que mantinha o interesse era a área de Telemática.

Os planos para 2002 incluíam a difusão do e-business e integração por toda a companhia, criando uma projeção da "experiência do consumidor" com marketing integrado, provendo e-Serviços para os dealers, desenvolver relacionamento de marketing um-a-um e continuar a desenvolver novos modelos de negócio e tecnologias.

Em termos de resultados nos dois anos de existência (1999-2001), o CEO ressalta:

-o site "eShop" nos Estados Unidos influenciou cerca de um milhão de vendas desde seu lançamento em março de 1999

-74.807 dessas vendas foram consideradas vendas "conquistadas" ou vindas de compradores que tinham a intenção de comprar de outra montadora

-Durante o ano de 2000 os esforços de e-commerce geraram US\$ 8 bilhões em vendas para a montadora $C$

-19.000 consumidores/hora visitam os sites da empresa e cerca de um milhão de pessoas inscreveram-se para possuir Telemática em seus carros.

Segundo o CEO ainda, o próximo esforço é integrar o e-business à fábrica.

Integrar e educar a organização sobre aqueles pontos que sejam críticos para operar online; o que se esperava era que não houvesse mais necessidade da existência do grupo "e-business C" para servir de "embaixador" das iniciativas de e-business para a empresa, ou seja, esperava-se que a empresa já tivesse 
absorvido esse conceito e gerasse seus próprios projetos a partir das áreas e não mais com uma estrutura centralizadora de iniciativas.

Foi em novembro de 2001 que os cerca de 300 mil funcionários da montadora C conectaram-se online.

Numa parceria com a AOL foi desenvolvido um novo portal dos funcionários, onde os mesmos tem acesso a um "host" de serviços personalizados de recursos humanos e informações corporativas no trabalho e em casa.

Oito mil funcionários tem acesso a um MBA online, reduzindo o orçamento em treinamento em US\$ 4 milhões por ano.

Em termos de e-business voltado para o fornecedor, ou B2B, a montadora C começou a usar a Internet para atividades de procurement em 1998 realizando algumas atividades de compras através da Exchange horizontal independente FreeMarkets.

O volume representado pelas compras da montadora $C$ era responsável por uma parte substancial das receitas da FreeMarkets em 1998 e 1999. Em novembro de 1999 a montadora C anunciou a criação de sua plataforma de procurement privada chamada nessa tese de ExchangeC (para não revelar o nome verdadeiro), voltada para a compra de componentes de carros novos.

A empresa $C$ também investiu cerca de US $\$ 96$ bilhões no COVISINT, um consórcio entre montadoras ou estrutura compartilhada online entre montadoras e fornecedores para melhor conectar montadoras e fornecedores, fornecendo ferramentas de procurement, leilões, catálogos, projetos colaborativos, dentre outros, ferramentas essas cujo objetivo é redução de estoques e permitir respostas rápidas às mudanças de mercado, além de aumentar a velocidade do desenvolvimento de veículos.

Nos Estados Unidos cerca de 135 mil veículos foram vendidos pelo site de vendas "Leilões inteligentes" da montadora C, o qual permite aos dealers leiloar carros usados uns para os outros, ao invés de usar casas tradicionais de leilões, o que economizou US\$ 500 por veículo. 
Em termos de CRM, a montadora C evoluiu de 40 call centers separados para apenas 3 nos Estados Unidos e globalmente de 19 databases de clientes para 3 deles combinados.

Ainda existem ferramentas baseadas na web sendo utilizadas no seu core business, ou seja, para desenho, engenharia e manufatura, para ajudar na produtividade e velocidade para o mercado.

Nesse sentido, a montadora $C$ também quer seguir o exemplo da Dell Computers, já explicado anteriormente, de configuração do produto online e sua construção em alguns dias.

Segundo estimativas do CEO, quando eles conseguirem implementar o modelo "build-to-order" nessa montadora, terão uma economia de aproximadamente US\$20 bilhões em estoques apenas na América do Norte.

No fim de 2001, segundo o CEO global da empresa, a liderança em ebusiness listava como uma das quatro prioridades para a companhia.

Grandes esforços foram feitos nos últimos anos para usar a tecnologia para melhor comunicação com os consumidores.

O CEO apenas lembra que eles precisam manter a perspectiva: a Internet não é um convite para mudar o modo tradicional como fazem negócios, mas uma oportunidade para melhorar o que eles realmente já fazem-que é construir, colocar no mercado e vender produtos automotivos e serviços no mundo.

É interessante verificar como o discurso mudou da época de meados de 1999 para final de 2001: o "entusiasmo" com o e-business tornou-se uma postura mais realista, avaliando a Internet como ferramenta e oportunidade para melhorar desempenho e obter oportunidades, mas não como algo que muda os negócios.

Isso vai de encontro à análise de Porter (2001) sobre o papel da Internet como ferramenta útil mas não como inovação que reestrutura o modelo de forças competitivas na indústria. 
Apresentação e Discussão dos Resultados dos Estudos de Caso

\subsubsection{DESCRIÇÃO DO CASO DA FILIAL BRASILEIRA DA MONTADORA C: VERIFICAÇÃO DA EXISTÊNCIA DE MODELO DE NEGÓCIO PARA ATIVIDADES DE E-BUSINESS}

A montadora $C$ no Brasil não utilizou o modelo de negócio voltado para ebusiness de forma idêntica à matriz: no Brasil, o uso de modelo de e-business ateve-se basicamente às atividades de relacionamento com os clientes: para essas atividades, a montadora $\mathrm{C}$ utilizou um modelo $\mathrm{B} 2 \mathrm{C}$.

As outras atividades de e-business, como o relacionamento com os fornecedores e o relacionamento dentro da empresa constituíram-se em atividades que não possuíam nenhum tipo de coordenação, não havia um conceito por trás das mesmas e nem estavam envolvidas e coordenadas para poderem ser definidas como integrantes do modelo de negócio voltado para ebusiness.

As atividades de e-business B2B aconteceram individualmente e constam basicamente de duas ferramentas:

-site "conexão com o fonecedor" (nome fictício) e atividades com o COVISINT, basicamente leilões.

São portais corporativos desenvolvidos pela matriz da montadora C.

Há cerca de 3 anos entrou em funcionamento o site "conexão com o fornecedor" na matriz.

É um Site informativo, não interativo, montadora $C$ usa e fornecedores também.

Funcionamento: montadora tem peça a ser aprovada, informa o fornecedor, ele manda de volta, correções, especificações do produto, não serve para fazer leilão.

É acesso restrito mas tem um portal acessível com informações gerais, biblioteca.

Dividido em 7 grandes áreas no site: compras, qualidade, engenharia, finanças, materiais, manufatura e logística.

Hoje comunicação entre montadora C Brasil e fornecedores é confusa, pois cada área tem sua maneira de se comunicar. 
Princípio do site do fornecedor: uniformizar comunicação.

Exemplo: contas a pagar ainda não está implantado.

Exemplo: contratos: acessados pela Internet

Tem várias ferramentas implantadas: contrato, qualidade.

Desenvolvimento de peças novas: pouca coisa-hoje, sistema mainframe gera programação, fornecedor acessa EDI. Idéia: migrar para o "conexão com o fornecedor".

Mais de $90 \%$ dos fornecedores de material produtivo usam esse sistema. 10\%-fornecedores pequenos que não tem Internet

-Foi desenvolvimento da matriz, foi implantada localmente nas diversas regiões com cronogramas separados.

A diretriz de uso do sistema veio por indicação da matriz .

Existem cerca de 20 mil fornecedores no mundo, existem $\mathrm{n}$ regiões no mundo, com n fábricas, escritórios, armazéns de vendas de peças. Uma grande população conversando com outra grande população.

Solução: web para padronizar as conversas.

Necessidade de linguagem comum.

A outra ferramenta usada pelo B2B é o COVISINT, para fazer leilões, porém ainda não utilizaram muito: cerca de três leilões em 2001.

A ferramenta de catálogo está em piloto- Covisint instalou software e montadora C - Brasil paga taxa de uso por mês- pegaram planta pequena e alguns fornecedores - usuário na linha de produção solicita, recebe os pedidos e manda material-interligado com compras, para ver se tem contrato.

Leilões reversos-já está implantado em compras- pouca utilização -só 3 no ano de 2002.

Com o uso de leilões, o prazo do processo de compras reduziu sensivelmente.

Antes marcava reunião com um fornecedor, depois outro no outro dia, exigia uma série de negociações.

Hoje faz um leilão em duas horas.

Problema: custo global alto.

-não mensuraram economia de custo 
-não há vontade em avaliar redução no número de compradores, que seria uma vantagem, não querem assumir o fato de que o comprador vai ter menos tempo necessário.

Como essas são as duas iniciativas isoladas em B2B, o modelo de ebusiness da montadora $\mathrm{C}$ no Brasil tem apenas o componente $\mathrm{B} 2 \mathrm{C}$, como mostra a figura a seguir:

FIGURA 48: MODELO DE E-BUSINESS DA MONTADORA C - BRASIL

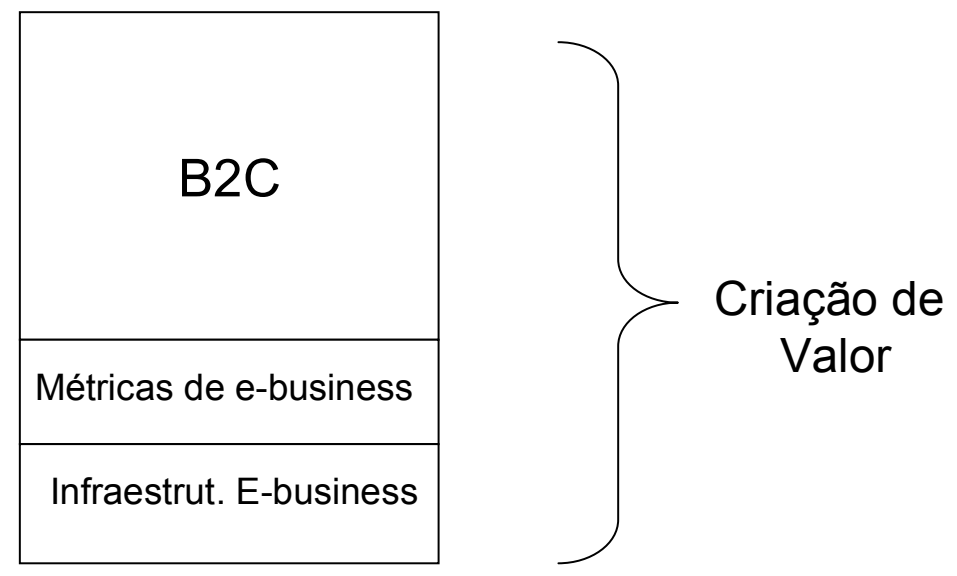

O maior projeto de e-business da montadora C - Brasil foi o de vendas diretas pela Internet.

Esse projeto gerou mudanças na estrutura organizacional da empresa, com contratação de pessoal e criação de novas áreas na empresa.

É interessante notar que foi o único caso onde houve uma evidência muito clara da relação entre estratégia da empresa - no caso estratégia da montadora C Brasil- com a formulação de um modelo de e-business.

A venda de carro pela Internet surgiu de uma estratégia da empresa de aumentar sua fatia de mercado no segmento de veículos populares.

A venda pela Internet faz, claramente, parte de uma estratégia maior, que é a busca por uma posição mais vantajosa nesse segmento de carros. 
Com investimentos superiores a US\$ 800 milhões, o carro popular da montadora C Brasil a ser lançado pela Internet significou a grande aposta da montadora C Brasil nas últimas décadas no mercado brasileiro.

Com ele, a empresa almejava se tornar competitiva no segmento mais atraente do setor: o de carros pequenos e populares.

Com ele, a empresa quer deixar de ter uma má colocação em relação aos seus concorrentes, pretendendo "encostar" em seu principal concorente e líder de mercado nesse segmento.

O êxito comercial desse carro popular também significaria a diferença entre o sucesso e o fracasso de uma estratégia desenhada em 1992. Na ocasião, a montadora C brasileira decidiu que teria produtos para todas as faixas de consumidores, dos populares aos caminhões pesados.

A estratégia tem sido bem-sucedida. Sua participação de mercado subiu de $21 \%$ para $25 \%$

O problema é que essa estratégia não se sustenta sem uma presença significativa na fatia de automóveis populares e pequenos, responsáveis por $70 \%$ das vendas de carros no Brasil. Um outro modelo popular da empresa foi utilizado para cobrir esse buraco. Sem grande sucesso. O veículo foi ultrapassado pelos seus dois concorrentes mais constantes.

Motivo: esse outro modelo popular da montadora $\mathrm{C}$ é o automóvel mais caro de uma categoria na qual o preço é fator determinante.

O problema é que a montadora C Brasil não utiliza a mesma plataforma para mais de um carro, como faz seu maior concorrente, levando esse carro a um preço que não pode ser considerado popular.

Com o pop1 (nome fictício do modelo popular vendido pela Internet pela montadora C Brasil) a empresa esperava entrar nesse segmento-o de carros populares de forma mais competitiva.

O preço ainda seria maior do que o do concorrente para enfrentá-lo, a montadora $\mathrm{C}$ apostou no design e na tecnologia de seu modelo.

Além da tecnologia do carro, a empresa usou um processo de produção barato e não apenas um projeto de carro barato, utilizando para isso o conceito 
da fábrica de consórcio modular e produção flexível, montada para produzir 120 mil veículos por ano.

Num consórcio modular, a montadora $\mathrm{C}$ mantem dezessete fornecedores localizados estrategicamente na mesma planta, estando conectados em tempo real, o que permite, por exemplo, que os fornecedores saibam exatamente o momento em que seus produtos devem entrar na linha de montagem.

Essa pequena introdução antes de entrar em detalhes e apresentar o modelo $B 2 C$ desenvolvido pela montadora $C$ foi feita para ressaltar a conexão dessa iniciativa de e-business com uma estratégia muito clara de aumento de fatia de mercado, utilizando uma tecnologia de produção que possibilita o funcionamento da venda direta.

$\mathrm{Na}$ época do início desse projeto (por volta de 2000) na empresa global da montadora $\mathrm{C}$ existia movimento mundial para dar prioridade para o ebusiness, tendo sido criada a estrutura "e-business C" na matriz.

Portanto a iniciativa de venda direta pela Internet vem de encontro a uma expectativa da matriz: houve uma diretriz clara partindo da matriz: "invistam em projetos de e-business".

Ao mesmo tempo exsitia a estratégia brasileira de querer ser líder no segmento de carros populares.

A partir disso, o diretor de Marketing da montadora C Brasil teve a idéia de confluir as duas diretrizes - a mundial de investimentos em e-business e a brasileira de aumentar fatia de mercado em carros populares-com o fato de existir uma fábrica nova que permitia fabricação num processo mais flexível.

A idéia inicial era usar o mesmo sistema "eShop" da matriz.

Esse sistema faz apenas a configuração do produto, diz preços e onde está o veículo mas não efetua a venda pela Internet.

No Brasil, Mkt foi mais ousado, site não só de configuração e de preço, mas completo de vendas.

Assim, criou-se uma estrutura no Brasil dedicada exclusivamente a desenvolver esse projeto de venda direta pela Internet. 
Segue a apresentação do modelo de venda direta ao consumidor utilizando a Internet elaborado pela área de marketing da montadora C Brasil em conjunto com a área de $\mathrm{TI}$.

\section{DESCRIÇÃO DO MECANISMO DE VENDAS PELA Internet}

O projeto do modelo $\mathrm{B} 2 \mathrm{C}$ de vendas do carro pop1 pela Internet teve 4 pilares:

-faturamento direto ao consumidor

-preço único para todo o Brasil para o produto (hoje não necessariamente é assim)

-entrega rápida

-já que vão ter que desenvolver sistemas para essa estratégia, fazer na Internet (porcausa do volume: automatizada e integrada-decisão pela Internet. Vantagem: conhecimento do cliente)

Sempre com a participação das concessionárias para entrega

Modelo de vendas:

Em termos fiscais: montadora C Brasil emite nota para dealers, onde incide PIS/COFINS.

Dealer para o consumidor-paga os mesmos pis cofins- Bitributação.

Com a venda através da Internet, existe isenção na venda direta ao consumidor.

\section{Vantagens do sistema de venda direta pela Internet para a montadora C Brasil:}

1)Montadora $\mathrm{C}$ economiza $5 \%$ do dealer-valor pode ser dado como desconto e é isso que está acontecendo.

2) Se montadora $C$ fabrica carro para entregar para dealer, implica em necessidade de manter estoque antes de entregar os carros para as concessionárias. 


\section{Estoque $=$ custo}

Quando a produção é voltada para o consumidor final-estoque final é menor - direto ao cliente.

-Se dealer não paga imposto, ele tem comissão menor (não paga pelo estoque e pelo imposto)-preço final para o consumidor é menor.

3) Contato direto com o consumidor final- obtem mais informações, pode utilizar informações para melhorar CRM .

Tipo de informações obtidas: O que é mais processado: cor, modelo, opcionais- faz base de dados e BI (Business intelligence)-futuro.

4)Se vende diretamente, conhece melhor desejo e reduz modelos necessários, reduz opções, facilita produção- reduz em função da procura.

5)se vende via Internet-tem financiamento-faz o cálculo para o banco do grupo da montadora-quando está no dealer está comprometido com outros bancos, atela mais financiamentos para o banco da montadora.

\section{Vantagens para o dealers:}

-Tinham desconfiança-achavam que iam ficar de fora.

Estavam contra e apreensivos.

Depende do modelo adotado: a montadora $C$ adotou um sistema que inclui os dealers, não os exclui.

Consumidor compra veículo, e pode selecionar concessionárias para entrega do veículo- as concessionárias recebem comissão (menor) pela entrega.

Esse tipo de comissão pode ser mais rentável, apesar de ter valor pago menor, pelo fato de não implicar em custos de estocagem para a concessionária, porém ela tem que ter bom sistema de custo para perceber que rentabilidade é maior.

Vantagem para o consumidor: pagar menos e entrega mais rápida (pois a partir das vantagens elencadas para a montadora, implicando em custo menor, pode repassar essa diminuição para o consumidor).

Dividiram o Brasil em 5 regiões-em cada uma delas tem um pátio para venda pela Internet. 
Quando libera carro, já tem que saber se é CDV -armazém para a Internet ou se é dealer.

CDV são centros de distribuição de veículos.

\section{FIGURA 49: ESQUEMA DE DISTRIBUIÇÃO DA MONTADORA C- BRASIL, POR VENDA PELA INTERNET}

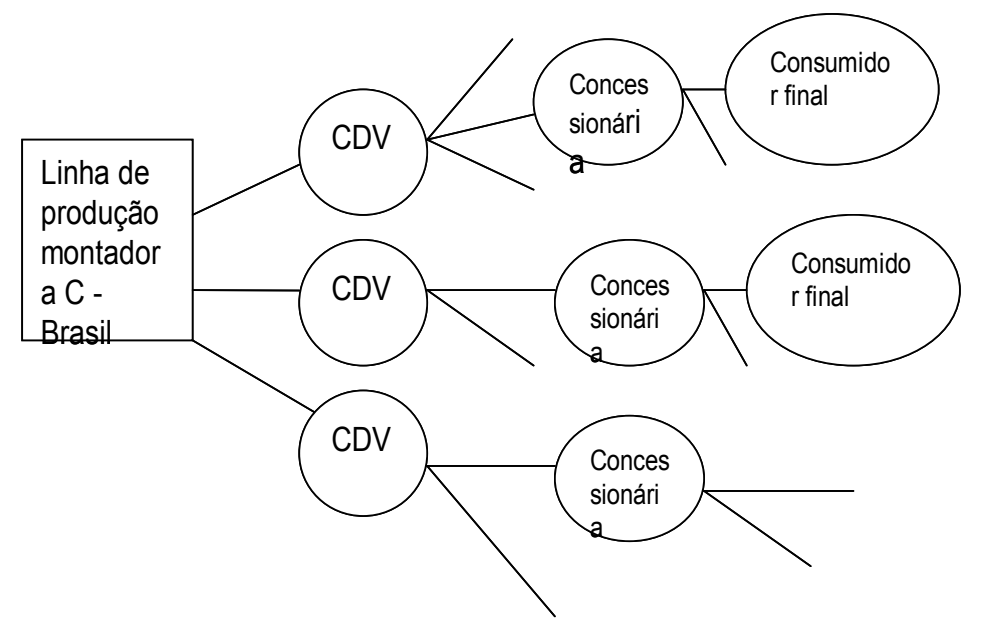

Quando o consumidor acessa a Internet e procura o carro na concessionária, no CDV ou no pátio, já pode reservar o carro que quer pela Internet e já recebe informação sobre o prazo de entrega.

Se não encontrar o carro desejado com as caracteríticas desejadas em nenhuma dessas, vai procurar na linha de produção.

Se não tiver, Internet vai sugerir outro produto, dá opção.

Os CDV's são as únicas estruturas novas da empresa criadas porcausa de necessidade gerada na Internet.

Todas as outras instalações não foram desenvolvidas em função da Internet- fábrica já existia, rede de concessionárias já está montada e assim por diante.

Quando se pode usar a estrutura existente, opta-se por ela.

Processo de vendedor da concessionária vendendo pela Internet: 
-consumidor faz escolhas pela Internet, guarda a configuração e vai na concessionária

-consumidor sem Internet: vai até a concessionária e navega pelo site de vendas para achar o carro. Vantagem para a concessionária: conseguir fazer venda sem o carro no pátio da concessionária.

Existe idéia de aumentar o número de produtos oferecidos diretamente. Cada inclusão de novo produto significa em mudanças no site.

Além disso, existem problemas de logística que tem que ser bem analisados antes de começar a vender novos modelos: porisso este modelo de e-business está intrisicamente relacionado com a estratégia da empresa: pois mexe direto com o produto "core" da empresa.

Existe previsão de lançamento de novos modelos a serem vendidos pela Internet ainda em 2002.

Prova: desconfiança do dealer não existe mais, acham que há benefícios para todas as partes.

É raro as outras áreas corporativas terem iniciativas de e-business .

As áreas da empresa sabem que existe essa área de e-business e existe um apoio das áreas para que os projetos funcionem.

Hoje $30 \%$ das vendas globais da montadora $C$ no Brasil são pela Internet (mas entrevistado não quis revelar sobre avaliação se vender pela Internet é mais caro ou não do que do jeito tradicional)

\section{Presença da montadora C - Brasil na Internet}

Montadora C no Brasil utiliza o conceito de "customer experience" que contempla todo ciclo da experiência do cliente com o produto (foi explicado no início desse capítulo):

"awareness>research>shop>purchase>ownership>relationship"

São as etapas do ciclo de vendas, para cada etapa dop ciclo, desenvolve uma funcionalidade no site (tanto no de vendas como no institucional).

Objetivos: criar para cada fase que o cliente passa, ter uma alternativa para ele responder a sua necessidade. 
Objetivo: atender os clientes em todas as fases.

Fonte de receita: -vendas

-exposição do produto

Outra atividade de e-business que envolve relacionamento com o cliente, portanto estaria dentro do modelo $\mathrm{B} 2 \mathrm{C}$, foi o desenvolvimento de um portal para quem já é cliente: "meu carro".

É um site de fidelização de pós-venda: foi desenvolvido pela área de Vendas que o desenvolveu com TI-tem coisas muito específicas de pós-vendas.

Não está integrado ao modelo B2C, pois não chegou a desenvolver um conceito de modelo de e-business, nem usou os conceitos desenvolvidos pelo modelo de venda direta ao consumidor.

-Supervisor da área de pós-vendas acumula as atividades rotineiras mais criação, manutenção e alimentação do site.

O gerente de e-business entrevistado vê como problema não haver envolvimento com área de e-business, pois pode haver duplicação de atividades.

Ocorreu por diferenças de prioridades das áreas: e-business e pósvendas.

Conflito fez surgir iniciativa em área separada de e-business.

O gerente de e-business comenta: "é fácil criar site, mas se não criar estrutura, por exemplo, "fale conosco" , como vão atender às solicitações?"

O que o gerente quis comentar é que não basta por o site para funcionar, tem que haver uma estrutura de apoio por trás que responda às solicitações feitas.

Fatores críticos de sucesso: compatibilidade entre as core competencies da empresa e adoção das atividades de e-business e Nível do comprometimento da alta administração em relação à implantação de e-business.

Esse empreendimento- as vendas diretas pela Internet - superaram as expectativas quanto a resultados: Com um desconto de $5,5 \%$ nas vendas do modelo de carro popular pela Internet, a montadora C - Brasil contabilizou 2.050 unidades vendidas - $50 \%$ do total - nos primeiros 14 dias de operação na Web. 
O sucesso da iniciativa teve repercussão mundial, é usado pelo CEO da matriz como exemplo de empreendimento de e-business bem sucedido.

É reconhecido mundialmente como sucesso de iniciativa em e-business.

O sucesso dessa iniciativa provocou uma "corrida" dos concorrentes para realizarem suas vendas pela Internet.

As vendas desse carro pela Internet equivalem a quase metade da receita gerada pelo comércio B2C em 2001 no Brasil.

\subsubsection{DESCRIÇÃO DOS CASOS NO QUE TANGE ÀS ESTRUTURAS ORGANIZACIONAIS PARA OPERACIONALIZAR AS ATIVIDADES DE E-BUSINESS DA EMPRESA}

Seguem-se as apresentações dos resultados encontrados quanto à identificação das estruturas organizacionais encontradas nas montadoras para operacionalizar o e-business.

Todas as filiais das montadoras tem uma estrutura organizacional mista, que mistura divisões regionais (América latina, Ásia, América do Norte, Europa, etc), uma divisão por produtos, além de terem as áreas funcinais (Marketing global, Finanças global, etc), além de divisão por marcas.

Todas essas filiais se reportam tanto para o vice-presidente regional quanto para as áreas funcionais respectivas (por exemplo, o diretor de marketing no Brasil se reporta ao presidente da empresa no Brasil, ao CEO da empresa na América Latina e ao diretor global de marketing do grupo).

Assim, mudanças organizacionais que acontecem na matriz se refletem nas áreas no Brasil.

Como houve várias mudanças nas estruturas organizacionais devido à implantação de e-business, optou-se por mostrar também nesse item os resultados encontrados sobre implantação de estruturas organizacionais nas matrizes e depois mostrar as alterações que ocorreram nas filiais, em itens separados.

$\mathrm{Na}$ descrição dos casos, foi ressaltada a estrutura organizacional para a área de TI da empresa, uma vez que a literatura mostrou que uma infraestrutura 
de TI adequada é uma condição necessária ao bom desempenho das atividades de e-business na empresa.

\subsubsection{ESTRUTURA ORGANIZACIONAL NA MONTADORA A: MATRIZ}

Em 1999, a empresa começou a se questionar se deveria seguir a indicação feita por consultores em geral sobre montar uma unidade de negócios separada da empresa cujo objetivo seria reformar o sistema de negócios para adaptá-lo à realidade do e-business.

Diante dos desafios colocados pelo crescimento do e-business (abertura de novas perspectivas de envolvimento com fornecedores numa rede, visitas de milhões de clientes aos sites da empresa com seu "showroom" e desejo de satisfação das necessidades desses clientes, a comunicação móvel ganhou importância nos últimos anos e como consequencia existe uma demanda por serviços integrados de telecomunicações aos veículos, número grande de funcionários - cerca de 300 mil ao redor do mundo, a possibilidade de cooperação em rede parecia razoável), a empresa colocou-se a seguinte questão:

Essas mudanças no ambiente de Internet realmente implicavam em mudanças nas regras básicas do negócio? Vendas e marketing, compras e logística teriam que mudar completamente?

A partir dessas questões, em 2000 a empresa empreendeu uma análise em cooperação com todas suas unidades de negócios e departamentos corporativos para examinar em que medida as novas condições estruturais requeriam um ajuste nas estratégias existentes.

A empresa concluiu que para ela, e-Business não é uma função separada da empresa, muito menos um negócio em si próprio.

Isso porque o valor adicionado pelo e-business reside na rede que perpassa toda cadeia de valor da empresa.

A partir da decisão de não criar uma empresa separada da montadora $A$ voltada para as iniciativas de Internet, essa empresa decidiu reunir as iniciativas de e-business numa única estrutura, como uma unidade distinta dentro da 
empresa (a estrutura de e-business ganhou o nome de "Iniciativa net", como já foi dito), com sua própria estrutura de governança.

Isso ocorreu em outubro de 2000.

A partir de outubro de 2000 foi criada a estrutura "Iniciativa net" (nome fictício) que procurou sistematizar as iniciativas de e-business da empresa, unificando uma variedade de esforços em uma única organização, de modo a alavancar os investimentos em tecnologias de Internet e operando conforme 0 modelo de negócio explicado no item 5.2.1.1.

Essa estrutura tinha a forma de uma holding que gerenciava os investimentos em e-business do grupo, sendo uma iniciativa "group-wide" cujos membros incluem representantes de todas as divisões da empresa e do Desenvolvimento Corporativo.

O capital inicial aportado para essa holding foi de US\$ 500 milhões.

A implementação das iniciativas de e-business são discutidas e postas em ação através de encontros mensais do e-Council (conselho formado para ebusiness) da empresa mais os representantes da "iniciativa net" .

Existem vários representantes da estrutura ( de todas as áreas da empresa onde haja algum projeto de e-business), na matriz e filiais mais o board corporativo, que são os responsáveis pelas decisões finais.

Sua estrutura organizacional tem a forma abaixo: 


\section{FIGURA 50: ESTRUTURA ORGANIZACIONAL ESQUEMÁTICA DE E- BUSINESS DA MONTADORA A}

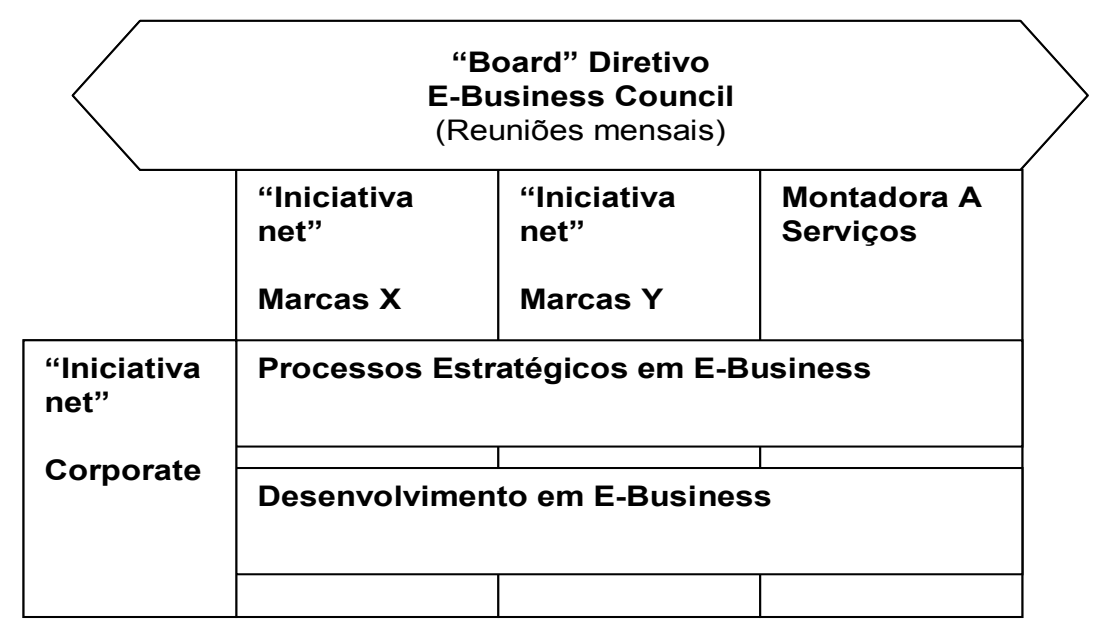

A figura mostra que se trata de uma estrutura matricial, com o desenvolvimento em e-business e a elaboração de processos estratégicos envolvendo pessoas da área corporativa da empresa, bem como das diversas marcas e da área de serviços da empresa.

As decisões são tomadas pelo board diretivo mais os representantes das diversas áreas envolvidas em atividades de e-business.

Conclui-se assim, que as decisões sobre investimentos em e-business acontecem de forma centralizada, ainda que contem com representantes de todas as áreas interessadas.

Essa estrutura não existe sem o apoio da empresa "real", pois existem relações com várias áreas dentro da empresa mãe, seja no uso das funcionalidades de TI da empresa "real", seja em outras formas de suporte.

Essa colaboração inclui times multi funcionais, relacionamentos de subordinação informais para colaboração (ou estruturas matriciais) e várias formas de compartilhamento de recursos.

Uma vez que existe essa cooperação tão próxima, qual o motivo de estabelecer essa unidade distinta focada em e-business?, questão proposta no artigo de Leibs (2000) sobre as modificações que estão sendo feitas nas empresas na área de TI para alavancar suas iniciativas de e-business. 
Segundo um vice-presidente para a plataforma de e-commerce da matriz da empresa $A$, essa unidade distinta "pode obter boas idéias de qualquer lugar dentro da companhia, priorizá-las e fazê-las acontecer".

Ou seja, é uma forma de alavancar as iniciativas de e-business, por foco nessas iniciativas.

Se não houver uma unidade de negócios dedicada a e-business resultará em duplicação de esforços, ou seja, o que uma área está desenvolvendo, pode estar sendo desenvolvendo em outra sem que se estabeleça comunicação entre elas, dadas as dimensões gigantescas da firma, que é mundial.

No começo de 2002, essa estrutura foi parcialmente desmontada na matriz, segundo informações do representante de e-business no Brasil, sendo que cada componente do modelo foi absorvido por uma determinada área:

-Conexão veículo foi incorporada à área de desenvolvimento/engenharia da empresa

-Conexão negócios foi incorporada à área de supply e procurement

-Conexão Cliente foi para a área de vendas e MKT

-Conexão força de trabalho- foi para área de Comunicação da empresa.

Segundo o entrevistado, o desmonte da estrutura foi devido ao fato dela já ter cumprido seu papel: o de alavancar os negócios de e-business.

Segundo ele, essa estrutura foi criada para centralizar as decisões de ebusiness e para mobilizar as diversas áreas da empresa quanto à necessidade de desenvolver projetos de e-business.

Com o sucesso das iniciativas alcançado, a estrutura está sendo desmontada aos poucos e incorporadas às áreas existentes que tenham afinidades com os projetos de e-business a elas associados.

A ligação entre estratégia e modelo de e-business apontada no modelo de pesquisa dessa tese encontra-se contemplado: o surgimento do e-business na montadora $\mathrm{A}$ vem atrelado a objetivos estratégicos relacionados a diminuição de custos na coordenação da cadeia de suprimentos, maior rapidez na produção 
dos veículos (redução do ciclo de tempo), melhor atendimento às necessidades do cliente, através de informações obtidas através da rede, inovações em veículos através do Telematics.

A importância estratégica do empreendimento é evidenciada pela sua organização, que foi concebida como uma holding do grupo, onde um grupo de altos executivos dá as diretrizes e tomas as decisões relativas a investimentos em e-business através de reuniões mensais, além de existir uma estrutura "corporate", que cuida dos assuntos estratégicos em e-business, como centralizar as idéias trazidas, priorizá-las e fazer que aconteçam.

Por outro lado, essa estrututra encontra-se em fase de desmantelamento desde o início de 2002, com a incorporação das atividades de e-business pelas áreas relacionadas, o que indica uma tendência que já fora prevista pela empresa, segundo a qual a "Iniciativa net" foi uma estrutura de alavancagem dos negócios de e-business, que serviu para sensibilizar as áreas já instituídas da empresa quanto à importância de gerar projetos em e-business.

\section{Área de TI da montadora A matriz e o e-business}

Como foi constatado na literatura, é relevante a importância da área de $\mathrm{TI}$ para o sucesso das iniciativas de e-business na empresa, uma vez que a infraestrututra de $\mathrm{TI}$ deve prover as ferramentas necessárias para seu bom funcionamento.

Existe uma grande quantidade de sistemas de processos e funções, adicionada ao fato de que toda espécie de informação pode fluir 'de' e 'para' as pessoas e departamentos, isso levou à criação da "Iniciativa net" que funciona como um "tanque de pensamentos" , coordenando as atividades de e-business de todas as unidades de operação.

O $\mathrm{ClO}$ da empresa matriz ressalta que essa estrutura trabalha muito próxima com e depende das operações de TI da empresa A, ou seja, o grupo de $\mathrm{TI}$ não pode ser separado. Existe um CIO de TI da empresa A que supervisiona as operações de TI requeridas pela "Iniciativa net". 
Houve muitas mudanças no departamento de TI da empresa, onde muitas funções foram centralizadas e foram criados centros de competência para explorar relações com o consumidor, inclusive havia um grupo dedicado a estudar as "best-practices" em E-business; porém o ClO da matriz da montadora A achou razoável a criação de um grupo dedicado a e-business, uma vez que muitas iniciativas em e-business atravessam várias partes da organização e ajuda haver um grupo que tenha essa visão geral.

\subsubsection{ESTRUTURA ORGANIZACIONAL NA MONTADORA A: BRASIL}

Até final de 2000 não havia uma área dedicada à e-business na empresa, as iniciativas estavam espalhadas pelas áreas.

Nesse período quem cuidava do site institucional da empresa era a área de marketing, que contratou empresa externa para desenvolvimento de site.

2001: foi criada área de e-business- que é uma "sucursal" da estrutura "Iniciativa net" da matriz, é um braço da estrutura da matriz.

A estrutura "Iniciativa net" veio a ser viabilizada para a América Latina por recomendação da matriz: em 2001 houve a indicação da filial latino americana, seguindo a estratégia da matriz de ter presença na Internet para melhor conectar-se ao seu consumidor, desenvolver iniciativas de e-business.

Para tanto, a matriz indicou um gerente da empresa que trabalhava na matriz com e-business para consolidar, desenvolver e alavancar as iniciativas de Internet na América Latina.

Esse gerente veio, com nível hierárquico ligado à presidência da empresa no Brasil e começou a desenvolver uma estrutura que pudesse fomentar iniciativas de e-business aqui.

A estrutura atual, que não se modificou desde que foi implantada em 2001 consta do gerente da matriz, um consultor da área de negócios, um trainee e uma secretária. 
Essa área tem status de área estratégica na empresa e tem nível de diretoria, cuidando das iniciativas de e-business não só do Brasil, mas de toda América Latina.

Foi adotada uma estrutura matricial: em cada uma das diretorias de área (manufatura, marketing, compras, etc), tem uma pessoa que representa o ebusiness e faz a ponte com a área estratégica de e-business.

A estrutura proposta para operacionalizar o modelo de negócio voltado para e-business na América Latina foi a seguinte:

FIGURA 51: ESTRUTURA ORGANIZACIONAL PARA IMPLANTAR MODELO DE NEGÓCIO PARA E-BUSINESS NA MONTADORA A DA AL

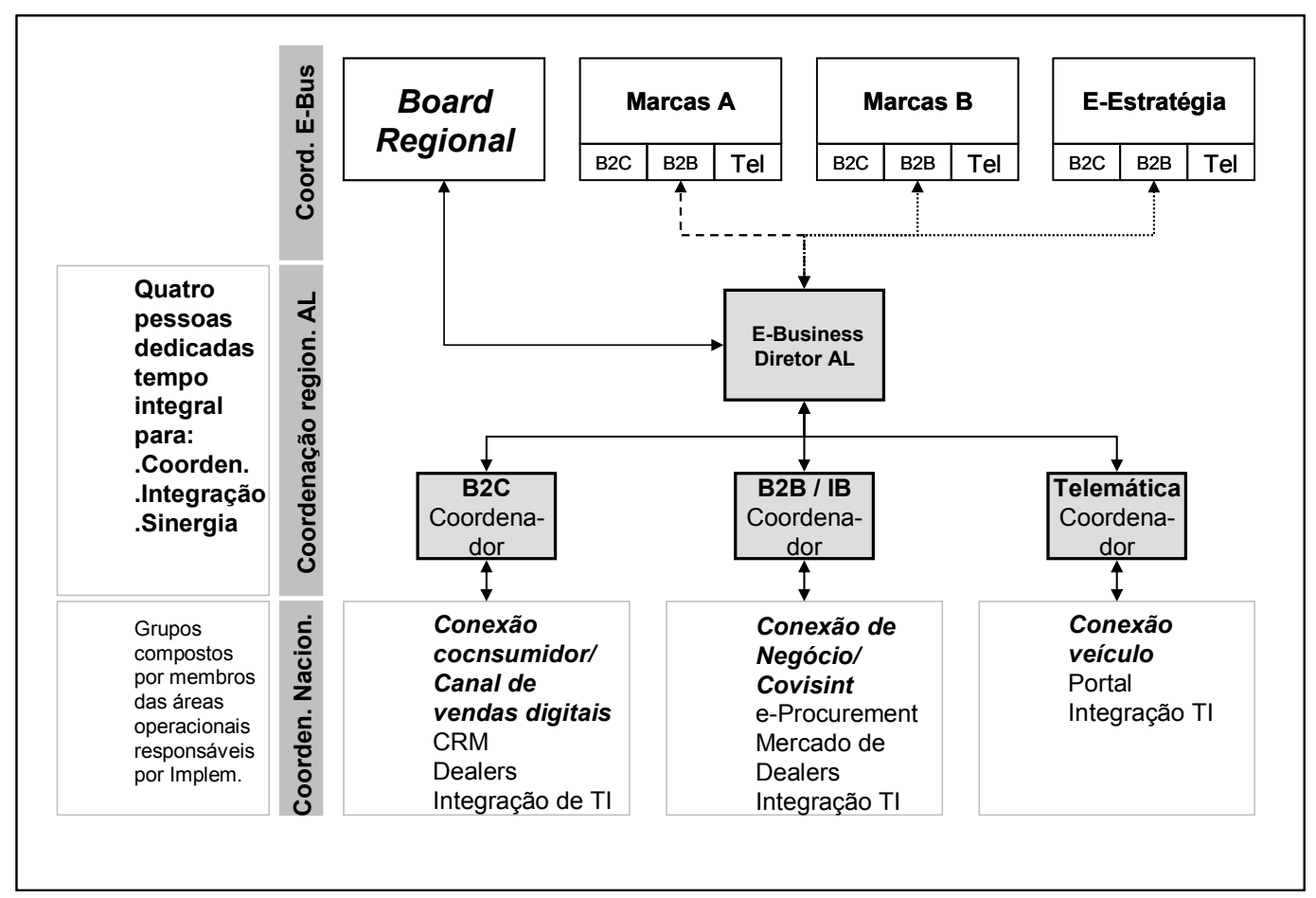

Para cada marca da montadora, existe uma área de B2B, B2C e B2V (business to vehicle ou Telemática) que responde ao diretor senior de ebusiness para a América Latina, que foi a pessoa vinda da matriz para coordenar os esforços de e-business. Essa pessoa está fisicamente instalada no Brasil e viaja pelos outros países para coordenar as iniciativas.

Esse diretor coordena as 3 áreas de e-business propostas no modelo.

Funções do diretor de e-business: 
-trazer a metodologia desenvolvida pela matriz para a implantação de projetos de e-business

-coordenar necessidades e desenvolver projetos

-levar necessidades para matriz (sinergia das idéias)

-negociar recursos com a matriz

Abaixo do diretor, deveria haver um coordenador para cada área, porém o que acontece na realidade é a alocação de uma só pessoa como coordenador de todas as áreas, o consultor de negócios já citado anteriormente.

A figura acima serve apenas para ilustrar níveis hierárquicos e funções de cada área, uma vez que na verdade existe apenas uma pessoa como coordenador abaixo do diretor de e-business.

As pessoas das outras áreas operacionais da empresa formam um grupo de e-business junto com o diretor de e-business, o coordenador, a secretária e o estagiário.

Não existe uma estrutura de comando da área de e-business sobre as outras áreas da empresa: o diretor de e-business apenas sugere projetos e ações de e-business, ele não tem autoridade sobre o grupo multidisciplinar de ebusiness quanto ao aspecto de tomada de decisão, que cabe ao diretor de cada área.

O organograma da empresa montadora A no Brasil fica assim:

Figura 52: Organograma da montadora A no Brasil incluindo área de ebusiness

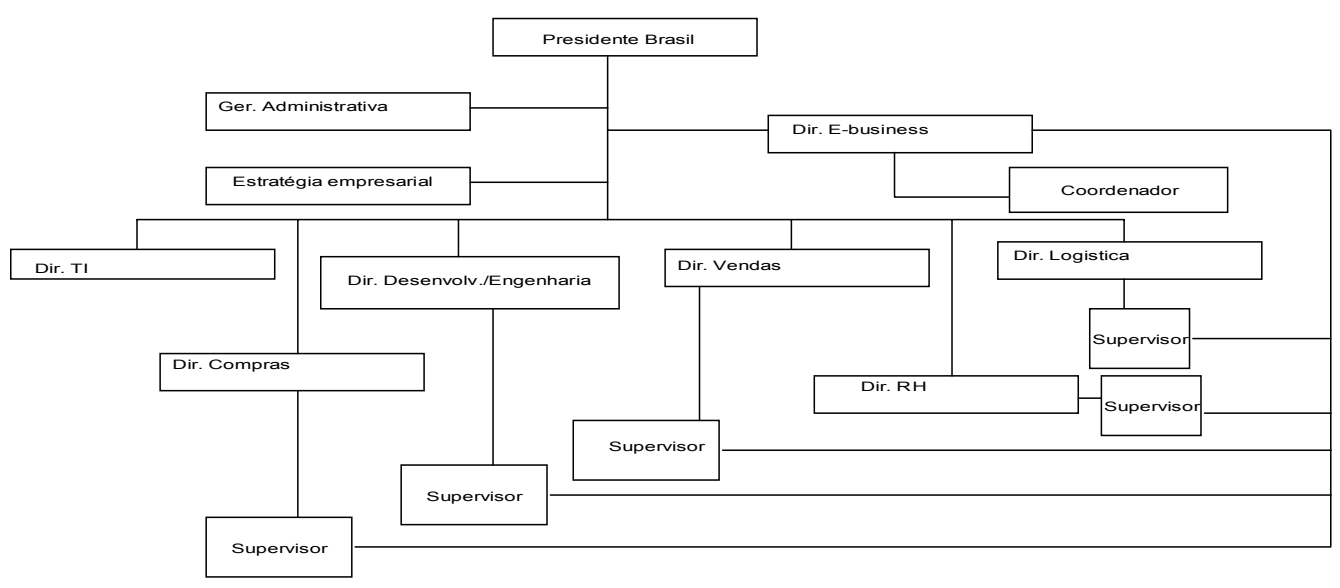


As pessoas nos retângulos indicando "supervisor" tem atividades compartilhadas: fazem atividades da sua área operacional e são responsáveis pela interlocução com a área de e-business.

Como funciona a área: a partir do gerente vindo da matriz, que no Brasil tem status de diretor, pois funciona como área estratégica ligada diretamente à presidência da empresa no Brasil, a área de e-business conecta-se às diversas outras áreas corporativas da empresa através de representantes da área de ebusiness nessas áreas que servem como interlocutores entre o e-business e as atividades da área.

O diretor de e-business faz propostas de como usar a Internet, o que é CRM, dentre outros projetos de Internet; é feita uma proposta de projeto de Internet e mostrada para o gerente da área. Se esse gerente de área acreditar que o projeto trará retornos para a área, ele vai tentar viabilizar o projeto.

Grande dificuldade: os projetos são oferecidos sem uma demanda e o coordenador de e-business precisa insistir e mostrar a viabilidade do projeto para tentar convencer os executivos das áreas a implantarem projetos.

A área de e-business não tem autoridade para tomada de decisão.

A alta cúpula no Brasil normalmente não apóia essas iniciativas, por acharem que não existe um retorno compensador. As pessoas de níveis hierárquicos mais baixos se envolvem mais com o assunto.

Na matriz: e-business-nível de diretoria com staff abaixo.

No Brasil, o gerente da matriz além de se reportar ao presidente da filial brasileira, também se reporta à estrutura "Iniciativa net" da matriz.

Quanto à seleção das pessoas envolvidas em e-business: o diretor de ebusinesss vindo da matriz escolheu-as segundo o critério de já haver envolvimento da pessoa da área com alguma atividade envolvendo e-business e pelo perfil de negócios da pessoa, no sentido de ter um bom conhecimento dos processos de negócio da área.

Desse modo, o coordenador foi escolhido pois já demonstrara interesse pela área e havia participado na área de Marketing de algumas iniciativas de ebusiness, ao desenvolver o site institucional da empresa versão regional. 
Nas demais diretorias -Logística, Compras, Marketing, e Telemáticaexiste um representante do e-business: foram selecionados pelo diretor de ebusiness vindo da matriz, a partir de projetos nos quais estavam envolvidos; o diretor percebeu perfis que os capacitam a atuar como representantes.

Cada representante tem suas atividades do departamento a que pertence e também é responsável pelas atividades de e-business, ou seja, nenhum membro do grupo de e-business tem dedicação exclusiva às atividades de ebusiness.

Exemplos de algumas atividades de e-business realizadas pelos diversos membros do grupo de e-business:

-Vendas: responsável pelo site e pelo database.

-Compras: organização online, bidding, leilões, desenvolveu catálogos e relatórios.

Antes, na área de mkt, e-business era uma iniciativa pessoal do atual coordenador de e-business, que via futuro nas atividades de e-business (em B2C) e teve um gerente de mkt que o apoiou. Quando esse gerente saiu, as iniciativas esmoreceram.

A estrutura inicial da "Iniciativa net" no Brasil foi prevista para dois anos.

Funções do diretor da área de e-business vindo da matriz:

-primeiro: alocar pessoas nas áreas. Perfil necessário para participar do grupo de e-busness: conhecimento das ferramentas de Internet, conhecimento dos processos de cada área-era uma pessoa que já coordenava as atividades de TI dentro da área.

-Segundo- Trabalhar com a alta direção (gerente para cima).

Verificar junto a esses executivos:

-“O que podemos fazer?"

-A idéia: aplicar todas as ferramentas da matriz que fossem pertinentes, para isso fazendo trabalho de disseminação de informações sobre e-businessworkshops, reuniões, discussões.

-Levantar quais as necessidades para encontrar a solução correta

-Escolher entre a solução local (realizada pela empresa parceira de $\mathrm{TI}$ local) ou verificar quando é melhor adotar uma solução de mercado, com 
aplicativos disponíveis, sem ser necessária a personalização: decisão da área + $\mathrm{TI}+$ e-business.

Como a área de e-business tem função estratégica, as áreas é que tem que tomar as decisões.

Com e-business, não tem autoridade para decisão e sim para sugestões.

Em junho de 2002 foi feito evento de meio dia voltado aos níveis hierárquicos superiores: de gerentes para cima para explicar o que significa ebusiness.

E cada diretor de área apresentou os projetos de e-business.

-repercussão do evento: convidadas duzentas pessoas e compareceram 300.

-depois várias idéias surgiram, as pessoas começaram a pensar em projetos.

Problema: os processos internos tem que estar bem resolvidos, para depois pensar em e-business.

Ex: vendas de carro pela Internet, se não tem o carro que se preste a esse tipo de venda, não dá para pensar nesse produto-venda direta.

A área de compras é a única que tem uma pessoa alocada com uma função formalmente definida no organograma relacionada a e-business, conforme figura a seguir: 


\section{FIGURA 53: ÁREA DEDICADA A E-BUSINESS NA ÁREA DE COMPRAS DA MONTADORA A BRASIL}

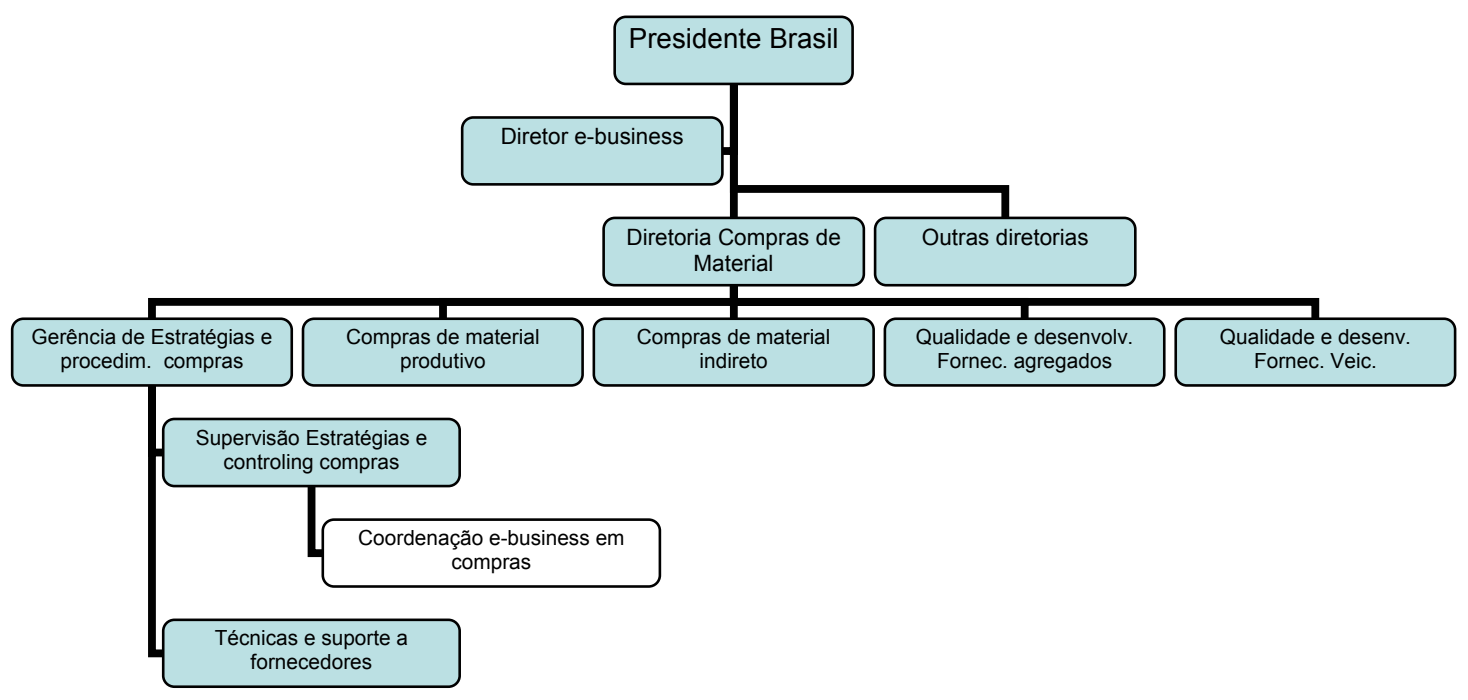

A área em destaque em branco possui uma pessoa que era totalmente dedicada a e-business desde meados de 2001 até início e 2002, quando passou a exercer outras atividades relacionadas a compras também.

A estratégia do diretor de e-business foi primeiro realizar os projetos que dessem resultados fáceis de serem visualizados, para depois mostrar para a diretoria.

Numa primeira fase da definição de e-business de cada área as seguintes questões foram colocadas:

-Quais expectativas?

-Quais necessidades?

-lista de ferramentas-verificação nas áreas do que se pode utilizar.

O grande papel da área de e-business no Brasil: uma grande troca de informações, estabelecer ambiente para pensar.

-Vendas: mais difícil de convencer a área, mais pessoas para convencer.

Diferentes "business units", várias marcas e produtos para coordenar. 
-Grande estrela do e-business: leilões reversos realizados pela área de compras.

Economia de $50 \%$-números fortes para discutir

-função do e-business-também é sugerir projetos, trocar informações.

Área de marketing: utiliza e-business para fazer comunicação com concessionárias.

Se existe um projeto interdepartamental, o grupo de e-business dá suporte para coordenar com situação de neutro, mas sempre com o aspecto de que a diretoria tem que ter responsabilidade. Não pode ser a responsabilidade do e-business, tem que ser da área para sair o projeto.

Responsabilidade da área de e-business: no início: "puxar" o projeto para que ele aconteça

-No fim do projeto: trocar informações.

Em 2003: a área de e-business como está constituída hoje vai mudar em princípio.

Espera-se que os projetos estejam em fase de realização , implementação.

Os projetos devem ficar dentro das áreas.

\section{Estrutura Organizacional da área de TI}

Atividades de $\mathrm{Tl}$ eram exercidas por uma empresa do grupo pertencente $100 \%$ à montadora.

Em 1998 houve a compra dessa empresa que era 100\% nacional pela empresa de TI mundial, pertencente ao grupo da montadora . Ainda assim, TI era $100 \%$ pertencente à montadora $A$, com $50 \%$ nacional e $50 \%$ de controle acionários da empresa de TI mundial pertencente à montadora $\mathrm{A}$.

Em 2000 um grupo de telefonia comprou a empresa global de TI do grupo da montadora A.

A montadora A criou uma empresa própria de $\mathrm{TI}, 100 \%$ pertencente à montadora A Brasil.

Hoje o organograma da área de TI da montadora A no Brasil é: 
FIGURA 54: ORGANOGRAMA DA ÁREA DE TI DA MONTADORA A BRASIL

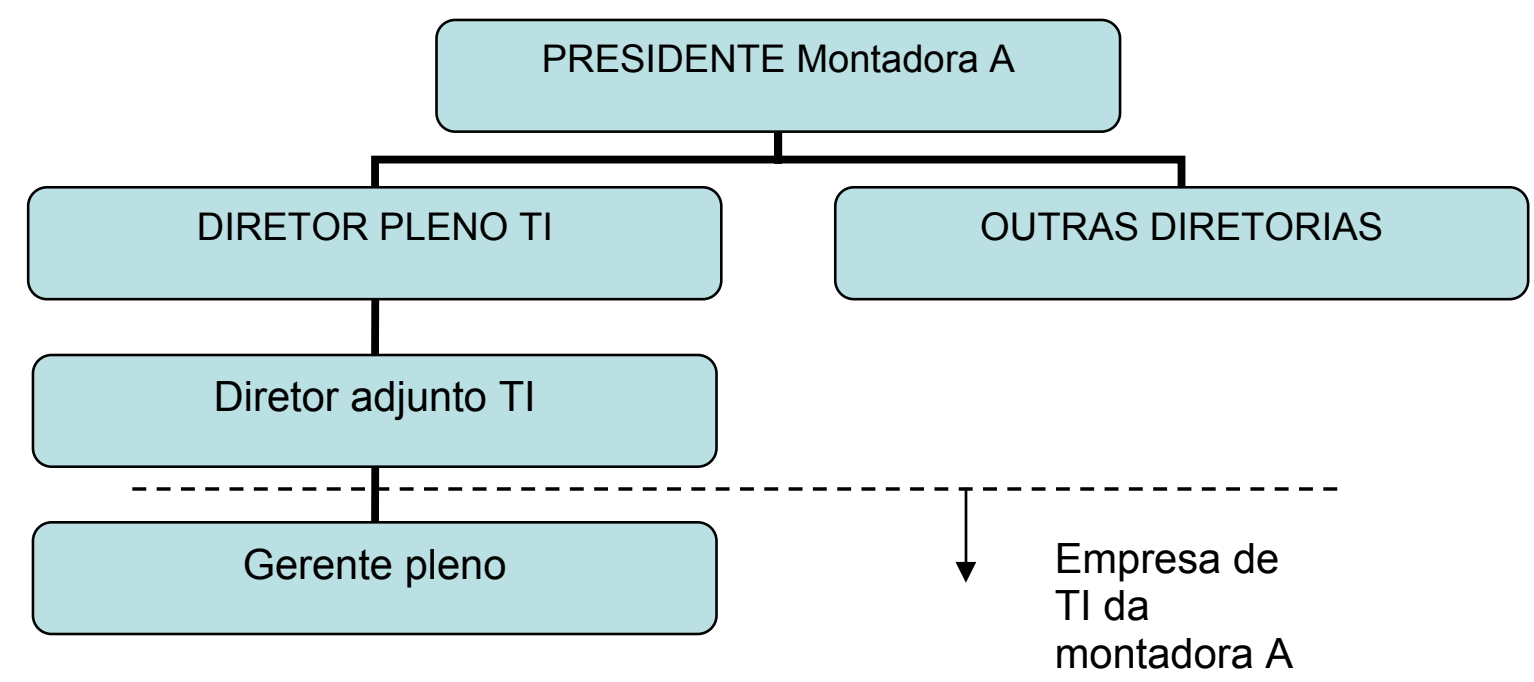

-Os reflexos da estrutura "Iniciativa net" na matriz da montadora começaram a aparecer no Brasil em 2000: padronização de páginas institucionais na Internet.

Já eram parceiros IBM.

A infraestrutura de banco de dados já era de aplicações em DB2.

A partir de negociações com a área de $\mathrm{mkt}$, $\mathrm{Tl}$ era responsável pela manutenção e suporte das páginas da empresa na Internet.

Foi uma substituição do papel por informações via Internet.

-Em 2001: e-procurement-área de compras.

Como as aplicações foram construídas aqui, já tinha o conceito de middleware, que dá independência dos programas para o banco de dados.

Posso transferir aplicações do mainframe para a Internet- pois são aplicações " webnabled" -uma tela que vê no mainframe, pode ser vista na Internet. 
O fato do mainframe ter sido concebido assim, mostrou resultado a longo prazo: aplicações modulares, conceito de microcódigos (bibliotecas)- faz processos para aplicação.

Tiveram que contratar pessoas exclusivamente para o "front-end", pois a parte de back-office/banco de dados são os mesmos.

Problema: segurança.

Modelo proposto de segurança está em fase de aprovação.

Não habilitam nada na extranet pelo fato do modelo de segurança não ter sido aprovado na Alemanha.

Produtos:

-extranet de vendas e compras-estão sendo desenvolvidas.

Solução por projetos: mesmas coisas pedidas por áreas diferentes

-cada departamento tem um representante e aí se discute tudo que se vai fazer: qual a ordem, qual a prioridade, para diretoria de vendas o que é mais interessante.

Todas as extranets foram unificadas.

Para a implantação de projetos de Tl existe uma metodologia de projetos:

-metodologia de desenvolvimento de sistemas-é um manual

-metodologia de gerenciamento de projetos

Foi desenvolvido pela área de TI da montadora A.

Área de TI tem 260 aplicações migrando para a Internet.

Montadora A: tem sistema no ponto da concessionária-já está tudo automatizado (por EDI, não usa Internet)

-Hoje as concessionárias estão totalmente integradas à empresa, fazem parte da mesma rede.

Hoje todas as soluções necessárias em e-b estão com a empresa de TI que prestava serviços para a montadora C até 2000 , a partir de 2002 começou processo dessa empresa terceirizada passar as atividades para a área de $\mathrm{TI}$ da montadora A.

Cada projeto tem seu gerente- definidas as responsabilidades, usam um aplicativo para gestão de projetos. O projeto tem gerente de área corporativa e tem gerente de TI para aquele projeto. 
Recurso alocado para o projeto é que vai determinar a prioridade- tem um budget.

Fase atual: fase de integração das extranets:

-padrão de layout

-segurança

-controle

Concluindo, a área de TI da montadora A não sofreu nenhuma mudança em sua estrutura para apoiar as atividades de e-business: continuou funcionando como sempre. Já existia a metodologia de trabalhar por projetos, antes do e-business, com a formação do time composta por pessoas de $\mathrm{Tl}$ e por pessoas da área de negócios.

Portanto, a adoção de e-business não alterou a forma organizacional de TI.

A priorização dos projetos é feita pelas diretorias das áreas corporativas interessadas e respeitam a condição de "budget" : os projetos que aportam mais dinheiro, são prioritários.

\subsubsection{ESTRUTURA ORGANIZACIONAL NA MONTADORA B: MATRIZ}

A criação de um modelo de e-business para a empresa partiu de seu nível hierárquico mais superior: um CEO que via a Internet como algo essencial para criar vantagem competitiva para seus negócios.

Para poder alavancar as iniciativas de e-business, foi criada uma unidade de negócio ou divisão específica para e-business, chamada nessa pesquisa de "Conexão com o Consumidor", que tem um presidente próprio, que também é um vice-presidente dentro da corporação como um todo.

Ou seja, a estrutura organizacional de e-business encontra-se totalmente integrada à empresa.

Segundo o CEO global da empresa, os objetivos do e-business na empresa eram a "computadorização" e conexão em rede de cada aspecto das 
operações globais da montadora $B$, desde atividade internas e comunicações até o relacionamento com o fornecedor; isso significava reconfigurar a empresa para entregar produtos mais rapidamente e customizados para seus clientes.

Com esses objetivos, o executivo principal da época comprometeu e envolveu toda a empresa num esforço de tornar a sua a primeira empresa automotiva com e-Business na Internet.

A visão e estratégia da montadora B focam quase exclusivamente em construção de relacionamentos através de ativos intangíveis, como global branding, satisfação do cliente e lealdade, uma idéia de "valor total" para o cliente.

As táticas da montadora B são desenhadas para manter as marcas, produtos e serviços da montadora na cabeça do consumidor, desde o processo inicial de compra, quando o cliente está procurando o produto, até os passos finais de posse do produto.

Deste modo, a estrutura organizacional da empresa é estabelecida de modo a manter esse foco no cliente.

Em julho de 1999 foi estabelecida uma nova unidade de negócios na montadora B, com o líder dessa unidade de negócios com status de vicepresidente.

A indicação desse executivo foi feita pelo CEO global da empresa.

Foi designado para a condução da unidade de negócios de e-business um executivo relativamente jovem, com uma visão voltada para dinamizar os negócios da empresa em torno do e-business, visão essa estimulada pelo CEO da corporação.

Esse jovem executivo era presidente da unidade de e-business e vicepresidente da corporação global, o que mostra a vontade de dar legitimidade às ações de e-business.

Ele formou sua equipe recrutando talentos dentro e fora da montadora $B$, pessoas vindas de outras consultorias e empresas de Internet.

Foram contratadas mais de 50 pessoas de fora, pessoas da área de Internet (Microsoft, oracle, Intel, propaganda para Internet), além das seguintes áreas: 
-área jurídica: $40 \%$ de pessoas da Montadora B que conheciam o business e o resto veio de fora

-área de novos negócios

-área de análise de novos investimentos

Para acelerar a produção de projetos de e-business, a unidade de negócios "Conexão com o consumidor" criou um modelo chamado: "businessdevelopment-accelerator-unit".

Esse modelo tinha como missão gerar oportunidades em e-business e ajudar a montadora $\mathrm{B}$ a focar naquelas mais críticas e foi explicado em detalhes no item 5.2.1.2 dessa tese que caracterizou o modelo de e-business da montadora B.

As pessoas que participavam dessas estruturas eram pessoas da área de Tecnologia de Informação e de negócios.

Cada estrutura era uma organização completa. As pessoas eram exclusivamente dedicadas ao e-business.

Essa estrutura começou a operar no final de 2000.

A operacionalização desse modelo de aceleração de iniciativas de ebusiness se deu através da seguinte estrutura organizacional: 
FIGURA 55 : ESTRUTURA ORGANIZACIONAL UTILIZADA PELO MODELO “ACELERADOR DE INICIATIVAS DE EBUSINESS" DA MATRIZ MONTADORA B

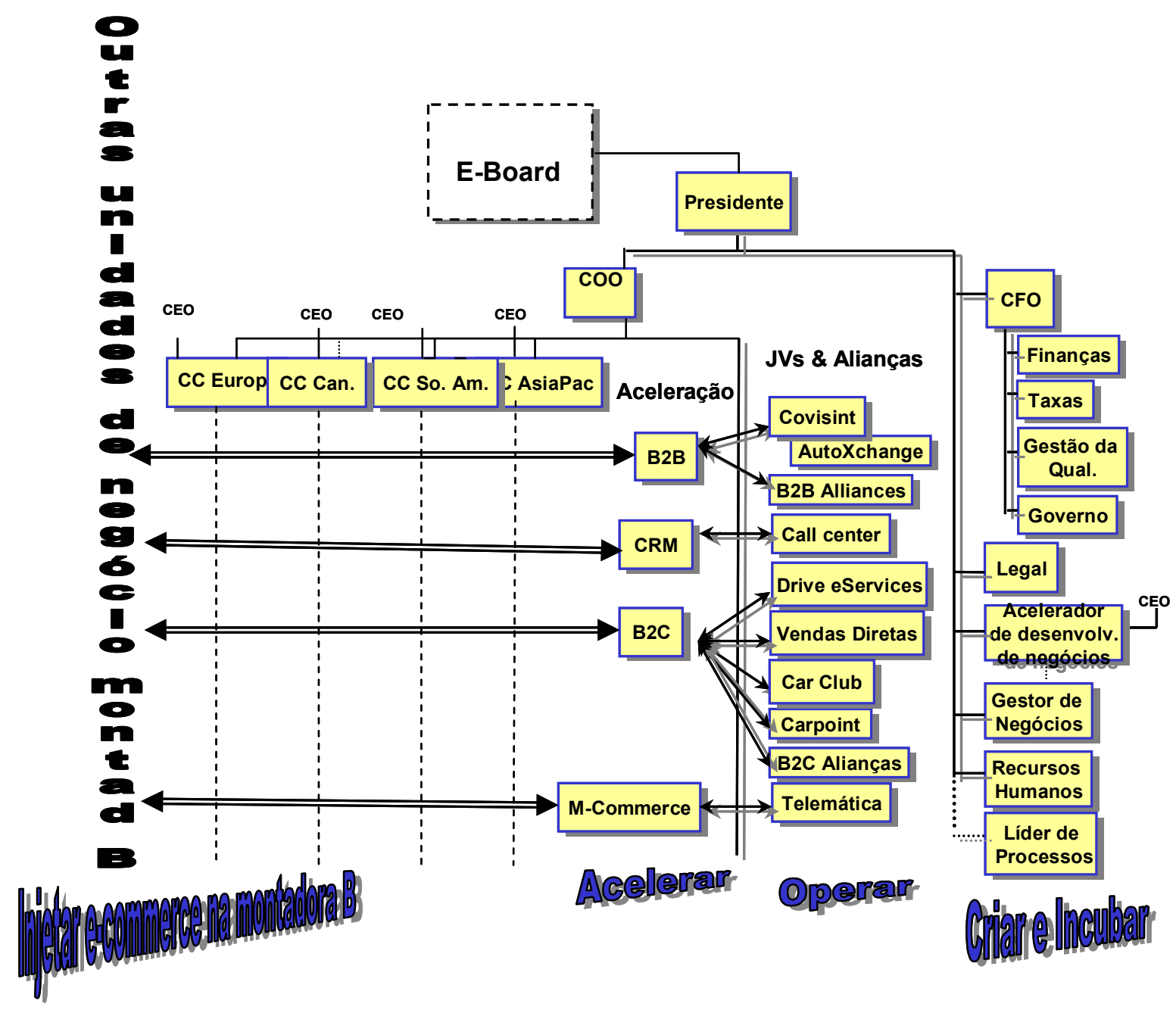

Obs: M-Commerce vem de móvel-commerce, que congrega as iniciativas em telemática, como projeto de computador central no carro para prover serviços de Internet dentro do veículo, como informações sobre a localidade onde se encontara o carro: hotéis, restaurantes, etc, além de fornecer serviços de orientação por satéliteGPS.

Essa estrutura mostra um modo de operar matricial no que se refere às unidades mundiais (Ásia pacífico, América do Sul, etc), com um bloco 
responsável pela criação e incubação de joint ventures entre a montadora B e empresas de tecnologia de Internet (Microsoft, Yahoo, Web Methods) dentre outras, para a criação de empresas que forneçam os produtos requeridos pela montadora em termos de e-business

Uma vez criadas as joint ventures, os responsáveis pelo contato com os empreendimentos externos estão no grupo "Operar". Esse grupo "operar" é composto por vários times de projetos (como mostrado na figura, por exemplo, o time do projeto COVISINT, o time do projeto call center, o time de vendas diretas, etc). cada time possuía pessoas da montadora B e das empresas parceiras.

O grupo "acelerar" é responsável por identificar as iniciativas mais prioritárias para a montadora e fazer com que aconteçam mais rapidamente, integrando-as às atividades da montadora $B$ (injetar atividades na montadora). São pessoas que estão dentro da montadora $B$ e fazem parte da unidade de negócios de e-business "Conexão com o consumidor". Sua função é então, fazer a ponte daquelas iniciativas com as áreas corporativas da montadora $\mathrm{C}$, priorizando os projetos e garantindo sua incorporação às áreas corporativas que são "clientes" desses projetos, no sentido que irão se beneficiar com os produtos resultantes.

Por exemplo, a área de Compras da empresa irá se utilizar das ferramentas de e-business geradas pelo projeto COVISINT e assim por diante.

Para injetar as iniciativas de e-business na montadora, o grupo que faz esse link é dividido nos grupos de B2B, B2C, B2M (móvel-ou telemática) dentro da estrutura "conexão com o consumidor", fazendo a ligação com áreas corporativas da empresa.

Essa estrutura pressupõe representantes na América do Sul, Ásia e Europa e chegou a congregar cerca de 350 funcionários.

Também é interessante observar que essa estrutura possui sua própria área financeira, $\mathrm{RH}$, legal , dentre outras, constituindo-se numa unidade autônoma, porém com ligações e compartilhamento de infraestrutura da montadora B. 
Não se constituiu portanto em unidade totalmente desvinculada da empresa, pois seu presidente tinha "status" de vice-presidente da montadora B.

Em 2000 muitas das iniciativas geradas pelo modelo de aceleração de atividades de e-business ainda não havia dado o retorno esperado pela empresa.

O ano de 2001 trouxe resultados aquém do esperado para a montadora $B$, não só em termos de e-business.

Com receitas geradas pelo e-business muito abaixo do previsto e investimentos altos nesse setor, em 2001 o CEO global da empresa foi substituído por outro considerado mais conservador.

A unidade de negócios "conexão com o consumidor" teve a substituição de seu executivo por outro executivo vindo de fora da empresa, do mercado da área de Internet, com experiência anterior em outra montadora.

O presidente da "conexão com o consumidor " foi promovido para uma área de relacionamento com os dealers, que estava se mostrando um ponto fraco na empresa.

O novo CEO da "conexão com o consumidor" deu prosseguimento aos projetos que estavam em andamento.

Sua função foi integrar os empreendimentos e tecnologias gerados nessa unidade para dentro dos negócios básicos (ou core operations) da empresa, ajudando a obter receitas e reduzir custos.

Em maio e junho de 2001 foi feito um levantamento para saber o que os "stakeholders" achavam do e-business naquele momento, para avaliar quais os benefícios percebidos por esses atores, para possibilitar um redirecionamento das atividades de e-business, focando naquelas que fossem identificadas como prioritárias naquele momento.

O resultado dessas entrevistas deveria conduzir as ações de e-business a partir daquele momento, reestruturando a organização do e-business, de modo a refletir as indicações levantadas pelos stakeholders.

O resultado é apresentado no seguinte quadro: 


\section{TABELA 12: RESULTADO DA PESQUISA JUNTO AOS STAKEHOLDERS PARA REDIRECIONAR O FOCO DO MODELO DE E- BUSINESS E ALTERAR A ESTRUTURA DA "CONEXÃO COM O CONSUMIDOR"}
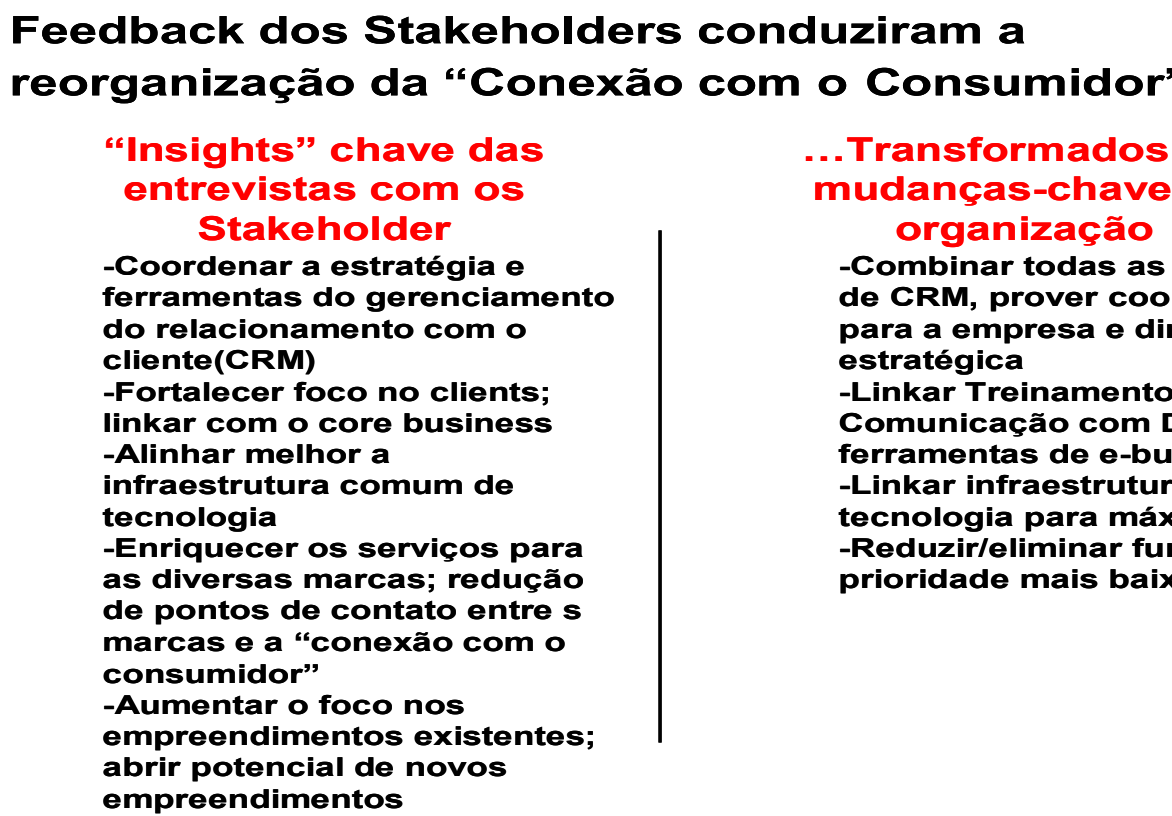

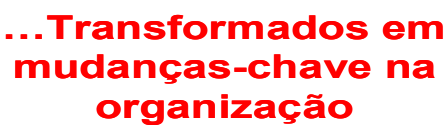

-Combinar todas as atividades de CRM, prover coordenação para a empresa e direção estratégica

-Linkar Treinamento e Comunicação com Dealers com ferramentas de e-business -Linkar infraestrutura de tecnologia para máximo retorno -Reduzir/eliminar funções de prioridade mais baixa.

A proposição dessas mudanças foi a de redirecionar as ações da estrutura "conexão com o consumidor" de tal forma que ela pudesse entregar os seguintes benefícios-chave para as marcas e para a empresa:

-Soluções de CRM

-Obter produtos e serviços "best-in-class" e preços vantajosos para a marca

-Integrar CRM para permitir realizar o complete potencial dos empreendimentos (call center, telemática, vendas diretas)

Após esse levantamento junto aos stakeholders, a estrutura de ebusiness "conexão com o consumidor" passou por uma transformação, onde essa organização definiu uma nova visão:

Ser um parceiro empreendedor que integra a "expertise" de "Customer Realtionship management", capacitações empreendedoras, ferramentas e 
"insights" para as áreas corporativas da empresa das diversas divisões do mundo e para os "dealers".

De modo a oferecer recomendações objetivas e analíticas que conduzam ferramentas e processos

Para auxiliar as áreas corporativas da empresa e suas divisões a construirem relacionamentos de longo prazo com os clientes e auxiliar a empresa a melhorar o valor para o acionista.

Essa nova visão deixa claro o aspecto do e-business como algo a auxiliar a empresa em aspectos práticos no relacionamento com o consumidor, e o envolvimento com as diversas marcas, ou seja, o e-business tem que ser uma ferramenta para melhorar o desempenho da marca e não um fim em si mesmo.

O que se aprende com o e-business deve ser transferido para as áreas corporativas.

Ao mesmo tempo percebe-se um foco no consumidor e principalmente em CRM.

A estrutura "conexão com o consumidor" coordena iniciativas de CRM por toda a empresa que não forem efetivas se conduzidas independentemente pelas áreas corporativas, ou seja, o papel da"conexão com o consumidor" é auxiliar aquelas áreas da empresa que não conseguem de forma independente obter sucesso ao conduzir iniciativas de CRM .

A estrutura "Conexão com o consumidor" iria coordenar as atividades da empresa em CRM e compartilhar as "best practices" ; às áreas corporativas da empresa cabia fazer a personalização das atividades.

Percebe-se também uma ênfase quanto à integração da infraestrutura de tecnologia: é função dessa estrutura capturar dados proprietários, integrar dados de terceiros, construir e manter infraestrutura de dados, além de definir e construir infraestrutura tecnológica.

Por tudo isso, essa nova fase da estrutura "conexão com o consumidor" , que se iniciou no primeiro semestre de 2001 , pode ser definida como:

-ênfase em CRM

-compartilhar o que foi aprendido com as áreas

-prover infraestrutura tecnológica. 
Em termos de organograma, a estrutura organizacional para implementar essas atividades pode ser assim representada:

FIGURA 56: ESTRUTURA ORGANIZACIONAL DA "CONEXÃO COM O CONSUMIDOR”NA MATRIZ APÓS JULHO DE 2001

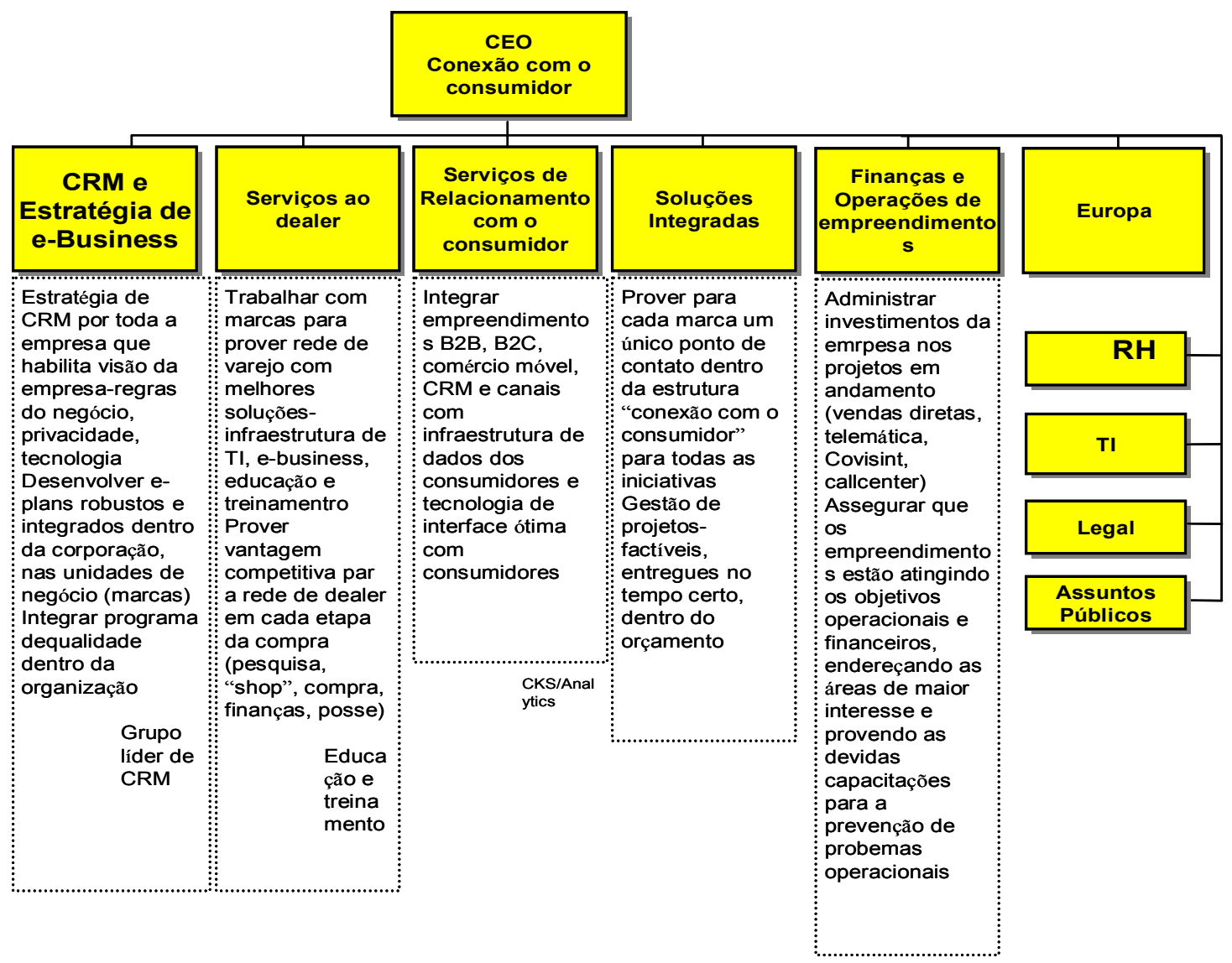

Essa estrutura mostra a preocupação com resultados e com o melhor controle sobre os empreendimentos, resultado de um orçamento mais controlado (o ano de 2001 não produziu bons resultados para a montadora B) e de uma necessidade de escolher projetos mais focados, que atendessem aos objetivos propostos de forma mais concreta.

Essas modificações, iniciadas em maio de 2001, inclusive com a saída do CEO que iniciara a estrutura, como já foi dito, e entrada de um novo CEO, 
visavam o início de um programa de absorção pelas diversas áreas e marcas da empresa da "expertise" adquirida com o e-business.

Com a transição feita, em julho de 2002, esse executivo saiu da empresa e o grupo "conexão com o consumidor" foi absorvido por outras áreas: a área de estratégia de-business e a área de integração de atividades, além da área de centros de relacionamento com o consumidor foi combinada com a área de Global Marketing do "conexão com o consumidor" .

A coordenação das diversas joint ventures do "conexão com o consumidor" vão se reportar diretamente ao vice-presidente de Marketing da empresa.

\subsubsection{ESTRUTURA ORGANIZACIONAL NA MONTADORA B: BRASIL}

Até 2000 , as atividades de e-business surgiam das áreas, sem uma coordenação central.

Em meados de 2000, a matriz aportou uma soma significativa de capital para ser investido em e-business.

Diante disso, a montadora A criou uma área de supervisão de e-business, com um supervisor dedicado tempo integral a essa atividade, como mostra a figura abaixo 


\section{FIGURA 57: ORGANOGRAMA DA MONTADORA B BRASIL DESTACANDO AS ÁREAS DEDICADAS A E-BUSINESS}

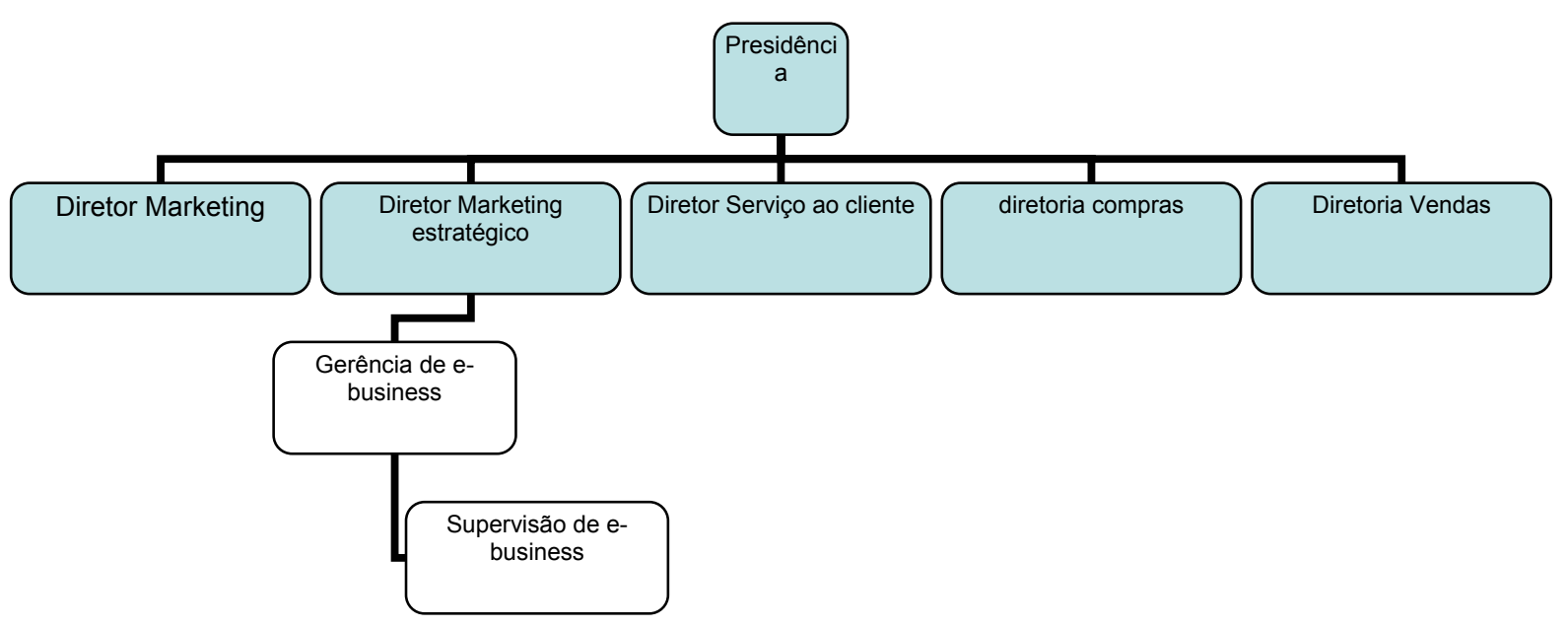

As áreas destacadas em branco foram áreas criadas com a finalidade de centralizar iniciativas de e-business na área de Marketing.

O dinheiro investido pela matriz foi entregue diretamente para as áreas, que começaram a investir desordenadamente em vários projetos, sem uma coordenação central.

Como conseqüência, no final de 2000 as atividades de e-business começaram a se sobrepor. Várias áreas diferentes fazendo coisas repetidas, ou não dando a solução ideal da primeira vez.

Em 2001: algumas das áreas da diretoria começaram a se organizar:

- Área de serviço ao cliente- criou uma área só para e-business, com um supervisor e mais 3 pessoas.

-Área de Marketing estratégico-gerente se organizou e tinha uma pessoa exclusiva para e-business

-Marketing: área de Internet reporta-se para mkt, publicidade, 1 para CRM e 2 pessoas para Internet.

-Áreas se estruturando para fazer próprios negócios. 
A comunicação começou a ser mais factível, pois havia liderançasrepresentantes de e-business nas áreas- e com foco de atuação em e-business.

Assim, a estrutura de e-business estava pulverizada por toda a empresa.

Havia uma coordenação central no que tangia a alocação de recursos, dado pela supervisão de e-business, que respondia à diretoria de marketing estratégico e vários representantes de e-business espalhados pelas áreas, que mantinham contato com esse supervisor de e-business.

A seguir serão dados alguns exemplos de estruturas organizacionais de e-business, uma vez que as atividades de e-business estão espalhadas pela empresa e cada área se organizou de um modo diferente da outra.

Exemplo da alocação de pessoa dedicada a e-business na área de serviço ao cliente:

\section{FIGURA 58: ESTRUTURA ORGANIZACIONAL DAÁREA DE SERVIÇO AO CLIENTE E IDENTIFICAÇÃO DE E-BUSINESS}

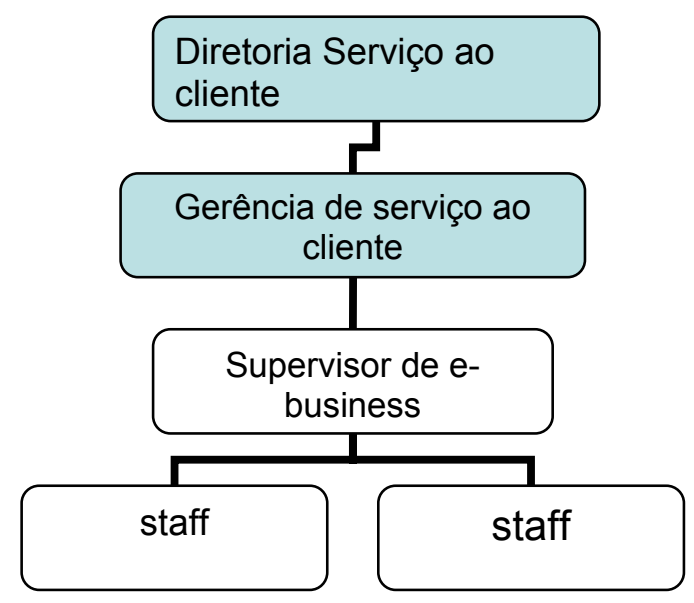

No início de 2001 o supervisor de e-business da área de serviço ao cliente tinha atividades totalmente dedicadas a e-business, com uma equipe de 3 pessoas respondendo diretamente a ele. 
Em 2002, houve a união de três diretorias: marketing estratégico, marketing e serviço ao cliente.

O supervisor de e-business da área de serviço ao cliente também passou a exercer outra atividade ligada à garantia, que não tinha nenhuma relação com e-business.

Essas junções ocorreram por questões meramente econômicas visando cortar custos na empresa (lembrar que foi dito no item anterior, que a matriz da montadora B não obtivera um bom resultado finaceiro em 2001).

A estrutura resultante é mostarda na figura abaixo:

FIGURA 59 : ESTRUTURA ORGANIZACIONAL DA MONTADORA B BRASIL APÓS UNIÃO DE ÁREAS

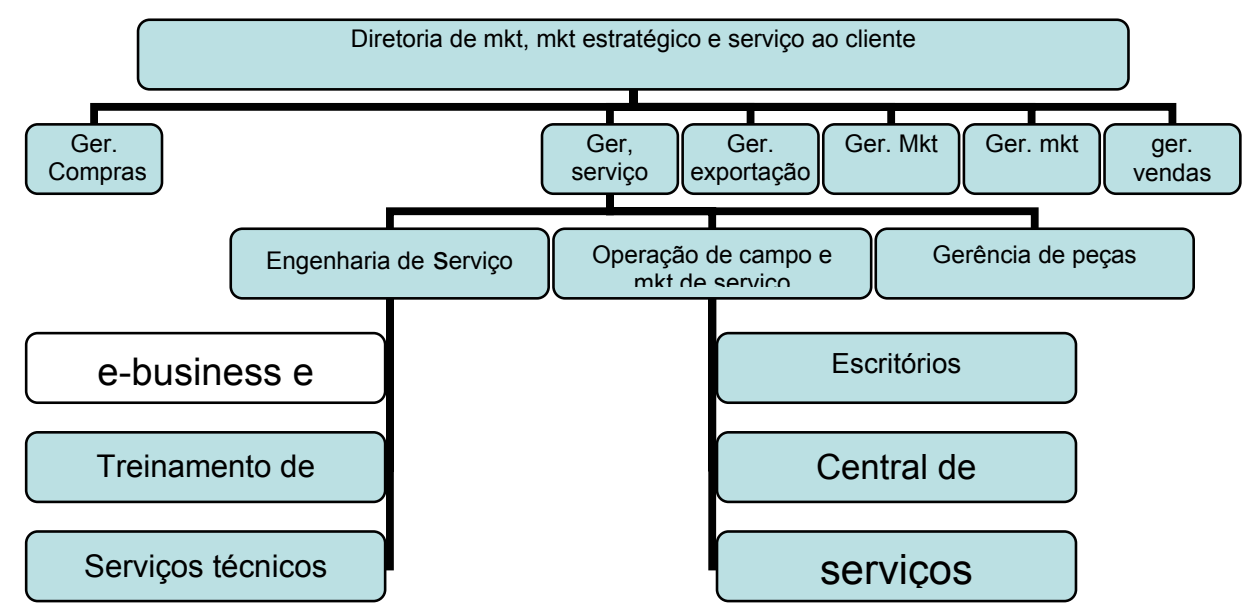

Em branco está a área de e-business, cujo supervisor também é responsável pela área de garantia. 
Essa união (e-business e garantia) ocorreu como conseqüência da economia, área de garantia ficou sem pessoa (redução de custos): as funções são completamente diferentes.

EM 2001, as áreas de marketing, mkt estratégico e serviço ao cliente se fundiram numa só diretoria- ajudou bastante a integração das atividades de ebusiness, quebraram-se feudos.

A idéia inicial seria que e-business reportasse diretamente ao gerente executivo. Por falta de disponibilidade, reporta-se a engenharia de serviços.

A área de e-business presta suporte para outras áreas fora da gerência de engenharia de serviços:

\section{FIGURA 60: RELACIONAMENTO DA ÁREA DE E-BUSINESS DENTRO DE SERVIÇO AO CLIENTE E OUTRAS ÁREAS}

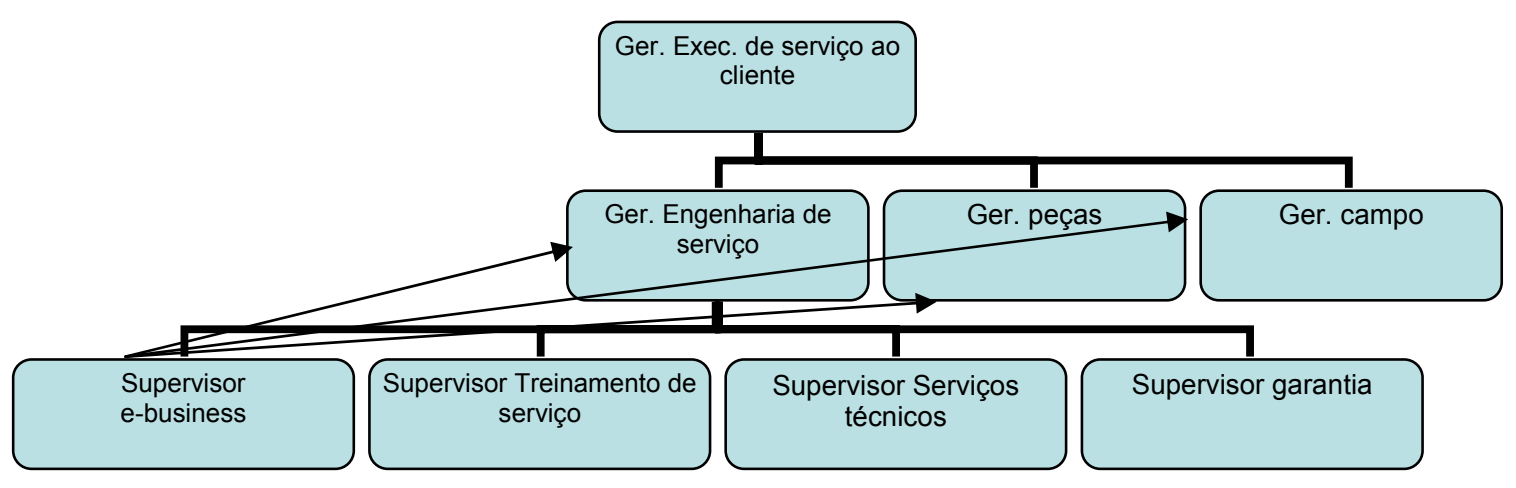

Existem representantes de e-business nas áreas de Marketing e Compras.

Como existem várias iniciativas de e-business espalhadas pela emrpesa, a figura a seguir vai indicar quais áreas na empresa possuem atividade de ebusiness. 
FIGURA 61: IDENTIFICAÇÃO DAS ÁREAS DE E-BUSINESS DENTRO DA MONTADORA B- BRASIL

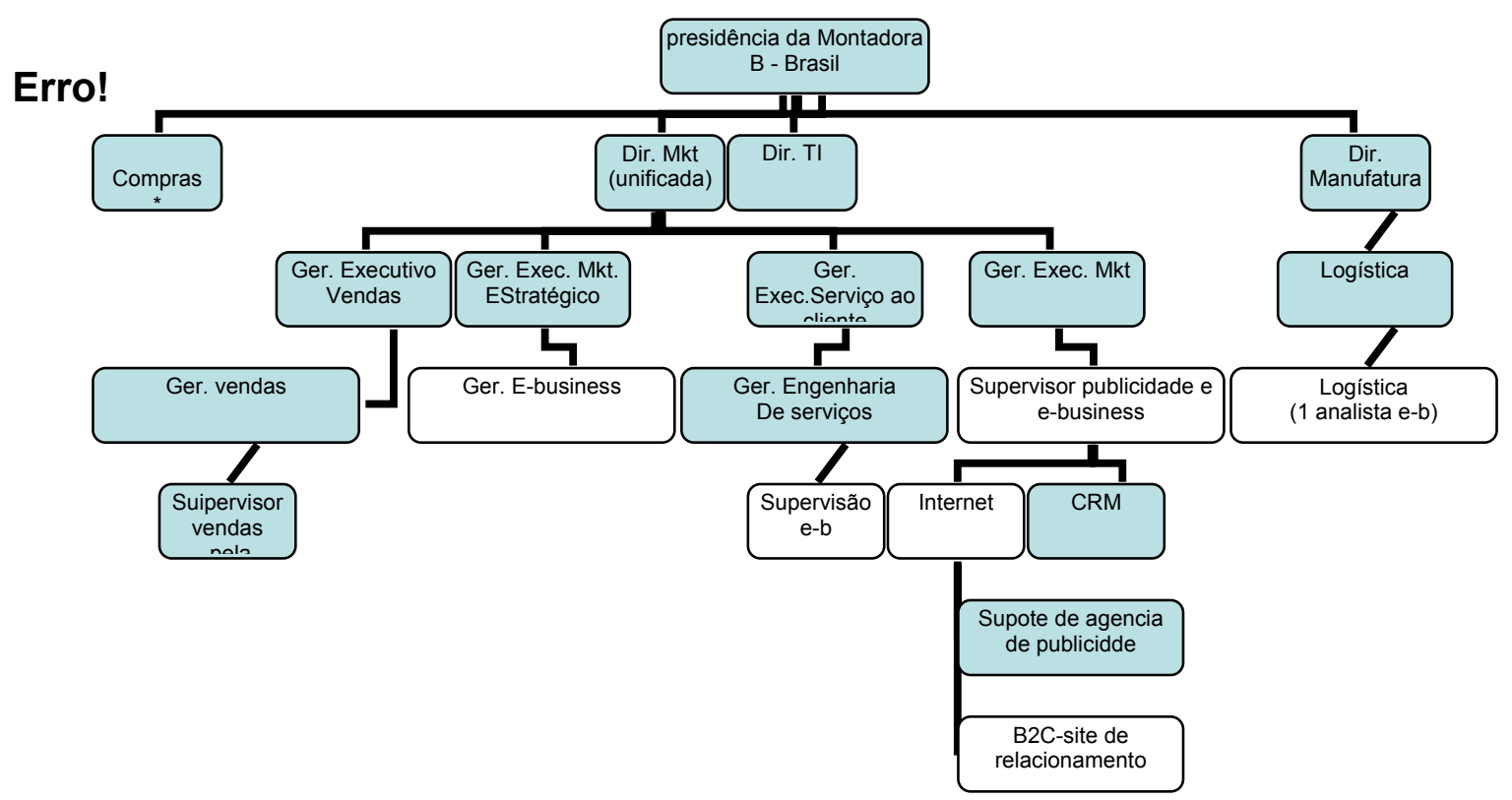

As caixas brancas identificam as áreas de e-business na empresa.

A gerência de e-business abaixo da gerência executiva de mkt estratégico era uma gerência dedicada a iniciativas de e-business para a América do sul, cuidando de iniciativas B2C, voltados para relacionamento com o cliente.

Foi a área responsável pela administração do budget global, receita vinda dos EUA especialmente para investimento em e-business.

Essa receita foi redistribuída pelas áreas.

As diversas áreas de e-business de toda a montadora B Brasil submetiam projetos para o MKT estratégico e conforme decisão do marketing, as verbas foram redistribuídas.

A área de e-business abaixo da gerência de serviço ao cliente tem um supervisor que tem o seu tempo compartilhado entre as atividades de e-business e outras atividades e a atividade principal em e-business trata do B2B com distribuidores. Além dessa atividade, esse supervisor também é responsável pela área de garantia, que não é de e-business. 
$\mathrm{Na}$ área de vendas, abaixo da gerência de vendas tem uma pessoa com cargo de supervisor que cuida das vendas pela Internet.

$\mathrm{Na}$ área de marketing, existe uma supervisora de publicidade e ebusiness que tem atividades compartilhadas e trata de Internet.

$\mathrm{Na}$ área de manufatura, abaixo da gerência de logística, tem um analista para e-business.

* Abaixo da diretoria de Compras tem a seguinte estrutura:

FIGURA 62: ESTRUTURA DA DIRETORIA DE COMPRAS REFERENTE A EBUSINESS DA MONTADORA B - BRASIL

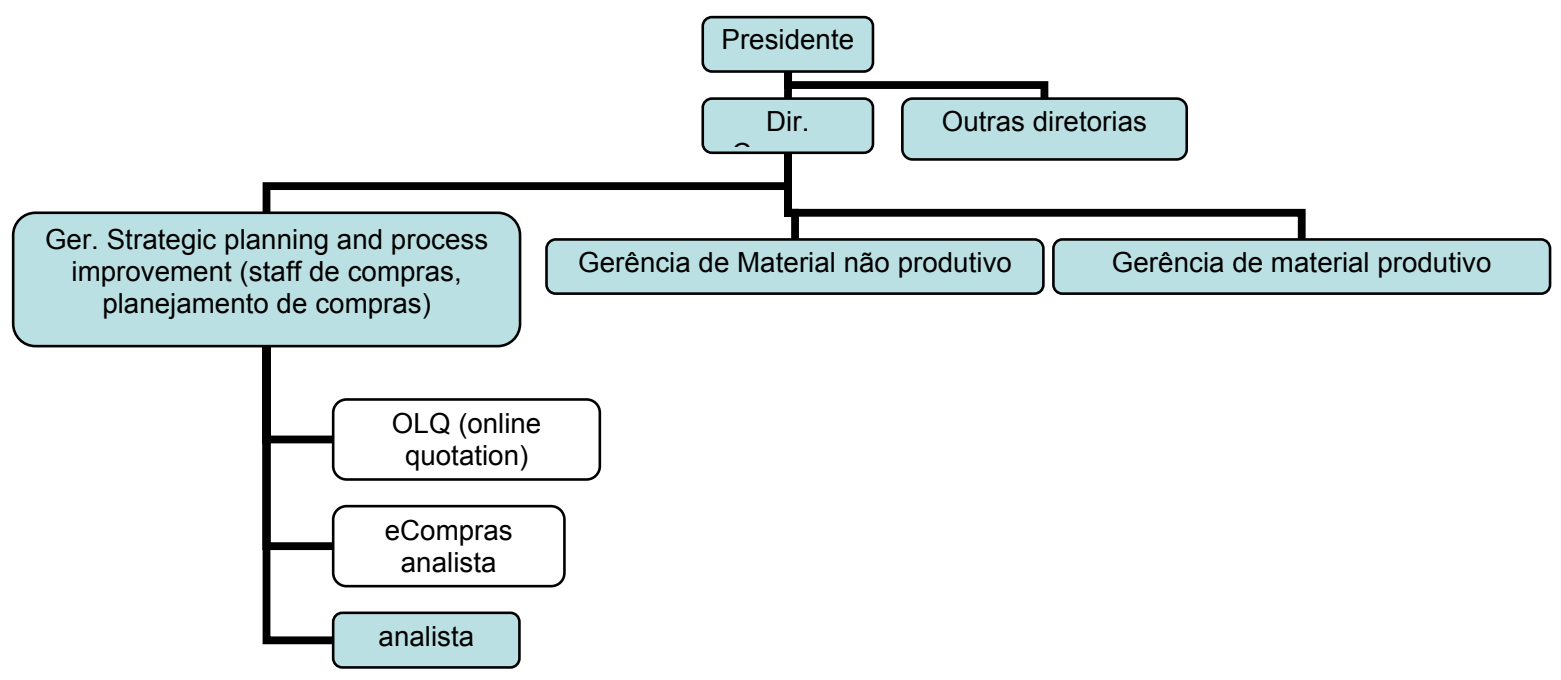

$\mathrm{Na}$ área de Compras existe uma pessoa que faz parte da equipe de trabalho para implantação do COVISINT e de um projeto maior na área de eprocurement, que é o "eCompras" (nome fictício para garantir sigilo). Essa pessoa está atualmente na matriz fazendo parte do time de elaboração desse projeto de e-procurement, que será uma plataforma global, que provavelmente será adotado no Brasil no final de 2003. 
Nessa área, tem equipe de 3 pessoas part time cuidando de B2B com fornecedores.

Não existe responsável que coordene todas as pessoas de e-business.

-Para as iniciativas novas de e-business trabalham por projetos multifuncionais e a coordenação fica a cargo da área que tem maior envolvimento com o projeto.

Por exemplo: projeto de relacionamento fica a cargo da área de mkt. Projeto que envolve serviço, fica a cargo da área de serviço ao cliente.

-Todo ano tem business plan-projetos são aprovados junto à gerência e entra nos objetivos da empresa para o ano.

-Não há um tratamento diferenciado para o e-business, é tratado como qualquer projeto, é mais uma ferramenta.

Área de TI: na época do "boom" de iniciativas de Internet, final de 2000 e início de 2001, foi criada uma equipe : "web solution group” , uma supervisão de TI.

Como eles se estruturaram antes das áreas de negócios, interfiriram nas decisões de negócios. Começou a ter e-business por e-business, sem sedimentar, coisas tiveram que ser refeitas, com mais escopo de negócios.

No início de 2002 foi dissolvido esse grupo

TI: tem uma estrutura que segue área de negócios: cada equipe de TI só atende a parte de serviços para cada área específica da área corporativa.

Web solution group-Grupo dissolvido e pessoas foram alocadas para as áreas de $\mathrm{Tl}$ específicas. Antes tinha dois grupos fornecendo serviços: a área de TI e o pessoal do e-business TI.

Hoje pessoas de grupos realocados prestam tanto serviço web quanto plataforma.

Houve conflitos na época que eram duas equipes: problemas de assumir responsabilidades, elas estavam difusas.

Para a implantação de projetos, usaram metodologia desenvolvida pela montadora B para projetos de TI : Escopo, Planejamento, Desenho, Construção, Implementação e Suporte e manutenção conforme figura abaixo: 
FIGURA 63: METODOLOGIA DE PROJETOS DA MONTADORA B-BRASIL

\section{Ciclo de vida do desenvolvimento do projeto}

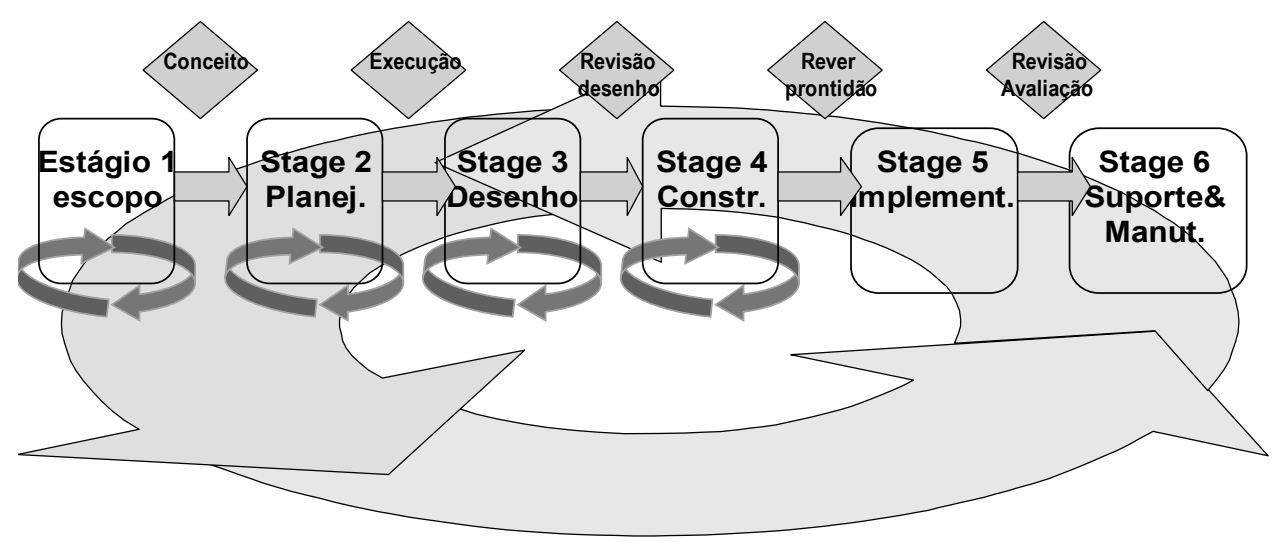

Os times de projeto tinham um "business owner" que era a área da empresa que se beneficiaria mais diretamente com aquele projeto, o representante da área de e-business estratégico, um líder de projeto e um representante de $\mathrm{TI}$.

Os times eram compostos por pessoas da área de negócios e da área de TI.

O acompanhamento do projeto não despertava interesse no pessoal do board diretivo, queriam ver como a Internet iria apoiar os negócios.

A alta administração em geral não chegou a se comprometer com as iniciativas de Internet.

Um grande problema citado pelo supervisor de e-business foi a não incorporação pelas áreas das métricas sugeridas para mensurar resultados.

Fica difícil fazer relatório dos resultados.

Alta direção da empresa não se sensibilizou com as iniciativas pois nao conseguiu avaliar claramente os resultados obtidos.

Dependendo do projeto a alocação de tempo dos participantes variava: dependia da importância que o gerente de área dava para o projeto.

Problemas: falta de tempo dedicado adequadamente levou a problemas. 
Pagamento: área estratégica pagava $\mathrm{TI}$, área não recebia nada .

Um caso de sucesso: site "meu carro" (nome fictício): mkt e serviços, mkt líder do projeto. Time era multifuncional: serviços, mkt, imprensa e TI.

Foi muito bem sucedido. O líder de projeto nesse caso tinha $80 \%$ de dedicação. O resto do tempo se dedicava a mkt direto, campanhas de mkt.

Caso de insucesso: site do frotista: fracasso.

Site desenvolvido fora da estratégia.

Não servia para o dealer, não servia para o frotista.

Faltou mapeamento de "customer needs".

Faltou tempo e dedicação. Gerente da área se ausentou, não deu atenção

Gerente de projetos: tinha outras prioridades (gastou 5\% do seu tempo para fazer escopo do projeto, deu para TI, que fez)

-recursos limitados

Tinha objetivos de vendas a perseguir, não tinha tempo para dedicar a essa atividade.

A única pessoa contratada para a área de e-business foi o supervisor de e-business, que veio de outra empresa do grupo, ou seja, foi realocado.

Todos os outros integrantes de projetos e atividades de e-business eram da própria montadora B Brasil, num esquema de dedicação ao e-business normalmente compartilhado com outras atividades.

\section{Projeto de venda de carro direto pela Internet - um caso de sucesso}

A área responsável pela venda online é chamada na empresa de área de Vanda direta.

Localização da área de venda direta na estrutura organizacional da emrpesa: 


\section{FIGURA 64: LOCALIZAÇÃO DA ÁREA DE VENDAS NA ESTRUT. ORG. MONTADORA B BRASIL}

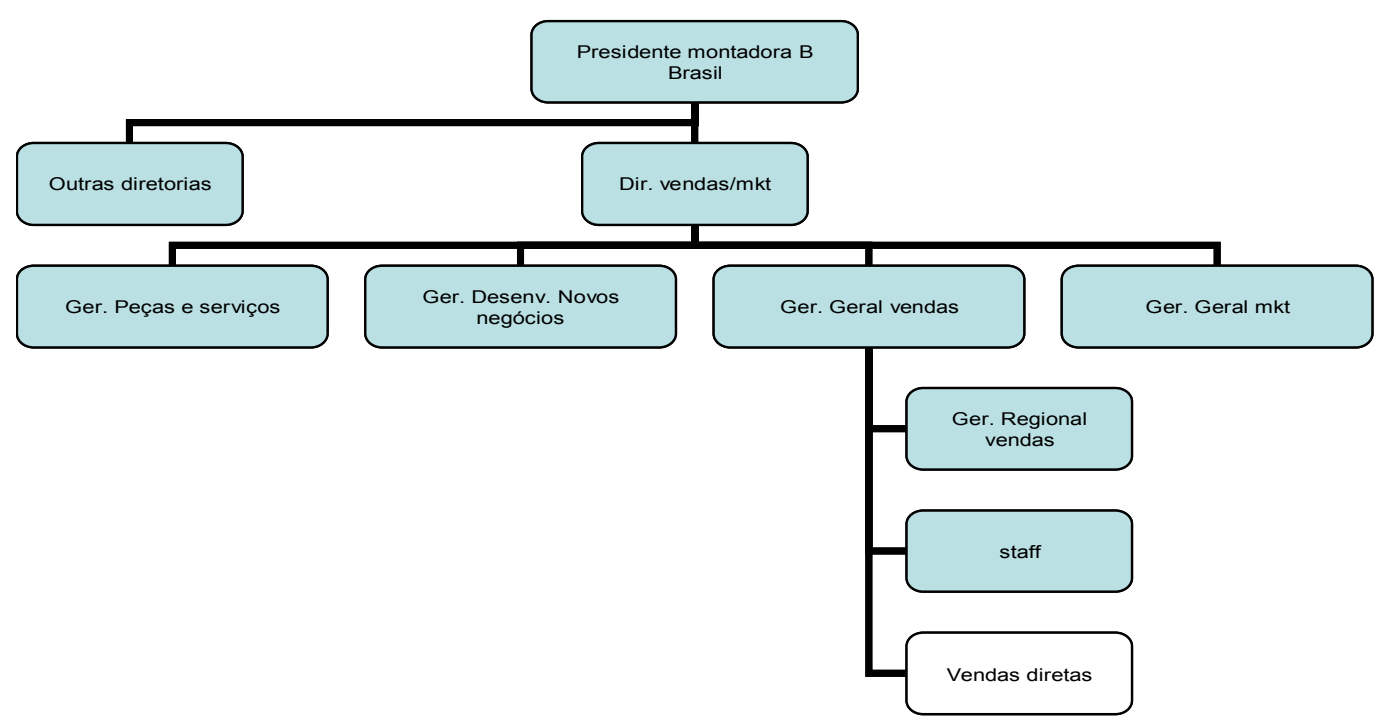

Durante elaboração do projeto de vendas diretas, essa área reportava-se diretamente à diretoria. Após implementação, passa a se reportar ao gerente geral de vendas.

Como surgiu o projeto:

-razão para implantar vendas diretas: atendimento ao cliente- fornecer ao cliente possibilidade de escolher produto exatamente como ele quer.

Hoje cliente se submete ao estoque dos fornecedores. Antes não podia comprar o que ele queria exatamente.

Apoio do distribuidor: fundamental

Compra tem cunho emocional, mas racional também pelo valor do investimento: o cliente precisa sentir o produto. Daí o uso do distribuidor, para que após feita configuração do carro, o cliente possa experimentar o carro no distribuidor.

$\mathrm{Na}$ verdade a maioria dos pedidos são feitos usando o site no distribuidor: ajuda a configurar o carro e verificar disponibilidade de itens. 
Aproveita para: ganho com reduções de estoque através de processos logísticos.

Estoque concentrado num centro de distribuição (fábrica) ao invés de pulverizado.-pode receber pedido de cliente que é processado na produção.

Dentro do programa de produção, um pedido pode modificar a programação da produção-conseguindo atender ao gosto do cliente.

Isso só foi possível com a inauguração de nova fábrica, mais flexível.

O lançamento do site de vendas diretas: setembro de 2000 .

-Projeto: modelo de carro popular, já fabricado em fábrica existente. Eram menos modelos disponíveis, pois linha de produção já estava em execução.

Vendas só pela Internet para aquele modelo. Mas, como ele era fabricado em fábrica já existente, com processos menos flexíveis, não existiam muitas opções de configuração diferentes.

O processo de compra utilizando a Internet : processos desde a colocação do pedido, escolha do carro pelo web site e processos internos para fazer que planejamento da produção fossem baseados nos pedidos pela Internet.

Até hoje é venda exclusiva pela Internet. Não houve necessidade de usar canal tradicional, diante do sucesso que foi o lançamento e a receptividade e aprendizado da rede de distribuição foi um sucesso.

Em 2001 iniciou-se projeto de venda direta pela Internet de um novo modelo, fabricado na nova fábrica, mais flexível.

Cliente vai ao distribuidor ou direto de casa, faz o pedido, indica o distribuidor onde vai receber.

Daí, pedido é faturado e verificam se existe carro na fábrica. Se não, altera linha de produção para o pedido ser efetivado.

A nova fábrica foi inaugurada com esse carro que só é vendido pela Internet.

-Fábrica: flexível, muito mecanizada- esse fato permite que o fenômeno da Internet seja viável, pois permite reverter produções mais rapidamente.

-No desenvolvimento do projeto, montaram comitê de distribuidores para serem envolvidos desde o começo; 
Distribuidores fizeram parte do desenvolvimento do projeto. Treinamento da rede foi fundamental.

-Idéia:surgida na área de mkt do Brasil. Não existe esse processo fora do Brasil.

O movimento de venda direta pela Internet foi iniciado pela montadora C presente nessa pesquisa, depois vieram outros seguidores.

Hoje, mais três montadoras possuem site de vendas diretas pela Internet.

Montadora C : lançamento da fábrica nova, aproveitaram para direcionar o produto para a Internet.

\section{Equipe de projeto da venda direta de carro já existente:}

-Composição da equipe do projeto:uma pessoa da área de vendas diretas, uma da área de estratégia de e-business e a área de tecnologia ( $\mathrm{TI}$ ).

Como não era um produto novo, era um processo novo em cima de um carro existente.

$\mathrm{Na}$ verdade esse projeto foi só adicionar um canal de distribuição- as atividades envolvidas eram compartilhadas com o dia-a-dia.

Esse lançamento inicial foi para não perder a oportunidade, para acompanhar tendência de mercado e ter visão de como seria receptividade dos distribuidores.

Em 2001, às vésperas do lançamento da nova fábrica e novo produto, identificaram a possibilidade dessa venda pela Internet.

Gerente de vendas diretas foi alocado full time para o desenvolvimento do projeto de vendas do novo produto-cerca de 8 meses.

A nova fábrica foi feita de forma mais flexível, não pela questão da Internet, mas seguindo tendência de mercado (como foi identificado no painel traçado sobre a indústria automobilística apresentado nessa tese)

A estrutura organizacional do projeto era a seguinte: 


\section{FIGURA 65: ESTRUTURA ORGANIZACIONAL DO PROJETO DE VENDA DIRETA DE NOVO MODELO DE CARRO POPULAR PELA MONTADORA B-BRASIL}

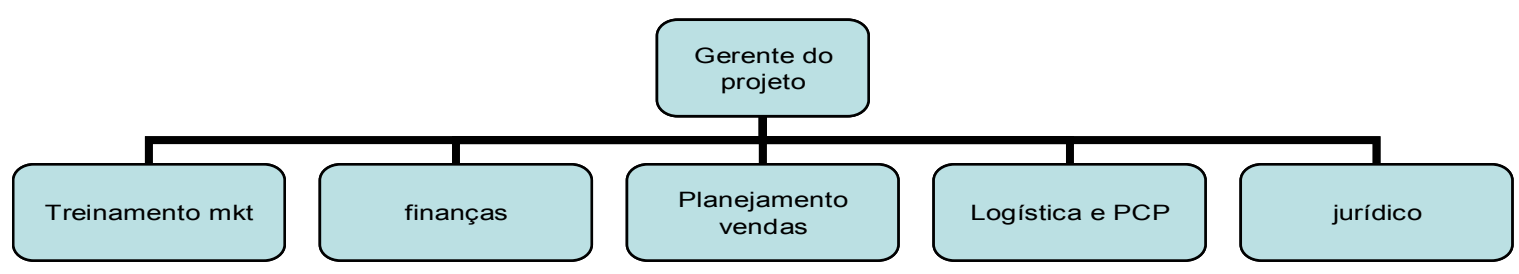

Existia uma pessoa para treinamento, da área de mkt, que deveria treinar os distribuidores em como abordar clientes e como utilizar sistemas.

Uma pessoa dedicada em tempo integral à área de finanças.

Uma pessoa dedicação exclusiva para planejamento de vendas, uma pessoa para logística e outra para planejamento da produção, dedicados tempo integral e uma pessoa para assessoria jurídica. Ainda havia duas pessoas da área de $\mathrm{Tl}$, dentro da área de tecnologia.

Os parceiros eram a rede de distribuidores. $\mathrm{Na}$ idealização, foi formado um comitê de distribuidores, que eram consultados em reuniões quinzenais.

Essa equipe foi organizada para montar o fluxo desde o recebimento do pedido até produção, encontrar o carro no estoque.

Essas pessoas ficaram num "war room" (fisicamente isoladas do resto do pessoal da empresa, numa sala particular). Quando precisavam, chamavam as pessoas de TI. Ficaram 8 meses em isolamento e dedicação total ao projeto.

Maio de 2002-lançamento do novo modelo de carro popular. Continuam vendas pela Internet exclusivas por boa aceitação da rede e do público.

-Cliente vai, vê o carro e faz o pedido num microcomputador do próprio concessionário.

95\% dos casos é no concessionário. 
$5 \%$ restante em casa, mas volta ao distribuidor para pegar o carro.

Atingiram expectativas de vendas

Vendidos aproximadamente 20 mil carros em 4 meses-superou as expectativas nos 2 primeiros meses.

Essa equipe se desfez em julho de 2002.

Quem não participa mais : finanças

Logística: continua fisicamente alocado com o gerente de vendas diretas.

Permanecem em vendas diretas:

\section{FIGURA 66: ESTRUTURA DA ÁREA DE VENDAS DIRETAS APÓS 0 TÉRMINO DO PROJETO DE VENDA DIRETA DE CARRO NOVO}

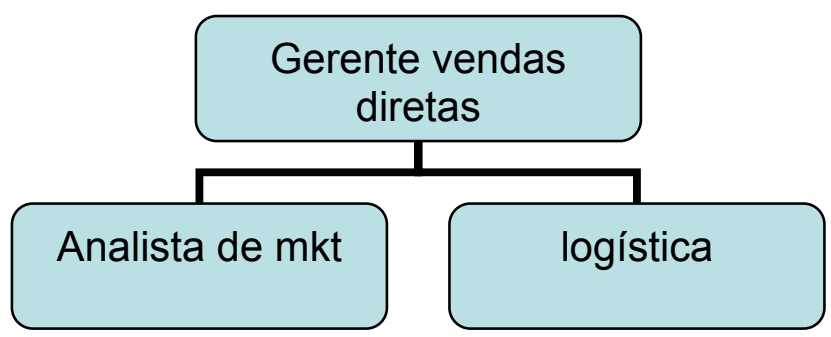

Gerente de vendas diretas respondendo ao gerente geral de vendas.

Logística: full time acompanha planejamento da produção e fluxo de informações e produtos. Analista de marketing- full time para internetgerencia preços, fiscaliza o site e controla.

As outras pessoas voltaram para suas áreas, elas continuam atuando na área de vendas pela Internet (atividades compartilhadas)

Após lançamento de site, supervisor de vendas diretas que gerenciou projeto assumiu atividades de gerente das vendas diretas. Mais duas áreas juntaram-se à área de venda pela Internet: venda para governo e frotistas.

Projeto: mudança de processos em várias áreas. Com essa experiência que esse gerente teve, pode expandir para outras áreas.

A participação nesse projeto alavancou a carreira e experiência desse gerente. 
Pode usar ferramentas de tecnologia para melhorar relacionamento de fornecedores e clientes numa área para comunicação e controle-hoje já se comunica com frotistas através de intranet.

Hoje, $40 \%$ das atividades desse gerente são dedicadas a Internet e $60 \%$ outras atividades.

-Projeto foi reconhecido como grande sucesso pela diretoria.

Papel da rede de distribuição é muito específico.

Estrategicamente tem que se trabalhar muito com a rede para escolher quais produtos a serem vendidos pela Internet.

Não foi para diminuir foco que gerente assumiu outras atividades processo de sucesso, está estável, equipe continua- dá estabilidade para melhorar processos, independente de ter gerente dedicado full time- grupo ficou hábil e autônomo, pois conhece todo processo nos detalhes.

Decisão sobre outros produtos, precisa ser tomado num âmbito mais estratégico, pois distribuição é muito complexa.

$\mathrm{Na}$ área de venda direta não existem hoje projetos novos de e-business.

Novos projetos são com o supervisor de e-business.

Esse projeto é peculiar ao mercado brasileiro, pois em nenhum outro lugar do mundo vende pela Internet.

Participação dos EUA: teve uma pessoa de mkt dos EUA, acompanhou todo projeto, não era exclusivo, era apenas observador, para reportar o projeto para a matriz.

Ficaram impressionados e até para pegar idéia e ver viabilidade de implementação em outros países. 


\section{Estrutura Organizacional da área de TI}

FIGURA 67: ESTRUTURA ORGANIZACIONAL DA ÁREA DE TI DA MONTADORA B

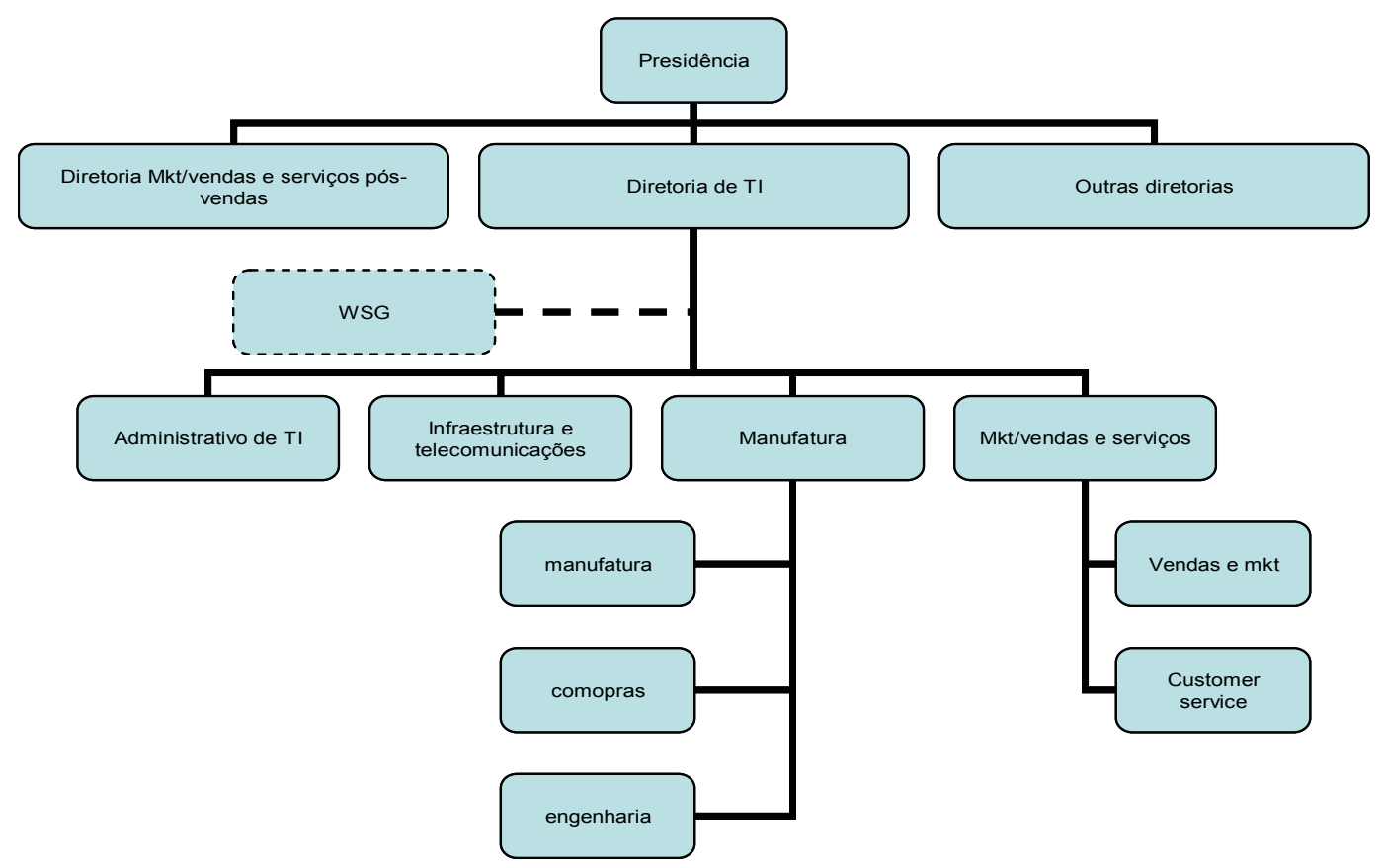

A caixa tracejada WSG que quer dizer Web Solutons Group foi criada em 2000: 1 supervisor mais 7 analistas, respondendo direto ao diretor. Foi extinta no início de 2002.

O cliente de cada área dentro de $\mathrm{Tl}$ é a respectiva área de negócios.

Área de $\mathrm{Tl}$ é formada por um diretor e abaixo existem várias gerências que se dedicam a cada área de negócio. Abaixo dessas gerências existem supervisões que são responsáveis por desenvolvimento e implementação.

$\mathrm{TI}$ começou a pensar em Internet e a atender projetos que áreas de negócios enxergavam.

Desafio principal: estruturação tecnológica. 
A tecnologia de Internet era conhecida mas não tinham aplicações dessa tecnologia ( trabalhavam com mainframe).

Existe uma terceirização parcial: quem solidificou os projetos foram software houses.

Modelo misto: efetivos: responsáveis pelos projetos, mão-de-obra operacional-terceirizada (já era assim antes do e-business).

Primeiro desafio: estruturação da arquitetura. Base do planejamento: foram os projetos para verificar o que precisavam em termos de negócios.

Primeiro: processos e negócios, depois utilizaram tecnologia para suporte.

Core: produzir veículos, não sistemas.

Os " business case" eram apresentados por uma pessoa do business, uma pessoa de TI e o supervisor de estratégia de e-business-eram apresentados para todos os níveis executivos (não mudou de como era antes).

O grupo "wsg" criado no final de 2000 tinha um supervisor que respondia direto à diretoria de $\mathrm{TI}$, trazido do mercado (conhecimento de Internet) por não ter o domínio das ferramentas de Internet.

Esse grupo era composto por um supervisor mais 7 analistas.

Alianças com grandes sites (yahoo)

O WSG não era suficiente para suportar tudo que tinha a fazer : virou linha de montagem.

Necessidade gerada no business.

WSG: viabiliza a idéia, desenvolve, faz parcerias com fábricas de software, faz a implantação e passa o sistema para a área responsável.

-linha de montagem: projeto entra na linha e volta para a área.

Surgiu a idéia do e-learning: treinamento, cursos, veio para o WSGviabiliza processos e implementa-passa para a área de TI responsável por $\mathrm{RH}$.

Daí, esse formato já era compatível com a dissolução do grupo.

Visão: transição de mainframe para essa plataforma, o fato de mudar de tecnologia não ia mudar a estrutura organizacional.

-Como não houve migração total dos processos de mainframe para Internet-grupos DS atuavam juntos desde o início com WSG. 
Para implantação dos projetos foi utilizada estrutura matricial:

-1 representante de DS (desenvolvimento de sistemas) da área envolvida

-1 representante de infraestrutura (parte de telecomunicações e infra)

-1 representante da área de banco de dados (telec)

-time do WSG (com número de elementos necessários)

-coordenador do projeto: vem da área de negócio (área de negócio, não de $\mathrm{TI})$

-quem dá as prioridades para alocação do tempo é a área de negócio.

Quem nomeia o coordenador:diretoria da área corporativa

Coordenador: alocação do tempo dependia da situação(mais de um projetos e mais atividades do dia-a-dia).

Manter as atividades do dia-a-dia-fazia os projetos ficarem eficientes.

Em 2002 (início) dissolveram o grupo .

$1^{\circ}$-ao longo do tempo foram passando o sistema (aplicativos) para as áreas de $\mathrm{TI}$ de negócios (arquitetura existente foi utilizada para essa nova tecnologia-só mudou aplicativos, linguagem)

-à medida que entregava para os DS (grupo dentro da área de TI que eram responsáveis por $\mathrm{TI}$ de áreas corporativas definidas), alcançaram maturidade no ambiente de web/Internet.

Em 2002 outras áreas foram absorvendo os projetos.

Segundo opinião do gerente de TI entrevistado, E-commerce era a grande promessa e não se viabilizou.

Qual foi o grande ganho?

Existe um patamar tecnológico, a Internet promete outro patamar tecnológico: investimentos foram feitos com aquela promessa, com o tempo:

Ganho: Avanço significativo em tecnologia. 


\section{FIGURA 68: AVANÇO TECNOLÓGICO APÓS E-BUSINESS NA EMPRESA B BRASIL}

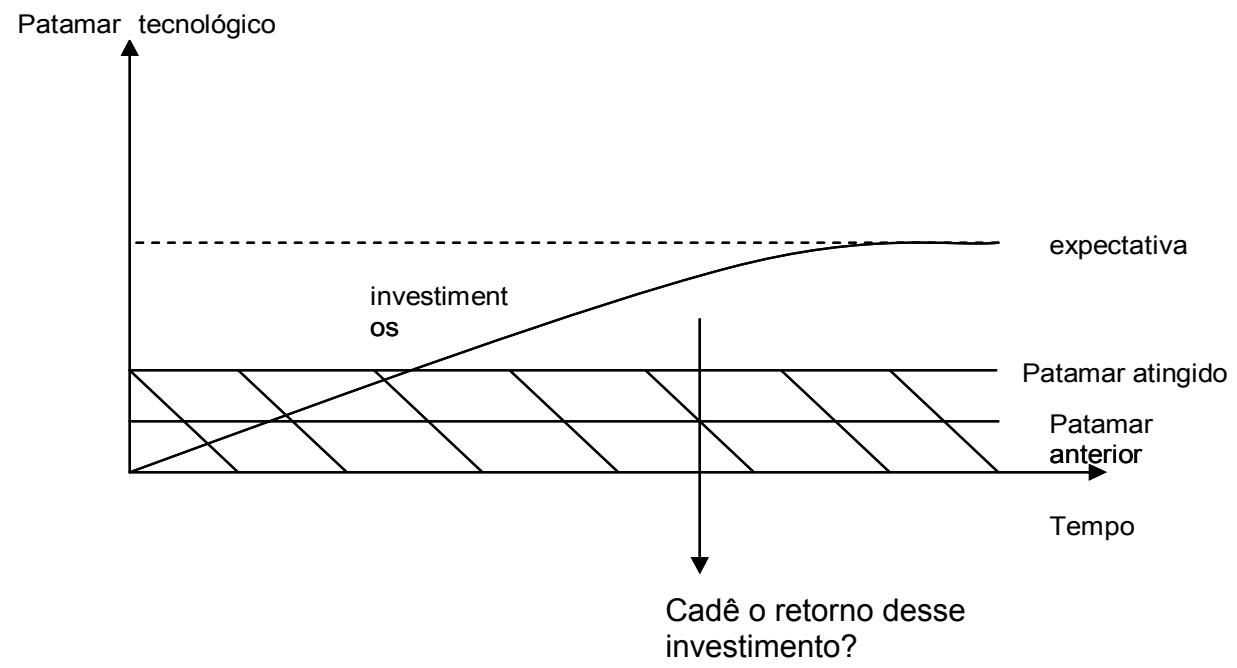

O que foi representativo nessa alavancagem?

B2S- relacionamento com fornecedor-agilizadas as trocas de informações.

Hoje uma das ferramentas da Internet importantes é o leilão reverso tendem ao crescimento.

Portanto o grande ganho foi o avanço do patamar tecnológico atingido.

\subsubsection{ESTRUTURA ORGANIZACIONAL NA MONTADORA C: MATRIZ}

Até 1999, existiam várias atividades de e-business sendo executadas pela matriz da montadora $C$, porém não havia nenhum tipo de coordenação entre elas, o que resultava em alto custo para a empresa, por duplicação de atividades e falta de compartilhamamento do conhecimento adquirido.

Por esse motivo, em agosto de 1999 foi formada uma estrutura dedicada a e-business chamada nessa tese de "e-business C" para nomear a estrutura de e-business criada pela montadora $\mathrm{C}$ voltada para e-business.

Tratava-se de uma unidade de negócios, cujo presidente era vicepresidente da firma global. 
Para isso, investiram em talentos, recrutando um experiente CEO para comandar a nova estrutura e forjaram alianças com empresas de Internet bem sucedidas, como AOL e e-Bay.

O CEO responsável por essa unidade de negócio, o "e-business C", responde diretamente ao líder global de vendas e marketing.

Esse CEO, que trabalha há anos para a montadora $C$, sendo sua última posição numa divisão de carros de pequeno porte, segundo o vice-presidente de vendas globais, tem uma história de inovação e uma característica de ser orientado para resultados, além de possuir experiência global e entender as exigências práticas necessárias para dirigir mudanças na empresa.

Entre 1999 e 2000 a unidade de negócios "e-business C" gastou a maior parte do tempo empreendendo o processo de organização.

Eles contrataram pessoal, além de terem feito parcerias com empresas de Internet, como já foi dito.

Essa organização chegou a ter cerca de 100 funcionários.

A estrutura organizacional dessa unidade de negócio pode ser assim descrita:

FIGURA 69: ESTRUTURA ORGANIZACIONAL DA UNIDADE DE EBUSINESS "E-BUSINESS C"

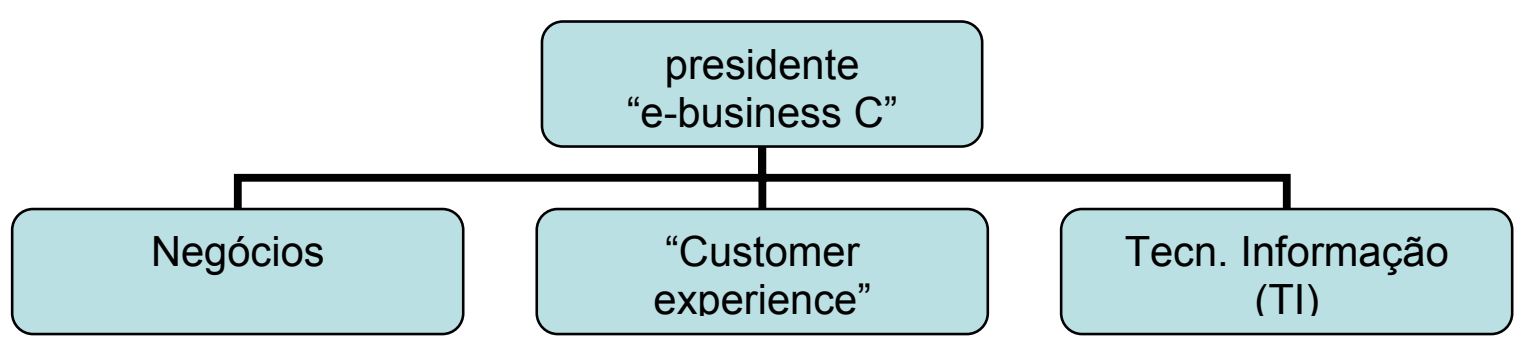


Nessa estrutura organizacional simplificada da unidade de negócios "ebusiness C", o presidente da unidade coordenava 3 áreas principais: a área de negócios, que se relacionava às áreas corporativas da empresa (produtos e marcas), a área de "customer experience", relativas às atividades de marketing relacionadas a todas as fases do ciclo de "customer experience" (awareness, research, shop, purchase, maintain e re-purchase) e finalmente uma área de TI voltada para aplicações de e-business.

É importante ilustrar as transformações que ocorreram na área de $\mathrm{Tl}$ da empresa para seguir as exigências de integração pela Internet.

Como um dos meios de parar com a diminuição do market share e estimular as vendas num ambiente econômico difícil, a montadora $\mathrm{C}$ acelerou uma estratégia para alavancar eficiências operacionais globalmente e apresentar uma única face para o consumidor através de seus produtos.

Para conduzir essas mudanças chamadas na empresa de "transformação nos negócios digitais" foi designado um novo ClO em 1996, que guiou a empresa através da separação de seu fornecedor de $\mathrm{Tl}$ terceirizado e a conversão para e-business.

Esse $\mathrm{ClO}$ tem importância estratégica na companhia.

Ele redesenhou muitas tecnologias e processos e ajudou o CEO global na mudança cultural empreendida na empresa chamada "Vá rápido".

O desafio foi a partir de 1996, com a competição acirrada com as montadoras japonesas.

Naquele momento, as operações de negócios da empresa $C$ não eram bem integradas com $\mathrm{Tl}$, de fato eles eram dois segmentos de negócio separados.

Isso trazia conseqüências em termos de custos e de tempo do ciclo dos processos.

A partir do potencial de integração das tecnologias de Internet, a empresa investiu cerca de US $\$ 1,7$ bilhões nos últimos 5 anos para livrar-se de sistemas legados e investir em novas aplicações de Internet, objetivando alinhar TI com os negócios. 
Ao ligar essas aplicações de Internet criou-se uma rede de negócios e essa abordagem de integração tem trazido melhorias tangíveis nos processos de negócio, desde o chão de fábrica até seus dealers e consumidores.

Ao trazer os parceiros de fornecimento online e encorajar os dealers a serem parceiros da montadora $\mathrm{C}$ em e-commerce, a empresa reduziu o ciclo de tempo de entrega de um veículo de 70 para 47 dias.

Como melhorar o tempo de entrega não depende somente de tecnologia, - ClO desenvolveu uma estrutura matricial que mescla as divisões de negócios da empresa com os "talentos" de TI necessários para entregar aplicações globais de e-business ao mesmo tempo que assegura que todas as divisões de produtos em massa estão sintonizadas.

A montadora C agora é uma empresa matricial, tanto nas áreas de $\mathrm{TI}$ quanto nas linhas de negócio.

Cada unidade de negócios-manufatura, cadeia de suprimentos, vendas e marketing- tem seu próprio $\mathrm{ClO}$ que se reporta tanto para o presidente da unidade quanto para o CEO global da empresa.

Foi criado um novo conjunto de gerentes corporativos (corporate officers), os PIOs (process information officers) que são seniors executivos com objetivo de reforçar padrões de tecnologia e assegurar que os projetos estejam alinhados através das divisões de negócios da montadora $\mathrm{C}$ globalmente.

Para assegurar esses objetivos, comunicação regular e estruturada entre as unidades é necessária.

PIOs encontram-se semanalmente para trabalhar em padrões de infraestrutura.

Eles também se encontram semanalmente com o CEO global e seus CIOs para manter os vários projetos em sincronia global.

Relatórios periódicos fornecidos aos executivos de TI mantem-nos atualizados quanto aos status dos projetos.

PIOs também analisam os processos existentes e buscam alavancar a Internet de novas maneiras.

Eles devem olhar o processo end-to-end e manter o foco no consumidor. 
Foram contratados 30 executivos, muitos dos quais foram recrutados de fora da empresa, sendo que muitos tinham altas posições em outras empresas, inclusive em empresas ponto.com. Eles deveriam ter habilidade em trabalhar num ambiente composto por times e ter "expertise" comprovada em Internet, além de conjugar conhecimentos tanto em tecnologia como em negócios.

A próxima preocupação foi com a construção de métricas de negócios, como produtividade, ciclo de tempo, qualidade, tempo de desenvolvimento de produto, ou seja, o $\mathrm{ClO}$ queria desenvolver medidas de $\mathrm{Tl}$ estritamente do ponto de vista de negócios.

A estrutura que vigorou desde 1999 até princípio de 2002 foi:

FIGURA 70: ESTRUTURA ORGANIZACIONAL DA MONTADORA C

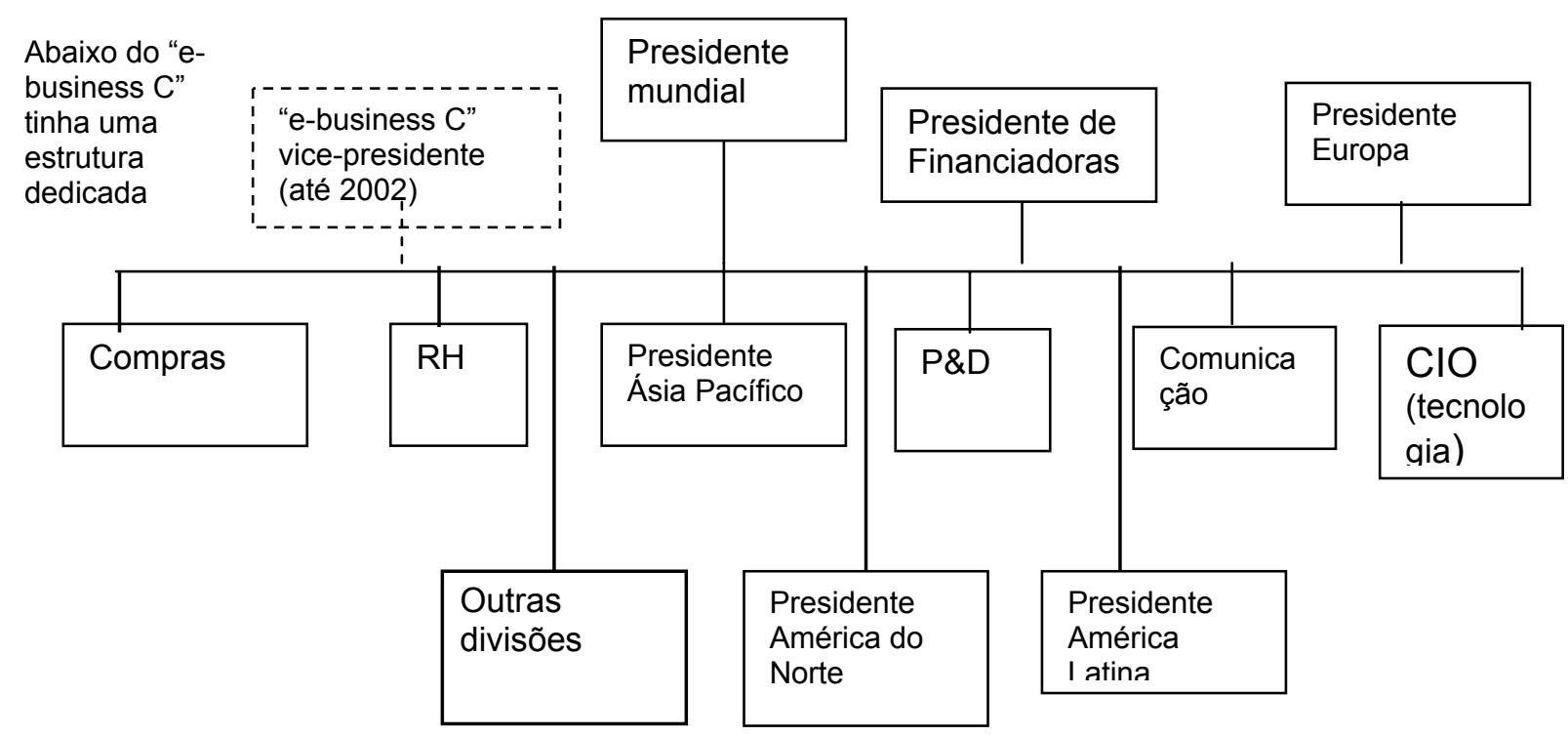

Em novembro de 2001 começou um processo de desmonte da estrutura dedicada "e-business C", no sentido de integrar as atividades de e-business às diversas áreas de negócio.

Em fevereiro de 2002, o CEO da divisão "e-business C" foi nomeado para uma outra divisão da companhia, o desenvolvimento avançado de veículos, área que foi criada a partir de uma reestruturação da empresa, juntando as áreas de 
desenho e desenvolvimento de veículos, realinhando vários times de linhas de veículos e criando a posição de vice-presidente para esse grupo, o de desenvolvimento avançado de veículos, para a qual foi o ex-vice presidente de "e-business C".

O CEO global da empresa afirmava em novembro de 2001 que o desmonte da área não implicava em uma falta de foco em e-business, que continuava a ser prioridade para a empresa.

Porém, com a designação do executivo de e-business para essa nova área, parece haver na empresa uma preocupação mais voltada para produto do que para Internet.

Essa reestruturação, levou à absorção das várias atividades de ebusiness por áreas determinadas: a área de Telemática e as outras atividades do "e-business C" reportam-se diretamente ao presidente da montadora $\mathrm{C}$ da América do Norte.

A estratégia por trás dessa decisão tem a ver com o desejo da empresa em reconfigurar os esforços em desenho, desenvolvimento de produto e engenharia visando perspectivas futuras da liderança da empresa no mercado.

\subsubsection{ESTRUTURA ORGANIZACIONAL NA MONTADORA C: BRASIL}

A estrutura de e-business da montadora C Brasil inserida no organograma da empresa pode ser assim descrita: 


\section{FIGURA 71: ESTRUTURA ORGANIZACIONAL DA MONTADORA C BRASIL E IDENTIFICAÇÃO DAS ÁREAS DE E-BUSINESS INÍCIO DE 2002}

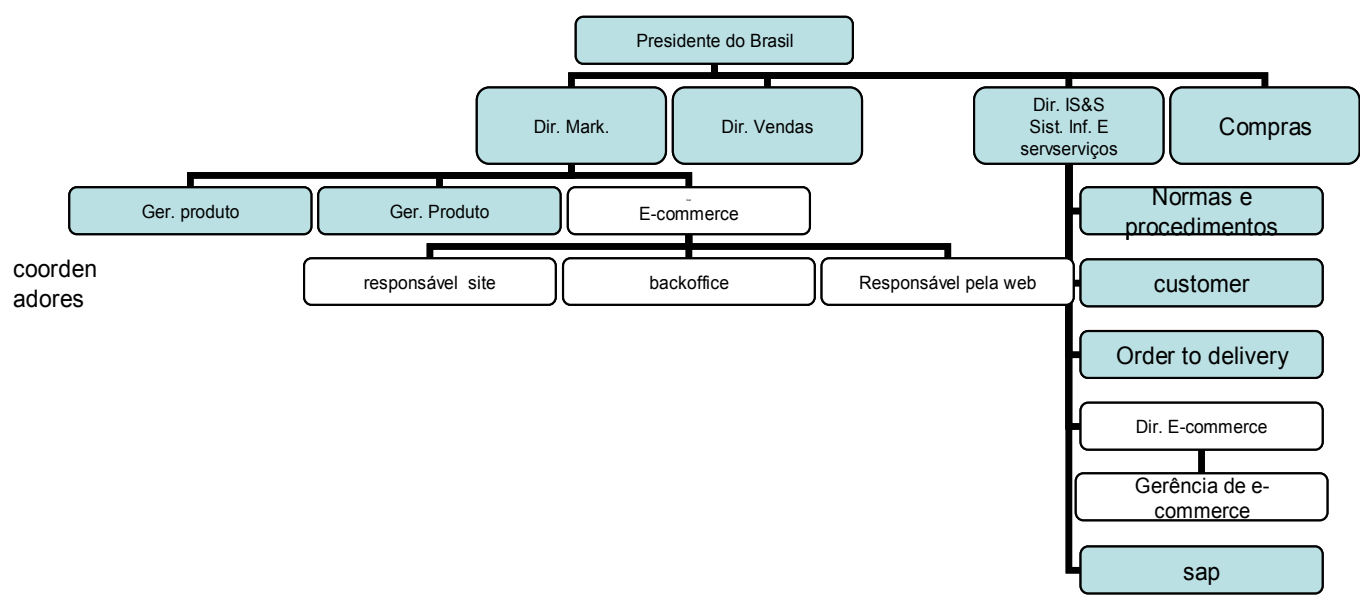

As áreas dedicadas a e-business são as mostradas na figura acima.

Existe uma gerência de e-business totalmente dedicada às atividades de $\mathrm{B} 2 \mathrm{C}$, respondendo para a diretoria de marketing.

Abaixo dessa gerência de e-business existem áreas de staff e técnicas, num total de cerca de dez pessoas.

No lado de $\mathrm{TI}$, existe uma gerência de e-commerce também completamente dedicado a essas atividades.

As outras iniciativas de e-business são exercidas na área de Compras (B2B) porém não tem o volume de negócios gerados pela área B2C.

A estrutura de e-business na área B2C sofreu a seguinte evolução pela empresa:

Em 1998 foi criada uma área de Internet dentro de Mkt estratégico.

Em 1999: criou duas diretorias só para e-business. 


\section{FIGURA 72: ÁREA DE E-BUSINESS DA MONTADORA C BRASIL EM 1999}

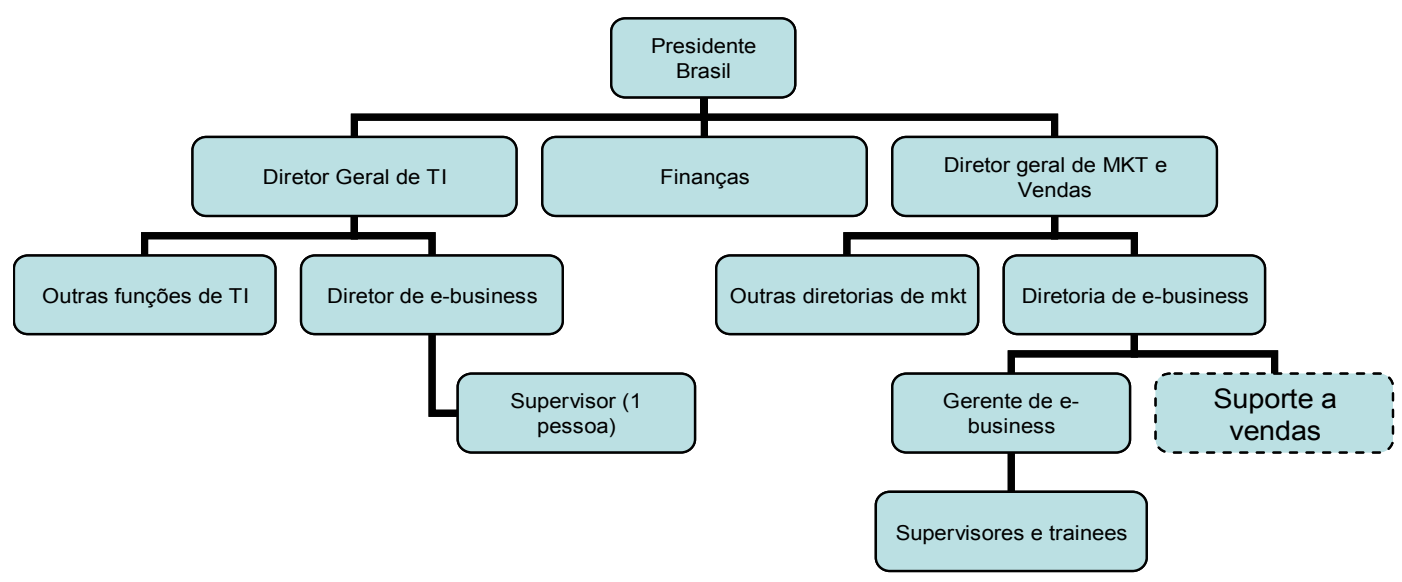

A área tracejada de suporte a vendas indica que no final de 2001 , o diretor de e-business foi promovido para a matriz e essa diretoria foi incorporada à área de suporte a vendas.

A partir desse ano (1999) são criadas duas novas diretorias: diretoria de e-business subordinada ao diretor de TI e diretoria de e-business subordinada a diretoria geral de marketing e vendas.

O diretor de e-business na parte de marketing já era recurso da empresa, era um gerente de marketing, tendo sido realocado para essa área e o diretor de e-business da área de TI foi contratado no mercado, para implantar o projeto de venda de carro popular pela Internet.

A partir de 2001, o diretor de e-business passa a exercer controle sobre a área de suporte a vendas em geral, não só vendas pela Internet.

O gerente de e-business trabalhava numa empresa prestadora de serviço da montadora $\mathrm{C}$, que era prestadora de serviços de $\mathrm{TI}$, já trabalhando na área de negócios e não somente na área técnica de TI. Essa pessoa iniciou na área como supervisor de e-business na estrutura anterior de 1998 e foi promovido para gerente de e-business a partir de 1999. 
Perfil: técnico mas com conhecimento da área de negócios na indústria automobilística e foco na área de marketing e vendas.

-A criação da nova área, dando maior status hierárquico para e-business foi para dar foco para a venda do carro popular pela Internet.

Toda essa nova estrutura surgiu a partir da idéia da venda do novo carro popular pela Internet.

Sobre os passos da transição organizacional: em 1999 lançam o Montadora $\mathrm{C}$ center -portal com informações da indústria automobilística em geral (conteúdo variado). Hoje: carro é o foco-notícias do mundo automobilístico.

Quanto à reformulação organizacional, foram alocados recursos para essa iniciativa, reformulando presença na Internet. Também foi refeito o site da montadora em 1999-criou coisa maior: parte institucional, produtos e notícias gerais.

A iniciativa de criação de nova área dedicada a e-business foi do diretor geral de Mkt e vendas -pois já tinha estratégia de venda pela Internet na matriz, o site "eShop"-era uma idéia pessoal de MKT do Brasil, que confluiu com as iniciativas americanas.

Não chegaram a utilizar o site da matriz: é um site que vê o produto, mas não faz a compra.

Diretor de mkt no Brasil teve a idéia da venda direta e foi aprovado por um comitê executivo: aprovaram a idéia e o orçamento, que foi global-apoio da estrutura "e-business C" da matriz, com pessoas e investimentos:resultou no piloto mundial de e-commerce em vendas diretas.

Em setembro de 2000: primeiro site de e-commerce do mundo: venda do "pop1" (nome fictício). Organograma do projeto "pop1": 


\section{FIGURA 73: ORGANOGRAMA DO PROJETO DE VENDA PELA INTERNET DO CARRO POPULAR MONTADORA C - BRASIL}

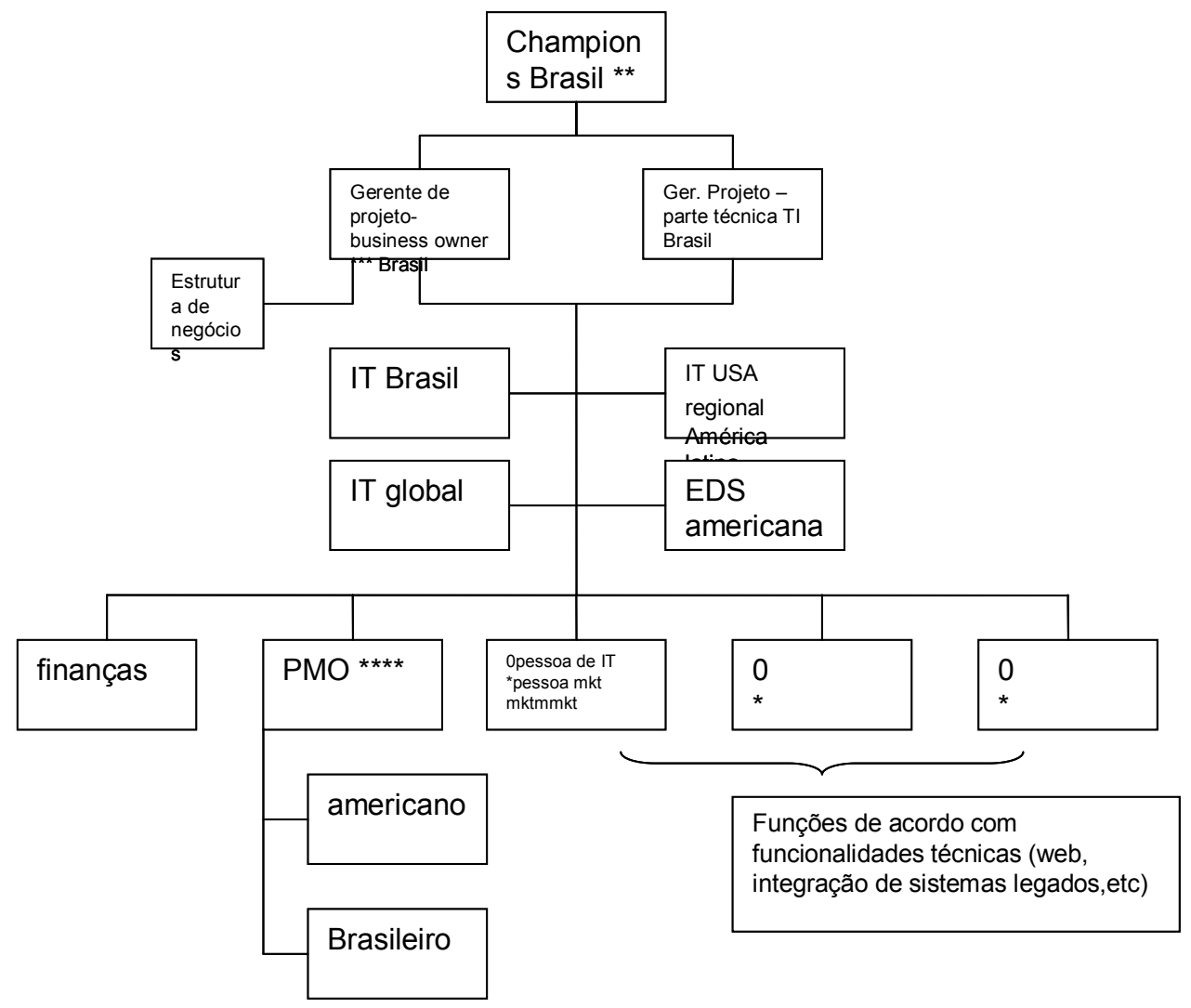

**Os “ champions Brasil” são os “ donos do negócio” , os que tem a responsabilidade, era composto pelo diretor de $\mathrm{TI}$ mais o diretor de Mkt e vendas.

Eles repassavam problemas (se fosse o caso ) para hierarquias superiores (regional e global)

${ }^{* * *} \mathrm{O}$ gerente de projeto Brasil ou business owner dava as diretrizes de negócios, desde qual a foto vai ser colocada no site até o processo todo de venda (toda a parte de processo para o cliente e para a empresa)

${ }^{* * * *} \mathrm{O}$ PMO (program managenment Office) era o gerente de projeto cuja função era integrar as diversas atividades do projeto.

Em cada gerência dedicada a uma determinada funcionalidade, havia um responsável por Ti e um responsável por negócios (mkt) 
0-pessoal de TI-a maioria era terceirizado-fora da empresa

*-pessoal de Mkt-do time da gerência de e-business, que pertencia a área de mkt.

Esse organograma foi colocado em prática no final de 1999 e no segundo semestre de 2000 houve o lançamento do site de vendas, ou seja, em menos de uma ano terminaram o projeto.

Quando terminou esse projeto, a área de business manteve-se como fora concebida e criou-se a área de manutenção em TI (diretor de e-business em TI mais poucas pessoas) para alimentar manutenção.

Houve parceria com a UOL , na parte de comunicação e manutenção do site institucional para os outros carros.

Fenômeno americano: criaram unidade de negócios de e-business para alavancar iniciativas. Agora, "devolveram" as iniciativas de e-business para a área de mkt e unidade de negócios foi extinta.

No Brasil não precisou desse movimento, pois não foi criada iniciativa separada e sim dentro da área de marketing.

Não existe um coordenador de negócios para todas as iniciativas de ebusiness.

Existe uma prospecção de novos produtos de e-business por essa área de e-business subordinada a Marketing, sendo que após o encerramento do projeto a estrutura foi mantida para isso- prospecção e planejamento de novas iniciativas.

No final de 2001-diretor de e-business no Brasil foi promovido para a matriz e área de e-business foi incorporada pela área de suporte a vendas. Existe sinergia das áreas porcausa das vendas pela Internet.

Opinião do gerente de e-business: não tirou foco do e-business, não enfraqueceu a área. Foi questão de não repor pessoa.

Apesar da fusão de diretorias (suporte a vendas mais e-business), a parte de gerência continua a mesma- função mais de prospeç̧ão.

Prioridade das atividades do grupo: é e-business, é a razão de ser e viver do grupo de e-business, porisso não compartilham atividades com outras dentro da área de marketing. 
Precisam de informações das outras áreas: gerência de marca (gerente de produto), área de preços, área de distribuição de veículos (ver que carros vão para onde- quem define quantos carros vão para os centros de distribuição), faturamento e contas a receber, área de vendas.

-o pessoal de e-business é que tenta entender o dia-a-dia das áreas para dar novas sugestões de novos projetos.

\section{Estrutura da área de TI}

Função do grupo de TI em e-business B2B: desenvolver sistemas para as áreas de compras, materiais e exportação e em paralelo realizar as OTD (order to delivery- pedidos de compras).

Sistemas "relacionamento com o fornecedor" foram desenvolvidos a nível mundial , só fez a implantação aqui.

Para implantação de projetos de TI utilizam metodologia desenvolvida na própria empresa pela área de $\mathrm{TI}$.

Objetivo de uso da ferramenta com os fornecedores é uniformização das informações -houve objetivo de economia de custo e velocidade de informações ( a quantificação desses objetivos não foi passada para o Brasil).

Não mensuraram redução de custo, não estimaram rapidez.

Entre as propostas desse sistema para os fornecedores está a agilização de soluções de problemas de qualidade de peças via web, em um sistema de permitirá à montadora informar a falha ao fabricante, que poderá acessar o desenho da peça e programar correções.

Existe uma equipe de TI de 26 pessoas, coordenadas por um diretor de $\mathrm{TI}$ que se concentram no desenvolvimento de estratégias de $\mathrm{TI}$, nos padrões tecnológicos, e no gerenciamento dos projetos, enquanto fornecedores, que empregam cerca de 300 funcionários, tratam de cumprir as metas.

$\mathrm{Na}$ área $\mathrm{B} 2 \mathrm{C}$, de vendas diretas para a Internet, do projeto inicial de implantação, restou uma equipe para parte operacional de hardware-pessoal específico 4 pessoas que ficam constantemente verificando o negócio: preço, 
modelo novo, tomam conta, são terceirizados da EDS-fisicamente na montadora C, para pequenas manutenções.

Grandes mudanças:elabora-se uma equipe de projeto

Pequenas mudanças: " ongoing"

O “ dono" do projeto não é de TI é de MKT, tem uma gerente -bola o negócio em si, as funcionalidades, tem grupo de pessoas que definem em termos de business como deve ser o requerimento e acompanha sistema: novas funcionalidades, melhorias, se está vendendo ou não.

TI: utiliza metodologia de TI para implantação do projeto, acompanhando todas as fases para a implantação.

Divisão em fases:

-Plan phase

-define phase

-design phase

-build phase

-test phase-ITL (integrated test)

ST (system test)

UST (user acceptance test) usuário final

Quando entraram no ITL tinahm 14 parceiros envolvidos

É um projeto corporativo, usa ferramentas corporativas- configurator (configura o veículo)

-Locator (ver se ele existe)

-financing(financiamentos)

-Content management(ferramenta que permite que mude os programas sem mudar o código).

O diretor de $\mathrm{TI}$ responsável pelas vendas diretas e seu gerente coordenam rede terceirizada.: desenvolvimento de sites e manutenção.

Atividades só relacionadas a e-commerce.

Estrutura de TI super enxuta: trabalha com terceirização.

Atualmente já está formalizada a área de e-commerce no organograma da empresa (conforme já foi descrita no início desse item).

E-business surgiu da área de MKT mas também envolve as áreas de : 
-produção

-logística

-vendas

-contabilidade (faturamento)

-Pois toda a produção da nova fábrica (que é mais flexível e trabalha com consórcio modular) era para a Internet (setembro de 2000: lançamento)

Matriz Indicou Project manager officer (PMO) que comandava de lá o que fosse preciso. Como era um projeto global, ficou hospedado lá: onde fica, qual equipamento, qual configuração, com quem falar quando der problema, estratégia para manutenção: quem providenciava era PMO nomeado por "ebusiness C".

Quanto ao projeto do carro popular: função do diretor de e-business de $\mathrm{TI}$ é: tecnologia-equipamento, operação do sistema, manutenção , desenvolvimento dos códigos.

É quem realiza as funcionalidades pedidas pelo pessoal do negócio.

Há sempre o trabalho em grupo, para as outras áreas definirem necessidades.

Durante fase de projeto, aquele organograma passou a funcionar como uma empresa.

As pessoas da montadora $\mathrm{C}$ alocadas exclusivamente para o projeto,

Metodologia: divide projeto em fases, para cada fase indicadores de sucesso da fase para poder avançar, a forma de como documentar o sistema, como escreve as funcionalidades, como documentar as mudanças.

Aspecto importante: bom, sistema de gerenciamento para poder gerenciar tantas pessoas, ferramenta para controle: Project da Microsoft.

Fizeram instrumento de avaliação de encaminhamento do projeto, 15 parceiros diferentes, que depois que site funcionou continuam: Credicard, banco da montadora $C$, sap-sistema integrado que contabiliza toda a venda é o SAP, com o site esses parceiros tem que operar.

Estrutura atual do grupo de e-business B2C da montadora C Brasil: 


\section{FIGURA 74: ESTRUTURA ORGANIZACIONAL DO GRUPO DE E-BUSINESS} B2C DA MONTADORA C - BRASIL 2002

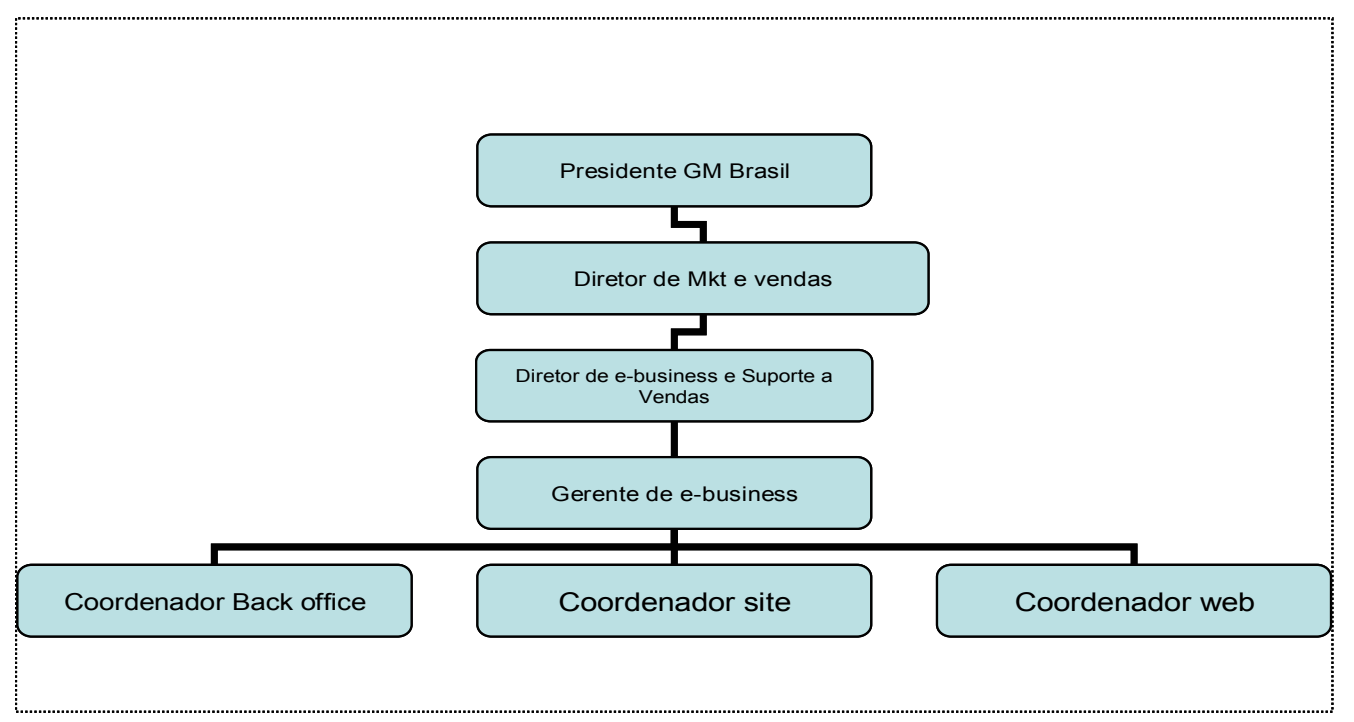

Quanto à autoridade para tomada de decisões, o gerente de ebusiness tem autoridade para algum nível de tomada de decisão. Depois é acionado o nível de diretoria, board, e assim por diante.

Depende do tipo de decisão que é requerida.

\subsubsection{QUADRO RESUMO PARA ANALISAR OS DADOS OBTIDOS SOBRE A VERIFICAÇÃO DA EXISTÊNCIA DE MODELOS DE NEGÓCIO PARA E-BUSINESS}

Esse ítem traz vários quadros resumo que serviram para analisar os dados obtidos sobre os modelos de negócio para e-business encontrados, algumas das análises apresentando as dimensões ressaltadas do modelo de pesquisa: caracterização do modelo, alguns resultados e papel da alta direção para os casos das filiais brasileiras e alguns comentários sobre as matrizes.

Quando não foram encontrados modelos de negócio para conduzir as atividades de e-business, foi feito algum comentário a respeito.

Nesse item serão apresentados diversos quadros e no ítem seguinte, alguns comentários serão elaborados para comentar os quadros apresentados

Os quadros 13 (matriz) e 14 (filiais) fazem a representação gráfica dos modelos de negócio encontrados para conduzir o e-business na empresa. 
Os quadros 15 e 16 a seguir analisam as características do modelo de negócio encontrado (ou não) através de alguns aspectos de suas dimensões: conceito, capacitações, valor.

Em seguida o quadro 17 levanta alguns resultados obtidos pelo uso de atividade de e-business para as matrizes e o quadro 18 para as filiais.

O papel da alta administração é apresentado nos quadros 19 e 20.

Finalmente o quadro 21 apresenta a comparação de alguns aspectos relevantes entre matrizes e filiais, quanto à adoção de modelo de negócio para e-business. 


\section{TABELA 13: REPRESENTAÇÃO GRÁFICA DOS MODELOS DE E-BUSINESS} IDENTIFICADOS PARA AS MATRIZES DAS MONTADORAS

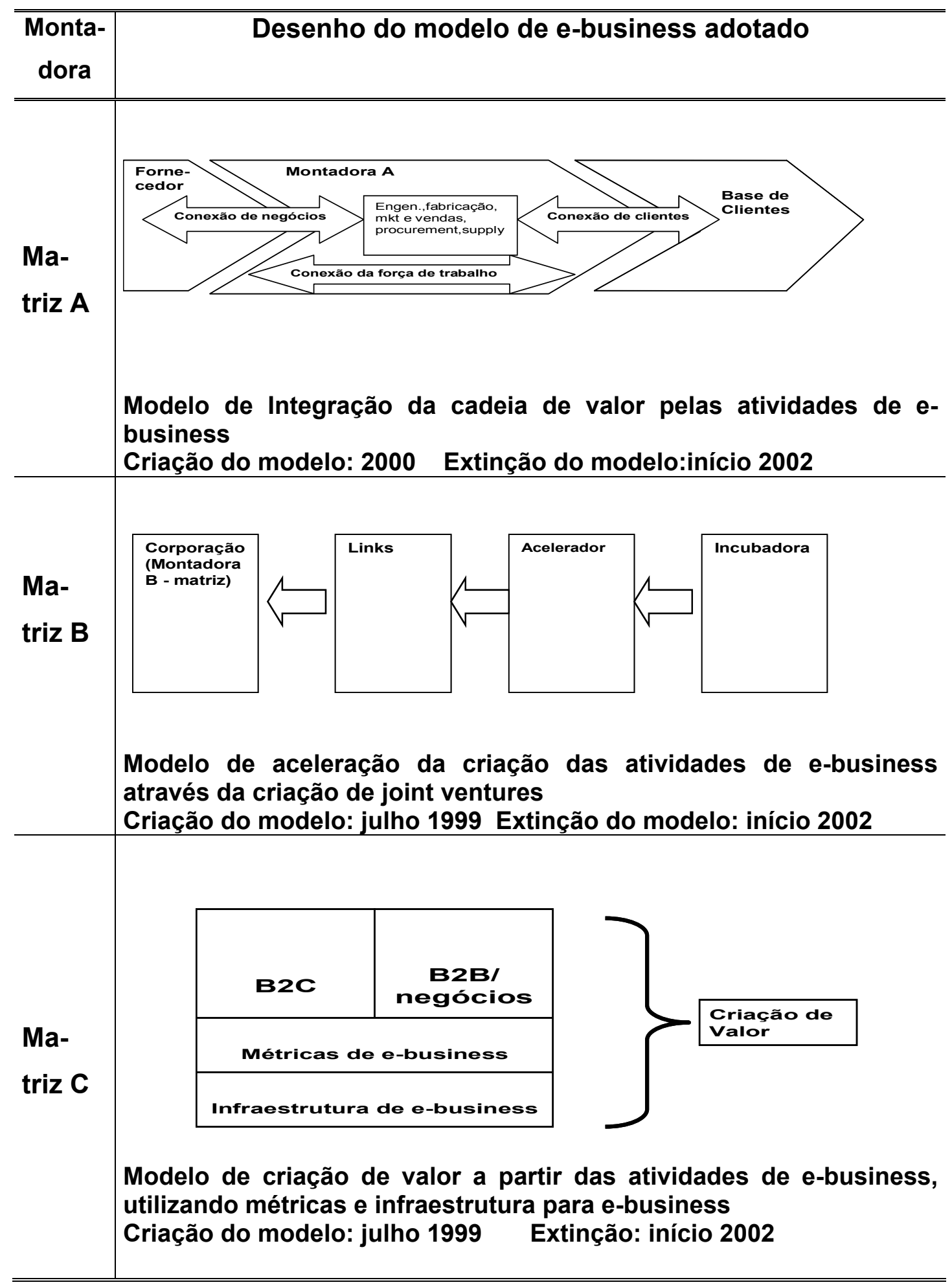


TABELA 14: REPRESENTAÇÃO GRÁFICA DOS MODELOS DE E-BUSINESS IDENTIFICADOS PARA AS FILIAIS BRASILEIRAS DAS MONTADORAS

\begin{tabular}{|c|c|}
\hline $\begin{array}{l}\text { Monta- } \\
\text { dora }\end{array}$ & Desenho do modelo de e-business adotado \\
\hline $\begin{array}{l}\text { Filial } \\
\text { A }\end{array}$ & $\begin{array}{l}\text { Modelo de Integração da cadeia de valor pelas atividades de e-business, ênfase } \\
\text { na conexão de negócios (seta sombreada) na figura acima. } \\
\text { Criação do modelo: } 2001 \text {. Extinção do modelo: } 2003 \text { (previsto) }\end{array}$ \\
\hline $\begin{array}{l}\text { Filial } \\
\text { B }\end{array}$ & $\begin{array}{l}\text { Não utilizou modelo de negócio para conduzir as atividades de e-business. } \\
\text { Houve uma verba vinda da matriz e qualquer área corporativa da empresa que } \\
\text { quisesse implantar projeto de e-business, apresentava o projeto e se fosse } \\
\text { aprovado por um "board" executivo, implantava. } \\
\text { Início da verba para e-business vinda da matriz: final de } 1999 \\
\text { Extinção da verba: final de } 2001 \text {. }\end{array}$ \\
\hline $\begin{array}{l}\text { Filial } \\
\text { C }\end{array}$ & \begin{tabular}{|l|l|}
\multicolumn{1}{|c|}{ B2C } \\
Métricas de e-business \\
\cline { 1 - 2 } Infraestrut. E-business \\
Modelo de criação de valor a partir das atividades de e-business voltadas para \\
O consumãão de \\
Valor \\
e-business. B2B: sem modelo, atividades isoladas sem direcionamento por \\
modelo de negócio. \\
Criação do modelo: final 1999 extinção: sem previsão
\end{tabular} \\
\hline
\end{tabular}




\section{TABELA 15: DESCRIÇÃO DO MODELO DE NEGÓCIO DAS MATRIZES PARA E-BUSINESS ATRAVÉS DAS DIMENSÕES: CONCEITO, CAPACITAÇÕES, VALOR}

\begin{tabular}{|c|c|c|c|}
\hline $\begin{array}{l}\text { Mont } \\
\text { a- } \\
\text { dora }\end{array}$ & Conceito do modelo de negócio & $\begin{array}{c}\text { Capacitações do } \\
\text { modelo de negócio }\end{array}$ & $\begin{array}{c}\text { Valor entregue pelo } \\
\text { modelo }\end{array}$ \\
\hline $\begin{array}{l}\text { Ma- } \\
\text { triz } \\
\text { A }\end{array}$ & $\begin{array}{l}\text { Foi usado o conceito de cadeia de valor para } \\
\text { definir os componentes do modelo de } \\
\text { negócio: conexão com o consumidor, } \\
\text { conexão negócios, conexão força de } \\
\text { trabalho. E-business como "conector" das } \\
\text { atividades da empresa ao longo da cadeia de } \\
\text { valor, para fazer melhor conexão ao cliente. } \\
\text { Objetivo da iniciativa: tornar a empresa } \\
\text { mais rápida, mais eficiente e mais } \\
\text { competitiva através de todas as áreas, desde } \\
\text { compras a vendas, alavancando iniciativas } \\
\text { de e-business. }\end{array}$ & $\begin{array}{l}\text { Foi utilizada infraestrutura } \\
\text { de TI da empresa, que foi } \\
\text { atualizada com } \\
\text { componentes web. }\end{array}$ & $\begin{array}{l}\text { Maior conexão com o } \\
\text { cliente final, e dentro da } \\
\text { empresa, com maior } \\
\text { rapidez, menor custo, e } \\
\text { maior eficiência. }\end{array}$ \\
\hline $\begin{array}{l}\text { Ma- } \\
\text { triz } \\
\text { B }\end{array}$ & $\begin{array}{l}\text { Foi usado o conceito de acelerador de } \\
\text { criação de iniciativas de e-business através } \\
\text { do uso de joint ventures. } \\
\text { Sua missão era reformular a montadora B de } \\
\text { uma empresa manufatureira para uma "Web- } \\
\text { savy" (inteligência em } \\
\text { web"),supercapacitada tecnologicamente } \\
\text { voltada totalmente para mercado e } \\
\text { consumidor, tornando-se a primeira empresa } \\
\text { em e-business do setor automotivo, com a } \\
\text { geração de muitas iniciativas de e-business } \\
\text { com foco no consumidor. Criado modelo } \\
\text { para coordenar e alavancar iniciativas de e- } \\
\text { business. Objetivo:ser "build-to-order" }\end{array}$ & $\begin{array}{l}\text { As capacidades } \\
\text { necessárias foram obtidas } \\
\text { dentro e fora da empresa, } \\
\text { com a utilização de joint } \\
\text { ventures para aquisição } \\
\text { de conhecimento sobre } \\
\text { Internet. } \\
\text { Recrutou executivo para } \\
\text { dirigir unidade de negócio } \\
\text { dedicada a e-business de } \\
\text { fora da empresa. Não } \\
\text { está evidente no modelo a } \\
\text { necessidade de } \\
\text { infraestrutura de TI. }\end{array}$ & $\begin{array}{l}\text { Melhorar o processo de } \\
\text { compras, enriquecer a } \\
\text { experiência do } \\
\text { consumidor e possuidor } \\
\text { de veículo de qualquer } \\
\text { marca da montadora B, o } \\
\text { B2B na empresa serviria } \\
\text { para cortar as perdas e } \\
\text { desperdícios na cadeia de } \\
\text { suprimentos e com o B2C } \\
\text { conectaria a cadeia de } \\
\text { suprimentos diretamente } \\
\text { com o comprador do carro }\end{array}$ \\
\hline $\begin{array}{l}\text { Ma- } \\
\text { triz } \\
\text { C }\end{array}$ & $\begin{array}{l}\text { Foi usado o conceito de entrega de valor ao } \\
\text { cliente através do uso de atividades B2B e } \\
\text { B2C, com a utilização de métricas bem } \\
\text { definidas para medir resultados e utilização } \\
\text { de uma infraestrutura de } \mathrm{TI} \text { adequada às } \\
\text { necessidades do e-business para melhor } \\
\text { conectar-se ao cliente. } \\
\text { Objetivo do modelo: coordenar e alavancar } \\
\text { iniciativas de e-business. Modelo deixa clara } \\
\text { necessidade de infr.TI }\end{array}$ & $\begin{array}{l}\text { Buscou capacidades } \\
\text { dentro e fora da empresa, } \\
\text { realocando executivos } \\
\text { internamente à empresa } \\
\text { para unidade de negócio } \\
\text { dedicada à e-business. } \\
\text { Usou joint ventures para } \\
\text { aquisição r de } \\
\text { conhecimento de Internet. }\end{array}$ & $\begin{array}{l}\text { Alavancar a "expertise in- } \\
\text { house"; fazer do e- } \\
\text { business o responsável } \\
\text { por uma porção da } \\
\text { criação de valor do } \\
\text { produto para o } \\
\text { consumidor. Menor custo, } \\
\text { maior rapidez, melhor } \\
\text { qualidade, crescimento } \\
\text { das receitas, liderança. }\end{array}$ \\
\hline
\end{tabular}




\section{TABELA 16: DESCRIÇÃO DO MODELO DE NEGÓCIO DAS FILIAIS BRASILEIRAS PARA E-BUSINESS ATRAVÉS DAS DIMENSÕES: CONCEITO, CAPACITAÇÕES, VALOR}

\begin{tabular}{|c|c|c|c|}
\hline $\begin{array}{l}\text { Monta- } \\
\text { dora }\end{array}$ & Conceito do modelo de negócio & $\begin{array}{c}\text { Capacitações do } \\
\text { modelo de negócio }\end{array}$ & $\begin{array}{l}\text { Valor entregue } \\
\text { pelo modelo }\end{array}$ \\
\hline $\begin{array}{l}\text { Filial } \\
\text { A }\end{array}$ & $\begin{array}{l}\text { No Brasil o modelo fornecido pela matriz } \\
\text { está sendo usado como instrumento para } \\
\text { sensibilizar a alta administração da } \\
\text { empresa quanto aos benefícios do e- } \\
\text { business: para isso, existe um foco nas } \\
\text { atividades B2B que apresentam } \\
\text { resultados mais facilmente mensuráveis } \\
\text { (diminuição de custo, p. ex. num leilão } \\
\text { eletrônico). O objetivo do uso do modelo é } \\
\text { alavancar atividades de e-business na } \\
\text { empresa. }\end{array}$ & $\begin{array}{l}\text { Foi utilizada infraestrutura de } \\
\text { TI da empresa, que foi } \\
\text { atualizada com componentes } \\
\text { web. } \\
\text { Quanto às pessoas, foram } \\
\text { realocadas de outras áreas } \\
\text { da empresa. O único } \\
\text { elemento de fora da filial, foi o } \\
\text { diretor de e-business, vindo } \\
\text { da matriz }\end{array}$ & Diminuição de custos \\
\hline $\begin{array}{l}\text { Filial } \\
\text { B }\end{array}$ & $\begin{array}{l}\text {-Não utilizaram nenhum modelo de } \\
\text { negócio para conduzir as atividades de e- } \\
\text { business. } \\
\text {-Modo "informal" de imitar o modelo } \\
\text { acelerador de iniciativas de e-business } \\
\text { usado pela matriz: a matriz investiu uma } \\
\text { soma alta na filial B destinada a } \\
\text { investimentos em atividades de e- } \\
\text { business. -Toda área que tivesse projetos } \\
\text { em e-business, receberia uma verba para } \\
\text { implantá-lo. "Informalmente" tal ação } \\
\text { incentivou a aceleração de criação de } \\
\text { iniciativas: em } 2001 \text { havia cerca de } 120 \\
\text { projetos de e-business em andamento. } \\
\text { Porém, não foi criado nenhum modelo de } \\
\text { negócio que orientasse essas iniciativas } \\
\text { segundo algum conceito. }\end{array}$ & $\begin{array}{l}\text { Apesar de não haver um } \\
\text { modelo orientandor as } \\
\text { atividades de e-business, } \\
\text { essas atividades utilizaram } \\
\text { capacidades necessárias } \\
\text { obtidas dentro da empresa, } \\
\text { com realocação da mão-de- } \\
\text { obra. Foram feitas algumas } \\
\text { parcerias com empresas de } \\
\text { Internet. } \\
\text { Utilizaram TI da empresa }\end{array}$ & $\begin{array}{l}\text { Sem modelo } \\
\text { conduzindo } \\
\text { atividades de e- } \\
\text { business implantadas, } \\
\text { não houve a definição } \\
\text { de criação de valor } \\
\text { especificada. } \\
\text { Cada atividade } \\
\text { entregava um valor } \\
\text { diferente para a área } \\
\text { na qual foi gerada. } \\
\text { Muitas vezes esse } \\
\text { valor criado não ficou } \\
\text { claro para a alta } \\
\text { administração da } \\
\text { empresa. }\end{array}$ \\
\hline $\begin{array}{l}\mathrm{Fi} \\
\mathrm{C}\end{array}$ & $\begin{array}{l}\text { Foi usado o conceito de entrega de valor } \\
\text { ao cliente através do uso de atividades } \\
\mathrm{B} 2 \mathrm{C} \text {, com a utilização de métricas bem } \\
\text { definidas para medir resultados e } \\
\text { utilização de uma infraestrutura de TI } \\
\text { adequada às necessidades do e-business } \\
\text { para melhor conectar-se ao cliente. O } \\
\text { conceito básico utilizado nesse modelo foi } \\
\text { de venda direta ao cliente. Atividades B2B } \\
\text { não usam conceito de modelo de negócio, } \\
\text { são atividades sem coordenação central. }\end{array}$ & $\begin{array}{l}\text { Buscou capacidades dentro e } \\
\text { fora da empresa, realocando } \\
\text { executivos dentro da empresa } \\
\text { para área de negócio } \\
\text { dedicada à e-business. } \\
\text { Contratou especialista de fora } \\
\text { da empresa em TI para } \\
\text { diretoria de TI voltada a e- } \\
\text { business. Estrut. de } \mathrm{TI} \\
\text { terceirizada. }\end{array}$ & $\begin{array}{l}\text { Geração de receitas } \\
\text { pela venda direta; } \\
\text { maior e melhor } \\
\text { relacionamento com o } \\
\text { cliente; maior rapidez } \\
\text { nos processos, } \\
\text { diminuição de custos. }\end{array}$ \\
\hline
\end{tabular}




\section{TABELA 17: ALGUNS RESULTADOS OBTIDOS PELO USO DE MODELO DE NEGÓCIO PARA ATIVIDADES DE E-BUSINESS PELAS MATRIZES DAS MONTADORAS}

\begin{tabular}{|c|c|c|c|}
\hline $\begin{array}{l}\text { Mon } \\
\text { tado } \\
r\end{array}$ & $\begin{array}{l}\text { Compon. } \\
\text { modelo } \\
\text { de neg. }\end{array}$ & $\begin{array}{l}\text { Ferramentas de } \\
\text { e-business }\end{array}$ & Alguns resultados \\
\hline \multirow[t]{4}{*}{$\begin{array}{l}\text { Ma- } \\
\text { triz }\end{array}$} & $-B 2 B$ & $\begin{array}{l}\text { e-procurement, e-supply, } \\
\text { e-engineering,e-ordering }\end{array}$ & $\begin{array}{l}\text {-redução no tempo do pedido de até } 80 \% \text {, } \\
\text {-redução de tempo para comunicação entre fornecedor } \\
\text { eempresa em } 92 \% \text {, redução tempo do processam. do pedido } \\
\text { de } 40 \text { dias para } 12 \text { dias } \\
\text {-Identificação de gargalos para medidas preventivas } \\
\text {-Evita excesso de capacidade } \\
\text {-Diminuição do uso de papel } \\
\text {-documentos transparentes para todas conexões de negócio }\end{array}$ \\
\hline & $-B 2 C$ & -sites institucionais & $\begin{array}{l}-50 \% \text { dos clientes vêem informações no site antes da compra } \\
-20 \text { milhões de visitas às páginas por mês }\end{array}$ \\
\hline & $-B 2 \mathrm{~V}$ & -Telemática & -avanços tecnológicos \\
\hline & $-B 2 E$ & -portal do funcionário & -oferta de serviços \\
\hline \multirow{4}{*}{$\begin{array}{l}\text { Ma- } \\
\text { triz }\end{array}$} & $-B 2 B$ & $\begin{array}{l}\text {-Exchange própria } \\
\text {-Covisint } \\
\end{array}$ & -Diminuição de custo nas atividades de e-procurement \\
\hline & $-B 2 C$ & $\begin{array}{l}\text {-venda direta } \\
\text {-site instititucional } \\
\text {-site dealer } \\
\text {-call center }\end{array}$ & $\begin{array}{l}\text {-melhor comunicação com o consumidor } \\
\text {-aumento dos "leads" junto aos dealers }\end{array}$ \\
\hline & $-B 2 E$ & 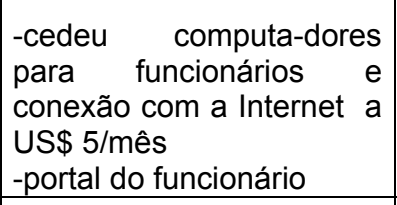 & -Melhor fluxo de informações entre funcionários \\
\hline & $-B 2 \mathrm{~V}$ & -telemática & -avanços tecnológicos, informações obtidas por satélite \\
\hline \multirow{4}{*}{$\begin{array}{l}\text { Ma- } \\
\text { triz }\end{array}$} & B2B & $\begin{array}{l}\text {-Exchange própria } \\
\text {-Covisint }\end{array}$ & -economias em compras \\
\hline & B2C & $\begin{array}{l}\text {-venda direta } \\
\text {-call center } \\
\text {-site instit. }\end{array}$ & $\begin{array}{l}\text {-de } 40 \text { call centers passou a } 3 \text { callcenters } \\
\text {-US\$ } 8 \text { milhões vendas diretas } \\
-19 \text { mil visitas/hora aos sites institucionais } \\
-79 \text { mil vendas conquistadas de outros pelo site } \\
-50 \% \text { vêem sites antes da compra }\end{array}$ \\
\hline & B2E & -portal do funcionário. & $\begin{array}{l}\text {-Treinamento on line-economia de US\$ } 4 \text { milhões. } \\
-8 \text { mil funcionários fazendo MBA online }\end{array}$ \\
\hline & B2V & -telematica & $\begin{array}{l}\text {-um milhão de pessoas se inscreveram para ter telemática } \\
\text { em seus carros }\end{array}$ \\
\hline
\end{tabular}




\section{TABELA 18: ALGUNS RESULTADOS OBTIDOS PELO USO DE ATIVIDADES DE E-BUSINESS EXECUTADAS PELAS FILIAIS BRASILEIRAS DAS MONTADORAS}

\begin{tabular}{|c|c|c|c|}
\hline $\begin{array}{l}\text { Mon- } \\
\text { tadora }\end{array}$ & $\begin{array}{l}\text { Componentes } \\
\text { do modelo } \\
\text { de e-business }\end{array}$ & $\begin{array}{l}\text { Ferramentas de e- } \\
\text { business }\end{array}$ & Alguns resultados \\
\hline \multirow{4}{*}{$\begin{array}{l}\text { Filial } \\
\text { A } \\
\text { Brasil }\end{array}$} & $-B 2 B$ & $\begin{array}{l}\text {-leilões } \\
\text {-projeto de uso de } \\
\text { catálogos }\end{array}$ & $\begin{array}{l}\text {-economia de até } 50 \% \text { nos leilões } \\
\text {-Foram realizados cerca de } 20 \text { leilões desde a } \\
\text { criação do modelo de e-business }\end{array}$ \\
\hline & $-B 2 C$ & $\begin{array}{l}\text {-relaciona-mento com } \\
\text { dealer } \\
\text {-site institucional } \\
\text {-call center }\end{array}$ & $\begin{array}{l}\text {-100 mil páginas vistas (dealer) } \\
\text {-ligação dealer com empresa (extranet)-20 mil } \\
\text { acessos/mês }\end{array}$ \\
\hline & $-B 2 V$ & -Telemática & $\begin{array}{l}\text {-segurança de caminhões, rastreamento de } \\
\text { cargas }\end{array}$ \\
\hline & $-B 2 E$ & -portal do funcionário & -Intranet com informações e serviços \\
\hline \multirow[t]{3}{*}{$\begin{array}{l}\text { Filial } \\
\text { B } \\
\text { Brasil }\end{array}$} & $-B 2 B$ & $\begin{array}{l}\text {-catálogos } \\
\text {-cotações } \\
\text {-leilões } \\
\text {-relacionamento com } \\
\text { dealers }\end{array}$ & $\begin{array}{l}\text {-economia de custo na compra de materiais por } \\
\text { leilões. } \\
\text {-economia de papel nas transações } \\
\text {-economia de tempo pelos compradores }\end{array}$ \\
\hline & $-B 2 C$ & $\begin{array}{l}\text {-venda direta } \\
\text {-site institucional. } \\
\text {-site dealer }\end{array}$ & $\begin{array}{l}\text {-Receitas acima do esperado c/ venda dir. } \\
\text {-melhoria do relacionamento com dealer: } \\
\text { treinamentos, avaliações, informações }\end{array}$ \\
\hline & $-B 2 E$ & $\begin{array}{lr}\text {-intranet } & \text { para } \\
\text { informações } & \mathrm{e} \\
\text { serviços } & \\
\end{array}$ & -melhoria da comunicação dentro da empresa \\
\hline \multirow[t]{2}{*}{$\begin{array}{l}\text { Filial } \\
\text { C } \\
\text { Brasil }\end{array}$} & B2B & $\begin{array}{l}\text {-Exchange própria } \\
\text {-Covisint } \\
\text { (ambas plataformas } \\
\text { desenvolvidas fora } \\
\text { Brasil) }\end{array}$ & $\begin{array}{l}\text {-site de relacionamento com fornecedor } \\
\text { desenvolvido pela matriz. Usuário de algumas } \\
\text { ferramentas. } \\
\text {-3 leilões usando Covisint em } 2002 \text { (pouco } \\
\text { usado ainda) }\end{array}$ \\
\hline & B2C & $\begin{array}{l}\text {-venda direta } \\
\text { (solução totalmente } \\
\text { criada no Brasil }-1^{\text {a }} \text { no } \\
\text { mundo) }\end{array}$ & $\begin{array}{l}\text {-sucesso de implantação do modelo de vendas } \\
\text { diretas pela Internet de carro popular. } \\
\text { Ultrapassou expectativa de vendas e de } \\
\text { repercussão, que foi mundial. Pioneira nessa } \\
\text { iniciativa mundialmente. }\end{array}$ \\
\hline
\end{tabular}




\section{TABELA 19: PAPEL DA ALTA ADMINISTRAÇÃO NA ADOÇÃO DE MODELO DE NEGÓCIO PARA DESENHO E IMPLANTAÇÃO DE E- BUSINESS DAS MATRIZES DAS MONTADORAS}

\begin{tabular}{|c|c|}
\hline Montadora & $\begin{array}{c}\text { Comprometimento da alta direção com o } \\
\text { uso do modelo }\end{array}$ \\
\hline Matriz A & $\begin{array}{l}\text {-Alto comprometimento da alta direção. } \\
\text {-Criação de e-business council para } \\
\text { tomada de decisões sobre investimentos }\end{array}$ \\
\hline Matriz B & $\begin{array}{l}\text { Total comprometimento da alta direção. } \\
\text { Das } 3 \text { montadoras, foi a que teve CEO } \\
\text { global totalmente focado em investimentos } \\
\text { em e-business. } \\
\text { Presidente da unidade de negócios de e- } \\
\text { business também era executivo totalmente } \\
\text { comprometido com e-business. Seu maior } \\
\text { intuito era acelerar a geração de iniciativas } \\
\text { de e-business. Queria transformar a } \\
\text { montadora C numa empresa "build-to- } \\
\text { order" através do uso da Internet. } \\
\text { Em } 2001 \text { mudam o CEO global e o CEO } \\
\text { da unidade de negócio para e-business, } \\
\text { numa tentativa de dar mais foco em } \\
\text { obtenção de resultados. }\end{array}$ \\
\hline Matriz C & $\begin{array}{l}\text { Grande comprometimento da alta } \\
\text { administração; CEO global responsável } \\
\text { por iniciativa de coordenar atividades. } \\
\text { CEO da unidade de negócio de e-business } \\
\text { comprometido com modelo de e-business. } \\
\text { CEO global declarou em 1999:"Internet } \\
\text { muda processos de negócio". } \\
\text { No final de 2001, o mesmo CEO:"Internet é } \\
\text { ferramenta para melhorar o que realmente } \\
\text { sabemos fazer :produzir e vender carros" }\end{array}$ \\
\hline
\end{tabular}




\section{TABELA 20: PAPEL DA ALTA ADMINISTRAÇÃO NA ADOÇÃO DE MODELO DE NEGÓCIO PARA DESENHO E IMPLANTAÇÃO DE E- BUSINESS DAS FILIAIS DAS MONTADORAS}

\begin{tabular}{|c|c|}
\hline $\begin{array}{c}\text { Montad } \\
\text { ora }\end{array}$ & Comprometimento da alta direção com o uso do modelo \\
\hline $\begin{array}{c}\text { Filial } \\
\text { brasi- } \\
\text { leira } \\
\text { A }\end{array}$ & $\begin{array}{l}\text { A matriz da montadora A determinou que sua filial deveria alavancar suas atividades de e- } \\
\text { business, como foi feito na matriz. Para isso, enviou um diretor de e-business para o Brasil, } \\
\text { para que ele montasse uma estrutura a partir do modelo de negócio para e-business na } \\
\text { matriz. Assim, o comprometimento da matriz com o desenvolvimento de atividades de e- } \\
\text { business em sua filial brasileira é alto. } \\
\text { Porém, a alta direção da empresa A no Brasil não se encontra no mesmo nível de } \\
\text { envolvimento: muitos diretores de áreas corporativas da empresa num primeiro momento } \\
\text { desconheciam quais seriam os benefícios do uso de e-business em suas áreas, daí certo } \\
\text { desinteresse em seu uso. A área mais comprometida com e-business foi área de Compras, } \\
\text { por vislumbrar benefícios imediatos de redução de custos com uso de ferramentas de e- } \\
\text { business. Por outro lado, os compradores estão resistentes à mudança. Desse modo, ainda é } \\
\text { baixo o comprometimento da alta direção da empresa A filial com o modelo de negócio para } \\
\text { e-business. }\end{array}$ \\
\hline $\begin{array}{c}\text { Filial } \\
\text { brasi- } \\
\text { leira } \\
\text { C }\end{array}$ & $\begin{array}{l}\text { Não foi utilizado modelo de negócio para e-business, o que já dá um exemplo sobre o } \\
\text { comprometimento da alta direção da empresa com o modelo. Como a matriz não exigiu nenhuma } \\
\text { ação específica por parte de sua filial para a execução das atividades, apenas declarou que a } \\
\text { verba era destinada a criar atividades de e-business, não estabelecendo nenhuma regra, o } \\
\text { comprometimento da matriz é médio, apenas esperam resultados. Do mesmo modo, os diretores de } \\
\text { área da montadora B no Brasil apenas estão interessados nos resultados que o e-business possa } \\
\text { trazer, não se envolvendo de maneira geral nos projetos e acompanhamento de projetos de e- } \\
\text { business. Exceção é feita ao diretor de marketing estratégico, que é quem coordena a alocação da } \\
\text { verba destinada à e-business juntamente com seu supervisor, que é bem interessado e até propôs a } \\
\text { implantação de algum modelo de negócio para direcionar as atividades de e-business, o que foi } \\
\text { recusado por falta de recursos, segundo a alta direção. Portanto, de maneira geral, baixo } \\
\text { comprometimento da alta direção com atividades de e-business por parte da alta direção da } \\
\text { empresa. }\end{array}$ \\
\hline $\begin{array}{l}\text { Filial } \\
\text { Brasi- } \\
\text { leira } \\
\text { C }\end{array}$ & $\begin{array}{l}\text { Alto comprometimento da alta direção da empresa brasileira C com a adoção de um modelo de e- } \\
\text { business. Aliás, partiu do diretor de marketing do Brasil a idéia do desenvolvimento de um modelo } \\
\text { de negócio voltado para atividades B2C, mais especificamente, para a venda direta de veículos } \\
\text { usando a Internet. Esse diretor foi totalmente apoiado pela matriz, pois essa iniciativa estava } \\
\text { alinhada com o objetivo estratégico de aumentar as vendas de carros populares, para melhorar o } \\
\text { posicionamento da montadora C brasileira nesse importante segmento de mercado no Brasil, no } \\
\text { qual não era competitiva. Desse modo, houve grande comprometimento da alta direção do Brasil } \\
\text { com o modelo de venda direta e da alta administração da matriz, que contribuiu com recursos } \\
\text { humanos e financeiros. }\end{array}$ \\
\hline
\end{tabular}




\section{TABELA 21: COMPARAÇÃO DE ALGUNS ASPECTOS ENTRE MATRIZES E FILIAIS DAS MONTADORAS}

\begin{tabular}{|c|c|c|c|}
\hline Aspectos & Matriz A X Filial A & Matriz B X Filial B & Matriz C X Filial C \\
\hline $\begin{array}{l}\text { Conceito do } \\
\text { Modelo de } \\
\text { Negócio para } \\
\text { e-business }\end{array}$ & $\begin{array}{l}\text { Matriz: modelo para alavancar e } \\
\text { coordenar atividades já existentes } \\
\text { e criar novas } \\
\text { Filial: modelo para sensibilizar alta } \\
\text { direção quanto ao uso de } \\
\text { atividades de e-business }\end{array}$ & $\begin{array}{l}\text { Matriz: modelo para } \\
\text { coordenar atividades já } \\
\text { existentes e gerar novas } \\
\text { iniciativas de e-business } \\
\text { Filial: sem modelo para } \\
\text { conduzir o processo, } \\
\text { apenas gerar grande } \\
\text { quantidade de atividades } \\
\text { de e-business, }\end{array}$ & $\begin{array}{l}\text { Matriz: modelo para } \\
\text { coordenar e alavancar } \\
\text { atividades, objetivando } \\
\text { aumentar o valor } \\
\text { entregue ao cliente. } \\
\text { Atividades B2B e B2C, } \\
\text { com ligeiro foco em B2C } \\
\text { Filial: modelo para } \\
\text { viabilizar iniciativa nova } \\
\text { de e-business, torná-la } \\
\text { viável, maximizando } \\
\text { valor entregue: coerência } \\
\text { entre modelos. Modelo na } \\
\text { filial usado só para B2C. } \\
\text { B2B ocorre sem modelo } \\
\text { para conduzir iniciativas. } \\
\text { Resultado: atividades } \\
\text { B2B ainda causam pouco } \\
\text { impacto na filial C }\end{array}$ \\
\hline $\begin{array}{l}\text { Capacita } \\
\text {-ções }\end{array}$ & $\begin{array}{l}\text { Matriz: usa capacitações internas e } \\
\text { algumas joint ventures } \\
\text { Filial: basicamente capacitação } \\
\text { interna }\end{array}$ & $\begin{array}{l}\text { Matriz: usa joint ventures } \\
\text { para gerar conhecimento } \\
\text { em Internet } \\
\text { Filial: usa capacitação } \\
\text { basicamente interna, } \\
\text { mais algumas parcerias } \\
\text { com firmas de Internet }\end{array}$ & $\begin{array}{l}\text { Matriz: uso de joint } \\
\text { ventures } \\
\text { capacitação mais } \\
\text { Ênfase na infraestrutura } \\
\text { de TI } \\
\text { Filial: uso de capacitação } \\
\text { interna mais contratação } \\
\begin{array}{l}\text { de diretor de TI do } \\
\text { mercado }\end{array}\end{array}$ \\
\hline Valor & $\begin{array}{l}\text { Matriz: ênfase em diminuição de } \\
\text { custos e conexão com o cliente } \\
\text { Filial: ênfase em diminuição em } \\
\text { custos }\end{array}$ & $\begin{array}{l}\text { Matriz: ênfase em foco no } \\
\text { consumidor } \\
\text { Filial: não ficou muito } \\
\text { claro o valor a ser } \\
\text { entregue, pois há muitos } \\
\text { projetos difundidos por } \\
\text { toda empresa, sem } \\
\text { centralização }\end{array}$ & $\begin{array}{l}\text { Matriz: ênfase em } \\
\text { métricas para resultados: } \\
\text { diminuição de custos, } \\
\text { aumento de receitas, } \\
\text { aumento da rapidez e da } \\
\text { qualidade, diminuição de } \\
\text { desperdícios, liderança } \\
\text { Filial: geração de receitas } \\
\text { e diminuição de custos, } \\
\text { mais rapidez nos } \\
\text { processos }\end{array}$ \\
\hline $\begin{array}{l}\text { Papel da } \\
\text { alta adminis- } \\
\text { tração em e- } \\
\text { business }\end{array}$ & $\begin{array}{l}\text { Matriz: alto comprometimento } \\
\text { Filial: baixo comprometimento }\end{array}$ & $\begin{array}{l}\text { Matriz: alto } \\
\text { comprometimento } \\
\text { Filial: baixo } \\
\text { comprometimento } \\
\end{array}$ & $\begin{array}{l}\text { Matriz: alto } \\
\text { comprometimento } \\
\text { Filial: alto } \\
\text { comprometimento }\end{array}$ \\
\hline Resultados & $\begin{array}{l}\text { Matriz: mais relacionados a B2B, } \\
\text { vasta gama de ferramentas B2B } \\
\text { utilizadas } \\
\text { Filial: mais relacionados a B2B. } \\
\text { Poucas ferramentas utilizadas } \\
\text { (leilão) }\end{array}$ & $\begin{array}{l}\text { Matriz: resultados mais } \\
\text { voltados para satisfação } \\
\text { do cliente } \\
\text { Filial: difusos: diminuição } \\
\text { de uso de pepel, } \\
\text { relacionamento com } \\
\text { cliente }\end{array}$ & $\begin{array}{l}\text { Matriz: mensuração de } \\
\text { bastante resultados } \\
\text { quanto a diminuição de } \\
\text { custos, aumento de } \\
\text { visitas a sites } \\
\text { Filial: resultados quanto a } \\
\text { vendas diretas }\end{array}$ \\
\hline
\end{tabular}


Apresentação e Discussão dos Resultados dos Estudos de Caso

\subsubsection{COMENTÁRIOS e ANÁLISES complementares sobre uso de modelos de negócio para desenhar e implantar atividades de e- busienss}

O surgimento das iniciativas de e-business de modo mais consistente, procurando criar modelo que conduzisse essas iniciativas pode ser relacionado no caso das montadoras $\mathrm{B}$ e $\mathrm{C}$ matrizes ao fato delas já estarem promovendo uma grande quantidade de atividades de e-business, porém de forma dispersa, causando duplicação de atividades e desperdício de esforços.

No caso da montadora A matriz, a iniciativa surge de uma análise do ambiente externo, da verificação da existência de oportunidades a serem exploradas. Nota-se um pequeno "delay" na adoção do modelo de e-business: as montadoras criam suas unidades de negócio dedicadas a e-business em 1999, enquanto que a montadora C matriz cria sua estrutura dedicada baseada num modelo em 2000.

A data de início das atividades de e-business a partir de um modelo definido para as montadoras $\mathrm{B}$ e $\mathrm{C}$ matrizes -coincide com o auge das iniciativas "ponto.com" nascidas na Internet: existe um grande volume de investimento em empresas da net, o que de certo modo impulsiona as montadoras a se dirigir no mesmo sentido.

Como objetivo da criação de um modelo de negócio voltado para ebusiness, todas as montadoras mostram de uma forma ou de outra o desejo de conexão com o consumidor: nesse primeiro momento do modelo o foco é muito mais no consumidor final.

O discurso é de obter vantagem competitiva ao conseguir integrar toda sua cadeia de valor ao consumidor final, seja por atividades B2B, diminuindo custos no SCM, e podendo oferecer preços melhores, seja em atividades de CRM, oferecendo produtos mais customizados.

$O$ que se observa no entanto, principalmente entre as montadoras $B$ e $C$ matrizes alguns elementos destacados na revisão da literatura dessa tese: -competição acirrada nessa indústria, com cada empresa tentando ser o "first mover" para obter vantagem competitiva distintiva, como analisa Porter(2001). 
Isso se observa pela quase inexistente diferença de tempo entre os lançamentos das atividades de e-business pelas matrizes dessas montadoras: a montadora C matriz criou o modelo de negócio para e-business em julho e logo depois nesse mesmo mês, a montadora B matriz anuncia a criação do seu próprio modelo de negócio voltado para e-business.

Em novembro de 99 as duas montadoras matrizes anunciam a criação de uma Exchange proprietária. As duas anunciam a criação de site pra configuração de produtos (venda direta) quase na mesma data, quando um anuncia melhorias em telemática, o outro anuncia outros recursos com esse fim e assim por diante.

A montadora C matriz segue essa competição à distância. Porém fica difícil identificar quem é o ganhador, lembrando mais uma vez Porter: a Internet diminui barreiras de entrada e faz a concorrência girar em torno de preço (que é o que acontece nos leilões), tornando aquela vantagem que seria distintiva, quase customizada.

Apesar de terem objetivos semelhantes, a forma do modelo é razoavelmente distintiva: a montadora $A$ matriz enfoca na conectividade da sua cadeia de valor, a montadora $B$ matriz tem foco no consumidor e faz com que todas suas atividades sejam para gerar iniciativas de forma acelerada para atendê-lo e a montadora C matriz é a única que explicita em seu modelo uma preocupação com métricas e com a integração de sua infraestrutura de $\mathrm{TI}$ gerando valor para o cliente.

O que distingue o modelo da montadora B matriz é sua preocupação pela geração de muitas iniciativas, o que era recomendado por Kanter (2001) em seu estudo: num primeiro momento a empresa deve gerar uma grande quantidade de iniciativas de e-business sem grande direcionamento, para num segundo momento escolher aquelas que parecem mais adequadas.

Essa atitude da montadora $B$ matriz vai se refletir no modo como ela trata a sua filial brasileira: fornece capital para investimento, sem direção, apenas para gerar muitas iniciativas.

A montadora C matriz tem outra abordagem: uma preocupação com resultados mais clara: a iniciativa de e-business tem que estar atrelada a 
resultados. A montadora A matriz é a que apresentou um modelo de e-business mais calcado em conceitos: utiliza exatamente o conceito de cadeia de valor desenvolvido por Porter (2001) e a necessidade de conectar todas as atividades de modo a entregar um valor distintivo ao cliente. Também se reflete na forma como a filial vai implantar seu modelo de e-business: seguindo os passos da montadora $A$ matriz: a filial $A$ foi a única que teve uma pessoa da matriz enviada para fazer a implantação do modelo.

-Todas as matrizes declararam que o objetivo da criação de um modelo de negócio voltado para e-business no caso das montadoras matrizes era para alavancar e coordenar atividades de e-business e que num determinado momento deveriam ser devolvidas para o negócio.

Foi exatamente o que aconteceu em 2002 com as estruturas dedicadas existentes nas matrizes: todas essas unidades dedicadas somente a e-business deixaram de existir.

Todas afirmam que isso não teve a ver com resultados abaixo do esperado: todas afirmam que desde o início de sua criação estava prevista essa volta para as áreas, o que parece razoável: esses modelos serviram para essas empresas tradicionais como um aprendizado intensivo para empresas de fora da "net" sobre esse novo meio.

Freeland e Stirton (2000) também preconizam essa atitude: um modelo de e-business serve para alavancar iniciativas, porém elas devem ser absorvidas pelas áreas para que esse aprendizado permita fazer com que as áreas corporativas tenham iniciativas a partir da sua experiência com o negócio, aproveitando a Internet como algo complementar e que adiciona valor, como recomenda Porter (2001).

-Quanto a resultados nas matrizes, a montadora B matriz investiu maciçamente na criação de joint ventures e muitas delas fracassaram causando um grande prejuízo. A montadora $\mathrm{C}$ matriz preocupou-se em levantar muitos números: números de acessos aos sites, reduções de custos, por exemplo com treinamento de funcionários online e com economia de papel, e assim por diante. 
A montadora A matriz também demonstrou preocupação com quantificação de resultados, parecendo estar mais focada naquelas relativas a B2B.

Ainda quanto a resultados, Segundo Amit e Zott (2001) valor é criado pelo e-business pelo modo como as transações são habilitadas.

Os autores elaboraram um modelo para avaliar a criação de valor em ebusiness onde existem quatro condutores de valor: -eficiência (ao reduzir assimetria das informações entre vendedores e compradores, velocidade da transmissão da informação, etc); -complementariedades (quando um conjunto de bens provê mais valor do que cada um individualmente); -retenção (valor em ebusiness é aumentado pelo quanto os consumidores são motivados a comprar novamente); -novidade ou inovação (p.ex., criar valor conectando partes que antes da inovação não eram conectadas).

Analisando os resultados encontrados nessa pesquisa sob essa ótica, pode -se perceber que as três montadoras matrizes preocuparam-se muito mais com as três primeiras dimensões (eficiência-demonstrada pela preocupação com corte de custos no uso de e-procurement, por exemplo), complementariedade (ao querer oferecer múltiplos serviços ao consumidor, para aumentar o valor percebido) e retenção (uso de sites para fidelização) do que com a dimensão de inovação.

$\mathrm{Na}$ verdade, a ferramenta mais inovadora refere-se aos leilões eletrônicos reversos, que como observa Timmers (1998) não são tão novos assim: o leilão é uma das mais antigas ferramentas de intermediação existentes.

Ainda quanto ao aspecto de inovação, Weil e Vitale (2001) comentam que um dos modelos de negócio para e-business mais inovadores é o "value net integrator", que é o modelo usado pela CISCO e pela DELL, que agregam valor na sua cadeias de valor de informações, no meio eletrônico e não no meio real: eles agregam valor das informações obtidas de seus fornecedores e clientes eletronicamente, cobrando uma taxa pela disponibilização da informação enriquecida. 
Elas usam o modelo "build-to-order" onde um computador só é montado quando um pedido é feito. Para que isso possa ocorrer, deve haver a possibilidade de montagem modular.

Ora, a montadora B matriz manifestou o desejo de se tornar uma "buildto-order", só que para isso, a capacidade de flexibilização da produção precisa estar disponível.

No Brasil, as empresas B e C já possuem plantas mais flexíveis, que permitiu a venda pela Internet: os clientes podem pedir detalhes customizados, graças a essa flexibilidade das fábricas e ao uso do consórcio modular (fornecedores dentro da fábrica) que garante maior rapidez de fabricação.

Nesse aspecto, o Brasil foi pioneiro no modelo de venda direto ao consumidor, pois nos outros países, o cliente só consegue configurar o carro vis Internet, apesar dos sites serem chamados de venda direta.

As montadoras brasileiras B e C filiais foram então, mais inovadoras do que suas matrizes nesse sentido, onde a definição de atividade inovadora na Internet segundo Timmers (1998) é aquela onde o uso da Internet permite ações que seriam impossíveis sem seu uso: a Vanda direta ao consumidor seria muito difícil para uma montadora se não fosse a facilitação oferecida pela Internet.

Quanto ao problema de conflito de canal apontado por muitos autores como gerador de canibalização do produto, onde os revendedores entrariam em conflito com a venda direta, esse problema foi solucionado no Brasil do seguinte modo: na montadora B a configuração e pedido do carro ocorre $95 \%$ das vezes numa distribuidora, que recebe uma taxa por esse serviço.

No caso da montadora B , a entrega do produto é sempre feita por uma concessionária, que ganha uma taxa para isso e a configuração pode ser feita também numa concessionária.

Um aspecto interessante trata do tipo de produto vendido: um carro tem que passar pelos estágios de "teste" pelo consumidor, o que o leva a uma concessionária para experimentar o produto através de test drives, mesmo que a compra seja feita pela Internet.

Assim, contorna-se o problema de canibalização. 
Ainda no caso das montadoras brasileiras, o que se pode observar foram três formas diferentes de adotar o modelo de e-business:

-A montadora A filial teve um representante de sua matriz para implantar o mesmo modelo utilizado na matriz. Dificuldades: como foi uma decisão que não tinha nada a ver com as prioridades da alta administração da filial brasileira, mais preocupada em se equilibrar no tênue fio da estabilidade econômica do momento (lembrar que essa iniciativa só começou em meados de 2001-meio de uma recessão econômica mundial) o representante da matriz tem tido dificuldade em implantar seu modelo, pois as iniciativas devem partir das áreas, ele apenas oferece opções estratégicas, não tem poder de tomada de decisão.

Apesar das iniciativas de sensibilização do grupo, o board da filial ainda não vislumbra as vantagens de participar do mundo virtual. $A$ única área que mais se sensibilizou foi a área de Compras, por perceber economias de custos com leilões e e-procurement. Mesmo assim , a área enfrenta rejeição por parte dos compradores, que tem um perfil mais tradicional e temem por seus empregos.

-Quanto à montadora B filial, não houve um modelo de e-business que norteasse suas iniciativas: houve apenas um aporte considerável de dinheiro (lembrar que isso ocorreu no fim de 1999 e início de 2000-auge da euforia com as ponto.com e de muitos investimentos).

Essa verba foi aplicada num primeiro momento sem critérios, o que gerou uma duplicação de atividades de e-business e de esforços.

O supervisor responsável pela área de e-business da empresa B filial apresentou uma opção de modelo condutor das iniciativas de e-business, necessitando para isso recursos humanos: sua proposta foi rejeitada e ele então propôs o estabelecimento de critérios que norteassem a designação da verba para os projetos, com alguma direção.

Houve a geração de cerca de 120 projetos, mas o que se pode notar é que a maioria deles servia para implementar coisas antigas de uma nova forma: como substituir papel por dados eletrônicos, rede de EDI por rede de Internet, e assim por diante. 
O leilão se mostrou uma ferramenta diferenciada, mas como o uso do Covisint é dispendioso, a empresa montou seu próprio esquema de leilão: porém as iniciativas nesse sentido tem diminuído, uma vez que escolhido um fornecedor, estabelece-se um contrato e o número de leilões deve diminuir para material não produtivo.

Outro projeto interessante foi a venda direta de veículos pela Internet, só que essa montadora foi um seguidor, pois o "dono " da iniciativa foi a montadora C filial. A montadora B filial também sentiu uma certa dificuldade em demonstrar os resultados obtidos para a alta direção da empresa, devido a métricas não muito esclarecedoras.

A montadora $C$ filial por sua vez foi a única que demonstrou ter uma ligação com a estratégia da empresa bem objetiva: a montadora $C$ no Brasil queria aumentar seu market share relativo a carros populares.

Para isso já possuía uma fábrica moderna, utilizando o conceito de consórcio modular, que foi explicado nessa tese no item "perfil da indústria", e seu diretor de marketing pensou em usar um meio que aproveitasse as vantagens tecnológicas existentes em todas as frentes: fábrica e meio eletrônico para se conectar com seu consumidor final diretamente, usar sua rede de distribuição vasta e estabelecida para entregar o carro e a Internet para interconectar todos os processos, até os financeiros, que trariam vantagem adicional , uma vez que o grupo possui instituição de crédito.

O modelo mostrou ser um sucesso. Por outro lado as iniciativas em B2B dessa firma são bem mais tímidas, com o uso de um aplicativo da matriz para relacionamento com os fornecedores.

\subsubsection{QUADRO RESUMO DAS ANÁLISES SOBRE ESTRUTURA ORGANIZACIONAL PARA OPERACIONALIZAR MODELO DE E- BUSINESS DAS MATRIZES}

Esse item apresenta uma série de quadros resumo que servem para analisar os dados obtidos através dos estudos de caso. 
As dimensões analisadas foram as levantadas no modelo de pesquisa dessa tese, quais sejam:

-Tipo de estrutura encontrada

-Grau de integração da estrutura à empresa

-Mudanças ocorridas no decorrer do tempo.

O quadro 22 apresenta o grau de integração entre as estruturas organizacionais para e-business às empresas matrizes e o quadro 23 às filiais.

Os critérios para definir o grau de integração à estrutura existente foram retirados de Muritiba e Vasconcellos (2001). O nível 1 de integração corresponde a empresa de e-business totalmente separada da empresa real. O nível 2 corresponde a unidade autônoma de negócios, com duplicidade de alguns recursos e compartilhamento de outros. O nível 3 de integração do e-business aos negócios reais corresponde a e-business subordinado a uma área da empresa compartilhando recursos e nível 4 de integração de e-business à empresa corresponde a atividades de e-business pulverizadas pelas diversas áreas corporativas da empresa, ou seja, totalmente integrado às atividades corporativas tradicionais.

O quadro 24 apresenta as estruturas organizacionais para e-business utilizadas no início do processo de adoção do modelo de negócio para ebusiness para as matrizes das montadoras e o quadro 25 apresenta esses resultados para as filiais brasileiras.

O quadro 26 apresenta a localização das áreas de e-business dentro do organograma da empresa.

O quadro 27 apresenta as modificações ocorridas na estruturas organizacionais para e-business das filiais.

O quadro 28 apresenta a estrutura organizacional de TI, no que tange a ebusiness para as filiais das montadoras.

O quadro 29 apresenta algumas comparações entre matrizes e filiais quanto a estruturas organizacionais para e-business. 
TABELA 22: DESENHO DO GRAU DE INTEGRAÇÃO ENCONTRADO PARA AS ESTRUTURAS ORGANIZACIONAIS DE E-BUSINESS DAS MATRIZES DAS MONTADORAS

\begin{tabular}{|c|c|c|}
\hline Montadora & $\begin{array}{c}\begin{array}{c}\text { Desenho do tipo de estrutura } \\
\text { obtida segundo grau de } \\
\text { integração }\end{array} \\
\end{array}$ & Comentário \\
\hline $\begin{array}{c}\text { Matriz } \\
\text { A }\end{array}$ & $\begin{array}{l}\text { Nível } 2 \text { de integração segundo } \\
\text { Muritiba e Vasconcellos (2001) }\end{array}$ & $\begin{array}{l}\text { O negócio eletrônico é } \\
\text { estabelecido como uma empresa } \\
\text { separada ou uma unidade } \\
\text { estratégica de negócios. Há áreas } \\
\text { em duplicidade, porém há também } \\
\text { alguns recursos sendo } \\
\text { compartilhados. }\end{array}$ \\
\hline $\begin{array}{c}\text { Matriz } \\
\text { B }\end{array}$ & Nível 2 de integração & $\begin{array}{l}\text { O negócio eletrônico é } \\
\text { estabelecido como uma empresa } \\
\text { separada ou uma unidade } \\
\text { estratégica de negócios. Há áreas } \\
\text { em duplicidade, porém há também } \\
\text { alguns recursos sendo } \\
\text { compartilhados. }\end{array}$ \\
\hline $\begin{array}{c}\text { Matriz } \\
\text { C }\end{array}$ & Nível 2 de integração & $\begin{array}{l}\text { O negócio eletrônico é } \\
\text { estabelecido como uma empresa } \\
\text { separada ou uma unidade } \\
\text { estratégica de negócios. Há áreas } \\
\text { em duplicidade, porém há também } \\
\text { alguns recursos sendo } \\
\text { compartilhados. }\end{array}$ \\
\hline
\end{tabular}


TABELA 23: DESENHO DO GRAU DE INTEGRAÇÃO ENCONTRADO PARA AS ESTRUTURAS ORGANIZACIONAIS DE E-BUSINESS DAS FILIAIS BRASILEIRAS DAS MONTADORAS

\begin{tabular}{|c|c|c|}
\hline Montadora & $\begin{array}{l}\text { Desenho do tipo de } \\
\text { estrutura obtida segundo } \\
\text { grau de integração }\end{array}$ & Comentários \\
\hline Filial A & $\begin{array}{l}\text { Nível } 3 \text { de integração segundo } \\
\text { Muritiba e Vasconcellos (2001) }\end{array}$ & $\begin{array}{l}\text { É estabelecida uma área } \\
\text { para o e-business. Há, } \\
\text { porém, compartilhamento } \\
\text { entre áreas da empresa } \\
\text { tradicional e não há áreas } \\
\text { em duplicidade }\end{array}$ \\
\hline Filial B & Nível 4 de integração & $\begin{array}{l}\text { O negócio eletrônico fica } \\
\text { descentralizado pelas áreas } \\
\text { da empresa }\end{array}$ \\
\hline Filial C & 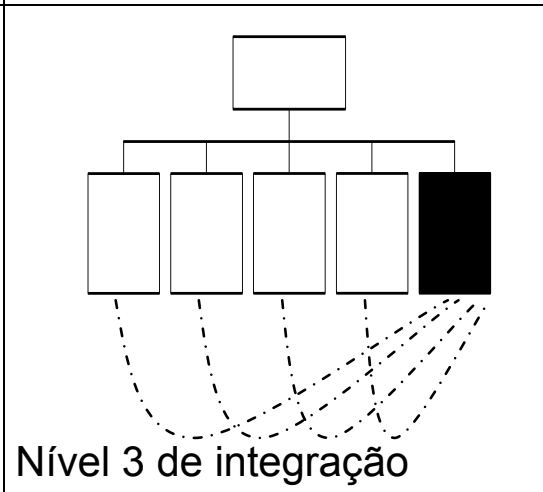 & $\begin{array}{l}\text { É estabelecida uma área } \\
\text { para o e-business. Há, } \\
\text { porém, compartilhamento } \\
\text { entre áreas da empresa } \\
\text { tradicional e não há áreas } \\
\text { em duplicidade }\end{array}$ \\
\hline
\end{tabular}


TABELA 24: DESENHO DA ESTRUTURA ORGANIZACIONAL INICIAL UTILIZADA PARA OPERACIONALIZAR ATIVIDADES DE E-BUSINESS NAS MATRIZES

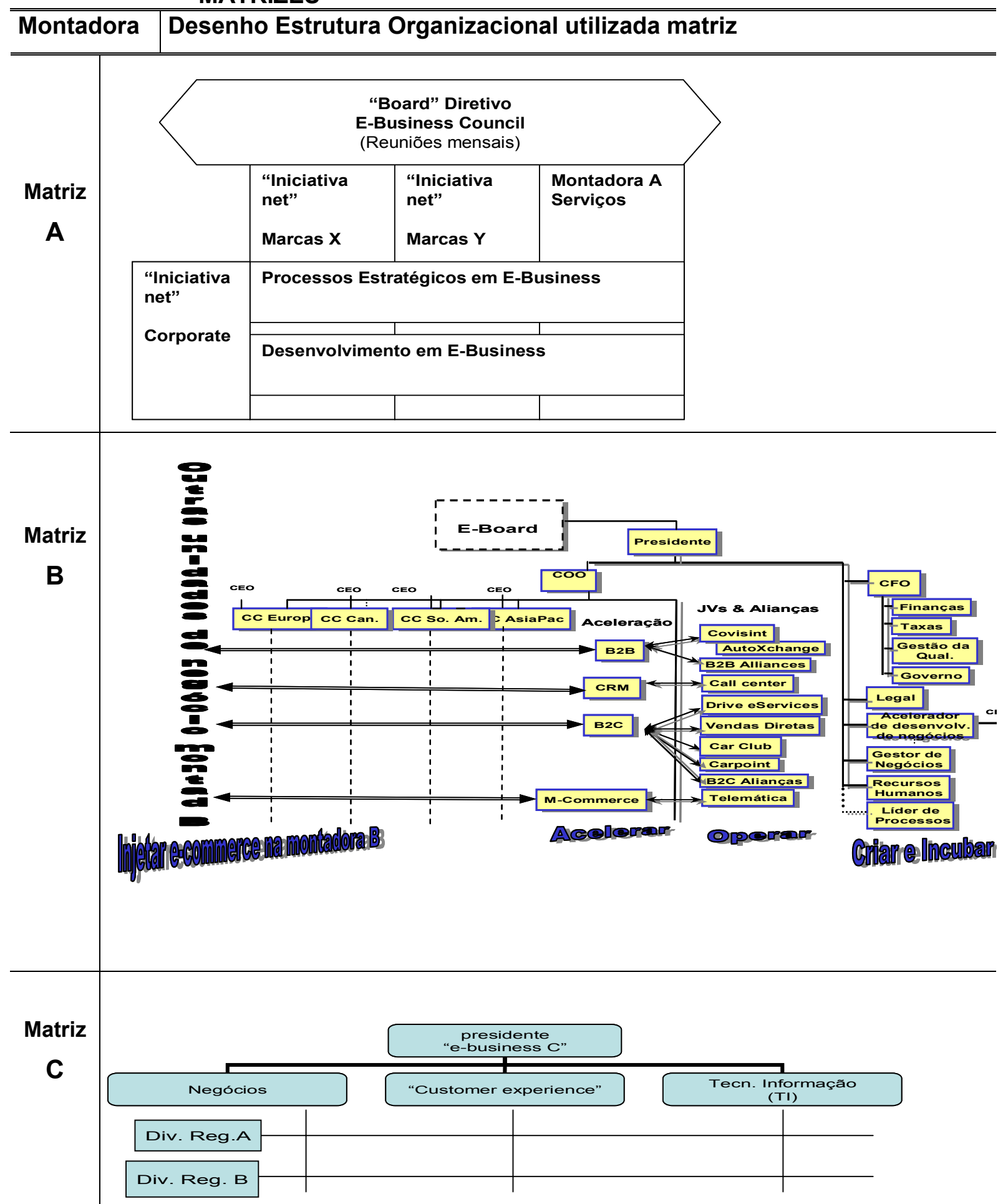


TABELA 25: ESTRUTURAS ORGANIZACIONAIS PARA E-BUSINESS UTILIZADAS NO INÍCIO DO PROCESSO DE ADOÇÃO DO MODELO DE NEGÓCIO PARA EBUSINESS PARA AS FILIAIS DAS MONTADORAS

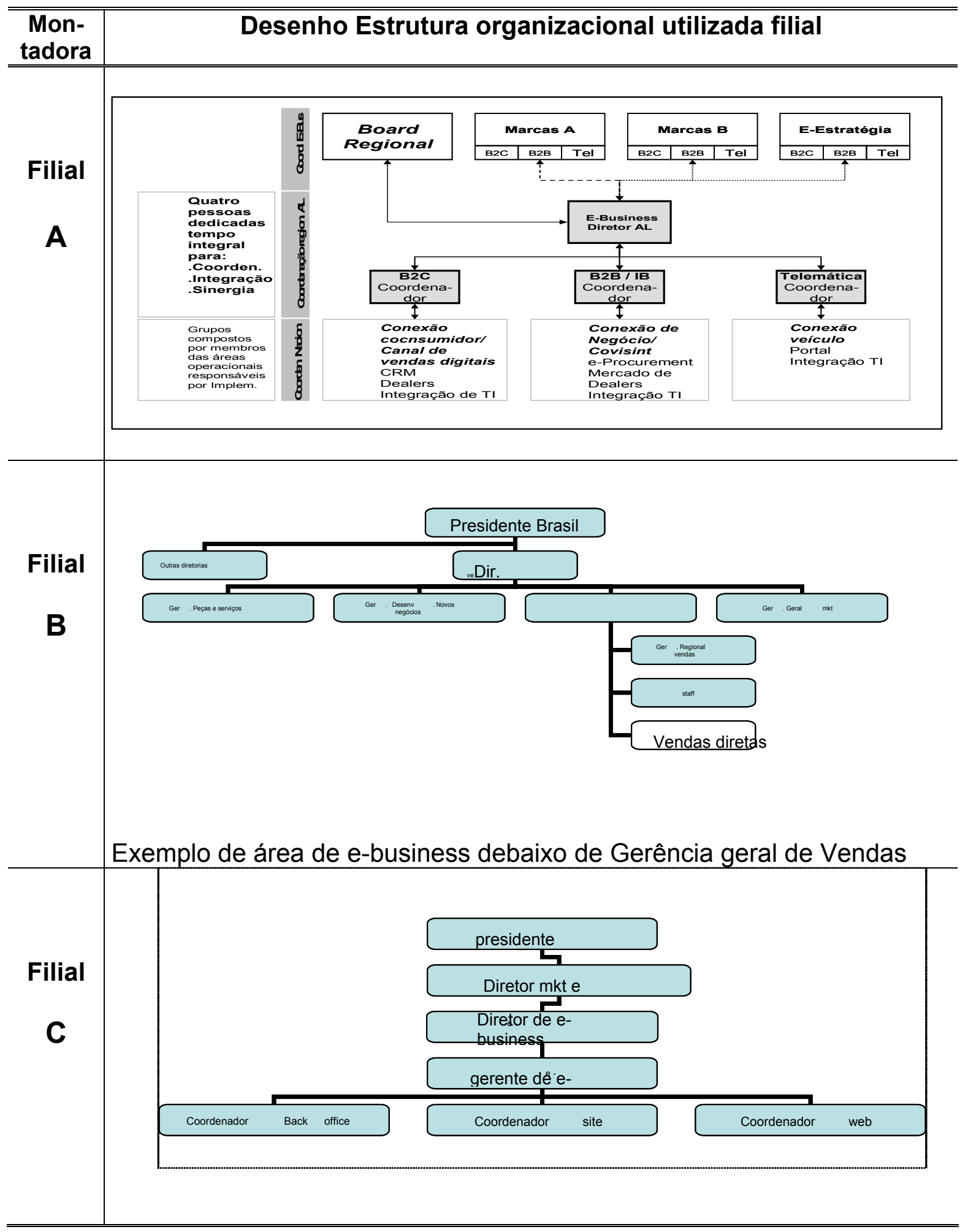




\section{FIGURA 26: LOCALIZAÇÃO DAS ÁREAS DE E-BUSINESS DENTRO DO ORGANOGRAMA DA EMPRESA - BRASIL}

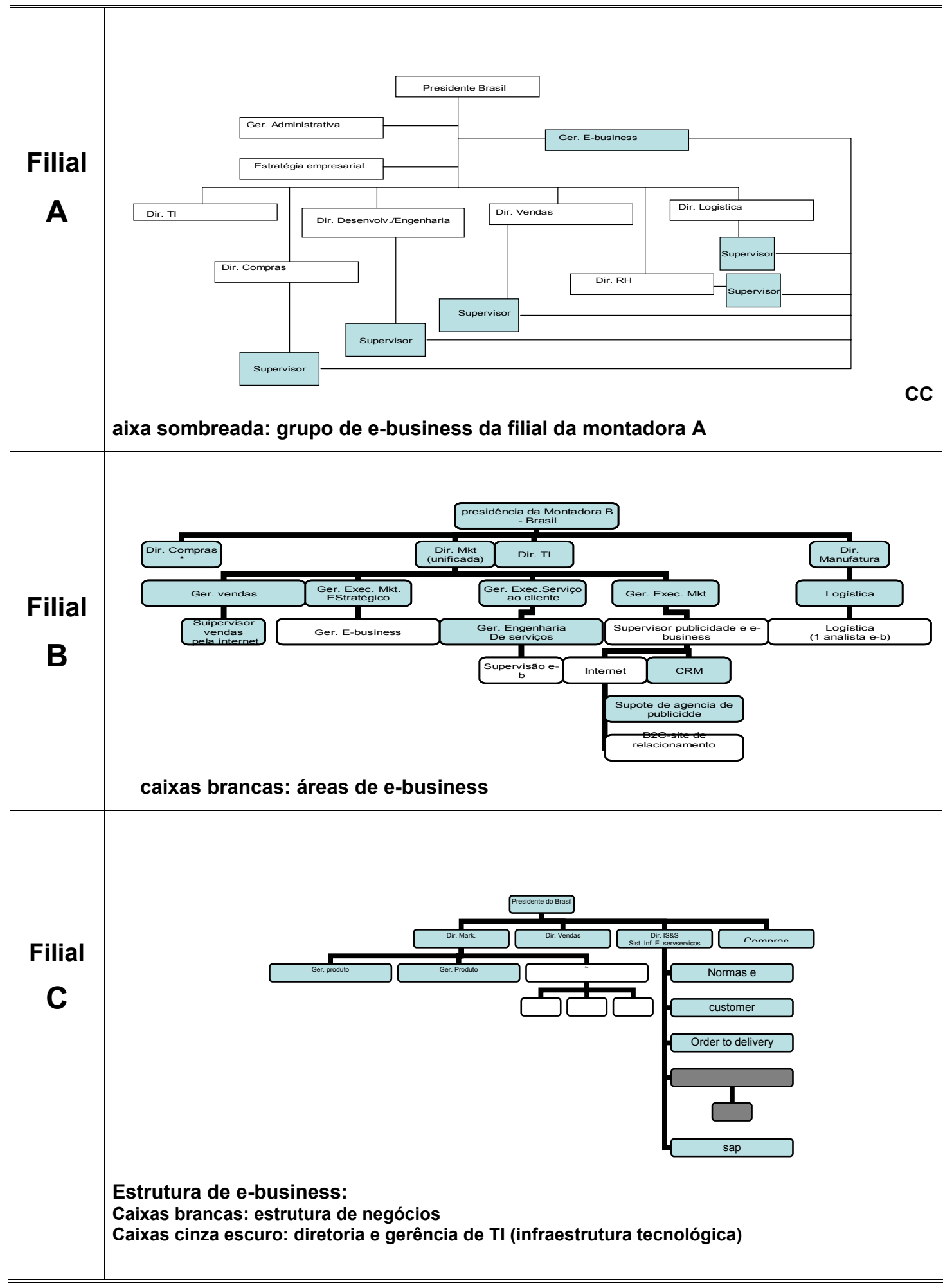




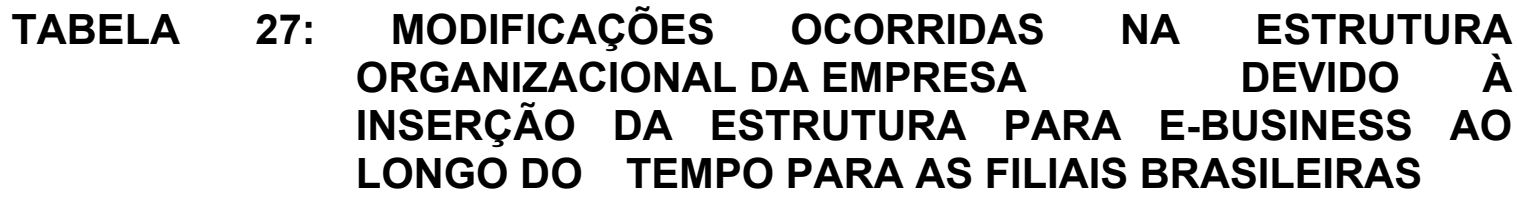

\begin{tabular}{|c|c|}
\hline Monta & Modificações na estrutura or \\
\hline
\end{tabular}

Filial A 1 A primeira modificação ocorreu em 2001, quando veio um diretor da matriz para implantar uma estrutura dedicada a e-business. Essa pessoa tem status de diretor e se reporta direto ao presidente. Abaixo dele tem um coordenador, um estagiário e uma secretária. Ele formou um grupo de e-business, que é uma estrutura matricial composta por elementos da empresa de outras áreas corporativas que estão envolvidos em atividades de e-business em suas respectivas áreas. Eles mantem encontros regulares com o diretor de e-business, que tem como função sugerir $e$ acolher projetos das diversas áreas para alavancá-los. Esse diretor de e-business não tem autoridade sobre as pessoas do grupo, apenas funciona como um centralizador das idéias. Essa foi a única mudança na estrutura organizacional por enquanto

Filial B A estrutura da empresa filial B sofreu uma série de modificações ao longo do tempo: em 1999 havia alguns projetos de e-business em diversas áreas da empresa, sem centralização: por exemplo: área de serviço ao cliente, tinha uma supervisora dedicada a algumas tarefas de e-business, compartilhando-as com outras; na área de marketing tinha a mesma situação, na área de vendas e assim por diante. Todos tinham nível hierárquico abaixo de supervisão. No final de 1999, com a verba vinda da matriz, foi criada área de e-business estratégico, reportandose à diretoria de marketing estratégico, para responder às atividades de $\mathrm{B} 2 \mathrm{C}$. $\mathrm{Na}$ área de serviço ao cliente, foi criada área de supervisão para e-business, que ganhou 3 analistas como staff. $\mathrm{Na}$ área de compras também foram alocadas 3 pessoas para e-business, dentre outras. $\mathrm{Na}$ área de $\mathrm{TI}$ foi criada uma estrutura dedicada a e-business com 7 pessoas para responderem aos diversos projetos existentes. No final de 2001, começo de 2002 novas mudanças: a área de TI dedicada desmontou-se e as pessoas foram absorvidas pela própria área de $\mathrm{TI}$ corporativo, a supervisão de e-business em serviços ao cliente fundiu-se com outra função que não tinha nenhuma relação com e-business (garantia) apenas por uma questão de contenção de gastos, a área estratégica de e-business também somou outras funções àquelas de e-business, enfim, as pessoas que estavam totalmente dedicadas a e-business, tiveram compartilhamento de atividades e em alguns casos, as atividades de e-business passaram para níveis hierárquicos inferiores.

Filial C No final de 1999 foi contratada uma supervisora de e-business para trabalhar subordinada à gerência de marketing. No final desse ano com o início do projeto de venda direta, essa pessoa ganhou status de gerente e uma estrutura dedicada abaixo dela, na área de negócios, com cerca de 7 pessoas. Também foi contratado um diretor de TI, abaixo do diretor geral corporativo de TI da empresa C brasileira, que tinha como função agilizar o andamento do projeto de venda direta. Foi criada uma equipe multidisciplinar de projeto, com recursos vindos da matriz e coordenação por um PIO (Process Information Officer) para garantir o alinhamento do projeto com as estratégias de TI e de negócios da empresa. Após o término desse projeto (10 meses), a estrutura de projeto se desfez, mas permaneceu a gerência de negócio e seu staff de 7 pessoas e o diretor de TI para e-business, com um subordinado. Acima da gerência de e-business, tinha um diretor de e-business, que se reportava ao diretor geral de Marketing Brasil. Em 2002, houve a fusão da diretoria de e-business com suporte a vendas, mas manteve-se a gerência dedicada a e-business. 


\section{TABELA 28 ESTRUTURA DE TI DAS FILIAIS BRASILEIRAS RELACIONADA A E-BUSINESS}

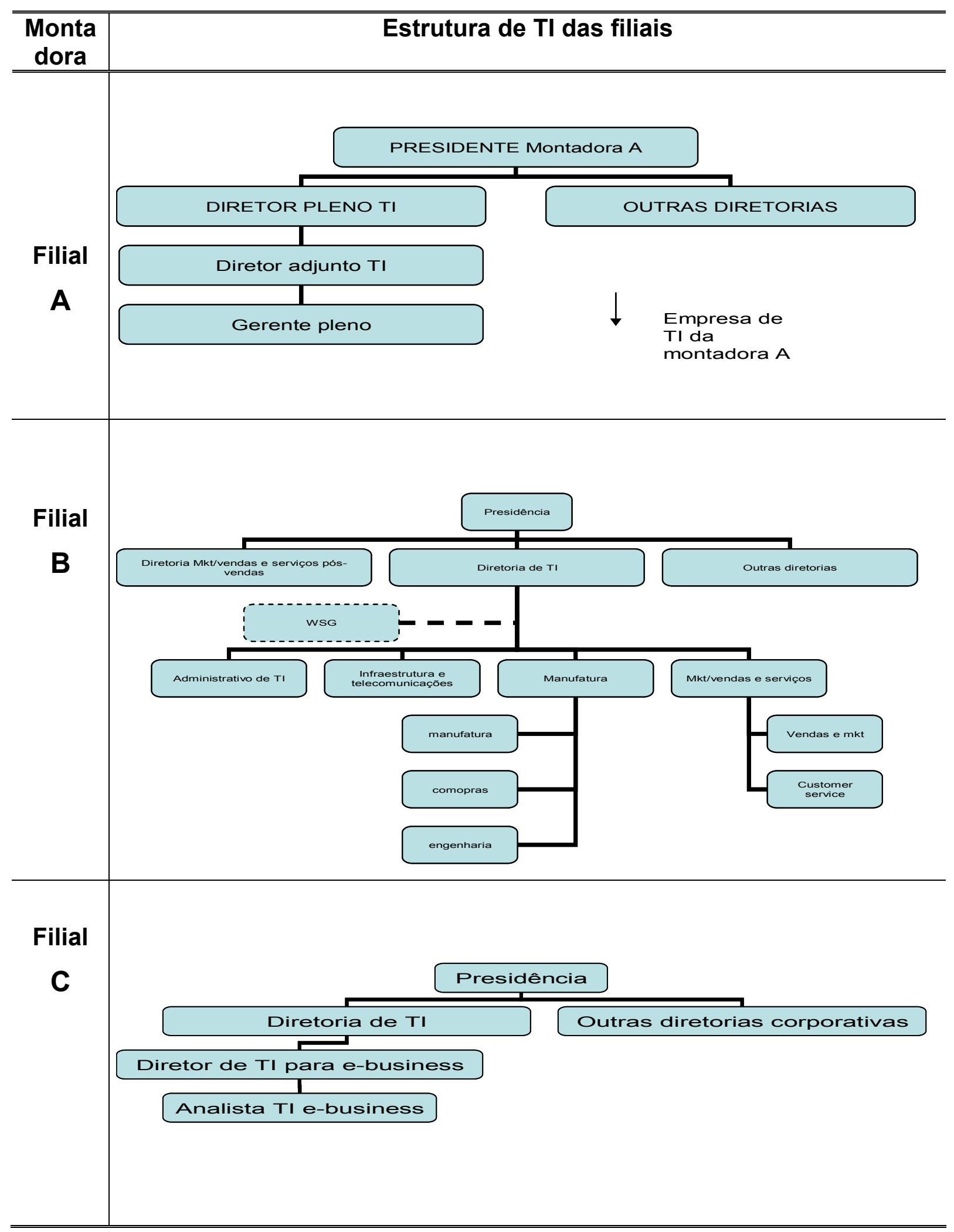




\section{TABELA 29: COMPARAÇÃO ENTRE MATRIZ E FILIAL NO QUE TANGE A ESTRUTURAS ORGANIZACIONAIS PARA E-BUSINESS}

\begin{tabular}{|c|c|c|c|}
\hline Montadora & Matriz A X Filial A & Matriz B X Filial B & Matriz C X Filial C \\
\hline $\begin{array}{l}\text { Grau de } \\
\text { integração da } \\
\text { estrutura de } \\
\text { e-business à } \\
\text { estrutura } \\
\text { existente }\end{array}$ & $\begin{array}{l}\text { Matriz A: unidade de } \\
\text { negócio autônoma.Nível } \\
2 \text { de integração } \\
\text { Filial A: área de } \\
\text { coordenação de e- } \\
\text { business é subordinada à } \\
\text { presidência brasileira, } \\
\text { compartilhando recursos } \\
\text { das áreas. Nível } 3 \text { de } \\
\text { integração }\end{array}$ & $\begin{array}{l}\text { Matriz B: unidade de negócios. } \\
\text { Nível } 2 \text { de integração } \\
\text { Filial } \quad \text { B: pulverizada pelas } \\
\text { diversas áreas da firma. Nível } 4 \\
\text { de integração }\end{array}$ & $\begin{array}{l}\text { Matriz C: unidade de } \\
\text { negócios. Nível } 2 \text { de } \\
\text { integração } \\
\text { Filial C: unidade subordinada } \\
\text { à área corporativa (diretoria } \\
\text { de marketing) compartilhando } \\
\text { recursos das áreas } \\
\text { Nível } 3 \text { de integração }\end{array}$ \\
\hline $\begin{array}{l}\text { Tipo } \\
\text { estrutura }\end{array}$ & $\begin{array}{l}\text { Matriz : estrutura mista: } \\
\text { funcional, por produtos, } \\
\text { por marcas, por divisões } \\
\text { regionais(mercados), } \\
\text { Filial: estrutura mista: por } \\
\text { marcas, por produtos, } \\
\text { funcional }\end{array}$ & $\begin{array}{l}\text { Matriz: estrutura mista: } \\
\text { funcional, por produtos, por } \\
\text { marcas, por divisões } \\
\text { regionais(mercados), } \\
\text { Filial: estrutura mista: por } \\
\text { marcas, por produtos, funcional }\end{array}$ & $\begin{array}{l}\text { Matriz: estrutura mista: } \\
\text { funcional, por produtos, por } \\
\text { marcas, por divisões } \\
\text { regionais(mercados), matricial } \\
\text { para área de } \mathrm{TI} \text {, marketing } \\
\text { dentre outras } \\
\text { Filial: mista: por produtos, } \\
\text { funcional, por marcas, } \\
\text { matricial }\end{array}$ \\
\hline $\begin{array}{l}\text { Mudanças } \\
\text { ocorridas }\end{array}$ & $\begin{array}{l}\text { Matriz: estrutura dedicada } \\
\text { para e-business em } \\
2000 \text {. Estrutura dedicada } \\
\text { a e-business desfeita em } \\
2002 . \\
\text { Filial: Apenas uma } \\
\text { mudança, quando foi } \\
\text { instituída área para e- } \\
\text { business em } 2001 .\end{array}$ & $\begin{array}{l}\text { Matriz:primeira mudança em } \\
\text { julho de } 1999 \text { criada unidade de } \\
\text { negócios de e-business. Em } \\
\text { 2001, muda CEO da estrutura e } \\
\text { CEO global, enxuga estrutura, } \\
\text { termina estrutura de aceleração } \\
\text { de iniciativas, estrutura mais } \\
\text { enxuta mais focada em } \\
\text { resultados } \\
\text { Filial:Várias mudanças: em } \\
\text { 1999: aumento de pessoas } \\
\text { envolvidas, níveis hierárquicos } \\
\text { superiores. 2001: diminuição do } \\
\text { "status" do e-business }\end{array}$ & $\begin{array}{l}\text { Matriz: } 1999 \text { criação de } \\
\text { unidade de negócios para e- } \\
\text { business.2002: extinção da } \\
\text { estrutura, e-business } \\
\text { subordinado a Mkt global } \\
\text { Filial: 1999: criação de } \\
\text { diretoria de de e-business } \\
\text { debaixo de MKT e diretoria de } \\
\text { TI para Mkt. Em 2002, cai } \\
\text { diretoria de e-business, mas } \\
\text { continua gerência de e- } \\
\text { business. }\end{array}$ \\
\hline $\begin{array}{l}\text { Estrutura da } \\
\text { área de } \mathrm{TI}\end{array}$ & $\begin{array}{l}\text { Filial: não existe área de } \\
\text { TI dedicada a e-business }\end{array}$ & $\begin{array}{l}\text { Filial: em } 1999 \text { criada área de } \\
\text { TI dedicada a e-business. 2001: } \\
\text { voltou ao que era. }\end{array}$ & $\begin{array}{l}\text { Filial: } 1999 \text { criada área de TI } \\
\text { dedicada a e-business } \\
\text { debaixo de diretoria global, } \\
\text { que se mantem até hoje }\end{array}$ \\
\hline
\end{tabular}




\subsubsection{COMENTÁRIOS E ANÁLISES ADICIONAIS SOBRE ESTRUTURAS ORGANIZACIONAIS}

A primeira análise relevante sobre as estruturas organizacionais para implementar o modelo de e-business adotado refere-se ao grau de integração da estrutura à empresa.

Todas as estruturas, sejam as da matriz, sejam as das filiais encontraramse totalmente integradas à empresa, seja na forma de unidade de negócios (todas as matrizes), seja na forma de áreas de e-business dispersas pela empresa (estrutura da filial B), ou na forma de estrutura matricial (filial A) ou seja com uma estrutura centralizada debaixo de uma área corporativa (filial C, sob a área de Marketing).

Isso parece ir de encontro às análises de vários autores sobre grau de integração da estrutura de e-business à empresa: Gulati e Garino (2000) indicam quatro variáveis a serem olhadas para a decisão sobre integrar ou separar a estrutura para e-business à empresa: marca, operações, administração e composição acionária.

A questão da marca é central nas montadoras, pois grande parte de seu esforço de marketing é investido em ações que tornem sua marca forte junto ao consumidor, porisso não faria sentido criar uma estrutura de e-business para realizar atividades ligadas às suas marcas longe da estrutura original.

Outra variável importante para essa análise é a questão das operações, que no caso das montadoras constitui-se no seu core business, daí mais uma vez não teria sentido separar a marca da iniciativa de e-business da estrutura já estabelecida.

Corrobora para esse fato a análise de Freeland e Stirton (2000) que propõe que uma iniciativa de e-business que permita que as atividades "core" da empresa cresçam com o uso de iniciativas de Internet leva a uma estrutura integrada à empresa que originou a iniciativa.

-Quanto à análise dos tipos de estrutura organizacionais encontradas, para o caso das matrizes, a montadora A manteve a mesma estrutura utilizada 
ao longo de seus dois anos de funcionamento. A matriz B operacionalizou seu modelo de "acelerador de iniciativas de e-business" através de uma complexa estrutura mista: matricial para as divisões regionais, por projetos no que tange à geração de joint ventures, com um representante da firma B matriz nessa estrutura , funcional nas áreas de "staff": financeira, jurídica, etc.

Essa estrutura tinha elementos na unidade de negócios que eram responsáveis por "injetar" tais iniciativas geradas nas joint ventures para dentro da área corporativa da empresa B matriz.

Em 2001, não havendo gerado os resultados esperados, há uma reestruturação nessa estrutura, que é simplificada e tem o intuito de finalizar as iniciativas geradas na fase anterior, tratando de sua incorporação pelas diversas áreas da firma.

Também procurou nessa fase integrar melhor seus esforços de TI.

A matriz $C$ utilizou uma estrutura matricial, porém com a área de ebusiness compondo os esforços de $\mathrm{TI}$ e negócio e uma área de "customer experience" para dar o foco no cliente exigido por essa montadora.

Foi a empresa que mais deu destaque à área de TI, deixando claro na estrutura que deve haver um trabalho integrado entre as áreas de negócio e TI.

Em meados de 2002, o principal executivo d e-business da firma $\mathrm{C}$ deixa essa estrutura , pois é promovido para uma área considerada mais estratégica: desenvolvimento de novos produtos.

Esses movimentos dos altos executivos dão uma idéia do movimento estratégico que a firma está fazendo. A área de e-business da empresa $C$ matriz foi incorporada `a área de Marketing global da empresa.

No Brasil, foi no final de 1999 e início de 2000 que os reflexos dessas diretrizes das matrizes para alavancar iniciativas de e-business ao redor do mundo chegam aqui.

É interessante observar que existe um laço bastante forte entre os representantes das áreas de e-business da matriz e seus representantes da filial: existem encontros periódicos e troca de informações, embora a matriz não opine absolutamente com conselhos sobre a melhor forma organizacional, a não 
ser no caso da montadora A que tece um representante da matriz trazido para implementar uma área destinada a e-business.

A montadora A optou por uma estrutura matricial, onde só existem duas pessoas realmente alocadas em e-business, sendo que o diretor de e-business se reporta diretamente ao presidente Brasil e à estrutura de e-business da matriz.

O resto dos participantes do "grupo de e-business", como eles o chamam, são representantes das diversas áreas corporativas da empresa que fazem a ponte entre e-business e negócios.

A maior dificuldade encontrada pela filial brasileira da montadora A trata da mobilização da alta direção da empresa, que não vê os benefícios advindos pelo uso de e-business, exceção feita à área de Compras da filial A que percebe resultados mensuráveis e tem um maior comprometimento. Justo porisso, nessa área tinha uma pessoa dedicada fulltime a e-business para atividades de eprocurement, mas que nos últimos meses teve seu tempo compartilhado com outras atividades, devido ao momento econômico (meados de 2002) ter deixado o setor automobilístico mais "parado".

A montadora filial $B$, que não estabeleceu um modelo definido de ebusiness e encara o e-business como algo para auxiliar as atividades e não algo inovador, seguindo a esteira de sua matriz, investiu numa profusão de atividades de e-business, envolvendo pessoas de todas as áreas da empresa, de vários níveis hierárquicos, normalmente abaixo de supervisão.

Essa atitude já dá indícios sobre a atitude da empresa com relação á importância de suas atividades.

A alta direção corporativa não se envolve diretamente nas atividades de planejamento dos projetos, esperando por resultados. Quando os tem, não parecem muito convencidos de seu retorno.

As tomadas de decisão são feitas conjuntamente pelo supervisor de ebusiness estratégico, junto com os "business owners" e líderes de projeto, após avaliação de business cases para priorização das atividades.

Um fato interessante aconteceu nessa empresa: foi formado um grupo de trabalho totalmente dedicado a e-business dentro da área de TI da empresa, 
com cerca de 7 participantes, devido à quantidade de projetos surgida.Eles sempre trabalhavam junto `a pessoa responsável pelo negócio.

Esse grupo foi dissolvido no início desse ano, quando o volume de projetos não mais justificava essa dedicação. Todos foram reabsorvidos pela área de $\mathrm{TI}$.

A montadora filial $C$ foi a única que apresentou uma relação clara entre as iniciativas de e-business e a estratégia da empresa: a iniciativa B2C empreendida deveria fazer com que aumentassem as vendas de determinado carro popular, segmento onde a empresa tem um ponto fraco.

Isso fez bastante diferença, refletindo-se na estrutura organizacional arranjada: com a mesma preocupação da matriz, essa montadora criou especialmente para o projeto - e continua em funcionamento - uma área de diretoria de TI totalmente dedicada às atividades do projeto de implantação de vendas diretas desse carro popular pela Internet.

Isso garantia uma infraestrutura de TI adequada. No lado do negócio, criaram uma estrutura de e-business totalmente dedicada à essas atividades de implantação de modo a garantir as funcionalidades necessárias atendendo às exigências dos clientes, dealers e fábrica.

Utilizaram uma estrutura matricial com elementos das áreas de $\mathrm{Tl}$ e de negócios para cada funcionalidade do sistema.

Recursos da matriz foram envolvidos, numa estrutura que além de aportar capital da matriz congregava especialistas de lá.

O envolvimento da alta diretoria foi total uma vez que o idealizador do projeto era o diretor de marketing da filial brasileira.

O resultado foi um projeto bem sucedido financeiramente e mercadologicamente, superando as expectativas.

Enquanto que na filial $B$ houve uma série de mudanças organizacionais desde o início do aporte financeiro em atividades de e-business, no final de 1999, até o final desse aporte em 2002, com a fusão de áreas que antes eram dedicadas exclusivamente a e-business e agora compartilham atividades de áreas corporativas com as atividades de e-business, a montadora filial $\mathrm{C}$ continua com a mesma estrutura proposta inicialmente. 
Isso se deve em parte ao sucesso da iniciativa da filial $\mathrm{C}$, que quer manter a estrutura ganhadora do mérito para manter as atividades B2C em alta.

As mudanças na estrutura organizacional na filial $B$, com o nível hierárquico das pessoas que cuidam de e-business mais baixo, denota a crescente perda de importância dessas atividades no último ano na filial B.

Já as atividades B2B nessa empresa filial C, que não tem um "dono" tem um desempenho que não se destaca.

Parece então, que a associação entre a existência de um modelo de negócio para conduzir as iniciativas de e-business mais o apoio da alta direção levam ao sucesso da iniciativa, enquanto que a falta de um desses componentes não permite a total realização do empreendimento.

Quanto ao uso de estruturas por projetos, a montadora C deu um belo exemplo de estrutura por projetos, com coordenação conjunta da filial e Brasil , com as áreas de $\mathrm{TI}$ e negócios administrando conjuntamente o projeto para venda direta de carro sobre a Internet.

A montadora C possui uma metodologia de implantação de projetos totalmente formalizada, criada na própria empresa, baseada nos conceitos de gestão de projetos, compreendendo todas as suas fases: escopo, planejamento, desenho,construção, implantação, suporte e manutenção.

A montadora B também se utilizou de metodologia de implantação de projetos para vários de seus projetos, sendo o de maior sucesso o projeto de venda direta, que se iniciou depois da montadora $C$, e como analisa Porter (1985), teve uma estratégia de ser o seguidor. Esse projeto durou 8 meses e envolveu cerca de 10 pessoas full time só do Brasil, não envolveu a matriz. 0 lançamento da venda direta aconteceu em 2002 e contemplou apenas um modelo de carro e não há planos de colocar outros modelos à venda no site por enquanto, pois como disse o entrevistado, tal decisão envolve análises estratégicas que fogem ao seu escopo.

Para esse projeto, foi utilizada a nova fábrica da montadora B filial, que tem produção flexível e usa o conceito de consórcio modular. 
Para o projeto de venda direta da montadora C filial, foram envolvidas cerca de 250 pessoas, daqui e da matriz, além dos parceiros desenvolvedores de tecnologia de Internet.

Esse projeto contou com uma organização extremamente sofisticada, sob a coordenação de um gerente de projeto (PIO-process information officer) e vários "business ownwers".

Foi um projeto muito bem sucedido e a empresa planeja lançar outros modelos de carro para venda pela Internet.

A parceria com, os dealers foi fundamental, para não haver conflitos de canal, onde o papel dos dealers foi o de posto de entrega do carro. Como disse Weil e Vitale (2001), uma forma de evitar conflito de canal é realinhar a função do distribuidor.

\subsubsection{ANÁLISES SOBRE ESTRATÉGIA, MODELOS DE E-BUSINESS E ESTRUTURA ORGANIZACIONAL}

Como foi mencionado nessa tese, as empresas não forneceram dados sobre suas estratégias corporativas. mas através das fontes secundárias (artigos, papers, etc) pode-se estabelecer algumas relações entre a estratégia das empresas $\mathrm{e}$ os modelos de e-business adotados $\mathrm{e}$ as formas organizacionais para operacionalizá-los, ainda que esse não seja o foco dessa pesquisa, como já foi dito.

Como foi dito na literatura, a Internet é uma ferramenta poderosa, mas não mudou o comportamento fundamental do consumidor como querem alguns: ainda é necessário na compra de carros, haver o contato com o produto: o consumidor não compra um carro pela Internet sem antes testá-lo, tocá-lo, experimentá-lo.

Porter (2001) analisa que muitas empresas estabelecidas em seus mercados entraram numa profusão de parcerias e relacionamentos com terceiros erodindo suas características distintivas ao ignorar suas estratégias, esquecendo o que as tornara únicas, as empresas correram a implantar 
aplicações de Internet e copiar produtos de outras empresas, podendo levar ao comprometimento de sua vantagem.

Essa afirmação lembra um pouco a matriz da montadora B que, teve em seu CEO o maior mentor de Internet, que chegou a dizer que queria tornar a empresa C uma empresa de Internet "build to order", correndo atrás de uma série de iniciativas, sem ter claro, ao que tudo indicou, os resultados precisos e objetivos estratégicos a serem atendidos por aquelas iniciativas.

A ausência de receitas que justificassem os altos investimentos em joint ventures para acelerar iniciativas de Internet, levou à demissão desse CEO, trocado por outro cujo objetivo era mais voltado a resultados e à integração das atividades de e-business àquelas corporativas.

Isso vai de encontro ao que diz Porter (2001) sobre o papel de complementariedade que deve ter a Internet: ela deve reforçar as vantagens competitivas da parte "real" da empresa.

Quando a Internet vem para reforçar uma estratégia, provê melhor resultado: é o que se viu na filial da montadora $\mathrm{C}$, onde a iniciativa de e-business na verdade veio de encontro a um objetivo estratégico bem definido: aumentar a fatia de mercado em carros populares, o ponto fraco da montadora $C$ filial.

Essa iniciativa foi pioneira no mundo - venda de carro direto pela Internete causou projeção mundial e reconhecimento da matriz.

Nesse caso, foi um uso inovador da Internet pois ela propiciou à empresa realizar uma atividade que sem o uso da Internet seria praticamente impossível: conectar o consumidor final à montadora.

Por outro lado, a Internet vem de encontro às estratégias atuais das montadoras, segundo estudo feito por Santos (2001) que abrangem diferenciação (Internet possibilita diferenciação em serviços, por exemplo), associações, alianças (facilitadas pela característica de interconectividade da Internet)e, principalmente, a expansão geográfica de sua atuação que também pode ser facilitada pela Internet, pela sua característica de alcance, abrangência.

$\mathrm{Na}$ busca crescente de redução de custos e aumento de lucros, as estratégias das montadoras evoluíram para uma redivisão da produção em bases mundiais com a incorporação das unidades dos mercados emergentes, 0 
que favorece o Brasil, que pode lançar modelos personalizados de carros, utilizando a Internet para venda direta, como foi explicado.

Fine e Raff (2000) enumeram uma série de maneiras de como a Internet pode alterar as práticas e a produtividade na indústria automobilística: 1Desenvolvimento de Produto; 2-Sistemas de manufatura,3-Procurement e Fornecimento; 4-Veículo "Order-to-Delivery" .

No Brasil, apenas na área de Procurement se vê alguma inovação, ma mesmo assim não muito significativa.

Quanto à posição estratégica ocupada pelas atividades de e-business, um interessante termômetro é dado pelo nível hierárquico mais alto ocupado com ebusiness na empresa e pelo tempo de tal pessoa dedicada a e-business na empresa:

No Brasil, a montadora $C$ tem pessoa de e-business com status de diretor até há pouco tempo e agora ocupa gerência: pode-se notar que a prioridade para essas atividades deu uma diminuída, mas mantem interesse, com área alocada permanentemente para suas atividades.

Já na montadora B, o e-business ocupava escalões baixos, foi "promovido", e a partir do momento que a matriz deixou de investir em suas atividades, retornou para os níveis inferiores da hierarquia, ou teve suas atividades divididas com outras.

$\mathrm{Na}$ montadora $\mathrm{A}$, que caminha um pouco atrás das outras duas em termos de atividades de e-business, existe envolvimento da alta administração da matriz para promover suas iniciativas, porém a alta direção da empresa ainda não se encontra sensibilizada a lançar um volume razoável de projetos de ebusiness. 
CAPÍTULO VI

CONCLUSÕES, LIMITAÇÕES DA PESQUISA, RECOMENDAÇÕES E SUGESTÕES PARA ESTUDOS FUTUROS 
Conclusões, Limitações da pesquisa, recomendações e Sugestões para estudos futuros

\section{Capítulo VI}

\section{CONCLUSÕES, Limitações da pesquisa, recomendações e Sugestões para estudos futuros}

\subsection{Conclusões}

- Nessa tese evitou-se falar em "modelo de e-business" como muitos autores fazem. Ao invés dessa abordagem preferiu-se utilizar o termo "modelo de negócio para desenhar e implantar atividades de e-buasiness".

Essa opção deu-se por vários motivos:

1. A grande confusão que o termo "modelo de e-business" gera: cada autor tem um tratamento distinto sobre o que considera modelo de ebusiness: alguns autores de 1999, 2000 consideram modelos de ebusiness como sendo aqueles modelos B2B ou B2C, ou seja, a partir do tipo de participantes no negócio (empresa ou cliente final) determinase o tipo de modelo de e-business. Nessa tese preferiu-se entender os termos B2B ou B2C como relativos a algo que se refere ao tipo de participantes nas atividades de e-business empreendidas. Porém, esse termo não encerra um conceito, capacidades e valor para definir essas relações como um modelo de negócio para e-business.

Outros autores julgam que "leilão eletrônico", ou "e-procurement" sejam modelos de e-business. Nessa tese, essas são ferramentas de e-business e não modelos.

Há ainda autores (Weil e Vitale, 2001) que chamam modelos nucleares de e-business aqueles determinados pelos fluxos de dinheiro, informações, produtos e serviços gerados pelos participantes numa transação de negócio eletrônica. Essa abordagem parece mais próxima do conceito geral de modelo de negócio como um instrumento para orientar as atividades de negócio segundo um conceito, usando capacidades e entregando valor. 
Conclusões, Limitações da pesquisa, recomendações e Sugestões para estudos futuros

Porém, o que se encontrou nas empresas estudadas foi o uso de modelo B2B, B2C, B2E, B2V, B2M, ou seja, as empresas definiam para cada tipo de relacionamento entre parceiros uma nomenclatura diferente, chamando isso de modelo. Nessa tese isso caracteriza o tipo de atividade de e-business: se é uma atividade voltada para uma empresa, para o consumidor final, para os funcionários da empresa, e assim por diante, mas não configura um modelo por si só, pois essas relações sozinhas, sem estarem envolvidas por um conceito (objetivos, estratégia, ...), sem haver a definição das capacidades necessárias para exercê-las e sem designar um valor a ser entregue não definem um modelo.

Os modelos de negócio encontrados nessa tese para as montadoras foram:

-Montadora A matriz: modelo de integração da cadeia de valor

-Montadora $A$ filial: o mesmo, porém restrito às atividades $B 2 B$

-Montadora B matriz: modelo acelerador de iniciativas de Internet

-Montadora B filial: sem modelo de negócio para atividades de ebusiness

-Montadora $C$ matriz: modelo gerador de valor ao cliente (utilizando atividades $\mathrm{B} 2 \mathrm{~B}$ e $\mathrm{B} 2 \mathrm{C}$ integrados por $\mathrm{TI}$, entregando valor ao cliente)

-Montadora C filial: modelo gerador de valor ao cliente, utilizando atividades $\mathrm{B} 2 \mathrm{C}$.

Todos os três modelos das matrizes das montadoras $A, B$ e $C$ pressupunham uma estrutura organizacional dedicada especialmente para ebusiness, na forma de uma unidade de negócios com um vice-presidente coordenando as atividades de e-business na empresa. Essa estrutura centralizadora das atividades de e-business é recomendada na literatura por Freeland e Stirton (2000) e por Plant (2000), para alavancar e coordenar as atividades de e-business da empresa.

2. Um segundo motivo para não usar o termo "modelo de e-business" e sim modelo de negócio para atividades de e-business, foi a constatação na literatura, de que as atividades de e-business estarão integradas à empresa e entregarão valor a ela, quando o "e-business" se tornar "business" (Porter, 2001, Weil e Vitale, 2001) . 
Conclusões, Limitações da pesquisa, recomendações e Sugestões para estudos futuros

Essa pesquisa também chegou a essa conclusão ao constatar que todos os modelos desenvolvidos pelas matrizes foram criados para coordenar as atividades de e-business, mais ou menos na mesma época ( em decorrência da competição acirrada entre as empresas do setor constatada no perfil da indústria automotiva citada nessa tese) no caso das montadoras $\mathrm{B}$ e $\mathrm{C}$ e um pouco mais tarde no caso da montadora A, mas o uso de uma estrutura dedicada baseada num modelo de negócio voltado exclusivamente para e-business extinguiu-se praticamente ao mesmo tempo para todas as montadoras na sua matriz (início de 2002) , seguidas por suas filiais brasileiras, caso da montadora B. As montadoras A e C ainda possuem um modelo exclusivo para e-business, porém não sabem por quanto tempo.

Isso é uma indicação clara do que foi prenunciado na literatura: não existe um modelo de e-business, mas sim um modelo de negócio onde as atividades de e-business terão o seu lugar, como as demais atividades da empresa, o que leva ao próximo comentário.

-O uso de modelos de negócio voltados para e-business explicou-se explicitamente no caso de todas as matrizes das montadoras estudadas como um instrumento para alavancar e coordenar as atividades de e-business, evitando duplicação de atividades e concentrando esforços para gerar resultados com o uso de e-business.

Todas matrizes das montadoras afirmam que a finalização de uma estrutura dedicada a e-business era prevista desde o início como estratégia da empresa, e essa estrutura centralizadora só serviu para alavancar as iniciativas de e-business e para "ensinar" as áreas corporativas da empresa a lidarem com essa nova ferramenta e absorverem essa nova tecnologia, e, quando todas as áreas tivessem condições de lançar suas próprias iniciativas de e-business conforme suas necessidades, a função dessa estrutura centralizadora, conduzida por um modelo próprio de negócio voltado para e-business, não teria mais razão de ser.

Essa função do modelo de negócio voltado para e-business, com uma estrutura central coordenadora das iniciativas de e-business extingui-se quando 
Conclusões, Limitações da pesquisa, recomendações e Sugestões para estudos futuros

todas as atividades geradas de e-business foram absorvidas pelas áreas corporativas envolvidas nessas atividades.

Nenhuma das três matrizes das montadoras declarou que o fim dos modelos dedicados a e-business tivesses se extinguido devido aos resultados obtidos terem sido abaixo das expectativas.

Porém , fica uma questão a ser respondida: se as receitas geradas pelas iniciativas de e-business coordenadas por um modelo com uma estrutura central de comando tivessem gerado receitas acima das expectativas, será que essas estruturas teriam desmoronado tão cedo? Ou pelo menos, será que não teria restado alguma pequena estrutura de coordenação para centralizar as atividades de e-business, mesmo que elas estivessem espalhadas pelas áreas corporativas?

Quanto a isso, é interessante um comentário feito por um diretor de $\mathrm{TI}$ da montadora B, que avaliou sobre qual foi, afinal, o ganho obtido com as atividades de e-business, se realmente as receitas geradas ficaram, em média, abaixo das expectativas. Para explicar o fenômeno, eis um gráfico:

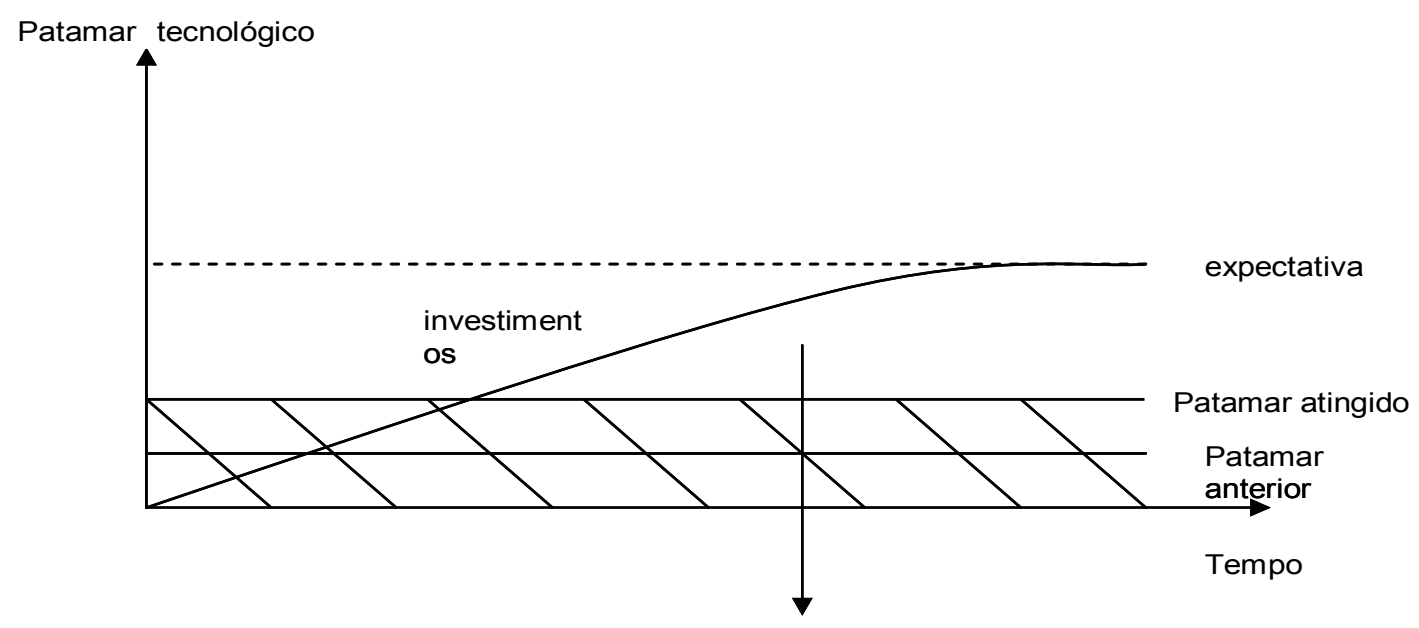

Por esse gráfico , o grande ganho com e-business foi a elevação do patamar tecnológico obtida com a utilização das atividades de e-business.

Claro que essa é a visão técnica sobre os benefícios gerados pelo ebusiness. 
Conclusões, Limitações da pesquisa, recomendações e Sugestões para estudos futuros

No caso das empresas brasileiras, apenas as montadoras A e C criaram modelos dedicados a e-business; a montadora B instituiu suas atividades de ebusiness sem um modelo de negócio condutor.

As estruturas montadas continuam a operar nas montadoras A e C por motivos diferentes: na empresa A, o modelo de e-business sugerido pela matriz ainda não conseguiu entrar plenamente em ação e só agora em 2002 começa a mostrar seus primeiros frutos, sendo que a estrutura gerada a partir do modelo deve continuar em operação até 2003, quando deverá ser extinta e espera-se , tenha gerado um aprendizado das áreas corporativas no uso das atividades de ebusiness para proveito próprio dentro da área, sem necessidade de coordenação externa.

No caso da montadora C, o modelo adotado teve tanto sucesso, que justificou, segundo os entrevistados, sua continuidade.

- Quanto aos modelos de e-businesss utilizados pelas filiais brasileiras, conclui-se que a montadora A adotou exatamente o modelo proposto pela matriz, que congrega atividades de B2B, B2C e B2E, apenas a utilização das ferramentas dentro de cada um desses modelos é mais restrita do que na matriz, atendo-se a ferramentas de e-procurement (leilões reversos basicamente) que representam o lado B2B do modelo, relações com dealers pela Internet e site institucional representando a faceta $\mathrm{B} 2 \mathrm{C}$ do modelo, intranet conectando a empresa representando a parte $\mathrm{B} 2 \mathrm{E}$.

Já a montadora B não adotou nenhum modelo formalmente, existindo uma profusão de atividades de e-business pela empresa, sem que houvesse uma coordenação entre elas, cada área era responsável por suas atividades de ebusiness, o que não configurou o uso de um modelo, uma vez que não atendeu aos preceitos conceituais que norteiam um modelo (existência de um conceito bem definido do negócio, de capacitações que permitam que aquele negócio realize o conceito e uma entrega de valor através da realização das atividades propostas pelos outros componentes)

Existiam atividades de B2B (e-procurement-leilões, uso de catálogo eletrônico), B2C (venda direta, sites de relacionamento com dealers, sites de 
Conclusões, Limitações da pesquisa, recomendações e Sugestões para estudos futuros

relacionamento com o consumidor, dentre outras atividades $\mathrm{B} 2 \mathrm{C}$ ). Ainda dentro das atividades $\mathrm{B} 2 \mathrm{C}$, foi a única montadora que apresentou um modelo de comunidade virtual, voltada para os "picapeiros" ou possuídores de "pick-ups", promovendo um site que traz informações para esse grupo, além de promover eventos para os seus associados. As atividades B2E foram: treinamento online, intranet fornecendo informações, dentre outras.

Porém, nenhum dos entrevistados identificou essas atividades dentro de um modelo global de e-business, que as abrangesse e explicasse, como foi definido por esa tese por exemplo por Applegate (2000) que preconiza um conceito que dê um sentido ao modelo.

A montadora $\mathrm{C}$ adotou de uma forma mais formalizada apenas o modelo $\mathrm{B} 2 \mathrm{C}$, sendo que esse modelo tem objetivos definidos a serem atendidos (conceito do modelo, na proposta de Appegate (2001) para conceituação de modelo) congregando uma série de atividades articuladas, utilizando os mesmos recursos humanos e infraestrutura de $\mathrm{TI}$ (parte de capacitações do modelo) que estão mobilizados para identificar novas oportunidades que gerem receitas, com objetivos financeiros a atingir muito bem definidos (parte relativa a valor na definição de modelo Segundo Applegate (2001).

As atividades B2B estão desagregadas e não são coordenadas pelo mesmo grupo que toca as atividades $\mathrm{B} 2 \mathrm{C}$.

Assim, obedece ao conceito de modelo de e-business apenas a parte B2C das atividades de $\mathrm{TI}$ da empresa. As outras atividades não possuem uma coordenação central nem atendem aos preceitos necessários para serem consideradas como um modelo de e-business.

As atividades de e-business mais bem sucedidas e reconhecidas dentro e fora da empresa envolvem justamente a área $\mathrm{B} 2 \mathrm{C}$, com o produto principal dessa área sendo a venda direta de veículos pela Internet, que foi uma iniciativa pioneira no Brasil e no mundo e obteve reconhecimento mundial.

Outras atividades de B2C da empresa C envolvem site institucional, site para relacionamento com dealers. 
Conclusões, Limitações da pesquisa, recomendações e Sugestões para estudos futuros

As iniciativas B2B atem-se a algumas atividades de e-procurement, porém a ferquencia de leilões é muito baixa. Outras atividades como catálogos são mais utilizadas.

Quanto aos modelos empregados nas matrizes, o que chama mais atenção é que todos eles acabaram de uma certa forma , quando desmontou-se a estrutura que dava forma a ele.

Assim, as evidências parecem apontar o que vários autores indicavam (Porter (2001), Weil e Vitale (2001)) que o e-business vai se tornar consistente quando o "e" se transformar em atividades corporativas, que é o que as empresas fizeram nas matrizes: um movimento em direção à absorção das atividades de ebusiness pelas áreas, fiando-se que essas áreas tenham aprendido a gerar iniciativas de e-business que lhes convenha.

As mudanças ocorridas nas estruturas organizacionais das matrizes são claros indicadores dessa nova fase: perda de autoridade, submetendo-se a níveis hierárquicos ocupados por pessoas das áreas corporativas e não totalmente voltados para e-business

- No Brasil, nem se pode dizer que houve a implantação de um modelo de e-business pelas montadoras filiais A e B cada uma por um motivo: a montadora A ainda está tentando empreender suas primeiras ações de e-business (configurando-se num "last mover" numa análise de Porter) e a montadora B nunca tentou implantar um modelo.

- Por outro lado a montadora C apresentou um modelo B2C consistente, suportado por uma infraestrutura de TI adequada e com a devida estrututra de comando e organizacional visando resultados estratégicos:parece ser a iniciativa de e-business mais bem sucedida.

Apesar da montadora B ter gerado uma quantidade muito maior de atividades de e-business, seus resultados não são claros para a alta diretoria: porém, isso é efeito de suas próprias ações, uma vez que tais atividades não mereceram um apoio ostensivo por parte dessa diretoria 
Conclusões, Limitações da pesquisa, recomendações e Sugestões para estudos futuros

-Os casos estudados evidenciam uma série de fatos levantados na literatura:

-Iniciativa deve estar amarrada a uma estratégia corporativa bem definida

-O apoio da alta direção da empresa é fundamental para que a iniciativa seja bem sucedida

- a estrutura organizacional escolhida pelas empresas denotam suas características : a empresa A mais centralizadora e paternalista, a montadora $B$ mais afoita em busca do novo, preferindo estruturas difusas e não centralizadas, que dão mais espaço para a criatividade: geram mais projetos. Porém a falta de coordenação implica em ônus para a empresa, pois os objetivos não estão muito claros e portanto dificultam a mensuração dos resultados

-a empresa $\mathrm{C}$ centrada em métricas para medir resultados e apoiada numa infraestrutura de tecnologia da informação bem arquitetada levou ao sucesso do empreendimento de forma mensurável e visível para a organização e para seu ambiente.

O exemplo da filial B vai de encontro ao que foi dito por Porter (2002). Segundo ele, empresas que já estão estabelecidas serão mais bem sucedidas quando desenvolverem tecnologias de Internet para reconfigurar atividades tradicionais ou quando as empresas encontrarem novas combinações entre as abordagens de Internet e tradicionais.

- Resumindo os dados encontrados nas filiais das montadoras e analisando-os:

-Empresa A com estrutura organizacional com diretor de e-business ligado à presidência , porém sem autoridade para tomada de decisão e alta diretoria pouco comprometida com atividades de e-business: dificuldade na implantação de novas iniciativas de e-business. Aplicação parca do modelo da matriz aqui, restringindo-se a poucas ferramentas de e-business e até perdendo sua conotação de e-business como agente integrador de toda cadeia de valor: aqui no 
Conclusões, Limitações da pesquisa, recomendações e Sugestões para estudos futuros

Brasil, esse modelo não consegue integrar toda cadeia de valor. Modelo serve num primeiro momento para sensibilizar alta administração quanto a benefícios do e-business. Resultado: baixo comprometimento da alta diretoria mais estrutura organizacional para e-business sem autoridade para tomada de decisão resulta em poucas iniciativas de e-business.

-Empresa B com estrutura organizacional para e-business espalhada por toda estrutura organizacional, em diversas áreas sem coordenação central e com nível hierárquico baixo para tomada de decisão, sem modelo de negócio para conduzir atividades, baixo comprometimento da alta diretoria, sem objetivos estratégicos para e-business claramente definidos, porém com grande aporte de capital numa primeira fase pela matriz para investimento em e-business: gerou uma grande quantidade de atividades, porém com resultados pouco mensuráveis, sem transparência para a alta administração, aparentemente benefícios gerados não causaram impacto sobre a alta administração.

Manter foco no consumidor (que é uma afirmação constante da montadora C matriz e conseqüentemente, da montadora C filial) sem deixar claro qual objetivo estratégico se quer alcançar com esse foco não garante o sucesso das iniciativas de e-business da empresa.

-Montadora C filial, com modelo de e-business voltado para o consumidor final, inserido na estratégia da empresa de aumentar fatia de mercado de carros populares, usando fábrica com produção flexível, consórcio modular, rede de distribuidores como o entregador do produto e aliado, sem haver conflitos de canal, envolvimento da alta diretoria (idéia de venda direta partiu de diretor de marketing), com aporte de capital e de recursos humanos vindos da matriz, apoio da alta direção da matriz, coordenação do projeto de implantação da atividade de e-business levado por uma pessoa de TI e uma de negócios, lado a lado, dando a importância necessária à infraestrutura de $\mathrm{TI}$ (contemplada no modelo de negócio), obedecendo a uma metodologia bem estabelecida de gestão de projetos, avaliando métricas quanto a resultados: sucesso da atividade de ebusiness-venda direta. Sucesso na geração de receitas, repercussão na matriz, repercussão na mídia, junto ao consumidor, em todo o mundo é citada como 
Conclusões, Limitações da pesquisa, recomendações e Sugestões para estudos futuros

iniciativa pioneira, resultando na manutenção da estrutura organizacional idealizada para o projeto: pessoas alocadas na área de marketing com dedicação exclusiva a e-business e diretor de TI dedicado exclusivamente a e-business, dando suporte técnico.

Esse exemplo bem sucedido reforça a questão colocada no início desse tópico de conclusões: se as iniciativas de e-business nas outras montadoras tivessem gerado receitas acima da expectativa, será que as estruturas organizacionais para e-business dedicadas teriam sido desmanteladas?

- O que se observou tanto para as montadoras matrizes quanto para as filiais brasileiras, é que num primeiro momento as atividades de e-business tiveram um foco considerável em atividades voltadas ao consumidor final, até porque esse movimento se iniciou com as empresas "ponto.com", cujo objetivo inicial foram as vendas ao consumidor individual através da Internet.

A montadora A matriz teve seu foco mais voltado a ferramentas de ebusiness voltadas a empresas: e-supply, e-ordering, e-Procurement. Porém, em seu modelo de negócio para e-business, o foco ainda é a conexão com o consumidor.

Aliás, a conexão com o consumidor e o foco no cliente são os discursos das empresas entrevistadas nessa primeira fase de instituição de um modelo de negócio, do período de meados de 1999 até início de 2002.

No Brasil, as iniciativas de e-procurement ainda estão engatinhando, com seu uso trazendo basicamente aspectos de substituição de um meio (papel) por outro (eletrônico).

O volume de leilões realizados pelas três empresas é substancialmente pequeno em comparação com o volume de compras

Espera-se alterações nesse cenário, uma vez que o próprio Covisint traz uma série de ferramentas que vão além do leilão eletrônico, possibilitando atividades colaborativas entre empresas, dentre outras ferramentas. 
Conclusões, Limitações da pesquisa, recomendações e Sugestões para estudos futuros

A montadora B mundial tem um projeto de e-procurement em desenvolvimento há dois anos, com previsão de lançamento para 2003, inclusive para o Brasil.

Esse projeto abrange o uso do Covisint para atividades de Compras, porém é mais extenso, atingindo toda cadeia de fornecimento, que deverá se tornar global.

Um problema atual levantado pela montadora B no Brasil para inserir seus fornecedores em atividades de Compras através do meio eletrônico dá-se por restrições desses fornecedores: muitos deles desistem no processo de cadastramento pela Internet, ao primeiro obstáculo surgido, apesar dos treinamentos feitos para uso do catálogo eletrônico, por exemplo. Outro problema refere-se ao porte desses fornecedores: muitos dos fornecedores no Brasil são de pequeno porte e nem tem acesso à Internet, ou não sabem inglês para poderem usar o site de procurement da montadora.

Outro problema trata da resistência dos próprios compradores da montadora, resistentes à mudança e com medo de perderem seu espaço na empresa com o uso do novo meio.

Mesmo com esses problemas, o caminho é irreversível: quando o portal global para procurement da montadora B for lançado, os fornecedores terão que se adaptar a ele.

Assim, se num primeiro momento do e-business nas montadoras o foco foi a conexão com o consumidor, a tendência parece apontar para um aumento progressivo nas atividades B2B. Essa tendência já existe em teoria, com maior movimentação de receitas, porém o que se verificou nessa pesquisa, foi que, na prática, para as montadoras entrevistadas, as atividades B2B não tiveram tanto foco como as B2C (principalmente para as montadoras B e C), o que deve sofrer modificações ao longo dos próximos anos. 
Conclusões, Limitações da pesquisa, recomendações e Sugestões para estudos futuros

\subsection{LIMITAÇÕES DO ESTUDO}

A própria metodologia já é um fator limitante do estudo, pois implica em viés, subjetividade e impossibilidade de extensão dos resultados para todo universo de montadoras.

Também foi estudado apenas o segmento de montadoras, sem focar nos fornecedores e distribuidores, que são parte importante do processo de adoção de e-business pelas montadoras. Apenas, por questão de foco, seria inviável estudar a cadeia toda. Daí, perde-se implicações relevantes sobre o envolvimento desses atores.

Como a pesquisa procurou ser abrangente, pois sua intenção foi dar uma visão geral sobre a implantação de e-business por montadoras, abordando superficialmente vários de seus aspectos, para poder fornecer uma espécie de fotografia inicial do processo, para que posteriormente futuros recortes possam aprofundar questões pertinentes, não foi possível aprofundar-se em determinados aspectos; porém foi intencional essa idéia de dar uma visão geral para que próximas pesquisas possam ser realizadas a partir de uma base de dados ampla.

Com isso perdem-se algumas informações que seriam necessárias para o aprofundamento de algumas questões.

Também foi fator limitante o tempo, que fez com que um número limitado de pessoas fosse entrevistado: não se entrevistou, por exemplo, ninguém na área de logística das empresas. Porém, como essa área não foi citada por nenhum entrevistado como fazendo parte do modelo de negócio voltado para e-business da empresa (apenas a montadora A citou o responsável por logística em seu modelo de negócio), a pesquisa ateve-se às pessoas indicadas pelos primeiros contatos na empresa.

Ainda sob esse aspecto, a representatividade do número de entrevistados é pequena frente à quantidade de pessoas envolvidas nas operações de uma montadora.

Porém, apesar do número limitado de pessoas, buscou-se entrevistar elementos representativos numa tentativa de minimizar essa limitação. 
Conclusões, Limitações da pesquisa, recomendações e Sugestões para estudos futuros

O problema do "corte" da pesquisa, que se restringiu ao papel do modelo de negócio e da estrutura organizacional no desempenho das atividades de ebusiness também pode ser considerado limitante, uma vez que existem outras variáveis importantes no fenômeno de adoção de e-business: cultura da empresa, "core competencies" da empresa, infraestrutura de TI (foi abordada de maneira superficial nessa tese), alinhamento estratégico entre e-business e $\mathrm{TI}$ e ebusiness e estratégia global da empresa, dentre tantos outros fatores que não foram avaliados, pela necessidade de "corte" para tornar a pesquisa factível.

\subsection{RECOMENDAÇÕES}

- Para empresas que estejam interessadas em desenvolver atividades de e-business, uma primeira recomendação é a avaliação atenta da própria estratégia corporativa, para verificar em quais pontos a utilização de atividades de e-business pode reforçar a vantagem competitiva da empresa.

- O uso de um modelo de negócio para e-business parece adequado quando o objetivo da empresa é alavancar iniciativas de e-business e coordená-las: quando existe um volume grande de atividades de e-business pela empresa, a ausência de coordenação num primeiro momento pode levar à dificuldade de avaliação dos benefícios auferidos

- o uso de modelo para e-business como ferramenta para aprendizado corporativo para posterior reabsorção pelas áreas corporativas: as iniciativas e projetos num segundo momento, passado o período de "aprendizado" advindo com o uso de modelo de negócio voltado para e-business, devem partir das áreas corporativa, que melhor entendem seu processo de negócio e sabem o que precisa ser melhorado e como usar a Internet para isso. Apenas parece razoável existri uma estrutura mínima para coordenação dessas atividades, que pode ser maticial com o 
Conclusões, Limitações da pesquisa, recomendações e Sugestões para estudos futuros

aproveitamento de tempo parcial dos envolvidos, para não deixar as atividades sem rumo

- Importância da existência de diálogo permanente entre as áreas de TI e áreas de negócio no que diz respeito ao desenvolvimento e aplicação de atividades de e-business pela empresa

- A estrutura organizacional deve refletir a relevância dada às atividades de e-business: se a empresa julga realmente necessário que determinado projeto de e-business seja bem sucedido para melhor aproveitamento pelas áreas, é necessário deixar isso claro através da estrutura organizacional empregada para executá-lo.

\subsection{SUGESTÕES PARA ESTUDOS FUTUROS}

Uma primeira sugestão é a extensão dessa pesquisa para os outros participantes da cadeia automotiva: dealers e fornecedores.

O papel de cada um deles é bastante relevante para que se possa ter uma compreensão holística do fenômeno de adoção de e-business pelas montadoras.

Também seria interessante aprofundar diversos pontos que essa tese apenas abordou superficialmente:

-O papel da cadeia de valor na determinação de um modelo de negócio voltado para e-business

-concentração em determinada área da empresa, para aprofundamento dos resultados. Por exemplo, ater-se á área de Compras, ou SCM da firma.

-papel da área de TI para adoção de e-business

-Mudanças na estrutura organizacional de uma determinada área devido ao impacto das atividades de e-business, identificando fatores relevantes .

-Realizar estudos estatísticos, para identificar correlações entre variáveis, como por exemplo, correlação entre estratégia e tipo de modelo adotado ou papel da alta administração e tipo de estrutura organizacional adotada, e assim por diante.

Aplicar o modelo de pesquisa a outros setores: 
Conclusões, Limitações da pesquisa, recomendações e Sugestões para estudos futuros

-setores que congreguem tanto empresas $100 \%$ nacionais como empresas globais, para propiciar um estudo comparativo do tipo de modelo de negócio adotado. Um bom exemplo de setor seria a agroindústria, que congrega empresas nacionais e globais. Outro setor interessante, seria a indústria de alimentos. 
CAPÍTULO VII

Referências Bibliográficas

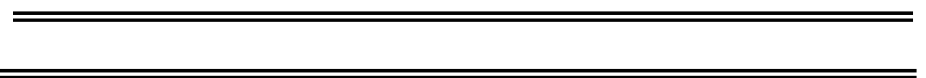




\section{Capítulo VII}

\section{REFERÊNCIAS BIBLIOGRÁFICAS}

1. A.T. Kearney (1998) "E-tailing Strategies for Automakers and dealers", obtido no site: www.atkearney.com/pdf

2. Aaker, D. A. \& Day, G. S..(1982) “Marketing Research” 3a. ed. ,John Wiley, U. S. A.

3. Andrews, Whit (2001) "B2B Technologies and Iniciatives start making sense", junho , extraído do site www.gartner.com.

4. Albrinck, Jill e Irwin, Giland Neilson, Gary e Sasina, Dianna (2000) "From Bricks to Cliks: The Four Stages of E-volution", in Strategy + Business, Issue 20, Third Quarter, Booz-Allen \& Hamilton, New York.

5. AlBeRTIN, A. L. $\left(2000^{a}\right)$ Comércio Eletrônico: Modelo, Aspectos e Contribuições de sua Aplicação. São Paulo: Atlas, $2^{a}$ edição.

6. AlBERTIN, A. L. (2000b) Comércio Eletrônico: Situação Atual e Tendências. Projeto de pesquisa desenvolvido com o apoio do Núcleo de Pesquisa e Publicações (NPP), da Escola de Administração de Empresas de São Paulo (EAESP), da Fundação Getulio Vargas (FGV). São Paulo: EAESP/FGV.

7. AlBertin, A. L.(2000c) Pesquisa FGV de Comércio Eletrônico no Mercado Brasileiro. Programa de Excelência em Negócios na Era Digital, do Centro de Informática Aplicada, da Escola de 
Administração de Empresas de São Paulo (EAESP), da Fundação Getulio Vargas (FGV). São Paulo: EAESP/FGV.

8. ALBERTIN, A. L.(1999) Administração de Informática: Funções e Fatores Críticos de Sucesso. São Paulo: Atlas, $2^{a}$ edição.

9. Amit, Raphael e Zott, Christoph (2001) "Value Creation in e-business" , paper obtido no site:

http://www-management.wharton.upenn.edu/amitresearch/documento

10. Angehrn, Albert (1997) "Designing Mature Internet Business Strategies: The ICDT Model", European Management Journal, 15 (4 agosto), 361-369.

11. Applegate, Lynda M. (2001) “Emerging E-Business Models: Lessons from the Field" , Harvard Business School, www.stuart.iit.edu/courses/ecom530/fall2001/bmodels2.pdf

12. Baldi, Stefan e Borgman,Hans (2001) "Consortium based B2B emarketplaces: A case study in the Automotive Industry", in Bled Electronic Commerce Conference, Bled, Slovenia, 25 e 26 de junho, obtido no site:www.ebs.de/

13. Bataglia, Walter (1998) "Tecnologia de Informação como Agente de Vantagem Competitiva", Anais do XX Simpósio de Gestão da Inovação Tecnológica, São Paulo, SP, Brasil.

14. Barrenechea,Mark J. (2001) "e-Business ou fora do negócio-a estratégia da Oracle para lucrar na nova economia", MAKRON BOOKS. 
15. Boyd, H. W. \& Westfall, R. (1987) "Pesquisa mercadológica: texto e

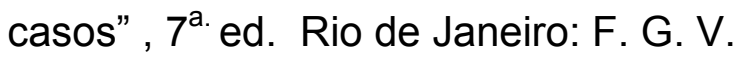

16. BRYMAN, A.(1989) "Research methods and organization studies" , Routledge, New York.

17. Bruno,Marcos Alberto Castelhano (1995) "Gestão da Cooperação Técnica entre Empresas e Estratégia Empresarial: estudos de caso no setor químico", tese apresentada à Faculdade de Economia, Administração e Contabilidade da universidade de São Paulo, para obtenção do título de doutor em Administração, sob orientação do prof. Dr. Eduardo P.G. de Vasconcellos.

18. Burgelman, Robert \& Maidique, Modesto (1998) "Strategic Management of Technology and Innovation" Richard D. Irwin, Inc.

19. Carvalho, Dirceu Tornavoi (1999) "Condicionantes de Estratégias para a Internet: Uma abordagem Inter-funcional", tese apresentada à FEA/USP para obtenção do título de doutor, São Paulo, sob orientação do prof dr. Marcos C.Campomar.

20. Castro, Cláusio de Moura (1977)“A prática da Pesquisa”, São Paulo, McGraw-Hill.

21. CEPAL (2002) "Estudo Econômico da América Latina e do Caribe 2001-2002, publicado pela Comissão Econômica para América Latina e o Caribe (CEPAL) em Agosto, obtido no site: www.mdic.gov.br/publica/SECEX/doc/200208acompanhaCEPAL .PDF 
22. Certo, Samuel C. e Peter, J. Paull (1993) "Administração Estratégica" , Makron Books do Brasil, São Paulo, Brasil.

23. Cesar, Ricardo P. (2002) “Motor Turbinado" , artigo publicado na revista Business Standard, maio 2002, obtido no site: www.businessstandard.com.br/bs/ecommerce/2002/06/0001/ind $\underline{\text { ex imprime }}$

24. Chesbrough, Henry e Rosenbloom, Richard S. (2001) " The role of the Business Model in capturing Value from Innovation: Evidence from Xerox Corporation's Technology Spinoff Companies" , paper obtido no site: www.hbs.edu/dor/papers2/0001/01-002.pdf

25. Christensen, Clayton M. (1997) "The Innovator's Dilemma" Harvard Business School Press, Boston Massachussets.

26. Chleba, Marcio (1995) "Marketing Digital: novas tecnologias e novos modelos de negócio", Ed. Futura, São Paulo.

27. Churchill, G. A. Jr.(1983) "Marketing research. Methodological foundations" , $3^{\text {rd }}$ ed.,Dryden Press, New York.

28. Cleland, David I. and King, William R. (1988) “Project Management handbook" , Van Nostrand Reinhold, New York.

29. Clemente, Peter (1997) "The State of the Net: the new frontier", New York, McGraw-Hill, Inc.

30. Czinkota, Michael R. \& Ronkainem, likka (1998) "International Marketing", $9^{\mathrm{a}}$ ed., Fort Worth, The Dryden Press. 
31. Cunningham,Michael J. (2001) "B2B:business-to-business: como implementar estratégias de e-commerce entre empresas", Rio de Janeiro, Ed. Campus.

32. Davenport, Thomas H. (1994) "Reengenharia de Processos-como inovar na empresa através da tecnologia da informação", Ed. Campus Ltda, Rj, Brasil.

33. Downes, Larry \& Chunka Mui (1998), "Unleashing the killer App: Digital Strategies for Market Dominance", Boston, Harvard Business School Press.

34. Elam, Joyce (1999)“The Adoption of retail Electronic commerce: an Empirical investigation", tese para obtenção de título $\mathrm{PhD}$, Florida International University, . Obtida pelo site: wwwlib.umi.com/dissertations

35. EASTERBY-SMITH, M., THORPE, R. \& LOWE A (1991) Management Research: An Introduction” . London: Sage.

36. Evans, Philip and Wurster, Thomas S. (1999) "Getting Real About Virtual Commerce" Harvard Business Review, nov-dez .

37. Fine, Charles H. e Raff, Daniel M. G. (2000) "Internet-Driven Innovation and economic Performance in the American Autromobile Industry", preparado para a conferência " The ebusiness transformation: sector developments and policy implications" , 26 e 27 de setembro, artigo obtido no site: www.economy.berkeley.edu/conferences/9-2000/EC-conference2000papers 
38. Fleury,André Leme (2001) "Dinâmicas Organizacionais em Mercados Eletrônicos", São Paulo, Ed. Atlas.

39. Freeland, Grant D. e Stirton, Scott (2000) "Organizing for Ecommerce", discussion paper do The Boston Consoulting Group Inc., obtido no site:

40. www.bcg.com/publications/files/organizing\%20ECommerce\%20Apr \%2000.pdf

41. Galbraith,Jay R. et alli (1995) "Organizando para competir no futuro", São Paulo, MAKRON Books.

42. Gay, L. R. \& Diehl, P. L.(1992) "Research methods for business and management" , New York, MacMillian.

43. Ghauri, P. N. \& Gronhaug, K. (1995) " Research methods in business studies. A practical guide", Prentice Hall, New York.

44. Gerstner, Lou, presidente e diretor geral da IBM (2000) "palestra proferida no eBusiness Conference Expo", dezembro, obtido no site: www-3.ibm.com/ebusiness/Br/webcast/speech.shtml.

45. Gulati,Ranjay \& Garino,Jason (2000) "get the Right Mix of Bricks \& Clicks", Harvard Business review, pag 107-114, maio-junho.

46. Gurovitz, Hélio (1999) "Planeta E", revista Exame, ed.690, ano 32, n.12, p.148-159, 16 jun.

47. Hagel III,John \& Brown,John Seely (2001) "Your next IT strategy", Harvard Business Review, pag 105-113, outubro. 
48. Hartman, Amir ,Sifonis, John and Kador, John(2000) "Net Ready: Strategies for Success in the E-conomy", McGraw-Hill, New York, USA.

49. Helper, Susan e MacDuffie, John Paul (2000) "E-volving the Auto Industry: E-commerce Effects on Consumer and Supplier Relationship" , obtido no site: www.economy.berkeley.edu/conferences/9-2000

50. Henderson,J \& Venkatraman,N. (1992) "Strategic Alignment: A model for organizational transformation through information technology" in T. Kochan\&M.Unseem, eds, Transforming Organizatios, Oxford University Press, NY.

51. IDG Now! "E-commerce no Brasil: US\$2,1 bilhões em 2001, diz FGV “ (2002), artigo obtido no site IDGnow.terra.com.br, abril.

52. Kalakota, Ravi \& Robinson, Marcia (1999) "e-Business-Roadmap for Success" Addisson Wesley Longman, Inc, Massachussets.

53. Kalakota, Ravi \& Whinston, Andrew B. (1997) "Electronic Commerce: a manager's guide", Reading, Mass., Addison-Wesley.

54. Kanter, Rosabeth Moss (2001) "The ten deadly mistakes of wannadots", Harvard Business review, pag 91-100, Janeiro.

55. Kerzner, Harold (1992) "Project management: a systems approach to planning, scheduling and controlling" , Van Nostrand Reinhold, New York. 
56. Leibs, Scott (2000) "The E-team: Companies are retooling their IT organizations to tackle an explosion of e-business opportunities", CFO magazine, dezembro, obtido no site: www.cfo.com.

57. Lewis, James P. (1995) “The project manager's desk reference”, Irwin Professional Publishing, Chicago.

58. Lientz,Bennet P. \& Rea, Kathrin P. (2001) "transform your Business into e", California, ACADEMIC PRESS.

59. Maitra, Amit K. "Building a Corporate Internet Strategy" (1996), International Thomson Publishing,Inc, New York, NY.

60. Marchi, Glenn Raymond (1999) "the role of internet in learning organizations", tese apresentada para obtenção de título de Phd, State University of New York at Albany, . Obtida pelo site : wwwlib.umi.com/dissertations.

61. Mattar, Fauze N.(1996)" Pesquisa de marketing”, São Paulo, Atlas.

62. MCT / SEPIN (Ministério da Ciência e Tecnologia) (2000). Sociedade da Informação no Brasil: livro verde. Brasília: Ministério da Ciência e Tecnologia, Setembro.

63. McAfee, Andrew (2000) " Economic Inpact of the Internet Revoluton: Manufacturing", obtido no site:

www.e-conomy.berkeley.edu/conferences/9-2000/Educonferences 2000 papers

64. Mintzberg,Henry (1995) "Criando organizações eficazes - estruturas em cinco configurações” ,São Paulo, Brasil, Ed. Atlas S.A. 
65. Mougayar, Walid (1998) "Opening Digital Markets: battle plan and business strategies for Internet Commerce", New York, McGrawHill.

66. Muritiba, Sérgio Nunes e Vasconcellos, Eduardo P.G. (2001) "Estrutura Organizacional como diferencial competitivo em negócios eletrônicos: Estudo de caso em uma empresa do ramo de Internet”, Trabalho apresentado à Faculdade de Economia, Administração e Contabilidade da Universidade de São Paulo como conclusão do curso de Graduação em Administração de Empresas, sob orientação do prof. Dr. Eduardo P.G. de Vasconcellos.

67. “O Estado de São Paulo" (2002) "Crise esfria o otimismo da indústria automobilística", publicado em 27 de julho.

68. O'Brien, J.B. (1994) “The project manager: not just a firefighter” , S.A.M Advanced Management Journal, janeiro.

69. O'Connel, Brian (2000) "B2B.com Cashing on the Business-toBusiness E-commerce Bonanza", Holbrook, MA, Adams Media Corporation.

70. Oliveira, Djalma de Pinho Rebouças de (2001)“ Sistemas , organização e métodos: uma abordagem gerencial” , Atlas, São Paulo.

71. Patel,Keyur e McCarthy,Mary Pat (2000) "The Essentials of EBusiness Leadership - Digital Transformation”, New York , McGraw-Hill 
72. PARASURAMAN, A.(1991) Marketing research, 2.ed. Reading, Mass: a. Addison-Wesley.

73. Pinto,J.K. , e Slevin,D.P (1988) “Project Success: Definitions and Measurement Techniques", Project Management Journal, 19(1), 67-72.

74. Plant, Robert (2000) "e-Commerce formulation of Strategy", NJ , Prentice Hall.

75. Porter, Michael E. e Millar V.E. (1985) " How information gives tou competitive advantage", Harvard Business Review, julho-agosto, p. 151.

76. Porter, Michael E. (1990) “Vantagem Competitiva” , Ed. Campus Itda., RJ, Brasil.

77. Porter,Michael E. (2001) "Strategy and the Internet", Harvard Business Review, pag 63-78, março.

78. Rappa, Michael (2002) "Business models on the web" ,retirado do site:http://digitalenterprise.org/models/models.html

79. Rayport, Jeffrey F. \& John Sviokla (1994) "Managing in the Marketspace", Harvard Business review, Nov-Dez , 141-150.

80. Reiley, David Lucking \& Spulber, Danmiel F.(2000) "Business-toBusiness Electronic Commerce",obtido do site: www.vanderbilt.edu, junho 23. 
81. Robert,Michael \& Racine,Bernard (2001) "e-Strategy Pure \& Simple", New York, McGraw-Hill.

82. Robles, Léo Tadeu (2001) "A prestação de serviços de Logística integrada na indústria automobilística no Brasil: em busca de alianças logísticas estratégicas", tese apresentada à faculdade de Economia, administração e Contabilidade como parte dos requisitos para obtenção do título de doutor em Administração, sob a oprientação do prof. Dr. Adalberto Américo Fischmann.

83. Rogers, Everett M. (1995) "Diffusion of Innovations", The Free Press, New York.

84. Saikovitch, Vera Lúcia (2000) "O Uso Estratégico da Internet pelas livrarias Brasileiras", tese apresentada ao Departamento de Administração da FEA/USP para obtenção do título de doutor em Administração.

85. Santos, Angela M. Medeiros M. (2001) "Reestruturação da Indústria Automobilística na América do Sul “ , BNDES Setorial, Rio de Janeiro, n. 14, setembro. retirado do site: www.bndes.gov.br/conhecimento/bnset/set1403.pdf

86. Sawhnew,Mohanbir \& Parikh,Deval (2001) "Where value lives in a networked world", Harvard Business review, pag.79-86, Janeiro.

87. Selltiz, Claire et al. (1975) "Métodos de pesquisa nas relações sociais" , São Paulo, Edusp, . 
88. Shtub, Avraham, Bard, Jonathan F. and Globerson, Shlomo (1994) “ Project management: engineering, technology and implementation", Prentice-Hall Inc., New jersey.

89. Silva, Andrea Lago da (1999) "A adoção de Tecnologia de Informação em canais de distribuição: um estudo multicaso na utilização de EDI entre varejo e indústria agroalimentar"-tese apresentada à FEA/USP para obtenção do título de doutor, sob orientação do prof. Dr. Adalberto Fischmann.

90. Slywotzky,Adrian J. \& Morrison,David J.(2000) "How Digital is your Business?",New York, Crown Publishing group.

91. Tapscott, Don (1993) "Paradigm Shift: the new promise of information technology", McGraw-Hill, Inc, USA.

92. Tapscott, Don, Lowy, Alex \& Ticoll, David (2000) "Plano de Ação para uma Economia Digital", Makron Books do Brasil Ltda.

93. Tapscott,Don et alli (2001) "Capital Digital”, São Paulo, MAKRON Books.

94. Timmers, Paul (1998) "Business Models for Electronic markets", EMEletronics markets, Site: www.electronicsmarkets.org/, vol. 8 , no 2, julho.

95. Tidd, Joseph, Bessant, John and Pavitt, Keith (1997) "Managing Innovation: integrating technological, market and organizational change", John Wiley \&Sons, New York, USA.

96. Triniños, A. N. S.(1990) "Introdução à pesquisa em Ciências Sociais. A pesquisa qualitativa em educação" , Atlas, São Paulo. 
97. Turban, Efraim et alli (2000) "Electronic Commerce a Managerial Perspective", New Jersey, Prentice-Hall Inc.

98. Vasconcellos, Eduardo (1979) "Centralização x Descentralização: uma aplicação para laboratórios de instituições de pesquisa e desenvolvimento", Revista da Administração - FIA/USP.São Paulo: Abril/Junho, p. 101-121.

99. Vasconcellos, Eduardo (1982) "Componentes da estrutura organizacional”. In: PINHO, D.B. Manual de Cooperativismo. São Paulo: Coopercultura CNPq, v3, 272p.

100. Vasconcellos, Eduardo, Hemsley, James R. (1997) "Estrutura das Organizações - Estruturas Tradicionais, Estruturas para Inovação e Estrutura Matricial", São Paulo, ed.Atlas.

101. Venkatraman,N. e Henderson, John C. " Real Strategies for Virtual Organizing" (1998), MIT Sloan Management Review, vol.40 (outono), num.1, pag. 33-48.

102. Waddington,Patricia (2002) "When is a suite really a suite? Oracle ebusiness suite: achieving daily business intelligence", retirado do site: www.oracle.com

103. Weil,Peter \& Vitale, Michael R. (2001) "Place to Space - migrating to e-business models", Harvard Business School Publishing Corporation, USA. 
104. Wise, Richard \& Morrison,David (2000) "Beyond the Exchange: the future of B2B", Harvard Business Review, pag 86 -96,nov-dez.

105. Yanakiew, Monica (1999) "Discriminação cibernética preocupa EUA", jornal "O Estado de São Paulo", caderno Geral, 25 de julho, p. A14.

106. YIN, R. K. (1994) Case Study Research: design and methods. Newburry Park: Sage Publications, $2^{a}$ edição.

Sites visitados:

www.oracle.comwww.ibm.com

www.umilib.com/dissertations

www.cfo.com

www.computerworld.com

www.IDGnow.terra.com.br

www.iautomotivo.com

www.b2bmagazine.com.br : Artigos extraídos:

B2B de ponta a ponta-abril 2002

Compugraf e .comDOMINIO unem ofertas e ampliam áreas de

atuação: maio 2001

Da fantasia à realidade: julho 2001

Dos clicks para os bricks: setembro 2001

Eu integro, tu integras...: agosto 2001

Fênix corporativo: abril 2002

Marketplaces e private exchanges: para aonde caminha a

humanidade: março 2002

No caminho dos gigantes: abril 2002

Unidos venceremos: março 2002 
Anexos

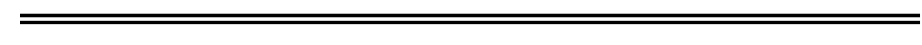




\begin{abstract}
ANEXO A
Roteiro de perguntas e assuntos abordados aplicados às áreas entrevistadas, com exceção de TI
\end{abstract}

\title{
I) Dados do entrevistado
}

Nome:

Cargo que ocupa:

Telefone para contato:

e-mail:

II) Questionário aplicado às empresas estudadas:

0-Quais aspectos a firma levou em conta para determinar seu portfolio de atividades de e-business (fatores que determinaram aquela escolha)

1- $\quad$ ESTRUTURA Organizacional :

Localizar no organograma da empresa as áreas de e-business e os níveis hierárquicos correspondentes

2- $\quad$ A partir de que área(s) surgiu (ram) a (s) iniciativa(s) de e-business?

Qual a relação dessa iniciativa com a estratégia global da empresa, se é que existia

2.1- Relação com a a matriz : existe estratégia que é seguida a partir de diretrizes da matriz? 
3-Evolução do e-business na empresa:

-Como foram as primeiras iniciativas em termos de organização do grupo, alocação de pessoal e atribuição de responsabilidades?

-Qual a prioridade que essas iniciativas tinham em relação a outras atividades dos membros do grupo envolvido em e-business?

-Quais os primeiros produtos elaborados e áreas envolvidas em seu desenvolvimento

-Como se constituíram as equipes para o desenho e implantação (foram pessoas diferentes para essas duas fases?)

-áreas envolvidas

-quem era o responsável (responsabilidade e autoridade)

-como era " cobrado"

-nível de formalização

-parceiros envolvidos (cliente, fornecedor, outro tipo de parceiwro)

-atribuições das áreas

-se houve contribuição a nível mundial, como ocorreu

\subsection{1- O que foio projeto " shadow" ?}

3.1-Quais os principais fatores que contribuíram para que a estrutura resultante tivesse essa forma (custos, recursos, tecnologia, cultura da empresa, tipo de cliente, tipo de fornecedor, produtos a serem oferecidos, tempo para a implantação)...)

3.2-Quais os objetivos pretendidos com a atividade de e-b e quais as fontes de receita a serem geradas 
3.3-Autoridade e responsabilidade: qual o cargo de maior nível hierárquico ligado ao negócio virtual?

--Esta pessoa foi contratada do mercado ou foi remanejada de alguma outra vaga existente na empresa tradicional? Qual vaga?

--Atualmente, esta pessoa é também responsável por outras atividades?

3.4-Preencha a tabela abaixo quanto aos aspectos de autoridade / responsabilidade dos responsáveis por e-business na empresa:

\begin{tabular}{l|l|l}
\hline \hline \multicolumn{1}{c|}{ Atividade } & Responsabilidade & $\begin{array}{c}\text { Autoridade para } \\
\text { tomada de } \\
\text { decisão }\end{array}$ \\
\hline \hline $\begin{array}{l}\text { Coordenação das atividades de e- } \\
\text { business }\end{array}$ & & \\
\hline Decisões sobre investimentos & & \\
\hline $\begin{array}{l}\text { Relacionamento com outros } \\
\text { departamentos/áreas da empresa }\end{array}$ & & \\
\hline $\begin{array}{l}\text { Decisão sobre objetivos do e- } \\
\text { business }\end{array}$ & & \\
\hline $\begin{array}{l}\text { Decisão sobre tipos de produtos } \\
\text { oferecidos de segmentos de }\end{array}$ & & \\
\hline $\begin{array}{l}\text { Identificação de disponível } \\
\text { clientes a atingir }\end{array}$ & & \\
\hline Relacionamento com cliente & & \\
\hline $\begin{array}{l}\text { Decisões quanto à Logística para e- } \\
\text { business }\end{array}$ & & \\
\hline Recrutamento de pessoas & & \\
\hline Alocação de pessoas & & \\
\hline Decisões sobre investimento em \\
treinamentos \\
\hline $\begin{array}{l}\text { Avaliação sobre a capacidade da } \\
\text { infraestrutura de tl } \\
\text { alocada para e-business }\end{array}$ & \\
\hline \hline
\end{tabular}

3.5-Houve alguma reestruturação interna na empresa em virtude do negócio virtual? 
3.6-Com relação ao relacionamento do negócio virtual com a empresa tradicional: -Foi detectado algum tipo de sobreposição entre os encarregados pelo negócio virtual e as pessoas encarregadas pelo negócio tradicional? Como isso foi ajustado?

-A comunicação entre as partes tradicional e virtual da empresa é eficiente e clara?

- Com relação a fornecedores e clientes, foi aumentado o poder de barganha ou agregados maiores benefícios? Houve alguma economia de escala e distribuição? Quais outros benefícios encontrados?

3.7-Com relação às áreas de apoio da empresa( $\mathrm{RH}$, financeiro, operações) ou outros recursos, foram criadas áreas específicas ou foi aproveitado o existente? Quais as mudanças?

4-a-Como foi o planejamento da integração do e-b com os processos atuais?

b-Houve coleta de informações externas (competição, e-b de outros, análise dos sistemas e tecnologia dos produtos a serem oferecidos)

5-Estágio atual

-Como está organizada a área hoje (como foi o aproveitamento das pessoas envolvidas nos projetos, o que ficou e o que se modificou na forma de trabalhar)

-Portfolio de serviços/produtos oferecidos

6-Qual a relação do e-business com a estratégia corporativa

-Objetivos e missão da empresa

-Objetivos e missão do e-business 
9-Resultados pretendidos e alcançados pela área

10-Planos para o futuro

11-Outras informações que considerar relevantes

\section{ANEXO B-Questionário aplicado às áreas de TI das empresas entrevistadas}

1-Organograma da área de $\mathrm{TI}$, ressaltando responsáveis por e-business (se pertinente)

1.1-Houve alguma alteração nesse organograma para a implantação das atividades de e-business?

2-Qual a prioridade que as iniciativas de e-b tinham em relação a outras atividades dos membros do grupo envolvido em e-business? Quem estabelece essas prioridades?

3-Existe alguma metodologia de implantação de projetos formalizada?

Qual?

Ela foi seguida para implantar ferramentas de e-business?

4-Evolução do e-business na empresa:

-Como se constituíram as equipes para o desenho e implantação (foram pessoas diferentes para essas duas fases?)

-áreas envolvidas

-quem era o responsável (responsabilidade e autoridade)

-como era " cobrado"

-nível de formalização

-parceiros envolvidos (cliente, fornecedor, outro tipo de parceiwro)

-atribuições das áreas 
-se houve contribuição a nível mundial, como ocorreu

5-Quais os principais fatores que contribuíram para que a estrutura de e-business existente hoje tivesse essa forma (custos, recursos, tecnologia, cultura da empresa, tipo de cliente, tipo de fornecedor, produtos a serem oferecidos, tempo para a implantação)...)

6- Objetivos pretendidos com a atividade de e-b eram conflitantes ou não com área de $\mathrm{TI}$

7-Existiu necessidade de algum tipo de qualificação específica que não havia na firma, para implantação das ferramentas? Se não havia a qualificação necessária, como foi suprida? (contratação externa, cursos, etc)

Em termos de plataformas?

8-Estágio atual

-Portfolio de serviços/produtos de e-business oferecidos no Brasil (que já estão em operação)

9-Relação do e-business com a estratégia de TI

-objetivos de $\mathrm{TI} X$ objetivos de e-business

-compartilhamento de recursos?

-Identificação dos processos-chave?

-Definição dos benefícios?

-Definição das necessidades?

10-A infraestrutura de TI mostrou-se adequada para a implantação das atividades pretendidas? (analisar nível de integração entre sistemas da firma existentes e 
aplicativos de e-b e outros sistemas necessários; avaliar equipamentos disponíveis, capacitação das pessoas)

11-Resultados pretendidos e alcançados pela área

12-Planos para o futuro 